\title{
Naar integrale logistiek in bedrijfsketens : ontwikkelingen in de bouw
}

Citation for published version (APA):

Voordijk, J. T. (1994). Naar integrale logistiek in bedrijfsketens : ontwikkelingen in de bouw. [Doctoral Thesis, Maastricht University]. Datawyse / Universitaire Pers Maastricht. https://doi.org/10.26481/dis.19940624jv

Document status and date:

Published: 01/01/1994

DOI:

10.26481/dis.19940624jv

Document Version:

Publisher's PDF, also known as Version of record

\section{Please check the document version of this publication:}

- A submitted manuscript is the version of the article upon submission and before peer-review. There can be important differences between the submitted version and the official published version of record.

People interested in the research are advised to contact the author for the final version of the publication, or visit the DOI to the publisher's website.

- The final author version and the galley proof are versions of the publication after peer review.

- The final published version features the final layout of the paper including the volume, issue and page numbers.

Link to publication

\footnotetext{
General rights rights.

- You may freely distribute the URL identifying the publication in the public portal. please follow below link for the End User Agreement:

www.umlib.nl/taverne-license

Take down policy

If you believe that this document breaches copyright please contact us at:

repository@maastrichtuniversity.nl

providing details and we will investigate your claim.
}

Copyright and moral rights for the publications made accessible in the public portal are retained by the authors and/or other copyright owners and it is a condition of accessing publications that users recognise and abide by the legal requirements associated with these

- Users may download and print one copy of any publication from the public portal for the purpose of private study or research.

- You may not further distribute the material or use it for any profit-making activity or commercial gain

If the publication is distributed under the terms of Article $25 \mathrm{fa}$ of the Dutch Copyright Act, indicated by the "Taverne" license above, 


\title{
NAAR INTEGRALE LOGISTIEK IN BEDRIJFSKETENS
}

\section{Ontwikkelingen in de bouw}

\author{
PROEFSCHRIFT
}

ter verkrijging van de graad van doctor aan de

Rijksuniversiteit Limburg te Maastricht, op gezag van de Rector Magnificus, Prof. dr. H. Philipsen, volgens het besluit van het College van Dekanen, in het openbaar te verdedigen op vrijdag, 24 juni 1994 om 14.00 uur

door

JOHANNES THEODORUS VOORDIJK 


\section{Promotor:}

Prof. dr. F. Prakke

\section{Co-promotor:}

Dr. B. Dankbaar

\section{Beoordelingscommissie:}

Prof. dr. J. Hagedoorn (voorzitter)

Prof. dr. J.F. den Hertog

Prof. dr. ir. A.W.J. Kolen

Prof. ir. M.J.M. de Vaan (VU Amsterdam)

Naar integrale logistiek in bedrijfsketens: ontwikkelingen in de bouw / Johannes Theodorus Voordijk. - Maastricht : Universitaire Pers Maastricht. - III.

Proefschrift Maastricht.- Met lit. opg. - Met

samenvatting in het. Engels

ISBN 90-5278-144-3

Trefw.: logistiek (bedrijfseconomic) / organisaticleer 


\section{Inhoud}

Voorwoord

1. Inleiding $\ldots \ldots \ldots \ldots \ldots \ldots \ldots \ldots \ldots \ldots \ldots \ldots \ldots \ldots \ldots \ldots \ldots \ldots$

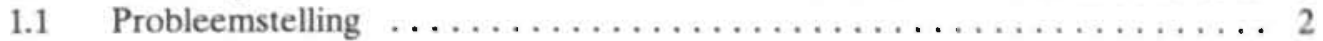

1.2 Methodologische verantwoording $\ldots \ldots \ldots \ldots \ldots \ldots \ldots \ldots \ldots \ldots \ldots \ldots \ldots \ldots \ldots$

1.3 Indeling van de studie $\ldots \ldots \ldots \ldots \ldots \ldots \ldots \ldots \ldots \ldots \ldots \ldots \ldots$

1.3.1 Integrale logistiek . . . . . . . . . . . . . . . . . . . 4

1.3.2 Toepassing van integrale logistiek in de bouw . . . . . . . . . . . . . 4

\section{DEEL I INTEGRALE LOGISTIEK: EEN VERKENNING}

2. Ontwikkelingen in de organisatie van de logistiek $\ldots \ldots \ldots \ldots \ldots \ldots \ldots$

2.1 Ontwikkelingen in de organisatie van de logistieke functie . . . . . . . . . 9

2.1 .1 De opkomst van het logistieke concept . . . . . . . . . . . . . . . 10

2.1.2 Toepassing van logistieke concepten op ondernemingsniveau . . . . . . . . 12

2.1.3 'Integrale logistiek' - verandering van focus: van onderneming naar keten . . . 14

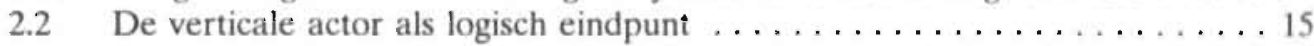

3. Toepassing van integrale logistiek als 'match' tussen markt en technologie . 19

3.1 Toenemende concurrentie ........................ 19

$3.1 .1 \quad$ Kwaliteit en customer service . . . . . . . . . . . . . . . . . . . 19

3.1.2 Uitbesteding en specialisatie als dominante concurrentie-strategie . . . . . . . 20

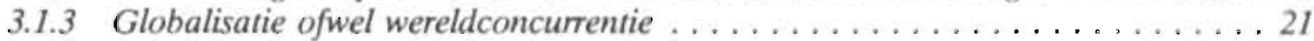

3.2 De veranderende produktie-technologie binnen bedrijven . . . . . . . 22

3.2 .1 Traditionele beheersing en inrichting van produktie . . . . . . . . . . . . 22

3.2 .2 De automatisering van de produktie . . . . . . . . . . . . . . . 24

3.2 .3 Nieuwe concepten van produktiebeheersing . . . . . . . . . . . . . 25

3.3 Nieuwe informatietechnologie . . . . . . . . . . . . . . . . . . . 29

3.3 .1 Informatietechnologie en integratie $\ldots \ldots \ldots \ldots \ldots \ldots \ldots \ldots \ldots \ldots$

$3: 3.2$ Videotex . . . . . . . . . . . . . . . . . . . . . . . 30

$3: 3.3$ Electronic Data Interchange $\ldots \ldots \ldots \ldots \ldots \ldots \ldots \ldots \ldots \ldots \ldots \ldots$

$3: 3.4$ Product Data Interchange . . . . . . . . . . . . . . . . . . 33

3.4 Toepassing van integrale logistiek als concurrentie-strategie . . . . . . 34

3.4 .1 Basistypen van concurrentie-voordeel . . . . . . . . . . . . . 35

3.4 .2 Concurrentie-voordeel door toepassing van integrale logistiek . . . . . . . . 36

4. Verandering van transactiepatronen $\ldots \ldots \ldots \ldots \ldots \ldots \ldots \ldots \ldots \ldots \ldots$

4.1 De externe organisatie van de onderneming . . . . . . . . . . . 39

4.1 .1 De transactiekostentheorie . . . . . . . . . . . . . . . . . 39

4.1 .2 Het netwerk als coördinatiemechanisme ................... 43 


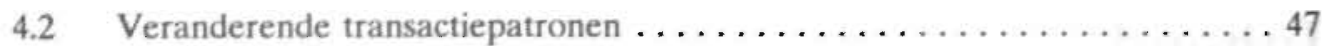

4.2 .1 Transactiespecifieke investeringen .................... 47

4.2.2 Overdracht van know-how, de eis van snelheid en wederzijds vertrouwen . . . . 49

4.3 Toepassing van integrale logistiek en verandering in transactiepatronen ....5 51

4.3.1 Toepassing van integrale logistiek en transactiespecifieke investeringen . . . . . 51

4.3.2 Toepassing van integrale logistiek en overdracht van know-how, de eis van snelheid en wederzijds vertrouwen $\ldots \ldots \ldots \ldots \ldots \ldots \ldots \ldots \ldots . \ldots \ldots$

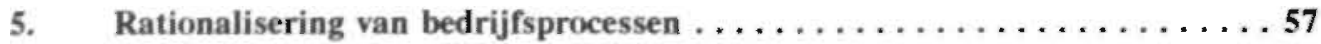

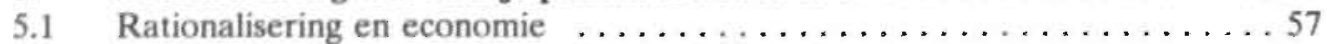

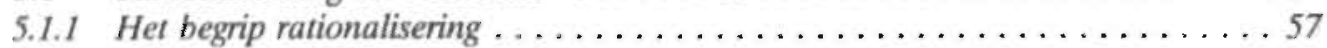

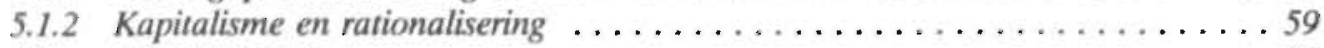

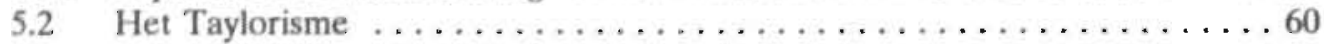

5.3 Crisis van het Tayloristisch model . . . . . . . . . . . . . . 62

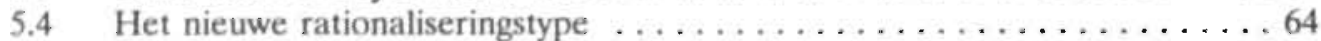

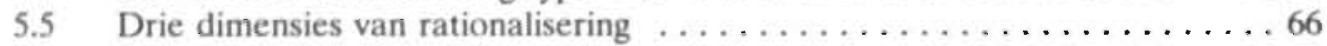

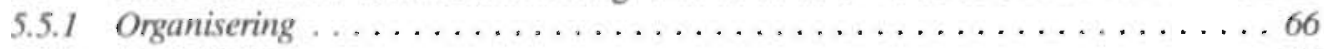

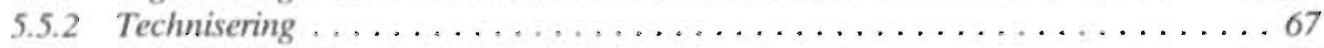

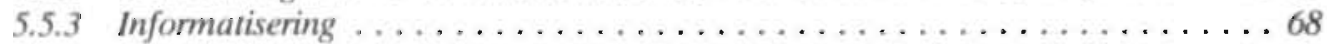

5.6 Rationalisering en toepassing van integrale logistiek $\ldots \ldots \ldots \ldots \ldots 69$

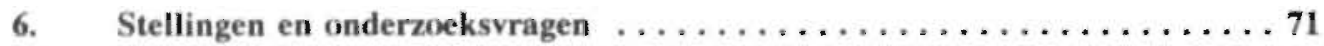

6.1 Voorwaarden voor het ontstaan van logistieke netwerken . . . . . . . . 71

6.2 Eigenschappen en gevolgen van toepassing van integrale logistiek $\ldots \ldots 72$

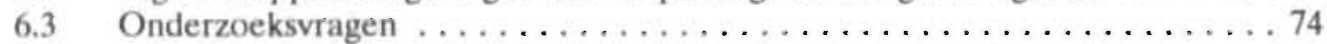

\section{DEEL II TOEPASSING VAN INTEGRALE LOGISTIEK IN DE BOUW}

7. Methodologie van het empirisch onderzoek ............... 79

7.1 Onderzoeksopzet . . . . . . . . . . . . . . . . . . . . . . . 79

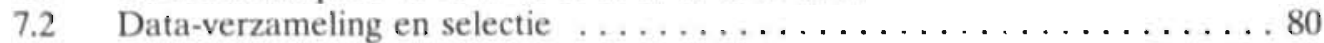

7.3 Hoofdstukindeling van deel II $\ldots \ldots \ldots \ldots \ldots \ldots \ldots \ldots \ldots \ldots \ldots \ldots \ldots \ldots \ldots$

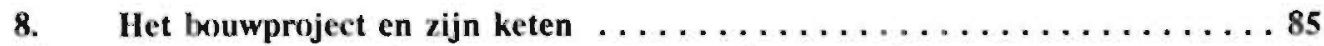

8.1 Het bouwproces als vorm van projectgewijze produktie $\ldots \ldots \ldots \ldots \ldots 85$

8.1 .1 Het bouwproces . . . . . . . . . . . . . . . . . . . . 86

8.1 .2 Aspecten van projectgewijze produktie $\ldots \ldots \ldots \ldots \ldots \ldots \ldots \ldots \ldots$

8.1 .3 Bouwmethode en logistieke keuzen .................. 89

8.2 De organisatie van de produktie bij toeleveranciers van de bouw . . . . . 99

8.2 .1 De bouwmaterialengroothandel .................... 91

8.2 .2 Industriële toeleveranciers . . . . . . . . . . . . . . . . . . . 94

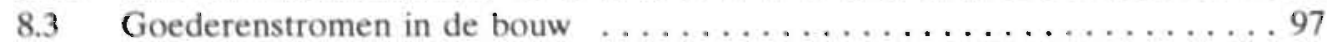

8.3 .1 Goederenstromen bij fabrikage en toelevering . . . . . . . . . . 97

83.2 Aflevering en verwerking van materialen op de bouwplaats . . . . . . . 100

8.4 Informatiestromen in de bouw . . . . . . . . . . . . . . . 101

8.4 .1 Bestek en tekeningen als basis voor de informatie-uitwisseling ..........101

8.4.2 Sturing van goederenstromen tussen bouwbedrijf en toeleveranciers . . . . . . 104 
9. Informatisering in de bouw: EDI en PDI $\ldots \ldots \ldots \ldots \ldots \ldots \ldots \ldots \ldots$

9.1 EDI in de Nederlandse bouw . . . . . . . . . . . . . . . . 108

9.1 .1 EDI-projecten in de bouw . . . . . . . . . . . . . . . . . . . 108

9.1.2 Herstructurering van de logistieke keten door EDI . . . . . . . . . . 111

9.2 PDI als logisch gevolg op EDI $\ldots \ldots \ldots \ldots \ldots \ldots \ldots \ldots \ldots \ldots \ldots$

9.2 .1 Beperkingen van het transactie-cluster . . . . . . . . . . . . . 117

9.2 .2 Standaarden voor produktmodellering .................. 118

9.3 PDI in de Nederlandse bouw . . . . . . . . . . . . . . . . . 120

9.3.1 IOP-Bouw en Nationaal Onderzoekskader Bouwinformatica . . . . . . . . 120

9.3.2 PDI en de herstructurering van het bouwproces . . . . . . . . . . . . 124

9.4 Knelpunten en strategieën bij implementatie van EDI en PDI in de bouw . 128

9.4 .1 De projectmatige produktiewijze en sectorstructuur als knelpunten . . . . . . 128

9.4 .2 De behoefte aan een collectieve instantie . . . . . . . . . . . . . 130

10. Innovaties in de organisatie van bouwprojecten $\ldots \ldots \ldots \ldots \ldots \ldots \ldots$

10.1 Van prijs- naar kwaliteitsconcurrentie . . . . . . . . . . . . . 134

10.1 .1 Het traditionele bouwproces . . . . . . . . . . . . . . . . . . . 134

10.1.2 Toenemende concurrentie en nieuwe marktvereisten . . . . . . . . . . . 135

10.1.3. De prestatie-werkwijze en kwaliteitsgericht denken in de bouw . . . . . . . . 137

10.2 De veranderende relatie tussen ontwerp en uitvoering $\ldots \ldots \ldots \ldots \ldots$

10.2.1 Integratie van ontwerp en uitvoering door de architect . . . . . . . . . 140

10.2.2 Integratie van ontwerp en uitvoering door het uitvoerend bouwbedrijf . . . . 144

10.2.3 De rol van de industriële toeleverancier . . . . . . . . . . . . . . . . . . . . 149

10.3 Integratie van ontwerp en uitvoering en de verticale actor $\ldots \ldots \ldots \ldots 2$

10.3 .1 Co-makership in de bouw . . . . . . . . . . . . . . . . . . . . . . . . . . . . .

10.3 .2 Opties voor de verticale actor . . . . . . . . . . . . . 155

11. Produktielogistiek in vier bouwprojecten en hun ketens $\ldots \ldots \ldots \ldots \ldots$

11.1 Gevalsstudies: vragen en methodologie . . . . . . . . . . . . . . . . . . 159

11.2 De keukenketen . . . . . . . . . . . . . . . . . . . . 161

11.2.1 Het bouwproject en de deelnemende bedrijven . . . . . . . . . . . . . . 161

11.2.2 Het order-en leverschema van keukens . . . . . . . . . . . . . 163

11.2.3 Analyse van de logistieke organisatie . . . . . . . . . . . . . 165

11.3 De keten vạn hout en installatiemateriaal . . . . . . . . . . . . . . 168

11.3.1 Het bouwproject en de deelnemende bedrijven . . . . . . . . . . . . . . 168

11.3.2 Het bestel- en aanvoerproces van het hout . . . . . . . . . . . . . . . . 170

11.3 .3 Analyse van het planningsproces . . . . . . . . . . . . . 17I

11.4 De keten van prefab gevelelementen $\ldots \ldots \ldots \ldots \ldots \ldots \ldots \ldots \ldots$

11.4 .1 Hel bouwproject en de deelnemende bedrijven . . . . . . . . . . . . 175

11.4.2 Produktie- en toeleverproces van prefab gevelelementen . . . . . . . . . 176

11.4 .3 Afstemming tussen ontwerp produktie en montage $\ldots \ldots \ldots \ldots \ldots$. . . . . I79

11.5 De keten van betonelementen . . . . . . . . . . . . . . . . 182

11.5.1 Het bouwproject . . . . . . . . . . . . . . . . . . . . . . . . . . . . 182

11.5.2. De goederenstromen . . . . . . . . . . . . . . . . . . . 184

11.5 .3 Prefabrikage als produktietechniek ................. 186

11.6 Aanzetten tot toepassing van integrale logistiek . . . . . . . . . . . . 188

11.6.1 Organisatievorm en logistieke afstemming . . . . . . . . . . . . . 188

11.6.2 Produktietechniek en logistieke afstemming . . . . . . . . . . . . . . . 190

11.6.3 Mogelijkheden voor logistieke afstemming . . . . . . . . . . . . I9i 


\section{DEEL III CONCLUSIES}

12. Conclusies: naar nieuwe structuren in de bouw . . . . . . . . . 197

12.1 Voorwaarden voor de ontwikkeling van logistieke netwerken . . . . . . 197

12.2 De gevolgen van logistieke netwerkvorming $\ldots \ldots \ldots \ldots \ldots \ldots \ldots \ldots$

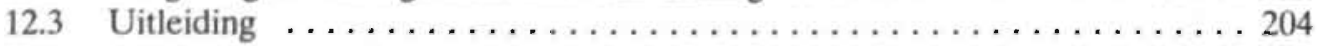

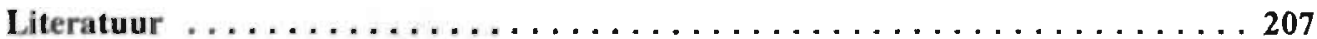

\section{Bijlagen}

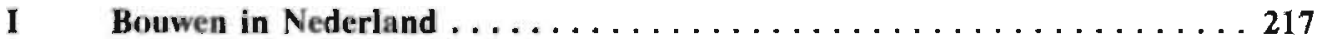

1 Ontwikkelingen in produktie en werkgelegenheid $\ldots \ldots \ldots \ldots \ldots \ldots \ldots$

1.1 Produktie en werkgelegenheid in de bouwnijverheid . . . . . . . . . . 21?

1.2 Produktie en werkgelegenheid bij de toeleverende branches . . . . . . . . . 221

1.3 De relatie tussen bouw- en bouwmaterialenproduktie . . . . . . . . . . 226

2 De bedrijfsstructuur van de bouwnijverheid en de toeleveranciers . . . . 228

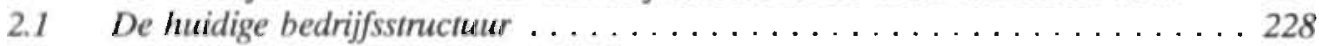

2.2 Ontwikkelingen in de bedrijfsstructuur . . . . . . . . . . . . . 235

3 Organisaties op bedrijfstakniveau $\ldots \ldots \ldots \ldots \ldots \ldots \ldots \ldots \ldots \ldots$

3.1 Branche-organisaties in de bouwnijverheid . . . . . . . . . . . 238

3.2 Branche-organisaties van toeleveranciers van de bouw . . . . . . . . . 241

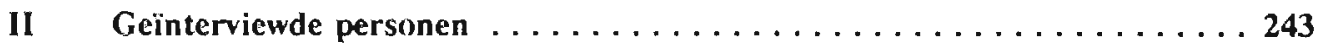

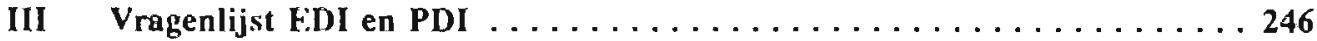

IV Vragenlijst Innovaties in de organisatie van bouwprojecten . . . . . . 249

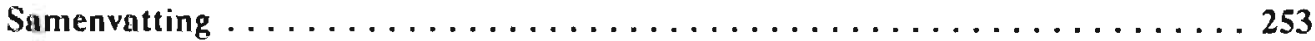

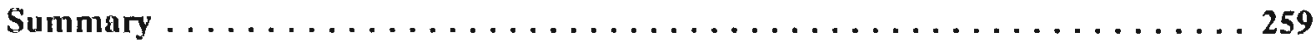

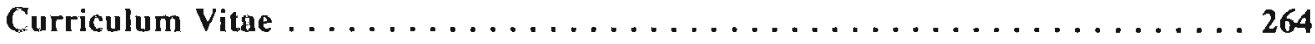




\section{Voorwoord}

Het onderzoek, dat in deze dissertatie beschreven is, startte in september 1989 bij het Maastricht Economic Research Institute in Maastricht (MERIT). Na in Rotterdam als algemeen econoom te zijn afgestudeerd was dit meer bedrijfskundige promotie-project aan de Rijksuniversiteit Limburg een nieuwe uitdaging. Achteraf gezien blijkt deze keuze voor Limburg een juiste te zijn geweest. Niet alleen in wetenschappelijk opzicht, ook geografisch en politiek gezien is het Limburgse land uitermate boeiend.

Zonder de uitstekende begeleiding van Ben Dankbaar zou het proefschrift, zoals het er nu ligt, niet tot stand zijn gekomen. Hij dwong mij tot het schrijven van 'strakke', consistente verhandelingen en nam iedere keer weer tijd om concepten van soms zeer fundamentele kritiek te voorzien. Daarnaast was het Frits Prakke die de grote lijn in de gaten hield en in de laatste fase de aanzet gaf voor een aantal wezenlijke verbeteringen. Op dit punt wil ik. ook de leden van de beoordelingscommissie, de hoogleraren John Hagedoorn, Friso den Hertog, Anton Kolen en Mat de Vaan, bedanken voor hun inzet en nuttige suggesties ter verbetering van het boek.

Jan Bakker en Willem-Otto Hazelhorst van het organisatie-adviesbureau Berenschot introduceerden mij in de bouwpraktijk van alle dag. Zij leerden mij dat het relevant kan zijn bouwprojecten vanuit logistiek perspectief te analyseren. Naast hen wilden ook vele andere personen tijd voor mij vrijmaken. Een aantal daarvan hebben mij verder de weg gewezen in de bouwwereld en wil ik hier speciaal noemen: T. Buytels, L.J. van Dam, J.J. Duivenvoorden, D. Gann, P.Ph. Janssen, T. Jutte, M. Nuyten en F.J. Westhoff.

De leden van het E-dispuut, een groep promovendi die zich richten op onderzoek in de informatietechnologie, hebben ook bijgedragen aan de totstandkoming van dit proefschrift. De soms zeer technische discussies over informatiesystemen waren yoor mij als niet-ingenieur af en toe volstrekt onbegrijpelijk. Toch waren deze discussies zeer nuttig omdat zij mij het jargon van de ingenieur leerden kennen. Deze kennis bleek een belangrijke steun in de rug te zijn bij het onderzoek naar nieuwe informatietechnologieën in de bouw.

Marcel Lever en Alwin Oerlemans dank ik voor het op peil houden van mijn motivatie. De bijna wekelijks terugkerende discussies over geloof en politiek relativeerden en stimuleerden ons economisch onderzoek. Zonder mijn kamergenoot Hugo Hollanders, die voor mij op geduldige wijze de geheimen van verschillende computerprogramma's ontsloot, zou de lay-out van aanzienlijk lagere kwaliteit zijn geweest. Ton Bestebreur worstelde zich als kritisch meelezer door het manuscript heen en stelde vele verbeteringen voor.

Tenslotte wil ik Margreet en mijn ouders bedanken voor hun 'moral support'. Op kritische momenten wees Margreet mij op de relevantie van het schrijven van een proefschrift.

Hans Voordijk

Maastricht, april 1994. 



\section{Inleiding}

Logistiek staat hedentendage volop in de belangstelling. Nadenken over logistiek wordt al lang niet meer alleen in militaire kringen gedaan. In de oorspronkelijke militaire betekenis van het woord heeft volgens de Van Dale logistiek. betrekking op alle voorberieidingen en handelingen die nodig zijn om de troepen op de meest doeltreffende wijze van goederen en voorraden te voorzien en onder de gunstigste omstandigheden te doen strijden. Het begrip logistiek is ten tijde van Lodewijk XIV geïntroduceerd in het Franse leger. Men zag in dat een goede organisatie van de logistiek een belangrijke voorwaarde was voor militair succes (Schaafsma, 1986).

Veel principes uit de 'militaire' logistiek zijn de afgelopen decennia ook in het bedrijfsleven toegepast. De logistieke functie is de bedrijfsfunctie die zich bezighoudt met de besturing van goederenstromen en de daaraan gekoppelde informatiestromen (Van Goor, 1988, 9). Ook voor bedrijven is de organisatie van de logistiek een belangrijke voorwaarde voor succesvol optreden geworden. Verschillende ontwikkelingen hebben hiertoe bijgedragen. Op verschillende nationale en internationale markten zijn produktie-ondernemingen in toenemende mate genoodzaakt om met verschillende produkten op de markt te komen, toegespitst op diverse segmenten. Dat maakt het onmogelijk om voor een anonieme markt te produceren. Men spreekt in dit verband ook wel van een overgang van een 'voorraadgestuurde' naar een 'ordergestuurde' produktie.

Snel inspelen op markten vereist een flexibele inzet van mensen en materialen. In het verleden werden klantgerichtheid en flexibiliteit meestal geassocieerd met een ambachtelijke produktie-organisatie. Kenmerkend voor de recente ontwikkelingen is dat (een gedeelte van) de flexibiliteit gezocht wordt in de toepassing van communicatie- en informatietechnologieën. Daarbij gaat het er met name om de toename in flexibiliteit zonder kostenstijging te doen plaats vinden en zo mogelijk zelfs te combineren met. een daling van de produktiekosten.

Gevolg van deze ontwikkelingen is dat de organisatie van het logistiek management de laatste jaren aan betekenis heeft gewonnen. Het streven naar een verdergaande integratie van bedrijfsprocessen staat hierbij centraal. Men spreekt in dit verband van interne en externe integratie. Interne integratie heeft betrekking op de koppeling en afstemming van activiteiten binnen de onderneming. Externe integratie heeft betrekking op de afstemming en koppeling van goederen- en informatiestromen tussen ondernemingen. In dat geval maken zelfstandige ondernemingen afspraken over de wijze waarop uitwisseling van goederen en informatie zal plaats vinden.

Dit kan uiteindelijk leiden tot het ontstaan van een geïntegreerde logistieke functie voor een keten of groep van bedrijven. De logistieke verantwoordelijkheden binnen en tussen verschillende organisatorische eenheden in een keten van bedrijven of bedrijfskolom worden dan opnieuw afgebakend. Wanneer de logistieke activiteiten van ver- 
schillende ondernemingen aan elkaar verbonden zijn, wordt in de literatuur gesproken van 'nieuwe' of 'integrale' logistiek. De ontwikkeling van integrale logistiek is nauw verbonden met de toepassing van informatietechnologie. Centraal onderwerp in dit onderzoek zijn de veranderingen in de organisatie van produktie-processen die samenhangen met de toepassing van informatietechnologie in de logistiek. Anders gezegd: onderwerp voor dit onderzoek zijn de voorwaarden en gevolgen van de toepassing van integrale logistiek.

\subsection{Probleemstelling}

De centrale probleemstelling van het onderzoek valt uiteen in twee delen:

1. Onder welke voorwaarden of omstandigheden zal het tot toepassing van integrale logistiek komen? De vraag is hier waar en wanneer we toepassing van integrale logistiek kunnen verwachten.

2. Welke veranderingen zullen bij toepassing van integrale logistiek zich voordoen in de organisatie van bedrijfsprocessen in een keten of groep van bedrijven? Deze vraag richt zich op 'eigenschappen' en gevolgen van toepassing van integrale logistiek.

Deze vragen worden onderzocht in een specifieke sector, nl. de bouwsector. Het empirisch onderzoek richt zich op het bouwproject en zijn keten van toeleveranciers. Een aantal argumenten hebben tezamen ertoe geleid dat voor dit onderzoeksobject is gekozen. Ten eerste is het qua onderzoek interessant als de logistiek van een complex produkt onderzocht wordt. Dit is het geval bij een bouwwerk. In de meeste gevallen is dit een tamelijk complex produkt. Ten tweede kan men verwachten dat toepassing van integrale logistiek in de bouw, gezien het 'versnipperde' karakter van de bouwsector, tot duidelijk waarneembare organisatorische veranderingen zal leiden. Een derde argument voor de keuze van de keten van een bouwwerk is dat, in tegenstelling tot bijvoorbeeld de auto-industrie en de consumenten-electronica, logistiek in de bouw een nog relatief weinig onderzocht verschijnsel is.

De relevantie van het onderzoek gaat verder dan de bouw. Ontwikkelingen in logistieke ketens in de bouw hoeven niet uniek te zijn. Zij kunnen exemplarisch zijn voor ontwikkelingen in verschillende andere bedrijfstakken.

\subsection{Methodologische verantwoording}

Toepassing van integrale logistiek in ketens van bedrijuen bevindt zich vaak nog in een pril stadium. Deze beperkte empirie vormt een probleem bij de beantwoording van de centrale onderzoeksvragen en met name bij de vraag naar de gevolgen van toepassing van integrale logistiek. Om dit probleem te ondervangen proberen we bij de beantwoording van de centrale onderzoeksvragen met de theorie als het ware in de toekomst te kijken. Onze theoretische verkenningen in het eerste deel van het onderzoek hebben tot doel nader inzicht te krijgen onder welke voorwaarden toepassing van integrale logistiek in een keten of groep van bedrijven zal plaats vinden, op welke wijze deze toepassing nader vorm zal krijgen en wat de implicaties daarvan zijn voor de organisatie van bedrijfsprocessen. Met andere woorden, concepten uit de theorieèn hebben de functie zicht te krijgen op de voorwaarden waaronder het tot toepassing van integrale logistiek komt en de 'wetmatigheden' van richtingen waarin toepassing van 
integrale logistiek zich nader kan concretiseren. Uit deze theoretische verkenningen vloeien stellingen voort die een aantal specifieke voorwaarden waaronder toepassing van integrale logistiek mogelijk wordt en de gevolgen daarvan voor de organisatie van produktieprocessen aangeven.

Met behulp van deze stellingen wordt een aantal onderzoeksvragen geformuleerd die in het tweede deel van dit onderzoek beantwoord worden aan de hand van een gedetailleerd empirisch onderzoek over logistiek in de bouwsector. Hiervoor wordt verschillend bronnenmateriaal gebruikt (de opzet van het empirisch onderzoek wordt in hoofdstuk 7 nader beschreven). Met dit materiaal worden veranderingen in de organi-satie van het bouwproject en zijn keten, het onderzoeksobject, vanuit twee verschillende invalshoeken geanalyseerd.

Ten eerste richt het empirisch onderzoek zich op een beschrijving van veranderingen in de 'omgeving' van bouwprojecten en hun ketens. Het gaat hierbij om een analyse van stimuleringsprogramma's, gericht op informatisering in de bouw, en om innovaties in de organisatie van bouwprojecten die het antwoord zijn op nieuwe marktvereisten. Het zijn deze ontwikkelingen die de context vormen waarbinnen veranderingen in de organisatie van concrete bouwprojecten en hun ketens plaats vinden.

Ten tweede worden vier case-studies van concrete bouwprojecten en hun ketens uitgevoerd. Yin $(1984,23)$ definieert de case-study of, in het Nederlands, de gevalsstudie als volgt:

'A case study is an empirical inquiry that:

- investigates a contemporary phenomenon within its real-life context; when

- the boundaries between phenomenon and context are not clearly evident; and

- multiple sources of evidence are used.'

Gekozen is voor de onderzoeksstrategie van de gevalsstudie omdat de bouwsector in het algemeen omschreven kan worden als een 'structured mess'. Bedrijven binnen deze sector verschillen sterk qua omvang, structuur, cultuur, activiteitengebied etc. Algemene uitspraken op basis van een 'sample' uit deze populatie zijn onbetrouwbaar. De beperkte mogelijkheden tot generalisatie bij analyse van specifieke bouwprojecten is hier dan ook geen groot nadeel. Een tweede argument voor deze methode is dat het onderzochte fenomeen, toepassing van integrale logistick, in de empirie verschillende uitingsvormen of concretiseringen aanneemt. Dit bemoeilijkt de beschrijving van algemene corzaak-gevolg relaties tussen toepassing van integrale logistiek en de organisatie van de keten. Een derde argument is dat een representatieve steekproef weinig inzicht zal geven. Omdat integrale logistiek nog niet wijdverbreid wordt toegepast is een generalisatie van de resultaten van zo'n steekproef moeilijk.

Beschrijving van veranderingen in de omgeving van bouwprojecten en hun ketens en de vier gevalsstudies dragen op verschillende manieren antwoorden aan op de centrale onderzoeksvragen onder welke voorwaarden het tot toepassing van integrale logistiek komt en wat de eigenschappen en gevolgen daarvan zijn. In het derde deel van dit onderzoek worden de resultaten van het empirisch onderzoek geconfronteerd met de op de theorieën gebaseerde: stellingen en onderzoeksvragen. Met gegevens uit het empirisch onderzoek wordt bezien in hoeverre de ontwikkelde stellingen geldig zijn voor de bouw. 


\subsubsection{Integrale logistiek}

In het eerste deel van de studie, de hoofdstukken 2 tot en met 6 , wordt het theoretisch onderzoek weergegeven. In de hoofdstukken 2 en 3 wordt ingegaan op de vraag wat in dit onderzoek onder toepassing van integrale logistiek wordt verstaan. In hoofdstuk 2 wordt aangegeven dat toepassing van integrale logistiek past in een trendmatige verandering van de organisatie van logistieke activiteiten. Hoofdstuk 3 behandelt ontwikkelingen die toepassing van integrale logistiek mogelijk maken. In hoofdstuk 4 en 5 wordt een theoretisch raamwerk ontwikkeld dat voorwaarden aangeeft waaronder integrale logistiek van toepassing wordt en wat de gevolgen daarvan zijn voor de organisatie van bedrijfsprocessen. Op basis van dit theoretisch raamwerk worden in hoofdstuk 6 stellingen en onderzoeksvragen afgeleid.

In hoofdstuk 2 wordt ingegaan op de vraag wat we in dit onderzoek onder toepassing van integrale logistiek verstaan door verschillende stadia in de historische ontwikkeling van de organisatie van de logistieke functie te beschrijven. We trekken de lijn in deze ontwikkeling door en geven aan welke organisatievormen het logisch eindpunt van dit proces zijn.

Hoofdstuk 3 richt zich op ontwikkelingen op de markt en in de technologie die toepassing van integrale logistiek hebben mogelijk gemaakt. Aangegeven wordt dat integrale logistiek als concurrentie-strategie het instrument kan zijn om deze ontwikkelingen op de markt en in de technologie te 'matchen'.

In hoofdstuk 4 wordt de vraag gesteld onder welke voorwaarden transactiepatronen tussen bedrijven zich wijzigen. Theorieën over de externe organisatie van de onderneming dienen in deze analyse als uitgangspunt en worden in dit hoofdstuk uiteengezet. Met concepten uit deze theorieën wordt aangegeven onder welke voorwaarden het tot een toepassing van integrale logistiek komt. Met deze analyse worden theoretische antwoorden gegeven op de eerste centrale onderzoeksvraag.

In hoofdstuk 5 wordt ingegaan op theorieën over rationalisering van bedrijfsprocessen. Toepassing van integrale logistiek is recentelijk omschreven als onderdeel van een nieuwe type rationalisering. In dit hoofdstuk wordt vanuit dit perspectief beschreven op welke wijze toepassing van integrale logistiek nader vorm krijgt en wat de implicaties daarvan zijn voor de organisatie van bedrijfsprocessen. Op deze wijze worden theoretische antwoorden gegeven op de tweede centrale onderzoeksvraag.

Op basis van de concepten uit de in de hoofdstukken 4 en 5 presenteerde theorieën worden in hoofdstuk 6 een aantal stellingen en vragen voor het empirisch onderzoek geformuleerd.

\subsubsection{Toepassing van integrale logistiek in de bouw}

Het empirisch onderzoek in de bouwsector wordt weergegeven in dee! II, de hoofdstukken 7 tot en met 11. De hoofdstukken 9, 10 en 11 richten zich op een toetsing van de in deel I ontwikkelde stellingen. In de hoofdstukken 9 en 10 wordt ingegaan op ontwikkelingen in de omgeving van bouwprojecten en hun ketens. Hoofdstuk 11 omvat 
de analyse van vier concrete bouwprojecten en hun ketens. De hoofdstukken 9 tot en met 11 dragen antwoorden aan op de vragen onder welke voorwaarden het tot toepassing van integrale logistiek komt en wat de implicaties daarvan zijn voor de organisatie van bouwprojecten en hun ketens.

Hoofdstuk 7 bevat de opzet van het empirisch onderzoek. Er wordt ingegaan op de opzet van de verschillende empirische deelonderzoeken en de wijze van dataverzameling.

Hoofdstuk 8 behandelt het onderzoeksobject, het bouwproject en zijn keten. Er wordt aangegeven hoe de produktie bij verschillende bedrijven, die deel uit maken van logistieke ketens in de bouw, georganiseerd is.

In hoofstuk 9 wordt ingegaan op verschillende stimuleringsprogramma's, gericht op informatisering in de bouw. Doel van deze programma's is de totstandkoming van een infrastructuur voor electronische communicatie tussen verschillende partijen in het bouwproces.

In hoofdstuk 10 worden innovaties in de organisatie van bouwprojecten beschreven die het antwoord zijn op nieuwe marktvereisten. Aangegeven wordt hoe relaties tussen ontwerpende, uitvoerende en toeleverende bedrijven in de bouw als gevolg hiervan veranderen.

In hoofdstuk 11 worden een viertal case-studies van concrete bouwprojecten en hun ketens uitgevoerd. Er wordt geanalyseerd in hoeverre in de bestaande bouwpraktijk organisatievormen te vinden zijn die als aanzetten tot of nadere concretiseringen van toepassing van integrale logistiek beschouwd kunnen worden.

In hoofstuk 12, deel III van het onderzoek, worden de stellingen uit het theoretisch raamwerk geconfronteerd met de resultaten van het empirisch onderzoek. Aangegeven wordt in hoeverre de ontwikkelde stellingen gelden voor de bouwsector:

Toepassing yan integrale logistiek vindt plaats in een bepaalde economische omgeving. Daarom wordt in bijlage I ingegaan op ontwikkelingen in produktie en werkgelegenheid, de bedrijfsstructuur van de verschillende branches die deel uitmaken van de keten en belangrijke branche-organisaties in de bouwnijverheid en de toeleveranciers van de bouwsector. 



\section{DEEL I}

\section{Integrale logistiek: een verkenning}





\section{Ontwikkelingen in de organisatie van de logistiek}

Logistiek is een term die naar een veelheid van produktie-, transport- en distributiehandelingen en -benaderingen verwijst. De logistieke functie wordt gedefinieerd als de bedrijfsfunctie die zich bezighoudt met de besturing van goederenstromen en daaraan gekoppelde informatiestromen (Van Goor, 1988, 9). In de literatuur wordt de ontwikkeling in de organisatie van de logistieke functie dikwijls als een voortgaand integratie-proces van deelfuncties beschreven. Deze integratie gaat gepaard met veranderingen in de wijze van beheersen en organiseren van de logistieke functie. Dit integratieproces kan zelfs de grenzen van de individuele onderneming overschrijden zodat de nadruk komt te liggen op integrale goederenstroombeheersing in ketens van bedrijven. In het laatste geval spreken we van integrale logistiek.

In de hoofdstukken 2 en 3 wordt een nadere uiteenzetting gegeven van wat in dit onderzoek onder toepassing van integrale logistiek verstaan wordit. Dit hoofdstuk geeft aan dat toepassing van integrale logistiek past in een trendmatige verandering van de organisatie van logistieke activiteiten. In hoofdstuk 3 wordt ingegaan op oniwikkeiingen die toepassing van integrale logistiek mogelijk maken. Na deze twee beschrijvende hoofdstukken zal in de hoofdstukken 4 en 5 een theoretisch raamwerk worden ontwikkeld dat antwoorden probeert te geven op de centrale onderzoeksvragen. Om nader aan te geven wat we onder toepassing van integrale logistiek verstaan zetten we in dit hoofdstuk in $\$ 2$.1 diverse stadia van het ontwikkelingsproces van de organisatie van de logistieke functie uiteen. Vervolgens wordt in $\$ 2.2$ ingegaan op organisatievormen die als logisch eindpunt van het integratie-proces van de organisatie van de logistieke functie zijn te beschouwen.

\subsection{Ontwikkelingen in de organisatie van de Iogistieke functie}

Botter omschrijft de logistieke functie als '... die bedrijfsfunctie, die zich bezighoudt met de besturing van goederenstromen en daaraan gekoppelde informatiestromen. Onder besturing verstaan wij hier zowel planning als beheersing; onder goederenstroom de gehele keten van zowel grondstoffen en onderdelen, als halffabrikaten en eindprodukten' (geciteerd in: Monhemius en Durlinger, 1989, 72). Logistiek heeft als verzameling activiteiten betrekking op fysieke distributie van eindprodukten, deelstukken uit produktie (magazijnen, materials handling, intern transport), en delen van de inkoopfunctie (De Vaan, 1988a). Uit het historische ontwikkelingsverloop van de organisatie van de logistieke functie blijkt dat het bereik van deze functie voortdurend is toegenomen. In deze paragraaf wordt op deze ontwikkeling ingegaan. 


\subsubsection{De opkomst van het logistieke concept}

De term logistiek komt oorspronkelijk uit de militaire wereld en is tot de jaren ' 50 ook uitsluitend in dat verband gebruikt. In die context wordt logistiek als volgt gedefinieerd:

'A logistic operation consists in the supply of definite quantities of physical means and services for activities that according to their missions consume these means and services in order that the activities be maintained at particular present or expected future rates. The supplies come from a source and must be moved, in other words, transformed in space and time, by means of transportation to the activity' (Morgenstern geciteerd in: Janssen en Nauta, 1986, 26).

Tot de jaren '50 organiseren ondernemingen hun logistieke functie op een gefragmenteerde basis (Bowersox, 1986). Van een samenhangend beleid ten aanzien van de organisatie van conventionele logistieke activiteiten als vervoer, opslag en distributie is geen sprake. Bij het management ontbreekt de visie dat integratie van logistieke activiteiten tot verbeterde prestaties leidt. Deze benadering hangt nauw samen met de Fordistische kijk op de organisatie. Het. Fordisme legt sterk de nadruk op optimalisatie van deelprocessen binnen ondernemingen. ${ }^{1}$ Ondanks het feit dat een aantal auteurs reeds in de jaren twintig had gewezen op het fundamentele belang van logistiek management voor de organisatie en ondanks dat kennis aanwezig was in de militaire wereld bleef een integrale benadering uit. ${ }^{2}$

Voor de Amerikaanse situatie geven Bowersox et al. (1986) een aantal redenen waarom op een bepaald moment in het bedrijfsleven toch behoefte ontstaat aan toepassing van concepten gericht op een integratie van logistieke activiteiten.

Ten eerste kan gewezen worden op de komst van computers en kwantitatieve technieken die een vruchtbaar gebied voor logistieke toepassingen bieden. Computers doen vanaf het midden van de jaren '50 hun intrede in bedrijven (Ballou, 1985). Lineaire programmering, theorieën over voorraadbeheersing en simulatie worden waardevolle instrumenten vooi het management. Men is nu beter in staat de optimale locatie van opslag- en distributiecentra te bepaleñ, voorraden op meerdere locaties integraal te beheersen en tot een betere route-planning van het transport te komen. Managers zien in dat toepassing van deze technieken bij de oplossing van logistieke problemen aanzienlijke kostendalingen tot gevolg kunnen hebben.

Een tweedie reden die tot de behoefte aan een geïntegreerde benadering van de logistiek leidt, is de introductie van het marketing concept. Toepassing van het marketing concept leidt tot een toenemende produktdifferentiatie en het verkopen van produkten via een variëteit van kanalen. Toepassing van het concept versterkt de gefragmenteerde en chaotische uitvoering van de logistieke functie (Bowersox et al., 1986). De suboptimalisatie die het resultaat is van deze ongecoördineerde uitvoering van de logistieke functie doet de behoefte ontstaan aan een geïntegreerde benadering.

${ }^{1}$ Zie voor achtergronden van het Fordisme hoofdstuk vije.

${ }^{2}$ Bowersox et al. (1986) wijzen op een aantal publicaties uit de jaren 20 die reeds het (strategisch) belang van de organisatie van de logistieke functie aangeven. 
Een belangrijke aanzet tot de ontwikkeling van concepten gericht op een integratie van logistieke activiteiten wordt gepresenteerd in een studie uit 1956 waarin het concept van de totale kosten analyse uiteen wordt gezet. ${ }^{3}$ Conclusie van deze studie is dat de meest efficiënte uitvoering van de logistieke functie binnen de onderneming gepaard kan gaan met een financieel onaantrekkelijke transporttechniek, in casu transport via de lucht. De totale kosten van de logistieke functie kunnen lager zijn indien hogere kosten worden gemaakt voor een specifieke deelactiviteit. Het concept van de totale kosten analyse introduceert voor het eerst een samenhangende visie op verschillende componenten van de logistieke functie binnen een onderneming (Bowersox et al., 1986; Heskett et al., 1973).

Deze visie leidt ertoe dat op een hoger besluitvormingsniveau een afstemming van logistieke deelfuncties moet plaats vinden. Op dit niveau worden in elkaar grijpende vraagstukken als materiaalverwerving, opslag, voorraadbeheersing, produktieplanning en transport in samenhang gecoördineerd. Deze afstemming van logistieke activiteiten kan in ondernemingen, gebaseerd op een functioneel gespecialiseerde organisatiestructuur, op een aantal punten tot problemen leiden (Monhemius en Durlinger, 1989, 68 e.v.). Met name het budgetteringsproces vormt in een functioneel-georganiseerde organisatie een obstakel in het streven naar een geïntegreerde logistieke organisatie.

Budgettering, zoals men die in de regel in dergelijke organisaties aantreft, is cen administratieve methode voor het beheersen van kosten van in te zetten produktiemiddelen. Ieder van de afdelingen krijgt binnen de organisatie een eigen gespecialiseerde taak toegewezen, waarbij de taakstelling voor elk. van deze afdelingen in financiële zin jaarlijks in afdelingsbudgetten wordt vastgelegd. Dit afdelingsbudget geeft aan de afdelingsleiding de financiële ruimte voor het uitvoeren van activiteiten en vormt de basis voor de jaarlijkse beoordeling van de afdeling. Deze zal ernaar streven de eigen gespecialiseerde taak zo efficiënt mogelijk te realiseren en financiële overschrijdingen te voorkomen, desnoods ten koste van andere afdelingen.

De afdeling verkoop streeft naar grote omzet met korte levertijden, een breed assortiment en kleine series. Daarentegen wenst de afdeling produktie grote fabrikageseries en liefst lange levertijden. De inkoop kijkt voornamelijk naar de mogelijkheden van leveranciers en de expeditie wil volle vrachtwagens. De wijze van budgetteren in een functionele organisatie is meestal gericht op efficiënte inzet van produktiemiddelen per afdeling. Andere doelstellingen als onderhanden werk, doorlooptijden, leverbetrouwbaarheid krijgen daarbij in de regel minder aandacht. Gevolg is dat een behoorlijke afstemming van opeenvolgende bewerkingen in logistieke ketens slechts moeizaam te verwezenlijken is.

Kenmerkend yoor het logistieke denken op bedrijfsniveau is dat tussen verschillende conflicterende kostenstructuren van door verschillende afdelingen uitgevoerde logistieke activiteiten trade-offs gemaakt moeten worden. Er vindt een, afwegingsproces plaats tussen produktie- en verwervingskosten, opslag- en distributiekosten en de service aan de klanten. Een voorbeeld daarvan is de afweging tussen de kosten van het nee-verkopen en de voorraadkosten. Verlaging van de kosten van het nee-verkopen kan een

${ }^{3}$ Lewis, H.T., Culliton, J.W., Steel, J.D., 1956, The Role of Air Freight in Physical Distribution, Boston, Harvard University. 
verhoging van voorraden op verkooppunten en hogere transportkosten betekenen. In figuur 2.1 zijn de kostencurves van voorraden en transport weergegeven. Een hogere frequentie van de belevering van voorraadpunten betekent hogere transportkosten. Op deze punten hoeft echter minder voorraad te worden aangehouden hetgeen weer tot een daling van de voorraadkosten leidt. Het optimale service-niveau is het minimum van de combinatie van de beide kostencurves. In de praktijk blijkt het kwantificeren van verschillende kostencurves en dus de bepaling van optima een moeilijke opgave te zijn.

FIGUUR 2.1 De afweging tussen transport- en voorraadkosien

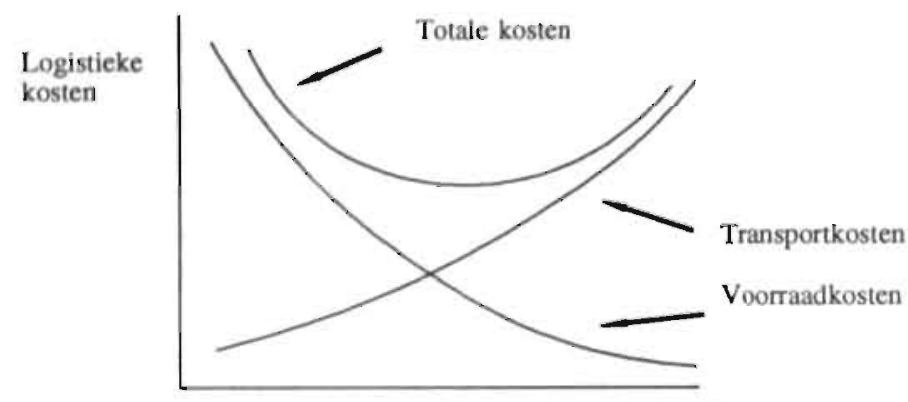

Frequentie van belevering

Het tegen elkaar afwegen van dergelijke kostenstructuren leidt tot een collectief optimum. Het logistieke denken of concept maakt bedrijven ervan bewust dat een geïntegreerde goederenstroombeheersing economisch gezien tot betere resultaten kan leiden.

\subsubsection{Toepassing van logistieke concepten op ondememingsniveau}

Toepassing van concepten die een geïntegreerde organisatie en beheersing van de logistieke functie voorstaan vindt voor het eerst in de jaren ' 60 plaats. Verschillende logistieke activiteiten worden geïntegreerd door toepassing van een tweetal concepten: 'physical distribution' en 'materials management'.

'Physical distribution' richt zich op een integratie van activiteiten gerelateerd aan de distributie van gereed produkt. Binnen de fysieke distributie kunnen een drietal deelsystemen onderscheiden worden (Van Goor et al., 1989; Monhernius en Durlinger, 1989).

Een eerste deelsysteem is het voorraadbeheer. Hier gaat het om beslissingen omtrent de optimale hoogte van voorraden in de diverse schakels van een distributiekanaal. Per voorraadpunt moet worden bepaald wanneer en hoeveel er moet worden afgeroepen. Een tweede deelsysteem heeft betrekking op de magazijnen. Hierbij staan beslissingen over de optimale keuze van een vestigingsplaats van een depot of magazijn en de meest efficiënte wijze van vervullen van de magazijnfuncties centraal. Bij magazijnfuncties kunnen we denken aan het opslaan van goederen (de voorraadfunctie), het hergroeperen van goederen (de groupagefunctie), het (opnieuw) verpakken en het 
overladen op een ander transportmiddel (de overslagfunctie). Het derde deelsysteem van fysieke distributie heeft betrekking op het kiezen van transportmiddelen en optimale planning van routes die deze transportmiddelen moeten afleggen.

'Materials management' ('Physical Supply Management') omvat alle activiteiten die gericht zijn op het verkrijgen en beheersen van materialen, nodig voor de fabrikage van het eindprodukt. 'Materials management' integreert delen van inkoopfunctie en onder handen werk en voorraden (Bardi en Coyle, 1985). Ook binnen 'materials management' kunnen een drietal deelsystemen onderscheiden worden (Van Goor et al., $1990)$.

Een eerste deelsysteem heeft betrekking op voorraadbeheer en -beheersing van gronden hulpstoffen, onderdelen, halffabrikaten en voorraden onderhanden werk. Een tweede deelsysteem is de produktieplanning en de beheersing van de uitvoering daarvan. Een derde deelsysteem is de 'materials handling', het verplaatsen van grondstoffen, halffabrikaten en goederen in bewerking. De handling van grond- en hulpstoffen is in dit verband de verzameling activiteiten gericht op de fysieke goederenstroom vanaf materiaalontvangst tot en met de materiaalverstrekking aan de fabrikage. Het magazijn neemt hierbij een belangrijke plaats in. Probleemgebieden binnen magazijnen zijn opslagmethoden, toepassing van hulpwerktuigen en orderverzameisystemen. Ook een aantal activiteiten die onder inkoop en verwerving vallen kunnen tot materials management gerekend worden. Inkoop en verwerving richt zich op de aanschaf van grondstoffen en halffabrikaten.

Inkoop en verwerving beïnvloedt de organisatie van de goederenstroom door de keten, maar niet alle daarbij behorende activiteiten van dit deelsysteem kunnen tot het materials management gerekend worden (Ballou, 1985, 481). Beslissingen met betrekking tot bepaling van inkoop-hoeveelheden, tijdstippen van binnenkomst van materialen en selectie van produktvorm en transportnnethode zijn belangrijke activiteiten die hier wel toe gerekend kunnen worden. Daarentegen vallen activiteiten met betrekking tot de onderhandeling over contracten, de evaluatie van toeleveranciers en de kwaliteitscontrole niet direct onder materials management. In het algemeen zou men kunnen stellen dat beslissingen over kwantiteit en beschikbaarheid van materialen activiteiten zijn die tot het materials management gerekend kunnen worden. Daarentegen behoren beslissingen met betrekking tot kwaliteit, prijs en leverancierskeuze daar niet toe.

De grens tussen de bedrijfsfuncties logistiek en produktie is ook niet zonder problemen. Activiteiten als produktieplanning en 'materials handling' kunnen zowel tot de functie logistiek als tot de functie produktie gerekend worden. Men kan beide functies in het bredere kader van het transformatie-proces van materialen plaatsen. De produktie-functie is binnen het transformatie-proces verantwoordelijk voor de directe bewerking van materialen. De logistieke functie verzorgt door intern en extern transport de transformatie naar plaats en, door opslag voor, tijdens en na bewerkingen van materialen, de transformatie naar tijd (Jansen en Nauta, 1986).

Toepassing van de twee logistieke concepten, 'materials management' en 'physical distribution', leidt tot een scheidslijn tussen de afhandeling van de inkoop en de aanvoer aan de ene kant en de verkoop en distributie aan de andere kant. Logistieke beslissingen in deze twee activiteitengebieden zijn niet met elkaar verbonden. Een belangrijk argument voor deze scheiding is dat logistieke aspecten van grondstoffen, 
halffabrikaten en onderhanden voorraden fundamenteel verschillen van logistieke aspecten van het gereed produkt (Bardi en Coyle, 1985, 19-20).

Gedurende de jaren '70 vervaagt echter de scheidslijn tussen de twee logistieke activiteitengebieden. 'Materials management' en 'physical distribution' vloeien samen in het concept 'business logistics'. Toepassing van laatstgenoemd concept heeft tot gevolg dat de distributielogistiek van gereed produkt wordt gekoppeld aan de interne logistiek van de aanvoer van grondstoffen en materialen.

Bardi en Coyle definiëren 'business logistics' als volgt (1985, 6 en 8):

'Business logistics is the systematic and coordinated set of activities required to provide the physical movement and storage of goods (raw materials, parts, finished goods) from vendor/supply sources through company facilities to the customer (market) and the associated activities including packaging, order processing, and others, in an efficient manner necessary to enable the organization to contribute to explicit goals of the company.'

Toepassing van het concept van 'business logistics' betekent dat men de logistieke functie zo tracht te organiseren, dat voor een produkt-marktcombinatie alle logistieke activiteiten op bedrijfsniveau in samenhang worden bestuurd (Monhemius en Durlinger, 1989, 72).

\subsection{3 'Integrale logistiek' - verandering van focus: van ondememing naar keten}

In de jaren '80 en ' 90 gaat de integratie van logistieke activiteiten nog een stap verder als zelfstandige ondernemingen afspraken maken over de wijze waarop uitwisseling van goederen- en informatiestromen zal plaats vinden. We hebben dit in hoofdstuk 1 aangeduid als de toepassing van integrale logistiek. Essentieel verschil met voorgaande concepten over de organisatie van de logistieke functie is dat nu niet het bedrijf maar de keten uitgangspunt is voor een integrale benadering van logistieke activiteiten. Toepassing van integrale logistiek betekent niet alleen de coördinatie van logistieke activiteiten binnen een bedrijf, maar ook de coördinatie van die activiteiten binnen een keten of groep van bedrijven.

In de oude situatie worden in- en verkoopbeslissingen tussen ondernemingen gedaan op basis van prognoses van elkaars mogelijkheden (Ribbers, 1991). De inkopende onderneming plaatst een order zonder informatie over levermogelijkheden van leveranciers. De leveranciers plannen op hun beurt de produktie zonder veel informatie over de vraag van de afnemende organisaties. Er is sprake van een duidelijk afbakening van organisatiegrenzen.

Gevolg is onzekerheid ten aanzien van de plannen van de handelspartners hetgeen weer kan leiden tot problemen met betrekking tot voorraden, levertijden en produktiecapaciteiten. De effectiviteit van de externe logistiek, de integrale beheersing van de externe goederenstromen, komt hierdoor onder druk te staan.

Die onzekerheid wordt bij toepassing van integrale logistiek verminderd door wederzijdse afstemming van beslissingen en onderlinge afspraken. Op operationeel niveau kunnen beslissingen worden gecoördineerd door het maken van onderlinge afspraken 
over de af te nemen hoeveelheid van bepaalde goederen per tijdseenheid. Een voorbeeld van zo'n afspraak is het afsluiten van afroepcontracten. Op tactisch niveau kunnen beslissingen worden gecoördineerd door het toepassen van just-in-time systemen (zie hoofdstuk 3). Op strategisch niveau kan men denken aan co-makership, strategische allianties en value added partnerships (Ribbers, 1991).

Er wordt bij toepassing van integrale logistiek gestreefd naar een economischer gebruik van de tijd en de route die een produkt aflegt tussen grondstof en consument. Gevolg is dat ook hier op verschillende punten in de keten trade-offs gemaakt moeten worden tussen conflicterende kostenstructuren van de door verschillende ondernemingen uitgevoerde logistieke activiteiten. Belangrijk verschil is dat de trade-offs nu niet alleen binnen maar ook tussen de, in ieder geval juridisch, zelfstandige actoren gemaakt worden. Dit wordt wel de 'total channel approach' genoemd (Poist, 1989). Uiteindelijk doel van toepassing van integrale logistiek is een integrale besturing van de goederenstroom, vanaf de aanvoer van grondstoffen en materialen bij de eerste meest 'stroomopwaarts' gelegen actor tot en met de aflevering aan de finale klanten, de laatste actor. Inkoop, produktie, opslag, vervoer en distributie gaan als één. geïntegreerd geheel functioneren.

\subsection{De verticale actor als logisch eindpunt}

Net als in de jaren '50 is het denken over logistiek de werkelijkheid vooruit gesneld. In de praktijk vinden we slechts eerste aanzetten tot toepassing van integrale logistiek en nog maar zelden of nooit een geïntegreerde logistieke functie voor een complete keten. Daartoe ontbreken ook veelal de organisatorische voorwaarden.

'Business logistics' heeft ertoe geleid dat binnen de onderneming centrale afdelingen zijn ontstaan, die zich uitsluitend richten op de coördinatie van logistieke activiteiten. Deze ontwikkeling is te omschrijven als een verzelfstandiging van de logistieke functie binnen de onderneming. Die verzelfstandiging kan zelfs leiden tot oprichting van een separaat bedrijf. Recent Nederlands voorbeeld daarvan is Hemex B.V., een nieuwe dochter van Fuji-Nederland. Bij Fuji ging de overgang van eilandautomatisering naar integrale informatisering samen met belangrijke organisatorische veranderingen. Het bedrijf streefde ernaar drie fabrieken met uiteenlopende eindprodukten en één centraal distributiecentrum met verschillende verzameltechnieken onder één besturingssyssteem te brengen. De overgang van eilandautomatisering naar dit centrale besturingssysteem betekende een flinke wijziging in de distributie-organisatie. Voorheen had iedere fabriek een eigen magazijn en werden eindprodukten verdeeld over twee distributiecentra. Met de invoering van integrale informatisering zijn alle logistieke activiteiten ondergebracht bij een apart bedrijf, Hermex B.V., dat functioneert als logistieke dienstverlener. Dit bedrijf is verantwoordelijk voor de opslag en distributie van eindprodukten en voor de interne goederenstromen binnen de Fuji-fabrieken. Hermex B.V. is te beschouwen als een onafhankelijke business unit van Fuji. Het is nog geen echt bedrijf in die zin dat het ook voor andere klanten dan Fuji werkt (LogistiekKrant, maart 1992).

Op vergelijkbare wijze kan bij toepassing van integrale logistiek deze verzelfstandiging van de logistieke functie in één organisatie zich ook op het. niveau van een keten van bedrijven gaan voordoen. Het is in principe mogelijk dat in een keten van bedrijven 
één onderneming de organisatie van (delen van) de logistieke functie gaat uitvoeren. Deze onderneming duiden wij aan als de 'verticale actor'. "Verticaal' omdat deze onderneming met zijn specifieke taak, de organisatie van de logistieke functie van een gehele bedrijfskolom, de verschillende bedrijven 'doorsnijdt' (zie figuur 2.2).

FIGUUR 2.2 De verticale actor

Bedrijfsketen

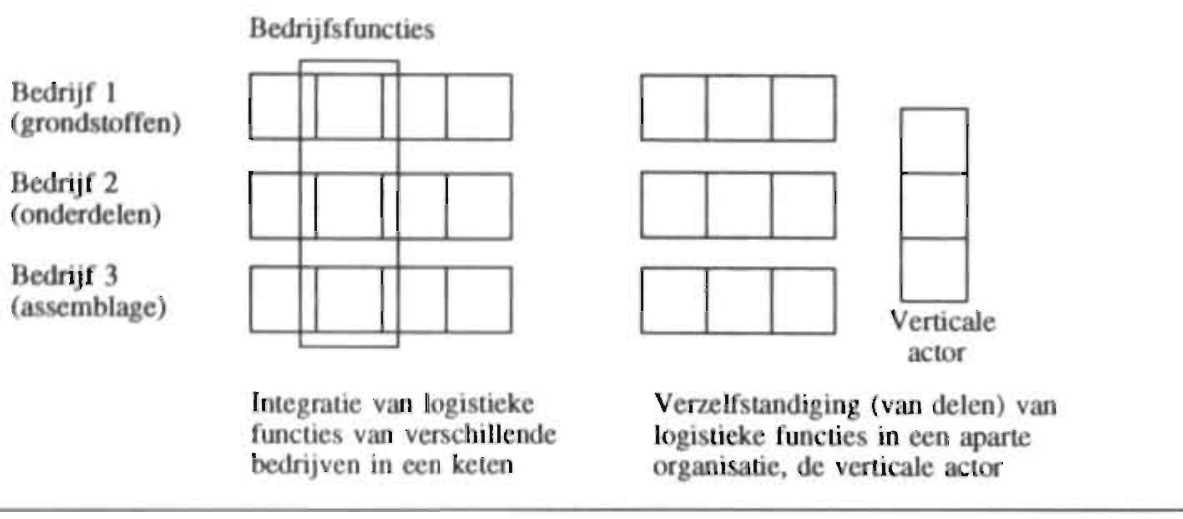

Toepassing van integrale logistiek gaat niet per definitie gepaard met de ontwikkeling van een verticale actor. Wel is de verticale actor te beschouwen als het logisch eindpunt van het integratie-proces van de organisatie van de logistieke functie. Integratic van logistieke activiteiten door deze actor binnen een keten of groep van bedrijven kan door verschillende organisatorische grondstructuren gerealiseerd worden.

Ten eerste kan de verticale actor een dominante onderneming binnen de keten zijn die het door hem gewenste logistieke systeem oplegt aan de andere ketendeelnemers. Feitelijk is dan sprake van verticale integratie. Kubicek (1988) noemt dit het 'Konzernmodell'. De dominante actor zal een logistieke organisatie proberen op te zetten die past binnen zijn eigen structuur. Dit heeft kans van slagen indien deze actor de omvang en daarmee macht en middelen bezit om andere actoren de eisen van het door hem gewenste logistieke systeem op te leggen.

Bedrijfsketens ontstaan in dat geval doordat een dominante onderneming het initiatief hiertoe neemt. Johnston en Lawrence (1988) noemen de McKesson keten. McKesson, een groothandel in farmaceutische en drogisterij artikelen, bouwde met bedrijfsoverstijgende informatietechnologie een netwerk op van producenten, distributeurs, groothandel en consumenten.

Dit sluit aan bij Nagel et al. (1990) die stelien dat toepassing van integrale logistiek feitelijk verticale integratie tot gevolg heeft. In hun case-study van de auto-industrie is de toeleverancier in praktijk niet meer dan een 'produktionstechnischen Betriebseinheit' van de fabrikant. De fabrikant fungeert hier als moederconcern; de juridische zelfstandigheid van toeleveranciers is niet meer dan een formele huls. 
Ten tweede kan de verticale actor door verschillende ketendeelnemers in het leven zijn geroepen. Ketendeelnemers delegeren logistieke activiteiten naar een op zichzelf staande organisatie die verantwoordelijk wordt voor (delen van) de organisatie van de logistieke functie in de keten. In onderling overleg maken ondernemingen afspraken over de wijze waarop goederen- en informatiestromen gecoördineerd worden. Delen van logistieke functies van een groep of keten van bedrijven worden geconcentreerd in één organisatie. Kubicek (1988) duidt dit aan als het 'Verbands-Modell'. 'Ein Betriebsverband zeichnet sich dadurch aus, daß eine gröBere Anzahl von Betrieben bestimmte Aufgaben an einen neuen, von ihnen gemeinsam getragenen Betrieb, den Verbandbetrieb, delegieren' (Kubicek, 1992, 27). Er is hier geen sprake van een dominante onderneming, die tot een beheersing van de keten tracht te komen, maar van een zekere gelijkwaardigheid tussen bedrijven.

De verticale actor kan in het 'Betriebsverband' op twee wijzen ontstaan. Ten eerste kan het een organisatie zijn die door de aanwezige actoren zelf in het leven is geroepen. Een andere mogelijkheid is dat verschillende, in logistieke deelfuncties gespecialiseerde, bedrijven zich ontwikkelen tot een verticale actor voor een specifieke keten. In beide gevallen is sprake van een zelfstandige organisatie die verantwoordelijk is voor (delen van) de organisatie van de logistieke functie in de keten.

Voor industriële bedrijven ziet men met name in de transport-, opslag- en communicatiebedrijven ondernemingen ontstaan die als 'verticale actor' kunnen functioneren. Daarbij kunnen drie vormen onderscheiden worden (Tanja en Smook, 1988).

Ten eerste zijn er de bedrijven die zich bezighouden met de fysieke beweging van goederen, zoals transportbedrijven. Het komt steeds vaker voor dat deze bedrijven in een nauwe samenwerking met verladers de warehousingfunctie met bijbehorende voorraadcontrole en -administratie op zich nemen. Een veel geciteerd voorbeeld van een nauwe samenwerkingsrelatie tussen verlader en vervoerder is de relatie Frans Maas - Rank Xerox. Het door Frans Maas verzorgde transport is geïntegreerd met op just-in-time principes gebaseerde produktieprocessen van Rank Xerox. Voor deze integratie is een speciaal volgsysteem ontwikkeld, het Frans Maas Tracking System. Dit systeem kan op ieder gewenst moment aangeven waar de goederen van de verlader zich bevinden.

De tendens dat vervoerders meer gaan doen dan transport alleen uit zich ook in de schaalvergroting bij deze bedrijven door een integratie met tussenpersonen in het transport zoals expediteurs etc. Dit resulteert in het ontstaan van zgn. multi-modale vervoersondernemingen of 'integrators' die met alle vervoerstechnieken (zee-, lucht-, weg- en spoorvervoer) 'van-huis-tot-huis'-diensten kunnen aanbieden. Bekende voorbeelden van "integrators" zijn Sea-Land en Nedlloyd. Sea-Land beschikt over informatie-systemen waarmee het voor een verlader mogelijk wordt zelf de routes voor zijn lading te kiezen en alle schakels daarbij direct te boeken. Nedlloyd heeft zich ontwikkeld van zeetransporteur naar intermodaal vervoerder. Deze onderneming beschikt over een 'company-wide' communicatie-netwerk waarop Nedlloyd-bedrijven (inclusief agenten en expediteurs) en officiële instanties als douane en havenbedrijven en verladers zijn aangesloten. Door integratie van verschillende activiteiten op gebied van opslag, transport, expeditie en distributie tracht men een totaal dienstverleningspakket aan te bieden. 
Er zijn verladers die naast de fysieke distributie ook een groot gedeelte van de informatiefunctie overdragen aan een gespecialiseerde logistieke dienstverlener. Dit wordt wel aangeduid met Public Warehousing. Deze specialist verzorgt de order-entry, kredietwaardigheidscheck, kwaliteitscontrole, facturering en de verzorging van relevante managementinformatie (Van Goor, 1988; Bowersox, 1990). Deze logistieke dienstverlener combineert goederenstromen van meerdere verladers hetgeen voor de individuele verlader tot een daling van de logistieke kosten leidt. Kosten door investeringen in automatisering, materials handling en transportapparatuur en gespecialiseerd knowhow worden door de logistieke dienstverlener over meerdere gebruikers uitgesmeerd.

Een tweede groep bedrijven die voor industriële bedrijven als de 'verticale actor' kunnen functioneren zijn de zgn. 'transportregelaars'. Deze bedrijven vervullen een intermediaire functie en verzorgen niet zelf het fysieke transport. Tot deze bedrijven behoren expediteurs, stuwadoors en cargadoors etc. Door hun kennis van het transportsysteem en hun bemiddelende functie zijn deze bedrijven geschikt om als 'architect van het transport' van een keten van bedrijven en zo als verticale actor te fungeren (Ganiotten, 1987).

Ten derde zijn er organisaties, instellingen en bedrijven, die zich uitsluitend bezig houden met het verzorgen van de informatie-uitwisseling tussen verschillende bedrijven in een keten. Ook deze groep bedrijven kan als verticale actor fungeren. Er zijn diverse organisaties in het leven geroepen die tot doel hebben handelsprocedures te vereenvoudigen en normen af te spreken om zo tot een brede invoering van bepaalde bedrijfsoverstijgende informatietechnologieën te komen. Voorbeelden zijn EDI-organisaties en beheerders van netwerken.

In dit hoofdstuk is aangegeven dat de ontwikkeling van de organisatie van de logistieke functie als een voortgaand integratie-proces is te beschouwen. Deze integratie heeft tegenwoordig zelfs een bedrijfsoverschrijdend karakter. We hebben deze verandering van relaties tussen bedrijven aangeduid als toepassing van integrale logistiek. Met behulp van concepten uit de theorie van de externe organisatie zullen in hoofdstuk 4 voorwaarden worden aangegeven waaronder het tot een dergelijke verandering van relaties tussen ondernemingen komt. Nog niet is ingegaan op de economische en technologisch ontwikkelingen die toepassing van integrale logistiek hebben mogelijk gemaakt. Dit vormt het thema van het volgende hoofdstuk. 


\section{Toepassing van integrale logistiek als 'match' tussen markt en technologie}

In het voorgaande hoofdstuk is aangegeven dat tegenwoordig de integratie van logistieke activiteiten soms een bedrijfsoverschrijdend karakter krijgt. We hebben dit aangeduid als toepassing van integrale logistiek. In dit hoofdstuk wordt ingegaan op recente economische en technologische ontwikkelingen die toepassing van integrale logistiek vereisen en mogelijk maken. Ten eerste zijn ontwikkelingen op de markt hiervoor verantwoordelijk. Een toenemende concurrentie stelt hogere eisen aan de logistieke organisatie. Ten tweede hebben nieuwe produktie- en informatietechnologieën bijgedragen aan toepassing van integrale logistiek. Daarbij kan worden gedacht aan nieuwe vormen van produktie-automatisering, nieuwe concepten van produktie-beheersing en bedrijfsoverstijgende data-uitwisselingssystemen. Tenslotte wordt aangegeven hoe toepassing van integrale logistiek als 'match' tussen deze trends op de markt en in de technologie fungeert.

Evenals in het vorige hoofdstuk is ook het doel van dit hoofdstuk aan te geven wat in dit onderzoek onder toepassing van integrale logistiek verstaan wordt. We doen dit door achtergronden bij toepassing van integrale logistiek te behandelen. Allereerst worden in $\$ 3.1$ ontwikkelinger omschreven die een toenemende concurrentie tot gevolg hebben gehad. Vervolgens wordt in $\$ 3.2$ ingegaan op ontwikkelingen in de produktietechnologie. In $\$ 3.3$ worden nieuwe bedrijfsoverstijgende data-uitwisselingssystemen behandeld. Paragraaf 3.4 geeft tenslotte aan hoe toepassing van integrale logistiek een 'matching' mogelijk maakt tussen toenemende concurrentie en technologie.

\subsection{Toenemende concurrentie}

De opkomst van Japan speelt een belangrijke rol bij recenie ontwikkelingen op de markt. Concurrentie uit Japan heeft ertoe geleid dat producenten meer nadruk op produkt - en proceskwaliteit zijn gaan leggen. Nadruk hierop in het eigen bedrijf vereist dat ook de toeleveranciers produkten leveren die van hoge kwaliteit zijn. Naast kwaliteit is flexibiliteit een tweede belangrijke concurrentie-factor geworden. Dit heeft ertoe geleid dat de in de jaren ' 70 gebruikelijke diversificatie-strategie in de jaren ' 80 veranderde in een 'back-to-core business' strategie. Gevolg hiervan is geweest dat bedrijven meer gingen uit- en doorbesteden. Een derde factor van belang is het feit dat concurrentie wereldwijd is geworden. Men spreekt wel van een globalisatie van de markt.

\subsubsection{Kwaliteit en customer service}

De hoge kwaliteit van de Japanse produktie heeft ertoe geleid dat kwaliteit een grotere rol is gaan spelen in de internationale concurrentie. Kwaliteit betekent in het algemeen 
het geheel van eigenschappen en kenmerken van een produkt of dienst dat van belang is om te voldoen aan vastgelegde of vanzelfsprekende behoeften van de gebruikers.

De hoge kwaliteit van Japanse produkten hangt nauw samen met het principe van Just-in-Time (JIT). ${ }^{1}$ De doelstelling van JIT is het realiseren van een directe afstemming van alle produktie-handelingen op de marktvraag met uitschakeling van onnodige handelingen en buffers. Door het elimineren van voorraden en buffers moet ieder onderdeel direct goed zijn. JIT vereist dan ook een 'zero-defects' produktie. 'Zero defects' betekent het perfectioneren van produktie- en proceskwaliteit, zodanig dat er geen fouten meer optreden en geen afkeur meer plaats vindt (De Vaan, 1988b). Vain de leverancier wordt vereist dat hij de kwaliteit van zijn leveringen op zodanige wijze garandeert dat ingangscontrole overbodig wordt. JIT heeft, in combinatie met 'zerodefects', tot het fenomeen geleid dat kostenbesparing en kwaliteitsverhoging samen gingen.

Een goed georganiseerde logistiek is ook essentieel om te voldoen aan de toenemende eisen die klanten stellen aan de verleende 'customer service'. Onder customer service vallen die elementen in de relatie met de klant die betrekking hebben op het beschikbaar en geschikt maken van het produkt voor die klant. Het omvat zaken als het uit. voorraad kunnen leveren, de levertijd (de tijd tussen bestelling en aflevering aan de klant), de leverbetrouwbaarheid (het zich houden aan de beloofde levertijden), klachtenbehandeling, spoedleveringen, informatie over de stand van een order etc. Met name de eerste drie genoemde elementen krijgen als onderdeel van de customer service een steeds grotere rol toebedeeld. Dit betekent dat ook hogere eisen aan de logistieke organisatie worden gesteld.

Al een aantal jaren is het in veel industrieẽn úe tendens dat de produktlevenscyclus korter wordt en de variëteit aan produkten toeneemt (Van Goor, 1988; Sharman, 1984). Er is sprake van een toegenomen differentiatie van de vraag. Voor veel individuele ondernemers betekent dit een groei van het aantal marktsegmenten. Dit heeft geleid tot een enorme vergroting van de aan te houden voorraden en tot een sterk vergroot risico van veroudering. Het gevolg hiervan is geweest dat afstand is genomen van de klassieke voorraadgestuurde produktie voor een anonieme markt (de "sellers market') (Tanja en Smook, 1988). Binnen produktiebedrijven wordt ernaar gestreefd minder op voorraad te produceren en meer op bestelling, de zogenaamde ordergestuurde produktie (de 'buyers market'). Dit vereist de mogelijkheid snel en flexibel te reageren op de veranderende marktvraag, hetgeen weer bijzondere eisen stelt aan onder meer de snelheid van produktontwerp, de flexibiliteit van capaciteiten en de produktiebeheersing.

\subsubsection{Uitbesteding en specialisarie als dominante concurrentie-strategie}

Tot voor kort was de hoofdreden voor uitbesteding het ontbreken van kennis of ervaring of omdat een ander het produkt goedkoper kon vervaardigen. Uitbesteden is echter steeds vaker een welbewuste strategie geworden om risico's van de snel wisselende vraag uit de markt te ontlopen en af te wentelen op toeleveranciers. Daarnaast makt uitbesteding het mogelijk dat de onderneming profiteert van cruciale technische

\footnotetext{
${ }^{1}$ Just-in-Time komt als. nicuwe produktiebeheersingsconcept in $\$ 3.2$ aan bod.
} 
bekwaamheden van toeleveranciers die anders slechts moeizaam en tegen hoge kosten verkregen kunnen worden. Uitbesteding maakt zo een betere prestatie mogelijk op die gebieden die men niet tot de kernactiviteiten van het bedrijf rekent.

De tendens van uitbesteding en specialisatie hangt samen met de strategie van "backto-core business'. Hiermee wordt het streven bedoeld zich te concentreren op produktie-activiteiten waar de onderneming goed in is. De 'back-to-core business' strategie vervangt de diversificatie-strategie die in de jaren zeventig populair was. Door middel van opkoop- en fusie-activiteiten breidden grote ondernemingen toen hun produktenpakket uit met als doel het ondernemingsrisico te spreiden. Uitbesteding en specialisatie betekenen dat ketens van produktieprocessen vaker tussen zelfstandige ondernemingen georganiseerd zijn. Dit betekent over het algemeen ook dat de relatie met de toeleverancier intensiever wordt dan vroeger.

Uitbesteding lijkt over de gehele linie een toename van het aantal (toe-)leveranciers te impliceren. Daartegenover staan echter ontwikkelingen die het aantal toeleveranciers doen verminderen. Een intensievere vorm van samenwerking kan slechts met een beperkt aantal leveranciers onderhouden worden. Een ontwikkeling van 'multiple sourcing' (meerdere leveranciers voor hetzelfde produkt) naar 'single' of 'double sourcing' (slechts één of twee leveranciers), is zichtbaar. De overgebleven toeleveranciers van een individuele onderneming worden voor de produktie van complete componenten of subassemblages verantwoordelijk (Hagedoorn, 1990). In dat geval neemt de waarde van de uitbesteding toe, maar het aantal toeleveranciers af. Ook deze toeleveranciers besteden weer een deel van de produktie uit. Dit proces van uit- en doorbesteden heeft een verdere specialisatie van bedrijven tot gevolg.

De intensievere samenwerking tussen bedrijven en hun toeleveranciers door uitbesteding en specialisatie kan ook met een zekere hiërarchisering gepaard gaan. Japan is hier een voorbeeld van. Relaties tussen toeleveranciers en een uitbesteder zijn in Japan langdurig. Er is sprake van kennisuitwisseling en technische ondersteuning. De 'main suppliers' zijn de schakel tussen de grote uitbesteders en het midden- en kleinbedrijf. De 'main suppliers' besteden op hun beurt activiteiten uit aan het midden- en kleinbedrijf, dat op hun beurt ook weer activiteiten uitbesteedt. Het klassiek Japanse model van produktie dat hieruit ontstaat kenmerkt. zich door een hiërarchisch geïntegreerde produktie. Het succes van dit Japanse model heeft tot gevolg gehad dat ook Westerse bedrijven bewuster zijn gaan nadenken over wat uitbesteed en wat zelf geproduceerd zou kunnen worden: de 'make or buy'-beslissing.

\subsubsection{Globalisatie ofwel wereldconcurrentie}

Marktverzadiging in het Westen heeft ertoe geleid dat producenten uit deze landen zich meer op andere delen van de wereld zijn gaan richten. Daarnaast zijn Aziatische landen als Zuid-Korea, Taiwan, Hongkong en Singapore geduchte concurrenten op de wereldmarkt geworden. Deze landen hebben in de jaren '80 een snelle economische groei kunnen realiseren. Deze groei is voornamelijk gebaseerd op een op export gericht beleid (Smeets, 1991). In de jaren '70 waren investeringen in deze landen nog gericht op relatief eenvoudige produktieprocessen en bestond de export voornamelijk uit textiel- en kledingprodukten, lederwaren en schoeisel. Met name Zuid-Korea en Taiwan hebben zich echter ontwikkeld tot producenten van produkten met een hoog technologie-gehalte. Deze ontwikkeling stelt hen in staat op de wereldmarkt te con- 
curreren in geavanceerde produktie en een nauwere aansluiting te vinden bij economieën van de OESO-landen.

Daarnaast dient zich een tweede groep van landen aan: Thailand, Maleisië, Indonesië en de Filippijnen. Ook ziet men een gestage opmars van China. Een land als Taiwan richt zich zoveel mogelijk op de ontwikkeling van geavanceerde kennis-intensieve industrie en heeft de op lage lonen gebaseerde activiteiten verplaatst naar armere landen als China, de Filippijnen en Indonesië. Gevolg van deze ontwikkeling is dat het aandeel van de Aziatische economieën aan de Stille Oceaan in het wereldinkomen kan stijgen van $24 \%$ in 1989 tot $35 \%$ in 2010 en tot meer dan 50\% in 2040 (OECD, 1992).

$\mathrm{Er}$ is sprake van een verdergaande globalisering van de markt. Concurrentie tussen ondernemingen is wereldwijd geworden en inkoop en distributie worden op wereldschaal geregeld. Het belang van informatie- en communicatiesystemen neemt toe omdat het alleen dan mogelijk is tot een goed afgestemd produktie- en transportproces te komen. Informatiesystemen maken een wereldwijde opsplitsing en integratie van produktie-activiteiten mogelijk. Veel produkten worden in principe voor een wereldwijde markt gemaakt door internationale ondernemingen. Deze ondernemingen kunnen alle voordelen van de verschillende markten benutten, zoals specialistische kennis, lage lonen, gunstige wisselkoersen en protectionistische maatregelen.

\subsection{De veranderende produktie-technologie binnen bedrijven}

Om aan de nieuwe marktvereisten te voldoen is flexibilisering van de produktietechnologie een strategische noodzaak. Produktiesystemen worden geconfronteerd met de ainame van de seriegrootte door een grotere produktvariëteit en met de toenemende complexiteit van produkten (Bemelmans et al., 1985; Bertrand et al., 1990; Van Goor, 1988). De eerste trend van dalende seriegroottes dwingt een onderneming tot flexibiliteit in termen van snel omstelbare produktiecapaciteiten met behoud van de efficiencyvoordelen van de massa- en grootseriefabrikage. De tweede trend van de toenemende complexiteit van produkten eist van een onderneming een meer complexe en op het individuele produkt gerichte besturing. Deze veranderingen dwingen bedrijven zich meer en meer te heroriënteren van massa- en grootserieproduktie naar enkelstuks- en kleinseriefabrikage. Deze heroriëntatie stelt andere eisen aan de organisatie van de produktie. De traditionele produktiebeheersing en inrichting van fabrieken en afdelingen veranderen door flexibele produktie-automatisering en nieuwe produktiebeheersingsconcepten die het mogelijk maken aan de veranderende eisen te voldoen.

\subsubsection{Traditionele beheersing en inrichting van produktie}

De traditionele produktiebeheersing, zoals die aan het begin van deze eeuw vorm $\mathrm{kreeg}$, was vooral een voorraadbeheersingssysteem en spitste zich toe op produktiebeheersing van afzonderlijke produktie-eenheden. Zodra een bepaald voorraadniveau een zeker minimum overschreed, werden er produktie-orders gegenereerd voor de voorafgaande produktie-afdeling. Dit kon leiden tot overschrijding van het minimum voorraadniveau binnen het voorafgaande voorraadpunt en dus tot nieuwe produktieorders voor de daaraan voorafgaande produktie-eenheid. 
In een traditionele fabriek is elk voorraadpunt autonoom: het plaatsen van bestellingen kan door elk voorraadpunt zelfstandig worden gedaan. Ook is elke produktie-afdeling in principe autonoom: de prioriteit die een order krijgt wordt lokaal bepaald. Het handelen van een functionaris op een afdeling is niet gericht op de globale optimalisatie van de logistiek voor een bedrijf of keten als geheel. Een dergelijke beheersing van de goederenstroom door autonome schakels noemt men wel een 'ontkoppelde' beheersing (Wortmann, 1992).

\section{FIGUUR 3.1 Traditionele beheersing}

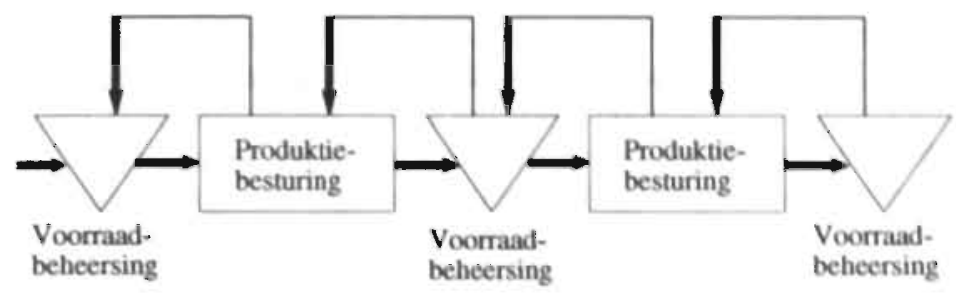

Bron: Wortmann (1992).

Aan deze klassieke vorm van produktiebeheersing in een keten van voorraadpunten tussen produktie-eenheden kleven een aantal nadelen die terug te voeren zijn op de afwezigheid van een geïntegreerde beheersing. De traditionele ontkoppelde beheersing leidt tot sterk wisselende doorlooptijden, hoge veiligheidsvoorraden en lange wachtrijen. Met name bij sterk wisselende vraag leidt deze wijze van beheersing tot de noodzaak hoge voorraden aan te houden en het ontstaan van zgn. keteneffecten. Beslissers in de keten hebben slechts zicht op een beperkt deel van de voorraden in de keten. Gevolg hiervan is dat variaties in de vraag op de markt tot overreacties in de voorafgaande schakels van de keten kunnen leiden. Men spreekt ook wel van opslingereffecten.

De inrichting van fabrieken munt traditioneel dan ook niet uit door coördinatie tussen opeenvolgende afdelingen. De meeste fabrieken zijn zodanig ontworpen, dat men met aanzienlijke seriegroottes werkt, terwijl in verschillende afdelingen ook nog eens verschillende seriegroottes worden gehanteerd. Een groot deel van de doorlooptijd gaat verloren met wachttijd.

Traditioneel kunnen fabrieken op twee manieren worden ingericht: als 'jobshop' en als 'flowshop'. Flexibiliteit wordt gerealiseerd door produktie-afdelingen te creëren die niet gericht zijn op grote aantallen standạardprodukten, maar op de fabrikage van klantspecifieke produkten in kleine aantallen, de 'jobshop'. Men kan elk gewenst produkt maken dat binnen de beschikbare capaciteit past. In jobshops staan gelijksoortige capaciteiten bij elkaar. Het is echter moeilijk om werk er snel doorheen te loodsen. Nadeel is dat men niet kan profiteren van de continuïteit en de schaaleffecten van massa- en grootseriefabrikage zoals bij de flowshops. In flowshops zijn de capaciteiten in een lijn geplaatst zodat werk erdoor kan stromen zonder wachttijden binnen de lijn. Traditionele flowshops zijn echter niet ingericht op snel omschakelen of veranderen, dat wil zeggen ze zijn wel snel maar niet flexibel. 
Problemen van de traditionele produktiebeheersing en inrichting kan men tegemoet komen door flexibele produktie-automatisering. In bepaalde gevallen kan automatisering ertoe leiden dat de produktie naar type (soort produkt) en volume (aantal produkten) met eenzelfde mate van efficiency als bij massa-produktie van identieke produkten kan plaats vinden. Daarnaast zijn er produktiebeheersingsconcepten die breken met de 'ontkoppelde' beheersing.

\subsubsection{De automatisering van de produktie}

In de produktie-sfeer is de oprukkende produktie-automatisering een dominante ontwikkeling. Produktie-automatisering is vanaf de jaren vijftig gebaseerd op numeriek bestuurde machines (Numerical Control Machines) (Janssen en Nauta, 1986). In de loop van de tijd is het aantal bewerkingen, dat een NC-machine kan uitvoeren, toegenomen. Het opnemen van computerbesturing in de NC-machines (Computer Numerical Control Machines) betekende een belangrijke stap voorwaarts. CNC-machines maken het onder bepaalde voorwaarden eenvoudiger in snel tempo verschillende bewerkingen uit te voeren. Door variabele programmering zijn snel verschillende bewerkingsvolgorden mogelijk. Omstellen staat gelijk met het starten van een nieuwe programma. Gevolg is een snellere doorlooptijd van produktie en het vermogen om vele produktie-varianten, aangepast aan de wensen van afnemers, te produceren. Daarnaast worden doorlooptijden ook korter omdat er een geringere noodzaak bestaat tot het opsparen van orders totdat produktie van grote series mogelijk is.

Technologieën als CAD/CAM, CAT en CAL zijn vormen van deze flexibele automatisering die een opzet van flexibele fabrikage systemen mogelijk maken. CAD/CAM richt zich op een integratie van ontwerp en fabrikage. Computer Aided Design (CAD) heeft betrekking op het technisch ontwerpen vañ objecten, prodlukten en fabrikage-processen met behulp van de computer. CAD maakt het mogelijk snel nieuwe produkten te ontwerpen. Indien de technische en administratieve gegevens van een ontwerp direct worden omgezet in gecodeerde instructies voor numeriek bestuurde bewerkingsmachines spreekt men van Computer Aided Manufacturing (CAM). Een verdere reductie vaii doorlooptijüen is mogelijk door het inschakelen vañ piogramimeerbare machines bij het inspecteren en testen van produktie (CAT: Computer Aided Testing) en het transporteien van ondeidelen en halffabrikaten (CAL: Computer Aided Logistics). Produktie-automatisering kan tot een onderlinge afstemming van alle produktie-activiteiten in de besturing leiden. In dat geval is er sprake van Computer Integrated Manufacturing (CIM).

Past men deze vormen van produktie-automatisering toe met als doel snel produktiecapaciteiten om te stellen voor andere produkten of produktfamilies, dan spreekt men wel van Fiexible Manufacturing Systems (FMS). Meestal heeft men het dan over een beperkt aantal bewerkingsmachines. Het inzetten van programmeerbare robots vereenvoudigt en versnelt het omstellen van de produktie, waardoor vroegere omstelproblemen verdwijnen. FMS maakt daarmee vergaande flexibilisering van primaire produktie-processen mogelijk. Kenmerkend is dat deze flexibiliteit naar type (soort produkt) en volume (aantal produkten) met eenzelfde mate van efficiency als bij massaproduktie van identieke produkten kan plaats vinden. Door FMS wordt het voor bedrijven mogelijk kleine series van verschillende produkten op economische wijze te produceren. Een verschuiving naar een klantgerichte produktie is hierdoor mogelijk. 
Naast produktie-automatisering is ook het modulariseren van de produktstructuur een middel dat tot de flexibiliteit van produktontwerp en -ontwikkeling bijdraagt (Mennega, 1987). Modulariteit is van belang waar produkten met een aantal varianten kunnen worden geleverd of waar sprake is produktfamilies. In dat geval kent het modulair opgebouwde produkt algemene modules, geldig voor elke variant en specifieke modules per variant. Een modulaire produktstructuur verhoogt de voorspelbaarheid van de vraag van de modules, daar deze op het algemene deel kan worden gebaseerd. In combinatie met $\mathrm{CAD}$ is het mogelijk snel klantspecifieke produkten te ontwerpen, uitgaande van een beperkt aantal standaard samenstellingen, en deze automatisch te vertalen in fabrikagetermen (fabrikagespecifikaties, routing, machine-instelling etc.). Hierdoor kan de doorlooptijd sterk bekort worden.

\subsubsection{Nieuwe concepten van produktiebeheersing}

Ter ondersteuning van een integrale benadering zijn de afgelopen decennia besturingsconcepten beschikbaar gekomen die tot veel verbeteringen in de produktiebeheersing en het voorraadbeheer binnen en tussen ondernemingen hebben geleid (Aggarwal, 1985; Bemelmans et al., 1985; Bertrand et al., 1990; Van Goor, 1988; De Vaan 1988b). De drie belangrijkste recente concepten zijn MRP (Material Requirements Planning en Manufacturing Resources Planning), JIT (Just-in-Time) en OPT (Optimized Production Technology).

\section{Materials Requirements Planning en Manufacturing Resources Planning}

MRP tracht de problemen met ontkoppelde beheersing op te vangen door binnen fabrieken principes van integrale beheersing toe te passen. Dit betekent niet dat de locale autonomie volledig verdwijnt, wel dat er zicht ontstaat op de goederenstroom als geheel. De eerste poging om tot integrale beheersing in een fabrieksomgeving te komen staat bekend als Materials Requirements Planning (MRP I). Deze benadering gaat uit van de verkoop-voorspellingen voor de eindprodukten in de fabriek, en berekent op die basis de gewenste goederenstroom in de hele fabriek (Wortmann, 1992). MRP-I stuurt de verschillende produktie-stadia vanuit de vraag naar eindprodukten en vormt een informatie-systeem, waarmee over de gehele keten heen gekeken kan worden. Voorspellingsinformatie wordt zonder tijdsvertraging aan iedere actor in de keten doorgegeven.

FIGUUR 3.2 Integrale beheersing door MRP-I

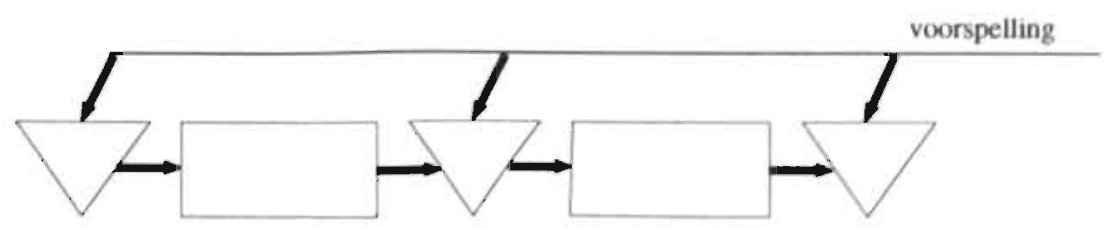

Bron: Wortmann (1992). 
Centraal idee bij MRP is dat een in de tijd gefaseerde behoefte aan eindprodukten vertaald wordt naar een (eerder) in de tijd gefaseerde behoefte aan haiffabrikaten en grondstoffen. MRP-II maakt het essentiële onderscheid tussen de onafhankelijke en de afhankelijke vraag. De onafhankelijke vraag is de vraag van de markt naar eindprodukten en reserve-onderdelen. Deze onafhankelijke marktvraag wordt vertaald in een afhankelijke vraag naar halffabrikaten en grond- en hulpstoffen. Terwijl de onafhankelijke vraag gebaseerd is op voorspellingen wordt de afhankelijke vraag berekend. MRP-I kan via een deterministische boekhouding van voorraden in de toekomst een berekening leveren van de gedetailleerde behoeften per periode per fabrikage proces (Brevé, 1988). Daarbij vereist MRP-I een strikte discipline van het personeel wat betreft invoer van data.

De MRP-I benadering heeft een aantal nadelen. Bij MRP-I wordt uitgegaan van onbeperkte capaciteiten. In de praktijk is hiervan geen sprake. Daarnaast gaat MRP-I uit van vraagvoorspellingen naar eindprodukten. Deze verkoopvoorspellingen kunnen zich echter voortdurend wijzigen, zodat de geplande goederenstromen ook steeds wijzigen (Bemelmans et al, 1985).

In het begin van de jaren tachtig is daarom een systeem ontwikkeld dat de tekorten van MRP-I ondervangt: Manufacturing Resources Planning (MRP-II). In dit concept wordt de toekomstige goederenstroom niet rechtstreeks afgeleid uit de voorspelling, maar uit een afgesproken hoofd-produktieprogramma, het Master Production Schedule (MPS). Dit MPS kan stabiliteit geven en zo worden opgesteld, dat de capaciteiten beschikbaar zijn. Naast capaciteiten houdt het management bij deze beslissing rekening met de gewenste flexibiliteit, beschikbare grondstoffen en arbeid etc. (Bemelmans et al., 1985; Brevé, 1988; Bertrand et al,, 1990; Monhemius en Dürlinger, 1989).

FIGUUR 3.3 Integrale beheersing dor)r MRP-II

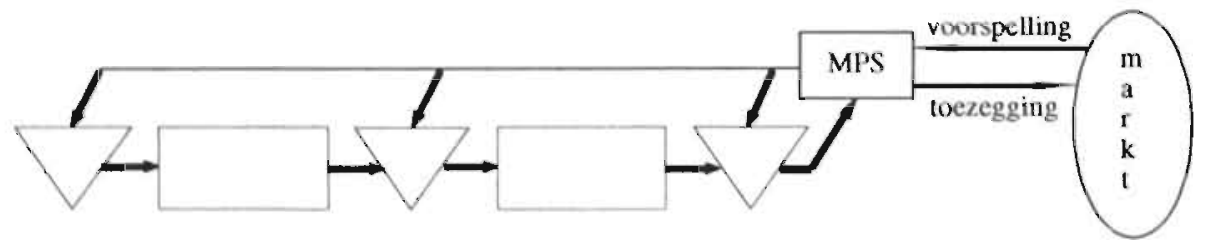

Bron: Wortmann (1992):

Ook in het distributie-traject kunnen MRP principes worden toegepast (Van Goor et al., 1989). Men spreekt dan wel van Distribution Requirements Planning (DRP-I) en Distribution Resources Planning (DRP-II). DRP.I is de functie die zich bezighoudt met het bepalen van de in-de-tijd gefaseerde behoefte aan herbevoorrading in distributiepunten. De som van de behoeften over de verschillende distributiepunten resulteert in een in-de-tijd gefaseerde behoefte bij de uiteindelijke leverancier. DRP-I heeft een beter beheer van voorraden in een distributieketen ten doel. Ook hier speelt het onderscheid tussen afhankelijke en onafhankelijke vraag een belangrijke rol. DRP-I behandelt de vraag tussen de verschillende schakels in een distributieketen echter als 
afhankelijke vraag. Hierdoor worden opslingereffecten en ongebalanceerde voorraden voorkomen. DRP-I houdt geen rekening met beschikbare capaciteiten in transport, magazijnen en fabrieken. DRP-II vormt hierop een aanvulling en tracht tot een optimale aanwending van de beschikbare capaciteiten op het gebied. van transport, magazijnen en voorraden te komen.

\section{Just-in-Time}

In toenemende mate wordt ingezien, dat men fabrieken die aan elkaar toeleveren ook moet inrichten op een wijze die de onderlinge afstemming en doorstroming bevordert. Dit staat wel bekend als het Just-in-Time (JIT) concept. Belangrijkste punten hierbij worden gevormd door het streven naar kleine series, het elimineren van overbodige handelingen, en het verkorten van de bestelprocedures. De JIT-benadering begint met het stroomlijnen van het primaire proces en is voornamelijk een aanpak die tot eenvoudige logistieke basisstructuren moet leiden. JIT verwerpt de gedachtengang dat voorraden en onderhanden werk nodig zijn als buffers tegen verstoringen en fluctuaties. Het is bij JIT juist zo dat voorraden en onderhanden werk worden weggehaald om storingen beter voelbaar te maken. Problemen worden daardoor beter zichtbaar en er is een mogelijkheid om de oorzaken van onregelmatigheden te elimineren. Zodoende kan de logistieke prestatie verbeterd worden.

In traditionele flowshops is het gebruikelijk om met grote series te werken. Bij grote series ontstaan voorraden door wachtrijen en lange doorlooptijden. Verkorting van omsteltijden kunnen wachtrijen, doorlooptijden en daarmee voorraden verkleinen. Bij invoering van JIT wordt dan ook gestreefd naar een reductie van de omsteltijden. In veel produktiebedrijven werd tot voor kort aan deze reductie niet zoveel aandacht besteed. De nadruk lag meer op de verhoging van de output van draaiende produktiemachines. Bij korte omsteltijden leiden kleinere produktieseries, in combinatie met een verhoogde omstelfrequentie, tot verkorting van de doorlooptijden en verlaging van de voorraden.

Voor een JIT-aanpak is naast het verkorten van omsteltijden ook een betere kwaliteitsbeheersing (Total Quality Control) en betrokkenheid en flexibiliteit van het personeel nodig (Aggarwal, 1985). JIT vereist strikte discipline en nauwe samenwerking tussen management en personeel. Bij de JIT-aanpak valt de nadruk in de eerste plaats niet op informatiesystemen. De aansluiting van produktiebeheersing op allerlei administratieve systemen, die bij MRP zo'n grote rol speelt, blijft bij JIT buiten beschouwing.

De opkomst van JIT is nauw verweven met het succes van Japanse produktiebedrijven en het door Toyota ontwikkelde KANBAN-systeem. Bij dit systeem worden de opeenvolgende produktiefasen beheerst via een pull-systeem. In plaats van vooraf vastgestelde produktie afspraken op van tevoren vastgestelde tijdstippen, wordt in dit systeem pas geproduceerd of aangekocht nadat opdrachten zijn binnengekomen. Opdrachten voor de produktie van eindprodukten leiden tot de vraag naar de beschikbaarheid van halffabrikaten. Dit heeft weer een vraag naar grond- en hulpstoffen tot gevolg. De materiaal-aanvoer is feedback geregeld: alle materialen die verbruikt zijn bij assemblage worden aangevuld. Zo wordt in het KANBAN-systeem de hele 'lijn' getrokken door de produktie van eindprodukten. 
Terwijl JIT in de oorspronkelijk betekenis nauw verbonden was met het door Toyota ontwikkelde produktie-systeem wordt de term tegenwoordig in ruimere zin gebruikt (Bertrand et al., 1990). JIT heeft dan betrekking op het precies op tijd produceren en afleveren in de juist hoeveelheid op de juiste plaats. In die betekenis zijn ook MRPsystemen, als ze goed functioneren, onderdeel van de JIT-benadering.

\section{Optimized Production Technology als combinatie van MRP en JIT}

In de oorspronkelijke MRP-benadering wordt materiaall naar de werkvloer gestuurd op basis van planning: men spreekt dan van een push-benadering. Het MRP-stelsel genereert voor ieder produktiebewerking precies op tijd de juiste produktie-opdrachten. Te beginnen bij de verwerving van benodigde grondstoffen stuurt MRP-II de order als het ware door het produktie-proces heen. Daarentegen is het KANBAN-systeem een aanvulsysteem dat uitgaat van een gedetailleerd plan op eindproduktniveau. Te beginnen bij de laatste bewerking in het produktie-proces initieert het KANBAN-systeem de produktie van de voorliggende bewerkingen. Tegenwoordig treft men alleriei mengvormen aan: in MRP-pakketten wordt materiaaluitgifte via de pull-benadering ondersteund, en in JIT-bedrijven komt men materiaalaanvoer via push-principes tegen.

Naast JIT en MRP is een derde concept van produktiebeheersing bekend onder de naam Optimized Production 'Technology (OPT). OPT is eind jaren '70 als een softwarepakket op de markt geïntroduceerd dat bedoeld was het management te helpen bij het bepalen van de juiste volgorde waarin bewerkingen voor de orders op machines in het bedrijf moeten worden uitgevoerd. De OPT-filosofie is een bepaalde manier van denken ten aanzien van het gebruik van capaciteiten in het bedrijf (Goldratt en Fox, 1987). Deze capaciteiten worden binnen deze filosofie gescheiden in bottle-necks en niet bottle-necks en ais volgt gedefinieerd: een bottle-neck is die capaciteitsbron waarvan de capaciteit kleiner of gelijk is aan de capaciteitsbehoefte vanuit de marktvraag. Een niet-bottleneck heeft altijd een zekere overcapaciteit.

Voor elke bottle-neck wordt een gedetailleerd produktie-schema gemaakt, waarbij omsteltijden zoveel mogelijk worden vermeden. Voor elke niet-bottle-nek capaciteit die aan de bottleneck vooraf gaat, wordt met een procedure, die veel op MRP lijkt, een plan afgeleid. Daarbij is OPT niet geïnteresseerd in het minimaliseren van omsteltijd, omdat een verloren uur op zulk een capaciteit relatief weinig kost. Het produktieschema op de bottle-neck fungeert als 'vraag' voor de andere capaciteiten. Voor de capaciteiten die na de bottle-neck komen, wordt de planning bepaald door het aanbod vanuit die bottle-neck. Daar geldt opnieuw dat kleine series geen bezwaar zijn, ook al zijn de omsteluren aanzienlijk. Op deze wijze creëert OPT een gedetailleerd plan voor de gehele fabriek.

Schematisch gezegd tracht OPT de goede punten van MRP-II en JIT te combineren. JIT en OPT vertonen grote overeenkomsten als het gaat om de reductie van omsteltijden, verkleining van de seriegroottes en verkorting van de doorlooptijden. OPT gaat er evenwel genuanceerder mee om omdat het een verschillende aanpak kent voor bottleneck- en niet-bottleneck-capaciteiten. OPT vertoont op andere punten een gelijkenis met MRP. Voor de besturing van het produktie-proces wordt bij OPT voor de nietbottlenecks, die aan de bottle-neck vooraf gaan, een plan afgeleid met een procedure die veel op MRP lijkt. Met MRP heeft ook OPT een groot vertrouwen in informatiesystemen gemeen (Brevé, 1988). 


\subsubsection{Informatietechnologie en integratie}

Hoge niveaus van leverbetrouwbaarheid en leverprestaties vragen om bedrijfsoverstijgende sturing, organisatie en beheersing van logistieke activiteiten. Beschikking over informatie is een essentiële voorwaarde om tot een integrale beheersing van logistieke activiteiten te komen. Voor het zo goed mogelijk op elkaar aansluiten van de verschillende logistieke deelsystemen in de keten is actuele informatie noodzakelijk. Op basis hiervan kan tijdig worden bijgestuurd in geval van onregelmatigheden. Informatiesystemen spelen hierbij een belangrijke rol. Een algemene definitie van een informatiesysteem luidt als volgt: 'het geheel van mensen, machines en activiteiten gericht op het verzamelen en verwerken van gegevens op zodanige wijze dat kan worden voorzien in de informatiebehoeften van een organisatie alsmede in die van externe belanghebbenden of belangstellenden' (Jans, 1987, 59).

In de jaren ' 80 hebben in het bedrijfsleven nieuwe informatiesystemen hun intrede gedaan. Deze technologieën hebben grote invloed op de organisatie van de logistieke functie vanwege de mogelijkheid tot een bedrijfsoverstijgende communicatie van computer tot computer te komen. Deelsystemen van de logistieke organisatie binnen verschillende bedrijven kunnen direct aan elkaar gekoppeld worden zonder menselijk ingrijpen. Technisch ontstaat daarmee binnen een keten van bedrijven de mogelijkheid voor toepassing van integrale logistiek.

In een bedrijfsketen zijn verschillende soorten bedrijfsoverstijgende data-uitwisselingssystemen aan te wijzen (Groenenboom, 1992).

Ten eerste kan een dergelijk informatiesysteem toegang verschaffen tot bepaalde gegevensverzamelingen en van daaruit data transporteren naar de eigen organisatie. Het interactief opvragen van gegevens d.m.v. zgn. 'Videotex' systemen is hiervan een voorbeeld. Een ander voorbeeld is het op afstand inzien van ontwerptekeningen en afleverschema's. Het overgebrachte bericht is ongestructureerd in die zin dat het ontvangende informatiesysteem het bericht alleen kan ontvangen en weergeven maar nog niet interpreteren (dat moet de gebruiker doen).

Ten tweede kan een bedrijfsoverstijgend data-uitwisselingssysteem gebruikt worden voor berichten-uitwisseling tussen organisaties. Het betreft hier systemen voor electronische post en electronische berichtenuitwisseling. Hierbij worden gestructureerde berichten uitgewisseld, hetgeen wil zeggen dat de mogelijkheid bestaat dat het ontvangende systeem het bericht kan interpreteren en verwerken. Systemen die vallen onder Electronic Data Interchange (EDI) en Product Data Interchange (PDI) zijn hier voorbeelden van. Het onderscheid tussen EDI en PDI ligt in de aard van de gegevens die uitgewisseld worden. Bij uitwisseling van administratieve gegevens zoals orders, offertes, facturen e.d. spreekt men van EDI. Bij uitwisseling van produktiegegevens en produktspecificaties zoals tekeningen en berekeningen spreekt men van PDI.

Videotex, EDI en PDI maken het mogelijk dat ondernemingen, die economisch en juridisch zelfstandig zijn, hun informatie- en communicatiesystemen op elkaar afstemmen. Deze systemen kunnen een belangrijk hulpmiddel vormen ten behoeve van Value Added Partnership: een verzameling juridisch onafhankelijke bedrijven, die nauw 
samenwerken, gericht op het optimaliseren van de goederenstroom langs de gehele waardeketen van grondstof tot klant (Johnston en Lawrence, 1988). Scott Morton (1991) geeft aan dat nieuwe informatietechnologie op vier verschillende wijzen tot een integratie van functies leidt.

Ten eerste is sprake van integratie 'within the value chain'. Functies als ontwerp en fabrikage worden binnen een onderneming door informatietechnologie direct aan elkaar verbonden. Een tweede vorm van integratie is 'end-to-end links of the value chains between organizations': nieuwe informatietechnologie leidt ertoe dat afdelingen van verschillende ondernemingen direct met elkaar verbonden kunnen worden. Nieuwe informatietechnologie makt ten derde mogelijk dat bepaalde taken of processtappen van een bedrijf via uitbesteding geheel worden uitgevoerd door derden. Een onderneming kan zijn toeleverancier vragen een nieuwe component te ontwerpen. Computer Aided Design maakt het mogelijk dat ontwerpers van de toeleverancier en de afnemer nauw met elkaar kunnen samenwerken. Een vierde vorm van integratie door informatietechnologie is het ontstaan van zgn. electronische markten. Voorbeeld zijn reisagenten die electronisch en automatisch plaatsen kunnen reserveren bij bus- en vliegtuigmaatschappijen.

\subsubsection{Videolex}

Videotex is een netwerkdienst waarbij de gegevensopslag en het interactief opvragen van gegevens op relatief eenvoudige wijze kunnen geschieden. De interactieve systemen - ook bekend onder de oudere naam viewdata - werken veelal via het telefoonnet en worden bediend door mensen. Omdat de gebruiker van dergelijke systemen rechtstreeks interactief kan werken, bieden deze systemen meer mogelijkheden dan alleen het opvragen van informatie met behu'p van $\mathrm{zgn}$. niet-interactieve systemen. Bestellen van artikelen, versturen van berichten naar andere gebruikers behoren tot die mogelijkheden. Bij niet-interactieve Videotex is de gebruiker niet bekend bij het systeem. De gebruiker vraagt informatie op door aan te geven welke informatie hij wil zien uit het totaalbestitind.

Videotex is een geschikt medium voor het raadplegen en uitwisselen van informatie die niet direct intern in een geformaliseerd informatiesysteem verder wordt verwerkt. Videotex is vooral interessant voor branches met een grote behoefte aan actuele, snelle en complete informatie omtrent produkten, markten en transacties. Videotex wordt bijvoorbeeld in de praktijk gebruikt voor communicatie tussen zelfstandige detaillisten en groothandelaren. Videotex biedt voor de gebruiker op eenvoudige wijze een uniforme toegang tot computers. Aan gebruikers kunnen op deze wijze de volgende functies worden aangeboden:

- databank functies: informatictoeleveranciers voeren vanuit hun systemen informatie in voor de zoekende gebruikers;

- hestelfuncties: met behulp van Videotex kunnen klanten bestellingen doen;

- electronic mail: berichten versturen middels Videotex, individuen communiceren met elkaar via informatienetwerken;

- telesoftware: distributie van software middels Videotex.

Vanuit diverse computertoepassingen zijn in de loop der tijd omvangrijke informaticbestanden opgebouwd. Videotex maakt het voor omvangrijke gebruikersgroepen met een grote onderlinge verscheidenheid mogelijk informatie te betrekken uit deze om. 
vangrijke bestanden (Ten Hove in: Ruiten, 1986). Het bereiken van omvangrijke gebruikersgroepen is mogelijk omdat toepassing van videotex geen uitgebreide investeringen vereist. Men spreekt van openbare Videotexsystemen wanneer de exploitant van een dergelijk systeem geen selectie van gebruikers en/of informatieaanbieders toepast. Bij besloten Videotex bepaalt de aanbieder van de informatie of de exploitant van het systeem welke gebruikers toegang hebben.

\subsubsection{Electronic Data Interchange}

Nieuwe samenwerkingsvormen tussen ondernemingen vereisen een goed afgestemde communicatie hetgeen nieuwe toepassingen op communicatiegebied vergt. EDI is één van die toepassingen (Bemelmans en Kreuwels, 1990). Een vrij algemeen geaccepteerde definitie van EDI luidt als volgt: 'EDI is de elektronische uitwisseling van gestructureerde en genormeerde gegevens tussen computers van bij (handels)transacties betrokken partijen' (Hofman, 1989, 13).'Gestructureerd' houdt in, dat het bericht is opgebouwd uit een gedefinieerde verzameling basis-elementen (data segmenten), die als bouwstenen kunnen worden gebruikt voor het samenstellen van een bericht. Een computer kan deze basiselementen herkennen en verwerken. 'Genormeerd' betekent, dat er afspraken zijn gemaakt over de structuur van een bericht. Als deze afspraken bekend zijn bij een computerprogramma, kan dit de binnenkomende berichten interpreteren en zelfstandig verwerken.

Er is bij EDI sprake van communicatie tussen computers. De computersystemen of programma's waartussen wordt gecommuniceerd hoeven niet gelijksoortige te zijn. Hierdoor houdt een bedrijf een bepaalde vrijheid bij het uitvoeren van eigen automatiseringsplannen. De uit te wisselen berichten worden door geautomatiseerde toepassingen geproduceerd en vertaald in standaardberichten en naar andere computers gestuurd, die ontvangen berichten opnieuw vertalen en verwerken en op grond hiervan eventuele vervolgacties opstarten. De betrokken partijen zijn in veel gevallen juridisch zelfstandige organisaties. Uitwisseling van berichten binnen één bedrijf word t meestal niet tot EDI gerekend, hoewel deze veel op externe communicatie kan lijken. De uitgewisselde berichten tussen bedrijven hebben vaak betrekking op order- en goederenstromen. Voorbeelden zijn orders, lever-, transport- en beladingsschema's, facturen, handelsdocumenten etc.

Datacommunicatie en gegevens- en berichtenuitwisseling, die tussen computers van bedrijven worden uitgewisseld, zijn bij EDI gestructureerd en genormeerd volgens bepaalde afspraken en normen. Op het gebied van datacommunicatie is het ISO-OSI (International Standards Organisation - Open Systems Interconnection) model de algemeen geldende standaard. Doel van deze standaard is datacommunicatie mogelijk te maken, onafhankelijk van het soort en type hardware. Het ISO-OSI model wordt door een groot aantal computerfabrikanten gevolgd. Het overzenden van bits van de ene naar de andere partner volgens de protocollen van het ISO-OSI model, is echter niet voldoende voor betekenisvolle communicatie.

Omdat bij EDI het lezen en interpreteren door de computer wordt overgenomen moeten vooraf tussen afzender en geadresseerde eenduidige afspraken gemaakt worden. Dit zijn afspraken over de syntax, de vorm van berichten, en de semantiek, de betekenis van berichten. Daarnaast stelt Kubicek. (1992) dat ook over de 'Pragmatik' van berichten afspraken gemaakt moeten worden. Onder 'Pragmatik' verstaat Kubicek 
'die Erwartung ... welche Aktivitäten eine übermittelte Nachricht beim Empfänger ausiösen wird und mit welchen Rückmeldungen zu rechnen ist' (ibid, 9). Een voorbeeld van een internationale standaard is EDIFACT (Electronic Data Interchange for Administration Commerce and Transport). Bij deze wereldwijde standaard bestaat hoofdzakelijk overeenstemming over de syntax van berichten. Afspraken over semantiek en pragmatiek zijn land- en branche-gebonden.

Er zijn diverse organisaties die tot doel hebben handelsprocedures te vereenvoudigen en normen af te spreken om zo tot invoering van EDI te komen. Deze afspraken kunnen leiden tot een open systeem, een 'gemeenschapssysteem' of een gesloten systeem (Ribbers, 1991).

In een 'open systeem' kan in beginsel met iedereen worden gecommuniceerd, doordat wereldwijde, algemeen aanvaarde standaards zijn afgesproken, waaraan een ieder zich conformeert. Dit systeem heeft de vorm van een electronische markt. In de praktijk komen dergelijke systemen niet voor. Binnen veel bedrijfstakken worden standaarden afgesproken die ertoe leiden dat men met behulp van een specifiek systeem binnen (een deel van) de bedrijfstak met elkaar kan communiceren. Er ontstaat hierdoor een veelheid van zgn. 'gemeenschapssystemen', die niet onderling communiceren. Hoewel op termijn 'interfaces' worden gebouwd, staat deze integratie nog in de kinderschoenen. Daarnaast ontstaan gesloten systemen, systemen met behulp waarvan slechts enkele actoren electronisch kunnen communiceren. Een dergelijk systeem kan ontstaan doordat actoren bilaterale overeenkomsten sluiten, waarbij gekozen wordt voor eigen standaards. Daarnaast kan een gesloten systeem ontstaan doordat een machtige onderneming in de markt zijn toeleveranciers of afnemers verplicht zijn standaarden in te voeren.

Tot 1985 bestonden er wereldwijd gezien twee standaarden voor EDI, te weten GTDI (General Trade Data Interchange rules) van de Economic Commission of Europe (ECE) van de VN en een standaard van het American National Standards Institute (ANSI). Begin 1985 heeft overleg hierover plaatsgevonden hetgeen tot de EDIFACT standaard geleid heeft. EDIFACT is een organisatie van de Verenigde Naties en opgedeeld in een aantal regio's waarvan West- en Oost-Europa er twee zijn. EDIFACT moet op termijn zorg dragen voor de mondiale afstemming van de berichtenontwikkeling. Momenteel zijn reeds een aantal berichten op international niveau gestandaardiseerd en goedgekeurd voor operationeel gebruik.

Toepassing van EDI kent diverse voordelen. Een eerste voordeel is de toegenomen snelheid. EDI maakt snel transport en een snelle automatische verwerking van grote hoeveelheden gegevens mogelijk. Daardoor is een versnelling in de verschillende bedrijfsprocessen mogelijk omdat goederen niet meer hoeven te 'wachten' op de bijbehorende informatie. De informatiestroom kan zelfs vooruit lopen op de goederenstroom. Ten tweede is door EDI informatie 24 uur per dag wereldwijd beschikbaar. EDI doet ten derde de betrouwbaarheid, voorspelbaarheid en controleerbaarheid toenennen. In principe hoeven berichten maar eenmaal ingevoerd te worden hetgeen tot een reductie van fouten leidt. Eenmalige invoering en reductie van fouten levert weer kostenbesparing op. 
Tussen Videotex en EDI zijn een aantal verschillen op te merken. Videotex is interactief en vereist een menselijke interpretatie van de binnengekomen informatie. Videotex is niet geïntegreerd met interne informatiesystemen terwijl EDI zich daar wel op richt.

\subsubsection{Product Data Interchange}

Product Data Interchange, de interne en externe uitwisseling van produkt- en produktiegegevens, is een logisch gevolg op EDI dat met name gericht is op de uitwisseling en standaardisatie van handelstransacties. Bij PDI wordt door middel van genormeerde en gestructuurde gegevens in berichten de vorm, samenstelling en bouw van een produkt beschreven. PDI heeft ten doel tot een koppeling van CAD-systemen onderling en het koppelen van $\mathrm{CAD}$ met CAM-systemen te komen. Hier wordt ingegaan op de ontwikkeling van internationale standaarden voor de uitwisseling van grafische en niet-grafische informatie. De standaardisatie van PDI bevindt zich nog in een beginstadium.

Afspraken over standaarden voor informatie-uitwisseling worden bij PDi vooraf gegaan door afspraken over de wijze waarop de structuur van een produkt vastgelegd moet worden. De logische structurering van een produkt vormt de basis voor het gegevensof produktmodel. Dit model is een computermodel dat een aantal gegevens bevat. In essentie is het een volledige, consistente en ondubbelzinnige beschrijving van een produkt of project. Het produkt- of gegevensmodel bevat informatie over de structuur van een produkt, materialen en kwaliteitsnormen, bewerkingskenmerken en administratieve gegevens. Het is mogelijk dat delen van het produktmodel bij informatiesystemen van verschillende ondernemingen liggen opgeslagen. Men spreekt dan van een gedistibueerde database. Met een gemeenschappelijk gegevens- of produktmodel kunnen uiteenlopende disciplines voor uiteenlopende toepassingen informatie uitwisselen. Probleem is het tot stand komen van een kern- of referentiemodel op basis waarvan een sector of een groot aantal partijen met elkaar wil communiceren. De hoeveelheid verschillende produktmodellen die mogelijk zijn belemmert de totstandkoming van zo'n referentiemodel.

Programma's die gebruik maken van het produktmodel of dit model opbouwen, kunnen dat slechts doen als de structuur van de informatie aan standaarden voor de uitwisseling van produktinformatie voldoet. Een van de eerste pogingen voor het ontwik= kelen van een dergelijke standaard was IGES (Interactive Graphics Exchange Specifi= cation). IGES is eind jaren '70 ontwikkeld in de vliegtuigbouw en had ten doel uitwisseling van gegevens tussen CAD en CAM-systemen mogelijk te maken. Sindsdien hebben vele industrieën de verdere ontwikkeling van deze standaard ter hand genomen. IGES is een 'public domain' standaard en niet het eigendom van een organisatie. De welwillendheid van fabrikanten van programmatuur bepaalt of deze standaard ondersteund wordt. Nadeel is dat het produktmodel achter de IGES-specificatie uitsluitend grafische uitwisseling toestaat waarbij veel functionele informatie verloren gaat.

Andere standaarden zijn DXF en SIF (NEDC, 1990). DXF (Autocad Data eXchange Format) is een standaard specifiek gericht op de uitwisseling van data tussen het CAD. prograrnma Autocad en andere programma's. DXF richt zich met name op uitwisseling van grafische data en is momenteel het meest gebruikte uitwisselformaat voor CAD. Deze fabrikantgebonden en wereldwijd gebruikte standaard is nog verre van perfect. De standaard is eigendom van het softwarebedrijf Autodesk Inc., de eigenaars van het Autocad programma. Een soortgelijke standaard is SIF (Intergraph Standard Inter- 
change Format), gericht op uitwisseling tussen Intergraph CAD software en andere $\mathrm{CAD}$ systemen. Het bedrijf Intergraph Inc. is eigenaar van deze standaard. De meeste uitgebreide grafische standaard is GKS (Graphics Kernel System). Deze standaard wordt als een basisnorm, een referentie voor diverse andere standaards beschouwd.

In de Verenigde Staten is het initiatief genomen voor de ontwikkeling van een 'Product Data Exchange Specification' (PDES). PDES vormt de basis voor de ontwikkeling van de internationale standaard bekend onder de naam 'Standard for the Exchange of Product Model Data' (STEP). Voor het ontwikkelingen van PDES/STEP is veel gebruik gemaakt van het werk uitgevoerd voor de Amerikaans luchtmacht bij de ontwikkeling van de Product Definition Data Interface (PDDI) en van de internationale groep Computer Aided Manufacturing International (NEDC, 1990).

Het doel van STEP is 'the creation of a standard that enables the capture of information comprising a computerised product model in a neutral form without loss of completeness and integrity, throughout the life cycle of the product' (NEDC, 1990, 73). De term produkt wordt in het algemeen gebruikt voor iets dat gefabriceerd of gebouwd wordt en waarvoor data noodzakelijk zijn. De data bevatten niet alleen grafische informatie maar ook attributen of kenmerken die een onderdeel, een geheel van onderdelen of het finale produkt definiëren. Daarbij streeft men naar een 'complete representation of a product as stored in a computer database and the exchange of this representation with other computer systems, and not simply graphical representation and exchange for which standards and specifications are already established.' (ibid, 75). Doel is gedurende de gehele produkt-levenscyclus een geïntegreerde informatievoorziening mogelijk te maken. STEP/PDES beogen uitwisseling van produktmodellen die voldoende informatie bevatten om direct door geavanceerde CAD/CAM-systemen en applicatie-programma's begrepert te worden.

\subsection{Toepassing van integrale logistiek als concurrentie-strategie}

In de afgelopen decennia heeft zich een wezenlijke verandering in de markt voltrokken. De markt veranderde van een verkoopmarkt naar een afnemersmarkt. Deze omwenteling betekent voor een organisatie dat men snel en flexibel moet kunnen inspelen op diverse klantenwensen. Een aantal ontwikkelingen op het gebied van produktieen informatietechnologie maakt dit mogelijk. Schematisch gesproken kunnen ontwikkelingen die tot een toegenomen concurrentie hebben geleid als 'pull'-factoren voor toepassing van integrale logistiek worden gezien. Hiermee bedoelen we dat deze ontwikkelingen om een integrale benadering van de organisatie van de logistieke activiteiten vragen. De toegenomen concurrentie vraagt om snel en flexibel inspelen op nieuwe marktontwikkelingen. Flexibele produktietechnologie, in combinatie met bedrijfsoverstijgende informatiesystemen, maken een integrale benadering van logistieke activiteiten mogelijk. Deze technologische ontwikkelingen zijn een 'push'-factor voor toepassing van integrale logistiek.

Toepassing van integrale logistiek is dan ook te beschouwen als een 'match' tussen technologie en markt en kan een bron van concurrentie-voordeel zijn (Burbridge, 1988; Shapiro, 1984; Sharman, 1984). Om die reden wordt in deze paragraaf toepassing van integrale logistiek gerelateerd aan de begrippen concurrentie-strategie en concurrentie- 
voordeel van Porter (1980; 1985). Eerst wordt kort op de begrippen van Porter ingegaan.

\subsubsection{Basistypen van concurrentie-voordeel}

Porter $(1980 ; 1985)$ concentreert zich in zijn werk met name op de concurrentie-strategie ('competitive' of 'business' strategie) van een onderneming op specifieke markten en binnen specifieke bedrijfstakken. Daarbij is één van de centrale vragen hoe een bedrijf concurrentie-voordeel kan creëren en behouden.

Porter (ibid) inventariseert op een systematische wijze de bronnen van concurrentie. Hij deelt in zijn schema de bronnen van concurrentie op in interne, externe en potentiële concurrenten. De analyse strekt zich dus uit tot voorbij de grenzen van de bestaande bedrijfstak door rekening te houden met externe concurrenten (kopers en verkopers die mogelijk verticale integratie overwegen), potentiële concurrenten (buitenstaanders die overwegen tot de bedrijfstalk toe te treden) en substituten (zie figuur 3.4). In dit model van Porter komt de keten als belangrijk onderdeel naar voren. Op de horizontale as staan de toeleveranciers, het bedrijf zelf en de afnemers. Omdat een keten van bedrijven een belangrijk onderdeel vormt van het model van Porter is dit model als uitgangspunt genomen voor de vraag hoe toepassing van integrale logistiek tot concurrentie-voordeel kan leiden.

FIGUUR 3.4 Concurrentie-bepalende factoren in een sector

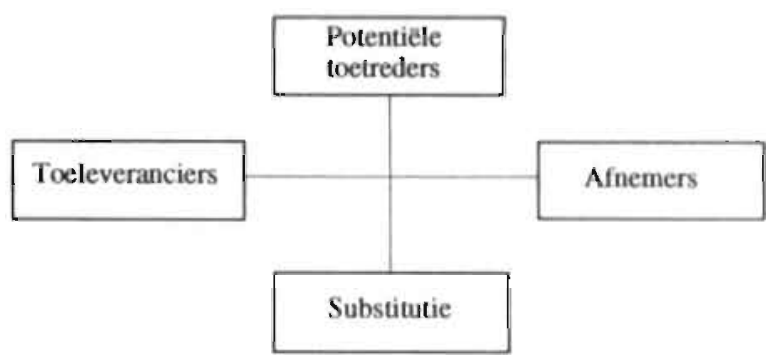

Bron: Porter (1980).

Vijf krachten (afnemers, toeleveranciers, substituten, potentiële toetreders en rivalen) bepalen de winstgevendheid van bedrijven in de bedrijfstak omdat ze de prijzen, kosten en benodigde investeringen van bedrijven in een bedrijfstak beïnvloeden (Porter, 1985). De onderhandelingspositie van de afnemer en de dreiging van substitutie beïnvloeden de prijzen die bedrijven kunnen bedingen. De onderhandelingspositie varn afnemers, ofwel de situatie op de afzetmarkt, kan ook de kosten en investeringen beïnvloeden omdat invloedrijke klanten kostbare service vragen. De dreiging van nieuwe toetreders remt te grote prijsstijgingen af. De onderhandelingspositie van toeleveranciers, ofwel de verhoudingen op de inkoopmarkt, bepaalt de kosten van grondstoffen en andere inputs. De intensiteit van rivaliteit beïnvloedt zowel de prijzen als de kosten van fabrikage-processen, produktontwikkeling en marketing. In het kader van toepassing van 
integrale logistiek is een belangrijke machtsfactor van de toeleveranciers de medewerking die zij willen verlenen aan ketenbeheersing.

Vooral de implicaties van mogelijke toetreders en potentiële concurrenten worden door Porter veider geanalyseerd (Van Cayseele en Schreuder, 1988). Het concept van toetredingsbelemmeringen speelt hierbij een belangrijke rol. Het opwerpen van toetredingsbelemmeringen is een van de middelen om de intensiteit van de concurrentie binnen de bedrijfstak te verminderen en zo de rentabiliteit van de onderneming te verbeteren. Verhoging van de concentratiegraad door overname en fusie is een tweede manier om de intensiteit van de concurrentie te verminderen. Een derde manier zijn marktafspraken tussen ondernemingen. Ten vierde kan vermindering van de onzekerheid over het strategisch gedrag van andere ondernemingen hiertoe bijdragen.

Naast vermindering van de intensiteit van de concurrentie kan de onderneming trachten haar relatieve positie ten opzichte van haar concurrenten te versterken. Ondernemingen kunnen op specifieke markten of binnen specifieke bedrijfstakken verschillende strategieën hanteren om de concurrentie op afstand te houden. Porter (1980) komt tot twee algemene strategieën: de kostenleidersstrategie en de differentiatiestrategie. De twee basistypen van concurrentie-voordeel zijn gebaseerd op lage kosten en differentiatie.

Bronnen voor hett relatieve kostenvoordeel kunnen zeer gevarieerd zijn. Voorbeelden zijn schaalvoordelen, ervaring met het bestaande produktieproces, vernieuwing van de produktietechnologie, een nieuwe vestigingsplaats of het invoeren van een andere interne organisatie-structuur ('Daems en Douma, 1984). Bij differentiatie streeft men ernaar dat de prijstoeslag groter is dan de kosten van differentiatie. Daartoe moet het produkt werkelijk iets zijn dat ais uniek wordt waargenomen. De onderneming kan een nneerpijs vragen omdat het produkt zich onderscheidt in andere eigenschappen dan alleen de prijs. Bij dit tweede basistype speelt marketing een belangrijke rol. Kostenbeheersing is wel van belang maar niet de voornaamste strategische doelstelling.

\subsubsection{Concurrentie-voordeel door foepassing van integrale logistiek}

Toepassing van integrale logistiek kan op verschillende wijzen een bijdrage leveren aan de twee onderscheiden basistypen van concurrentie-voordeel.

De eerste stategie richt zich op lage kosten: toepassing van integrale logistiek kan een nieuwe dominante kostenverlagende factor zijn. Een goede afstemming tussen toeleveranciers, producenten en afnemers reduceert voorraden in een keten en kan zo tot een drastische verlaging van de voorraadkosten leiden. Minder strikte eisen stellen aan de versheid van het produkt (vers in de ruimste zin van het woord: recent automodel, actueel nieuws of modieuze kleding) en een beperking van het assortiment scheppen extra mogelijkheden voor grote kostenbesparingen door toepassing van integrale logistiek. Kostenvoordelen, gevolg van toepassing van integrale logistiek, leiden ertoe dat concurrenten, die onderdeel vormen van andere ketens, op afstand worden gehouden. Lagere kosten kunnen eventueel tot een hogere contributie-marge leiden hetgeen nieuwe investeringen mogelijk maakt. Deze nieuwe investeringen kunnen een concurrentic-voordeel opleveren. 
In het geval van de differentiatie-strategie wordt een produkt gekenmerkt door unieke eigenschappen die door klanten hoog gewaardeerd worden. De unieke kenmerken van een produkt kunnen betrekking hebben op vaste eigenschappen die de produktie aan het produkt meegeeft, het produkt-imago en een goede service. Toepassing van integrale logistiek kan ervoor zorgen dat het produkt aan bepaalde kwaliteitseisen voldoet wat betreft beschikbaarheid, versheid en verkoopgereedheid (Pino en Van 't Eind, 1990). Een goede afstemming tussen ondernemingen in een keten kan de servicegraad voor de finale klant ten goede komen. Toepassing van integrale logistiek kan ook bij een differentiatie-strategie een bijdrage aan kostenbeheersing leveren door produktdifferentiatie betaalbaar te maken. Kostenverlaging speelt dan een belangrijke rol maar is niet de dominante marktstrategie.

Toepassing van integrale logistiek kan dus zowel de kosten van activiteiten in een keten verlagen, als door produktdifferentiatie waarde toevoegen. Informatie-uitwisseling is een belangrijk middel voor realisering van genoemde strategieën. Informatiesystemen leiden tot "comparative efficiency by both internal efficiency and interorganizational efficiency, and bargaining power by unique product features, switching costs, and search-related costs' (Johnston en Vitale, 1988, 156). Met 'comparative efficiency' wordt bedoeld dat de organisatie goederen en diensten goedkoper kan produceren dan de concurrenten. 'Bargaining power' duidt op het feit dat een organisatie in staat is 'bargaining' situaties op te lossen met toeleveranciers en klanten die voor de onderneming voordeel opleveren.

Conclusie is dat toepassing van integrale logistiek te beschouwen is als een 'match' tussen toenemende concurrentie en de nieuwe technologische mogelijkheden. Met behulp van nieuwe informatietechnologie kan toepassing van integrale logistiek als concurrentie-strategie tot concurrentie-voordeel leiden. 



\section{Verandering van transactiepatronen}

In de vorige hoofdstukken hebben we gezien dat toepassing van integrale logistiek een verandering van relaties tussen ondernemingen betekent. Met andere woorden, de externe organisatie van de onderneming wijzigt zich. De theorie van de exierne organisatie onderzoekt de voorwaarden voor het ontstaan en de ontwikkeling van relaties tussen bedrijfshuishoudingen en de daaruit voortvloeiende organisatie-vormen of transactiepatronen. In dit hoofdstuk willen we op de eerste centrale onderzoeksvraag van deze studie ingaan door te analyseren of de theorie van de externe organisatie kan bijdragen aan inzicht in voorwaarden of omstandigheden waaronder toepassing van integrale logistiek een succesvolle strategie kan zijn. Eén theorie vormt in dit hoofdstuk uitgangspunt van analyse, nl. ce transactiekostentheorie van Williamson. Deze theorie geeft aan hoe kenmerken van transacties en de daarbij behorende transactiekosten tot bepaalde vormen van externe organisatie leiden.

Behalve dit hoofdstuk bevat ook het volgende een theoretische verkennning die ingaat op de centrale onderzoeksvragen van deze studie. Zoals gezegd behandelt hoofdstuk 4 de voorwaarden waaronder het tot een toepassing van integrale logistiek komt. In hoofdstuk 5 wordt ingegaan op kenmerken en mogelijke gevolgen van toepassing van integrale logistiek. De opzet van dit hoofdstuk is als volgt. Ten eerste wordt in $\S 4.1$ ingegaan op transactiekostentheorie en theorieën over netwerken. Vervolgens wordt in $\S 4.2$ op basis van deze theorieën aangegeven onder welke voorwaarden de externe organisatie of transactiepatronen zich wijzigen. Tenslotte wordt in $\$ 4.3$ een relatie gelegd tussen deze theorieën en toepassing van integrale logistiek.

\subsection{De externe organisatie van de onderneming}

\subsubsection{De transactiekostentheoric}

In zijn klassieke artikel 'The nature of the firm' (1937) stelde R.H. Coase de fundamentele vraag waarom er ondernemingen ontstaan in een economie waar het prijsmechanisme door middel van markttransacties de produktie coördineert. In zijn analyse makkte Coase een onderscheid tussen coördinatie via de markt en coördinatie binnen ondernemingen. Oprichting van een onderneming betekent een verandering van het mechanisme dat economische activiteiten coördineert. Het prijsmechanisme van đe markt wordt vervangen door de hiërarchische gezagsstructuur van een organisatie: niet meer de markt maar de ondernemer coördineert activiteiten.

De reden voor coördinatie via ondernemingen wordt door Coase gezocht in het bestaan van kosten gerelateerd aan het gebruik van het prijsmechanisme. Coördineren van transacties via de markt vindt plaats door het tot stand brengen van contracten tussen actoren op de markt. In contracten worden afspraken voor deze transacties vastgelegd. Kosten die hiermee gepaard gaan zijn het gevolg van het opsporen van 
relevante prijzen, het opstellen van een contract (onderhandeling en contractspecificatie) en het toezicht op naleving ervan. Soms is het moeilijk of zelfs onmogelijk om tot een volledig gespecificeerd contract te komen dat als basis kan dienen voor een markttransactie. In dat geval kan het gunstiger zijn een organisatorische relatie aan te gaan op basis van een tamelijk ongespecificeerd contract voor de langere termijn (voorbeeld hiervan is een arbeidscontract).

Het is Williamson die met zijn transactiekostentheorie op de inzichten van Coase voort bouwt. In zijn standaardwerk 'Markets and Hierarchies' (1975) zet hij de beginselen van deze transactiekostentheorie uiteen. Essentie van de transactiekostentheorie is dat de keuze van het coördinatiemechanisme in een bepaalde situatie afhangt van de verhouding tussen transactiekosten en interne coördinatiekosten. Zijn transactiekosten hoger dan interne coördinatiekosten, dan wordt gekozen voor een meer hiërarchisch coördinatiemechanisme (er is sprake van 'market failure'). Geldt het omgekeerde ('organizational failure'), dan zal gekozen worden voor een coördinatiemechanisme dat meer marktelementen bevat.

Dit falen van markt of hiërarchie vindt ten eerste zijn oorzaak in de beperkte rationaliteit van actoren, hetgeen voortkomt uit de complexiteit en onzekerheid van de orngeving. ${ }^{1}$ Ten tweede kunnen actoren zich opportunistisch gedragen. Mogelijkheden voor dit gedrag nemen toe bij kleine aantallen participanten en een ongelijke verdeling van informatie over de partijen. Bij oligopolistische marktstructuren (Williamson spreekt van 'small numbers') kan door samenspannend gedrag de concurrentie zodanig worden uitgeschakeld, dat opportunistisch gedrag aantrekkelijk wordt. Williamson duidt de relatie tussen enerzijds gedragsverondersteilingen (beperkte rationaliteit en opportunisme) en omgevingsfactoren (onzekerheid/complexiteit en 'small numbers') en anderzijds de wijze waarop deze factoren de externe organisatie beînvloeden aan als het 'Organizational Failures Framework" (1975). ${ }^{2}$

Belangrijke toevoeging aan de transactiekostentheorie is de introduktie van het concept 'governance structure' (Williamson, 1979). De beweging van markt naar hiërarchie en andersom betekent in termen van Williarnson dat de 'governance structure' verandert. Onder 'governance structure' verstaat Williamson 'the explicit or implicit contractual framework within which a transaction is located' (1981, 1544). In de analyse van de verschillende 'governance structures' zijn studies van contracten van groot belang. Verschillende 'governance structures' corresponderen met verschillende contractvormen. Williamson (1979) maakt een onderscheid tussen het klassieke, het neo-klassieke en het relationele contract.

\footnotetext{
${ }^{1}$ Simon drukt beperkte rationaliteit als yolgt uit: The capacity of the human mind for formulating and solving complex problems is very small compared with the size of the problems whose solution is required for objectively rational behavior in the real world' $(1957,198)$.

${ }^{2}$ Englander (1988) onderscheidt drie fasen in het, werk van Williamson. In de eerste fase staat het. 'Organizational Failures Framework' centraal (Williamson, 1975). Een analyse van đe aard van transacties vindt nauwelijks plaats. Deze analyse vormt volgens Englander de kern van de tweede fase in het werk van Williamson (1979; 1981). In de derde fase staat cen specifieke dimensie van transacties centraal, nl. 'asset specificity' (Williamson, 1981; 1985).
} 
Het klassieke contract is bruikbaar voor transacties, die de korte termijn betreffen en waarbij van duidelijke meetbare grootheden sprake is. Ex ante worden alle mogelijke zaken die zich in de relatie tussen participanten kunnen voordoen vastgelegd. Deze contractvorm correspondeert met 'market governance'. Daarentegen betreft het relationele contract de langere termijn en kan zowel nauwkeurig meetbare als onmeetbare grootheden betreffen. In het relationele contract kan niet alles voldoende nauwkeurig worden geregeld; in de loop van de tijd moet de relatie concreter vorm worden gegeven. Complexiteit en onzekerheid, in combinatie met een beperkte rationaliteit, maken het onmogelijk ex ante over alle mogelijke toekomstige eventualiteiten afspraken te maken. Deze contractvorm correspondeert met de 'governance structure' van hiërarchie. Daarnaast onderscheidt Williamson ook nog het neo-klassieke contract dat tussen het klassieke en het relationele contract in ligt. Deze contractvorm correspondeert met 'trilateral governance'. Daarmee worden organisatievormen bedoeld waar partijen in geval van een conflict een beroep op kunnen doen. Voorbeeld zijn arbitrage commissies. $^{3}$

In deze contractuele benadering van organisatievormen wordt de onderneming soms als 'a nexus of contracts' beschreven. ${ }^{4} 5$ In de recente theorievorming wordt echter

${ }^{3}$ Williamson. (1979) past deze contractuele benadering op verschillende activiteiten toe. Een voorbeeld van een relationeel contract zijn langlopende arbeidscontracten. Deze hebben het voordeel dat niet ieder moment over de beloning voor een prestatie onderhandeld moet worden. Nadeel van deze lange-termijn contracten is echter dat ze incompleet zijn. De te leveren prestaties zijn niet volledig gespecificeerdi hetgeen weer mogelijkheden opent voor opportunistisch gedrag. Men kan dit ondervangen door een goede werking van een interne arbeidsmarkt binnen de hierrarchic. Voordeel van het lange-termijn aspect van veel arbeidscontracten is dat het mogelijk word om bedrijfsspecifieke investeringen in de werknemers te doen.

${ }^{4}$ De contractuele benadering bij de analyse van het specifieke karakter van de onderneming leidt bij Alchian en Demsetz (1972) tot de conclusie dat er uiteindelijk geen principieel verschil bestaat tussen coördinatic via de markı of via de onderneming. $\mathrm{Zij}$ beschouwen de onderneming voornamelijk als een geheel van contracten, 'a nexus of contracts', en verwerpen het idee dat binnen de onderneming een specifieke machtsverhouding zou bestaan tussen werkgever en werknemer. Bij Alchian en Demsetz is het enige belangrijke verschil tussen onderneming en markt het bestaan van teamproduktie binnen de onderneming en de problemen de individuele bijdrage van medewerkers aan hell collectief́ resultaat te meten. Dit vereist 'monitoring', d.w.z het meten van prestaties, toewijzing van beloningen en de hoeveelheid 'inputs' in de gaten houden. De 'monitor' (dat is de werkgever) maakt winst. 'not only by prices that he agrees to pay the owners of inputs, but also by observing and directing the actions or uses of those inputs' (ibid, 782). Dit geeft aan dat 'the firm takes on characteristics of an efficient market in that information about productive characteristics of a large set of specific inputs is now more cheaply available' (ibid, 795). De werkgever wordt hierbij beschouwd als dirigent van de markt binnen de onderneming. Volgens Hodgson (1988) rekken Alchian en Demsetz het begrip "markt" zo ver op dat deze term bijna nietszeggend is geworden. Daartegenover staat het conceptueel model van Coase en Williamson dat wel een duidelijk. onderscheid maakt tussen markt en onderneming. Alchian en Demsetz stemmen met Williamson overeen wat betreft hun contractuele perspectief op organisaties.

${ }^{5}$ Recente aanvulling op deze contractuele benadering is de theorie van de incomplete contracten (Grossman en Hart, 1986; Hart en Moore, 1990). Vanuit de eigendomsrechten-benadering gaan Hart en Moore (ibid) in op de vraag wat onder eigendom en beheersing van bedrijfsmiddelen verstaan moet worden. Uitgangspunt van hun analyse is dat opportunistisch gedrag en onzekerheid het opstellen en afdwingen yan complete contracten onmogelijk maakt of met zeer hoge kosten gepaard gaat. Contracten. zijn 'typically incomplete: there are always unforeseen states of nature ... that cannot be contracted on' (Moore, 1992, 496). De vraag is wie bepaalt hoe "physical assets" (machines, voorraden) gebruikt mogen worden bij 'uncontracted-for eventualities'. Deze vraag wordt beantwoord door onderscheid te maken 
voorgesteld niet meer te spreken over de onderneming als 'nexus of contracts' maar over de onderneming als 'nexus of treaties' (Williamson, 1990). De term 'contract' zou te veel geassocieerd worden met formele wetten en de betrokkenheid van een derde partij, bijvoorbeeld de rechter, bij oplossing van conflicten. Praktijk is dat vele conflicten onderhands worden opgelost zonder dat hierbij een derde partij aan te pas komt. Deze 'bilateral governance', waarbij sprake is van niet-standaard contracten wordt door Williamson 'private ordering' genoemd. Door de term 'contract' te vervangen door 'treaty' wordt het belang deze 'private ordering' aangegeven. Williamson verruimt met de introduktie van tussenvormen als 'bilateral' en 'trilateral governance' de stricte keuze tussen markt en hiërarchie.

Williamson (1979) geeft drie dimensies van transacties aan die van invloed zijn op de keuze voor of de verandering van een bepaald transactiepatroon: 'asset specificity', frequentie en onzekerheid van transacties, waarbij de eerste de belangrijkste is.

Er is sprake van 'asset specificity' wanneer partijen voor het realiseren van bepaalde transacties specifieke investeringen hebben gedaan, die in andere situaties niet zouden plaatsvinden. De wederzijdse afhankelijkheid, die tussen de partijen door de specifieke investeringen ontstaat, kan tot een 'locked-in' situatie leiden. Dit betekent dat bij opportunistisch gedrag van een van de handelspartners niet gemakkelijk en slechts tegen hoge kosten kan worden uitgeweken naar andere handelspartners. Het voorkomen van opportunistisch gedrag of het opstellen van spelregels hoe te handelen als één van de partijen dreigt met opstappen kunnen niet of alleen tegen zeer hoge kosten in een marktcontract worden geregeld. Het alternatief is de internalisatie van transacties (in $\$ 4.2 .1$ wordt verder op 'asset specificity' ingegaan).

Een tweede criterium waarmee Williamson transacties typeert is de frequentie. Bij afwezigheid van transactiespecifieke investeringen doet het er volgens de transactiekostentheorie niet toe of de transactie eenmalig of frequent is; in beide gevallen zullen de transactiekosten laag zijn vanwege de afwezigheid van "hold-up" situaties. Komt een transactie frequent voor en gaat deze gepaard met specifieke investeringen dan kan het voor de betrokkenen doelmatig zijn tot een andere 'governance' te komen. Bedrijven kunnen bijvoorbeeld jaarcontracten met elkaar afsluiten of relaties aangaan zonder vaste looptijd. Ook bij onzekerheid, het derde criterium waarmee Williamson transacties typeert, geldt dat bij afwezigheid van transactiespecifieke investeringen de markt bij toenemende onzekerheid het dominante transactiepatroon blijft. Bij transacties die gepaard gaan met specifieke investeringen kan toenemende onzekerheid wel tot verandering van markt naar hiërarchie leiden.

Kernargument is dat transacties die gekenmerkt worden door onzekerheid over hun uitkomst, frequent voorkomen en substantiële transactiespecifieke investeringen vereisen (geld, tijd en energie die een onderneming niet of slechts tegen hoge kosten voor een andere transactie kan inzetten) efficiënter binnen hiërarchisch georganiseerde structuren kunnen plaats vinden. In recent werk heeft Williamson $(1988 ; 1991)$ ook vijf

tussen 'specific rights' en 'residual rights'. Met dit onderscheid wordt tevens eigendom gedefinieerd: de eigenaar van bedrijfsmiddelen bezit 'residual rights', d.w.z. het recht bedrijfsmiddelen op iedere wijze te gebruiken uitgezonderd hetgeen in bepaalde contracten is gespecificeerd. De onderneming wordt in deze benadering gedefinieerd als cen verzameling 'physical assets' waarvan de eigenaar over de 'residual control rights' beschikt. 
dimensies van 'governance structures' aangegeven: het aanpassingsmechanisme van de autonomie en van de coōperatie, de 'incentive intensity', 'administrative controls' en de contractvorm.

De eerste twee dimensies van een 'governance structure' betreffen de aanpassingsmechanismen. Op markten worden veranderingen in de vraag-aanbod verhouding van goederen gereflecteerd in de prijs. Op basis daarvan passen autonome consumenten en producenten hun gedrag aan. Partijen die langdurige relaties met elkaar onderhouden kunnen afhankelijk van elkaar worden hetgeen mogelijkheden biedt voor opportunistisch gedrag. Dit gedrag kan voorkomen worden door de autonomie van verschillende partijen te vervangen door een gezagsstructuur gericht op coöperatie. Het aanpassingsmechanisme van autonomie (A) wordt vervangen door dat van coöperatie (C). Een 'governance structure' kan zowel elementen van aanpassingsmechanisme A (dimensie 1) als van $\mathrm{C}$ (dimensie 2 ) bevatten.

Een derde dimensie is de 'incentive intensity' van een 'governance structure', Op de markt is sprake van 'high-powered incentives' (Williamson, 1988). Een actor kan zijn gemaakte winsten direct toeëigenen zonder dat andere partijen daar claims op leggen. Dit. stimuleert het streven naar kostenverlaging en efficiency. Met de integratie van activiteiten in een hiërarchie verliest men een deel van die 'high-powered incentives' en nemen de interne coördinatie-kosten toe. ${ }^{6}$ De vierde dimensie heeft betrekking op de mogelijkheid 'administrative controls' toe te passen. In tegenstelling tot de markt bestaan binnen een hiërarchie meer mogelijkheden voor dwang tot continuïteit van levering, toezicht op produktie en de daarbij gemaakte kosten en oplossing van geschillen. De vijfde dimensie heeft ten slotte betrekking op de diverse contractvormen, zoals die reeds behandeld zijn: het klassieke, neo-klassieke en het relationele contract.

\subsubsection{Het netwerk als coördinatiemechanisme}

Kritiek op de visie van Williamson op coördinatie-vormen omvat ten eerste de beperktheid van het continuüm met als polen markt en hiërarchie. Een tweedie punt van kritiek, dat met het eerste samenhangt, is de eenzijdigheid van de verklaring van oorsprong en ontwikkeling van coördinatie-yormen. Deze worden uitsluitend verklaard met argumenten van economische efficiency.

Een belangrijke tekortkoming in de theorie van Williamson is dat de nadruk van zijn analyse ligt op de tweedeling markt-hiërarchie, d.w.z. coördinatie via het prijsmechanisme of coördinatie via de onderneming. ${ }^{7}$ Williamson sluit met zijn tweedeling aan bij de klassieke benadering binnen de economische wetenschap waarbij alleen maar ruim-

${ }^{6}$ Binnen een bedrijf kunnen bepaalde bedrijfsondelen redeliike argumenten hebben om een deel van de winst van anđere onderdeten op te eisen. Daarnaast kunnen bepaalde verlieslijdende bedrijfsonderdelen aangeven waarom zij niet verantwoordelijk zijn voor het verlies. Gevolg is daling van de 'incentive intensity" (Williamson, 1991).

"Beschouwen we de typologie van Mintzberg (1979) dan valt daaruit op te maken dat de transactiekostentheorie de coördinatie-problematiek sterk simplificeert. Mintzberg onderscheid in zijn organisatietheoretisch werk vijf à zes vormen van coordinatie binnen organisaties en baseert daarop zijn organisatietypologic. Binnen de transactiekostentheorie is, in termen van Mintzberg bij 'hiêrarchie' uitsluitend sprake van 'direct supervision'. Mintzberg laat zien dat naast dit coordinatie-mechanisme nog cen aantal andere bestaan zoals 'mutual adjustment', 'standardization of work processes, output, skills and norms'. 
te is voor coördinatie via de markt of via de onderneming. De economische werkelijkheid wordt echter gekenmerkt door allerlei vormen van samenwerking tussen formeel onafhankelijke ondernemingen. Of zoals Williamson het zelf stelt: '... the argument throughout has emphasized polar firm and market choices. This facilitates analysis, but it ignores an important class of hybrid modes of organization - of which joint ventures, and of a variety of complex forms of 'relational contracting' are examples' (Williamson, 1985, 376).

In recent werk analyseert Williamson $(1988 ; 1991)$ de 'hybrid mode of organization' door deze met behulp van de vijf dimensies van een 'governance structure' ten opzichte van de 'polar modes' markt en hiërarchie te plaatsen. Volgens Williamson nemen hybride organisatievormen op alle genoemde dimensies een tussenpositie in. $\mathrm{Bij}$ 'hybrids' blijft sprake van autonome partijen (aanpassingsmechanisme A) hetgeen een hoge 'incentive intensity' uitlokt. Omdat echter sprake is van wederzijdse afhankelijkheid zullen contracten ondersteund worden met bepaalde controle-mechanismen zoals die gebruikelijk zijn in een hiërarchie, bijvoorbeeld wederzijdse inspectie van produktie-processen. Dit vergemakkelijkt aanpassingen van het type $\mathrm{C}$ maar kan ten koste gaan van de 'incentive intensity'. 'Hybrids' zijn geschikt voor transacties die een 'mixed adaptation' vereisen: meer coöperatief gedrag dan op de markt, meer autonomie dan in een hiërarchie. Ondanks meer aandacht voor 'hybrid modes of organization' blijft Williamson in essentie vasthouden aan het continuüm met markt en hiërarchie als polen. 'Hybrids' worden niet gezien als derde aparte organisatievorm, naast markt en hiërarchie, maar als tussenvorm.

Powell (1990) stelt daarentegen dat deze "hybrids" wel als een aparte vorm van economische organisatie gezien moeten worden. Hij onderscheidt dan ook naast coördinatie vis het prijsmechanisme in heı klassieke model van de markt en coördinatie via gezagsrelaties in de hiërarchie nog een derde op zich zelf staand coördinatiemechanisme: het netwerk. Poweli presenteert markt, hiërarchie en netwerk als de drie verschillende vormen van economische organisatie die duidelijk met elkaar verschillen in normatieve basis, communicatiemiddelen, methoden van conflictoplossing, flexibiliteit, 'commitment' en de mate van onderlinge afhankelijkheid.

Markten zijn relatief flexibel, staan open voor iedereen en coördineren zonder te dwingen. In het klassieke model van de markt is informatie vrij beschikbaar, zijn er voldoende kopers en verkopers en heeft de ene transactie geen invloed op een andere. In het traditionele marktmodel zijn actoren non-coöperatief en uitsluitend gericht op direct eigen belang. Iedere partij tracht intern gedefinieerde doelen te bereiken. In een hiërarchie worden interacties bepaald door een gezagsstructuur. De organisatie-vorm is minder flexibel, maar meer betrouwbaar en berekenbaar en gericht op integratie. Medewerkers vormen onderdeel van de gezagsstructuur en hun functies zijn gedefinieerd door superieuren. De verschillende werkzaamheden zijn in het algemeen sterk onderling afhankelijk en, als het goed is, gericht op eenzelfde doel. Het netwerk is flexibeler en complexer dan hiërarchieën. In vergelijking met markten zijn netwerken sterker op het punt van integratie en bieden zij meer mogelijkheden voor leerprocessen en overdracht van kennis. Individuele actoren in een netwerk ontwikkelen zich in onderlinge afhankelijkheid en ondersteuning. De nadruk. ligt op wederzijdse (lange termijn) verplichtingen. Er is veel energie en tijd geïnvesteerd in de relaties en daarom zullen eventuele problemen eerder aanleiding geven tot hernieuwde onderlinge afstemming dan tot het stop zetten van de relatie. Dit laatste zal eerder bij marktrelaties. 
plaats vinden. Netwerken worden dan ook gekenmerkt door een combinatie van flexibiliteit en afhankelijkheid (Wassenberg, 1980). ${ }^{8}$

In de netwerken is coördinatie gebaseerd op 'mutual orientation' van twee of meer organisaties ten opzichte van elkaar (Hakansson, 1987; Johanson en Mattson, 1987). Transactiepatronen tussen bedrijven kunnen als relaties beschreven worden die tot stand zijn gekomen op basis van het marktmechanisme. Vaak spelen in werkelijkheid marktsignalen (prijzen) in de coördinatie van transacties maar een ondergeschikte rol vergeleken met persoonlijk kennis en contacten, traditie, historisch gegroeide afhankelijkheden en daarop gebaseerd wederzijds vertrouwen (Dankbaar, 1991). Deze 'mutual orientation' impliceert dat ondernemingen elkaars belangen respecteren en wederzijds bedrijfsinformatie overdragen. 'Mutual orientation' kan zich verder uitdrukken in gemeenschappelijk jargon en standaardisatie van processen, produkten en routines.

Een tweede punt van kritiek op de visie van Williamson is dat oorsprong en ontwikkeling van coördinatie-vormen eenzijdig verklaard worden met efficiency-argumenten.

Powell (1990) benadrukt dat de keuze voor een coördinatie-mechanisme niet gebaseerd hoeft te zijn op minimalisatie van transactiekosten. Bepaalde strategische voordelen van bijvoorbeeld een netwerk kunnen van groter belang zijn dan de eventueel hogere transactiekosten indien deze organisatie-vorm vergeleken zou worden met markt of hiërarchie. Hiermee oefent hij kritiek uit op de visie van Williamson die oorsprong en ontwikkeling van coördinatie-vormen eenzijdig verklaard met efficiencyargumenten.

Ook Jarillo (1988) bekritiseert deze eenzijdige benadering en beschouwt netwerken niet alleen als middel tot minimalisatie van transactiekosten maar ook als een organisatievorm gericht op concurrentie-voordeel. Jarillo spreekt daarom van 'strategic networks': 'I see strategic networks as long-term, purposeful arrangements among distinct but related profit organizations that allow those firms in them to gain or sustain competitive advantage vis-à-vis their competitors outside the network' (ibid, 32). Jarillo plaatst het strategisch netwerk in het kader van vier mogelijke coördinatie-mechanismen en maakt daarbij gebruik van het werk van Ouchi en Williamson.

Ouchi (1980) relativeert de indeling markt-hiërarchie door hiërarchieën op te delen in bureaucratiën en 'clans'. Het eerste type zou elementen van de markt hebben omdat binnen de bureaucratie verschillende partijen doelen nastreven die niet overeen hoeven te stemmen met die van de organisatie (een lage 'congruence of goals').' Bij 'clans' is van deze tegenstrijdigheid minder sprake omdat door socialisatie individuele en collectieve doelen op elkaar zijn afgestemd. Er is minder supervisie nodig dan in een bureaucratie. Jarillo (1988) deelt ook markten in twee categorieën in: klassieke markten en strategische netwerken. Op de klassieke markt zien partijen zich als spelers in een

8 Thorelli (1986) gebruikt de term netwerk om aan te geven dat de grenslijnen tussen markt en hiêrarchie in werkelijkheid vloeiender verlopen dan in de theorie. Bedrijven handelen in een complexe omgeving en geen bedrijf kan begrepen worden zonder verwijzing naar zijn relaties. Het netwerk duidt op allerlei vormen van samenwerking tussen formeel onafhankelijke bedrijven.

${ }^{9}$ Imai en Itami (1984) hebhen het markt-hiërarchie onderscheid genuanceerd door aan te geven dat principes van de markt zich binnen organisaties voordoen en andersom. 
'zero-sum game' (competitief), in strategische netwerken als spelers in een 'non zerosum game' (coöperatief). In het laatste geval streven partijen naar 'joint value maximization' (Zajac en Olsen, 1993). Relaties worden in dat geval gekenmerkt door 'hierarchical relationship: relatively unstructured tasks, long-term point of view, relatively unspecified contracts. These relationships have all the characteristics of 'investments', since there is always a certain 'asset specificity' to the know-how of, say, dealing with a given supplier instead of a new one' (Jarillo, 1988, 34). De vierdeling van Jarillo is figuur 4.1 weergegeven.

FIGUUR 4.1 Vier coordinatie-mechanismen

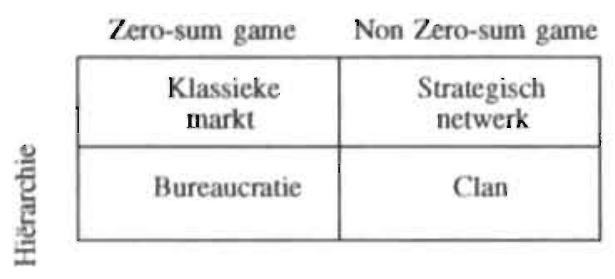

Bron: Jarillo (1988, 34).

Zajac en Olsen (1993) geven aan dat de 'pursuit of greater joint value requires the use of governance structures that are less efficient from a transaction cost perspective' (ibid, 132). Transactiekosten vormen een deel van de totale kosten die met een samenwerkingsrelatie gepaard gaan. Bij een samenwerking moet de totale kosten vergeleken worden met de totale opbrengsten of toegevoegde waarde. Indien de toename van de toegevoegde waarde de toename van de transactiekosten overstijgt zullen de bedrijven hun relaties blijven onderhouden.

De verklaring van Williamson voor het ontstaan van de 'governance' van de onderneming kan ook vanuit andere perspectieven bekritiseerd worden. Ten eerste is de functie van de onderneming niet alleen het streven naar minimalisatie van transactiekosten maar ook de ontwikkeling en reproduktie van kennis, vaardigheden en technologieën, 'routines' (Nelson en Winter, 1982; Winter, 1988). Ten tweede kan gesteld worden dat niet efficiency maar macht, oorsprong en ontwikkeling van coördinatie-vormen verklaren (Marglin, 1974). Dit blijkı in de praktijk doordat inefficiënte structuren blijven bestaan en mogelijk efficiënte structuren niet tot stand komen. De onderneming geeft de kapitalist de mogelijkheden tot vergaande beheersing van processen te komen. De onderneming is dan ook een machtsinstituut en niet alleen het gevolg van efficiency overwegingen. 


\subsubsection{Transactiespecifieke investeringen}

De waarde van de transactiekostentheorie is gelegen in de mogelijkheid om aan te geven onder welke omstandigheden veranderingen in de externe organisatie optreden. Het concept 'asset specificity' vormt de belangrijkste factor in de verklaring van markt naar netwerk of hiërarchie (Riordan en Williamson, 1985; Englander, 1988; Joskow, 1988). ${ }^{10}$ Williamson ziet 'asset specificity' als de 'big locomotive to which transaction cost economics owes much of its predictive content' $(1985,56){ }^{11}$

Williamson spreekt van 'asset specificity' indien een onderneming voor realisering van bepaalde transacties specifieke investeringen heeft gedaan, zgn. transactie-specifieke investeringen. Wat betreft de toeleverancier-afnemer verhouding komt het bijvoorbeeld voor dat de leverancier aan specifieke wensen van de afnemer moet voldoen en daarvoor investeringen in produktiemiddelen en personeel doet, die niet voor een andere afnemer kunnen worden ingezet. Grossman en Hart (1986) spreken van 'relationshipspecific investments'. Investeringen kunnen specifiek zijn voor de transactie zonder betrekking te hebben op het produkt dat wordt uitgewisseld. Men kan hier denken aan zoek- en marketingkosten: investeringen in kennis over transactiepatronen van een specifieke afnemer (zijn behoeften, logistiek, administratieve procedures). Daarnaast kunnen specifieke investeringen betrekking hebben, op de benodigde produktietechnologieën. Ook als alleen de leverancier deze specifieke investeringen doet kunnen beide partijen te maken hebben met 'asset specificity'. Specifieke investeringen kunnen tot een speciaal produkt of een speciale prijs voor de afnemer leiden die niet, of althans niet direct, door een alternatieve leverancier kan worden geëvenaard. In dat geval is niet alleen de leverancier maar ook de afnemer kwetsbaar voor discontinuïteit van de transactie (Nooteboom, 1992).

In zo"n situatie van wederzijdse afhankelijkheid kan één van de partijen dreigen zich terug te trekken, tenzij het contract in zijn voordeel wordt herzien. In een toeleverancier-afnemer verhouding kunnen 'opbrengsten' van specifieke investeringen van de ene partij đoor de andere worden toegeëigend. Klein et al. (1978) nemen als centrale veronderstelling dat '...as assets become more specific and more appropriable quasi rents are created (and therefore the possible gains irom opportunistic behavior increase), the cost of contracting will generally increase more than the cost of vertical integration' (ibid, 298). Verticale integratie kan een tegen-strategie van ondernemingen zijn om te voorkomen dat zgn. 'quasi-rents' op gespecialiseerde 'assets' (bijvoorbeeld technologie) door anderen worden toegeëigend. Volgens Hagedoorn zal (achterwaartse)

10 Williamson $(1991,281)$ onderscheidt zes vormen van 'asset specificity': '(1) site specificity, as where successive stations are located in a cheek-by-jowl relation to each other so as to economize. on inventory and transportation expenses; (2) physical asset specificity, such as specialized dies that are required to produce a component; (3) hwman-asset specificity that arises in learning by doing; (4) brand name capital; (5) dedicated assets, which are discrete investments in general purpose plant that are made at the behest of a particular customer; (6) temporal specificity, which is akin to technological nonseparability and can be thought of as a type of site specificity in which timely responsiveness by onsite human assets is vital":

${ }^{11}$ Het angelsaksische begrip 'asset' heeft enerzijds betrekking op activa of bedrijfsmiddelen, anderzijds op cen waardevolle eigenschap in het algemeen. 
integratie in het bijzonder plaatsvinden 'als er relatief weinig onduidelijkheid is over de technologische ontwikkeling, als de overnemende partij in belangrijke mate afhankelijk is van de technologie die in de toellevering ligt besloten en als die daardoor een belangrijk aspect van haar (innovatie-)strategie wordt' $(1990,24)$.

Teece (1986) vult de transactiekostentheorie aan door aan te geven dat naast 'asset specificity' ook het 'toeëigeningsregime' en 'complementaire assets' factoren zijn die de keuze voor een bepaalde governance bepalen. ${ }^{12}$ Het toeëigeningsregime bestaat uit de effectiviteit van juridische beschermingsmechanismen (voorbeelden zijin patenten en copy rights) en de aard van de technologie. Bij een sterk toeëigeningsregime is een innovatieve technologie eenvoudig te beschermen en behoudt de innovator een voorsprong op imitatoren. Bij een zwak regime is een dergelijke bescherming niet goed mogelijk en kunnen snelle imitatoren zich de opbrengsten van de innovatie toeëigenen. Onder complementaire assets verstaat Teece ondersteunende functies, zoals marketing, produktie, 'after-sales' service, noodzakelijk voor de introduktie en verkoop van de nieuwe technologie op de markt. Deze complementaire assets kunnen een algemeen karakter hebben of specifiek zijn toegespitst op de innovatie. De contractuele samenwerking tussen de inncvator en 'leverancier' van complementaire assets heeft de voorkeur als deze assets een algemeen karakter hebben en sprake is van een sterk toeëigeningsregime; de technologie kan makkelijk worden beschermd. Is echter het spiegelbeeld het geval, de technologie is moeilijk te beschermen en er zijn specifieke complementaire assets vereist, dan is integratie van activiteiten het meest verstandig.

De centrale hypothese dat bij substantiële transactiespecifieke investeringen transactiekosten bij internalisatie of integratie aanmerkelijk lager zijn dan bij marktrelaties wordt door verschillend empirisch onderzoek ondersteund. Monteverdi en Teece (1982a) benadrukken het belang van 'specialized, nonpatentable know-how' in de beslissing de produktie te internaliseren. $\mathrm{Zij}$ vinden een significante relatie tussen verticale integratie en transactiespecifieke technische know-how. In een tweede artikel stellen Monteverde en Teece (1982b) dat zgn. 'vertical quasi-integration' toeëigening van opbrengsten door opportunistisch gedrag kan voorkomen. Verticale quasi-integratie wordt gedefinieerd als de situatie waarin een afnemer bepaalde kapitaalgoederen of essentiële middelen van een toeleverancier bezit. ${ }^{13}$ Masten (1984) analyseert de 'make-or-buy' beslissing van bedrijuen in de vliegtuigindustrie en komt eveneens tot de conclusie dat de mate van 'asset specificity' van grote invloed in op de keuze tussen zelf een component maken of het aankopen op de markt. Anderson en Schmittlein (1984) richten zich op de beslissing marketing-functies al dan niet uit te besteden: een eigen afdeling verkoop of werken met onafhankelijke verkoopagenten. Het blijkt dat een toenemende "human asset specificity' eerder tot integratie leidt.

12 Naası đe factoren 'toeëigeningsregime' en 'complementaire assets' noemt Teece (1986) het 'dominant design paradigma' als derde factor. Hiermee wordt bedoeld dat in het beginstadium van een technologische innovatie de concurrentic tussen bedrijven zich toespitst op een concurrentic tussen ontwerpen. Als uiteindelijk cen bepaald ontwerp dominant is geworden verandert de concurrentie tussen ontwerpen in een prijsconcurrentie. We laten deze factor verder buiten beschouwing omdat de eerste twee genoemde factoren de grootste invloed hebben op de 'make-or-buy' beslissing van een bedrijf.

13 Bij Blois (1972) duidt de term 'vertical quasi-integration' op een lange termijn relatie tussen toeleverancier en afnemer waarbij van de toeleverancier een aanzienlijk deel van de produktie naar die ene afnemer gaat. De toeleverancier zal zich dan ook richten op de specifieke eisen van die afnemer. 
In bovengenoemd empirisch onderzoek staat met name de relatie tussen 'asset specificity' en de 'make-or-buy' beslissing centraal (Joskow, 1988). In later empirisch onderzoek is aangegeven dat bij 'asset specificity' ook lange-termijn contracten vanuit transactiekosten-perspectief een goed alternatief zijn naast 'spot market' transacties. Goldberg en Erickson (1987) richten zich op 'relational contracting' van olieraffinaderijen. Palay $(1984 ; 1985)$ analyseert de ontwikkeling van informele contracten tussen de spoorwegen en schippers. Joskow (1987) gaat in op de duur van contracten tussen kolenleveranciers en electriciteitsbedrijven.

Een tekortkoming van bovengenoemd recent empirisch onderzoek is dat alleen sprake is van een ordinale rangschikking van de efficiency van de alternatieve 'governance structures' (Joskow, 1991). Om tot een goede afweging tussen deze 'governance structures' te komen bestaat echter behoefte aan het kwantificeren van transactiekosten. Probleem is echter dat transactiekosten moeilijk meetbaar zijn. Dit belemmert een 'harde', kwantitatieve toetsing van de hypothesen. Masten et al. (1991) heeft recent een poging gedaan met econometrische technieken op basis van kenmerken van transacties tot een nauwkeurige schatting van de kosten van diverse 'governance structures' te komen. De analyse had betrekking op de 'make-or-buy' beslissing van componenten in de scheepsbouwindustrie. De resultaten van het onderzoek ondersteunden de hypothese dat bij 'temporal specificity' en 'relation-specific human capital' integratie aannemelijk wordt (zie noot 10).

\subsubsection{Overdracht van know-how, de eis van snelheid en wederzijds vertrouwen}

Uit het bovenstaande blijkt dat volgens de transactiekostentheorie van Williamson de mate waarin een transactie wordt ondersteund door transactiespecifieke investeringen een voorname verklaring vormt voor een beweging van markt naar netwerk of hiërarchie. Transactiespecifieke investeringen, in combinatie met een minimalisatie van transactiekosten, zijn blijkbaar een belangrijke factor in de verklaring voor veranderingen van transactiepatronen. In navolging van de kritiek van Powell (1990) op de transactiekostentheorie kunnen naast minimalisatie van transactiekosten nog andere motieven aangegeven worden die tot netwerkvorming leiden, $\mathrm{nl}$. het toenemend belang van overdracht van know-how, de eis van snelheid en wederzijds vertrouwen.

Powell stelt dat de overdracht van meer tastbare goederen over het algemeen plaats vindt op markten of binnen hiërarchieën. Daarentegen kan uitwisseling van meer kwalitatieve zaken beter plaats vinden binnen netwerken. Dit geldt met name voor kennis-intensieve activiteiten die gebaseerd zijn op gespecialiseerde know-how. Knowhow bestaat deels uit 'tacit knowledge', kennis die moeilijk te codificeren en naar anderen te communiceren is (Nelson en Winter, 1982). Een dergelijk 'asset' is moeilijk te 'verhandelen' via de markt of te communiceren via een bedrijfshiërarchie. Een 'asset' als know-how bevindt zich 'in the minds of talented people whose expertise cannot easily be purchased or appropriated and who commonly prefer to ply their trade in a work setting that is not imposed on them "from above" or dictated to them by an outside authority. Indeed, markets or hierarchical governance structures may hinder the development of these capabilities because of the most critical assets - the individuals themselves - may choose to walk away' (Powell, 1990, 324).

Netwerken zijn goed bruikbaar in omstandigheden waar behoefte is aan efficiënte en betrouwbare informatie. Informatie die via de formele hiërarchie naar beneden sijpelt 
of wordt weergegeven door prijssignalen hoeft niet betrouwbaar te zijn. Informatie door netwerken "is "thicker" than information obtained in the market, and "freer" than communicated in a hierarchy' (Powell, 1990, 304). Netwerken creëren mogelijkheden tot leerprocessen. $\mathrm{Zij}$ bieden de mogelijkheid tot het leggen van nieuwe verbanden tussen verschillende soorten kennis en zo tot het ontstaan van nieuwe ideeën (Hakansson, 1987). Daar waar overdracht van know-how aan belang toeneemt ontstaat de behoefte aan netwerkrelaties.

Een tweede motief voor netwerkvorming, dat met overdracht van know-how nauw samenhangt, is de eis van snelheid. Als concurrentie-voorsprong gebaseerd is op het vermogen ontdekkingen en ideeën snel te vertalen in produkten zijn netwerken geschikter đan markt of hiërarchie. In een samenwerking tussen twee bedrijven kan bijvoorbeeld sprake zijn van een 'pooling' van patenten. Feitelijk is een patent niet alleen het recht op een bepaald proces of ontwerp, maar ook het recht op de toegang tot een bepaalde markt. Door over en weer patenten uit te wisselen zijn snellere introdukties van nieuwe produkten op nieuwe markten mogelijk (Contractor en Lorange, 1988). Harrigan (1988) stelt dat samenwerking met name kans van slagen heeft als sprake is van 'partner asymmetry', d.w.z. iedere partner heeft datgene nodig wat de ander kan leveren op het gebied van produktiemiddelen, management etc. Zolang deze situatie bestaat zullen de bedrijven met elkaar blijven samenwerken.

Een voorbeeld is een bedrijf dat veel geïnvesteerd heeft in een bepaalde technologische doorbraak, maar over onvoldoende know-how op het gebied van marketing en produktie beschikt om de nieuwe technologie snel op de markt te brengen. De benodigde complementaire assets voor introduktie en verkoop van de innovatie liggen buiten de 'core business' van de onderneming. Het bedrijf staat voor de keuze deze zelf te produceren of uit te besteden. Hierbij zal het bedrijf zich moeten afvragen in hoeverre de innovatie met bijbehorende specifieke know-how juridisch beschermd wordt als tot 'out-sourcing' wordt overgegaan. 'Out-sourcing runs the risk of creating circumstances whereby innovators are no longer able to profit from innovation, despite the fact that they are highly innovative' (Teece, 1988, 277). Is dit risico groot, dan zal het bedrijf de produktie zelf ter hand nemen door overname of directe investeringen. Bij een klein risico zijn mengvormen van beheersing (bijvoorbeeld joint ventures en franchising) goede alternatieven. Dergelijke samenwerkingsverbanden met andere ondernemingen kunnen een belangrijk hulpmiddel zijn bij een snelle introduktie en terugverdienen van de gedane investering.

Een derde motief voor netwerkvorming is de aanwezigheid van wederzijds vertrouwen. Thorelli $(1986,38)$ heeft vertrouwen gedefinieerd als 'an assumption or reliance on the part of $\mathrm{A}$ that if either $\mathrm{A}$ or $\mathrm{B}$ encounters a problem in the fulfillment of his implicit or explicit transactional obligations, B may be counted on to do if B's resources were at A's disposal'. Zoals gezegd heeft Williamson beargumenteerd dat door opporiunistisch. gedrag in bepaalde gevallen de hiërarchie wordt verkozen boven de markt. Opportunistisch gedrag betekent de afwezigheid van wederzijds vertrouwen en het ontstaan van transactiekosten. Is dit vertrouwen wel aanwezig dan betekent dit dat de noodzaak. wordt weggenomen om niet voorzienbare gevolgen in contracten te specificeren. Gevolg is dat, in de woorden van Williamson (1979, 241), 'idiosyncratic exchange relations, which feature personal trust will survive greater stress and display greater adaptability'. Beslissers durven openlijk met elkaar informatie uit te wisselen en hoeven zich niet in te dekken tegen opportunistisch gedrag. 
Axelrod (1984) heeft aangegeven dat personen die weten dat men ook in de toekomst met elkaar zal samenwerken, zich eerder coöperatief zullen opstellen en niet coöperatief gedrag afstraffen. Door nadruk te leggen op het continue karakter van een relatie en de aanwezigheid van 'forbearance', verdraagzaamheid, ontwikkelt zich een wederzijds vertrouwen. Dit wederzijds vertrouwen ontmoedigt opportunistisch gedrag hetgeen een beperkte behoefte aan hiërarchische controle-mechanismen tot gevolg heeft (Jarillo, 1988). Een bedrijf is zich bewust van het feit dat het slechter af is bij opportunistisch gedrag. Betrouwbaarheid en kwaliteit worden belangrijke 'assets' van bedrijven die regelmatig met elkaar zaken doen. Een betrouwbare reputatie opbouwen is te beschouwen als een investering en vereist in bepaalde gevallen van een bedrijf dat het afziet van voordelen op de korte termijn (Buckley en Casson, 1988).

\subsection{Toepassing van integrale logistiek en verandering in transactiepatronen}

In de vorige hoofdstukken hebben we gezien dat voor toepassing van integrale logistiek wederzijdse technologische en organisatorische aanpassingen van ondernemingen noodzakelijk zijn. Deze aanpassingen en veranderingen in relaties zijn niet direct in te passen in de klassieke economische tweedeling van markt of hiërarchie. We duiden deze veranderingen dan ook aan als het ontstaan van logistieke netwerken. Concepten uit de twee theoretische invalshoeken, de transactiekosten-benadering en theorieën over netwerken, kunnen worden gebruikt om aan te geven onder welke voorwaarden deze logistieke netwerkvorming ontstaat.

\subsubsection{Toepassing van integrale logistiek en transactiespecifieke investeringen}

In de transactiekostentheorie van Williamson zijn het met name efficiency-argumenten die bepalen of een verandering van transactiepatronen optreedt. Deze theorie voorspelt dat vooral transactiespecifieke investeringen tot een overgang van markt naar netwerk zullen leiden.

Bij toepassing van integrale logistiek zijn bedrijfsoverstijgende informatiesystemen een voorbeeld van transactiespecifieke investeringen. Dit heeft te maken met het feit dat in dit stadium van technologische ontwikkeling veel bedrijfsoverstijgende informatiesystemen een gemeenschapskarakter hebben en dus min of meer gesloten zijn. ${ }^{14}$ Men kan slechts binnen (een deel van) de bedrijfstak met elkaar communiceren (zie \& 3.3). Met de transactiekostentheorie is het mogelijk aan te geven hoe implementatie van deze informatiesystemen tot een verandering van transactiepatronen tussen ondernemingen leidt.

Men kan een verband leggen tussen verschillende verschijningsvormen van bedrijfsoverstijgende informatie-systemen en de mogelijke invloed van deze systemen op de transactiepatronen (Ribbers, 1991). De verschijningsvorm van de gehanteerde informatiesystemen bepaalt in sterke mate de transactiespecificiteit van investeringen in deze systemen. Met name investeringen in gemeenschappelijke en gesloten informatie-

${ }^{14}$ In termen van Teece (1986) zijn deze informatiesystemen te beschouwen als complementaire assets die zich nog in de 'pre-paradigmatische fase' bevinden, dat wil zeggen dat er nog geen algemeen geaccepteerde en dominante communicatie-standaard voor deze systemen is uitgekristalliseerd. 
systemen hebben een transactiespecifiek karakter. Deze investeringen zijn gericht op de realisering van transacties met bepaalde toeleveranciers of afnemers. De specificiteit heeft betrekking op de IT-gerelateerde investeringen in koppelingen tussen afnemer en leverancier. Indien de informatiesystemen volledig open zijn en iedereen kan participeren is van transactiespecifieke investeringen niet of nauwelijks sprake.

Het bestaan van min of meer gesloten gemeenschapssystemen dwingt potentiële deelnemers te overwegen voor welk systeem zal worden gekozen. De lange terugverdienperiode van een investering in een gemeenschapssysteem betekent dat actoren, die gekozen hebben voor een bepaald systeem, voor een zekere periode in meer of mindere mate 'locked in' raken. Dit is met name het geval indien bedrijven niet het financiële draagvlak hebben om voorzieningen te treffen voor een ander systeern. Deze bedrijven kunnen niet of aanzienlijk moeilijker ruilhandelingen verrichten met bedrijven die gebruik maken van een ander systeem. Zou men dit toch willen, dan brengt dit zgn. 'switching costs' met zich mee. Min of meer gesloten gemeenschapssystemen kunnen ook een toetredingsdrempel vormen voor 'externe' partijen. Voor ondernemingen dreigt dus zowell het geval 'locked in' te zijn als 'locked out' te worden.

Een voorbeeld van transactiespecifieke investeringen in bepaalde informatiesystemen is de implementatie van CAD-systemen (Nooteboom, 1992). Overdracht van informatie via $C A D$ tussen een afnemer en een leverancier vergt van de leverancier gebruik van een CAD-systeem dat compatibel is met dat van de afnemer. Als het CAD-systeem uniek is voor die afnemer, is de investering voor de leverancier transactiespecifiek. De leverancier dreigt hierdoor 'locked in' te raken omdat er omschakelingskosten verbonden zijn met de overgang naar een andere afnemer. Dit 'locked in' raken geldt echter ook voor de afnemer in het geval de leverancier de enige is die de gewenste CADverbinding kan of wil bieden. Een bekend voorbeeld, dat lijkt op laatstgenoemde situatie, is het geval van American Hospital Supplies (AHS). Deze groothandelaar makte zijn afnemers afhankelijk door als eerste een geautomatiseerd bestelsysteem met terminals in de ziekenhuizen te bieden. Na installatie en implementatie (opleiding, ervaring) van dat systeem waren er omschakelingskosten verbonden aan de stap naar andere leveranciers.

Bij investeringen die zich kenmerken door een hoge transactiespecificiteit leidt volgens de transactiekostenbenadering verticale integratie tot een minimalisatie van de transactiekosten. Dit kan de reden zijn voor het ontstaan van de organisatie-vorm die wij in hoofdstuk 2 hebben aangeduid als de verticale actor. Waar gebruik wordt gemaakt van gesloten informatiesystemen is de komst van een verticale actor waarschijnlijker dan daar waar gebruik wordt gemaakt van wereldwijde standaards. De hoge transactiespecificiteit van eerstgenoemde systemen kan tot gevolg hebben dat (bepaalde delen van) logistieke functies van verschillende ondernemingen in een nieuwe organisatie geïntegreerd worden. Gevolg is het ontstaan van een nieuwe hiërarchie.

Zoals gezegd zijn investeringen in informatiesystemen transactiespecifiek indien deze systemen een meer gesloten karakter hebben. Gevolg is de beweging van markt naar een zekere netwerkvorming. Deze opvatting staat haaks op die van Malone et al. (1987). Zij stellen dat door nieuwe informatietechnologie hiërarchische coördinatievormen van toeleverings- en afnemersrelaties door electronische markten worden vervangen. Theoretische basis voor deze stelling is eveneens de transactiekostentheorie. De auteurs stellen dat informatietechnologie tot een daling van de coördinatiekosten 
leidt. Deze kosten hebben o.a. betrekking op uitwisseling en verwerking van informatie. Een tweede argument is dat informatietechnologie twee specifieke factoren beïnvloedt: 'complexity of product description' en 'asset specificity'.

Informatietechnologie maakt het ten eerste mogelijk complexe produkt omschrijvingen eenvoudiger naar de markt toe te communiceren. Gevolg is een 'vertical disintegration'. Het voorbeeld dat Malone et al. (ibid) geven is het reserveringsysteem van luchtvaartmaatschappijen. Vroeger kon alleen gereserveerd worden bij een afdeling van een specifieke luchtvaartmaatschappij. Door informatietechnologie is reservering een aparte branche geworden die met luchtvaartmaatschappijen marktrelaties onderhoudt. Ten tweede vermindert informatietechnologie 'asset specificity'. Hiermee doelen Malone et al. op flexibele produktietechnologieën. Door deze technologieën is het mogelijk voor kleine markten specifieke componenten te produceren zonder hoge omstelkosten. Produktie van bepaalde componenten vereist minder 'asset specificity'.

De argumentatie van Malone et al. ziet echter complexe afstemmingsprocessen over het hoofd en overschat de tegenwoordig beschikbare mate van technische standaardisering. Daardoor onderschatten zij de betekenis van gemeenschapssystemen. In veel gevallen zal door gemeenschapssystemen alleen geen nieuwe markt ontstaan. Veel meer worden op reeds bestaande markten vormen van direct persoonlijke of schriftelijke communicatie door electronische berichtuitwisseling vervangen.

\subsubsection{Toepassing van integrale logistiek en de overdracht van know-how, de eis van snelheid en wederijds vertrouwen}

Toepassing van integrale logistiek kan ook een poging zijn om aan andere eisen te voldoen dan alleen transactiekostenminimalisatie. Het is daarom van belang een theoretische invalshoek te nemen die andere notieven aangeeft ter verklaring van veranderende transactiepatronen. Genoemde netwerktheorie, of aanzetten daartoe, van Powell (1990) is zo'n invalshoek. Powell beweert dat netwerken ontstaan indien bij transacties tussen bedrijven overdracht van know-how, snelheid en wederzijds vertrouwen van toenemend belang worden. Deze factoren leiden ertoe dat transactiepatronen veranderen van markt naar netwerk. Bij toepassing van integrale logistiek zijn deze factoren vooral van belang bij het streven naar produiktontwvikkeling en -kwaliteit.

Strategische voordelen van samenwerkingsverbanden zijn de toegang tot nieuwe markten en de ontwikkeling van nieuwe produkten (Porter en Fuller, 1986). Nieuwe produkten ontstaan vaak daar waar verschillende disciplines over en weer informatie en knowhow uitwisselen. Hakansson stelt (1987, 3): 'An innovation, therefore, should not be seen as the product of only one actor but as the result of an interplay between two or more actors; in other words as a product of a 'network' of actors'. Om tot een dergelijke 'pooling' van know-how te komen gaan bedrijven allerlei samenwerkingsverbanden met elkaar aan. Men verwacht door het bijeen brengen van verschillende soorten kennis en ervaring tot produktinnovatie te kunnen komen (Contractor en Lorange, 1988). Een speciaal geval is de uitwisseling tussen toeleverancier en afnemer: '...the needs of the buyer are confronted with the possible technical solutions known by the seller. This provides an opportunity to revise and redefine both the needs and the solutions and in this way find new possibilities' (Hakansson, 1987, 4). 
Dit laatste is in toenemende mate het geval. Uitbesteders gaan steeds meer een beroep doen op kennis en know-how bij toeleveranciers ten aanzien van produktontwikkeling. Toeleveranciers brengen hun unieke produkt en produktie know-how in bij het meedenken met hun afnemers. Door oog te hebben voor de maakbaarheid, monteerbaarheid en de logistiek van produkten kan deze inbreng tot aanzienlijke kostenbesparingen leiden. Niet alleen de ontwikkeling van een nieuw produkt, ook de verdere inpassing daarvan in bestaande bedrijfsprocessen vereisen aanpassingen en leerprocessen binnen en tussen ondernemingen. Met name bij complexe technologische en organisatorische aanpassingen is overdracht van know-how van groot belang. Naarmate de gewenste processen sterker afwijken van de bestaande, zal meer behoefte bestaan aan externe informatie, d.w.z. informatie van buiten de onderneming. In dat geval kunnen kennis en informatie beter in netwerken worden overgedragen dan via marktrelaties (Powell, 1990). Daarnaast kan een onderneming actief zijn op een markt waar snel opeenvolgende innovaties van produkt en technologie plaats vinden. Op een dergelijke markt is het reactievermogen van de onderneming van groot belang. Uitwisseling van kennis en ervaring in netwerken kan dit reactievermogen aanzienlijk vergroten.

Uitbesteders vertalen het op de eindmarkt gevraagde hogere kwaliteitsniveau in hogere eisen aan de toeleverancier. De uitbesteder wil de kwaliteit van kritische bedrijfsprocessen gewaarborgd zien door middel van certificering en inzicht in de kwaliteit van ontwikkelings- en produktie-processen bij toeleveranciers. Indien de produkt en produktie know-how voornamelijk bij de afnemer ligt dan kan deze van de toeleveranciers de invoering van bepaalde kwaliteitssystemen vereisen. Toeleveranciers worden dan mede onder druk van hun afnemers verplicht tot produkt- en procescertificering. Omgekeerd wordt de toeleverancier betrokken bij het ontwerpproces van de uitbesteder van geavanceerde anderdelen, wasdbor naast functioneic eisen ook de 'maakbaarheid' in het ontwerp wordt meegenomen. Door deze wederzijdse betrokkenheid, gericht op een toenemende kwaliteit van produkt en produktieproces, verschaft men inzicht in elkaars organisaties en werkwijzen. Toeleveranciers worden zo mede verantwoordelijk voor de kwaliteit van het eindprodukt. Overeenkomsten over de te gebruiken kwaliteitssystemen en betrokkenheid van toeleveranciers bij produktontwikkeling hetekenen dat bepaalde onzekerheden tussen partijen worden weggenomen en een vertrouwensrelatie kan worden opgebouwd.

Hakansson (1987) wijst erop dat het innovatief vermogen versterkt wordt als onafhankelijke markipartijen streven naar meer duurzame relaties. Van de andere kant hebben Piore en Sabel (1984) aangegeven dat flexibiliteit en innovatief vermogen bereikt kan worden door de 'governance' van een hiërarchie te vervangen door kleine onafhankelijke produktie-eenheden waarvan de onderlinge relaties gekenmerkt worden door wederzijds vertrouwen. In het eerste geval is sprake van een beweging van markt naar netwerk, in het tweede geval van hiërarchie naar netwerk. In beide gevallen geldt dat het gedrag van bedrijven niet meer gebaseerd is op het streven naar winst op de korte termijn, maar gericht op het verkrijgen van opbrengsten uit een serie van transacties. Partijen zijn bereid specifieke en betrouwbare informatie uit te wisselen. Hierdoor ontvangt men informatie die niet altijd via de markt te verkrijgen is. Een dergelijk strategisch gedrag, gebaseerd op duurzame samenwerkingsrelaties, maakt een meer op kwaliteit gerichte concurrentie mogelijk.

Miles en Snow (1986) geven aan dat de eisen van snelheid en innovatieve produkten tot een nieuw type organisatie van bedrijfsprocessen leidt dat zij aanduiden als het 
'dynamisch netwerk' (zie figuur 4.2). ${ }^{15}$ Het dynamisch netwerk bestaat uit steeds wisselende combinaties van zelfstandige bedrijven als ontwerpers, aanbieders, producenten en distributeurs. In een dergelijk. netwerk spelen 'brokers', bedrijven die de leiding nemen bij het op elkaar afstemmen van verschillende bedrijven, een belangrijke rol. 'Because each function is not necessarily part of a single organization, business groups are assembled by or located through brokers. In some cases, a single broker plays a lead role and subcontracts for needed services. In other cases, linkages among equal partners are created by various brokers specializing in a particular service. In still others, one network component uses a broker to locate one or more other functions' (ibid, 64).

De bedrijfsoverstijgende coördinatie door een dergelijke 'broker' gaat niet ten koste van de flexibiliteit. Deze wordt gewaarborgd door het bestaan van marktrelaties tussen de verschillende actoren. Zoals gezegd, kunnen bij toepassing van integrale logistiek delen van de logistieke functie van bedrijven gecoördineerd worden door een nieuwe hiërarchie, de verticale actor. Het is deze verticale actor die de 'broker' functie in het logistieke netwerk vervult.

FIGUUR 4.2 Het dynamisch netwerk

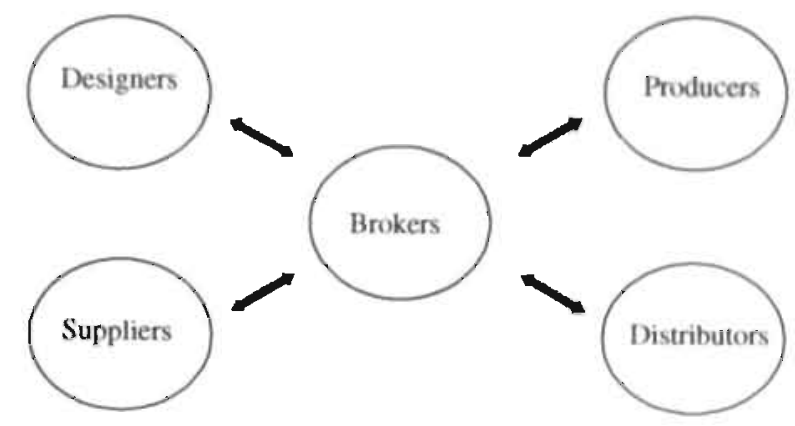

Bron: Miles en Snow $(1986,65)$.

Wanneer we de inzichten uit bovengenoemde theorieën toepassen op de ontwikkelingen in de logistiek, dan kunnen we het volgende vaststellen. Toepassing van integrale logistiek leidt tot een versterking van het 'netwerk' karakter van de relaties tusssen ondernemingen in een keten. Dit 'netwerk' karakter kan zich ten eerste voordoen in samenhang met. transactiespecifieke investeringen. Deze hebben bij toepassing van integrale logistiek met name betrekking op bedrijfsoverstijgende informatiesystemen. Naarmate de transactiespecifieke investeringen bij toepassing van integrale logistiek in een bepaalde keten hoger zijn, is de kans op het ontstaan van een nieuwe hiërarchie

${ }^{15}$ Miles en Snow $(1986 ; 1992)$ onderscheiden naast het dynamische netwerk ook het stabiele en het interne netwerk. In een stabiel netwerk onderhoudt een kernbedrijf relaties met cen beperkt aantal zorgvuldig geselecteerde toeleveranciers of afnemers. Van een intern netwerk is sprake als ontwerp-, fabricage-, distributie- en andere afdelingen binnen een bedrijf marktrelaties met elkaar aangaan. 
groter. De beweging gaat dan in de richting van wat we hierboven de 'verticale actor' genoemd hebben. Daarnaast leggen motieven als het toenemend belang van overdracht van know-how, de eis van snelheid en wederzijds vertrouwen de basis voor logistieke netwerkvorming. 


\section{Rationalisering van bedrijfsprocessen}

Rationalisering van bedrijfsprocessen is onderdeel van een lange termijn ontwikkeling die door Weber (1976) wordt aangeduid als het rationaliseringsproces van samenleving en economie (Brubaker, 1984; Littek et al., 1983; Sombart, 1929). Dit rationaliseringsproces ligt volgens Weber ten grondslag aan de structuur van de arbeidsdeling in de westerse samenleving en heeft tot gevolg dat ondernemingen naar 'rationeel model' georganiseerd worden. De ontwikkelingen die wij als toepassing van integrale logistiek omschreven hebben, zijn door anderen geplaatst in het kader van deze rationaliseringsbeweging. Zij spreken van 'een nieuw type rationalisering'. In dit hoofdstuk onderzoeken wij de literatuur over rationalisering vanuit dit perspectief.

Het doel van dit hoofdstuk is om kenmerken en mogelijke gevolgen van toepassing van integrale logistiek voor de organisatie van produktieprocessen in kaart te brengen. Op deze wijze wordt ingegaan op de tweede centrale onderzoeksvraag van deze studie zoals geformuleerd in hoofdstuk 1 . In $\$ 5.1$ worden eerst algemene kenmerken van het rationaliseringsproces aangegeven. Vervolgens komen twee rationaliseringstypen van bedrijfsprocessen aan de orde. Paragraaf 5.2 zet het eerste model van rationalisering, het Taylorisme, uiteen. In $\$ 5.3$ worden vervolgens factoren aangegeven die ertoe hebben geleid dat het Tayloristische rationaliseringstype niet meer voldoet. Er lijkt een nieuw type rationalisering zijn intrede te doen. Paragraaf 5.4 gaat op de contouren van dit nieuwe rationaliseringstype in. Paragraaf 5.5 geeft aan op welke wijze de organisatie van bedrijfsprocessen verandert bij het nieuwe rationaliseringstype. In $\$ 5.6$ wordt met de rationaliseringstheorieën aangegeven wat eigenschappen en gevolgen van toepassing van integrale logistiek zijn.

\subsection{Rationalisering en economie}

\subsubsection{Het begrip rationalisering}

Rationalisering is een term die verwijst naar een geheel van samenhangende processen dat zich binnen de westerse samenleving voordoet (Brubaker, 1984): de toenemende betekenis van gespecialiseerde kennis, een depersonificatie of 'Versachlichung' van sociale relaties en een verfijning, van calculatietechnieken. Het doel van rationalisering is het bereiken van een grotere voorspelbaarheid en berekenbaarheid van sociale en natuurlijke processen. Het is dit geheel van samenhangende processen dat volgens Weber de specifieke rationaliteit van de westerse samenleving kenmerkt. Rationaliteit wordt door hem in de meest brede zin gedefinieerd als het kiezen van bepaalde middelen om een specifiek doel te bereiken. ${ }^{1}$

${ }^{1}$ Deze vage definiêring van rationaliteit leidt ertoe đat gebruik van dit begrip verre van cenduidig is. Brubaker onderscheidt. bij Weber maar liefst zestien verschillenđe betekenissen $(1984,2)$ : '...deliberate, systematic, calculable, impersonal, instrumental, exact, quantitative, rule-governed, predictable, methodi- 
Weber makt een belangrijk verschil tussen formele en substantieve rationaliteit. Formele rationaliteit verwijst naar de berekenbaarheid van middelen en procedures, substantieve rationaliteit heeft betrekking op de waarde (vanuit een specifiek standpunt) van gewenste doelen of resultaten. Indien men de berekenbaarheid van processen wenst te maximaliseren dan kunnen ongeacht het doel, kapitalisme, wetenschap en technologie zeer rationeel zijn. Deze rationaliteit kan echter op gespannen voet staan met substantieve rationaliteit, rationaliteit vanuit een specifieke waarde of doel. Het geheel van processen dat betrekking heeft op de rationalisering van de westerse samenleving is nauw gerelateerd aan formele rationaliteit, het type rationaliteit dat berekenend handelen stimuleert gericht op welk doel dan ook. Het is volgens Weber deze neutraliteit ten opzichte van waarden en doelen die de moderne Westerse samenleving kenmerkt. Op drie aspecten van het rationaliseringsproces wordt hier nader ingegaan.

Het eerste aspect van de westerse rationaliteit is het toenemend belang van kennis. Vanuit een aantal invalshoeken geeft Weber het toenemend belang van kennis in de moderne samenleving aan. Ten eerste leidt de groeiende complexiteit van het technische en economische systeem tot een vraag naar gespecialiseerde kennis ('Fachwissen'). Deze vraag bepaait ten tweede het karakter van het onderwijssysteem. Dit systeem richt zich volgens Weber steeds meer op vorming van gespecialiseerde technische experts ('Fachmensch') en minder op de algemene ontwikkeling van individuen. Ten derde heeft de opkomst van moderne wetenschap geleid tot een 'onttovering', een 'demystificatie' van het wereldbeeld. Dit proces leidt ertoe dat mensen geen geloof hechten aan bovennatuurlijke krachten en meer doelrationeel gaan handelen. Kennis wordt van groter belang omdat individuele handelingen meer dan voorheen zijn gebaseerd op bewuste reflectie en berekening.

Het tweede aspect van het proces van rationalisering is wat Weber de 'Versachlichung der Gewaltherrschaft', de depersonificatie of objectivering van gezagsstructuren, noemt. Zowel in het economische als het politieke leven wordt deze depersonificatie waargenomen.

In het politieke leven is gezag onderworpen aan een 'allgemeine Versachlichung'. Weber's typologie maakt onderscheid tussen gezag dat is verkregen op grond van traditie en charisma en gezag op grond van onpersoonlijke procedures. In de moderne samenleving verkrijgt men gezag door laatstgenoemde procedures te volgen. Het functioneren van dit politieke systeem is typisch voor de westerse samenleving. Introductie van het kapitalisme heeft tot gevolg dat in het economisch leven de onpersoonlijke wetten van de markt het gedrag van actoren gaan bepalen. Deze 'Versachlichung' en de daarmee samenhangende objectivering en depersonificatie is ook gekoppeld aan de westerse 'Berufsethik': '...ohne Haß und deshalb ohne Liebe, ohne Willkür und deshalb ohne Gnade, als sachliche Berufspflicht und nicht kraft konkreter persönlicher Beziehung erledigt der homo politicus ganz ebenso wie der homo economicus heute seine Aufgabe...' (Weber, 1976, 361).

Het thema van toenemende beheersing van individuen en objecten, het derde aspect van het geheel van rationaliseringsprocessen, speelt in alle discussies over rationalisering een belangrijke rol. Effectieve beheersing over mens en natuur is gebaseerd op

cal, purposeful, sober, scrupulous, efficacious, intelligible and consistent.' 
berekenbaarheid. De reikwijdte van de beheersing van sociale en natuurlijke processen neemt in de westerse samenleving voortdurend toe en dringt in ieder aspect van het leven door. Weber houdt zich met name bezig met de toenemende beheersing van arbeid in ondernemingen en andere 'bureaucratieën'.

Processen van rationalisering vinden in vele geledingen van de samenleving plaats: in de economie, de rechtspraak en het bestuur. In deze institutionele sferen gaat rationalisering gepaard met een depersonificatie van machtsstructuren en een toenemende beheersing van maatschappelijke processen. De kapitalistische organisatie-vorm is het voorbeeld van een rationalisering van de economie waarbij efficiency de drijvende kracht is. Dit efficiency-streven leidt volgens Weber tot een arbeidsdeling waarbij werk zo georganiseerd is dat deze bijdraagt tot een optimale produktiviteit en winst voor de ondernemer.

De drie aspecten van rationalisering zijn nauw met elkaar verweven. Toenemende (wetenschappelijke) kennis maakt een verdere rationale beheersing van sociale en natuurlijke processen mogelijk. Deze beheersing gaat gepaard met een 'Versachlichung' van sociale relaties.

\subsubsection{Kapitalisme en rationalisering}

Kenmerkend voor transacties en organisaties, binnen het kapitalisme is hun doelrationaliteit. Aan deze diagnose ligt Weber's typologie van verschillende handelingsoriëntaties ten grondslag.

Volgens Weber zijn er vier handelingsoriëntaties te onderscheiden: (1) doel-rationeel handelen ('zweck-rational'), handelen met het oog op een gericht doel, (2) waarderationeel handelen ('wert-rational'), handelingen op basis van ethische, politieke of religieuze waarden, (3) handelen op basis van affecties en emoties, (4) traditioneel handelen, handelen uit gewoonte (Weber, 1976). Doel-rationeel handelen vormt het hart van het kapitalisme. In markttransacties en organisaties wordt dit kenmerk van het kapitalistisch systeem teruggevonden. Op beide wordt hier kort ingegaan.

Het marktgedrag is gebaseerd op doel-rationeel, berekenend handelen. Volgens Weber is de markt 'der [Archo-] Typos alles rationalen Gesellschaftshandelns' (Weber, 1976, 382). Markttransacties worden uitsluitend door "Interesse an den Tauschgütern" (383) gekarakteriseerd. Markten zijn in negatieve zin rationeel omdat ze idealiter vrij zijn van handelingen gebaseerd op tradities en emoties. Markten zijn in positieve zin rationeel omdat op markten uitsluitend 'zweck-rational' handelen plaats vindt, gebaseerd op de gegeven mogelijkheden om optimale transacties af te sluiten. Actoren handelen op basis van vooraf gemaakte calculaties die tot een maximalisatie van het eigen voordeel moeten leiden. In het voorgaande hoofdstuk is aangegeven dat in de transactiekostentheorie van Williamson dit type handelen één van de veronderstellingen is.

Rationalisering van de economie heeft tot gevolg dat de onderneming naar rationeel model georganiseerd wordt. Kenmerken van dit rationele of, zoals Weber het noemt, bureaucratische model zijn doelgerichtheid en formalisme (Scott, 1987). Maximale. berekenbaarheid en disciplinering is mogelijk door middel van deze organisatie-vorm. Het in de volgende paragraafi te bespreken Tayloristische organisatie-model is hier een voorbeeld van. 
Het eerste kenmerk van de organisatie naar rationeel model is doelgerichtheid. De organisatie-structuur is een middel gericht op het zo efficiënt bereiken van een specifiek doel. Volgens Etzioni $(1964,3)$ zijn 'organizations ... social units (or human groupings) deliberately constructed and reconstructed to seek specific goals.' Het rationele model van de organisatie is 'the social arrangement of people into a production-machine to achieve a specifically chosen end or goal...' (Krause, 1982, 45). Activiteiten en interacties van participanten worden centraal gecoördineerd om de specifieke doelen op een efficiënte wijze te realiseren.

Naast doelgerichtheid is formalisme een tweede kenmerk van het rationele model van de organisatie. De organisatie wordt volgens het rationeel model beheerst door formele en abstracte regels. Deze regels definiëren de gezagsrelaties, rechten en plichten bij de verschillende posities en procedures ter uitvoering van deze rechten en plichten. Deze formalisering van de organisatie-structuur tracht door standaardisatie en regulering gedrag meer voorspelbaar te maken. Doel is de vorming van "..stable expectations by each member of the group as to the behavior of the other members under specified conditions. Such stable expectations are an essential precondition to a rational consideration of the consequences of action in a social group' (Simon, 1957, 100).

De rationele organisatie functioneert als een mechanisch geheel. Snelheid, duidelijke gezagsrelaties en afgebakende taken voor de verschillende rollen in de organisatie maken een optimale beheersing mogelijk. De structuur van de organisatie is rationeel in die zin dat regels ervoor zorgen dat individuen zich zo gedragen dat de berekende doeleinden ook inderdaad gehaald worden (Scott, 1987). In het rationele model vereist deze wijze van beheersing centralisering van besluitvorming.

Weber onderscheidt een aantal instituties die het in de westers samenleving mogelijk maken tot een optimale berekenbaarheid van het produktieproces en een onderneming georganiseerd naar rationeel model te komen (Brubaker, 1984). Ten eerste beheerst de ondernemer de produktie-middelen. Alleen bij een centrale beheersing daarvan kan de ondernemer er zeker van zijn dat gewenste prestaties geleverd worden. Dit veronderstelt een 'Expropriation des einzelnen Arbeiters vom Besitz der sachlichen Beschaffungsmitteln' (Weber, 1976, 77). Voor Weber is deze 'Expropriation' van het individu vañ materiële middelen niet alleen karakteristiek voor de kapitalistische onderneming. Het is ook een aspect van de moderne staat, het leger, de kerk en de universiteit. Technische kennis is een tweede factor waarvan de berekenbaarheid en beheersing van het produktieproces afhankelijk is. Effectieve beheersing van produktiemiddelen vereist aanwezigheid van gespecialiseerde kennis. Met name praktische toepassing van natuurwetenschappelijke kennis speelt hierbij een belangrijke rol. Een derde factor die optimale beheersing van het produktie-proces mogelijk maakt is het systeem van formeel vrije arbeid en een gedisciplineerde beheersing van de werknemers door de ondernemers. We spreken van formeel vrije arbeid omdat deze meestal genoodzaakt is arbeidsvermogen te verkopen op de markt om in zijn levensonderhoud te voorzien.

\subsection{Het Taylorisme}

De ideeën van F.W. Taylor, de grondlegger van het 'scientific management' in het begin van deze eeuw, complementeren de ideeën van Weber. Ondanks zijn nadruk op rationaliteit in de onderneming, ging Weber niet expliciet in op de rol van het mana- 
gement daarbij. Daarentegen ontwerpt Taylor een aantal methoden die juist gericht zijn op een 'wetenschappelijk' management van de organisatie. Taylor tracht via werkmethodenonderzoek en tijdsstudies tot het opstellen van prestatienormen te komen. Met deze normen kunnen arbeidsprestaties zo objectief mogelijk beoordeeld worden. Daaraan worden prestatiebeloningsmethoden gekoppeld, gericht op verhoging van de arbeidsproduktiviteit (Botter, 1984). Het Taylorisme kan als een rationalisering van bedrijfsprocessen worden aangeduid. Kennis van het arbeidsproces wordt gebruikt voor het tot stand brengen van een 'Versachlichung' van gezagsrelaties en een beheersing van arbeidsactiviteiten.

Ten eerste wil Taylor met 'wetenschappelijke' methoden tot een 'Versachlichung' van gezagsrelaties binnen de onderneming komen. Met behulp van deze methoden tracht Taylor beheersing van produktie-middelen niet meer door traditionele gezagsrelaties maar door 'objectieve' procedures te laten plaatsvinden. Hij probeert het voortdurend touwtrekken tussen arbeiders en management om tot door beide geaccepteerde prestaties te komen op een kwantitatief-normatieve grondslag te brengen. Daarmee wil Taylor af komen van de gewoonte om prestaties (en daarmee het loon) gevoelsmatig en via onderhandeling tot stand te laten komen. Met behulp van tijd- en werkmethodenstudies kunnen objectieve en wederzijds aanvaardbare normen voor het werk worden opgesteld en op basis daarvan tot een acceptabele taakstelling en beloning worden gekomen. Door dit streven naar objectieve regels en procedures kan gezegd worden dat Taylor bijgedragen heeft tot de bureaucratisering van de onderneming.

Het Taylorisme komt ten tweede neer op een volledige beheersing van de feitelijke uitvoering van iedere arbeidsactiviteit. Arbeid wordt als een passieve produktie.factor beschouwd. Van de arbeidskracht die een werknemer kan leveren, kan pas optimaal gebruik worden gemaakt wanneer alle beslissingen, die in een arbeidsproces moeten worden genomen, worden beheerst. Taylor's doel was om iedere vorm van beheersing van werknemers over de produktie - 'soldiering' genaamd - weg te nemen. Daarbij onderscheidt hij 'natural' en 'systematic soldiering'. 'Natural soldiering' is de 'the natural instinct and tendency of men to take it easy' (Taylor, 1903, 30, in: Littler, 1982, 51). 'Systematic soldiering' heeft betrekking op activiteiten van de werknemer die maximalisering van eigen belang en het streven naar werkzekerheid tot doel hebben. Om de problemen, die hiermee gepaard gaan, op te lossen introduceert Taylor managementprincipes gericht op arbeidsdeling en centralisering van de beheersingsmacht (Littek et al., 1983; Littler, 1982).

Het eerste principe van Tayloristische rationalisering is de bepaling van de meest economische wijze van de arbeidshandelingen. Beheersing van tijds- en bewegingsaspecten kan tot een verdere opdeling van taken en intensivering van het gebruik van arbeidskracht leiden. Een tweede principe is de toewijzing van arbeidsplaatsen, waarbinnen de arbeidstaken zijn vastgelegd, aan de meest geschikte werknemers. Met de beheersing van recrutering van arbeiders en de vorm van arbeidsplaatsen kan het management binnen bepaalde grenzen het kwalificatie-niveau bepalen. Een derde principe is de beheersing van de beloningsstructuur. Een vierde principe is de scheiding tussen planning en uitvoering van de arbeid. Door deze scheiding is een centralisering van de beheersingsmacht mogelijk. Die komt bij de leiding van de onderneming te liggen. Deze beheersingsmacht kan tijdsvolgorde, vorm en methode van het arbeidsproces tot op zeer gedetailleerd niveau besturen en beheersen. 
Volgens Braverman (1974) kan het Taylorisme gezien worden als het onafhankelijk maken van het arbeidsproces van de kwalificaties van de werknemers door de scheiding tussen denkwerk en uitvoering en de gebruikmaking van het kennismonopolie ter beheersing van iedere stap in het arbeidsproces en wijze van uitvoering daarvan. Een degradatie van de arbeid is volgens hem een gevolg. Ambachtelijk werk en geschoolde arbeid degraderen tot ongeschoold werk en beslissingsmogelijkheden en vrije speelruimte worden bij de uitvoering van arbeid overgeheveld naar bazen en de werkvoorbereiding.

Met de specifieke Tayloristische arbeidsdeling en beheersingsstructuur worden twee problemen ondervangen waarmee volgens Braverman (1974) werkgevers in het algemeen geconfronteerd worden. Ten eerste is de werkgever genoodzaakt de kosten van arbeid te minimaliseren om winst te maximaliseren. Een arbeidsdeling die met 'deskilling' gepaard gaat maakt dit mogelijk. Een tweede probleem is dat werkgevers bij de aankoop van arbeid ervoor moeten zorgen dat bepaalde arbeid daadwerkelijk geleverd wordt. Met een Tayloristische beheersingsstructuur, centralisering van de beheersingsmacht, wordt ook dit probleem ondervangen.

Het Taylorisme is het prototype van rationalisering van produktieprocessen (Littler, 1982). Het richt zich op een systematische analyse van het arbeidsproces en de arbeidscleling op basis van verschillende principes. Daarbij staat centraal dat het voor een goede bedrijfsvoering absoluut noodzakelijk is werknemers precies op te dragen op welke wijze werk verricht moet worden. Weber noemt het 'scientific management' van Taylor als het voorbeeld van disciplinering en beheersing op basis van kennis.

De inzichten van Taylor zijn op diverse wijzen verder uitgewerkt. Eén van de bekendste uitwerkingen van het Taylorisme is het Fordisme (Mathews, 1989). Innovaties die Ford in zijn produktieprocessen doorvoerde waren direct beïnvloed door het Taylorisme. De arbeidsorganisatie van het Fordisme gaat gepaard met een sterke arbeidsdeling, een hoge graad van mechanisatie en werk. aan de lopende band. Het Fordisme is te beschouwen als Taylorisme in massaproduktie. Het Fordisme werd in de jaren '20 voor het eerst in de V.S. ingevoerd en verspreidde zich vervolgens naar Europa en Japan. leder land ontwikkelde een eigen variant op het Fordisme. Niet iedere industrie was in stant Fordistische principes te implementeren. In de bouw- en procesindustrie en de dienstensector zijn deze principes op minder grote schaal ingevoerd. Men name in de industrie was en is het Fordisme nog steeds een dominant organisatie-model.

Het Taylorisme en Fordisme hebben jarenlang model gestaan voor rationalisering van hedrijfsprocessen. In de volgende paragraaf wordt op ontwikkelingen ingegaan die een breukloze voortzetting van dit traditionele rationaliseringstype in de weg staan.

\subsection{Crisis van het Tayloristisch model}

Het Taylorisme is lange tijd het voorbeeld van rationalisering van produktie-processen geweest. In studies van Piore en Sabel (1984) en Kern en Schumann (1985a) wordt: echter gesteld dat, onder andere onder invloed van moderne technologische ontwikkelingen, het organiseren van arbeid volgens Tayloristische principes tot het verleden gaat behoren. Piore en Sabel analyseren de crisis van de Westerse economieën als in wezen een crisis van het stelsel van Fordistische massaproduktie. Ook Kern en Schumann 
constateren een breuk met traditionele produktie-concepten. De ver doorgevoerde arbeidsdeling, gevolg van het Taylorisme is op z'n grenzen gestuit.

Tegenwoordige veranderingsprocessen worden in studies hieromtrent als een transformatie van het Tayloristisch model aangeduid (Dankbaar, 1993). Oorzaken voor deze transformatie zijn een 'interne Krise des tayloristischen Paradigmas' en een 'externe Krise des Modells der Massenproduktion' (Wittke in: Bergstermann en BrandhermBöhmker, 1990).

De interne crisis van het Taylorisme duidt op het feit dat dit rationaliseringstype zelf bepaalde structuren in het leven heeft geroepen die een breukloze voortzetting van deze vorm van rationalisering in de weg staan. Volgens Kern en Schumann (1985) zijn het technologische ontwikkelingen die ingrijpende veranderingen in bedrijfsprocessen bevorderen. Vervanging van arbeid door kapitaal heeft een andere arbeidsorganisatie tot gevolg. Dit leidt enerzijds tot de opheffing van de polarisatie tussen hoog en laag gekwalificeerde functies, anderzijds tot een minder strikte scheiding tussen directe en indirecte arbeid. Deze veranderde arbeidsstructuren en -functies maken op een bepaald moment een verdere Tayloristische rationalisering onmogelijk.

Technologische ontwikkelingen hebben er tevens toe geleid dat economisering van kapitaalkosten, doorlooptijden en voorraden meer benadruki worden. Een optimale benutting van kapitaal is van groter belang geworden. Deze gewijzigde efficiency-overwegingen, in combinatie met de beperkingen waaraan het Taylorisme onderhevig is, leiden tot anderssoortige rationaliseringsmaatregelen. Er lijkt een fundamenteel ander type rationalisering zijn intrede te doen waarbij arbeid op een andere manier wordt ingezet dan tot dan toe gebruikelijk.

De externe crisis van het Tayloristisch model van massa-produktie duidt op het feit dat Tayloristische produktie-structuren niet de flexibiliteit bezitten snel op nieuwe ontwikkelingen op de markt in te spelen. Dit terwijl veranderde marktontwikkelingen er juist toe hebben geleid dat flexibiliteit en innovatie centrale ondernemingsdoelstellingen zijn geworden. Deze eis van flexibiliteit heeft ten eerste tot veranderingen in de interne organisatie van de onderneming geleid. Ten tweede heeft flexibilisering tot veranderingen in de externe organisatie geleid en zijn relaties tussen ondernemingen gewijzigd.

In het verleden trachtte de ondernemer tot een voorspelbare en beheersbare organisatie van de produktie te komen, door 'slack' in de systemen toe te laten (Galbraith, 1973). Door een overmaat aan capaciteit en voorraad werd de mogelijkheid geschapen om fluctuaties te beheersen. Hierdoor kon de produktie-organisatie naar Tayloristisch model georganiseerd worden. Deze strategie van voorraden als buffer tegen onzekerheden gaat in een dynamische omgeving echter met te hoge kosten gepaard. De 'slack' is daarom gaandeweg uit de produktiesystemen verdwenen en daarmee zijn de mogelijkheden beperkt om een produktiesysteem naar Tayloristisch model te organiseren. Informatietechnologie is het nieuwe instrument geworden om fluctuaties op te vangen. Met behulp van deze technologie worden toeleveranciers, producenten en afnemers aan elkaar gekoppeld en bij elkaars interne produktieprocessen betrokken.

Ondernemingen besteden niet alleen delen van hun produktie uit, maar ook de ontwikkeling van componenten van produkten. Centralisering van alle mogelijke functies in een bedrijf is niet, meer vanzelfsprekend. Voordelen van centralisering gaan ten 
koste van het dicht bij de markt zitten en de flexibiliteit van de onderneming. Decentralisering van grootschalige industriële complexen is het gevolg. Het streven naar flexibilisering heeft tot het tegenovergestelde van verticale integratie geleid. Gevolg van deze tendens is dat per onderneming in een keten minder waarde wordt toegevoegd.

De veranderende bedrijfs- en bedrijfsoverstijgende arbeidsdeling leidt tot een toenemend belang van relaties met toeleveranciers en afnemers. De verschillende bewerkingsstappen van een produktieproces vinden steeds vaker in verschillende ondernemingen plaats en niet, zoals vroeger, binnen een onderneming. Door informatietechnologie worden relaties tussen deze ondernemingen transparanter. Andere ontwikkeling is dat toeleveranciers volgens bepaalde gegarandeerde kwaliteitsstandaards gaan werken. De traditionele ingangscontrole van goederen, symbolisch voor het met marktrelaties gepaard gaande wantrouwen, komt hiermee te vervallen. Bedrijfs- en ondernemingsgrenzen verliezen hun remmende werking op de doorlooptijd van goederen door de keten.

Beide ontwikkelingen, veranderingen in de interne en de externe organisatie van ondernemingen, leggen beperkingen op aan de rationaliseringsstrategie van het Taylorisme. Zoals gezegd zijn door het verdwijnen van 'slack' uit de systemen de mogelijkheden beperkt om tot verdere rationalisering volgens het Tayloristische model te komen. In bureaucratische produktie-structuren vindt optimalisatie plaats door te streven naar maximale benutting van op zich staande produktiecapaciteiten. Gevolg zijn relatief lange doorlooptijden en hoge voorraden. Een lagere toegevoegde waarde per schakel in een bedrijfsketen doet echter het belang om kostenverlagingen op het omloopkapitaal te realiseren toenemen. Onderhanden werk en voorraden worden een belangrijke kostenfactor. Verlaging van doorlooptijden en voorraden betekent in dit opzicht zowel kostenverlaging als toename van flexibiliteit. Realisatie van dergelijke doelen vereist een niet-Tayloristische arbeidsorganisatie.

In het voorgaande is aangegeven dat het Taylorisme tot bepaalde structuren geleid heeft die een breukloze voortzetting van deze traditionele rationaliseringsstrategie in de weg staan. Daarnaast hebben exteme factoren ertoe geleid dat het Taylorisme als rationaliseringsmethode zijn beperkingen heeft. 'Man trifft heute in wichtigen Bereichen der Industrie auf eine markt- und produktökonomischen Konstellation, die keine Rationalisierung nach tayloristischem Muster mehr trägt' (Kern en Schumann, 1985a, 323). Een nieuw type rationalisering lijkt zijn intrede te doen. In de volgende paragraaf worden contouren van dit nieuwe rationaliseringstype aangegeven.

\subsection{Het nieuwe mationaliseringstype}

In de Duitse industriesociologie zijn een aantal publicaties verschenen die stellen dat, mede onder invloed van technologische vernieuwingen, zich een nieuwe vorm van rationalisering aftekent die niet meer vergelijkbaar is met de oude, op Tayloristische leest geschoeide, rationalisering (Altmann et al., 1986; Baethge en Oberbeck, 1986; Altmann en Sauer, 1989a en 1989b). Dit nieuwe type rationalisering kenmerkt zich door het feit dat '... unter Nutzung neuer, mikroelektronisch basierter Datenverarbeitungs- und Kommunikationstechnik der betriebliche und überbetrieblichter Informationsfluß, die Kommunikation über und die Kombination von Daten, die Organisation der Betriebsabläufe und die Steuerung der unterschiedlichen Functionsbereiche in 
einer Verwaltung ... neu gestaltet werd' (Baethge en Oberbeck, 1986, 22). Bij dit nieuwe type rationalisering worden '...der integrative, prozeB- und betriebsübergreifende Charakter und die Tendenz zu inner- und zwischenbetrieblicher Vernetzung auf der Basis neuer Informationstechnologien' (Altmann en Sauer, 1989b, 7-9) benadrukt.

Ten eerste richt deze nieuwe vorm van rationaliseren zich niet primair op een optimalisatie van afzonderlijke arbeids- en produktieprocessen, maar op een optimale coördinatie van een keten van verschillende bedrijfsprocessen. Deze coördinatie, deze 'systemische' of integrerende rationalisering van deelprocessen wordt mogelijk gemaakt door nieuwe informatietechnologieën.

Doel van 'systemische rationalisering' is de optimalisatie van (markt)relaties tussen de verschillende deelprocessen en hun terugkoppeling naar besturing en fabrikage. Hierdoor wordt de effectiviteit van meerdere op elkaar ingrijpende activiteiten door optimale coördinatie verhoogd. Systemische rationalisering neemt het geheel van bestaande functies, deelprocessen en relaties en de daaraan gekoppeide communicatie- en besluitvormingsprocessen in beschouwing. Ontwikkeling en implementatie van 'systemische' rationalisering vereist dan ook een 'top-down' benadering waarbij juist deze samenhangen duidelijk zijn. Dit staat haaks op traditionele rationaliseringsmaatregelen die vooral gericht zijn op specifieke deelprocessen, zonder veel te kijken naar de samenhang. In fabrikage richt men zich bijvoorbeeld op zichzelf staande bewerkingsstappen, op de verhoging van de prestatie van enkelvoudige deelprocessen. Daarbij zijn de kosten van arbeid een voornaam doelwit van rationaliseringsmaatregelen. Het nieuwe type rationalisering richt zich daarentegen op verkorting van de totale doorlooptijd en de verbetering van de benuttingsgraad van het geheel van processen. Centraal instrument hiervoor zijn de nieuwe informatie-, organisatie- en sturingstechnologieën.

Ten tweede heeft de integrerende rationalisering ook betrekking op processen die buiten het bedrijf plaatsvinden, zoals toelevering, verwerking en distributie. Met behulp van informatietechnologie is het mogelijk bedrijfsexterne processen technisch-organisatorisch direct aan bedrijfsinterne processen te koppelen. Bij rationaliseringsmaatregelen worden de uitwerkingen op processen van en relaties met andere ondernemingen, toeleveranciers en afnemers nadrukkelijk in de beschouwing betrokken. Relaties tussen bedrijven gaan daarmee verder dan het aangeven van kenmerken waaraan de toe te leveren goederen moeten voldoen. 'Systemische' rationalisering heeft dus niet alleen betrekking op de koppeling van verschillende functies binnen één onderneming maar ook op een koppeling van specifieke functies van verschillende ondernemingen. Hierdoor is een snellere reactie en anticipatie op marktontwikkelingen mogelijk.

$\mathrm{Bij}$ het al dan niet uitbesteden is niet meer primair de vraag of het bedrijf potentieel in staat is bepaalde produkten te leveren, maar hoe besturings- en fabrikageprocessen tot een optimaal geïntegreerd geheel kunnen komen. Netwerktechnologieën maken het mogelijk dat taken op afstand van de onderneming worden uitgevoerd. De keuze bepaalde activiteiten al dan niet uit te besteden wordt in toenemende mate bepaaid door de mogelijkheden bedrijfsprocessen met behulp van informatietechnologieën te koppelen (Sauer et al., 1986).

Ten derde kenmerkt het nieuwe type rationalisering zich door het realiseren van flexibiliteit door gebruikmaking van technologie. Flexibiliteit wordt dus niet direct gezocht in kwantitatieve en kwalitatieve elasticiteit van menselijke arbeid maar in nieuwe tech- 
nologieën. Ontwikkelingen op het gebied van informatie- en communicatietechnologieën vormen de technologische basis voor het nieuwe type rationalisering. Nieuwe informatietechnologie wordt ook wel gerelateerd aan de toenemende 'Abstraktifizierung' van arbeid (Bergmann e.a., 1986). Met 'Abstraktifizierung' van arbeid wordt in dit verband de objectivering van kennis van een produktieproces in computerprogramma's en gebruik van deze kennis door het management bedoeld. Nieuwe informatietechnologie maakt het mogelijk verschillende produktie-activiteiten in een abstracte symboliek te vertalen.

Met de toegenomen inzet van technologie als centraal flexibiliseringsinstrument verbindt zich een nieuwe strategie van economisering (Bergstermann en BrandhermBöhmker, 1990). Bedrijven zijn gedwongen tot een optimale benutting van het ingezette kapitaal te komen. Centrale doelstelling is de produktiviteit en rationaliteit van het geheel van bedrijfs- en bedrijfsoverstijgende produktiesystemen te verhogen en met name het kapitaalbeslag in het systeem te reduceren.

De vraag is in welke richting de veranderingen in de organisatie van bedrijfsprocessen zich bewegen bij dit nieuwe rationaliseringstype. Bij beantwoording van deze vraag worden in de volgende paragraaf drie algemene dimensies van rationalisering van bedrijfsprocessen onderscheiden: organisering, technisering en informatisering (Altmann et al., 1978; Jokisch, 1982; Littek et al., 1983). Aangegeven wordt welke organisatorische veranderingen per dimensie optreden.

\subsection{Drie dimensies van rationalisering}

\subsubsection{Organisering}

Een eerste dimensie van rationalisering van produktie-processen is de organisering van de arbeid. Met dit begrip wordt keuze, accomodatie, coöperatie en beheersing van arbeidskrachten bedoeld. Organisering betekent dat er sprake is van een 'hierarchischen Stufung und Zentralisierung der Entscheidungs- und Kontrollmacht' (Littek et al, 1982, 45). Doel is om tot een verhoging van berekenbaarheid en voorspelbaarheid, van het arbeidsproces te komen. Hiertoe worden arbeidskrachten bijeengebracht, de uit te voeren taken gedifferentieerd en de tijdsvolgorde van arbeidshandelingen gecoordineerd. Een bepaalde organisering van de arbeid betekent tegelijkertijd een bepaalde structuur van de arbeidsdeling. Het essenticle van organisering is dat de verschillende vermogens van mensen om arbeid te leveren met elkaar verbonden raken.

Bij de analyse naar de gevolgen van het nieuwe type rationalisering voor de arbeidsdeling kan gebruik worden gemakt van begrippen uit de sociotechnische systeemtheorie. Deze thearic beschrijft organisaties in termen van de structuur van de arbeidsverdeling. Het gaat hierbij on de verdeling van uitvoerende en regelende functies over mensen en machines. Deze theorie lat zien dat er een nauwe relatie bestaat tussen de kwaliteit van de arbeid en de manier waarop het geheel van uitvoerende en regelende taken in een fabriek is gescheiden en gesplitst (De Sitter, 1986).

In termen van De Sitter (1981) betekent het nieuwe rationaliseringstype dat de besturingsstructuur van de bedrijfsketen zich wijzigt. Regelende activiteiten, betrekking hebbend op de organisatie van bedrijfsprocessen, worden nu niet alleen op bedrijfsni- 
veau maar ook op het niveau van de keten op elkaar afgestemd. Ondernemingen hebben onderling afspraken gemaakt over de wijze van uitwisseling van goederen- en informatiestromen. Deze organisering kan betekenen dat regelende activiteiten worden ondergebracht in een toezichthoudende, regulerende taak. Deze organisering kan betekenen dat de organisatie van logistieke activiteiten in nieuwe hiërarchieën plaats vindt. In hoofdstuk 2 hebben we deze organisatie-vorm aangeduid als de verticale actor.

\subsubsection{Technisering}

Een tweede dimensie van rationalisering is technisering van bedrijfsprocessen. Schematisch gesproken heeft organisering betrekking op arbeid, technisering op arbeidsmiddelen. Organisering, is gericht op vastlegging van de wijze van arbeidsinzet, technisering betekent dat bepaalde arbeidsfuncties of -handelingen door technische middelen worden uitgevoerd (Altmann et al., 1978; Littek et al., 1983). Technisering kent een tweetal aspecten.

Een eerste aspect is dat bepaalde sturings- en beheersingsfuncties door technische middelen worden uitgeoefend. Dit staat in tegenstelling tot het "traditionele' produktieproces dat gekenschetst kan worden als het afwezig zijn van iedere vorm van autonomie van arbeidsmiddelen: iedere activiteit moet door menselijke handelingen geïnitieerd, gestuurd en gecontroleerd worden (Altmann et al., 1978). Veranderingen door technisering in het traditionele produktieproces leiden ertoe dat arbeidsmiddelen een relatief zelfstandig geheel worden ten opzichte van arbeidshandelingen van mensen. Sturings- en beheersfuncties worden overgedragen aan een systeem van automatisch werkende mechanismen, worden 'versachlicht'. Gevolg is dat leiding, sturing en beheersing met behulp van abstracte regelsystemen plaats vindt. Sombart (1927) spreekt over een 'Entmenschlichung im technischen Denken'.

Een tweede aspect van technisering is dat deze autonomisering gepaard gaat met substitutie van arbeid door arbeidsmiddelen. Arbeidstaken verdwijnen, nieuwe verschijnen of veranderen fundamenteel van karakter.

'Jeder Einstellung einer neuen, technisch vollkommeneren Maschine bedeutet einerseits Ausschaltung einer Reihe von Arbeitsprozessen, die zur Bedienung der bisher verwendeten Werkzeuge erforderlich waren, und das heißt: Entbehrlichwerden bestimmter, bisher erforderlicher Qualitäten der Arbeiterschaft, andererseits: Verwendung von Arbeitern, welche die neu eingestellten Maschinen zu bedienen haben und, um dazu geeignet zu sein, ihrerseits gewisse andere Qualitäten entwickeln müssen...' (Weber, 1924, 6)

Technisering betekent dat technische middelen bepaalde functies overnemen die daarvoor werdien uitgevoerd door arbeid. Technische middelen hebben bepaalde voordelen boven aĩbeidskracht. Technische middelen hoeven niet aan disciplinerende, normerende en motiverende: middelen onderworpen te worden. Een hogere graad van precisie, berekenbaarheid en daarmee beheersing kan hierdoor mogelijk zijn.

In de produktie-sfeer wordt technisering van het nieuwe rationaliseringstype vooral gekenmerkt door flexibele automatisering. Deze automatisering maakt een flexibilisering van produktieprocessen mogelijk. Flexibiliteit kon in het oude type rationalisering 
alleen gerealiseerd worden door de fabriek of afdeling als 'jobshop' in te richten (zie § 3.2). Nadeel van de 'jobshop' is dat men niet kan profiteren van de efficiency-voordelen van massafabricage zoals in de 'flowshop'. De flowshop is echter niet ingericht op snel omschakelen en veranderen en dus niet flexibel. Kenmerkend is dat bij het nieuwe rationaliseringstype de flexibiliteit naar type (soort produkt) en volume (aantal produkten) met eenzelfde mate van efficiency als bij massa-produktie van identieke produkten kan plaats vinden. Hierdoor is een verschuiving naar een klantgerichte produktie mogelijk. Deze flexibiliteit wordt gerealiseerd door programmering van computers die produktie-apparatuur aansturen.

\subsubsection{Informatisering}

Bij het nieuwe rationaliseringstype heeft technisering ook betrekking op de overdracht van informatie. Deze wordt deels uitgevoerd door informatie-systemen. Bij bepaalde toepasșingen van bedrijfsoverstijgende informatietechnologie is sprake van een vergaande autonomisering. Bij dergelijke toepassingen worden menselijke interacties in de overdracht van informatie tussen verschillende organisatie-eenheden geëlimineerd. Met name administratief werk met een routine-matig karakter, gericht op overdracht van informatie, wordt overbodig.

Naast organisering en techrisering wordt daarom tegenwoordig een derde dimensie van rationalisering onderscheiden: informatisering (Littek et al., 1983; Jokisch, 1982). Met informatisering wordt een effectieve schematisering en codificering van aanwezige kennis en gegevens bedoeld. Daarvan was al sprake in de tijd dat er nog geen informatietechnologie bestond. Door de komst van computers is deze informatisening echter veel belangrijker gewoĩden. Tegenwoordig staat informatisering vaak gelijk met het vastleggen van administratieve handelingen en procedures in programmeertaal vooi computers. Dit maakt een technische vorm van informatisering door middel van geautomatiseerde informatie-systemen mogelijk.

Door intensivering van het berichtenverkeer is sprake van een toenemende druk om op simpele universele wijze met logistieke partners gegevens te kunnen uitwisselen. Ondernemingen die zich op een kruispunt van logistieke informatiestromen bevinden worden in de oude situatie vaak geconfronteerd met diverse typen systemen van informatieuitwisseling. Dit betekent dat dergelijke bedrijven een groot aantal verbindingen of computersystemen hebben geïnstalleerd die op verschillende wijzen, dezelfde soort gegevens uitwisselen met hun logistieke partners. Daarbij verschillen de berichten op grond van de communicatiestandaard, de syntax, de gehanteerde data-elementen en hun aard.

Naarmate het aantal partijen dat met elkaar gecomputeriseerde berichten uitwisselt toeneemi, neemt het aantal bilaterale contactmogelijkheden met een veelvoud toe. Om te voorkomen dat voor elk van deze aansluitingen aparte conversies moeten worden ontwikkeld wordt als onderdeel van het nieuwe type rationalisering gestreefd naar én standaard of conversie-mogelijkheid. Implementatie van een standaard betekent een beperking van de wijzen waarop contact wordt onderhouden. Deze beperking kan in bepaalde gevallen nadelig zijn voor de vereiste flexibiliteit. Daar staat tegenover dat het maken van interfaces, noodzakelijk bij het ontbreken van algemeen geldige standaards, tot verleden gaat behoren. Bij het nieuwe type rationalisering vindt informatisering van bedrijfsfuncties dus niet alleen op bedrijfs- maar ook op ketenniveau plaats. 
Op het niveau van de keten wordt een uniforme schematisering en codificering van logistieke informatie gebruikelijk.

Er vindt een objectivering van logistieke kennis in computerprogramma's plaats die door het management gebruikt worden ter beheersing van de goederenstroom. Op deze manier bevordert informatisering een formalisering van bedrijfsfuncties en de koppeling van 'in-house' applicaties. Deze herstructurering van de interne organisatie door informatisering binnen de onderneming is noodzakelijk om het bedrijf in staat te stellen met standaardberichten informatie uit te wisselen en deze berichten ook zelf te produceren.

\subsection{Rationalisering en toepassing van integrale logistiek}

In dit hoofdstuk is aangegeven dat de rationaliseringsmethode van het Taylorisme op haar grenzen is gestuit. Er tekent zich een nieuwe rationaliseringsvorm af die zich richt op het. geheel van bedrijfsprocessen binnen en tussen ondernemingen. Hierbij wordt door coördinatie met behulp van informatietechnologie de effectiviteit van meerdere op elkaar ingrijpende activiteiten verhoogd. We hebben al gezien dat bij toepassing van integrale logistiek organiserende en coördinerende activiteiten met betrekking tot de goederenstroombesturing in een rationalisering betrokken worden waaraan meerdere schakels uit een bedrijfsketen deelnemen. Dit heeft tot gevolg dat relaties tussen ondernemingen geformaliseerd worden en de effectiviteit van de logistieke organisatie op ketenniveau toeneemt.

Wanneer we toepassing van integrale logistiek beschouwen als onderdeel van het nieuwe rationaliseringstype dan kunnen we per rationaliseringsdimensie aangeven wat de gevolgen van toepassing van integrale logistiek voor de organisatie van de produktie zijn. De drie rationaliseringsdimensies geven als het ware 'wetmatigheden' in uitingsvormen of nadere concretiseringen van toepassing van integrale logistiek aan.

Organisering betekent bij toepassing van integrale logistiek dat de regelende activiteiten op het terrein van de sturing van goedeienstromen op het niveau van een bedrijfsketen op elkaar worden afgestemd. Deze activiteiten kunnen worden ondergebracht in een toezichthoudende, regulerende taak. Een aparte groep regelaars bewaakt diverse aspecten van de logistieke organisatie. Deze organisering betekent dat de organisatie van logistieke activiteiten op het niveau van een bedrijfsketen kan plaats vinden in nieuwe hiërarchieën. Deze nieuwe hiërarchieën zijn door ons aangeduid als 'verticale' actoren: de organisaties die delen van logistieke functies van bedrijven in een keten in zich integrereri.

Toepassing van integrale logistiek heeft ook een technisering van produktie-activiteiten tot gevolg. Deze technisering richt zich op nieuwe arbeidsmiddelen voor de produktie binnen de onderneming en voor de overdracht van informatie tussen ondernemingen. Het betreft hier enerzijds een interne logistieke integratie door nieuwe vormen van produktie-äutomatisering, anderzijds een externe logistieke integratie door bedrijfsoverstijgende informatisering. De verwachting is dat deze technologieën tot een arbeidsbesparing en een substitutie van arbeid door arbeidsmiddelen leiden. 
Informatisering heeft bij systemische rationalisering betrekking op de gebondenheid van een groep van bedrijven aan geformaliseerde en gestandaardiseerde afspraken met betrekking tot de uitwisseling van informatiestromen. Met informatisering vindt er een objectivering van orders en offertes, produktinformatie, technische specificaties en ontwerpspecificaties in computerprogramma's plaats. Informatisering bevordert de formalisering van logistieke functies en de koppeling van 'in-house' applicaties. Deze herstructurering van de interne organisatie door informatisering binnen de onderneming is noodzakelijk om het bedrijf in staat te stellen met standaardberichten informatie uit te wisselen en deze berichten ook zelf te produceren. 


\section{Stellingen en onderzoeksvragen}

In het betoog van de hoofdstukken 2 en 3 is nader uiteen gezet wat in dit onderzoek onder toepassing van integrale logistiek verstaan wordt. Daarbij is in hoofdstuk 2 naar voren gekomen dat ontwikkelingen in de organisatie van de logistieke functie als een voortgaand integratie-proces van logistieke activiteiten zijn te beschouwen. Dit integratie-proces wordt gezien als een lange termijn trend die uitloopt op het aan elkaar koppelen van logistieke activiteiten van verschillende produktiebedrijven. Deze bedrijfsoverstijgende koppeling is aangeduid als toepassing van integrale logistiek. Zelfstandige ondernemingen maken hierbij afspraken over de wijze waarop uitwisseling van goederen- en informatiestromen zal plaats vinden. Gevolg is een meer geïntegreerde logistieke functie op het niveau van een keten of groep van bedrijven. In hoofdstuk 3 is aangegeven dat een aantal ontwikkelingen op de markt en in de technologie toepassing van integrale logistiek mogelijk maken. Daar is ook aangegeven dat toepassing van integrale logistiek als concurrentie-strategie te beschouwen is als 'match' tussen trends op de markt en in de technologie.

Onze theoretische verkenningen in de hoofdstukken 4 en 5 hadden tot doel nader inzicht te krijgen onder welke voorwaarden toepassing van integrale logistiek zich in welke richtingen kan ontwikkelen of concretiseren. Met andere woorden, met de theorie is getracht zicht te krijgen op "wetmatigheden" in de gevolgen of nadere ontwikkelingsvormen van toepassing van integrale logistiek. De stellingen, die in dit hoofdstuk worden weergegeven en uit het theoretisch kader voortvloeien, geven een aantal specifieke voorwaarden waaronder het tot toepassing van integrale logistiek komt en in welke richtingen zich dit kan concretiseren.

\subsection{Voorwaarden voor het ontstaan van logistieke netwerken}

De theorie van de externe organisatie, die we behandeld hebben in hoofdstuk 4 , suggereert dat toepassing van integrale logistiek gezien kan worden als een verandering in de externe organisatie van ondernemingen in de richting van netwerkvorming. Bij toepassing van integrale logistiek zijn marktrelaties in veel gevallen onvoldoende om de vereiste wederzijdse technologische en organisatorische aanpassingen van ondernemingen mogelijk te maken. Toepassing van integrale logistiek vereist specifieke informatie, informatie die niet altijd via de markt te verkrijgen is maar wel een noodzakelijke voorwaarde vormt voor optimale wederzijdse aanpassingen. De theorie van de externe organisatie geeft aan onder welke voorwaarden transactiepatronen zich bewegen van markt, naar netwerk. In de transactiekostentheorie zijn het met name efficiency-argumenten die bepalen of een verandering van transactiepatronen optreedt. Theorieën over netwerken geven aan dat daarnaast ook andere motieven het ontstaan van netwerken in plaats van markten of hiërarchieën verklaren. 
De transactiekostentheorie geeft aan dat transactiespecifieke investeringen een belangrijke verklaring vormen voor de overgang van markt naar netwerk of hiërachie. Op grond hiervan kunnen we veronderstellen dat toepassing van integrale logistiek zich vooral in samenhang met transactiespecifieke investeringen zal voordoen. Bij toepassing van integrale logistiek hebben deze investeringen met name betrekking op bedrijfsoverstijgende informatiesystemen. Investeringen in een meer gesloten informatiesysteem hebben een meer transactiespecifiek karakter. Het zijn deze investeringen die het ontstaan van logistieke netwerken bevorderen. Naarmate deze transactiespecifieke investeringen in een bepaalde keten hoger zijn, is de kans op het ontstaan van een nieuwe hiërarchie groter. De beweging gaat dan in de richting van wat we in hoofdstuk 2 de 'verticale actor' genoemd hebben.

Stelling 1: investeringen in informatiesystemen met een gemeenschaps- of gesloten karakter bevorderen door hun transactiespecifieke karakter het ontstaan van logistieke netwerken.

Theorieën over netwerken geven ter verklaring van veranderende transactiepatronen andere motieven dan transactiekostenminimalisatie aan. Een drietal motieven voor het ontstaan van netwerken boven markten of hiërarchieën zijn het toenemend belang van overdracht van know-how, snelheid en wederzijds vertrouwen. Bij toepassing van integrale logistiek zijn deze factoren vooral van belang bij het streven naar produktkwaliteit en -innovatie. Netwerken zijn geschikt voor de uitwisseling van cruciale kennis en vaardigheden, innovatief vermogen van een onderneming en leerprocessen.

Stelling 2: een toenemend belang van overdracht van know-how, snelheid en wederzijds vertrouwen zijn factoren die de ontwikkeling van logistieke netwerken bevorderen.

Met andere woorden, de theorie van de externe organisatie geeft aan dat toepassing van integrale logistiek zich kan ontwikkelen op grond van transactiespecifieke investeringen en op grond van motieven voor transacties tussen bedrijven die verder gaan dan het streven naar efficiency of de prijs van een produkt.

\subsection{Eigenschappen en gevolgen van toepassing van integrale logistiek}

In hoofdstuk 5 is aangegeven dat rationalisering van bedrijfsprocessen onderdeel is van een lange termijn ontwikkeling die door Weber wordt aangeduid als het rationaliseringsproces van samenleving en economie. Dit rationaliseringsproces heeft tot gevolg dat ondernemingen naar 'rationeel model' georganiseerd worden. Daarbij worden drie dimensies onderscheiden: organisering, technisering en informatisering. De ontwikkelingen die wij hier als toepassing van integrale logistiek omschreven hebben, zijn door anderen geplaatst in het kader van deze rationaliseringsbeweging. Met de drie rationaliseringsdimensies is het mogelijk eigenschappen van toepassing van integrale logistiek en de gevolgen daarvan in kaart te brengen.

Er zijn twee typen rationalisering te onderscheiden: het Taylorisme en 'systemische' rationalisering. 'Systemische' rationalisering richt zich op een integrale benadering van bedrijfsprocessen binnen en tussen ondernemingen en breekt met bepaalde Tayloristische principes van rationalisering. Deze integrerende rationalisering koppelt processen van verschillende ondernemingen aan elkaar in één netwerk. In dit netwerk is 
het mogelijk dat taken op afstand van een onderneming worden uitgevoerd. Het nieuwe rationaliseringstype richt zich, in tegenstelling tot het Taylorisme, niet op de optimalisatie van deelprocessen en besparing van arbeidskosten maar tracht tot een optimale integratie en koppeling van de verschillende deelprocessen te komen.

Volgens deze benadering kan toepassing van integrale logistiek gezien worden als onderdeel van systemische rationalisering. Dit betekent dat toepassing van integrale logistiek gepaard gaat met organisering, technisering en informatisering. Deze eigenschappen van toepassing van integrale logistiek en de gevolgen daarvan voor de organisatie van de produktie kunnen met deze dimensies worden weergegeven.

De eerste dimensie van systemische rationalisering, organisering, geeft aan dat bij toepassing van integrale logistiek regelende activiteiten op het terrein van de sturing van goederenstromen op ketenniveau op elkaar worden afgestemd. Deze activiteiten kunnen worden ondergebracht in een toezichthoudende, regulerende taak. Deze organisering betekent dat de organisatie van logistieke activiteiten op het niveau van een bedrijfsketen binnen nieuwe hiërarchieën plaats vindt. Dit hebben we eerder aangeduid als het ontstaan van de verticale actor. De verticale actor is een hiërarchie die delen van logistieke functies van bedrijven in een keten in zich integreert.

Stelling 3: bij toepassing van integrale logistiek zal een bedrijfsoverstijgende organisering optreden die ertoe kan leiden dat de organisatie van logistieke netiviteiten in een bedrijfsketen in nieuwe hiërarchieën plaats vindt.

Technisering heeft als tweede rationaliseringsdimensie bij systemische rationalisering betrekking op nieuwe arbeidsmiddelen voor de produktie binnen de onderneming en voor de overdracht van informatie tussen ondernemingen. Het betreft hier enerzijds een interne logistieke integratie door nieuwe vormen van produktie-automatisering, anderzijds een externe logistieke integratie door bedrijfsoverstijgende informatisering. De verwachting is dat deze technologieën tot een substitutie van arbeid door arbeidsmiddelen leiden.

Stelling 4: toepassing van integrale logistick gaat gepaard met een technisering die zich richt op nieuwe vormen van produktie-automatisering en bedrijfsoverstijgende informatiscring en die substitutie van arbeid door arbeidsmiddelen tot gevolg heef.

De derde rationaliseringsdimensie, informatisering, heeft betrekking op de gebondenheid van een groep van bedrijven aan geformaliseerde en gestandaaidiseerde afspraken met betrekking tot de uitwisseling van informatie- en goederenstromen. Informatisering bevordert de formalisering van logistieke functies en de koppeling van 'in-house' applicaties. Deze herstructurering van de interne organisatie door informatisering binnen de onderneming is noodzakelijk om het bedrijf in staat te stellen met standaardberichten informatie uit te wisselen en deze berichten ook zelf te produceren.

Stelling 5: toepassing van integrale logistiek vereist een herstructurering van de interne organisatie door informatisering binnen de onderneming die het bedrijf in staat stelt met standaardberichten informatie uit te wisselen en deze berichten zelf te produceren. 


\section{Stellingen}

1. De toename van transactiespecificiteit door implementatie van informatiesystemen met een gemeenschaps- of gesloten karakter bevordert het ontstaan van logistieke netwerken.

2. Een toenemend belang van overdracht van know-how, snelheid en wederzijds vertrouwen zijn factoren die de ontwikkeling van logistieke netwerken bevorderen.

3. Bij toepassing van integrale logistiek zal een bedrijfsoverstijgende organisering optreden die ertoe kan leiden dat de organisatie van logistieke activiteiten in een bedrijfsketen in nieuwe hiërarchieën plaats vindt.

4. Toepassing van integrale logistiek gaat gepaard met een technisering die zich richt op nieuwe vormen van produktie-automatisering en bedrijfsoverstijgende informatisering en die substitutie van arbeid door arbeidsmiddelen tot gevolg heeft.

5. Toepassing van integrale logistiek vereist een herstructurering van de interne organisatie door informatisering binnen de onderneming die het bedrijf in staat stelt met standaardberichten informatie uit te wisselen en deze berichten zelf te produceren.

\subsection{Onderzoeksvragen}

Met behulp van bovengenoemde stellingen kunnen een aantal onderzoeksvragen geformuleerd worden. Uit iedere stelling is één onderzoeksvraag afgeleid. Deze onderzoeksvragen zullen beantwoord worden aan de hand van een gedetailleerd onderzoek over logistiek in de bouw. In volgende hoofdstukken wordt bezien in hoeverre de ontwikkelde stellingen geldig zijn voor logistieke ketens in de bouw. Figuur 6.1 geeft schematisch de opzet van het onderzoek weer.

Ten eerste zijn onderzoeksvragen geformuleerd die betrekking hebben op de voorwaarden waaronder logistieke netwerkvorming in de bouw zal ontstaan. Deze vragen. luiden:

1. Waar is in logistieke ketens in de bouw sprake van transactiespecifieke investeringen gericht op de sturing van goederenstromen tussen bedrijven?

2. Waar zijn bij transacties tussen bedrijven in de bouw overdracht van know-how, hogere eisen aan snelheid en wederzijds vertrouwen van toenemend belang geworden?

Ten tweede zijn een aantal onderzoeksvragen geformuleerd die ingaan op de eigenschappen of gevolgen van toepassing van integrale logistiek in de bouw. De vragen spitsen zich toe op aanzetten of nadere concretiseringen van organisering, technisering en informatisering in de bestaande bouwpraktijk en luiden:

3. Is bij bouwprojecten sprake van een organisatie van logistieke activiteiten in nieuwe hiërarchieën? 
4. Is in logistieke ketens in de bouw sprake van substitutie van arbeid door (flexibele) produktie-automatisering en bedrijfsoverstijgende informatisering?

5. In hoeverre leidt implementatie van informatiesystemen in bouwketens en -processen tot een herstructurering van de interne organisatie door informatisering binnen de onderneming?

FIGUUR 6.1 Schematische opzet van het onderzoek

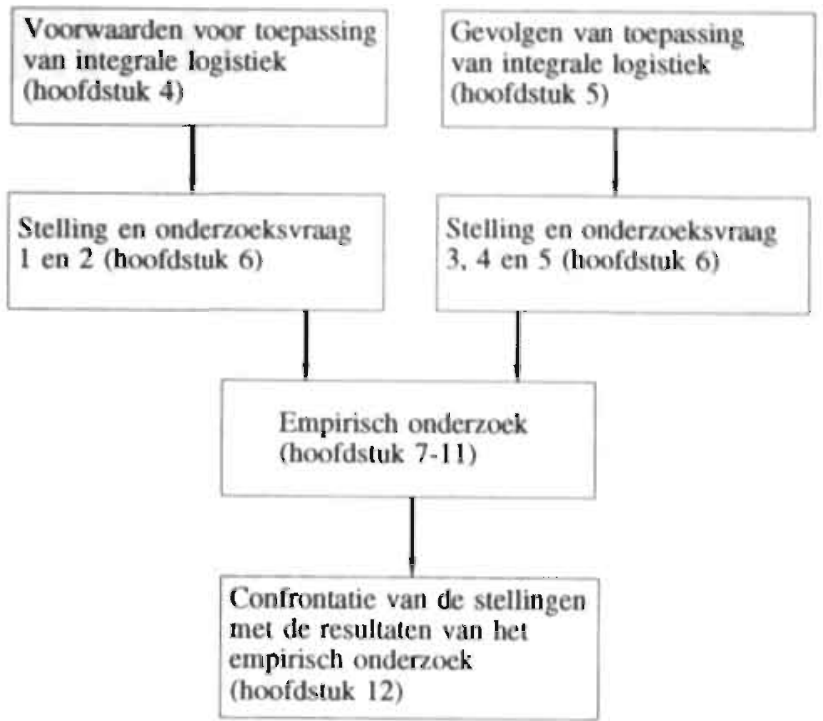





\section{DEEL II}

\section{Toepassing van integrale logistiek in de bouw}





\section{Methodologie van het empirisch onderzoek}

In deell II van deze studie wordt getracht de in deel I ontwikkelde onderzoeksvragen te beantwoorden aan de hand van een gedetailleerd onderzoek. naar logistiek in de bouw. Dit empirisch onderzoek heeft ten doel te analyseren in hoeverre de in hoofdstuk 6 ontwikkelde stellingen geldig zijn voor bouwprojecten en hun logistieke ketens. In dit hoofdstuk wordt een verantwoording gegeven voor de wijze waarop het empirisch onderzoek is uitgevoerd. Er wordt ingegaan op de onderzoeksopzet, data-verzameling en selectie en de hoofdstukindeling van dit deel van de studie.

\subsection{Onderzoeksopzet}

De in hoofdstuk 6 geformuleerde stellingen en onderzoeksvragen hebben enerzijds betrekking op de voorwaarden waaronder het tot een toepassing van integrale logistiek in de bouw komt, anderzijds op de eigenschappen en gevolgen daarvan voor de organisatie van de produktie. Om de onderzoeksvragen te beantwoorden is een onderzoeksopzet vereist. Onder een onderzoeksopzet verstaat Yin (1984) de logica, die de vragen, die beantwoord, en de gegevens, die verzameld moeten worden, verbindt met de te trekken conclusies.

Het empirisch onderzoek omvat drie onderdelen. Het eerste onderdeel bestaat uit een. analyse van stimuleringsprogramma's, gericht op informatisering in de bouw. Het tweede onderdeel gaat in op innovaties in de organisatie van bouwprojecten. Beide analyses beschrijven de context waarbinnen veranderingen in de organisatie van concrete bouwprojecten plaats vinden. Het derde empirische deelonderzoek omvat vier gevalsstudies van concrete bouwprojecten en hun ketens.

In hoofdstuk 4 is aangegeven dat logistieke netwerkvorming zich kan ontwikkelen op grond van transactiespecifieke investeringen. De eerste onderzoeksvraag is dan ook waar in logistieke ketens in de bouw sprake is van transactiespecifieke investeringen gericht op de sturing van goederenstromen tussen bedrijven. In de bouw blijkt dat deze investeringen met name betrekking hebben op bedrijfsoverstijgende informatisering. Om die reden en het feit dat bedrijfsoverstijgende informatisering in de bouw nog in de kinderschoenen staat zijn in het empirisch onderzoek een aantal stimuleringsprogramma's, gericht op EDI en PDI in de bouw, geanalyseerd. Analyse van deze programma's geeft ook deels antwoord op de vierde onderzoeksvraag, de vraag of in de bouw sprake is van substitutie van arbeid door bedrijfsoverstijgende informatisering. Tevens wordt met deze analyse ingegaan op de vijfde onderzoeksvraag: in hoeverre leidt implementatie van informatiesystemen in bouwketens en -processen tot een herstructurering van de interne organisatie door informatisering binnen de onderneming? 
Deze laatste twee onderzoeksvragen richten zich op de in hoofdstuk 5 onderscheiden rationaliseringsdimensies technisering en informatisering.

In hoofdstuk 4 is voorts aangegeven dat logistieke netwerkvorming zich kan ontwikkelen op grond van andere motieven dan alleen het streven naar efficiency. Aangegeven is dat een toenemend belang van overdracht van know-how, snelheid en wederzijds vertrouwen tot logistieke netwerkvorming leidt. Daarom luidt in hoofdstuk 6 de tweede onderzoeksvraag: waar zijn bij transacties tussen bedrijven in de bouw overdracht van know-how, snelheid en wederzijds vertrouwen van toenemend belang geworden? Analyse van innovaties in de organisatie van bouwprojecten, die het gevolg zijn van nieuwe marktvereisten, kan antwoord geven op de vraag waar in de bouw andere motieven dan efficiency van toenemend belang worden en dus de basis leggen voor logistieke netwerkvorming. In deel I hebben we op verschillende plaatsen aangegeven dat toepassing van integrale logistiek ertoe kan leiden dat delen van de logistieke functie van verschillende bedrijven gecoördineerd worden door een nieuwe hiërarchie: de verticale actor. Met de analyse van genoemde innovaties in de organisatie van bouwprojecten kan ook aangegeven worden welke partijen de rol van verticale actor op zich kunnen nemen. Deze analyse sluit aan bij de derde onderzoeksvraag uit hoofdstuk 6, de vraag of bij bouwprojecten sprake is van een organisatie van logistieke activiteiten in nieuwe hiërarchieën. Deze onderzoeksvraag richt zich op de in hoofdstuk 5 onderscheiden rationaliseringsdimensie 'organisering'.

Ten derde kunnen de vragen 3, 4 en 5, vragen naar aanzetten of nadere concretiseringen van toepassing van integrale logistiek, toegespitst worden op de bestaande bouwpraktijk. Ter beantwoording van deze onderzoeksvragen zijn een viertal concrete bouwprojecten en hun ketens geanalyseerd. De tijdelijkheid van relaties tussen bedrijven in de sector is de reden om concrete bouwprojecten als uitgangspunt te nemen voor de analyse van goederen- en informatiestromen in ketens van bedrijven in de bouw. Deze analyse geeft in de eerste plaats antwoord op de derde onderzoeksvraag, de vraag of bij bouwpirojecten sprake is van een organisatie van logistieke activiteiten in nieuwe hiërarchieën. Tevens wordt geanalyseerd in hoeverre er in de bestaande bouwpraktijk sprake is van substitutie van arbeid door nieuwe produktie-technieken, de vierde onderzoeksvraag. Tenslotte zoeken we met de gevalsstudies antwoord op de vijfde onderzoeksvraag, de vraag of bedrijfsoverstijgende informatiesystemen in de bestaande bouwpraktijk een herstructurering van de interne organisatie tot gevolg hebben. Figuur 7.1 geeft een schematisch overzicht van het empirisch onderzoek.

\subsection{Data-verameling en selectie}

In de drie empirische deelonderzoeken, stimuleringsprogramma's gericht op informatisering in de bouw, innovaties in de organisatie van bouwprojecten en concrete bouwprojecten en hun ketens heeft data-verzameling plaats gevonden door documentenanalyse en interviews.

In het eerste empirisch deelonderzoek is door analyse van stimuleringsprogramma's, gericht op informatisering in de bouw, ingegaan op electronische communicatie tussen bedrijven. Ten eerste zijn twee EDI-stimuleringsprogramma's nader geanalyseerd. Deze twee programma's zijn de tot nu toe enige twee EDI-initiatieven in de bouw. 
FIGUUR 7.1 Schematische opzet van het empirisch onderzoek

\begin{tabular}{|c|c|c|c|}
\hline Empirische deel-onderzoeken & A & B & C \\
\hline $\begin{array}{l}\text { 1. Waar is in logistieke ketens in de bouw sprake van transactie- } \\
\text { specifieke investeringen gericht op de sturing van goederen- } \\
\text { stromen tussen bedrijven? }\end{array}$ & $\cdot$ & & \\
\hline $\begin{array}{l}\text { 2. Waar zijn bij transacties tussen bedrijven in de bouw overdracht } \\
\text { van know-how, snelheid en wederzijds vertrouwen van toenemend } \\
\text { belang geworden? }\end{array}$ & & * & \\
\hline $\begin{array}{l}\text { 3. Is bij bouwprojecten sprake van een organisatie van logistieke } \\
\text { activiteiten in nieuwe hiërarchieên? }\end{array}$ & & $\cdot$ & * \\
\hline $\begin{array}{l}\text { 4. Is in logistieke ketens in de bouw sprake van substitutie van } \\
\text { arbeid door (flexibele) produktie-automatisering en bedrijfsover- } \\
\text { stijgende informatisering? }\end{array}$ & * & & - \\
\hline $\begin{array}{l}\text { 5. In hoeverre leidt implementatie van informatiesystemen in } \\
\text { bouwketens en -processen tot een herstructurering van de interne } \\
\text { organisatie door informatisering binnen de onderneming? }\end{array}$ & $\cdot$ & & • \\
\hline $\begin{array}{l}\text { A. stimuleringsprogramma's gericht op informatisering in de bouw } \\
\text { B. innovaties in de organisatie van bouwprojecten } \\
\text { C. gevalsstudies van concrete bouwprojecten en hun ketens }\end{array}$ & & & \\
\hline
\end{tabular}

Een selectie van functionarissen heeft plaats gevonden door EDI-managers van bedrijven te benaderen die betrokken waren bij deze programma's (zie bijlage II). Tijdens de interviews is gebruik gemaakt van een vragenlijst die al bij eerder EDI-onderzoek gebruikt was (zie bijlage III). Ten tweede is een stimuleringsprogramma, gericht op PDI in de bouw, geanalyseerd. Dit programma omvatte PDI-projecten in de woningen utiliteitsbouw en in de grond-, weg- en waterbouw. Naast een documentenanalyse hebben interviews plaats gehad met functionarissen van branche-organisaties betrokken bij de PDI pilot-projecten (zie bijlage II). Ook deze interviews vonden plaats aan de hand van een vragenlijst (zie bijlage III). Uit deze interviews bleek dat binnen de bouw op het moment van onderzoek bedrijven in nog maar geringe mate ervaring hadden met PDI. Het interviewen van functionarissen van bedrijven werd daarom niet zinvol geacht. Het uiteindelijke verslag is voor commentaar aan de geïnterviewden teruggezonden en op individuele basis besproken.

Het tweede deel van het empirisch onderzoek richt zich op innovaties in de organisatie van bouwprojecten. Er zijn functionarissen van ontwerpende, uitvoerende en toeleverende bedrijven geînterviewd die in diverse branche-tijdschriften stelden op een innovatieve wijze bouwprojecten te organiseren, d.w.z een wijze van organiseren gericht op nieuwe marktvereisten. De geïnterviewden behoorden tot de directie of hoger management van de bezochte bedrijven (zie bijlage II). Er zijn dertig bedrijven benaderd waarvan er zeventien hun medewerking hebben verleend. Daarnaast heeft een interview plaats gevonden met een beleidsmedewerker van een branche-organisatie. De bedrijven behoorden tot een drietal branches: bouwnijverheid, zakelijke dienstverlening en bouwmaterialenindustrie. Per bedrijf is één functionaris geïnterviewd. Het interview 
heeft plaats gevonden aan de hand van een semi-gestructureerde vragenlijst, aangepast aan de branche (zie bijlage IV). De uiteindelijke verslagen zijn op individuele basis met de geïnterviewden besproken.

In het derde empirisch deelonderzoek is aan de hand van een viertal gevalsstudies van bouwprojecten geanalyseerd waar in de bouw aanzetten te vinden zijn voor toepassing van integrale logistiek. Van de vier projecten vonden er twee plaats in de woningbouw en twee in de utiliteitsbouw. ${ }^{1}$ Bij ieder bouwproject is vooraf vastgesteld op welke produkten de analyse zou worden uitgevoerd om zo tot een heldere formulering van de te onderzoeken keten te komen. Vervolgens zijn bij diverse bedrijven in de ketens gegevens verzameld met betrekking tot het produktassortiment, organisatie, produktieproces, materiaalverwerving/inkoop en diverse aspecten van het concrete bouwproject. Deze analyse is bedoeld om mogelijke factoren die logistieke prestaties kunnen beïnvloeden te achterhalen. De analyse is bij drie van de vier bouwprojecten uitgevoerd door interviews met sleutelfunctionarissen. Deze functionarissen kwamen uit het midden en hoger kader van bedrijven betrokken bij de geformuleerde produktketens (zie bijlage II). Per bouwproject hebben vijf tot tien interviews plaats gevonden. Deze interviews hadden een open eind karakter. Bestudering van één bouwproject is voornamelijk uitgevoerd door documentenanalyse. De vele publicaties over dit bouwproject maakten een goed beeld van de logistieke organisatie mogelijk. De verslagen van de twee gevalsstudies in de woningbouw zijn in één sessie geëvalueerd waarbij alle geïnterviewde functionarissen aanwezig waren. De verslagen van de gevalsstudies in de utiliteitsbouw zijn op individuele basis met de geïnterviewden en betrokkenen besproken.

\subsection{Hoofdstukindeling van deel II}

Hoofdstuk 8 behandelt het onderzoeksobject, het bouwproject en zijn keten. Er wordt aangegeven hoe de produktie bij verschillende bedrijven, die deel uit maken van logistieke ketens in de bouw, georganiseerd is.

De hoofdstukken 9, 10 en 11 richten zich op een 'toetsing' van de in deel I ontwikkelde stellingen. In de hoofdstukken 9 en 10 wordt ingegaan op veranderingen in de omgeving van bouwprojecten en hun ketens. Hoofdstuk 11 omvat vier gevalsstudies van concrete bouwprojecten en hun ketens.

In hoofstuk 9 worden verschillende stimuleringsprojecten, gericht op de totstandkoming van bedrijfsoverstijgende informatisering in de bouw, onder de loep genomen. Er wordt ingegaan op strategieën en knelpunten bij implementatie van EDI en PDI in de bouw.

${ }^{1}$ De twee case-studies in de woningbouw hebben plaats gevonden in het kader van het programma Kwaliteit en Logistick van het Ministerie van Economische Zaken. Op initiatief van de Vereniging Logistick Management is tezamen met de Nehem een project opgezet ter verbetering van logistiek management. Hiertoe zijn een drietal bedrijtstakken geselecteerd, waaronder de bouw. In deze bedrijfstak is Stichting Bouwresearch aangezocht als opdrachtgever. In opdracht van deze stichting heeft het organisatic-adviesbureau Berenschot in 1991 het project 'Customer service en doorlooptijdverkorting in de bouw' uitgevoerd. Laatsi genoemd onderzoeksproject omvatte de analyse van twee woningbouwprojecten en had tot doel te bezien hoe drie achter elkaar geschakelde bedrijven in een keten door afstemming van hun logisticke activiteiten tot cen optimale customer service naar de finale klant toe kunnen komen (zie \$ 3.1 voor het begrip 'customer service'). 
In hoofdstuk 10 worden innovaties in de organisatie van bouwprojecten beschreven. Aangegeven wordt hoe transactiepatronen tussen ontwerpende, uitvoerende en toeleverende bedrijven in de bouw als gevolg hiervan veranderen.

Hoofdstuk 11 analyseert in hoeverre in de bestaande bouwpraktijk organisatievormen te vinden zijn die als aanzetten tot of nadere concretiseringen van toepassing van integrale logistiek beschouwd kunnen worden. Hiervoor zijn een viertal gevalsstudies van concrete bouwprojecten en hun ketens behandeld. 



\section{Het bouwproject en zijn keten}

Doel van dit hoofdstuk is inzicht te krijgen in de organisatie rondom een bouwproject en zijn logistieke keten. Eindpunt van een keten van bouwmaterialen is meestal de produktie op de bouwplaats, d.w.z. het proces waarbij materialen in of aan het bouwwerk worden aangebracht. Daarom zal dit hoofdstuk beginnen met de beschrijving van de organisatie van de bouwproduktie, ofwel de beschrijving van de verschillende fasen in een bouwproces. Vervolgens zal de organisatie van de produktie van bedrijven beschreven worden die materialen toeleveren op de bouwplaats. Nadat zo is ingegaan op de verschillende produktiewijzen in de diverse bedrijven, die bijdragen aan de constructie van een bouwwerk, worden karakteristieken van de daarbij behorende goederen- en informatiestromen beschreven.

De opzet van dit hoofdstuk is als volgt. Paragraaf 8.1 en 8.2 gaan in op de organisatie van de produktie bij de verschillende bedrijven in logistieke ketens in de bouw. In paragraaf $8.1 \mathrm{komt}$ het bouwproces in het algemeen aan de orde en wordt de wijze van produktie van de bouwnijverheid behandeld. Paragraaf 8.2. gaat in op de organisatie van de produktie bij twee groepen van toeleveranciers van de bouwnijverheid: de bouwmaterialengroothandel en de industriële toeleveranciers. In $\S 8.3$ en 8.4 staan de karakteristieken van resp. goederen- en informatiestromen in de keten centraal.

\subsection{Het bouwproces als vorm van projectgewijze produktie}

De relatie tussen bouwproces en toelevering is in figuur 8.1 uitgebeeld: op de horizontale as staat het bouwproces, op de verticale as de toelevering.

FIGUUR 8.1 Bouwproces en toelevering in de bouw;

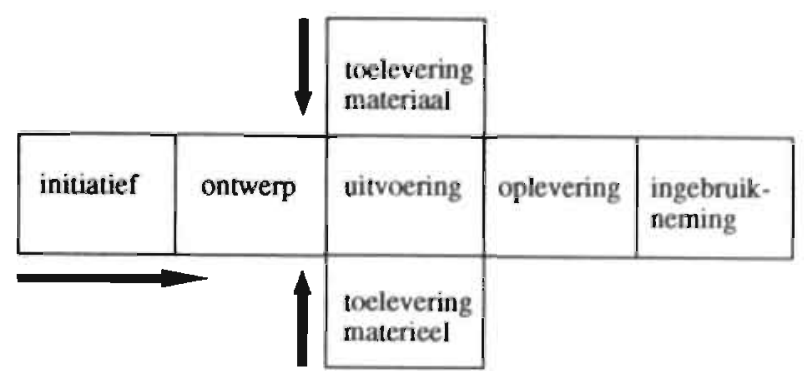


Het bouwproces kan omschreven worden als 'het geheel van processen, invoeren en relaties, dat nodig is om een bouwkundig werk te realiseren' (SBR, 1977, 16). Initiatief, ontwerp, uitvoering en oplevering zijn de voornaamste fasen in het bouwproces. Tijdens de uitvoering wordt materiaal (beton, prefab-gevelelementen etc.) en materieel (kranen, steigers, etc.) naar de bouwplaats of de magazijnen van uitvoerende partijen getransporteerd. In het empirisch onderzoek richten we ons vooral op de bouwmaterialenstroom. De toevoer van materieel krijgt slechts zijdelings aandacht. In bovenstaande figuur zijn oplevering en ingebruikneming als de laatste twee fasen van het bouwproces aangeduid. Na het bouwproces kunnen nog twee fasen onderscheiden worden: onderhoud en beheer (tijdens gebruik van het gebouw) en sloop.

\subsubsection{Hel bouwproces}

De start van een bouwproces ligt bij de opdrachtgever. Deze initiatiefnemer kan de daadwerkelijke gebruiker zijn, bijvoorbeeld een fabrikant of een bewoner, een beheerder, bijvoorbeeld een woningbouwcorporatie, of een projectontwikkelaar. De laatste is vaak gelieerd aan de beleggingswereld. Opdrachtgevers kunnen in de volgende twee categorieën ingedeeld worden (SBR, 1988):

- de professionele opdrachtgever: deze bouwt meestal iets dat voorziet in de behoefte van potentiële gebruikers van bouwwerken;

- de incidentele opdrachtgever: deze bouwt met het oog op voorziening in eigen behoefte.

Tot de initiatieffase, de eerste fase van het bouwproces, behoort het formuleren van de huisvestingsbehoeften op basis van een via marktonderzoek gesignaleerde vraag of op basis van een analyse van de te huisvesten organisatie. De wensen en behoeften van de opdrachtgever worden vertaald in een Programma van Eisen. Dit omvat gebruikseisen, functies en prestaties en voorwaarden.

In de tweede fase wordt dit Programma van Eisen vertaald in een ontwerp. Het Programma van Eisen is de schakel tussen wensen van klant en het ontwerp. Partijen in de ontwerpfase zijn architecten en technische adviseurs. Wanneer een architect voor een onderdeel van de opdracht behoefte heeft aan de bijstand van een specialist kan hij of zij zo'n specialist voor eigen rekening en verantwoording inhuren. Voorbeelden van specialisten zijn werktuigbouwkundig adviseurs (klimaatbeheersing, akoestiek, liften e.d.) en electrotechnische adviseurs (verlichting, electronica e.d.). De ontwerpfase resulteert in een pakket informatie voor het uitvoerend bouwbedrijf. Het ontwerp vormt het uitgangspunt voor de uit te voeren activiteiten door de aannemer. Afhankelijk van het soort opdrachtgever en het soort eindprodukt kunnen in praktijk de initiatief- en de ontwerpfase in elkaar schuiven. De initiatiefnemer hoeft niet per definitie een architect in te schakelen voor het ontwerp. Voorbeeld is de woningbouwvereniging die zelf het initiatief neemt en intern het Programma van Eisen in een ontwerp vertaalt.

Vanuit het definitieve ontwerp wordt bepaald welke activiteiten tijdens de uitvoering verricht moeten worden, welke bouwstoffen of -materialen gebruikt moeten worden en aan welke kwaliteitseisen ze moeten voldoen. Deze informatie wordt opgenomen in een bestek (een bestek is de beschrijving van een bouwkundig werk). Als het plan besteksgereed is vraagt doorgaans de architect namens de opdrachtgever bij diverse aannemers prijsaanbiedingen. Dit is de aanbesteding van het project. 
Na de vraag een offerte uit te brengen en aan te geven of het bouwbedrijf het project aan kan, start feitelijk de fase van uitvoering door het bouwbedrijf, de derde fase (RBB, 1991). ${ }^{1}$ De aanvraag wordt geanalyseerd (bestek en tekeningen) en de bouwen werkmethoden vastgesteld. Aan de hand van bestek en tekeningen, die uit te splitsen zijn in gespecificeerde 'elementen' of gebouwdelen, is het de taak van het uitvoerend bouwbedrijf het project te realiseren. Aan de hand van de omsehrijving van de elementen bepaalt het bouwbedrijf de methode van werken (bijv. dak prefab aanbrengen of 'traditioneel' timmeren). Voor de realisatie van het project heeft het bedrijf mensen, materiaal en materieel nodig. Over een aantal van deze benodigdheden zal een onderneming zelf beschikken, andere worden aangeleverd door toeleveranciers. Op basis van deze overwegingen worden de eerste (grove) planningen samengesteld, de keuze wat zelf te doen en wat uit te besteden gemaakt en de calculatie afgerond. De opdrachtgever 'gunt' vervolgens het werk aan de laagste aanbieder. Deze aanbieder makt met de opdrachtgever het contract van aanneming op. Hierin staat de aanneemsom, de aanvangs- en opleveringsdatum en diverse technische en administratieve bepalingen.

Na opdrachtverwerving begint binnen het bouwbedrijf de projectvoorbereiding, inkoop, produktievoorbereiding en produktie.

In de fase van projectvoorbereiding vinden onder leiding van de projectleider van het aannemersbedrijf de volgende activiteiten plaats (RBB, 1991):

- de samenstelling van het projectteam;

- bepaling van de onderaannemers en de toeleveranciers;

voorbereiding van het startgesprek;

bepaling van het budget voor zowel interne als externe activiteiten (bijvoorbeeld inkoop materiaal en diensten);

opstelling van het projectdraaiboek met verfijningen van de eerder gemaakte (grove) planningen.

Het projectdraaiboek bevat algemene randvoorwaarden voor de realisatie van het bouwproces en de argumentatie voor de opzet van de planning voor de diverse bij het bouwproces betrokken partijen, met name de onderaannemers en toeleveranciers.

Aan de hand van deze randvoorwaarden richt de inkoopfunctie van de hoofdaannemer zich op de procesbeheersing en -bewaking van alle externe activiteiten die met de toelevering samenhangen. De functie inkoop vertaalt wensen en eisen van het bouwbedrijf naar de toeleveranciers en ziet toe op naleving van gemaakte afspraken. Directe controle bij toelevering vindt op de bouwplaats door de (assistent-)uitvoerder van de aannemer plaats. Op basis van daar afgetekende bonnen ('de poot van de uitvoerder') en regelmatige contacten met de uitvoerder controleert de afdeling inkoop of toeleveranciers zich aan de afspraken houden.

De afdeling produktievoorbereiding moet bekend zijn met de gemaakte afspraken ten aanzien van toe te leveren materialen, materieel en diensten. Op basis hiervan worden voorbereidingen getroffen voor de organisatie van de fysieke produktie. Men zou kunnen zeggen dat de functie inkoop van het aannemingsbedrijf zich richt op externe procesbeheersing, de produktievoorbereiding op interne procesbeheersing.

${ }^{1}$ Het aanbestedingsstelsel komt in hoofdstuk elf uitgebreider aan de orde. 
De produktie is ten slotte de uitvoering van de in de voorgaande stappen genomen beslissingen en keuzes. Er vindt verwerking en assemblage van toegeleverde materialen plaats. Produktie wordt hier gedefinieerd als het proces waarbij materialen in of aan het gebouw worden aangebracht. De voorgaande fasen kunnen tezamen als een besluitvormingsproces beschouwd worden, de produktie als uitvoering van handelingen die het resultaat zijn van dit besluitvormingsproces.

\subsubsection{Aspecten van projectgewijze produktie}

De produktie van een bouwkundig werk heeft een aantal kenmerken die tot een specifieke organisatie van de logistieke functie leiden (SBR, 1989a). Ten eerste heeft de organisatie van het produktieproces in beginsel een tijdelijk en eenmalig karakter. Ten tweede worden bouwwerken steeds op lokatie uitgevoerd. Ten derde is er in veel gevallen een strikte arbeidsdeling tussen de betrokken bedrijven. Op deze drie aspecten zal hier verder worden ingegaan.

Het produceren van een bouwkundig werk is ten eerste een voorbeeld van een projectgewijze produktie. Het bouwprodukt is zeer gedifferentieerd en gebrek aan standaardisatie maakt de bouw tot voorbeeld van stukproduktie. Een belangrijk aspect van deze produktiewijze is dat een groot deel van de produktie-organisatie iedere keer weer opnieuw moet worden ingericht. Er moeten opnieuw werkmethoden worden bepaald, voortgangstempi worden vastgesteld en inkoopprocedures worden opgestart. Daarnaast moeten plannen voor de inzet van mensen en hulpmiddelen en afroepschema's voor toe te passen materialen worden gemaakt. leder project kent nieuwe tekeningen, een nieuwe opdrachtgever, een nieuwe lokatie, een nieuwe aannemer etc. In het fabrikageproces op de bouwplaats staat de handmatige assemblage van produkt-onderdelen centraal. De organisatiekenmerken van projectgewijze produktie worden echter minder dominant omdat steeds vaker gebruik wordt gemaakt van standaardcomponenten.

Een tweede kerimerk van het bouwproces is dat bouwwerken steeds op lokatie worden uitgevoerd. Het eindprodukt is immobiel. Een zeer belangrijk aspect van dit werken op lokatie is het aan- en afloopeffect van de verschillende deelwerkzaamheden. Dit aanen afloopeffect - te maken kosten naar en van lokatie - is een sterke drijfveer alleen in volle dagtaken te werken. Een dergelijke werkwijze leidt in veel gevallen tot het vergroten van intervallen en daarmee tot verlenging van de bouwtijd. Deelbewerkingen die sneller gaan dan het algemeen voortgangstempo hebben een grotere werkvoorraad nodig voor dagproduktie. Wil er een dagtaak voor een specialist zijn, dan moet een aantal werkzaamheden worden opgespaard. De ontstane intervallen kunnen verkleind worden door verhoging van het algemene voortgangstempo. In dat geval is de benodigde werkvoorraad voor de snel lopende deelbewerkingen eerder beschikbaar.

Naast het aan- en afloopeffect is ook de afhankelijkheid van weersomstandigheden een gevolg van het werken op lokatie. Het produktie-proces is op bepaalde punten gevoelig voor ongunstige weersomstandigheden of vraagt in dat opzicht om extra maatregelen. Ondanks die weersgevoeligheid vereisen de relatief lage winstmarges een zeer 'strakke' (tijdkritische) planning. Dit om leegloop van capaciteiten en investeringen in bouwmaterialen zo gering mogelijk te doen zijn. Gevolg is dat hoge eisen aan afstemming en communicatie tussen de verschillende partijen gesteld worden. 
Een derde kenmerk van het produktieproces in de bouw is de strikte verdeling van verschillende soorten werkzaamheden over een relatief groot aantal autonome bedrijven. In het bouwproces zijn vaak geheel verschillende ondernemingen verantwoordelijk voor ontwerp, uitvoering en toelevering. In traditionele bouwprocessen vormen het Programma van Eisen en het ontwerp vaak een afgebakend geheel ten opzichte van de uitvoerende partij, de aannemer. Naast de scheiding tussen ontwerp en uitvoering, is ook binnen het uitvoeringsproces sprake van een sterke functiegerichte opzet. De verschillende soorten werkzaamheden zijn ondergebracht in een groot aantal relatief autonome bedrijven, die per project bij elkaar worden gebracht. Naast de hoofdaannemer zijn vaak een groot aantal gespecialiseerde onderaannemers actief.

Betrokken partijen zijn de opdrachtgever, de architect, de hoofdaannemer, het ingenieursbureau, de onderaannemer, de installateur, de toeleveranciers (en producenten van bouwmaterialen) en de tussenhandel van bouwmaterialen. ledere specialisatie heeft zijn eigen cultuur en werkwijze. Men heeft daardoor in de bouw van oudsher bepaalde afstemmingsproblemen. Deze problemen hangen ook samen met de horizontale produktie-organisatie in de bouw: de produktie-organisatie kenmerkt zich door 'volgtijdig geschakelde deelprocessen' (SBR, 1989a, 22).

\subsubsection{Bouwmethode en logistieke keuzen}

Ontwerpende partijen leggen in het begin van een bouwproces een aantal primaire keuzen vast die grote consequenties hebben voor de organisatie van de logistiek tijdens de uitvoering. Deze keuzen hebben betrekking op de aard van de toegepaste deelprodukten, de verwerving van materialen en diensten, de inschakeling van middelen voor horizontaal en verticaal transport, de inrichting van de bouwplaats en de inzet van specifieke transportmensen. Met name de keuze voor een bepaalde bouwmethode bepaalt karakteristieken van de logistieke organisatie tijdens de uitvoering.

Bij het onderscheiden van diverse bouwmethoden is het gebruikelijk de constructie centraal te stellen. Reden hiervoor is dat, afgezien van de fundering, in feite alle werkzaamheden op de bouwplaats (inclusief materiaalgebruik) beïnvloed worden door de gekozen werkwijze bij de draagconstructie. Een gangbare indeling van diverse bouwmethoden is het onderscheid tussen stapelbouw, gietbouw en montagebouw (ook wel aangeduid als grote-elementenbouw) (Benes en Diepeveen, 1977). Stapelbouw wordt in de regel als traditionele bouw beschouwd, montage-bouw is per definitie niet traditioneel.

Traditionele bouw wordt ten eerste gekenmerkt door een vloerconstructie van hout (balklaag en houten delen) die in het werk wordt vervaardigd, of van beton die in het werk in niet-gestandaardiseerde bekistingen is gestort. Een tweede kenmerk is een draagwandconstructie van in het werk gemetselde bakstenen, kalkzandstenen of van beton dat in het. werk in niet gestandaardiseerde bekistingen is gestort. Bouwen met een vloer-en diaagwandconstructie die aan bovenstaande kenmerken voldoet wordt als traditioneel aangemerkt. Door de vinding van gewapend beton wordt de basis gelegd voor een compleet nieuwe bouwwijze, waarbij handmetselen en bijbehorende afwerking vervangen wordt door het assembleren van geprefabriceerde elementen en inzet van gestandaardiseerde bekistingen. 
De stapelbouwmethode kenmerkt zich door aanvoer van bouwmaterialen op het werk die zowel nat (metselwerk, beton, tegelwerk) als droog (bakstenen, kalkstandstenen, hout, metaal, kunststof) worden verwerkt. Bouwmaterialen hebben hier meestal geen grote afmetingen zodat zij met de hand zijn te hanteren. Zij zijn meestal direct bij de tussenhandel verkrijgbaar. Grondprincipe bij stapelbouw is dat de constructie van de wanden los gezien kan worden van die van de vloer. De stapelbouw kan in de regel als traditioneel beschouwd worden.

De tweede methode is de gietbouwmethode. Kenmerkend voor deze methode is dat bouwstoffen op het werk aangevoerd worden en daar verder nat verwerkt worden. De bouwstoffen die in de gietbouw worden gehanteerd zijn de zogenoernde vormloze bouwstoffen, zoals zand en cement. Grondprincipe bij gietbouw is dat de wand- en vloerconstructie met behulp van bekisting op de bouwplaats gestort wordt. Bij de traditionele gietbouw gaat het om op de bouwplaats samengestelde unieke bekistingen terwijl het bij niet-traditionele gietbouw om gestandaardiseerde bekistingen gaat.

Bij de derde bouwmethode, de montage- of grote-elementenbouw, wordt gebruik gemaakt van bouwelementen die op het werk aangevoerd worden. De montagebouw is per definitie niet-traditioneel. In tegenstelling tot gietbouw gaat het om zogenaamde grote elementen die buiten de bouwplaats in fabrieken geprefabriceerd zijn en op de bouwplaats geassembleerd worden. De elementen zijn in de fabriek al voorzien van diverse sparingen, leidingen e.d. Bij de uitvoering is speciaal materieel vereist. Zeer belangrijk is de montagekraan die een grotere capaciteit dient te hebben dan bij de gietbouwmethode.

Het bovenstaande geeft aan dat de keuze voor een bouwmethode tegelijkertijd voor een belangrijk deel het te gebruiken materiaal en materieel bepaalt. De stapelbouwmethode maakt gebruik van universele bouwmaterialen die op de bouwplaats worden verwerkt, hetgeen geen speciaal materieel vereist. De gietbouwmethode maakt gebruik van 'vormloze' bouwstoffen. Bij deze methode bestaan de dragende delen uit op de bouwplaats gegoten beton. Hierbij is, evenals bij de grote-elementenbouw, speciaal materieel vereist.

\subsection{De organisatie van de produktie bij toeleveranciers van de bouw}

De plaats van de toeleveranciers in de keten (de verticale as in figuur 8.1) is in grote lijnen in figuur 8.2 weergegeven.

De binnenlandse en importerende handel vormt een schakel tussen enerzijds binnenlandse en buitenlandse producenten en anderzijds de bouwbedrijven en de overige afnemers. Sommige bouwmaterialen worden niet uitsluitend voor de bouwproduktie gebruikt, maar tevens voor andere doeleinden. Zo is hout bijvoorbeeld niet alleen een belangrijke grondstof voor de bouwnijverheid, maar ook voor de meubel- en papierindustrie. Naast andere bedrijfsklassen gebruiken ook particulieren voor bouwen in eigen beheer en doe-het-zelf werkzaamheden bouwmaterialen. Tevens wordt een deel van de in Nederland geproduceerde bouwmaterialen geëxporteerd. 


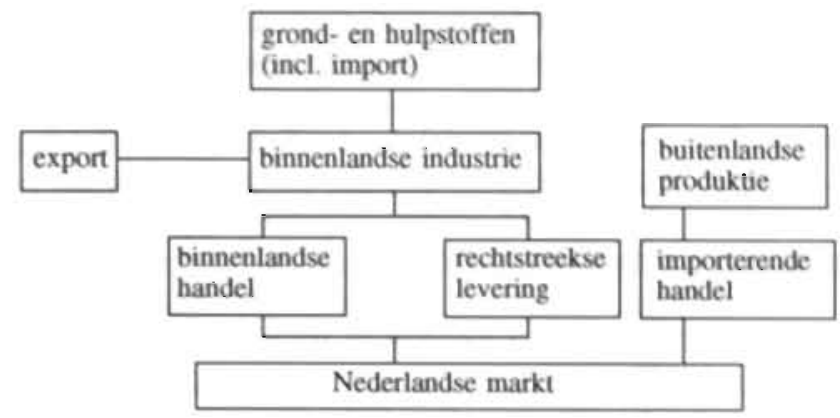

\subsubsection{De bouwmaterialengroothandel}

Ondernemingen worden tot de groothandel gerekend als ze 'voor eigen rekening goederen verhandelen die niet in de eigen onderneming zijn vervaardigd en deze afzetten aan groot- en/of detailhandelaren, bedrijfsmatige gebruikers en/of grootverbruikers.' (EIM, 1991, 13). Het voornaamste verschil met de detailhandel is dat de groothandel voornamelijk aan bedrijfsmatige afnemers levert. De functie van de groothandel ligi in het zo goed mogelijk. overbruggen van het spanningsveld tussen voortbrenging en verbruik of aanbod en vraag op een viertal aspecten, namelijk het plaats-, tijds-, hoeveelheids- en hoedanigheidsaspect (EIM, 1984). ${ }^{23}$

2 Voor alte groothandels geldt dat ze het spanningsverschil van plaats overbruggen door ergens anders te verkopen dan waar ingekocht wordt. Het tijdsaspect betekent dat de groothandel voorraad aanhoudt om het tijdsverschil tussen voortbrenging en vraag te overbruggen. De vraag naar een goed is zelden constant, terwijl de fabrikant daarentegen continuīteit in het produktieproces nastreeft. Andersom heeft het aanbod soms een periodiek verloop, zoals in de agrarische sector, terwijl de produkten het hele jaar door gevraagd worden. Met het hoeveelheidsaspect wordt bedoeld dat de groothanđel verschillen in aangeboden en gevraagde hoeveelheid opheft door het verzamelen, assembleren en splitsen van goederen. Hierbij moet een onderscheid gemaakt worđen tussen de collecterende en đistribuerende handel. De collecterende groothandel koopt relatief kleine pariijen in $c \pi$ verkoopt relatief grote partijen. De distribuerende groothandel koopt relatief grote partijen in en verkoopt relatief kleine hoeveelheden. Het hoedanigheidsaspect slaat op het overbruggen van een heterogeen aantod met cen heterogene vraag door het aanhouden van een bepaald assortiment en het uitvoeren van veredelingsactiviteiten, zoals zagen, snijdèn, wegen en verpakken. Ook service wordt tot dit aspect gerekend: alinemers wensen het gekochte goed omkiced te zien met bepaalde zekerheden en garanties nadat de aankoop is gedaan. De economische produktiviteit van de groothandel ligt in het feit dat de groothandel de transformatie van inkoop- in verkoopvoorwaarden goedkoper kan vervullen dan de ieverancier resp. de afnemer van het handelsbedrijf. De groothandel wordt echter voortdurend geconfronteerd met zogenaamde in- en uitschakelingstendensen, waarbij] handelsfuncties worden opgenomen, c.q. afgestoten door producenten en/of afnemers.

${ }^{3}$ Het ElM onderscheidt een vijftal typen groothandelsbedrijven (1991): - verkoopkantoor van een buitenlandse onderneming: onderneming importeert de helft of meer van de inkoop en behaalt meer dan de helft van de omzet met allecnvertegenwoordigingen.

- merkimporteur: niet-buitenlandse onderneming die de helft of meer van de inkoop importeert en meer dan de helft van de omzet behaalt met alleenvertegenwoordiging.

- exporteur: behoort niet tot voorgaande bedrijfstypen en exporteert de helft of meer van de omzet. 
Om deze functie te vervullen worden binnen de groothandel een aantal activiteiten verricht. Hierbij zijn drie hoofdactiviteiten te onderscheiden (Thies in: EIM, 1984):

- de communicatie (informatiestromen);

- de fysieke distributie en kwalitatieve transformatie (goederenstromen);

- de betaling en dienstverlening (gelldstromen).

Deze paragraaf gaat alleen in op onderdelen van fysieke distributie en kwalitatieve transformatie. Het eerste activiteitengebied komt in $\$ 8.4$ aan de orde. Het derde activiteitengebied wordt niet behandeld omdat dit gebied niet direct met de organisatie van de logistiek te maken heeft.

Fysieke distributie kan verder gesplitst worden in transport, voorraadbeheer en magazijnen (Van Goor et al., 1989).

Wat betreft het transport, het eerste onderdeel van fysieke distributie, bepalen samenstelling van de klantenkring, aard van het afzetgebied en gemiddelde afleveringsgrootte of transport al dan niet wordt uitbesteed. Uit onderzoek van het EIM (1991) blijkt dat de binnenlandse groothandel in het algemeen, dus niet alleen bouwmaterialengroothandels, relatief vaker alle transport in eigen beheer heeft (43\% van dit type groothandel). Voor andere typen groothandel - verkoopkantoren, merkimporteurs, importeurs en exporteurs - is dit maar 9 tot $18 \%$. Bekend argument voor eigen vervoer is dat de service-verlening beter gewaarborgd is dan bij vreemd vervoer. Ook wordt direct contact met de afnemers als waardevolle bron van informatie en als klantenbindend element beschouwd (EIM, 1984). Tevens wordt bij kwetsbaar materiaal en complexe handling de voorkeur gegeven aan eigen vervoer.

De binnenlandse bouwmaterialengroothandel levert vaak binnen een straal van enige tientallen kilometers en is dus sterk regionaal gebonden. De service op het afleveringspunt beperkt zich veelal tot bezorging vóor het magazijn van de aannemer of op de bouwplaats. De groothandel brengt produkten tot de verharde weg bij de bouwplaats, eventueel voor of in de nishut (de nishut is een vaak van hout en golfplaat gemaakte voorraad- en werkplaats op de bouwplaats). Soms wordt op de eerste of tweede verdieping van een bouwwerk afgeleverd, bijvoorbeeld bij bundels hout. Belangrijke beperking voor de aanlevering van bouwmateriaal op de bouwplaats is het feit dat de meeste bouwplaatsen alleen van 7.00 uur 's ochtends tot 16.00 uur 's middags beleverd kunnen worden. Alleen dan zijn medewerkers op de bouwplaats aanwezig, noodzakelijk voor de administratieve afhandeling en verdere opslag van de geleverde goederen.

Tot voor kort kwam het tweede onderdeel van fysieke distributie, het voorraadbeheer, binnen de bouwgroothandel vaak neer op 'papier en potloodwerk'. Van een strak beleid gericht op beheersing en terugdringing van de voorraden en de daarmee verbonden kosten was niet direct sprake. Door invoering en toepassing van geautomatiseerde voorraadsystemen is binnen de branche een kentering hierin opgetreden.

Voor de Nederlandse groothandels gespecialiseerd in hout is wel eens een voorstel gedaan om voor het houden van voorraad een scheiding aan te brengen tussen groot-

\footnotetext{
- imporieur: behooni niet tot voorgaande bedrijfstypen en importeert de helft of meer van de inkoop. - binnenlandse groothandel (of grossier): behoort niet tot een van de voorgaande bedrijfstypen en importeert minder dan de helft van de inkoop en exporteert minder dan de helft van de omzet.
} 
handel en grossiers. ${ }^{4}$ Grossiers moeten voor groothandels als depots gaan functioneren, waarop altijd een beroep gedaan kan worden. Groothandels kunnen dan volstaan met het in voorraad houden van de in hun marktsegment gangbare houtsoorten. Door voorraad op een efficiënte wijze over de geledingen van de distributiekolom te verdelen, worden op die manier de totale voorraadkosten voor de branche teruggedrongen. Serviceverlening aan afnemers op het punt van levering en assortiment hoeft daar niet onder te leiden. Feitelijk heeft deze ontwikkeling zich ook voorgedaan. Door schaalvergroting en fusering hebben grote bouwmaterialengroothandels hun eigen centrale opslagplaatsen waarop detaillisten een beroep kunnen doen. Door deze concentratietendens is het aantal partijen afgenomen.

De opslag van bouwmaterialen voor het af- en inbouwgebeuren bij de bouwmaterialengroothandel, het derde onderdeel van fysieke distributie, moet in veel gevallen overdekt zijn. Veelal geschiedt de opslag dan ook in loodsen. Het intern transport vindt onder meer plaats met vorkheftrucks en zijladers. Orders worden met wagentjes verzameld om vervolgens naar de expeditieloods getransporteerd te worden. Een andere mogelijkheid is het zgn. drive-in systeem. In dat geval rijdt de klant de loods binnen, laadt het materiaal op de auto, tekent de bon af en rijdt weg. Van dit systeem maken met name kleine (onder)aannemers gebruik.

Kwalitatieve transformatie valt in drie delen uiteen: assortimentsvorming, de service en de fysieke produktveredeling (EIM, 1984).

Voor de bouwmaterialengroothandel geldt dat de ontwikkeling van het assortiment een steeds belangrijkere functie wordt. Grotere produktdifferentiatie maakt het aanbod ondoorzichtig. De taak van de groothandel is om de klant over het bestaande aanbod voor te lichten.

Naast assortimentsvorming neemt ook service aan belang toe. In sommige gevallen vereist toenemende complexiteit van bouwsystemen extra ondersteuning van toeleverende partijen in de ontwerp- en uitvoeringsfase. De veelheid aan marktpartijen maakt het voor de meeste toeleveranciers onaantrekkelijk on deze functie zelf te vervullen. Andere voorbeelden van de hogere eisen die aan service gesteld worden zijn de bewaking van leveringen tijdens een project en het samenstellen van complete bouwdelen, die op het werk 'gesteld' of gemonteerd worden.

De derde groep van kwalitatieve transformatic-activiteiten binnen de bouwmaterialenhandel ligt op het terrein van de fysieke produktveredeling. Voorbeelden hiervan zijn assembleren, sorteren, mengen, afwerken, snijden, wassen, verpakken en opslaan. Fysieke veredelingsactiviteiten van bijvoorbeeld hout zijn het herzagen van hout tot de gewenste maten, het schaven van ruw hout tot glad hout en eventueel het drogen en bewerken van het hout (bijvoorbeeld profielbewerking, impregneren en het maken van kozijnen e.d.).

\footnotetext{
${ }^{4}$ Structuurschema van de Nederlandse Houthanđel, Nehem, 's Hertogenbosch, 1982.
} 


\subsubsection{Industriële toeleveranciers}

Industriële toeleveranciers van de bouw kunnen in twee categorieën worden onderverdeeld. Enerzijds zijn er leveranciers en producenten van 'elementaire' bouwcomponenten, zoals beton(elementen), hout, staal, bakstenen, kozijnen/deuren en installaties. Op staal na vinden zij vooral in de bouw hun belangrijkste toepassing. Anderzijds zijn er de toeleveranciers en producenten van produkten en materialen die in verschillende sectoren worden gebruikt, zoals verven, lijmen en elektrische onderdelen. Mischgofsky (1991) spreekt in dit verband van een bouwende kern met twee schillen: een eerste schil omvat met name de toeleverende bouwmaterialenindustrie, de tweede perifere bedrijven (zie figuur 8.3). De eerste schil is eerder 'low- en medium tech' en kleinschalig, de periferie meer 'high-tech' en gedomineerd door multinationals. Met name de eerste schil, die het meest afhankelijk is van de bouw en sterk op bulkprodukten gericht, is zeer kwetsbaar voor teruglopende bouwvolumes.

FIGUUR 8.3 Indeling van de bouwsector in bouwende kern, toeleverende en perifere bedrijven

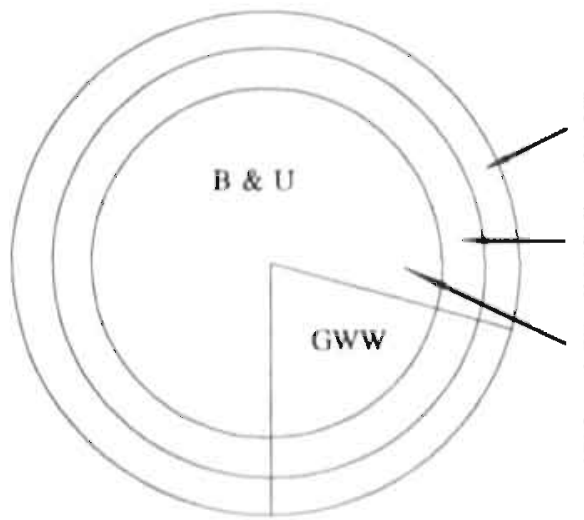

periferie (verf, electra. vangrails, installaties, stoplichten)

rand (toelevering

bouwmaterialen, elementen installaties)

kem (ontwerp, uitvoering. onderhoud, beheer)

B \& U: Burgerlijke en Utiliteitsbouw GWW: Grond-, water- en wegenbouw

Bron: bewerking van Mischgofsky (1991, 7).

Bedrijven uit de eerste categorie behoren voor een groot deel tot de hout- en meubelindustrie en de bouwmaterialenindustrie. ${ }^{5}$ Variwege de veelheid van bedrijfsgroepen worden er op twee nader ingegaan: de timmer- en parketvloerenindustrie en de betonen cementwarenindustrie. Bedrijven uit de tweede categorie behoren tot uiteenlopende sectoren als de basismetaalindustrie, metaalproduktenindustrie en de chemie. De metaalproduktenindustrie is in deze categorie de voornaamste toeleverancier van de bouwnijverheid. Er wordt nader ingegaan op de bedrijfsgroep 'overige constructiewerkplaatsen'.

${ }^{5}$ In bijlage 1 wordt mei statistische gegevens en onderzoek van het Economisch Instituut voor de Bouwnijverheid (EIB) onderbouwd dat genoemde SBI-bedrijfsklassen en -groepen de voornaamste inđustričle toeleveranciers van de bouwnijverheid zijn (SBI staat voor de Standaard Bedrijfsindeling). 
Ook produktieprocessen van bouwmaterialen kunnen onderscheiden worden in serie-, "batch" en stukproduktie. Serieproduktie heeft betrekking op sterk gestandaardiseerde materialen die veelal continu worden geproduceerd en waarvan meestal een voorraad wordt gevormd om pieken in de vraag op te vangen. Voorbeelden zijn kalkzandsteen en baksteen. Soms worden produkten in beperkte series ('batches') gemaakt. Als bijvoorbeeld bij een utiliteitsbouwwerk van een bepaald kozijn veel stuks moeten worden verwerkt en dit zeer verspreid in de tijd gebeurt, kan het wenselijk zijn dat deze kozijnen in een aantal 'batches' worden gemaakt. Bij stukproduktie gaat het meestal om eenmalige produkten. Voorbeeld is het samenbouwen van een deel van een luchtbehandelingsinstallatie die compleet op het dak van een bouwwerk wordt geplaatst. De directe beschikbaarheid van bouwmaterialen bij de fabrikant wordt sterk bepaald door het feit of al dan niet in serie geproduceerd wordt.

\section{De timmer- en parketvloerenindustrie}

Het produktie-programma van de timmer- en parketvloerenindustrie heeft zich in de loop van de laatste jaren qua samenstelling belangrijk veranderd. Naasi traditionele produkten als ramen, kozijnen en trappen is het produktieprogramma uitgebreid met geprefabriceerde elementen voor de bouw, zoals kapspanten, dakelementen en gehele gevels of delen daarvan. Bovendien is de afwerking daarvan verplaatst van de bouw. plaats naar de fabriek. Schilderwerk, het aanbrengen van isolatiemateriaal en vensterglas e.d. vinden vaak in de fabriek plaats. Probleem voor de houtverwerkende industrie is de voortdurende dreiging dat hout wordt weggedrukt door kunststoffen. Voorbeeld zijn de kunststof kozijnen in de renovatie-sector. De opmars van kunststof produkten wordt nog eens versterkt door de onrust over de ontbossing van de tropische regenwouden. Volgens de milieubeweging zijn met name voor hardhout voldoende alternatieven voorhanden zoals grenen en kunststof produkten.

Het produktieproces van de timmer- en parketvloerenindustrie bestaat uit de bewerking van hout tot gerede produkten zoals kozijnen, deuren, keukens en trappen. Ontwerp en constructie worden overwegend nog conventioneel uitgevoerd. CAD/CAM systemen die ontwerpen direct vertalen in machinale instructies komen echter steeds vaker voor. De meeste bewerkingen zijn echter betrekkelijk eenvoudig van aard en kunnen in beginsel niet-machinaal worden uitgevoerd. Problemen in de bewerking worden vaak veroorzaakt door het feit dat hout geen homogeen materiaal is. Voor het herstellen van onvolkomenheden worden methoden als 'proppen', 'vullen' en 'vingerlassen' gehanteerd. Bij de eerste twee methoden wordt de onvolkomenheid verwijderd en in het gat materiaal gelijmd dat uit dezelfde houtsoort is gemaakt, het 'proppen', of met een speciaal vulmiddel gevuld. Bij 'vingerlassen' worden houten delen via 'tandverbindingen' in de lengterichting aan elkaar verlijmd. Het produktieproces wordt gekenmerkt door een hoge arbeids- en grondstoffenintensiteit.

Houtbewerkingsmachines worden voornamelijk uit West-Duitsland geïmporteerd. Deze machines, die in het algemeen afgestemd zijn op produktie in grote series, zijn in Nederland alleen bij de grote ondernemingen in gebruik. De gemiddeide seriegrootte van de meeste houtprodukten is de laatste jaren echter teruggelopen. Dit heeft ertoe geleid dat het moeilijker is geworden met bovengenoennde bewerkingsmachines remdabel te werken vanwege lange omsteltijden bij kleine series. Oplossing hiervocir zijn computergestuurde machines voorzien van 'gereedschaps-magazijnen" met zeer korte omsteltijden. Deze CNC-machines deden vanaf het begin van de jaren ' 80 hun intrede 
in de timmer- en parketvioerenindustrie. CNC-machines verkorten wachttijden, bijvoorbeeld bij het zagen van plaatmateriaal en het afkorten (op maat brengen), schaven en frezen van hout. De machines maken een grotere flexibiliteit en een daling van tussenvoorraden mogeiijk. Obstakel is echter dat deze flexibele automatisering met forse investeringen in apparatuur, organisatie en mensen gepaard gaat.

\section{De betonwarenindustrie}

De betonwarenbedrijven produceren afzonderlijke betonprodukten zoals heipalen, prefab-eiementen, buizen en trottoirbanden. Deze produkten zijn, al naar gelang hun besternming in een aantal groepen te verdelen: woning- en utiliteitsbouw, straataanleg en wegenbouw, buizen, hulpstukken en kolken, kunstwerken, weg- en waterbouw, agrarische toepassingen en overige betonprodukten. Er wordt in deze bedrijfstak een onderscheid gemaakt tussen 'handelsartikelen' en 'opdrachtsartikelen'. Onder handelsartikelen verstaat men produkten die zonder specificatie van de opdrachtgever - veelal op voorraad - gefabriceerd worden. Te denken valt hierbij aan betontegels, stoepbanden en rioleringsbuizen. Opdrachtsartikelen worden, zoals uit de naam bijikt, slechts in opdracht vervaardigd. Hieronder vallen met name betonconstructies. Vloerelementen en heipalen, die over het algemeen wel in standaardmaten worden geleverd, worden ook gerekend tot de categorie opdrachtsartikelen.

De betonmortelindustrie levert de bouw een in hoofdzaak uniform produkt toe: vloeibaar beton. Dit produkt kent verschillende varianten. De afzet van betonmortel stagneert sinds de jaren '70 en daarom is men sindsdien overgegaan tot het ontwikkelen van een aantal nieuwe betonsoorten. Nieuwe produkten zijn schuimbeton, collö̈daal beton (beton met lijm erin) en vezelversterkt beton (met als meest succesvolle het staalvezelbeton). Door deze produktvernieuwingen zijn bedrijven genoodzaakt meer technologische kennis in huis te halen.

De betonwaren- en de betonmortelindustrie kennen een verschillend produktieproces. Basisgrondstoffen voor de fabrikage van betonwaren en betonmortel zijn het bindmiddel cement en de toeslagmaterialen zand, grind en steenslag. In de betonwarenindustrie worden betonelementen geproduceerd. Het vloeibaar beton wordt in malien gegoten, waarna het beton wordt verdicht en gedroogd. De betonelementen worden eventueel nog verder afgewerkt en getransporteerd. Hier worden discrete produkten voortgebracht. Voordeel van prefab beton-elementen is dat ze onder alle weersomstandigheden geproduceerd kunnen worden. Een aantal regelmatig terugkerende knelpunten bij deze prefab-elementen zijn passingsproblemen door afwijkingen van instortdelen, te grote wisselingen bij naden en voegen, beschadigde elementen en kleurverschillen in het oppervlak. De betonmortelproduktie heeft, anders dan de betonwarenindustrie, een proceskarakter. Dit proces bestaat uit het mengen van diverse droge grondstoffen (zand, grind, enz.) met water en eventuele chemische toevoegingen (verhardingsmiddelen, kleurstoffen) tot vloeibaar beton.

Ook in de betonwarenindustrie wordt de computer bij diverse onderdelen van het bedrijfsproces ingeschakeld. Voorbeeld is een fabrikant van vloerelementen. Deze wordt geconfronteerd met een groot aantal opdrachtgevers, die allerlei soorten platen, in verschillende formaten, op bepaalde tijdstippen aangeleverd wil hebben. Omdat vloerelementen in precies de juiste volgorde op de bouwplaats moeten worden aangeleverd vereist dit een behoorlijke planning. Voor een soepele en flexibele combinatie 
van opdracht, ontwerp, produktie, opslag en transport, alsmede het inbouwen van een kleine, tussentijdse orders is computerondersteuning bijna onontbeerlijk.

In de betonmortelindustrie worden sinds de jaren ' 80 procescomputers gebruikt in het mengproces. Deze maken het mogelijk een nauwkeuriger gedoseerd produkt te maken. Hierdoor is een besparing op de grondstofkosten mogelijk. Ook wordt in deze industrie gebruik gemaakt van geautomatiseerde planning- en distributiesystemen. Deze systemen leiden tot een verhoging van de bezettingsgraad van de truckmixers.

\section{Overige constructiewerkplaatsen}

'Overige constructiewerkplaatsen' is de grootste bedrijfsgroep binnen de metaalproduktenindustrie. Produktie-processen in de metaalproduktenindustrie zijn in te delen naar aard van het technologisch proces: enerzijds de 'spaanloze' en anderzijds en 'verspanende' bewerking (Ministerie van Economische Zaken, 1981). Verspanen wordt wel gedefinieerd als al die bewerkingen van metalen en andere harde stoffen waarbij vorm gegeven wordt door het wegnemen van kleine deeltjes. De belangrijkste verspanende bewegingen zijn draaien, frezen, schaven, vijlen, slijpen, polijsten en alle varianten en combinatie daarvan. Onder spaanloze bewerkingen vallen gieten, smeden, lassen, solderen, snijden, buigen, strekken etc. 'Overige constructiewerkplaatsen' vormt samen met de tank-, reservoir- en pijpleidingbouw de staalconstructie-industrie. De bedrijfstak overige constructiewerkplaatsen kent een grote verscheidenheid aan bedrijven, zowel qua omvang als naar produkten. Gemeenschappelijk kenmerk van deze bedrijven is de betrekkelijk eenvoudige materiaalvoorbereiding en een produktietechniek nagenoeg geheell gebaseerd op lassen.

Bij de bedrijven komt zowel serie- en massaproduktie voor, zoals van ramen en deuren, als stukproduktie op specificatie, zoals van bruggen, sluizen, skeletten en ander constructiewerk. De grote bedrijven zijn in staat omvangrijke en zware constructies te fabriceren, zoals waterstaatswerken en offshore-constructies. Vooral in de fabrieken van stalen en non-ferro metalen ramen, deuren, wanden e.d. (SBI 34.41) vindt serie- en soms massafabrikage plaats. De voornaamste markt is de bouwwereld, hoofdzakelijk de utiliteitsbouw, omdat in de woningbouw, en zeker in de particuliere woningbouw, hout de boventoon voert. Wat de aard van ontwerpen en de fabrikage betreft is er een onderscheid tussen gestandairdiseerde constructies, die in grote aantallen worden gefabriceerd, en specifiek intworpen constructies voor één of een beperkte serie van gebouwen.

In de metaalproduktenindustrie vindt men diverse toepassingen van informatietechnologie ten behoeve van planning, voortgangsbewaking, logistiek e.d. In het produktieproces wordt gebruik gemaakt van $\mathrm{CNC}$-machines, automatische gereedschapswisselaars, palletiseringssystemen, lasrobots en geautomatiseerde assemblagelijnen.

\subsection{Goederenstromen in de bouw}

\subsubsection{Goederenstromen bij fabrikage en toelevering}

AJgemeen gesteld is het centrale logistieke probleem in bouwketens hoe, wanneer en in welke hoeveelheden bouwmateriaal naar de werkplekken kan worden getranspor- 
teerd, nadat het op de fabriek is geproduceerd. Het gaat om het overbruggen van het gat tussen produktie van het materiaal op de fabriek en de verwerking van het materiaal aan of in het gebouw (SBR, 1977). In een gebouw worden zeer veel produkten verwerkt en deze produkten komen via sterk verschillend gestructureerde produktketens van fabriek naar bouwplaats. Met andere woorden, de materialen doorlopen een groot aantal verschillende bewerkings- en verplaatsingsactiviteiten. Nadat het bouwmateriaal op de fabriek is geproduceerd, ondergaat het een aantal overslag-, opslag- en vervoersactiviteiten voor het op de bouwplaats in een gebouw wordt verwerkt. Deze activiteiten worden uitgevoerd met behulp van overslagmiddelen (bijv. laad- en losinstallaties), vervoersmiddelen (bijv. vrachtauto's) en opslagmiddelen (bijv. magazijnstellingen).

Bij de bouwmaterialenfabrikage en de toelevering van materialen naar de bouwplaats zijn verschillende goederenstromen aan te geven.

$\mathrm{Bij}$ de bouwmaterialenfabrikage kunnen vier verschillende stromen onderscheiden worden (UCB, 1991):

a. de meest eenvoudige stroom is die waarbij grondstoffen de invoer vormen en de bouwstof als uitvoer resulteert (voorbeeld is de produktie van bakstenen);

b. gecompliceerder is het proces waarbij eerst een halfprodukt (bouwstof) wordt vervaardigd en vervolgens het eindprodukt (bouwprodukt) wordt samengesteld (voorbeeld is het proces waarbij van dorpels en regels kozijnen worden vervaardigd);

c. er zijn echter ook bouwmaterialen waarbij de produktie door twee of meer ondernemingen geschiedt. Een onderneming die toelevert aan een volgende onderneming (bijvoorbeeld glas naar de kozijnenfabrikant) is daarvan een eenvoudige vorm;

d. de meest ingewikkelde vorm is de vorm waar meerdere bouwmaterialen naar één eindfabrikant gaan die het uiteindelijke bouwprodukt fabriceert (voorbeeld is de produktie van binnenspouwbladen met kozijnen, ramen, deuren, glas en hang- en sluitwerk).

Bij toelevering van materialen naar de bouwplaats kan onderscheid gemaakt worden naar de ondernemingen die bij de stroom betrokken zijn. De keten wordt gekenmerkt door twee typen ondernemingen die aan de uitvoering op de bouwplaats vooraf gaan: de industriële toeleverancier en de bouwmaterialengroothandel. Dit onderscheid resulteert in een drietal verschillende stromen (UCB, 1991):

a. de fysieke stroom van de industriële toeleverancier, via de bouwmaterialengroothandel naar de bouwplaats;

b. de fysieke stroom direct van de industriële toeleverancier naar de bouwplaats maar met een bemiddelende, administratieve rol van de bouwmaterialengroothandel;

c. de fysieke stroom direct van de industriële toeleverancier naar de bouwplaats.

In figuur 8.4 zijn twee voorbeelden aangegeven van een logistieke keten waarbij de fysieke stroom direct van de industriële toeleverancier naar de bouwplaats gaat.

Voorbeelden van materialen die vaak rechtstreeks van de fabrikant naar de bouwplaats getransporteerd worden zijn vaak elementaire bouwcomponenten als:

- metselbaksteen, kalkzandsteenprodukten, dakpannen, betonmortels en ketels voor c.v. installaties uit de categorie standaardprodukten;

- kozijnen, trappen, deuren, prefab-betonelementen, radiatoren en luchtbehandelingskanalen uit de categorie produkten die in beperkte series ('batches') gemaakt worden; 
- ketels voor centrale verwarminginstallaties in utiliteitsbouwwerken uit de categorie stukproduktie.

Materialen die ook in andere sectoren dan de bouw worden gebruikt worden vaker via de voorraadhoudende tussenhandel naar de bouwwerken getransporteerd.

\section{FIGUUR 8.4, Voorbeelden van bouwmaterialenstromen}

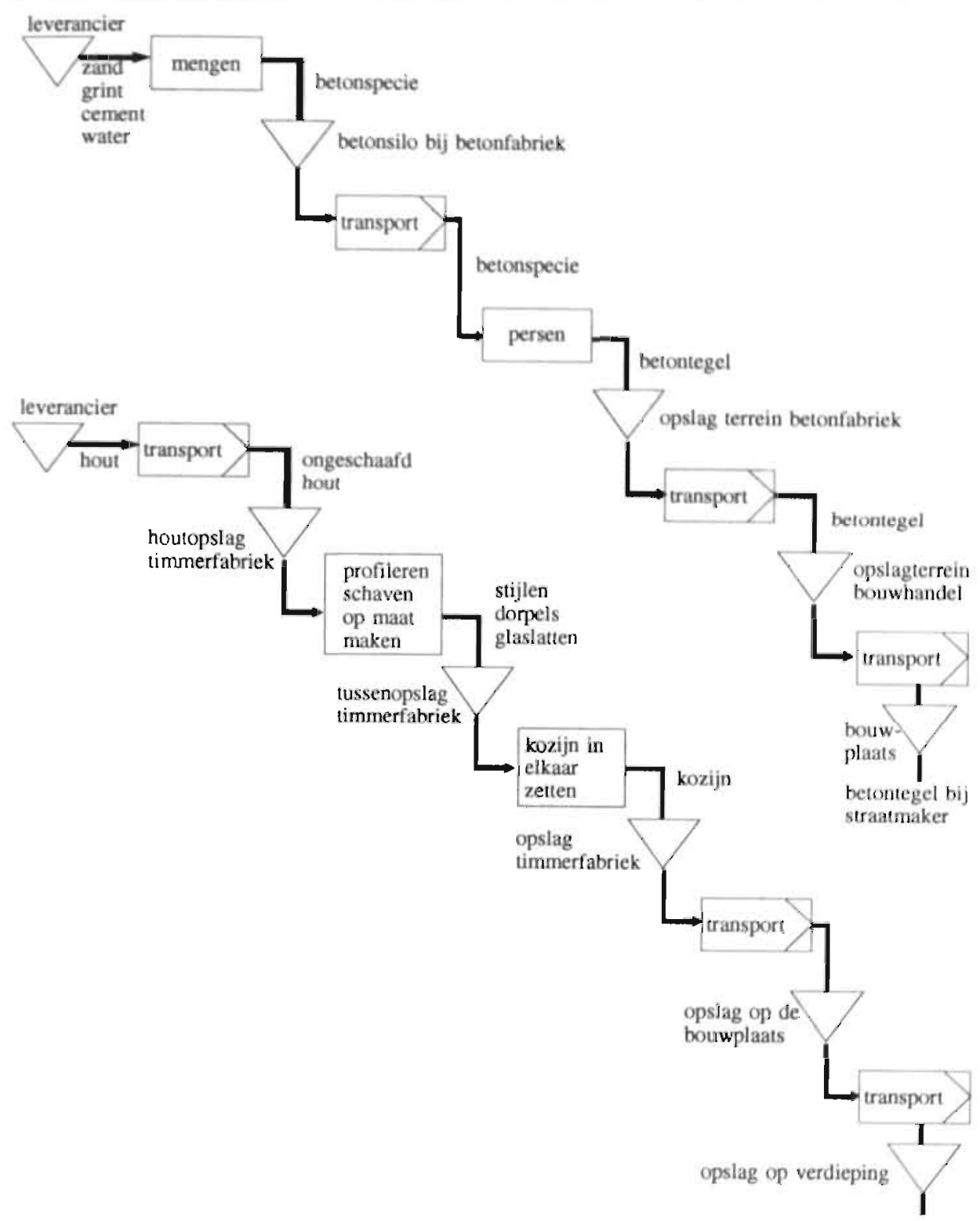

timmerman

Bron: UCB (1991, 12). 
De leverancier kan ten aanzien van de aflevering van goederen eisen stellen aan de afnemer. Deze eisen kunnen betrekking op minimale hoeveelheid per keer en een minimale levertijd. Dit laatste is de tijd tussen het moment van bestellen of afroepen en de aflevering bij de afnemer. Deze wordt mede beïnvloed door de wijze van produktie van de materialen. Eisen van de afnemer ten aanzien van de aflevering hebben betrekking op de plaats van aflevering, het tijdstip, de hoeveelheid materialen - rekening houdende met de verwerking - en de vorm van het bouwmateriaal. De plaats van aflevering kan de nishut (een meestal van hout en golfplaat gemaakte voorraad- en werkplaats op de bouwplaats), het opslagveld of het magazijn van de aannemer zijn. De aanvoer kan direct gekoppeld zijn aan verwerking. Dit betekent dat de aanvoer vanaf de leverancier exact op de produktie op de bouwplaats afgestemd. Voorbeeld is een situatie waarbij de beladen vrachtwagen op het geplande tijdstip op de bouwplaats aankomt en de materialen vanaf de vrachtwagen direct in het werk worden aangebracht. Bij deze manier van werken worden hoge eisen gesteld aan betrouwbaarheid naar plaats en tijd van levering, hoeveelheid en kwaliteit van materialen.

Vaak kan de hoeveelheid aangevoerd materiaal niet direct worden verwerkt. Er is dan sprake van een ontkoppeling van aanvoer en verwerking. In deze ontkoppelpunten ontstaan (buffer-)voorraden. Hiervoor zijn verschillende oorzaken aan te geven. Ten eerste kan de beladingsgraad van de vrachtwagen vereisen dat bijvoorbeeld alleen in volle vrachten wordt geleverd. Indien geen volle vrachten worden afgenomen dient toch de vervoersprijs aan de leverancier betaald te worden. Ten tweede kan sprake zijn van minimale afname-hoeveelheden. Ten derde kunnen eventuele verwachte problemen bij de toelevering of bij het vervoer een reden zijn om voorraden aan te leggen. Voorbeeld is de plotseling moeilijke verkrijgbaarheid van grondstoffen voor een fabrikant. Van bouwmaterialen die kritisch zijn voor de voortgang van het bouwproject zal men snel geneigd zijn een extra voorraad aan te leggen.

Bij toelevering van bouwmaterialen op de bouwplaats doet zich voor de aannemer een dilemma voor. Een lage voorraad is voor aannemers voordelig met het oog op het risico van diefstal op de bouwplaats en de geringe opslagcapaciteit aldaar. Daarentegen bestaat de kans dat de extra levering niet op tijd plaats vindt, waardoor stagnatie in de voortgang van het werk kan optreden.

De uiteindelijke verwerking van bouwmaterialen vindt plaats in de uitvoeringsfase van het bouwproces. Het eindprodukt van een bouwproces is een gebouw bestaande uit verschillende onderdelen. Onderscheiden worden de fundering, de vloeren (beganegrond en verdiepingsvloeren), de draagconstructie, de niet-dragende wanden, de gevels en het dak. In een gebouw wordt een grote variëteit aan bouwmaterialen verwerkt. In figuur 8.5 staan een aantal veel gebruikte bouwmaterialen opgesomd, afkomstig van de hout- en meubelindustrie, de bouwmaterialenindustrie en de metaalproduktenindustrie.

Op de bouwplaats zijn verschillende vakmensen actief: schilders, timmerlieden, installateurs etc. Deze vakmensen zijn terug te vinden in de verschillende 'werksoorten'. Werksoorten zijn 'door arbeidsdeling in de praktijk van het bouwen gevormde groepen van handelingen die een specialistische deskundigheid vereisen en gekenmerkt worden door een geheel eigen materiaal- en materieelgebruik' (UCB, 1991,15). Elke afzonderlijke materiaalstroom eindigt bij de verwerking van het materiaal door zo'n deskundige. 
De werksoort vormt het einde van de stroom en geeft aan welke combinatie van mens en mechanisme het materiaal verwerken tot een deel van het gebouw. Naast werksoort is van belang waar de materiaalstroom in het gebouw moet eindigen. Het gaat hierbij om bijvoorbeeld de vraag of het materiaal in de fundering verwerkt wordt of in de binnenwanden. Met andere woorden: in welk element van het gebouw vindt het betrokken materiaal zijn definitieve bestemming.

TABEL 8.1 De belangrijkste bouwmaterialen

\section{SBI Bouwmateriaal}

25.1 planken, balken, latten, plinten, dorpels etc.

25.2 triplex-, fineer-, vezel- en spaanderplaat

25.3 kozijnen, deuren, trappen, kasten, keukenelementen, parket- en hardhouten vloeren etc.

32.1 keramische dakpannen, straat- en metselstenen

32.2. grof aardewerk (o.a. wand- en vloertegels, plavuizen, vensterbankplaten, sanitair)

32.3 kalkzandstenen (kleinformaten, blokken, elementen)

32.4 cement, kalk, gips en kalkmortel

32.5 betonnen heipalen, bouwelementen, trottoirband en -tegels, buizen en putten etc.

32.6. platen, dorpels, vensterbanken etc.

34.2. allerhande massaprodukten (schroeven, muurijzers etc.)

34.3. leidingen, opslagtanks

34.4 stalen en aluminium kozijnen, ramen, deuren, wanden etc.

34.7 radiatoren, verwarmingsketels

34.8 hang-en sluitwerk

Bron: EİB, 1988, 22.

In de bouw is geen sprake: van fysieke distributie van het eindprodukt, maar wel van bouwmaterialen. Wat betreft die bouwmaterialen bestaan er in principe geen verschillen tussen goederenstromen bij bouw- en industriële bedrijven. In het trajectdeel dat valt onder 'materials management' van de aannemer vindt, zoals in vele andere bedrijven, ook voorraadvorming plaats. Hier is dat op de bouwplaats en/of in het magazijn van de aannemer. Tevens is ook in de bouw sprake van voorraad onderhanden werk. Het vermogen dat in de voorraad onderhanden werk is vastgelegd betekent een verlies aan rentekosten. Rentekostenverlaging en met name de post 'Algemene bouwplaatskosten' vormen de sterke prikkels om tot bouwtijdverkorting te komen. Laatstgenoemde kosten staan voor een belangrijk deel los van de eigenlijke produktiewerkzaamheden en lopen min of meer synchroon met de bouwtijd. Het gaat hier om kosten van de werkkleding, van keet- en terreinvoorzieningen, verzekeringen e.d.

\subsection{Informatiestromen in de bouw}

\subsection{Bestek en tekeningen al's basis voor de informatie-uitwisseling}

Bestek en tekeningen vormen de basis voor de informatie-uitwisseling tussen ontwerpende en uitvoerende partijen in de bouw. De inhoud van een bestek bestaat uit de beschrijving het werk, eventueel daarbij behorende tekeningen en de voor het werk 
geldende voorwaarden. Bestekken komen in uiteenlopende vormen voor en kunnen ook verschillende functies hebben. Het bestek vervult een juridische functie als het onderdeel vormt van een aannemingsovereenkomst. Economisch gezien kan het bestek dienen als begroting en technisch als beschrijving van het werk.

Tekeningen geven de indeling van ruimten en de plaats, vorm en afmetingen van het gewenste bouwwerk aan. De ruimtelijke vormgeving wordt vastgelegd in de vorm van overzichts- en detailtekeningen, plattegronden, aanzichten en doorsneden. De tekening wordt in de bouw als de primaire weergave van een project beschouwd. Het bestek, de begroting en dergelijke zijn de secundaire (afgeleide) weergaves van het project. Omdat de informatiebehoefte is gerelateerd aan de ruimtelijke vormgeving van een bouwwerk is in het bouwproces veel informatie van de tekening afgeleid of verwijst daarnaar.

Voor steeds meer onderdelen van het bouwwerk geldt dat zij vooraf worden geproduceerd. Voor de produktie van bouwmaterialen in de fabrick zijn speciale produktietekeningen nodig. Voor het aanbrengen van bouwprodukten op de bouwplaats zijn weer andere tekeningen nodig die liefst zo weinig mogelijk gegevens bevatten, die niet relevant zijn voor de montage op het werk. De tekening is hier een schakel in een proces waarbij de geleverde informatie 'input' is voor een volgende bewerking, al dan niet door een andere betrokkene.

Het traditionele bestek is tekstuele projectinformatie geordend naar werksoort: betonwerk, metselwerk, timmerwerk (Flapper, 1989). De besteksschrijver interpreteert de ontwerpinformatie vanuit het perspectief van een bestekssystematiek en beschrijft door middel van werksoorten wat er gebouwd gaat worden. De calculator bij een aannemer gebruikt het bestek als leidraad voor het schrijven van de regels voor een begroting. Aan elke besteksregel zijn begrotingsregels te koppelen. Bijvoorbeeld: bepaald metselwerk heeft als begrotingsregels levering stenen, levering metselspecie, profielen stellen, arbeidstijd voor metselen en arbeidstijd voor steigerbouw. De begroting wordt dan ook in besteksvolgorde geschreven.

Een algemeen gebruikte bestekssystematiek in de bouw is STABU (Standaardbestek Burger- en Utiliteitsbouw). STABU is een gezamenlijk initiatief van bedrijven uit de bouwnijverheid en de overheid. De ontwikkeling van het STABU-bestek maakt in principe een uniforme codering en ordening van de tekstuele projectinformatie mogelijk. STABU is te beschouwen als een breed verbreide standaard in de bouwwereld. ${ }^{6}$ De huidige STABU-systematiek kent drie onderdelen (SBR, 1989b):

- de Standaardbepalingen (administratief en technisch);

- de Aanvullende Technische Bepalingen (administratief en technisch);

- de Werkomschrijvingen.

De administratieve bepalingen leggen rechten, plichten en verantwoordelijkheden van de contractpartijen vast. De technische bepalingen bevatten nadere eisen die aan de uitvoering worden gesteld. In het gedeelte 'Werkomschrijvingen' wordt beschreven wat er gebouwd gaat worden. Het is een schriftelijke weergave van het ontwerp. In dit

" Het RAW-bestek van de voormalige Stichting Rationalisatie en Automatisering Grond-, Water- en Wegenbouw (RAW) is een tweede bekend standaardbestek in de bouw. 
gedeelte zijn de bestekposten opgenomen, waar de aannemer zijn begroting op baseert.

Tekeningen moeten naar informatie-inhoud duidelijk onderscheiden worden van het bestek. Het bestek geeft aan wat er gemaakt moet worden, de bestektekeningen geven aan hoe en hoeveel van wat. In het bestek staan zelden echte hoeveelheden vermeld. De calculator moet deze vanaf de tekeningen uittrekken. Voor de ruwbouw is dat vrij eenvoudig, maar voor de afbouw is dat erg arbeidsintensief omdat voor elk materiaal in een ruimte telkens opnieuw gemeten moet worden.

Traditioneel ligt in het bestek de nadruk op de beschrijving van het werk: het bestek is in werksoorten ingedeeld. Het accent is echter steeds meer komen te liggen op het uitvoeringsresultaat. De door het vakmanschap gerealiseerde onderdeel van het werk vormt de basis voor het meten van de geleverde prestaties. Met de toename van het aantal buiten de bouwplaats gemaakte produkten die alleen gemonteerd moeten worden, is voor veel onderdelen van het werk de vraag naar het toegeleverde materiaal belangrijker geworden dan het vakmanschap (Van Hezik en Woestenenk, 1992). Er is een behoefte ontstaan aan een indeling van het bestek op basis van bouwelementen, ook wel aangeduid als een 'elementenbestek'. Volgens de Stichting STABU is de zgn. NL/SfB-elementenclassificatie (elementenmethode) hiervoor een bruikbare standaard. ${ }^{7}$

De NL/SfB-classificatie deelt delen van het bouwobject verder in naar elementen en elementenverzamelingen. Het systeem maakt gebruik van vijf tabellen (Klein, 1992):

- tabel 0 staat voor de bebouwde omgeving (gebouwtypen, woongebieden en ruimten);

- tabel 1 omvat de delen van gebouwen (elementencode);

- tabel 2/3 staat voor werksoorten/materiaalcode;

- met tabel 4 kunnen begrippen als activiteiten en eigenschappen worden weergegeven.

Door de codes uit de vijf tabellen te combineren kan alle informatie worden afgelezen. Zo betekent de reeks $81(21) \mathrm{F}(\mathrm{g} 2) \mathrm{J} 6$ dat het gaat om woningen (81), in het bijzonder de buitenwanden daarvan (21), gemaakt van stenen (F), uit gebakken klei (g2), bestand tegen bepaalde trillingen (J6). Als bestekssystematiek heeft deze methode echter nooit grote ingang gevonden, met name omdat de werksoorten in dit systeem nooit goed zijn uitgewerkt. Het onderdeel dat wel redelijk ver is uitgewerkt, en ook op grote schaal toepassing heeft gevonden, is tabel 1 van de methode, de bouwdelen.

Een voordeel van een elernentensysteem is, dat alle stukken combineerbaar, uitwisselbaar en direct vergelijkbaar worden, wanneer zij zijn geclassificeerd volgens SfB. Deze

${ }^{7}$ De NL/SIB-meihođie is ontwikkeld als standaardsysteem om alle op het bouwproces betrekking hebbende informatie te beheersen. De NL/SrB-classificatie is het resultaat van Zweeds, Engels en Frans onderzoek, dat tussen 1947 en 1976 is uitgevoerd. SfB staat voor 'Samarbetskommitten for Byggnadsfragor' (vrij vertaald: Gezamenlijke Werkcommissie voor Bouwproblematicken). Deze Zweedse commissie werd in 1947 ingesteld met als opdrachl een standaardsysteem te ontwikkelen. In 1958 werd het SfB-systeem door het CIB (International Council for Building Research, Seudies en Documentation) en de FID (Fédération Internationale du Documentation) tot internationale standaard verheven. In 1975 werd door het STAGG (Stichting Architekten-onderzoek Gebouwen Gezondsheidszorg) de studieresultaten gepresenteerd van een begrotingssysteem op basis van het SfB-systeem. De Vereniging UGCB (Vereniging voor de ontwikkeling van Uniforme Grondslagen en Coördinatie van informatieverzorging in het Bouwwezen) heeft vervolgens praktijkervaringen met elementenbegrotingen getvalueerd en het SRB-systeem verder uitgewerkt. (UGCB, et al., 1985). 
mogelijkheid komt vooral tot zijn recht wanneer alle informatie vanaf het eerste initiatief door alle fasen van het bouwproces, tot en met het toekomstig onderhoud wordt geclassificeerd volgens het SfB-systeem, zodat oorspronkelijke uitgangspunten en alle daarna beschikbaar gekomen gegevens, in dezelfde rubrieken zijn terug te vinden.

De Stichting STABU en de Stichting Bouwkwaliteit werken aan een koppeling tussen de Elementenmethode en de STABU-bestekssystematiek. ${ }^{8}$ Bij aansluiting op de Elementenmethode wordt de NL/SfB tabel $2 / 3$ vervangen door de STABU-codering voor materialen en werksoorten. Dit maakt het mogelijk dat een bestek zowel naar werksoorten als naar bouwdelen ingedeeld kan worden. De STABU-bestekssystematiek en de Elementenmethode zijn methodicken die een belangrijke rol spelen bij de ontwikkeling van uniforme systemen voor classificatie en codering van bouwinformatie.

\subsubsection{Sturing van goederenstromen tussen bouwbedrijf en toeleveranciers}

Het bestek van de opdrachtgever is ook van belang voor de informatie-uitwisseling tussen hoofdaannemer en onderaannemers of toeleveranciers. De hoofdaannemer vraagt voor delen van het bestek prijsopgaven van onderaannemers of toeleveranciers. De antwoorden die vervolgens binnen komen worden verwerkt in de inschrijving aan de opdrachtgever. De informatie tussen twee partijen in dit 'tender' proces betreft steeds grotendeels dezelfde basisinformatie, bijvoorbeeld bestekposten, aangevuld met extra informatie, bijvoorbeeld prijzen voor een produkt of dienst.

In de bestaande bouwpraktijk bestaat bij inkoop van materialen door bouwbedrijven geen voorgeschreven structuur voor offertes en offerte-aanvragen. Er zijn wel gestructureerde formulieren voor deze transacties ontwikkeld, maar deze worden in de bouw niet gebruikt. Jeder bedrijf heeft zijn eigen formulieren. De vaak informele en weinig gestandaardiseerde werkwijze van inkopers van bouwbedrijven hebben vaak langdurige onderhandelingen tot gevolg. Een voorbeeld daarvan zijn de onderhandelingen over leveringsvoorwaarden. Het gaat hierbij om thema's als moment van eigendomsoverdracht, garantiebepalingen en boeteclausules voor te laat leveren.

Tijdens de produktie op de bouwplaats is bij de toelevering van kritische materiaien een voortdurend contact tussen groothandel of fabrikant en de vitvoerder over de voortgang van het project van groot belang. Lange levertijden van bepaalde produkten leiden met name tijdens de opstart-fase van een projekt vaak tot problemen. In deze fase is men vaak nog niet ingespeeld op de lange levertijden. Indien een uitvoerder van een bouwproject de groothandel tijdig inseint kunnen deze problemen voorkomen worden. Lastig voor de groothandel is dat kleine aannemers vaak niet zo goed plannen, hetgeen veel kleine extra leveringen voor de groothandel met zich meebrengt. Voor de groothandel zijn dergelijke afnemers weinig aantrekkelijk, maar om geen omzet verloren te laten gaan zullen ze deze klanten toch blijven bedienen.

Sturing van de goederenstroom loopt bij veel groothandels via een medewerker die in een vroeg stadium de aannemer om de bouwplanning vraagt en vervolgens in overleg met de uitvoerder uitlevert. Voor een order moet de groothandel vaak bestellingen bij

${ }^{8}$ Stichting Bouwkwaliteit houdt zich o.a. bezig met de coördinatie van certificatie-systemen die betrekking hebben op kwaliteitszorg in de bouw. 
verschillende toeleveranciers doen en op verschillende tijdstippen uitleveren. Bij grote bouwprojecten onderhoudt een medewerker van de groothandel contact met de uitvoerder of werkvoorbereider over het verloop van het project en kent de medewerker van de groothandel de verschillende levertijden van de diverse produkten. Voor industriële toeleveranciers is belangrijk inzicht te hebben in wanneer wat afgeroepen zal worden door de aannemer of andere afnemers. Op basis daarvan kunnen de toeleveranciers produktieschema's maken. Een duidelijk bestelschema geeft toeleveranciers ook inzicht of bestellingen volgens plan worden gerealiseerd. Bij signalering van afwijkingen kan worden bijgestuurd.

Transportprocessen moeten ervoor zorgen dat de materialen op de bouwplaats beschikbaar komen volgens de gestelde eisen. Voor de planning van het transport van de bouwmaterialenhandel of fabrikant zijn aflevertijdstippen (wanneer moet worden afgeleverd), routeschema's (welke volgorde van afleveringen) en beperkingen in de route relevant. Lading- en route-schema's geven aan welke volgorde van beladen de voorkeur verdient, eventueel in samenhang met de route die wordt gereden. Voorbeelden van beperkingen zijn dat bepaalde materialen voor een bepaald tijdstip of op een bepaalde hoogte afgeleverd moeten worden. Bij het laden zijn orderpickingbonnen van belang. Deze geven aan wat en hoeveel uit de opslag - het magazijn - worden gehaald en waar het is opgeslagen. Vervolgens geven vrachtbonnen aan wat en hoeveel naar een bepaalde plaats of afnemer gebracht moet worden. Bij de aflevering van bouwmaterialen op de bouwplaats is de codering van goederen en daarmee de herkenbaarheid van het aangevoerde goed relevant. Probleem hierbij is echter dat in de bestaande bouwpraktijk van een voorgeschreven uniforme produktcodering geen sprake is. Toeleveranciers gebruiken vaak hun eigen produktcodering in de offertes.

Communicatie tussen de verschillende partijen in het bouwproces vond tot voor kort grotendeeis plaats door middel van post, telefoon en fax. Ontwikkelingen op het gebied van 'order-entry-systemen' en Electronic Data Interchange leiden tot een uitbreiding van het aantal beschikbare communicatiemiddelen in logistieke ketens. Branche-organisaties in de bouw introduceren projecten voor implementatie van bedrijfsoverstijgende informatietechnologieën. Voornaamste doel van deze projecten is te komen tot een verbetering van logistieke processen door communicatie tussen aannemers, handelsbedrijven en toeleveranciers langs electronische weg te laten plaats vinden. De afwezigheid van een gestructureerde communicatie in de bouw wijst er echter op dat ook zonder electronica winst gemaakt kan worden door standaardisatie. 



\section{Informatisering in de bouw: EDI en PDI}

In hoofdstuk 4 is aangegeven dat logistieke netwerkvorming zich kan ontwikkelen op grond van transactiespecifieke investeringen gericht op de sturing van goederenstromen tussen bedrijven. In de bouw hebben deze investeringen, die de basis leggen voor logistieke netwerkvorming, betrekking op computersystemen gericht op de uitwisseling van berichten tussen bedrijven. De implementatie van deze systemen in de bouw staat nog maar in de kinderschoenen. Hieronder wordt een aantal stimuleringsprogramma's geanalyseerd die zich richten op de totstandkoming van EDI en PDI in de bouw. Aan de hand van deze analyse wordt ingegaan op knelpunten en strategieën bij implementatie van deze informatiesystemen in de bouw. Dit sluit aan bij de eerste onderzoeksvraag, geformuleerd in hoofdstuk 6, naar de voorwaarden waaronder het tot een toepassing van integrale logistiek komt. Tevens wordt de vraag behandeld hoe implementatie van EDI en PDI tot een herstructurering van de interne organisatie door informatisering binnen de onderneming leidt, de vijfde onderzoeksvraag. Ook wordt deels antwoord gegeven op de vierde onderzoeksvraag, de vraag of in de bouw sprake is van substitutie van arbeid door bedrijfsoverstijgende informatisering. De mate waarin deze herstructurering of substitutie optreedt is sterk afhankelijk van het feit of EDI- en PDIsystemen direct aan interne applicaties van een onderneming gekoppeid worden. We zullen de verschillende programma's dan ook vanuit dit perspectief analyseren.

Dit hoofdstuk vormt het resultaat van een 19-tal interviews met 25 managers en vertegenwoordigers van branche-organisaties (zie bijlage II). Ten eerste zijn in 13 interviews EDI-managers geïnterviewd van bedrijven betrokken bij de enige twee EDI-stimuleringsprogramma's in de bouw, EDIBOUW (7 interviews) en HCP ( 6 interviews). Tijdens deze interviews is gebruik gennaakt van een vragenlijst die al bij eercier onderzoek naar toepassingen en gevoigen van EDI gebruikt is (zie bijlage III). Ten tweede hebben 4 interviews plats gehad met functionarissen van branche-organisaties betrokken bij pilot-projecten die deel uitmaakten van een PDI-stimuleringsprogramma in de bouw (zie bijlage II). Ook deze interviews vonden plaats aan de hand van een vragenlijst (zie bijlage III). Uit deze interviews bleek dat binnen de bouw op het moment van onderzoek bedrijven in nog maar geringe mate ervaring hadden met PDI. Het interviewen van functionarissen van bedrijven werd daarom niet zinvol geacht. Ten derde is in twee interviews zowel ingegaan op de EDI- als de PDI-stimuleringsprogramma's. Het ene interview vond plaats met een expert van Ballast Nedam, een van de grootste bouwbedrijven van Nederland, het andere met twee ambtenaren van het Ministerie van Economische Zaken. De interviews duurden 1 à 2 uur. Naast interviews zijn ook documenten geanalyseerd die betrekking hadden op de stimuleringsprogramma's.

Zowel dit hoofdstuk als het volgende gaat in op ontwikkelingen in de omgeving van het bouwproject en zijn keten. Paragraaf 9.1 beschrijft kort Nederlandse stimuleringsprogramma's op het gebied van EDI in de bouw en geeft de gevolgen van EDI voor de 
organisatie van logistieke ketens in de bouw aan. Vervolgens geeft $\S 9.2$ aan hoe Product Data Interchange (PDI) een logisch vervolg vormt op EDI. In $\S 9.3$ komen Nederlandse PDI-stimuleringsprogramma's aan de orde en wordt aangegeven hoe deze technologie een bedrijfsoverstijgende koppeling van bedrijfsfuncties tijdens het bouwproces mogelijk maakt. In $\$ 9.4$ wordt ingegaan op knelpunten en strategieën bij implementatie van EDI en PDI in de bouw.

\subsection{EDI in de Nederlandse bouw}

\subsubsection{EDI-projecten in de bouw}

In Nederland zijn twee initiatieven genomen om te komen tot EDI-systemen in de bouw: EDIBOUW en het HIBIN-Communicatie-Project (HCP). EDIBOUW organiseert vooral de grote aannemers en industriële toeleveranciers, HCP de kleinere bouwmaterialenhandelaren en eveneens de industrie.

\section{EDIBOUW}

In 1987 werd er binnen het CIAD (Vereniging voor Computer Toepassingen in de Ingenieurspraktijk) door een viertal bedrijfsleden een onderzoek uitgevoerd onder de titel 'CIM in de bouw" (Duivenvoorden, 1988). Deze leden waren Ballast Nedam, de Hollandsche Beton Groep, Volker Stevin en Wilma Bouw. Het onderzoek had tot doel te bezien op welke gebieden deze bedrijven tot samenwerking konden komen om gemeenschappelijk een aantal stappen in de richting van CIM (Computer Integrated Manufacturing) te zetten.

Volgens het rapport 'CIM in de bouw' heeft eilandautomatisering ertoe geleid dat gegevens programma-gebonden zijn, d.w.z. gegevens zijn niet vrij toegankelijk en niet. te gebruiken door andere computerprogramma's dan het oorspronkelijke. Voor oplossing van dit probleem is een programma-onafhankelijke beschrijving van gegevens nodig. Een eerste stap in die richting is een uniforme reglementering van de beschrijving, benaming en codering van gegevens binnen een bedrijf. Als een bedrijf in staat is intern programma-onafhankelijke gegevens te produceren en te gebruiken dan is de basis gelegd voor een uitwisseling van gegevens tussen bedrijven. De interne herstructurering en integratie van computersystemen heeft. dan ook volgens het rapport prioriteit omdat deze vooraf gaat en voorwaarde is voor een externe integratie van bedrijven. Op basis van deze analyse zijn vervolgens twee aanbevelingen gedaan.

Ten eerste werd het zaak zich te gaan bezighouden met het concept 'Construction Resource Planning". Dit zou een soort MRP-programma zijn, maar dạ specifiek voor het bouwbedrijf. Construction Resource Planning zou als hulpmiddel van het bedrijfs. bureau binnen het bouwbedrijf gebruikt kunnen worden, gericht op de bewaking van de toewijzing van 'resources' binnen de onderneming. Ten tweede was het volgens het rapport nodig in het kader van procesbeheersing de invoeringsmogelijkheden voor EDI in de bouw te onderzoeken. Daarbij werd gedacht aan toepassingen op het gebied van het selecteren van huisleveranciers, de onderlinge facturering, de onderlinge planningsuitwisseling en de electronische transportbewaking. 
De aanbeveling om de toepassingsmogelijkheden van EDI in de Nederlandse bouw te onderzoeken vormde een impuls voor EDI-ontwikkeling in deze sector. Op basis van de studie 'CIM in de bouw' werd in 1988 door de grote aannemers besloten te gaan experimenteren met EDI. Zij namen het initiatief tot de oprichting van EDIPRAKT. EDIPRAKT was een project dat zich richtte op de beheersing van materiaalstromen en in het bijzonder op de uitwisseling van gegevens tussen aannemer en industriële toeleverancier. Tijdens dit project werden de EDI-berichten inkoop-opdracht en factuur uitgewisseld tussen aannemers en industriële toeleveranciers. Zaken als afroeporders en leveringsschema's volgden in een later stadium. Er was nog geen sprake van een koppeling naar interne applicaties. Deelnemende aannemers waren Ballast Nedam, de BAM, de Hollandsche Beton Groep, Koninklijke Volker Stevin en Wilma Bouw. Tot de deelnemende toeleveranciers behoorden BetonSon, Bruynzeel Zaandam, Durox Gasbeton (tegenwoordig Ytong) en Polynorm Holland. De deelnemende aannemers waren grootbouwbedrijven die een substantieel aandeel van het Nederlands bouwvolume voor hun rekening nemen.

De proeffase was vooral bedoeld om aan te tonen, dat EDI in de bouw technisch realiseerbaar is en een haalbare zaak zou zijn. Als vervolg op EDIPRAKT is in 1990 de stichting EDIBOUW in het leven geroepen. EDIPRAKT heeft zich uitsluitend gericht op het testen van berichtuitwisseling tussen p.c.'s zonder koppeling naar systemen binnen de onderneming. EDIBOUW stelde zich onder andere ten doel zich te richten op de doorkoppeling van EDI-berichten naar interne applicaties. Binnen EDI. BOUW wordt gewerkt aan de verdere ontwikkeling van berichten zoals het factuur, de inkooporder en orderbevestiging en de afroep. Daarnaast wordt aandacht besteed aan software, produktcodering, algemene in- en verkoopwaarden en juridische aspecten van EDK. Ook wordt aandacht besteed aan de fiscale aspecten van EDI, de relatie tussen EDI en het uitwisselen van tekeninggegevens en de verzorging van opleidingen voor het gebruik van EDI in de bouw.

Zowel EDIPRAKT als EDIBOUW maakten onderdeel uit van het stimuleringsprogramma Voorbeeldprojecten EDI (VEDI). In dit kader zijn in verschillende sectoren pilot-projecten tot stand gebracht waarvan twee in de bouw. EDIPRAKT was de naam van het eerste pilot-project in de bouw. Door EDIPRAKT ontstond de eerste dwarsverbinding tussen de ontwikkelingen in de bouw en de ontwikkelingen in andere bedrijfssectoren. Vanwege het succes van EDIPRAKT heeft de VEDI-commissie EDIBOUW als tweede pilot-project in de bouw gesubsidieerd. De VEDI-commissie is in mei 1992 opgeheven.

\section{HIBIN-CP}

Een tweede EDI-stimuleringsprogramma in de bouw komt van de bouwmaterialengroothandel. De branche-organisatie HIBIN, de Vereniging van Handelaren In Bouw-

${ }^{1}$ In 1989 werd door het ministerie van EZ de commissie Voorbecldprojecten EDI (ook wel genoemd commissie Wormmeester naar de voorzitter, toenderiijd president-directeur van ECT) ingesteld. VEDI richte zich op de bevordering, van de invoering van EDI in de verschillende bedrijfssectoren in Nederland. De achterliggende gedachte was dat als Nederland als handelsnatie wil blijven concurreren, de beschikking over een effectieve telematica-infrastructuur noodzakelijk is. Met 25 projecten, waarin meer dan 200 bedrijven en organisaties hebben geparticipeerd, heeft men getracht een bijdrage te leveren aan de ontwikkeling van deze infrastructuur. 
materialen In Nederland, introduceerde in 1989 het HIBIN-Communicatie-Project (HCP). HCP richt zich op het traject tussen handel en fabrikant. Tussen deze bedrijven speelt zich dagelijks een intensief berichtenverkeer af, waarbij veel gebruik wordt gemaakt van fax, telefoon en post. De berichten worden vaak handgeschreven, hetgeen veel fouten met zich meebrengt. Tussen verzending van het bericht en verwerking zit enige tijd, waarbij het voor de verzender niet duidelijk is of het bericht in de juiste vorm is ontvangen en verwerkt (EDIFORUM, 1990). Voornaamste doel van het HCP is te komen tot een open transactiesysteem voor electronische communicatie tussen handelsbedrijven en toeleveranciers.

Het voorbereidend werk van de doe-het-zelf-branche is een belangrijke stimulans geweest om tot implementatie van integrale informatiesystemen in de bowwmaterialenhandel over te gaan. Een aantal fabrikanten, die tegelijkertijd lid van de HIBIN zijn, hebben zodoende al ervaring opgedaan met electronische orders afkomstig van de doehet-zelf sector. Een bedrijf als Gamma heeft in laatst genoemde sector een belangrijke rol vervult bij de implementatie van EDI. Bepaalde software die bedrijven als Gamma en Praxis ontwikkeld hebben is ook bruikbaar gebleken voor de groothandel in bouwmaterialen. Voorbeeld is software die de benodigde hoeveelheden bouwmaterialen voor bouwprojecten vertaalt naar standaard bestel-hoeveelheden.

De HIBIN werkt nauw samen met de Stichting UAC en UAC/Transcom B.V. UAC/Transcom B.V. richt zich op de ontwikkeling van een uniforme produktcodering (UAC staat voor Uniforme Artikel Codering). Hierdoor kunnen informatiesystemen makkelijker met elkaar communiceren. Standaarden vooi produktcodering hebben enerzijds betrekking op nationale standaarden, dat is waar de naam Transcom aan wordt gelieerd. Anderzijds onderhoudt de Stichting UAC intensieve contacten met de internationale organisatie EANCOM (EAN = European Article Numbering association). De Stichting UAC is een beheersorganisatie van de standaarden.

In november 1989 is met de eerste fase van het HCP-project gestart. Deze fase liep tot en met april 1990 en werd voor een belangrijk deel gebruikt voor een uitgebreide oriëntatie naar aard en omvang van informatiestromen tussen afzonderlijke bedrijven. Concreet leidde dit tot een inventarisatie van de toepassingsgebieden, de berichtsoorten, de verwachte gevolgen voor de administratieve organisatie, het beheer, de beveiliging en de gebruiksvriendelijkheid van het systeem. Daarnaast: werd een schatting gemaakı van de kosten van ontwikkeling en invoering.

De resultaten uit de eerste fase vormden de basis voor het pilot-project, de tweede fase. Aan deze pilot werd deelgenomen door een vijftal speerpuntbedrijven. In januari 1990 vond de installatie van het softwareprogramma in deze bedrijven plaats. De speerpuntbedrijven maakten gebruik van een viertal berichten: afroeporder, afroepbevestiging, artikeimutatie en verzendbericht. Het programma werd vervolgens getest om zo tot een optimaal systeem te komen. Er is een stand alone werkstation ontwikkeld met EDI-programmatuur voor de inkoop. De strategie hierachter is dat bedrijven leren werken met EDl bij de inkooporders voor de fabrikant en los daarvan in hun eigen tempo de administratie automatiseren en integreren met EDI. Daarnaast werden meer dan 25 ondernemingen nauw bij de praktijkproef betrokken. Zij konden direct na afsluiting van de praktijkproef overgaan tot invoering van electronische transactiecommunicatie binnen hun onderneming. 
De derde fase is medio 1992 gestart en is de branche-gewijze invoering van het systeem. Daarbij zijn alle uitvoerende activiteiten uitbesteed aan het Opleidingsinstituut voor de Distributie (de OVD-Groep). Dit instituut ontwikkelt en verzorgt in de bedrijfstakken detail- en groothandel een uitgebreid pakket beroepsopleidingen. De OVD-Groep geeft een cursus van vier dagen waarbij de betekenis van EDI bij logistiek aan de orde komen en men vingeroefeningen doet met de medewerkers van bedrijven betrokken bij HCP. Daarnaast heeft de OVD-Groep een zgn. profielenboek gemaakt dat aangeeft hoe bestaande werkzaamheden veranderen na introductie van EDI. Met een software-programma is het mogelijk voor individuele werknemers een gedetailleerd overzicht te maken van zijn of haar takenpakket. Aan iedere ingevulde taak wordt de corresponderende 'EDI-taak' gekoppeld. Op deze wijze krijgt de werknemer inzicht in de gevolgen die EDI heeft voor zijn of haar taakuitvoering. Ook maakt men gebruik van de zgn. innovatie-graadmeter. Hiermee wordt inzicht verkregen in hoeverre de organisatie gereed is voor toepassing van EDI. Op basis hiervan en het inzicht in de veranderingen in individuele taken wordt de organisatie aangepast.

Electronische transactie-communicatie betekent dat een aantal afspraken gemaakt dienen te worden die specifiek gelden voor de bouwmaterialenbranche. Hiervoor is de Stichting HCP-Infra opgericht. Officiële doelstelling van deze stichting is het "bevorderen van het gebruik van EDI als hulpmiddel voor de optimalisering van het logistieke proces in de bouwmaterialenbranche' (EDIFORUM, 1992, 59). HCP-Infra is een organisatie die namens haar leden ervoor zorgt dat de afspraken worden beheerd. HCP-Infra is verantwoordelijk voor de verdere ontwikkeling van een efficiënte en effectieve EDI-structuur voor de bouwmaterialenbranche. Activiteiten die daartoe ondernomen worden zijn onder andere bericht- en software ontwikkeling, ondersteuning van gebruikers en opleidingen. Bij HCP-Infra waren eind 199230 fabrikanten en 40 groothandels aangesloten. Daarin zijn ook drie inkoopverenigingen begrepen met in totaal 80 aangesloten groothandels.

\subsubsection{Herstructurering van de logistieke kelen door EDI}

De EDI-projecten in de Nederlandse bouw richten zich op een formalisering van relaties tussen de producent van bouwmaterialen, de tussenhandel en de aannemer. Het betreft de relaties producent-tussenhandel, producent-aannemer en tussenhandelaannemer (zie figur 9.1).

FIGUUR 9.1 Goederenstromen in de logisticke keten

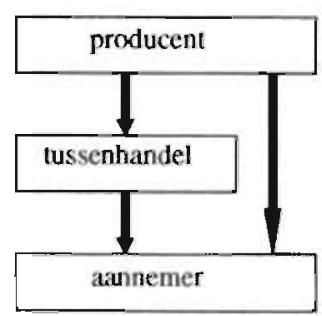


In de inleiding van dit hoofdstuk is al aangegeven dat de vraag of een herstructurering van de interne organisatie en substitutie van arbeid plaats vindt sterk afhankelijk is van het feit of in de EDI-projecten een directe koppeling van EDI met interne applicaties plaats vindt. We zullen hier analyseren of in de verschillende schakels van de logistieke keten zo'n directe koppeling tot stand komt.

\section{Producent-tussenhandel}

Leveranties van grondstoffen aan de producent van bouwmaterialen zijn vaak gebaseerd op langdurige afspraken. De grondstoffen worden meestal in bulk aangevoerd. Daarbij is sprake van een incidentele informatie-uitwisseling. Toepassing van EDI levert hier geen echte voordelen op (De Groot, 1993). Dit geldt niet voor de schakel producent-tussenhandel. Afstemming tussen de verkoop bij de producent en de inkoop bij de tussenhandel kan voor beide partijen tot een verandering van de interne organisatie leiden. Dit komt omdat juist in deze schakel van de logistieke keten informatietechnisch gezien er gunstige voorwaarden aanwezig zijn voor de toepassing van EDI en de koppeling van EDI met interne applicaties:

- standaardprodukten kunnen door produktcodering eenduidig worden vastgelegd;

- de relaties tussen beide partijen kenmerken zich door redelijk vaste afspraken;

- er worden grote hoeveelheden korte berichten uitgewisseld (facturen, bestellingen enz.).

Een belangrijke voorwaarde voor een automatisch doorkoppelen naar interne systemen is het tot stand komen van standaarden voor produktcodering. Momenteel zijn er afspraken over streepjescodering waarvoor de EAN artikelcode wordt gevolgd. Deze codering ondersteunt de administratieve registratie van gereed produkt voor in- en verkoop. De EAN-code is een identificerende code. Het beschrijft alleen de 'buitenkant' van het produkt, het heeft een 'aanwijs' functie. De EAN-codering is zeer geschikt voor de uitwisseling van informatie tussen in- en verkoopafdelingen en magazijnen met standaardprodukten. De codering blijkt in praktijk goed bruikbaar te zijn in de schakel tussenhandel-producent. De EAN-codering vereist van individuele bedrijven dat zij hun interne codering hier op afstemmen. Zolang dit niet het geval is, zullen bedrijven met verschillende coderingen geconfronteerd worden. Bij Sphinx, producent van sanitair en tegels en deelnemer van het HIBIN-Communicatie-Project, heeft dit ertoe geleid dat op een bepaald moment binnen het bedrijf met drie verschillende produktcoderingen gewerkt moest worden. Momenteel worden bij dit bedrijf twee produktcoderingen gehanteerd: een commerciële EAN-codering en een interne codering.

Een tweede gunstige voorwaarde voor implementatie van EDI is dat relaties tussen de bouwmaterialenhandel en producenten zich vaak kenmerken door redelijk vaste afspraken. Een reden hiervoor is dat in de bouwmaterialenbranche een aantal concerns en inkoopcombinaties actief zijn die met producenten relaties aangaan in de vorm van raamcontracten. Voorbeelden van dergelijke concerns zijn PontMeyer, Van Neerbos en De Boo, voorbeelden van inkoopcombinaties zijn Alpha Ciboma en Imabo. Deze organisaties stellen jaarlijks voor de groothandels die deel uitmaken van het concern of lid zijn van de inkoopcombinatie contracten op met een aantal producenten.

De grote hoeveelheden uitgewisselde berichten is in de schakel producent-tussenhandel een derde gunstige voorwaarde voor implementatie van EDI. De dakpannenproducent 
RBB gaf bijvoorbeeld aan dat alleen al van de bouwmaterialenhandelaren dagelijks 180 bestellingen binnenkomen. Dit resulteert in ongeveer 40.000 bestellingen per jaar met een gemiddelde van 6 à 7 regels, dus totaal al snel 280.000 bestelregels. Daarnaast blijkt gemiddeld 1 op de 2 bestellingen nog te veranderen. Van al deze bestellingen komt bij RBB $60 \%$ binnen via de fax en $40 \%$ telefonisch. Deze faxen en telefonische bestellingen worden op bestelformulieren genoteerd die vervolgens naar de afdeling Order Entry gaan. Daar doen een aantal mensen de hele dag niets anders dan het intikken van bestellingen en het doorvoeren van eventuele correcties. Binnenkomst van bestellingen via EDI levert enorme voordelen op. Bestellingen komen gestructureerd binnen en kunnen automatisch in de interne systemen ingelezen worden.

Toepassing van EDI schept de mogelijkheid in- en verkoopfuncties door te koppelen naar interne bedrijfsfuncties zoals voorraadbesturing bij de tussenhandel en produktie bij de toeleverancier. EDI kan voor beide partijen ook tot een stroomlijning van de administratieve organisatie leiden. De orderadministratie, facturering, de debiteurenen voorraadadministratie en administratie in magazijn en expeditie kunnen allen gebaseerd zijn op hetzelfde bericht. Op termijn kan EDI een koppeling mogelijk maken tussen de produktieplanning van producenten en de vervoersplanning van transporteurs van de tussenhandel. Deze laatste partij kan zijn transport- en laadplanning vroegtijdig afstemmen op ophaal- en afleveradressen.

Gevolg is dat EDI zowel bij producenten als in de bouwmaterialengroothandel tot belangrijke veranderingen in commerciële en administratieve functies leidt. Volgens Kreuwels en Van Voorthuijsen (1991) vindt voor in- en verkopers van de bouwmaterialenhandel een verschuiving plaats van routine-werk naar het verhelpen van problemen en het persoonlijk benaderen van leveranciers en klanten. Routine-matige administratieve werkzaamheden worden uitgevoerd door informatiesystemen. Advisering met betrekking tot produkten en diensten zal een belangrijke plaats gaan innemen. Deze ontwikkelingen doen zich ook voor producenten van bouwmaterialen: 'Wij verwachten ten aanzien van de orderaanname minder uren te hoeven maken, datzelfde geldt ook voor de order-entry, die manuren kunnen beter worden besteed aan belangrijker werk: het doen van analyses, het geven van adviezen en het onderhouden van relaties met de indirecte klant' (R.A. Bakker, HIBIN-CP projectleider binnen RBB, tijdens themabijeenkomst HIBIN-CP op 12 december 1990).

\section{Producent-aannemer}

Ook bij de aannemer kan EDI door koppeling van de inkoopadministratie met interne systemen tot een stroomlijning van het inkoopproces leiden. Met name de inkoopadministratie van het bouwbedrijf is geschikt voor een computer ondersteunde communicatie vanwege het routinematige karakter van deze communicatie. Het orderbericht, door de afdeling inkoop gemaakt, kan rechtstreeks doorgekoppeld worden naar interne afdelingen van het bouwbedrijf zoals calculatie, planning, werkvoorbereiding of projectadministratie. Inkoopfacturen van de leveranciers, die goederen geleverd hebben, hoeven in principe niet meer met de bestelorders gecontroleerd te worden omdat zowel aan inkoopfactuur als bestelorder hetzelfde orderbericht ten grondslag ligt.

Voor grote bouwbedrijven kan het voordelig zijn de inkoop van diverse werkmaatschappijen te coördineren met behulp van EDI. Een systematische evaluatie van de prestaties van leveranciers, leveranciers 'ranking', en het op elkaar afstemmen van 
inkoopvolumes van de diverse werkmaatschappijen zijn daardoor beter mogelijk. Volgens Duivenvoorden van Ballast Nedam kan door EDI de inkoop veranderen van Jokaal naar globaal optimaliseren. Ook tijdens de uitvoering kan een standaardisering van berichtenuitwisseling tot voordelen leiden. Met behulp van EDI kunnen tijdens het bouwproces via projectplanning en voorraadregistratie automatisch bestellingen bij toeleverancier als tussenhandel worden gegenereerd. De uitvoerder hoeft in principe slechts te accorderen.

Informatietechnisch is de situatie voor implementatie van EDI tussen producent en aannemer echter ongunstiger dan in de schakel producent-1ussenhandel. Dit heeft enerzijds te maken met de relatief minder intensieve berichtenstroom tussen de producent en de aannemer, anderzijds met de aard van de uitgewisselde produkten. De directe kostenvoordelen zijn daardoor minder groot dan bij de schakel producent-tussenhandel.

Ten eerste is tussen de aannemer en de producent sprake van een relatief minder intensieve berichtenstroom die vaak niet langer duurt dan de cluur van één bouwproject. Omdat EDI in de bouw nog niet zo wijd verbreid is als fax of telefoon zijn investeringen in deze technologie alleen rendabel als frequentie en aantal factuurregels van voldoende omvang zijn om met een aantal partners een EDI-relatie voor een langere periode aan te gaan. EDI is daarom vaak alleen kostendekkend met toeleveranciers waar regelmatig contact mee wordt onderhouden. Dit betekent dat ondersteuning van berichtenuitwisseling met behulp van EDI voor veel bedrijven alleen rendabel is indien het aantal toeleveranciers beperkt wordt. Bedrijfsoverstijgende informatietechnologie kan zo tot een aantasting van de externe flexibiliteit leiden. Indien een bedrijf door investeringen in EDI zich bindt aan een beperkt aantal toeleveranciers kan dit ertoe leiden dat het bedrijf niet altijd meer het goedkoopste alternatief kan kiezen. Dit betekent een verandering van transactiepatronen van betrokken ondernemingen en een verlaging van de flexibiliteit. Volgens een aantal geînterviewden kan EDI wel rendabel zijn bij grote projecten. Daar vindt veel cornmunicatie plaats in de vorm van afroepen, wijzigingen etc.

Ten tweede hebben de goederenstromen in de relatie tussen producent-aannemer nog al eens betrekking op specifiek voor een bepaald te bouwen object gemaakte produkten. Deze produkten worden op maat gemaakt in kleine series. Voorbeelden zijn prefab betonelementen en betonwapening. De kans om tot een bedrijfsoverstijgende produktcodering te komen is bij dergelijke produkten kleiner. In de schakel tussenhandel-producent betreffen de goederenstromen voornamelijk produkten uit serie- en massaproduktie. Informatie-uitwisseling over laatstgenoemde produkten is relatief eenvoudig en vindt voornamelijk plaats in de uitvoeringsfase van het bouwproces. Het HIBIN-Communicatie-Project richt zich met name op dit traject. Bij bedrijven betrokken bij EDIBOUW, voornamelijk aannemers en producenten, heeft de communicatie echter niet alleen betrekking op serie- en massaprodukten maar eveneens op produkten uit zeer kleine series. Voor deze meer op maat gemaakte produkten is vooral communicatie in de voorbereidingsfase vereist en de totstandkoming van uniforme produktcodering moeilijker.

Binnen de Stichting EDIBOUW is een werkgroep 'Produktcodering' actief geweest die een aanbeveling heeft opgeleverd hoe met produktcoderingen om te gaan bij de EDIcommunicatie. Er is een oplossing voorgesteld waarbij zo min mogelijk ingegrepen 
wordt in de interne coderingen van de bedrijfssystemen van de deelnemende bedrijven. Uitgangspunt van EDIBOUW is dat EDI zich vooral richt op afspraken van 'voordeur tot voordeur'. Volgens de aanbeveling moet EDI zoveel mogelijk ontkoppeld zijn, omdat anders veranderingen in EDI invloed krijgen op en ongewenste kosten veroorzaken in de eigen informatiehuishouding. Een systeem voor uitwisseling van standaardberichten komt alleen dan van de grond. Volgens directeur Jutte van EDIBOUW hoeven bedrijven hun eigen codering dan ook niet aan te passen en de praktijk is nu dat iedere producent zijn eigen produktcodering hanteert.

Dit wil niet zeggen dat door deze 'ontkoppelde' toepassing van EDI geen veranderingen kunnen optreden in de interne organisatie. EDI wordt bij bepaalde bouwbedrijven als breekijzer gebruikt om functies bij bepaalde afdelingen meer structureren. EDI bevordert de formalisering van interne functies. In de bouw geldt dit met name voor de inkoopfunctie. EDI vereist van inkopers van bouwbedrijven een 'strakke' werkwijze. Informele overeenkomsten, zeer gebruikelijk in de bouw, zijn niet meer mogelijk. Weerstand tegen invoering van EDI komt volgens geïnterviewden dan ook met name van deze afdelingen.

\section{Tussenhandel-aannemer}

Veel aannemersbedrijven vallen in de sector 'kleinbedrijf'. Een groot aantal van deze kleine bedrijven betrekt hun produkten bij de tussenhandel. Voor hen is EDI niet interessant vanwege de vereiste automatiseringsgraad en de aard van de informatiestromen. De interne automatiseringssituatie laat bij deze aannemers nog al eens te wensen over, de informatiestromen zijn incidenteel en bestaan vaak uit kleine bestelhoeveelheden. Voor deze bedrijven is de fax een goed alternatief en levert een technologie als EDI nauwelijks voordelen op. Daarentegen is voor de tussenhandel een automatische afhandeling van berichten wel degelijk interessant. Een combinatie van videotex en EDI kan hier de oplossing bieden (De Groot, 1993). In dat geval kan de kleine aannemer electronische gegevens uitwisselen via videotex, een technologie waarvoor geen interne automatisering noodzakelijk is. De tussenhandel verwerk deze informatie. stroom als EDI waardoor deze de voordelen heeft van de automatische koppeling naar de interne informatiesystemen.

Een systeem dat voor de schakel tussenhandel-aannemer gebruikt kan worden is CIN. BOUW (Communicatie- en InformatieNetwerk voor de bouw). Dit systeem is in 1991 opgezet door leden van de Zuid Nederlandse Aannemers Vereniging (Z.N.A.V.). CINBOUW wil een electronisch communicatie- en informatienetwerk voor de bouwbedrijfstak realiseren en exploiteren. Via dit netwerk kan met behulp van telecommunicatie gebruik worden gemaakt van reeds beschikbare en nog te ontwikkelen electronische dienstverlening. Tijdens de proeffase in 1991 behoorden alleen bouwbedrijven tot de doelgroep van CIN-BOUW. Nu kunnen echter ook partijen als toeleveranciers, architecten, producenten etc. tot het netwerk toetreden.

CIN-BOUW levert op dit moment diensten die men met keuzemenu's via Videotex kan opvragen. Er is geen sprake van een directe koppeling met interne applicaties van ondernemingen, zoals in principe mogelijk bij een EDI-bouwberichtennetwerk. Het overhevelen van informatie uit CIN-BOUW van en naar deze applicaties blijt handwerk. In een echt EDI bouwberichtennetwerk is deze koppeling wel aanwezig en kan optimaal van interne en externe informatie gebruik worden gemaakt. Denkbaar is dat 
CIN-BOUW door een Videotex-EDI-conversie als basis voor een bouwberichtennetwerk kan fungeren (Duivenvoorden, 1992b). Feitelijk ontstaat dan een infrastructuur met twee ingangsmogelijkheden, namelijk via EDI en via Videotex. De Videotex-ingang kan hierbij gebruikt worden door de aannemer, een EDI-ingang door de tussenhandel.

Op dit. moment lijkt in de schakel aannemer-tussenhandel Videotex het meest geschikte communicatie-middel. Het door de HIBIN (de branche-organisatie van bouwmaterialengroothandels) en het NVOB (Nederlands Verbond van Ondernemers in de Bouwnijverheid) gestarte Videotex-systeem Bomatel speelt hierop in. Met Bornatel kunnen aannemers informatie opvragen bij de bouwmaterialenhandel en orders plaatsen.

\section{EDI in het bouwproces}

EDI richt zich niet alleen op transacties tussen aannemer, tussenhandel en producent. Ei wordt in Europees verband ook gewerkt aan berichten die bruikbaar zijn in het offerte-stadium van het bouwproces. Gebruik van deze berichten maakt een efficiënte informatie-uitwisseling mogelijk tussen opdrachtgever, inschrijver (de aannemer) en toeleverancier of onderaannemer. Toepassingsmogelijkheden van EDI hebben dan voornamelijk betrekking op het electronisch uitwisselen van besteksinformatie. Initiatieven om het bestek electronisch vast te leggen komen van STABU (Standaard Bestek Burger- en Utiliteitsbouw) en RAW (Rationalisatie en Autonatisering Grond-, Wateren Wegenbouw). ${ }^{2}$

In dit verband is EDIBOUW eind 1991 een samenwerkingsverband aangegaan met Stichting STABU (Standaard Bestek Burger- en Utiliteitsbouw). Doel van deze samenwerking is tot een electronische uitwisseling van besteksgegevens via EDI-berichten te komen. STABU en EDIBOUW onderzoeken in samenwerking met bedrijven als Ballast Nedam, HBG, Wilma, VGBouw (de Vereniging Grootbedrijf Bouwnijverheid), Forum (het overkoepelende orgaan van twaalf Nederlandse software-leveranciers aan de bouw) en Kraan Bouwcomputing of de internationaal ontwikkelde EDI-besteksberichten geschikt zijn om STABU-bestekken tussen partijen in de Nederlandse bouw electronisch uit te wisselen.

Bijna alle systeemhuizen hebben de STABU-methodiek gebruikt om hun bestekkenprogramma's te koppelen met hun calculatie-, begrotings- en tekenprogramma's. Deze bedrijven hebben hun programmatuur aan het STABU UitwisselingsFormaat (SUF) aangepast. Hierdoor kunnen gegevens uit bestekken uitgewisseld worden met andere pakketten die binnen de normen vallen voor de bestekssystematiek voor de woning- en utiliteitsbouw, in dit geval STABU-2.

Volgens Duivenvoorden van Ballast Nedam kunnen aanmerkelijke besparingen gerealiseerd worden als van de papieren bestekscommunicatie wordt overgestapt op EDI. Duivenvoorden schat dat per jaar in de burgerlijke en utiliteitsbouw (B\&U) ruw geschat 30.000 bestekken worden uitgegeven. Een gemiddeld B\&U-bestek bestaat uit 80 -

${ }^{2}$ De Stichting STABU is opgericht met het doel te komen tot eén gestandaardiseerd bestek voor de woning- en utiliteitsbouw. De voormalige Stichting RAW had dat doel ten aanzien van de grond-, wateren wegenbouw. Activiteiten van laatstgenoemde stichting worden voortgezet in het CROW, het Centrum voor Regelgeving en Onderzoek in de Grond-, Water-en Wegenbouw en de Verkeerstechniek (zie $\$ 9.3 \mathrm{en} \& 3$ van bijlage D). 
200 A4-pagina's bestekstekst en omvat ca. 500 besteksposten. Elke bestekspost is aanleiding voor een aantal prijsopgaven en wijziging daarvan bij toeleveranciers. De documenten- en papierstroom die hiermee gepaard gaat is enorm en vraagt zelf weer een aantal administratieve handelingen die nauwelijks waarde aan het proces toevoegen, zoals overtypen en opzoeken van delen van het bestek.

In de toekomst kan een opdrachtgever bepaalde onderdelen van een bestek per diskette of via een EDI-bericht gelijk naar meerdere bouwbedrijven sturen die hierop een aanbieding kunnen doen. Bij een bestek via EDI koppelt de calculator van een bouwbedrijf de codering van de besteksregels aan de codering van de begrotingsregels uit het calculatiebestand en levert het calculatie-programma een uitgeschreven begroting. Electronische bestekscommunicatie betekent ook dat bouwbedrijven electronische besteksposten kunnen gebruiken voor aanvragen van offertes bij producenten van bouwmaterialen en de tussenhandel. Aannemers kunnen automatisch goederen 'uittrekken' voor deze aanvragen. Alle EDI-offerteberichten van de diverse toeleveranciers komen weer binnen bij het bouwbedrijf die op basis daarvan een keuze doet.

Uit het voorgaande blijkt dat in de schakel producent-tussenhandel de voorwaarden het meest gunstig zijn voor een koppeling van EDI met interne applicaties. In deze schakel zal, vanwege deze directe koppeling, EDI tot een herstructurering van de interne organisatie van betrokken bedrijven leiden. Ook zijn mogelijkheden aanwezig voor substitutie van arbeid. In de relaties tussen aannemers en partijen als tussenhandel en producent komt het vaker voor dat EDI hooguit tot een integratie van de randen van de onderneming leidt. Bij laatst genoemde relaties is sprake van een 'ontkoppelde' toepassing van EDI waardoor EDI minder snel een herstructurering van de interne organisatie en een arbeidsbesparing tot gevolg heeft.

\subsection{PDI als logisch vervolg op EDI}

\subsubsection{Beperkingen van het transactie-cluster}

EDI-berichten richten zich nu nog, voornamelijk op het vergemakkelijken van transacties tussen ondernemingen binnen een logistieke keten. Bij deze externe communicatie zijn het met name in- en verkoopafdelingen die berichten met elkaar uitwisselen. Met uitzondering van de schakel producent-tusssenhandel leidt EDI in dit stadium van technische ontwikkeling hoogstens tot een zekere integratie van de randen van de. onderneming. We kunnen dit ook aanduiden ăls het ontstaan van een transactie-cluster. Naast dit transactie-cluster is echter ook een produktie-cluster aan te wijzen. In het produktiecluster wisselen met name ontwerp- en produktie-afdelingen berichten met elkaar uit. Bij informatie-uitwisseling tussen in- en verkoopafdelingen, het transactiecluster, kunnen artikelcodes voldoende zijn. Als ontwerp- en produktie-afdelingen van bouwbedrijven berichten gaan uitwisselen is een produktcodering meestal niet toereikend. Deze afdelingen zijn met name geïnteresseerd in zgn. functionele specificaties van een produkt, d.w.z. informatie over het produkt of onderdeel zelf, die niet in een produktcodering kan worden opgenomen (SBR, 1992b).

Naast handelstransacties doen zich in de bouw dus een veelheid aan anderssoortige berichtenstromen voor. De eerste EDI initiatieven in de bouw zijn reeds geconfronteerd met de beperkingen van transactie-berichten. Men wil niet simpelweg 1000 betonblok- 
ken bestellen, maar veeleer een aantal vierkante meters aan muur oppervlak met de vereiste functionele specificaties. Bestaande transactie-gerichte berichten moeten uitgebreid worden met berichten die meer produkt(ie)informatie bevatten. Een aanzet daartoe is bestekscommunicatie via EDI. In dit opzicht is Product Data Interchange (PDI), de interne en externe uitwisseling van produkt- en produktiegegevens, een logisch gevolg op EDI. Initiatieven op het gebied van PDI kunnen bijdragen tekortkomingen van EDI-communicatie ondervangen.

Beoogd doel van PDI is de koppeling van CAD-systemen onderling en het koppelen van CAD met CAM-systemen. Deze systemen worden met name toegepast in de ontwerpfase van het bouwproces en bij de koppeling van ontwerpactiviteiten met de produktie van bouwmaterialen. In de ontwerpsfeer kan PDI worden ingezet voor een betere coördinatie van verschillende (architectonische, constructieve en installatietechnische) ontwerpdisciplines (De Groot, 1993). De totale ontwerpfase: kan daardoor efficiënter verlopen, waardoor ontwerpkosten gedrukt kunnen worden. Door een betere afstemming van de (on)mogelijkheden van de ontwerpen van de verschillende disciplines kan ook de kwaliteit van het ontwerp worden verhoogd. Bij de koppeling tussen ontwerpactiviteiten en de produktie van materialen kan een betere informatie-uitwisseling door PDI leiden tot verkorting van de doorlooptijd.

Electronische berichten, die ontwerpinformatie bevatten over eenzelfde produkt, kunnen in een veelheid aan verschillende vormen voorkomen. Binnen een bepaald vakgebied kan sprake zijn van een eenduidige classificatie en codering van produktgegevens. Deze ordening makak de communicatie en informatie-uitwisseling efficiènter. Deze ordening kan echter ook tot misverstanden leiden als personen uit verschillende vakgebieden met elkaar gaan praten. Zo kan een muur bij architecten onder de groep afscheidingen vallen, bij de installateur onder de groep obstakels en bij de constructeur. onder de groep steenachtige constructies. Verschillende partijen hebben verschillende 'views' op produktgegevens. De verschillende 'views' bepalen de verschillende classificaties en coderingen van gegevens en daarmee vorm en inhoud van electronische berichten.

De gegevens in de berichten, waarvoor men standaarden wil vastleggen, hebben echter betrekking op één en hetzelfde produkt dat ontworpen, gemaakt en onderhouden moet worden. Om tot standaardisatic van de gegevensoverdracht te komen zal er eerst een model van een produkt moeten worden gedefinieerd, waarin dit produkt volledig en eenduidig wordt vastgelegd. Dat wil zeggen dat alle informatie over een produkt voor alle betrokken partijen in een bouwproces in dit model is beschreven. Dit inzicht heeft geleid tot het ontstaan van zgn. produktmodellen en het formuleren van uitwisselingsformaten daarvoor.

\subsubsection{Standaarden voor produktmodellering}

Een produktmodel is een gestructureerde gegevensverzameling van een bouwwerk of delen daarvan. Het produktmodel is in essentie is een volledige, consistente en ondubbelzinnige beschrijving van een produkt of project (Gielingh en Kuiper, 1988). Dit betekent dat niet alleen geometrische gegevens, maar ook gegevens over structuur van het produkt, materialen, kwaliteitsnormen, bewerkingskenmerken en administratieve gegevens worden vastgelegd. In het produktmodel wordt informatie opgeslagen in een structuur die afgeleid is van de structuur van het produkt zelf. Een gebouw kan onder- 
scheiden worden naar zijn topologie, zijn gebouwmodules en zijn ruimtemodules. De topologie geeft aan, welke modules aan elkaar grenzen en waar ze zich bevinden. Een gebouwmodule is elk fysiek onderdeel van het gebouw, kleiner dan het gebouw zelf. Een ruimtemodule is elk samenstel van ruimten kleiner dan de gehele gebouwruimte. Het werken met produktmodellen vereist dat precies afgesproken wordt, hoe een gebouw wordt gedecomponeerd in modules, hoe die modules heten, wat de ontwerpkenmerken zijn, welke de relaties tussen deze modules zijn en welke informatie bij deze modules opgeslagen kan worden.

Diverse disciplines kunnen hun eigen aspectmodel definiëren, dat wil zeggen een produktmodel gebaseerd op de 'view' van de discipline. Voorbeelden zijn de aspectmodellen constructies en architect. Een aspectmodel is weer verder te specialiseren. Zo is het aspectmodel constructies te specialiseren in beton- en in staalconstructies. Deze aspectmodellen moeten, om uitwisseling te kunnen garanderen, eenzelfde (classificatie)structuur bevatten. De verschillende 'views' moeten op elkaar afgestemd worden. Dit maakt het mogelijk dat de diverse aspectmodellen via het kernmodel met elkaar kunnen communiceren (de aspectmodellen communiceren niet rechtstreeks met elkaar). Het produktmodel van een gebouw, de gegevens van objecten die tezamen een gebouw beschrijven, is dus meestal niet een grote centrale gegevensverzameling die door één partij wordt beheerd. Het is vaker een 'gedistribueerde database': bij diverse disciplines zijn stukjes van het totale model aanwezig.

FIGUUR 9.2 Kern en aspectmodellen

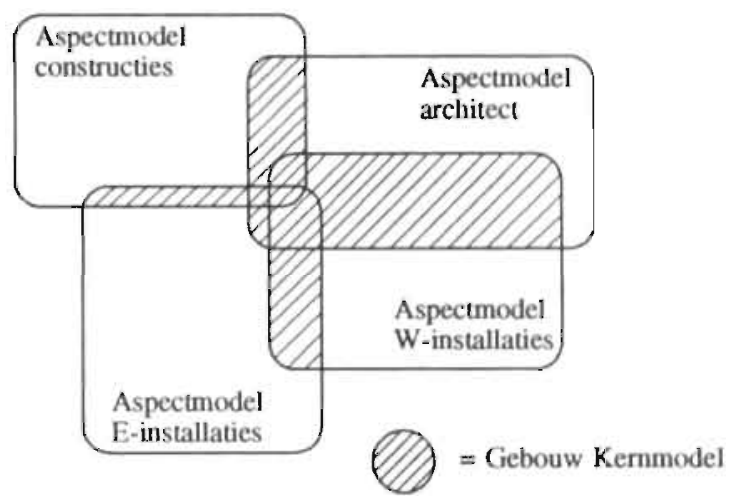

Bron: CIAD/STABU (1993).

Het internationale produktmodelleringsonderzoek (waarin Nederland een bijdrage heeft vanuit het meerjarenonderzoek van Rijkswaterstaat en TNO-Bouw) heeft in het kader van ISO-STEP de basis gelegd voor standaarden voor produktmodellen. Produktmodellering voor de bouw vindt bij ISO-STEP in een commissie plaats gericht op 'AEC' (Architecture Engineering and Construction) toepassingen. De ontwikkeling van deze toepassingen zijn binnen het STEP-kader relatief laat gestart. Met name Groot Brittannië, de Verenigde Staten, Duitsland en Nederland zijn hier nauw bij betrokken (NEDC, 1990, 78). De AEC-commissie. stelt zich ten doel: 
'To provide a general framework for the organisation of product data which are exchanged by various disciplines in the AEC area for the support of various organisations. The aim is to cover all significant data exchanges in the industry and not to be limited to an enterprise. The AEC area is considered to be very wide, covering products such as building (...), building components, public works, process plant construction, shipbuilding and so on. The intent is to cover product data for the whole product life cycle, from concept design to demolition.' (NEDC, 1990, 78)

Een op STEP gebaseerde: applicatie voor de bouw is het internationaal referentiemodel GARM (General AEC Reference Model). GARM principes worden gebruikt voor het definiëren van de basisstructuur voor produktmodellen en hebben internationaal erkenning gekregen. GARM onderscheidt op bedrijfstakniveau vijf klassen van produkten: schepen, 'plants', gebouwen, wegen en bruggen. Voor classificatie van bouwelementen van een gebouw kunnen verschillende systemen gebruikt worden. Voorbeelden zijn onder andere het Zweedse BASB, het Britse BIC, SfB (internationaal afgekort als CIB). De CIB/SfB code identificeert zeven klassen van bouwelementen die weer verder onderverdeeld worden (de SfB-code behoort niet tot de STEP-standaard). TNO heeft in het kader van de ontwikkeling van het BasisWegModel (BWM) ervaring opgedaan met het gebruik van het GARM als basisstructuur.

Het ontstaan van standaard produktmodellen heeft een aantal gevolgen (Maliepaard en Swets, 1989). Ten eerste kan produktmodellering op termijn de basis vormen voor de ontwikkeling van een informatie-technische infrastructuur, een stelsel van afspraken waarmee communicatie tussen bouwpartners via geautomatiseerde informatiesystemen mogelijk wordt. Ten tweede zal produktmodellering de opbouw en structurering van bouwgegevens zoals tekeningen, bestekken, begrotingen e.d. gaan bepalen. Huidige methoden voor het maken van belangrijke informatiedragers als bestek en tek.eningen zullen gaan veranderen en nieuwe methoden ontstaan. Ten derde wordt de basis gelegd voor een integrale aanpak van automatisering in de bouw. Geïsoleerde automatiseringstoepassingen worden op elkaar afgestemd.

\subsection{PDI in de Nederlandse bouw}

\subsubsection{IOP-Bouw en Nationaal Onderzoekskader Bouwinformatica}

Het in 1985 ingestelde Innovatiegericht Onderzoeks Programma voor de Bouw (IOP. Bouw) is een belangrijk overheidsinitiatief geweest voor het stimuleren van informatisering in de Nederlandse bouw. ${ }^{3}$ Beoogd doel van IOP-Bouw is enerzijds geweest dat bedrijven, universiteiten en onderzoeksinstellingen met elkaar leerden samenwerken op het gebied van informatica-ontwikkelingsprojecten. Anderzijds heeft IOP-Bouw zich gericht op de totstandkoming van een informatie-technische infrastructuur, d.w.z. een stelsel van afspraken waarmee communicatie tussen bouwpartners via geautomatiseerde systemen mogelijk wordt.

${ }^{3}$ In de in 1979 verschenen Innovatienota werd het concept IOP geìntroduceerd en formeel ging in 1983 het eerste IOP van start. In een IOP wordt strategisch onderzoek verricht dat 'pre-competitief is: het onderzock is van belang voor het bedrijfsteven in het algemeen, maar speelt nog geen rol in de onderlinge concurrentic. De dertien IOP's zijn cen belangrijk instrument in het technologiebeleid van de overheid. Tussen 1990 en 1996 worden de verschillende IOP's afgesloten. 
$\mathrm{Er}$ is in de bouw nu nog vaak sprake van eilandautomatisering. Gegevens voortkomend uit of nodig voor een programma worden handmatig overgedragen van of naar een ander programma. De informatie-technische infrastructuur biedt uiteindelijk de mogelijkheid voor communicatie tussen computersystemen. De informatie van de ene participant kan gebruikt worden door een andere participant en vice versa.

FIGUUR 9.3 Eilandautomatisering versus informatic-technische infrastructuur

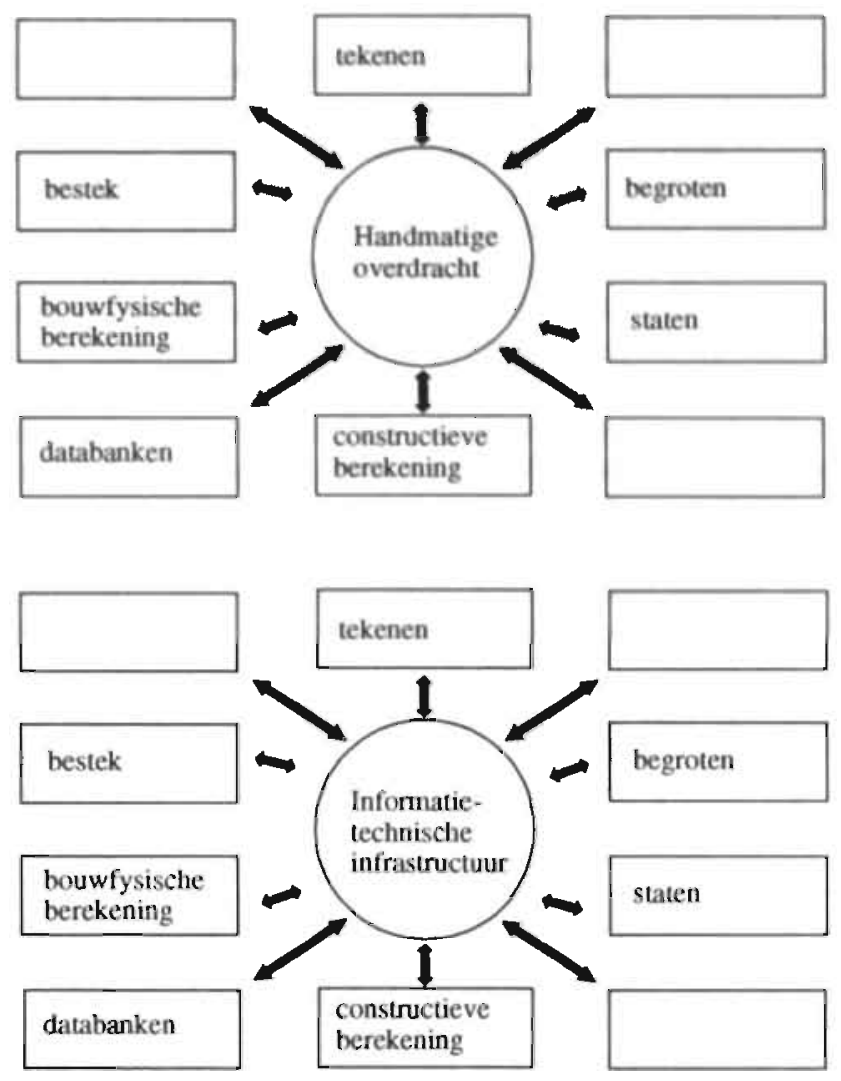

Bron: PCR, Nationaal Onderzoekskader Bouwinformatica (1991).

Het in 1989 afgekomen en door IOP-Bouw ontwikkelde Bouw Informatie Model (BIM) had als standaard produktmodel dan ook als doel de basis te vormen voor een informatie-technische infrastructuur in de bouw. Met het BIM-model is geprobeerd tot deze infrastructuur te komen door een sector omvattende methodiek of standaard te ontwikkelen. In de perceptie van de bouwwereld is het BIM door zijn abstracte karakter, noodzakelijk om de standaard sector omvattend te doen zijn, niet echt succesvol geweest. Wel wijst het Algemeen Verbond Bouwbedrijven (AVBB) erop dat het IOPBouw ertoe geleid heeft dat mensen in de onderzoeks- en bouwwereld elkaar hebben leren kennen en nu op verschillende niveaus intensief met elkaar samenwerken (Inge- 
nieurskrant 19 november 1992). Daarnaast wordt het denken in produktmodellen als een belangrijk resultaat van IOP-Bouw gezien.

Eind 1989 liep het IOP-Bouw programma af en stelde EZ geld beschikbaar voor een vervolg op dit BIM-model. Verschillende organisaties kwamen met initiatieven om een vervolg te geven aan het BIM-model. Het IGBI, de Initiatief Groep Bouw Informatica, was bedoeld om verschillende initiatieven te coördineren. ${ }^{4}$ Het Nationaal Ontwikkelplan Bouw Informatie Systeem (NOBIS) van IGBI was een eerste opzet, gericht op een vervolg, van de top-down benadering zoals die tot nu toe was gevolgd. Ongeveer tegelijkertijd werd door de COPI's het Nationaal Onderzoekskader Bouwinformatica (NOBI) opgezet. ${ }^{5}$ In tegenstelling tot het NOBIS kenmerkte het NOBI zich door een bottom-up benadering waarbij ervaringen en problemen van bedrijven in de bouw het uitgangspunt waren. NOBIS is uit beeld geraakt en in kader van het NOBI werken nu een groot aantal bedrijven en instellingen aan de ontwikkeling van een informatietechnische infrastructuur. Volgens secretaris Spekkink van de Adviesraad Technologie:beleid Bouwnijverheid (ARTB) ${ }^{6}$ is voor de ontwikkeling van bouwinformatica in Nederland het IGBI meer het beleidsplatform geworden waar bedrijven en organisaties elkaar kunnen informeren en het NOBI de uitvoerende instantie.

In het dilemma - tussen sectoromvattende afspraken versus snelheid - heeft NOBI gekozen voor een concrete, relatief snelle en operationele oplossing voor een deel van de infrastructuur met de mogelijkheid van uitbouw op lange termijn. Het in één stap tot stand brengen van een volledige telematica-infrastructuur voor de gehele sector, zou geruime tijd in beslag nemen. Een dergelijke top-down benadering zou pas op

4 Het IGBI is september 1989 opgericht door een zes branche-organisaties in de bouw: de BNA (Bond van Nederiandse Architekten), NVTB (Nederlands Verbond Toetevering Bouw), ONRI (Orde van Nedeilandse Raadgevende Ingenieurs.). UNETO (Unie van Nederlandse Electrotechnische Ondernemingen) en VNI (Vereniging Nederlandse Installaticbedrijven) en mede namens ERRI (Elektronisch. Rekencentrum Raadgevende Ingenieurs), VABI (Vereniging voor Automatisering in Bouw- en Insiallatietechnick) en VCA (Vereniging Computergebruik Architektenbureaus). Het IGBI stelt zich ten doel omi tussen de dịverse informaliserings-initiatieven cen zekere coördinatie te realiseren. Want 'ẹ moet. nog heel wat gediscussieerd en gemasseerd worden voordal de Nederlandse bouw op het gebied van informatica op een lijn zit', aldus !GBl-voorzitter ing. H.P. Barth (De Haan, 1993).

s Onder de COPI's, de Collectief Onderzoek Programmerende Instellingen, vallen vier onderzoeks. instellingen die een zekere coordinerende functie vervullen ten aanzien van met name onderzoek dat collectief en openbaat is. De vier instellingen zijn het ISSO (Instituut voor Studie en Stimulering van Onderzoek op het gebied van gebouwinstallaties), de SBR (Stichting Bouwresearch), het CUR (Civieliechnisch Centrum voor Uitvoering Research en Regelgeving) en CROW (Centrum voor Regelgeving en Onderzoek in de Grond-, Water- en Wegenbouw en de Verkeerstechniek). De Programma Coördinatie Raad (PCR) is het overleg-orgaan van de COPI's waar onderzoeksprogramma's en projecten op elkaar worden afgestemd. De PCR heeft in het verleden een viertal thema-velden vastgelegd: bouwin: formatica, kwaliteitszorg, levensduur en duurzaamheid en energie en milieu.

${ }^{6}$ De in augustus 1990 ingestelde Adviesraad Technologiebeleid Bouwnijverheid (ARTB) richt zich. vooral op het ontwikkelen van visies op branche-overschrijdende thema's die voor de bedrijfstak bouw van strategisch belang zijn in het kader van technologiebeleid. Voorbeelden van die thema's zijn integrale kwaliteitszorg in het bouwproces, bouwinformatica, logistiek, mechanisatie en produktie-automatisering, verbeteren van arbeidsomstandigheden, milieu en de ruimteproblematiek. De ARTB stemt initiatieven op het gebied van onderzoek en technologic-ontwikkeling in de bouw op elkaar af. Daartoe. onderhoudt de ARTB nauwe contacten met bouwgerelateerde ministeries (VROM, V\&W en EZ), de COPI's, de bouwfaculteiten van de TU's en de grote technische instituten zoals bijvoorbeeld het TNO. 
langere termijn kans van slagen bieden. Men verwacht dat de bottom-up aanpak het op korte termijn mogelijk maakt dat bedrijven op beperkte schaal electronisch informatie met elkaar uitwisselen. Het idee is dat de ontwikkeling van een informatie-technische infrastructuur het beste binnen de bedrijven, beroepsverenigingen en branches kan geschieden. Waar individuele projecten elkaar tegen komen moeten afspraken op een hoger niveau gemaakt worden. Daarbij moet aangesloten worden op internationale standaarden. Deze implementatie-strategie is gebaseerd op het inzicht dat uniformiteit in de bouw onhaalbaar is. Men hoopt dat de concrete informatiseringsprojecten een uitbouw naar een grootschalige infrastructuur tot gevolg hebben.

Het NOBI omvat acht projecten die te onderscheiden zijn naar praktijkprojecten en algemene projecten. Ieder praktijkproject wordt gecoördineerd door een COPI en een belanghebbende branche-organisatie. De praktijkprojecten zijn:

1. Data-Uitwisselingssysteem (DUS): project gericht op de ontwikkeling van een gebouwmodel installatietechniek voor de gegevensuitwisseling tussen installatietechnisch ontwerper en uitvoerend installateur (coördinatie is in handen van het ISSO en de $\mathrm{VABI}$ (Vereniging voor Automatisering in Bouw- en Installatietechniek));

2. Budgetteren, Bestekken en Begroten (BBB): project gericht op de ontwikkeling van een produktmodel voor de uitwisseling van kostengegevens tussen ontwerpende en uitvoerende partijen door koppeling van de NL/SfB-Elementenmethode als ontwerpinformatiesysteem en STABU-2 als besteksinformatiesysteem (coördinatie door de SBR en de VCA (Vereniging Computergebruik Architektenburo's)); ${ }^{7}$

3. Wapening en Informatisering (WAPINFO): project gericht op de ontwikkeling van een uitwisselingsformaat voor de gegevensoverdracht tussen constructie-ontwerpers en producenten van betonwapening (coördinatie door het CUR en het CIAD (Vereniging voor Computertoepassingen in de Ingenieurspraktijk));

4. Tekening-Verkeer van de Weg (TVW): project gericht op de structurering van informatiestromen tussen teken- en ontwerpsystemen bij de bouw van een (spoor)weg (coördinatie door het CROW);

5. Wegontwerp En Electronische Theodoliet (WEET): project gericht op de structurering van informatiestormen tussen teken- en ontwerpsystemen en inmeet- en uitzetsystemen (coördinatie door het CROW). ${ }^{8}$

De algemene projecten zijn:

6. MONITOR: 'monitoring' van de nationale en internationale ontwikkelingen met betrekking tot PDI en EDI in de bouw;

7. ABI: Afsprakenstelsel Bouwinformatica;

8. KO-generiek: Coördinatie Kennisoverdracht (KO) en Voorlichting.

De eerste drie praktijkprojecten zijn gericht op de utiliteitsbouw, de laatste twee op de grond-, weg- en waterbouw. Bij de eerste drie projecten wordt gebruik gemaakt van eenzelfde kantoorgebouwontwerp. De laatste twee projecten richten zich op de bouw van een (spoor)weg. De projecten in de utiliteitsbouw lopen van eind 1991 tot eind 1993, die in de grond-, weg- en waterbouw van eind 1992 tot eind 1993. De praktijk-

\footnotetext{
${ }^{7}$ Zie voor de NL/SfB-Elementenmethode en het STABU-bestek $\S 8.4$.

${ }^{8}$ Een theodoliet is een landmeetkundig apparaat voor het uitzetten van hoeken.
} 
projecten genereren naast concrete oplossingen ook produktmodellen. Voor een effectieve ontwikkeling van PDI in de Nederiandse bouw wordt het van belang geacht deze produktmodellen op te nemen in een samenhangend kader. Dat is het doel van het project $\mathrm{ABI}$. Het $\mathrm{ABI}$ integreert de algemeen bruikbare resultaten van de praktijkprojecten in één architectuur. Daarnaast ondersteunt het $A B I$ de opzet van de referentiemodellen voor de praktijkprojecten en toetst de architectuur aan de praktijk beproefde modellen.

Tussen de praktijkprojecten en het ABI bestaat dus een voortdurende wisselwerking. Het project MONITOR is opgezet vanuit de gedachte dat de projecten mede gestuurd moeten worden vanuit een algemeen zicht op de nationale en internationale ontwikkelingen. Het project MONITOR verschaft dit gewenste zicht. Tot slot is het van belang dat geïnteresseerden de voortgang van het projectprogramma kunnen volgen en van de resultaten gebruik kunnen maken. Hierin voorzien de afzonderlijke praktijkprojecten en het project $\mathrm{KO}$.

\subsubsection{PDI en de herstructurering van het bouwproces}

Produktmodellering maakt in principe een koppeling van functies van verschillende bedrijven mogelijk. In de inleiding van dit hoofdstuk is gezegd dat een directe koppeling van PDI-systemen met interne applicaties bepaalt of een herstructurering van de interne organisatie en een substitutie van arbeid optreedt. Om hier enig zicht op te krijgen wordt hier aangegeven welke partijen door de te ontwikkelen produktmodellen in de PDI-projecten aan elkaar gekoppeld worden.

De PDI-projecten in de utiliteitsbouw, DUS, BBB en WAPINFO, betekenen een verandering van relaties tussen de architecten, installatie- en constructie-ontwerpers, installateurs, aannemers en fabrikanten van prefab betonelementen.

FIGUUR 9.4 PDI in de utiliteitsbouw

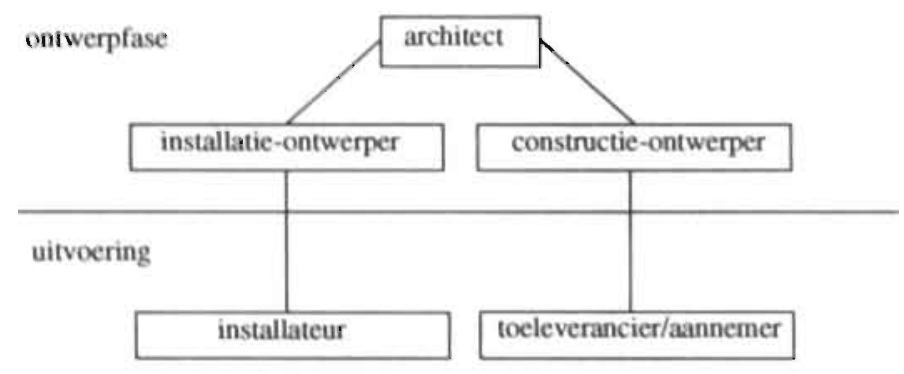

Bron: bewerking van De Groot (1993).

De architect is het startpunt van de informatiestromen over het te bouwen object. Bij de architect ontstaat het ontwerp in de vorm van tekeningen, berekeningen en specificaties waar de overige disciplines mee verder moeten werken. Het ingenieursbureau moet zijn ontwerp baseren op dat van de architect. Juist voor het ingenieursbureau is 
PDI interessant omdat het zowel aan de inputzijde als aan de outputzijde met technische informatie-uitwisseling te maken heeft (De Groot, 1993). Aan de inputzijde krijgt het ingenieursbureau het architectonisch ontwerp. De output bestaat uit specifieke constructie of installatie ontwerpen. Met deze output worden de maatprodukten in de fabriek (installaties, prefab betonelementen of betonwapening) geproduceerd of uitvoeringswerkzaamheden op de bouwplaats (bekisting, landmetingen of gronduitgravingen) in gang gezet. De koppeling tussen ontwerp en fabrikage kan voordelig zijn voor toeleveranciers die maatprodukten leveren. Als ontwerpspecificaties door het ingenieursbureau electronisch worden aangeleverd en de toeleverancier heeft zijn produktie-proces geautomatiseerd met CAM-systemen dan kunnen voordelen ontstaan als doorlooptijdverkorting en snellere produktinnovatie.

Voor een architect kan PDI een middel zijn om meer kostenbewust te ontwerpen. Het project BBB (Budgetteren Bestekken en Begroten) kan hiertoe bijdragen. Het kernmodel maakt een koppeling mogelijk tussen specifieke detailmodellen. Op basis van een Programma van Eisen voor een gebouw wordt bijvoorbeeld gekozen om een bepaalde functie uit te voeren in baksteen. Gezien de detaileisen van de opdrachtgever wordt gekozen voor een geglazuurde baksteen van een zekere kwaliteitsklasse en een bepaalde kleur. Het vastleggen van deze specificatie-beslissing gebeurt in het bestek. Om te controleren of de gekozen technische oplossing (geglazuurde baksteen) voldoet aan de budgeteisen, die door de opdrachtgever zijn gesteld, kan met behulp van de begrotingsapplicatie worden gecontroleerd of de realisatie van het gebouw volgens de opgestelde specificaties binnen het budget mogelijk is. In dit voorbeeld halen de besteksfunctie en de begrotingsfunctie beide de gegevens uit het produktmodel, om deze vervolgens te bewerken en weer toe te voegen aan het informatiemodel (VCA, 1992).

Volgens A.J. Molendijk van de Bond van Nederlandse Architekten heeft bij architecten lange tijd een grote emotionele aversie bestaan tegenover informatietechnologie. Momenteel is in de architectenwereld duidelijk sprake van een omslag. Een reden hiervoor is dat informatietechnologie wordt gezien als een belangrijk instrument om de coordinerende rol van de architect te behouden of verder te ontwikkelen." Het DUSproject uit de installatiebranche vormt voor de architecten in het project Budgetteren Bestekken en Begroten (BBB) een belangrijk uitgangspunt. De VCA (Vereniging Computergebruik Architektenburo's) was op het moment van onderzoek nog niet zover dat processen zodanig in kaart waren gebracht dat de ontwikkeling van produktmodellen mogelijk was. De VABI (Vereniging voor Automatisering in Bouw- en Installatietechniek) is daarentegen al sinds 1987 bezig met de ontwikkeling van het Data-Uitwisselingssysteem en speelt hier duidelijk een voortrekkersrol. De VC.A werkt dan ook met de VABI samen met als doel het niveau van produktmodellering binnen de architectendiscipline binnen korte tijd op het zelfde niveau als dat van de installatietechnische discipline te brengen.

De projecten DUS (Data-Uitwisselingssysteem) en WAPINFC (Wapening en Informatisering) scheppen mogelijkheden voor een snellere feedback tijdens een bouwproces. Een ontwerp van een betonnen balk door de constructeur kan bijvoorbeeld door de installatie-adviseur worden opgehaald. Die bepaalt vervolgens welke sparingen op

${ }^{9}$ Op deze functie van informatictechnologie voor de architectenbranche wordt in $\$ 10.2$ verder ingegaan. 
welke plaats moeten komen ten behoeve van de leidingen. De gegevens over zowel de sparingen als de gehele balk kunnen door de architect worden gebruikt voor het beoordelen van het totaalconcept, terwijl sparingsgegevens voor de constructeur invoer kunnen zijn voor het berekenen van plaats en eigenschappen van de waperiing. De wapening gegevens worden vervolgens weer aan het informatiesysteem toegevoegd, waar de aannemer ze weer op kan halen voor het bestellen van wapening bij de buigen vlechtcentrale.

De te ontwikkelen produktmodellen kunnen een efficiënter tekeningenverkeer mogelijk maken. Tot nu toe is gebruikelijk dat de architect tekent, de installateur bouwtechnisch moeilijke dingen voor zijn situatie 'hermaakt' en vervolgens de constructeur weer opnieuw begint. Ook de aannemer hermaakt de tekeningen voor toeleveranciers en constructeurs. Door produktmodellering wordt dit dubbelwerk voorkomen en bestaat er minder kans op fouten die het gevolg zijn van het 'hermaken' van tekeningen.

De PDI-projecten TVW en WEET in de grond-, weg- en waterbouw richten zich op de informatie-uitwisseling rondom het produkt (spoor)weg.

FIGUUR 9.5 PDI in de grond-, weg- en waterbouw

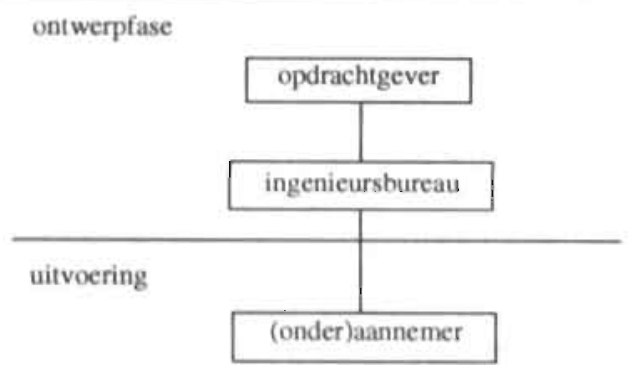

Bij het inmeten en tekenen van een (spoor)weg spelen verschillende partijen een rol: de opdrachtgever, het architectenbureau, het landmeetkundig ingenieursbureau en de aannemer. De twee PDI-projecten in de grond-, weg- en waterbouw hebben met name betrekking op de relatie tussen opdrachtgever, ingenieursbureau en aannemer.

Een tendens is dat in de GWW-sector grote infrastructuurbeheerders zoals Rijkswaterstaat, de NS, provincies en gemeenten, geleidelijk overgaan tot turn-key aanbesteding. ${ }^{10}$ Het bedrijfsleven krijgt bij de turnkey-organisatievormen te maken met het hele ontwerpproces waarbij uitwisselen van informatie een belangrijke rol speelt. De opdrachtgever beperkt zich tot het stellen van een Programma van Eisen en de aanzet van het ontwerp met behulp van een 3D (drie-dimensionaal) ontwerpsysteem. Dit

${ }^{10} \mathrm{Bij}$ een turnkey-organisatie stelt een opdrachrgever slechts een globaal Programma van Eisen (PvE) op. Daarmee gaat hij naar eén of meer turnkey-organisaties voor aanbiedingen. Na keuze voor een turnkey-organisatic is dat de enige partij waarmee de opdrachtgever een rechtstreeks contract sluit. Deze turnkey-organisatic contracteert zelf een architect, eventuele extra adviseurs, onderaannemers en tocleveranciers (SBR, 1992a). 
ontwerp wordt vervolgens verder uitgediept bij ingenieursbureaus en aannemers met eigen ontwerpafdelingen, veelal op een ander 3D-ontwerpsysteem. Overdracht van reeds beschikbare digitale informatie ontbreekt hierbij. Verdere detaillering van het ontwerp binnen hetzelfde bureau gebeurt doorgaans met een 2D-tekensysteem, eveneens zonder digitale overdracht van gegevens. Bijstelling van ontwerp, aangedragen door opdrachtgever of het ontwerpbureau zelf, gebeurt bij de huidige beperkte communicatiemogelijkheden met hetzelfde 2D-tekensysteem. De overdracht van de gegevens naar de uitvoeringsfase (het bestek) gebeurt eveneens op 2D-niveau.

In de toekomstige situatie zal men na het inmeten en het verwerken van de meetwaarden de gegevens verder laten verwerken door landmeetkundige verwerkingssoftware. Hierna volgt de vertaling naar het 'WEET'-formaat, waarna men beschikt over een file die op verschillende typen systemen verwerkt kan worden. Vervolgens kan een verdere, goeddeels automatische, vertaalslag plaats vinden van het 'WEET'-formaat (3D) naar een tekening (zie figuur 9.6).

FGUUR. 9.6 Het proces van inmeten en uitzetten met een WEET-file

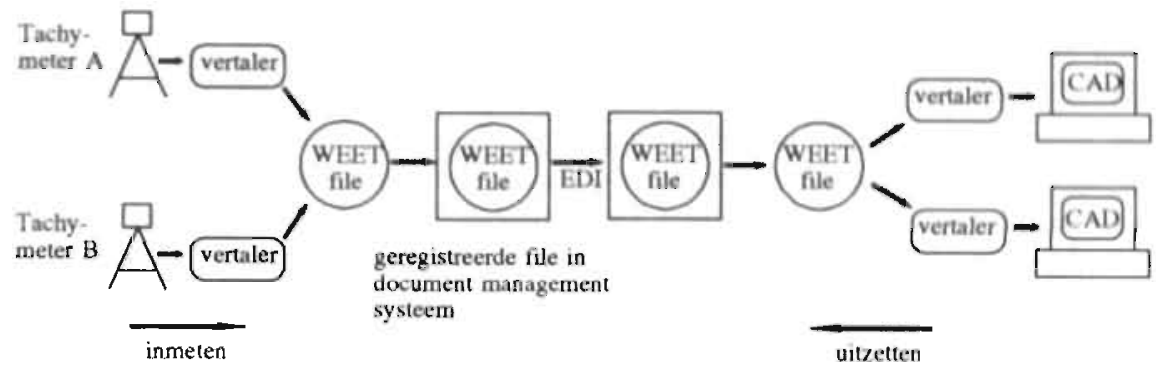

Bron: CROW.

De deelnemers aan het PDI-project 'WEET' hopen dat op termijn de meeste 2Dtekensystemen de standaard uitwisselingsformaat 'WEET' zullen ondersteunen. Hierdoor krijgt de gebruiker de vrije keus om ingemeten waarden op verschillende typen systemen verder te verwerken. Na de introductie en acceptatie van het 'WEET'-formaat zal er een grotere keuzevrijheid bestaan bij de inzet van CAD-systemen en tachymeters. ${ }^{11}$ Hierdoor zal het uitbesteden van tekenwerk en landmeetkundig werk - en inherent daaraan ook de communicatie tussen de verschillende partijen in het bouwproces - toenemen. Gegevensuitwisseling via EDI-berichten kan hierbij een belangrijke rol spelen. Met behulp van EDI-software kan bijvoorbeeld een file samen met informatie afkomstig uit het archiefsysteem van de verzender verstuurd worden. Bij de ontvanger kan de file met bijbehorende informatie weer in het archiveringssysteem van de ontvanger worden geplaatst.

${ }^{11}$ Een tachymeter is een electronisch landmeetkundig apparaat voor het uitzetten van afstanden en hoeken. 
Gezien het experimentele stadium waarin de ontwikkeling van PDI zich bevindt is nog moeilijk aan te geven op welke wijze deze tot een herstructurering van de interne organisatie en arbeidsbesparing leidt. Wel is duidelijk dat PDI voor de architect een middlel kan zijn om meer kostenbewust te ontwerpen. Tevens lijkt PDI met name voor de ingenieursbureaus belangrijke veranderingen kunnen betekenen omdat deze bedrijven zowel aan de input- als aan de output zijde met PDI te maken krijgen.

\subsection{Knclpunten en strategieên bij implementatie van EDI en PDI in de bouw}

\subsubsection{De projectmatige produktiewijze en sectorstructuur als knelpunten}

EDI en PDI-projecten zijn aanzetten tot de ontwikkeling van een collectieve bouwtaal. Die formele bouwtaal kan men tegenover de huidige wijze van communiceren zetten. Aan de ene kant staat informatie-overdracht door middel van vrije tekst en beeld van mens tot mens. Aan de andere kant staat een gestructureerde vorm van informatieuitwisseling via een formele taal, die is geïmplementeerd in software (zie figuur 9.7).

FIGUUR 9.7 De huidige wijze van communiceren tegenover de formele bouwtaal

\begin{tabular}{ll}
\hline Communiceren in tekst en beeld & Communiceren in formele bouwtaal \\
\hline Tekstrege! & Produktmodel \\
Tekening & Data \\
Uniek bestek & (Besteks)taal \\
Ontwerpproces persoonsgebonden & Ontwerpproces open voor samenwerking \\
\hline
\end{tabular}

Bron: Mooy (1992).

In het voorgaande hoofdstuk is aangegeven dat de produktiewijze van een gebouw zich kenmerkt door projectmatige aanpak, locatie-gebondenheid en een stricte arbeidsdeling. De complexiteit en tijdelijkheid van processen en de diversiteit van partijen, inherent aan de projectmatige aanpak, bemoeilijkt het tot stand komen van een collectieve bouwtaal waarbij verschillende partijen tijdens het bouwproces op basis van dezelfde standaarden met elkaar kunnen communiceren.

In het traditionele bouwproces komt de bouwondernemer via aanbesteding aan werk (daarom wordt hij 'aannemer' genoemd). De opdrachtgever kiest meestal degene die tegen de laagste prijs ingeschreven heeft. Inkopers van de aannemer, aan wie het project gegund is, trachten op hun beurt weer een zo laag mogelijke prijs bij toeleveranciers en onderaannemers te bedingen. Deze prijsconcurrentie, in combinatie met het meestal unieke en gecompliceerde karakter van een bouwproject, heeft tot gevolg dat bij ieder project weer opnieuw namens of door de opdrachtgever met een groot aantal verschillende bedrijven aparte contracten gesloten wordt.

Bedrijven werken steeds in wisselende samenwerkingsverbanden aan steeds andere projecten. Ontwerpende, uitvoerende en toeleverende partijen spreken ieder hun eigen taal en allen hebben een eigen benadering van een bouwwerk. Gedurende een bouwproces gebruiken deze partijen een groot aantal computersystemen, netwerken, opslag- 
structuren, protocollen en gegevensdefinities. De afzonderlijke bedrijven, producenten, groothandelaren, architecten, toeleveranciers, onderaannemers, installateurs en dienstverleners hebben allen hun eigen computersystemen voor de interne communicatie. Daarnaast zitten grote bouwbedrijven door overnames en fusies vaak met verschillende interne standaarden. Contracten met systeemhuizen kunnen soms een belemmering vormen voor het tot stand komen van één standaard voor het gehele bedrijf.

Na voltooiing van een project valt het team aannemer en onderaannemers weer uiteen. De tijdelijkheid van relaties en de bestaande projectmatige produktie-wijze hebben tot een cultuur geleid waarbij men in de bouw sterk op de korte termijn denkt. De bouwcultuur is gericht op improviseren op de locatie, de bouwplaats. Er heerst daarbij een voorkeur om alle problemen maar tijdens de uitvoering van de bouw op te lossen. Werken met een visie voor de lange termijn is in veel bedrijven afwezig. Deze improvisatie-cultuur vormt een belangrijke belemmering voor het doen van investeringen in informatietechnologie die een tijdshorizon voor de langere termijn vragen.

Naast tijdelijkheid van relaties vormt de sectorstructuur een tweede probleem voor het tot stand komen van eenduidige communicatie-standaarden. De sector wordt namelijk gedomineerd door het kleinbedrijf en de afwezigheid van een dominante onderneming.

Bij de invoering van een 'industry-wide' automatiseringssysteem als EDI neemt een grote onderneming als Albert Heijn, Philips of Akzo meestal het voortouw. In de Nederlandse bouw is echter geen duidelijke marktleider die een potentiële standaard voor een informatietechnologie kan zetten, waaraan de bouwwereld zich conformeert. Hierin verschilt Nederland van Frankrijk waar grote bouwbedrijven enorme invloed op technologische ontwikkelingen in de sector hebben. Qua omvang is de grootste Nederlandse aannemer, de Hollandsche Beton Groep (HBG), in Europees perspectief klein. HBG komt op de Europese lijst niet bij de eerste 20 bouwbedrijven voor. Daarbij komt ook nog dat de grote Nederlandse concerns in de meeste gevallen uit vele kleinere en los van elkaar opererende werkmaatschappijen bestaan.

Afwezigheid van een dominante onderneming in de bedrijfstak bemoeilijkt ook het tot stand komen van een uniforme produktcodering. Praktijk is dat iedere producent zijn eigen produktcodering hanteert. Zelfs een relatief eenvoudig produkt als een heipaal is op dit moment niet gestandaardiseerd. In bepaalde gevallen kan een aannemer eein toeleverancier een codering opleggen. Bij grote klanten moet de toeleverancier zich wel aanpassen, wil hij niet een belangrijk deel van de omzet verliezen. Van een uniforme externe automatisering is pas sprake als een groot aantal partijen het eens zijn over standaarden voor berichtenuitwisseling. Het uiterst gefragmenteerde karakter van het de bouwsector bemoeilijkt deze ontwikkeling.

Gevolg van de projectmatige produktiewijze en de gefragmenteerde sectorstructuur is dat de ontwikkeling van bouwautomatisering in Nederland tot nu toe wordt gekenmerkt door geïsoleerde toepassingen. Weliswaar wordt de computer veelvuldig gebruikt in de bouw, maar dat betreft toch hoofdzakelijk de standaard toepassingen in functies als ontwerp, calculatie en administratie. Bij de invoering van deze toepassingen veranderde er organisatorisch weinig, de acceptatie verliep relatief snel en zonder problemen en de voordelen waren eenvoudig aantoonbaar (Augenbroe, 1991). Met informatietechnologieën als EDI en PDI ligt dat anders. Deze technologieën zijn bedrijfsoverschrijdend, dat wil zeggen dat ze alleen kunnen worden toegepast als meerdere func- 
ties, bij voorbeeld de aannemer èn architect, gezamenlijk daarvoor kiezen en hun wijze van werken daarop afstemmen. Alleen dan kan het rendement van zo'n bedrijfsoverschrijdende technologie optimaal zijn.

\subsubsection{De behoefte aan een collectieve instantie}

Duivenvoorden (1992b) wijst erop dat in de traditionele bouwcultuur men wacht met. EDI totciat het door de markt in zodanige vorm, prijs en kwaliteit wordt aangeboden, dat niet gebruiken nadeliger wordt dan wel gebruiken. Bouwbedrijven willen graag tegen een lagere prijs hun bouwprodukten aanbieden. Als EDI of PDI een middel kan zijn dat een directe kostenbesparing oplevert zullen bedrijven in de bouw tot implementatie overgaan. Dit betekent dat invoering van EDI en PDI zo weinig mogelijk risico in zich moet dragen. Het meest extreme middel om dit risico te beperken is het initiatief en risico van de invoering van deze netwerktechnologie te verplaatsen van een individueel bedrijf naar een collectieve voorziening. Deze collectieve instantie zou verantwoordelijk moeten zijn voor het aanleggen van een laag drempelige berichtennetwerk.

Bij EDI pleit Duivenvoorden (1992b) voor implementatie-strategieën waarbij een collectieve instantie een belangrijke rol speelt. Een collectieve voorziening zou een algemeen EDI-bouwberichtennetwerk moeten aanleggen en zorg dragen voor de aansluitingen op het netwerk. De leverancier van deze voorziening is verantwoordelijk voor ontwikkeling, bouw en exploitatie van dit netwerk. Het netwerk maakt het mogelijk dat verschiliende applicaties direct gekoppeld worden met de interne applicaties van (bouw)bedrijven. Deze leverancier van netwerkdiensten kan bij grote bouwprojecten een belangrijke rol gaan spelen. Hij maakt het mogelijk dat alle bij deze projecten betrokken partijen optimaal met elkaar electronisch kunnen communiceren. Het is een vertrouwenspositie, want alle partijen, ook concurrenten, gaan van dezelfde leverancier gebruik maken. Naast de leverancier zijn andere partijen in het netwerk deelnemers van EDI-organisaties met hun inbreng van EDI-berichten, de softwarebranche met bouwapplicatie-software, het bouwbedrijfsleven en de grote groep instanties zoals de belastingdienst, het Sociaal Fonds Bouwnijverheid, banken en verzekeringsmaatschappijen. We kunnen deze netwerkbeheerder ook interpreteren als een nadere concretisering van het in hoofdstuk 2 geïntroduceerde concept van de verticale actor. Het is de netwerkbeheerder die de (logistieke) informatie-uitwisseling van een keten of groep van bedrijen verzorgt.

Aanzetten voor een EDI berichtennetwerk zijn in de Nederlandse bouw aanwezig. Het EDI-initiatief HCP van de HIBIN is hier een voorbeeld van. De tussenhandel probeert haar functie als logistiek dienstverlener veilig te stellen door eigen EDI-initiatieven te ontwikkelen. Hierbij heeft de horizontale samenwerking via de overkoepelende branche-organisatie HIBIN een branche-gewijze implementatie van EDI in de bouwmaterialengroothandel tot gevolg. De ontwikkelingskosten van de EDI-berichten worden gezamenlijk (door concurrenten) gedragen. Evenals de tussenhandel zijn ook de grote aannemers goed georganiseerd. Binnen de stichting EDIBOUW werken zij aan hun EDl-initiatieven.

De belangrijkste initiatieven, EDIBOUW van de aannemers en HCP van de tussenhandel, zoeken nog geen aansluiting bij elkaar. Beide partijen, tussenhandel en aannemers, lijken daarentegen te concurreren om marktkanalen (De Groot, 1993). De tussenhan- 
del wil haar afzetkanalen controleren terwijl de aannemers dit juist voor de toelevering van bouwmaterialen willen doen. Beide partijen pretenderen te domineren en zijn geneigd de ander te dwingen de door één partij gemaakte afspraken na te volgen. Het gezamenlijk belang van EDIBOUW en HCP is echter een meer efficiënte goederenstroombesturing naar de bouwplaats. EDIBOUW en HCP zouden wat deze goederenstroombesturing betreft naast de eigen initiatieven aansluiting moeten zoeken bij de lopende initiatieven van de andere partij. Op die manier kunnen beide profiteren van wat al door anderen is gedaan. Volgens critici probeert EDIBOUW zich als dé EDIorganisatie van de bouw te presenteren. Op die wijze trachten aannemers volgens de critici hun coördinerende rol in het bouwproces te handhaven of te versterken ten opzichte van industriële toeleveranciers die door het toenemende 'bouwdeel denken' toegevoegde waarde naar zich toetrekken.

Ondertussen blijkt ook voor PDI dat het vanzelf ontstaan van een informatie-technische infrastructuur voor de bouw door het koppelen van bottom-up initiatieven niet erg soepel verloopt. Volgens Spekkink, secretaris van de ARTB, ziet een groot deel van de bouwbedrijven wel de noodzaak van koppeling en samenwerking in, maar zijn zij het oneens over welke afsprakensystemen en benaderingen bepalend moeten zijn. Volgens Spekkink kijkt een groot deel van de bouwwereld vanaf de zijlijn toe en wacht af welk systeem uiteindelijk boven komt drijven.

We kunnen vaststellen dat de ontwikkeling van een algemeen geaccepteerde standaard voor produktmodellen een afstemming van de verschillende disciplines en daarmee een coördinatie tussen verschillende sectoren vereist. Organisaties als de Bond van Nederlandse Architekten, de Unie van Elektrotechnische Ondernemers, de Adviesraad Technologiebeleid Bouwnijverheid en TNO-Bouw kunnen hierbij een belangrijke rol spelen. Het gevaar is aanwezig dat, bij afwezigheid van coördinatie, iedereen voor zichzelf produktmodellen gaat ontwikkelen die niet compatibel zijn met die uit andere sectoren. De voordelen zijn dan voor de verschillende partijen minimaal. 



\section{Innovaties in de organisatie van bouwprojecten}

In hoofdstuk 4 is aangegeven dat logistieke netwerkvorming zich kan ontwikkelen op grond van andere motieven dan alleen het streven naar efficiency. Die andere motieven, een toenemend belang van overdracht van know-how, snelheid en wederzijds vertrouwen, spelen een belangrijke rol bij het streven naar kwaliteit en produktontwikkeling. De vraag rijst of ook in de bouw deze andere motieven dan efficiency van belang worden en dus de basis leggen voor logistieke netwerkvorming (de tweede onderzoeksvraag uit hoofdstuk 6). Om die vraag te kunnen beantwoorden onderzoeken we in dit hoofdstuk recente innovaties in de organisatie van bouwprojecten. In deel I is gesteld dat toepassing van integrale logistiek ertoe kan leiden dat delen van de logistieke functie van verschillende bedrijven gecoördineerd worden door een nieuwe hiërarchie: de verticale actor. Met de analyse van bovengenoemde innovaties kan ook aangegeven worden welke partijen de rol van verticale actor op zich kunnen nemen. Dit sluit aan bij de derde onderzoeksvraag, de vraag of bij bouwprojecten sprake is van een organisatie van logistieke activiteiten in nieuwe hiërarchieën.

Voor dit hoofdstuk zijn gegevens verzameld door interviews met functionarissen van ontwerpende, uitvoerende en toeleverende bedrijven die in diverse branche-tijdschriften stelden op een innovatieve wijze bouwprojecten te organiseren, d.w.z. een wijze van organiseren gericht op de nieuwe marktvereisten waarbij kwaliteit een belangrijke rol speelt. De geïnterviewden behoorden tot de directie of hoger management van de bezochte bedrijven (zie bijlage II). Daarnaast heeft een interview plaats gevonden met een beleidsmedewerker van een branche-organisatie. Er zijn dertig bedrijven benaderd waarvan er zeventien hun medewerking hebben verleend. De bedrijuen behoorden tot een drietal branches: bouwnijverheid ( 5 interviews), zakelijke dienstverlening ( 7 interviews waaronder het interview met een medewerker van een branche-organisatie) en bouwmaterialenindustrie ( 6 interviews). Per bedrijf is één functionaris geïnterviewd aan de hand van een vragenlijst, aangepast aan de branche (zie bijlage IV). De interviews duurden 1 à 2 uur. De uiteindelijke verslagen zijn op individuele basis met de geïnterviewden besproken. Op grond van deze interviews is het mogelijk een beschrijving te geven van ontwikkelingen in de organisatie van bouwprojecten. Wel moet onderkend worden dat bepaalde 'statements' van de geïnterviewden door commerciële belangen kunnen zijn ingegeven en eerder toekomstvisies dan de werkelijkheid weerspiegelen.

Evenals het vorige hoofdstuk, behandelt dit hoofdstuk ontwikkelingen in de omgeving van bouwprojecten en hun ketens. Ten eerste wordt in $\$ 10.1$ ingegaan op achtergronden bij innovaties in de organisatie van bouwprojecten. Beschreven wordt hoe nieuwe marktvereisten naast prijs- ook kwaliteitsconcurrentie in de bouw tot gevolg hebben. Vervolgens wordt in $\S 10.2$ behandeld dat door deze nieuwe marktvereisten organisatievormen ontstaan die afwijken van de traditionele organisatie van het bouwproces. 
Ten slotte worden in $\S 10.3$ deze organisatievormen in verband gebracht met de onderzoeksvragen.

\subsection{Van prijs- naar kwaliteitsconcurrentie}

\subsubsection{Het traditionele bouwproces}

In grote delen van de bouwsector is de traditionele organisatie van een bouwproject de gebruikelijke organisatievorm. In een traditioneel bouwproces vormen een groot aantal betrekkelijk zelfstandig opererende onderaannemers en specialisten gedurende het bouwproject een coalitie. Deze bedrijven verschillen vaak sterk van elkaar qua omvang, marktomgeving en cultuur. Door het meestal unieke en gecompliceerde karakter van een bouwproject wordt bij ieder project weer opnieuw namens of door de opdrachtgever met een groot aantal van deze verschillende, relatief autonome bedrijven aparte contracten gesloten. Deze zgn. bilaterale contractering is de oorzaak voor vele onvolkomenheden en onzekerheden (SBR, 1988).

Met bilaterale contractering wordt bedoeid dat bouwpartners rechtstreeks met de opdrachtgever of hoofdaannemer rechten en plichten vastleggen en dat in veel mindere mate onderiing doen. Een optimale afstemming is daardoor niet gewaarborgd omdat iedere onderneming zijn bronnen alloceert volgens het overeengekomen contract. ledere actor is alleen verantwoording verschuldigd voor zijn specifieke inbreng. Een optimale afstemming wordt verder belemmerd door het feit dat de verschillende partijen los van elkaar zijn geselecteerd en niet steeds op de hoogte zijn van de afspraken die met andere partijen gemaakt zijn. Gevolg van deze gebrekkige afstemming is 'een kreupel proces met veel verspilling door bijvoorbeeld tussentijds wijzigende tijdschema's, een sterke variatie in capaciteit, overbodige wachttijden, extra herstelkosten etc. Het just-in-time principe moet niet alleen gelden voor het logistieke deel, maar ook en vooral voor een goed geplande inbreng van produktkennis in het ontwerpproces' (Bakens en De Mos, 1993a, 25).

Daarnaast ontbreken in veel bouwcontracten vaak precieze omschrijvingen van de verlangde prestaties. Als een bestek (ten dele) ontbreekt, heeft de aannemer veel bewegingsvrijheid. In het traditionele bouwproces ontbreken ook vaak technieken voor het nauwkeurig meten van de geleverde prestaties. Door de bilaterale en via onderaanbesteding 'getrapte' contractering ontstaat een complex geheel van activiteiten, dat. technisch-organisatorisch moeilijk te coördineren is. Vele onduidelijkheden en onzekerheden zijn het gevolg. Bijkomende complicatie is dat belangen van de verschillende participanten in een bouwproject niet synchroon Iopen: de ontwerper optimaliseert zijn ontwerp, de aannemer zijn voortbrengingsproces en de opdrachtgever het te verkrijgen produkt. Aanbevolen kostenredukties in de vorm van ander materiaalgebruik, voorgesteld door een onderaannemer, kunnen in dit klimaat gemakkelijk door andere partijen van tafel worden geveegd. Het bedrijfsbelang prevaleert boven het projectbelang hetgeen vaak tot een sfeer van onderling wantrouwen leidt.

De produktie-organisatie is bij het traditionele bouwproces versnipperd. De verschillende functies en de daaraan gerelateerde goederen- en informatiestromen zijn over verschillende bedrijven verdeeld. Hiermee onderscheidt de bouw zich van de industrie. De ontwerp- en produktie-functies zijn in de bouw, in tegenstelling tot de industrie, 
over verschillende bedrijven verdeeld. Daarnaast is de relatie tussen beide functies van een kortstondig karakter. Bij ieder project wordt weer opnieuw een produktie-apparaat opgebouwd met nieuwe ontwerpende en uitvoerende partijen.

De afwezigheid van stabiele samenwerkingsrelaties, die gedurende een aantal projecten blijven voortbestaan, vindt deels zijn oorzaak in de op prijs gefixeerde cultuur in de bouw. In het traditionele bouwproces komt de bouwondernemer via aanbesteding aan werk. De opdrachtgever kiest meestal degene die tegen de laagste prijs ingeschreven heeft. Inkopers van de aannemer, aan wie het project gegund is, trachten op hun beurt weer een zo laag mogelijke prijs bij toeleveranciers en onderaannemers te bedingen. De belangrijkste reden voor het voortbestaan van de traditionele wijze van organiseren is dat het, ondanks genoemde problemen, een grote mate van flexibiliteit mogelijk maakt.

Prijsconcurrentie heeft tot gevolg dat de rentabiliteit van bouwondernemingen laag is. HBG haalde in 1990 een netto-winst die slechts 1,6 procent van de omzet bedroeg. NBM Amstelland bereikte 1,8 procent, Volker Stevin 1,4 en de BAM 2,2. Alleen Ballast Nedam kwam boven de middelmaat uit met een netto winst van 3,9 procent. Prijsconcurrentie heeft tot gevolg dat innovaties grotendeels betrekking hebben op efficiëntie-verbeteringen op de bouwplaats. De sector besteed ook weinig aandacht aan onderzoek en ontwikkeling. Bedrijven in de bouwsector besteden per jaar ongeveer een half procent van de omzet aan R\&D. Het nationaal gemiddelde bedraagt $2,4 \%$ (Mischgofsky, 1991).

\subsection{2' Toenemende concurrentie en nieuwe marktvereisten}

Veranderingen op de markt hebben ertoe geleid dat zowel aan bouwprocessen als bouwprodukten nieuwe kwaliteitseisen gesteld worden. Een belangrijke ontwikkeling op de markt voor woningen en gebouwen is de geleidelijke overgang van een aanbiedersmarkt (alles wat gebouwd wordt, wordt verkocht) naar een vragersmarkt (alleen bouwen wat zeker in de behoefte past).

Belangrijke oorzaak voor de ontwikkeling van een aanbieders- naar een vragersmarkt in Nederland is de geleidelijke terugtrekking van de overheid als regelgevende en controlerende instantie uit de markt. Het kwantitatieve woningtekort is sterk gedaald en et is daardoor minder behoefte aan de beschermende rol van de overheid (Bakens, 1986). De sterk door de overheid geruguleerde woningbouwmarkt ontwikkelt zich geleidelijk in de richting van een zich zelf regulerende markt. Daarnaast worden in de woningbouw bevoegdheden en verantwoordelijkheden van de rijksoverheid naar lagere overheden overgeheveld. Bouwbedrijven krijgen hierdoor steeds vaker te maken met de gemeente en de provincie als opdrachtgever. Meer markt en minder overheid betekent in dit geval meer invloed van de consument op het eindprodukt. Een toenemende vraag naar diversiteit in het aanhow, zowel in prijs als in afwerkingsniveau, is het gevolg.

Op de internationale markt neemt de concurrentie toe. Japanse bouwconcerns rukken op in Europa. Marktleider Shimizu bouwde als grootste project de $700 \mathrm{mln}$. gulden kostende Toyota autofabriek in het Engelse graafschap Derby. Naast Shimizu zijn ook bouwgiganten als Taisei, Kajima, Ohbayashi en Takenaka actief in Europa. De Japanse bouwbedrijven zien met name Oost-Europa als belangrijke markt (Fuchs, 1993). Voor- 
beeld van een Japans bouwbedrijf in Nederland is Takenaka. Eigenlijk is dit bedrijf een fors uitgevallen ingenieurs- en architectenbureau, dat het hele traject van ontwerp tot en met uitvoering voor zijn rekening neemt. Takenaka is in staat een compleet functionerend bedrijf af te leveren, inclusief bijbehorend personeel. De komst van deze Japanse bouwondernemingen vormt voor de Nederlandse bouw een van de stimulansen te streven naar meer integratie in bouwprocessen.

De dreiging van internationale concurrentie komt niet alleen uit Japan. In het kader van de economische eenwording van Europa is een Europese richtlijn in de maak voor het aanbesteden van diensten. Ruwweg komt die richtlijn, die in de loop van 1993 van kracht is geworden, erop neer dat overheden en andere publiekrechtelijke organen, zoals waterschappen, universiteiten en TNO hun opdrachten internationaal moeten aanbesteden. Daarbij gaat het om opdrachten ter grootte van 200.000 ecu en meer (Van Kasteren, 1991). Om het hoofd te bieden aan deze toenemende internationalisatie van de concurrentie is kwaliteitsgericht denken nodig, gericht op versterking van de concurrentie-positie van het bouwbedrijfsleven.

Duidelijke aarssprakelijkheidsregelingen vereisen eveneens kwaliteitsgericht denken. Zoals in vele landen binnen de EG gebruikelijk is willen opdrachtgevers in geval van schadeclaims een partij aansprakelijk kunnen stellen in plaats van afhankelijk te zijn van vaak langlopende arbitrage processen met soms onduidelijke uitspraken. Onduidelijke en vaak niet op elkaar aansluitende aansprakelijkheidsregelingen kunnen een belangrijke belemmering zijn voor het toepassen van nieuwe, nog relatief onbekende produkten in de bouw. Een meer geëntegreerde en naar de opdrachtgever duidelijker organisatie van het bouwproces is vereist. Kwaliteitsssystemen, waarbij duidelijk ieders verantwoordelijkheden staan omschreven, maken dit laatste mogelijk.

Ook een aantal meer specifieke factoren hebben ertoe geleid dat nieuwe kwaliteitseisen aan gebouwen gesteld worden.

Tot voor kort waren alleen stichtingskosten van een gebouw relevant voor opdrachtgevers, beheerders en gebruikers. Recentelijk zijn gebruiks- en exploitatiekosten gedurende de levensduur van een gebouw belangrijker geworden. Partijen aan de vraagzijde. van de markt zijn steeds meer bereid extra geld uit te geven aan die kwaliteiten die zich in de exploitatic terugbetalen. De opdrachtgever accepteert tegenwoordig hogere stichtingskosten, als duidelijk is dat dit resulteert in lagere gebruiks- en expioitatiekosten. Het gaat niet langer om de minimalisatie van de bouwkosten, maar om die van de kosten gedurende de gehele levensduur ('life cycle costing'), kosten die de bouwkosten vele malen overtreffen. Een aantal bedrijven en semi-overheidsinstellingen ais Shell, Philips, de NS en het ABP eisen dat bij investeringen in nieuwe gebouwen de verwachte kosten op het gebied van onderhoud, energieverbruik en beheer in de begroting worden opgenomen (Jakobs et al., 1992).

Een ander resultaat van het denken in termen van gebruikskosten, is de vraag naar grotere flexibiliteit in het gebruik van woningen en andere gebouwen. Indien de gebruikseisen veranderen, moet een gebouw daar flexibel aan kunnen worden aangepast. De recente leegstand in bepaalde typen woningen en de slechte verhuurbaarheid van verouderde kantoren heeft duidelijk gemaakt dat niet of alleen zeer moeilijk aan te passen gebouwen na verloop van tijd verouderd zijn. Een rendabele exploitatie is dan niet meer mogelijk. Behalve technische veroudering ten gevolge van achterstallig on- 
derhoud, kan ook sprake zijn van functionele veroudering. Het gebouw kan niet of alleen tegen hoge kosten aangepast worden aan de nieuwe gebruikseisen. Deze functionele veroudering kan voorkomen worden door bij de bouw technische maatregelen te treffen ten behoeve van een hogere flexibiliteit.

Naast gebruikskosten zijn technische mogelijkheden een tweede oorzaak voor de nieuwe kwaliteitseisen die aan gebouwen gesteld worden. Utiliteitsgebouwen lijken steeds vaker op zgn. "smart" of "intelligent buildings'. Hierbij gaat het om de toenemende toepassing van geavanceerde computersystemen in het technisch beheer van gebouwen (klimaatbeheersing, veiligheid, verlichting etc.) en om de technische voorzieningen die getroffen moeten worden voor toenemend computergebruik in het gebouw. Vanuit beide soorten van computergebruik worden meer eisen gesteld aan het ontwerp, de uitvoering en de integratie daartussen. Opdrachtgevers wensen bouwopdrachten dan ook alleen uit te laten voeren door bedrijven die bekend staan als technisch geavanceerd. Opdrachten voor intelligente gebouwen komen vooral van bedrijven die financiële diensten aanbieden en van multinationale ondernemingen. Bouwbedrijven moeten kunnen inspelen op deze vraag naar communicatiediensten gebaseerd op informatietechnologie en voorstellen kunnen doen voor de benodigde bouwkundige voorzieningen.

Deze nieuwe eisen hebben tot gevolg dat in Europa nieuwe samenwerkingsvormen tussen bouw- en telecommunicatiebedrijven ontstaan. Een voorbeeld is Bouygues, het leidende Franse en grootste bouwbedrijf van Europa, dat is gaan samenwerken met IBM Frankrijk en Bull. Ook een onderneming als Digital, van oorsprong een hardwarefabrikant, richt zich steeds meer op de markt van intelligente gebouwen. Men verwacht dat deze markt de komende jaren aanzienlijk zal groeien (De Vrede, 1992).

Deze nieuwe concurrentie betekent dat op de markt van intelligente gebouwen en tijdens het bouwproces daarvan traditionele bouwbedrijven een minder dominante positie innemen. Deze ontwikkeling wordt nog eens versterkt door het feit dat bij de bouw van 'intelligent buildings' vaker prefabrikage wordt toegepast. Daarnaast bestaat de waarde van 'intelligent buildings' voor een veel groter deel uit technische en electronische voorzieningen. Deze voorzieningen leiden ertoe dat bouwprocessen logistiek gezien aanmerkelijk complexer worden.

\subsubsection{De prestatie-werkwijze en kwaliteitsgericht denken in de bouw}

Toenemende concurrentie gaat gepaard met hogere kwaliteitseisen ten aanzien van bouwproces en -produkt. Deze nieuwe eisen gaan samen met de trend waarbij opdrachten steeds vaker in de vorm van prestaties worden geformuleerd, in plaats van te leveren materialen en produkten. De nieuwe marktvereisten vormen een belangrijke drijfveer om tot integrale kwaliteitszorg in de bouw te komen. Zowel de prestatie-werkwijze als kwaliteitssystemen betekenen dat uitvoerende partijen niet meer alleen op prijs moeten concurreren, zoals in het traditionele bouwproces, maar ook op kwaliteit.

\section{De prestatie-werkwijze in de bouw}

In zijn meest algemene vorm wordt de prestatie-werkwijze gekenmerkt doordat een vragende partij aan een biedende partij een produkt vraagt zonder dat produkt direct te umschrijven, maar door de prestaties aan te geven die dat produkt moet leveren. 
Het gebruik van het begrip prestatie en het toepassen van de prestatie-werkwijze kunnen op verschillende niveaus plaatsvinden (Sluizer, 1993):

- op dat van de gemeenschap: tussen overheid en bouwpartners (voorbeeld hiervan is het Bouwbesluit);

- op dat van een gebouw: tussen opdrachtgever en architect (voorbeeld hiervan is het Programma van Eisen (PvE));

- op dat van bouw- en installatiedelen: tussen architect en aannemer (voorbeeld is het. bestek), of tussen aannemer en onderaannemer/toeleverancier (als afgeleide van het. bestek).

Belangrijke stimulans voor het gebruik van de prestatie-werkwijze op het eerste niveau in Nederland is het nieuwe door de overheid uitgevaardigde Bouwbesluit. Dit besluit bevat voor alle soorten bouwwerken bouwtechnische voorschriften en is vanaf 1 juli 1992 van kracht. In dit nieuwe besluit is het begrip prestatie-eis een belangrijk gegeven. In de oude situatie schreef de Woningwet voor dat alle gemeenten er een bouwverordening op na moesten houden. De wet stelde niet dat deze allemaal exact gelijk moesten zijn. In die bouwverordeningen was veelvuldig sprake van 'functionele eisen' ofwel 'iets moest voldoende zijn'. Wat voldoende was, werd echter niet gedefinieerd. In de nieuwe situatie worden technische voorschriften niet meer per gemeente maar door het Rijk gegeven. In het Bouwbesluit kan worden verwezen naar normen, model-aansluitvoorwaarden (electriciteit, gas, water) en kwaliteitsverklaringen. Voor de bepaling of aan een eis is voldaan, wordt regelmatig verwezen naar bepalingsmethoden (Hage, 1992). Die methoden zijn neergelegd in NEN's: normen die worden uitgegeven door het Nederlands Normalisatie-Instituut (NNI). Het NNI geeft ook nog praktijkrichtlijnen uit (NPR's) ter ondersteuning van de geldende NEN's. Discussies over wat 'nodig' of 'voldoende' is blijven achterwege omdat de prestatie-eisen in belangrijke mate objectieve eisen bevatten.

Het prestatiebestek, het derde niveau van de prestatie-werkwijze, staat de laatste jaren sterk in de belangstelling. In de praktijk wordt het prestatie-bestek nog nauwelijks toegepast. Bij het prestatie-bestek gaat het om een wijze van aanbesteden waarbij de vertaalslag van prestaties naar omschrijvingen door de aannemer wordt gemaakt. Hiermee wordt bedoeld dat de opdrachtgever bij een prestatie-bestek zijn gebruikseisen formuleert, de architect deze vertaalt in een materiaalloos ontwerp en dat specificeert in een prestatiegericht vraagbestek. Met dit vraagbestek als aanbestedingsdocument maken de inschrijvende partijen een aanbodbestek, waarin zij de technische invulling geven. De aannemer is in deze opzet verantwoordelijk voor keuze van materialen, de constructie en de installaties. In het prestatie-bestek wordt door de architect slechts een minimum aan objectieve prestatie-eisen opgenomen ten aanzien van veiligheid, materiaal en constructie. In 'traditionele' bestekken is meestal sprake van een volledig voorgeschreven bouwmethodiek en materialengebruik. Tussen een volledig materiaalloos ontwerp en een tot de laatste schroef gedetailleerd model liggen uiteraard talloze varianten.

Het vertalen van prestatie-eisen uit het Bouwbesluit of uit het Programma van Eisen (PvE) in concrete oplossingen door de architect in zijn ontwerp en bestek heeft wel met prestatiebeheersing te maken, maar valt niet onder de prestatie-werkwijze zoals bij het derde niveau aangeduid. Ook turnkey-aanbiedingen, waarin ontwerp en uitvoering gezamenlijk worden aangeboden, op basis van prestatie-eisen, valt niet bij de op het derde niveau beschreven werkwijze. Bij dit niveau gaat het met name om de relatie 
tussen ontwerpende en uitvoerende partijen of tussen uitvoerende partijen onderling. Het vertalen van het PvE in concrete oplossingen en turnkey-aanbiedingen hebben betrekking op de relatie tussen opdrachtgever en een bouwpartner

\section{Kwaliteitszorg in de bouw}

De essentiële achterliggende gedachte van de prestatie-werkwijze is dat uitvoerende partijen niet alleen worden uitgenodigd op prijs te concurreren, maar ook op kwaliteit. Het denken in prestaties vormt dan ook een belangrijke stimulans voor het ontstaan van kwaliteitssystemen in de bouw. Sinds kort lijkt in de bouw het besef door te dringen dat bij goede aansluiting van de werkzaamheden van de verschillende actoren een kwalitatief beter eindprodukt kan worden gerealiseerd. Afzonderlijke bouwpartners kunnen weliswaar een goed deelprodukt leveren, bij een slechte aansluiting garandeert dit nog niet een goed totaalprodukt. Dit streven naar kwaliteit kan op termijn een belangrijke drijfveer vormen om tot een meer geïntegreerde organisatie van het bouwproces te komen. Aannemer en toeleverancier kunnen afspraken maken over uit te voeren activiteiten in het kader van de kwaliteitsborging. ${ }^{1}$ Invoering van integrale kwaliteitszorg in de bouw wordt echter belemmerd doordat het traditionele bouwproces in teveel van elkaar gescheiden fasen en verantwoordelijkheden is opgedeeld.

Een manier om aan te tonen dat een bedrijf op een systematische wijze aan kwaliteitszorg doet is dit door een bevoegde instantie te laten controleren en te bevestigen door middel van certificatie en classificering. Certificatie betekent dat een onafhankelijke derde verifieert of het bedrijf aan zijn kwaliteitsverplichtingen voldoet. Voor het beoordelen van kwaliteitssystemen worden de ISO 9000-normen als referentie gebruikt. ISO-9000 certificaten worden verleend door certificerende instellingen die onder toezicht staan van de Raad van Certificatie. ${ }^{2}$ Het streven naar objectieve kwaliteitsnormen is in feite een poging te komen tot standaarden voor communicatie over de kwaliteit van een produkt. Classificering en certificering zijn gangbaar in Franse en Belgische bouw. In Nederland is een dergelijke drempelverhoging niet populair. Al vanaf 1973 woedt een discussie over een classificatie en certificeringssysteem: de grote bouwers zijn voor, de kleine tegen.

De ervaringen die men in de bouw met kwaliteitssystemen heeft zijn tot nu toe zeer verschillend. Bouwbedrijven, die vanuit offshore-ervaring al jaren geleden zijn geconfronteerd met de noodzaak aan kwaliteitszorg te doen, kunnen terugvallen op de daar opgedane know-how. Ook specialistische bedrijven, zoals vloerenbedrijven, betonreparatiebedrijven, installatiebedrijven hebben reeds in een relatief vroeg stadium kwaliteitssystemen ingevoerd (Souwerbren, 1989). Men name bij kleine en middelgrote aannemers wordt nog weinig aan kwaliteitszorg gedaan. De toeleveringsindustrie is het verst met georganiseerde kwaliteitszorg. Een aantal bedrijfsgroepen heeft daar al een langere traditie van produkt- en procescertificatie.

\footnotetext{
${ }^{1}$ Kwaliteitsborging is het geheel van activiteiten. nodig om in voldoende mate het vertrouwen te geven dat een produkt of een dienst voldoet aan de gestelde kwaliteitseisen.

${ }^{2}$ De ISO 9000 normen van de International Organization for Standardization (ISO) zijn onderverdeeld in 9001 tot en met 9004 . ISO 9001 vormi de meest uitgebreide ISO 9000 norm en geeft een organisatiemodel voor kwaliteitszorg bij ontwerp, vervaardiging, installatie en nazorg.
} 
Bij de grote aannemers verwierf de Hollandsche Beton Maatschappij, een dochter van HBG, in 1990 als eerste het ISO-9001-certificaat. De Vereniging Grootbedrijf Bouwnijverheid (VGBOUW, de landelijke vereniging van de 200 grootste bouwbedrijven in Nederland) heeft voor bouwbedrijven recent het Model Kwaliteitssysteem Bouw (MKS Bouw) geïntroduceerd. Lidbedrijven van VGBouw, die zich voor het kwaliteitsprogramma aanmelden, worden geplaatst in groepen met een gemiddelde omvang van acht bedrijven. Deze groepen werken in nauw contact met elkaar een programma af, dat twee en een half jaar duurt. In april 1993 waren bij VGBouw zeven groepen operationeel.

\subsection{De veranderende relatie tussen ontwerp en uitvoering}

Toenemende concurrentie vereist van bedrijven in de bouw, zowel uitvoerende als ontwerpende, dat zij actief de markt op gaan met een compleet produkt. Opdrachtgevers vragen een totaal eindprodukt met bijbehorende garanties. Aanbieden van een totaalprodukt vereist nieuwe organisatievormen van bouwprojecten, in die zin dat de traditionele scheiding tussen ontwerpende en uitvoerende partijen wordt opgeheven. De grootste uitdaging wordt in dit verband wel genoemd het integreren van 'design for purpose' en 'design for manufacturing'. De architecten- en ingenieursbureaus zijn sterk in het 'design for purpose' omdat ze dichter bij de opdrachtgever staan. De aannemers zijn sterk in het 'design for manufacturing', zij staan dichter bij het uitvoeringsproces.

Om deze integratie te realiseren kunnen uitvoerende bouwbedrijuen ontwerpende disciplines in eigen gelederen integreren, maar ook regelmatig gaan samenwerken met deze bedrijuen. Samenwerking tussen architect en hoofdaannemer maakt het mogelijk zich gezamenlijk op de markt. te presenteren met een 'totaalprodukt'. Zowel vanuit de ontwerpende als uitvoerende en toeleverende bedrijven worden initiatieven genomen om tot een integratic van ontwerp en uitvoering te komen:

a. het architecten- en ingenieursbureau, verantwoordelijk voor ontwerp en uitvoering; b. het bouwbedrijf dat aan projectontwikkeling doet en turnkey-projecten uitvoert; dit kan een traditionele aannemer of een industriële toeleverancier zijn.

Deze paragraaf gaat op basis van gegevens uit interviews met functionarissen van dergelijke innovatieve bedrijven in op innovaties in de organisatie van bouwprojecten. Deze innovaties hebben met name betrekking op de relatie tussen ontwerp en uitvoering en vormen een antwoord op de in $\$ 10.1$ beschreven nieuwe marktvereisten. Met deze analyse wordt aangegeven waar in de bouw overdracht van know-how, snelheid en wederzijds vertrouwen van toenemende belang zijn geworden.

\subsection{Integratie van ontwerp en uitvoering door de architect}

\section{De bedreigde positie van de architect}

In het verleden was de architect de vertrouwensman van de opdrachtgever. Namens de opdrachtgever kon de architect autonoom bepalen wat en hoeveel er gebouwd moest worden. In die hoedanigheid vervulde de architect meestal drie functies (Kettlitz, 1992c): hij trad op als intermediair namens de opdrachtgever, als bouwkundig adviseur van de opdrachtgever en als vormgever. Twee van de drie functies zijn om verschillende redenen onder druk komen te staan. 
Door het toenemende aantal bureaus op het gebied van projectmanagement is ten eerste de rol als intermediair onder druk komen te staan. Deze ontwikkeling wordt versterkt door het steeds deskundiger worden van opdrachtgevers en een groeiende aandacht van de aannemerij voor produkt- en marktontwikkeling. Opdrachtgevers als woningbouwverenigingen halen bijvoorbeeld steeds meer kennis in huis en hebben daardoor de mogelijkheid het bouwproces meer naar hun hand te zetten. Voorbeeld is de woningbouwvereniging die een bouwkundig werk intern ontwerpt zonder dat daar een architect aan te pas komt. Ten tweede staat de rol van de architect als bouwkundig adviseur al geruime tijd onder druk door de opkomst van specialistische adviesbureaus op het gebied van o.a. bouwfysica, dak- en gevelconstructies en kostenmanagement. De rol van de architect als vormgever wordt (nog) niet betwist.

Specifieke marktontwikkelingen versterken de ontwikkeling dat de architect bezig is zijn coördinerende taak te verliezen. Van alle opdrachtgevers zijn het vooral woningbouwverenigingen die de architect een flink takenpakket opleggen, zoals begroting, bestek en werktekeningen. Aangezien de opdrachten in deze hoek gaan afnemen concludeerde een studie van het Economische Instituut voor de Bouwnijverheid (EIB) dat in diverse opzichten de positie van de Nederlandse architecten wordt uitgehold en dat hun activiteiten hoe langer hoe meer zullen worden beperkt tot hun kerntaak: vormgeving en tekenwerk (Lourens, 1990). Veel andere aspecten van het bouwproces, vooral liggend op het technische, financiële en organisatorische terrein, worden al door andere partijen behartigd.

Deze ontwikkelingen hebben ertoe geleid dat het geen vanzelfsprekendheid meer is dat de ontwerpende architect ook de directievoering bij de realisatie van het bouwwerk krijgt. Het projectmanagementbureau, de aannemer of de kostendeskundige kunnen allen deze taak overnemen. De architect krijgt 'onvolledige' opdrachten, bijvoorbeeld alleen voor het ontwerp, en is vaak niet meer verantwoordelijk voor het 'volledige' bouwproces, dat wil zeggen van ontwikkeling tot oplevering. 'Het verwerven van volledige opdrachten blijkt voor architecten, in een markt die beheerst wordt door geprofessionaliseerde opdrachtgevers, moeilijk te worden. Dit geldt (nog) in beperkte mate voor de sector gesubsidieerde woningbouw, maar des te sterker in de sectoren van woning- en utiliteitsbouw waar met winstoogmerk wordt gebouwd. Daar opereren projectontwikkelaars en bouwondernemers die voor het ontwerp dikwijls geen onafhankelijke architect inschakelen. Indien zij dit wel doen is van een volledige opdracht toch geen sprake.(...) Bij projectontwikkeling is voor architecten dus een beperkte rol weggegeld' (Zwinkels, 1990, 51).

\section{De architect als 'general comiractor'}

Volgens het in 1991 verschenen rapport van de projectgroep RISA (RISA staat voor Referentie Informatie Strategie Architectendiscipline) van de Bond van Nederlandse Architekten (BNA) dient de architect in een positie te komen die het hem mogelijk maakt om in alle opzichten als eindverantwoordelijke voor de opdrachtgever te functioneren (BNA, 1991). ${ }^{3}$ De opdrachtgever moet een 'general contract' kunnen afsluiten,

3 Het rapport RISA is een verslag van de BNA-project Referentie Informatie Strategie voor de Architectendiscipline. Ten eerste hebben deelnemers aan dit project, BNA-leden en informatici van het adviesbureau Schröter \& Partners, de architectendiscipline in kaarı gebracht. De resultaten zijn vervolgens becommentarieerd door een klankbordgroep van BNA-leden en cen vertegenwoordiger van het 
waarin architect - of architectenteam - als eindverantwoordelijke voor de uitvoering is aangewezen. ${ }^{4}$ De projectgroep stelt dat een van de kritieke succesfactoren voor overleving van de branche is dat de architect de verantwoordelijkheid en de aansprakelijkheid op zich moet nemen die hoort bij het managen van het bouwproces. Kleinere bureaus zouden zich hierbij moeten specialiseren in min of meer vaste samenwerkingsverbanden om zo de beheersing van het proces kwalitatief verantwoord te kunnen aanbieden.

Uitvloeisel van deze visie is dat de BNA architecten aanmoedigt 'de markt op te gaan' en daarmee de positie van de architect te versterken. Met de leus 'de ondernemende architect' wordt de architect gestimuleerd zelf initiatieven te ontplooien en keuzes te maken om de coördinerende rol in het bouwproces te bevestigen en te ontwikkelen. Daartoe dienen architecten 'hun deskundigheid te verbreden door kennis, inzicht en ervaring te verwerven bijvoorbeeld op het gebied van integraal ontwerpen, automatisering van het ontwerptekenwerk en project-management met geavanceerde technieken, automatisering en procesmanagement, kwaliteitszorg en advisering in het gehele huisvestingsproces van initiatief tot en met beheer' (Zwinkels, 1990, 53).

Dit wil niet zeggen dat de BNA propageert dat architecten alleen als 'general contractor' kunnen werken. Het is namelijk niet voor ieder willekeurig architectenbureau haalbaar om naar volledige opdrachten te streven en zo de coördinerende rol in het bouwproces te verzekeren. Wel moet volgens de BNA de architect die dat niet doet, naar opdrachtgevers toe aangeven waarvoor hij of zij dan wel verantwoordelijkheid kan nemen. De BNA legt er dan ook de nadruk op dat een bureau zich moet 'classificeren" naar soorten werkzaamheden. Hiermee wordi bedoeld dat een architectenbureau voor zich moet bepalen in welke soort werkzaamheden het gespecialiseerd is of wil specialiseren. Bepaalde bureaus kunnen zich profileren als bedrijven die de coördinatie van het complete bouwproces voor hun rekening nemen, andere specialiseren zich in een deel daarvan.

De BNA wijst erop dat informatisering een belangrijk hulpmiddel kan zijn voor het bevestigen of verder ontwikkelen van de coördinerende rol van de architect in het

IGBI (de InitiatiefGroep BouwInformatica, de organisatie die tot een afstemming van de diverse informatiserings-initiatieven in de bouw tracht te komen). Daarnaast is, onder andere op basis van diverse inierviews, geanalyseerd wat de opties voor de toekomst van de architectendiscipline zijn.

${ }^{4}$ General contracting is een organisatievorm die vooral in de V.S. opgang doet, maar ook in ons land vastere voet aan de grond krijgt (SBR, 1992a). Oorzaak hiervoor zijn activiteiten van een aantah Japanse bedrijven in ons land en enkele grotere opdrachtgevers. Een "general contractor" biedt de volledige coordinatie van het bouwproces als dienst op de markt aan en neemt de totale verantwoordelijkheid voor het ontwerp en de uitvoering van de opdrachtgever over. General contractors zijn vaak: gespecialiseerde bedrijven, die het bouwproces als eén van de participanten van binnenuit kennen. Dat kan cen constructie-adviseur, een projectmanagementbureau, een architect of een aannemer zijn. Deze bedrijven hebben 'general contracting' als een extra dienst ontwikkeld. De onderneming wordt daartoe uitgebreid met bedrijfskundig, juridisch en/of financieel-economische expertise met (vaste) partners. De opdrachtgever laat zich naar de bouwpartijen toe vertegenwoordigen door een general contractor. Deze gaat relaties aan met ontwerpende, uitvoerende en toeleverende disciplines en contracteert ze rechtstreeks. In veel gevallen neemt de general contractor ook het financiele risico over van de opdrachtgever. Hij biedt de ontwikkeling van een bouwwerk 'at risk' voor een totaalprijs aan, inclusief zijn eigen vergoeding. In andere gevallen blijf het financięle risico voor rekening van de opdrachtgever en brengt de general contractor een management fee in rekening. 
bouwproces. In het RISA-rapport is aangegeven dat informatietechnologie bijdraagt aan een verbeterde bedrijfsvoering en zo voorwaarden schept om als architect het totale bouwproces te kunnen managen. In dit rapport wordt de BNA opgeroepen om de benodigde automatiseringshulpmiddelen tot stand te brengen. 'Enerzijds om de implementatie van nog te ontwikkelen standaards te kunnen waarborgen en anderzijds om voldoende 'countervailing power' in de richting van de ontwikkelaars van geautomatiseerde hulpmiddelen in stelling te kunnen brengen' (BNA, 1991, 50).

Ook ir. J.C. Hubers van de VCA (Vereniging Computergebruik Architektenburo's) geeft aan dat informatietechnologie kan voorkomen dat de rol van de architect minimaal wordt: 'Er valt een tendens te ontdekken waarbij architecten langzamerhand de grip op bouwprojecten verliezen. Aannemers trekken steeds meer bevoegdheden naar zich toe. Als deelnemer in een bouwproject winnen ze aan macht. De architect die $\mathrm{CAD}$ op de juiste manier in zijn werkwijze inbouwt, kan zijn positie als 'spin in het web' handhaven. Hij beheert dan de gegevens van een bouwproject en behoudt als eigenaar van die informatie maximale controle op projecten. Mijn inziens valt er daarom alleen al aan CAD niet te ontkomen' (De Boer, 1992, 35). Ook voor architecten die zich bewust op een deel van het bouwproces richten is informatietechnologie relevant, bijvoorbeeld bij Europese aanbestedingen waarbij bestekken via EDI verzonden worden.

Volgens architect Levy, werkzaam bij de HBG, zullen binnen de branche met name de grotere architectenbureaus zich op den duur tot hoofdaannemer ontwikkelen en daarmee de klassieke positie van de architect als bouwmeester weer innemen. 'Architect' staat hier dan wel voor een team van mensen en niet meer voor een individu. Er zijn bepaalde architectenbureaus die, om het gehele bouwproces in eigen hand te houden, overgaan tot een voorwaartse of achterwaartse integratie van activiteiten in het bouwproces.

Een voorbeeld van een architect die naast ontwerp ook de hoofdverantwoordelijke is voor de uitvoering is het Delftse bureau Cepezed. Voornaamste drijfveer voor Cepezed om zich met andere zaken bezig te houden dan alleen met ontwerpen is dat dit architectenbureau talloze problemen had met traditioneel bouwende aannemers die niet uit de voeten konden met de ontwerpen die het bureau maakte. De door Cepezed gehanteerde geïndustrialiseerde bouwmethodiek vraagt om grote maatvoeringsprecisie en een goed georganiseerde planning op de bouwplaats. Volgens Cepezed beschikte de improviserende aannemer vaak niet over dergelijke vaardigheden. Dit heeft ertoe geleid dat het bureau besloot om eigen ontwerpen in delen aan te besteden en de regie over de uitvoering in eigen hand te nemen. Cepezed heeft een eigen aannemersbedrijf, Bouwteam General Contractors B.V., dat de verantwoordelijkheid en de coördinatie voor het totale project in eigen hand houdt. Bouwteam verricht zelf geen arbeid op het werk. Het organiseert, regelt, administreert, controleert en rekent af. Alle verantwoordelijkheid en aansprakelijkheid voor de uitvoering is in principe doorgeschoven naar de onderaannemers.

Projectontwikkeling door de architect is een voorbeeld van achterwaartse integratie in de bedrijfskolom. Een voorbeeld daarvan geeft het Buro Wiegerinck Architekten, een van de tien grootste architectenbureaus in Nederland. Voor de niet-professionele opdrachtgevers heeft het bureau een uitgebreid dienstenpakket ontwikkeld op financieel gebied en bouwmanagement. Men gebruikt hiervoor het begrip 'total enginee- 
ring'. Een van de diensten is dat voor de opdrachtgever in spe lokatie- en haalbaarheidsstudies worden verricht. Indien gewenst doet het bureau aan projectontwikkeling en voert opdrachten turn-key uit. Ook worden op basis van het voorlopig ontwerp huurprijsberekeningen en een rendementsbegroting gemaakt en wordt zonodig een belegger gezocht. Centraal uitgangspunt van het bureau is de uiteindelijke gebruiker van het gebouw. Als de gebruiker en de eigenaar niet dezelfde persoon zijn zoekt het bureau een financier voor een project. Zo ontstaat een driehoeksverhouding waarbij de architect zowel voor belegger als gebruiker een Programma van Eisen maakt en op elkaar afstemt. Volgens directeur Van Veersen komt het voor dat het bureau een heel project voor zijn rekening neemt: ontwerpen, het zoeken van financiering en de bouwbegeleiding.

Fusie van architectenbureaus is naast achter- en voorwaartse integratie een derde strategie om de: coördinerende rol in het bouwproces te kunnen handhaven. Vroeger kon een architect als enig persoon het gehele bouwproces overzien en beschikte hij over de benodigde kennis voor de diverse taken. Door de vergaande professionalisering van afzonderlijke taken is de vraag geworden of één architect nog alles in huis kan hebben. Om toch zoveel mogelijk specialisaties intern te hebben kan fusie een oplossing zijn. Een voorbeeld van een zo'n fusie is die tussen architectenbureaus Kruisheer Partners en Elffers Partners (Tangel, 1992). De resulterende onderneming, Kruisheer Elffers B.V., heeft naast een moedermaatschappij vier dochters: adviseurs, bouwkostenadviseurs, constructeurs en architecten. Met de fusie heeft men de uitholling van het architecten-beroep wilien voorkomen en er bewust naar gestreefd de architect niet alleen vormgever maar ook bouwmeester te laten zijn.

\subsubsection{Integratie van ontwerp en uitvoering door het uitvoerend bouwbedrijf}

\section{Projectontwikkeling}

Het uityoerend bouwbedrijf is vaak nog aannemer, leverancier en organisator van capaciteit. Een dergelijk bedrijf is traditioneel afhankelijk van werk dat door anderen is gespecificeerd en vervolgens wordt aanbesteed. De aannemer 'mag een project, dat vaak een jarenlange voorbereiding heeft gehad, in ongeveer drie weken calculeren en daarna alle risico's van voorbereiding en uitvoering tegen een scherpe prijs op zich nemen. In zo'n situatie wordt hij gekenmerkt als dienstverlener. De volledige ondernemersfunctie wordt door hem dan niet uitgeoefend. Een ondernemer, in het algemeen gesproken, neemt immers zelf het initiatief tot produktie, zorgt voor een ontwerp, neemt de produktie ter hand en zorgt voor afzet. In de bouw is de situatie duidelijk afwijkend van dit normale patroon. Planontwikkeling, ontwerp en uitvoering van een willekeurig project - of het nu wegen zijn, een brug, een gebouw of een woning - wordt traditioneel gedaan door verschillende disciplines.' (Van Dijke, 1992, 3).

Volgens directeur Blok van ERA Bouw, ontwikkelt de aannemer zich echter ook tot ondernemer (Bakens, 1989, 73): 'De moderne bouwondernemer creëert zelf kansen. Hij doet dat door produktontwikkeling, zowel technisch als in diensten, planontwikkeling en (risicodragende) projectontwikkeling. Bij deze drie dingen staat het oplossen van problemen van de klant centraal. Daarbij is de techniek niet meer de doelstelling van het bouwen, maar slechts middel om aan de wensen van de opdrachtgever te voldoen ... Wij zijn nu bezig met het ontwikkelen van woonconcepten in samenwerking met marktonderzoekers, architecten, onderaannemers en leveranciers. 
Deze ontwikkeling van aannemer naar bouwondernemer maakt het mogelijk dat ontwerp en uitvoering vanuit een punt worden gestuurd. De aannemer neemt hierbij naast uitvoering ook een stuk ontwerp en ontwikkeling voor zijn rekening. Binnen het uitvoerend bouwbedrijf treedt sinds een aantal jaren dan ook een duidelijke accentverschuiving op van uitvoerings- naar projectontwikkelingstaken.

Projectontwikkeling wordt gedefinieerd als het risicodragend initiëren, organiseren, uitvoeren (of doen uitvoeren) en coördineren van alle taken die nodig zijn voor het realiseren van het onroerend goed, inclusief het verwerven van grond. Veel gebouwen in de marktsector komen in Nederland tot stand door middel van projectontwikkeling. Kenmerkend voor projectontwikkeling is dat het initiatief tot het bouwen niet uitgaat van een gebruiker die een gebouw laat neerzetten om in zijn eigen huisvestingsbehoeften te voorzien. Projectontwikkeling kan bijvoorbeeld worden opgezet door zelfstandige projectontwikkelingsbedrijven of projectontwikkelingsafdelingen van beleggers en banken maar gebeurt nu ook door bouwbedrijpen en woningcorporaties. Voor de grootste bouwbedrijven in Nederland is projectontwikkeling niet nieuw. Zij beschikken al lang over dochterbedrijven die zich hierop richten.

Actieve participatie van een bouwbedrijf bij projectontwikkeling kan enerzijds betekenen dat bij een concreet woningbouwproject actief wordt meegedacht en mede ontwikkeld met opdrachtgever, architect en andere bouwteamleden en anderzijds dat het bouwbedrijf projectongebonden woningconcepten ontwikkelt om op die wijze meer grip te krijgen op marktontwikkelingen (Waegemaekers, 1992). Kenmerkend voor een bouwteam is dat de belangrijkste partners in het bouwproces als 'team' verantwoordelijk zijn voor het gehele bouwproces. ${ }^{5}$ Kortom, enerzijds kan men spreken van projectontwikkeling in bouwteamverband, anderzijds van risicodragende woningbouwconcepten.

Dat meedenken en mee ontwikkelen in bouwteamverband kan verschillende vormen aannemen. Nevanco (woningbouw) en Heembeton (fabrikant van prefab beton elementen), twee dochters van de NBM-Amstelland Groep, zijn gespecialiseerd in bouwen vanuit bepaalde systematiek waarbij veel gewerkt wordt met prefabrikage. Bij Nevanco wordt bij een project het plan van de architect 'omgebouwd' voor deze systematick. Men zoekt daarbij evenwicht tussen uitvoeringstechniek en plan van de architect. Deze wijze van werken vereist dat het bouwbedrijf al vroeg bij een project betrokken wordt. Om die reden worden bij Nevanco $90-95 \%$ van de projecten in bouwteamverband uitgevoerd. Bij voorbereiding binnen het bouwbedrijf zijn bouwkundige medewerkers nodig die een sterke affiniteit moeten hebben met architectuur en technisch/uitvoeringsgericht onderlegd zijn. Deze werkwijze van Nevanco heeft lagere uitvoeringskosten maar hogere voorbereidingskosten tot gevolg.

Ook bij een bouwbedrijf als de Koninklijke IBC heeft projectontwikkeling vooral betrekking op het in samenwerking met anderen ontwikkelen van een idee of produkt (bijvoorbeeld in samenwerking met een provincie of gemeente) en daar klanten bij zoeken. Het IBC benadert vooraf klanten voor een bepaald nog te realiseren idee en is verantwoordelijk voor de uitvoering daarvan. Worden voor het idee geen klanten gevonden dan zijn de ontwikkelingskosten voor IBC en wordt het project niet uitge-

${ }^{5}$ In $\$ 11.6$ wordt verder op de organisatievorm van het bouwteam ingegaan. 
voerd. Deze benadering staat tegenover de 'traditionele' projectontwikkeling waarbij eerst het gebouw wordt gerealiseerd en vervolgens de klanten worden gezocht.

\section{Projectongebonden bouwconcepten}

Er zijn ook bouwbedrijven die met projectongebonden bouwconcepten de markt opgaan. Hierdoor trekt het bouwbedrijf een stuk coördinatie naar zich toe. In dit verband gaan bouwbedrijven structurele samenwerkingsverbanden met architecten aan. Het gaat hierbij om architecten, die geen intermediaire rol namens de opdrachtgever vervullen, maar wel de kennis en vaardigheden hebben om de wensen en behoeften van een klant te vertalen in een concreet produkt. Voorbeeld is een aannemer die een architect ingehuurd heeft voor ontwerp van een aantal standaardtypen woningen: ' $\mathrm{Er}$ staat wel altijd een architect achter ons produkt; die begeleidt de gang van zaken ... Hij heeft ook alle standaardtypes mee ontwikkeld, de architectonische kant van het geheel. Als onze verkoper met een particulier veranderingen afspreekt, dan bekijkt de architect dat, zet er zijn handtekening onder en verzorgt de welstandsaanvraag. Zodra die akkoord bevonden is, verzorgen wij zelf de werktekeningen...' (Bakens en Feddema, 1990, 16).

Het werken met een eigen gestandaardiseerd bouwconcept wordt wel het zgn. 'brochure-plan' bouwen genoemd. De brochureplan-organisatie biedt de uitvoering van standaard-bouwplannen aan, die project- en locatie-ongebonden zijn ontwikkeld. Meestal zijn wel variatiemogelijkheden ingebouwd, maar afstemming van het ontwerp op specifieke wensen van de opdrachtgever is doorgaans beperkt mogelijk. Brochureplannen worden meestal gemaakt voor projecten van beperkte omvang, bijvoorbeeld in de woningbouw en kleine industriële bouw (SBR, 1992a). Bij de methodiek van een brochureplan wordt het gehele bouwproces voor de opdrachtgever geregeld, tot en met. de sleutel in de voordeur, turnkey dus.

Een gestandaardiseerd bouwconcept kan betekenen dat een bouwbedrijf veel met prefab-elementen werkt. In dat geval wordt de scheiding tussen uitvoerend bouwbedrijf en industriee $\|$ toeleverancier diffuus. Voorbeeld is het bouwbedrijf Sterk Bedrijven Rossum. Dit bedrijf biedt prefab woningen op de markt aan waarbij gevelelementen inclusief metselwerk, hang- en sluitwerk, kozijnen en glas geprefabriceerd worden. Het bedrijf heeft eigen ontwerpers in dienst die met CAD-systemen een woning voor een klant ontwerpen. Met behulp van CAD-apparatuur wordt de klant geconfronteerd met de gevolgen van mogelijke keuzes voor de te bouwen woning. Een architect komt hierbij niet aan de pas. Vervolgens worden voor de woning de elementen apart geproduceerd en op de bouwplaats geassembleerd. Sterk. beheerst het hele traject van ontwerp tot oplevering.

Er zijn een aantal redenen aan te geven waarom bouwbedrijven met projectongebonden bouwconcepten komen. Ten eerste dwingt de marktsituatie hen daartoe. Het aanbod overstemt de vraag en er moet gezocht worden naar mogelijkheden om zelf de omzet te handhaven. Ten tweede vraagt de meer professionele opdrachtgever op de bouwmarkt steeds meer om gegarandeerde topkwaliteit. Ook worden in met name dat deel van de markt de eisen ten aanzien van garantie steeds zwaarder. Het als bouwondernemer op de markt brengen van zelf ontwikkelde en gestandaardiseerde bouwconcepten past hier goed in. Men kan makkelijker bepaalde garanties op de kwaliteit van 
het geleverde werk geven omdat men de bepalingen van het bestek zelf in de hand heeft.

Een compleet bouwprodukt op de markt aanbieden (tegen een relatief lage prijs) is echter niet bij voorbaat succesvol. Een aannemer gaf het voorbeeld van een bouwconcept voor een prefab ziekenhuis dat voor $20 \%$ onder de normale prijzen gerealiseerd kon worden. Dit bouwconcept is niet aangeslagen. Voornaamste probleem is geweest dat deze opdrachtgevers vaak eisen dat de bedrijven waarmee zij al relaties hebben het project hoe dan ook moeten uitvoeren. De financiële kant van een project is voor een ziekenhuisbestuur in dit geval van secundair belang.

\section{Prestatie-bestek}

Een minder vergaande toekomstige vorm van integratie tussen technisch ontwerp en uitvoering bij de aannemer is het hanteren van het reeds in $\$ 10.1 .3$ besproken prestatie-bestek. Door het prestatie-bestek verandert de taakverdeling tussen architect en aannemer (zie figur 10.1).

FIGUUR 10.1 De veranderende taakverdeling tussen architect en aannemer bij het prestatie-bestek

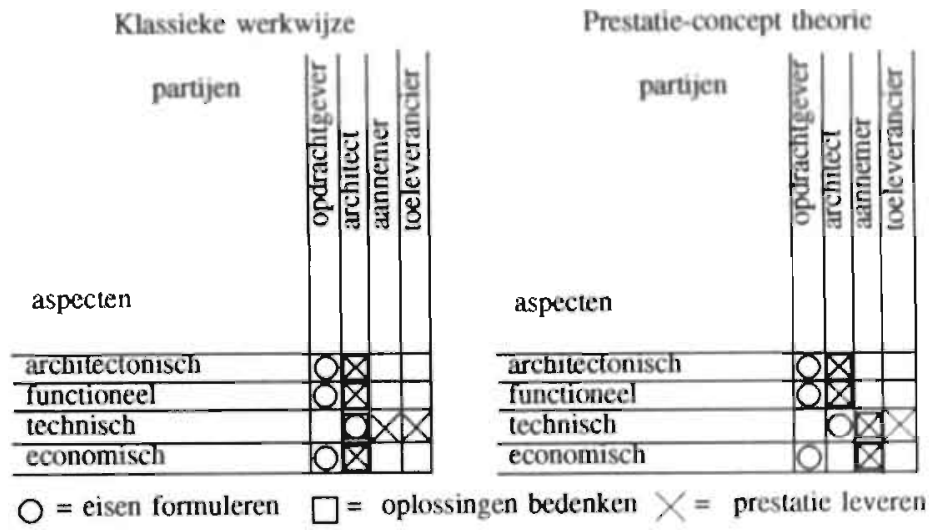

Bron: Spekkink en Gerritse $(1992,45)$.

Het prestatie-bestek legt naast de uitvoering ook een deel van de ontwerptaak bij het bouwbedrijt. Als de houwvergunning rond is, worden enkele bouwbedrijven geselecteerd om een aanbieding te doen. Elk van de geselecteerde bedrijven maakt zijn aanbodbestek. Dit omvat een technisch ontwerp, een aanbiedingsprijs en bewijzen die aangeven dat de verlangde prestaties worden bereikt. Het technisch ontwerp is de vertaling van het functionele ontwerp, dat wil zeggen het ruimtelijk ontwerp en de prestatie-eisen. Het bedrijf kan bij het aanbodbestek uitgaan van methoden, produkten, materialen en leveranciers waarmee het goede ervaringen heeft.

Het prestatie-bestek kan in de architectenwereld tot het ontstaan van twee specialismen leiden, elk met een eigen markt (Bonjer en Noorman, 1990). Aan de kant van de 
opdrachtgever is de architect de specialist die het vraagbestek maakt, met ruimtelijke, esthetische en functionele specificaties voor het verlangde gebouw. Voor het bouwbedrijf werkt de architect als specialist aan het aanbodbestek, waarin elk schroefje wordt verantwoord.

Eerstgenoemde architect stelt het ruimteplan op (plattegronden en gevelindelingen), bepaalt de bouwmassa, formuleert vormeisen en is verantwoordelijk voor esthetische aspecten. Naast deze ontwerptaak beoordeelt de architect de aanbestedingen van bouwbedrijven en doet hij als adviseur aanbevelingen aan de opdrachtgever. De architect die als bouwkundig, adviseur het bouwbedrijf terzijde staat lijkt nog het meest op de huidige traditionele architect, die materialen, constructies, en installaties kiest en details uitwerkt. Dit is geen turnkey omdat het bouwbedrijf geen gebouwontwerp met. technische uitwerking presenteert, maar slechts een uitwerking van het ontwerp van de vrager, de opdrachtgever. De architect bij het bouwbedrijf krijgt een meer adviserende en sturende functie. Hij werkt hierbij nauw samen met constructeur, produktieafdeling, calculator en kwaliteitsbewaking.

Deze scheiding van taken van de architect ligt zeer moeilijk bij architecten: 'De architect zal grote moeite hebben met één van de belangrijkste uitgangspunten: loskoppeling van vormgeving, materiaalkeuze en detaillering. (...) Dit uit elkaar trekken van esthetisch ontwerp en de beslissing over het materiaalgebruik wil er bij ons niet in. Zo. werkt dat niet in de hersenpan van een ontwerper: vormgeving en materiaalgebruik horen onlosmakelijk bij elkaar' (Spekkink en Gerritse, 1992, 44-45). Vanuit de architectenbranche wordt gesteld dat aannemers minder affiniteit hebben met architectuur. De locatiegebondenheid van een bouwwerk stelt vanuit architectonisch perspectief eisen aan een ontwerp. Volgens architecten zullen bij aannemers bouwtechnische overwegingen te groot stempel op het ontwerp drukken.

Volgens aannemers ieidt het prestatie-bestek tot innovatief gedrag in de bouw omdat het voor een bouwbedrijf de moeite waard wordt te investeren in zaken die pas bij volgende projecten hun rendement opleveren. Een slimme produktietechniek kan men nu bij meerdere projecten toepassen. Gevolg is een efficiënter bouwproces. 'Dit laatste. geldt met name voor de hoofdconstructie en de grote elementen, de ruwbouw, waarbij de inzet van hulpmaterialen en materieel vaak doorslaggevend is. Voor de inbouwpakketten, de afbouw, geidt dit niet of in veel mindere mate omdat deze meestal via onderaannemers van de markı worden gehaald. De kennis van de inbouwpakketten bij de architect is gelijk aan, of zelfs groter dan die van de aannemer, zodat de voordelen die van de prestatie-werkwijze kunnen worden verwacht vaak eerder de ruwbouw betreffen dan de afbouw' (Sluizer, 1993, 8).

Aannemers die met bouwconcept of prestatie-bestek werken krijgen de verantwoordelijkheid voor de technische kwaliteit van het eindprodukt. In het prestatie-bestek wordt het bouwbedrijf als producent, bedenker en realisator van technische ideeën beschouwd. De kwaliteit van het uiteindelijke produkt is afhankelijk van de kwaliteit van de produkten en diensten die onderaannemers en hun toeleveranciers leveren. De selectie van toeleveranciers c.q. onderaannemers zal steeds vaker plaats vinden op basis van kwaliteit, betrouwbaarheid en technische know-how en pas in tweede instantie op basis van prijs (Kettlitz 1992b). Mogelijk is dat de aannemer de toeleverancier. c.q. onderaannemer nog voor de gunning bij een specifiek project betrekken. De aannemer is zo met de kennis en kunde van de gespecialiseerde toeleverancier c.q. onder- 
aannemer in staat een aantrekkelijke aanbieding te doen. Deze aanpak vereist een zorgvuldige voorselectie van toeleveranciers en onderaannemers die kan leiden tot langdurige verticale samenwerkingsverbanden.

De praktijk is nu dat nog vaak de projectleider of uitvoerder zijn eigen netwerk van onderaannemers heeft opgebouwd en deze beoordeelt op prijs en ervaringen uit het verleden. Verschillende bouwbedrijven breken met deze subjectieve beoordeling en gaan in hun kwaliteitssystemen steeds vaker over tot een objectieve meting van de geleverde prestaties van toeleveranciers. ERA.Bouw is een bedrijf dat met behulp van standaardformulieren onderaannemers en leveranciers beoordeelt op het gebied van offerte-gedrag, assistentie bij de werkvoorbereiding, omgaan met afval, nazorg bij de oplevering, interne communicatie en hulp bij noodgevallen. Elke partner in een bouwproject krijgt van een aantal functionarissen een beoordeling. Bij een slecht totaaloordeel wordt de partner niet meer bij nieuwe projecten gevraagd; wie als matig uit de bus komt krijgt een uitnodiging voor een gesprek. Het streven naar langdurige samenwerking is de centrale gedachte achter dit beoordelingssysteem. Op basis hiervan. ontstaat een bestand met een selecte groep van vaste onderaannemers. Ook bij andere bouwbedrijven worden met behulp van een checklist toeleveranciers en onderaannemers geèvalueerd.

Het prestatie-bestek, vereist dat de marktkennis van het bouwbedrijf omtrent verlangde prestaties en overige wensen van de opdrachtgever moet worden vergroot. Deze meer marktgerichte oriëntatie vergt marktonderzoek, marktbewerking, meer aandacht voor specifieke vragen van de klant, research en versterking van technologische deskundigheid. Zeker bij de woningbouw was er vroeger een mentaliteit van 'niet zeuren, wij bepalen wel hoe het moet' en dus nooit een grote drang om sterk klantgericht te werken. Nieuwe marktvereisten vragen echter anders opgeleide mensen, een aangepaste bedrijfscultuur en andere interne en externe samenwerkingsstructuren.

\subsubsection{De rol van de industriële toeleverancier}

Tot nu toe zijn organisatie-vormen beschreven waarbij de architect of de aannemer verantwoordelijk worden voor de integratie van ontwerp en uitvoering. Gevolg van deze innovaties in de organisatie van bouwprojecten is dat genoemde partijen vaker delen van de produktie uitbesteden naar andere bedrijven maar de verantwoordelijkheid voor de algehele coördinatie zelf behouden. In verband met risico's, duidelijkheid naar de klant toe, inspanning en tijdsbeslag bij de opstelling van een aumbieding en coördinatie-kosten zal een architect of aannemer bij inschrijving zo weinig mogelijk toeleveranciers c.q. onderaannemers willen betrekken. Dit heeft tot gevolg dat industriële toeleveranciers of onderaannemers delen van het ontwerp-en assemblageproces overnemen door een afgerond gebouwdeel voor hun rekening te nemen. Hierbij kan men denken aan fundering, draagconstructie, gebouwschil, installaties en binnenafbouw. Een gevelleverancier levert dan bijvoorbeeld ook het glas, de deuren, eventueel metselwerk, dakbedekking, technische know-how en arbeid. Of de toeleveringsindustrie het produkt zelf levert of daarvan weer gedeelten uitbesteedt is van geen belang zolang het geen consequenties voor de kosten of voor het eindresultaat heeft. Ontwikkelingsactiviteiten worden van de architect of aannemer naar de toeleverancier verschoven. Hierdoor wordt de oplossing van een probleem bij de toeleverancier neergelegd in plaats van het slechts produceren van een onderdeel volgens nauw omschreven specificaties. 
Nederlandse bedrijven, die actief zijn geweest in Groot-Brittannië, hebben reeds ervaring opgedaan met de wijze van organiseren waarbij complete gebouwdelen aan aparte bedrijven worden aanbesteed. Dit is vaak het geval bij 'management contracting', een organisatievorm die in Groot-Brittannië al lange tijd gebruikelijk is. Bij deze organisatievorm wordt in een vroeg stadium een uitvoeringsdeskundige aan het ontwerpteam toegevoegd. De management contractor wordt geselecteerd op zijn managementkwaliteiten en uitvoeringsdeskundigheid. Hij heeft tot taak de opdrachtgever te adviseren over uitvoerings- en kostenaspecten in de ontwerpfase en - zodra hij dat mogelijk oordeelt - de verschillende (onder)aannemers te contracteren en hun werkzaamheden te coördineren. De contract-manager is verantwoordelijk voor de logistieke organisatie, het financiële management en de kwaliteitsbewaking. Hij treedt in alle bevoegdheden van de bouwheer en is er alleen voor planning en coördinatie.

FIGUUR 10.2 Organisatie bij management contracting

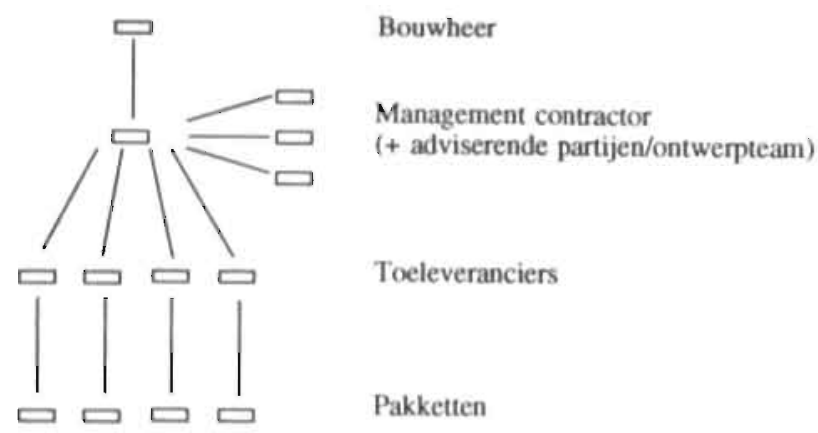

Alle bij de realisatie van een bouwwerk betrokken leveranciers staan in een gelijke positie ten opzichte van de contract-manager. Zelf neemt deze in principe geen deel aan de uitvoering; hij ontvangt een managementfee. Zowel de adviseurs als de toeleveranciers worden door de management contractor aangestuurd. Om mogelijkheden van veranderingen zo goed mogelijk open te houden, wordt het totale bouwwerk dikwijls in een aantal delen opgesplitst. De delen worden in afzonderlijke eenheden ontworpen, aanbesteed en uitgevoerd door verschillende (onder)aannemers (SBR, 1992a). Een voorbeeld van zo'n opsplitsing is:

- het bouwrijp maken van het terrein;

- frame - ruwbouw draagcontructie;

- 'cladding'/envelope' - complete buitenkant d.w.z. betonelementen, ramen, deuren, zonwering etc.;

- dak etc.

Schokbeton heeft als leverancier van prefab elementen ervaring met management contracting opgedaan in projecten in London tijdens de bouw-'boom' van ' 85 tot ' 90 . Het pakket van Schokbeton betrof bij deze projecten naast gevelelementen ook onder andere ingangspartijen waaronder ramen. 'Als subcontractor krijgen wij dan bijvoorbeeld de gehele zone van de gevel toebedeeld. Wij op onze beurt moeten dan weer een relatie aangaan met de ramenfabrikant enzovoort. Als subcontractor draag je dus 
verantwoordelijkheid voor jouw zone en daarmee voor het werk van de sub-subcontractors - in dit geval - de ramenfabrikant. Een verantwoordelijkheid die wij op onze beurt overigens weer gedeeltelijk doorschuiven naar die ramenfabrikant...' (Bakens en De Mos, 1993a, 26). Schokbeton heeft hiervoor in 5 van 6 projecten samengewerkt met het bedrijf De Vries Robbé en dit werk niet aanbesteed. Tussen De Vries Robbé en Schokbeton bestond een zgn. 'back-to-back contract': afspraken die Schokbeton met de management contractor had golden ook De Vries Robbé.

FIGUUR 10.3 Back-to-back contract

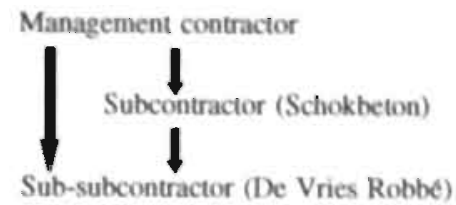

Een ander voorbeeld van een bedrijf dat ervaring heeft met denken op bouwdeelniveau is dakpannenproducent RBB. In samenwerking met de dakdekker en de leverancier van de onderdakconstructie wordt een compleet bouwdeel aangeboden. Dit complete bouwdeel omvat de onderconstructie, dakbedekking, goten etc. inclusief montage daarvan. Het werken op bouwdeelniveau vereist volgens RBB dat in het bouwproces vroegtijdig direct contact bestaat met de projectleider. Volgens RBB zijn er nog maar weinig producenten van (niet-projectgebonden) massa-artikelen die zich duidelijk als partner van de aannemer profileren (Bakens en De Mos, 1993b).

Een ontwikkeling, die met het denken in bouwdelen samenhangt, is het feit dat in Nederland toeleverende bedrijven zich steeds vaker profileren als subcontractor. Installatietechnische bedrijven zijn volgens geïnterviewden de eersten geweest die zich als subcontractor gingen presenteren. Een voorbeeld daarvan is het landelijk opererende installatiebedrijf GTI. Subcontracting heeft zich de laatste jaren ook sterk bij bedrijven actief in de ruwbouw ontwikkeld. Tot deze bedrijven behoren naast aannemers ook prefab betonleveranciers die zich richten op constructie en draagstructuren. In Nederland profileren bedrijven als BetonSon, Haitsma, de Voorbij Groep en Schokbeton zich als subcontractor en co-maker.

Soms kan een industriële toeleverancier zelf de integratie tussen ontwerp en uitvoering verzorgen. Dit is het geval als de leverancier met een vergaand gestandaardiseerd bouwconcept complete huisvesting op de markt aanbiedt. Bekend Nederlands voorbeeld hiervan uit het verleden is het bedrijf Polynorm. Dit bedrijf werd na de oorlog als een staatsonderneming opgezet ten behoeve van de fabrikage van woningen met een stalen draagconstructie. Polynorm beleverde de internationale markt met fabriekshallen, semi-permanente kantoorgebouwen, vakantiebungalows, Polyhutten etc. Ook Fokker, Shell, DSM en Hoogovens zijn in het verleden betrokken geweest bij de ontwikkeling van 'industriële' woningbouwsystemen in Nederland. Woningbouw was één van de markten waar expansie van het verbruik van 'nieuwe' materialen mogelijk leek (Delsing, 1989). 
Een hedendaags voorbeeld van een industriële toeleverancier die complete bedrijfshuisvesting aanbiedt is Unidek, een bedrijf dat is voortgekomen uit een handels- en produktiebedrijf. Dit bedrijf prefabriceert bouwdelen voor bedrijfshallen en kantoren en assembleert die vervolgens binnen enkele weken op de bouwplaats. Men werkt met op het produkt afgestemde werkploegen en onderaannemers. Unidek heeft met 45 bedrijven jaarcontracten voor de levering van onderdelen voor de bedrijfshallen en, afhankelijk van het contract, verwerking daarvan op de bouwplaats. Unidek heeft zijn interne organisatie als de calculatie, inkoop, planning en werkvoorbereiding volledig op de bouw van prefab bedrijfshallen afgestemd.

In bepaalde gevallen kunnen ook fabrikanten van prefab betonelementen als leverancier van een compleet gebouw optreden. Voorbeeld zijn parkeergarages. Bij parkeergarages bestaat een aanmerkelijk deel van de bouwsom uit fabrikage en montage van prefab elementen.

\subsection{Integratie van ontwerp en uitvoering en de verticale actor}

\subsubsection{Co-makership in de bouw}

In de inleiding van dit hoofdstuk is de vraag gesteld waar in de bouw overdracht van know-how, snelheid en wederzijds vertrouwen van toenemend belang zijn geworden. Deze vraag hebben we proberen te beantwoorden door in te gaan op innovaties in de organisatie van bouwprojecten die een antwoord vormen op nieuwe marktvereisten. Er is aangegeven dat een toenemende concurrentie en morktvereisten die veruler gaan dan de prijs van een produkt tot de opheffing van de traditionele scheiding tussen ontwerpende en uitvoerende partijen leidt. Dit streven naar integratie heeft ertoe geleid dat: bedrijven het management van het gehele bouwproces op zich (willen), nemen.

Aannemer of architect worden verantwoordelijk voor de integratie van ontwerp en uitvoering. Dit heeft tot gevolg dat deze partijen afgeronde bouwdelen uitbesteden aan industriéle toeleveranciers en onderaannemers die daardoor tevens delen van het ontwerpen assemblageproces voor hun rekening nemen. Er ontstaat een situatie waarbij architect of aannemer in nauw overleg met toeleveranciers of onderaannemers bouwdelen ontwikkelen en produceren. Laatstgenoemde partijen profileren zich dan ook steeds vakei als subcontractors. Een dergelijke samenwerking doet zich ook bij projectontwikkeling voor als opdrachtgever, architect, aannemer en andere partijen in bouwteamverband gezamenlijk werken aan de realisering van een bouwproject. Tevens is aangegeven dat bij aannemers die met een bouwconcept of prestatie-bestek werken de selectie van toeleveranciers c.q. onderaannemers steeds vaker zal plaats vinden op basis van kwaliteit, betrouwbaarheid, technische know-how en pas in de tweede instantie op basis van prijs. Dit betekent een breuk. met transactiepatronen zoals gebruikelijk bij traditionele bouwprocessen waar fixatie op kosten en prijs de voornaamste kenmerken zijn van transacties tussen bedrijven.

We zien dat door genoemde veranderingen in de organisatie van bouwprojecten het belang van overdracht van technische know-how en wederzijds vertrouwen toeneemt. Hiermee wordt de basis gelegd voor logistieke netwerkvorming en co-makership in de bouw. Met het analytisch kader van Broersma (1991) kan aangegeven worden dat op drie hoofdaspecten sprake is van een groeiende co-makership in de bouw, te weten: 
logistiek, kwaliteit en ontwikkeling. Met hetzelfde analytisch kader kan tevens worden ingegaan op veranderingen in de intensiteit waarmee bedrijven samenwerken. Broersma (ibid) onderscheidt vier categorieën van intensiteit: willekeurige leveranciers ('prijskopers'), vaste leveranciers, concentratie van leveranciers en co-makership 'optima forma'. Hoofdaspecten van co-makership en mate van intensiteit zijn twee dimensies van bedrijfsrelaties die door Broersma in een schema worden weergegeven (zie figuur 10.4). Met dit schema kunnen de in dit en het voorgaande hoofdstuk beschreven ontwikkelingen nader geanalyseerd worden. Daarmee geven we tevens de huidige situatie en mogelijkheden in de toekomst voor co-makership in de bouw aan.

Zoals in $\S 10.1 .1$ aangegeven, is het traditionele bouwproces een standaardvoorbeeld van 'prijskopen'. Via een aanbestedingsprocedure kiest de opdrachtgever meestal die aannemer uit die tegen de laagste prijs ingeschreven heeft. Inkopers van deze aannemer trachten op hun beurt weer een zo laag mogelijke prijs bij toeleveranciers en onderaannemers te bedingen. Figuur 10.4 geeft aan dat dit prijskopen duidt op een minimale (logistieke) samenwerking tussen aannemers en partijen als toeleveranciers en onderaannemers (score 1 in de figuur).

Deze minimale samenwerking is overigens niet overal in de bouw de praktijk. In het voorgaande hoofdstuk is aangegeven dat met name relaties tussen producenten en bouwmaterialenhandel zich kenmerken door redelijk vaste afspraken. In de bouwmaterialenhandel zijn een aantal concerns en inkoopcombinaties actief die met producenten relaties aangaan in de vorm van raamcontracten. Figuur 10.4 geeft aan dat deze contractvorm op een vergaande logistieke samenwerking duidt (score 3). Gezien de gunstige voorwaarden voor de totstandkoming van EDI in de schakel producent-bouwmaterialenhandel lijken deze partijen geschikt te zijn voor een verdergaande logistieke samenwerking in de vorm van co-makership 'optima forma' (score 4). EDI maakt een bedrijfsoverstijgende koppeling en sturing van logistieke systemen mogelijk.

De kwaliteit van bouwmaterialen wordt in het traditionele bouwproces alleen bij aankomst op de bouwplaats door de aannemer gecontroleerd. Daarnaast beoordeelt de vitvoerder prestaties van toeleveranciers en onderaannemers op basis van prijs en ervaringen uit het verleden. Figuur 10.4 geeft aan dat in dit geval op het aspect kwaliteit van afstemming nauwelijks sprake is (score 1). Nieuwe marktvereisten vormen echter een belangrijke drijfveer om tot meer geformalisecrde kwaliteitscontroles en kwaliteitssystemen te komen. Verschillende bouwbedrijven breken met hun subjectieve beoordeling van toeleveranciers en gaan over tot een objectieve meting van de geleverde prestaties. Onderdeel van zo'n kwaliteitssysteem is dat leveranciers worden opgenomen in een bestand en regelmatig beoordeeld worden, zodat iedere inkoper de staat van dienst kan inzien.

Bij bepaalde bouwprojecten fungeert het kwaliteitssysteem van de hoofdaannemer als uitgangspunt voor de door betrokken partijen uit te voeren werkzaamheden. Dit betekent dat systematisch wordt vastgelegd welke werkafspraken gemaakt zijn. Voorbee]den hiervan zijn afspraken met leveranciers over keuring, behandeling, opslag en aanlevering van materialen. De afspraken tussen aannemer en toeleverancier kunnen tevens betrekking hebben op activiteiten in het kader van kwaliteitsborging (score 3). Het kwaliteitssysteem vormt zo een belangrijke drijfveer om tot een meer geïntegreerde organisatie van het bouwproces te komen. Het opheffen van ingangscontroles, zero- 
FGUUR 10.4 De mate van intensiteit van samenwerken en de afstemmingen op drie aspecten

\begin{tabular}{|c|c|c|c|c|}
\hline $\begin{array}{l}\text { Mate van } \\
\text { intensiteit }\end{array}$ & $\begin{array}{c}1 \\
\text { Willekeurige leveranciers } \\
\text { ("prijskopen") }\end{array}$ & $\frac{2}{2}$ & $\begin{array}{c}3 \\
\text { Concentratie } \\
\text { van leveranciers }\end{array}$ & $\begin{array}{l}4 \\
\text { Co-makership, } \\
\text { "optima forma" }\end{array}$ \\
\hline Logistick & $\begin{array}{l}\text { - incidentele orders } \\
\text { - } \\
\text { - levering per order }\end{array}$ & $\begin{array}{l}\text { regelmatige orders } \\
\text { voorrad bij weleverancier } \\
\text { minimale leverafspraken: } \\
\text { geen verplichtingen }\end{array}$ & $\begin{array}{l}\text { raamcontracten: leveringen } \\
\text { op afroep } \\
\text { oriëntatie aan toeleveranciers } \\
\text { systematiek afgestemd } \\
\text { gedeeltelijke voorraad- } \\
\text { buffers }\end{array}$ & $\begin{array}{l}\text { gekoppelde systemen } \\
\text { - } \quad \text { flow-produktie } \\
\text { besturing over de bedrijfs- } \\
\text { grenzen } \\
\text { geen voorradbuffers } \\
\text { EDI (Electronic Data } \\
\text { Interchange) }\end{array}$ \\
\hline Kwaliteit & $\begin{array}{l}\text { handelskwaliteit } \\
\text { ingangscontrole bij } \\
\text { uitbesteder } \\
\text { kwaliteitseisen per bedrijf }\end{array}$ & $\begin{array}{l}\text { kwaliteitscontrole bij } \\
\text { toeleverancier en uitbesteder } \\
\text { geen gemeenschappelijke } \\
\text { kwaliteitsbarging }\end{array}$ & $\begin{array}{l}\text { kwaliteitscontrole bij } \\
\text { toeleverancier } \\
\quad \text { kwaliteitsbarging afgestemd }\end{array}$ & $\begin{array}{l}\text { - integrale kwaliteitsborging } \\
\text { - } \quad \text { zero-defect } \\
\text { - } \quad \text { Totalemd proces } \\
\text { hele keten }\end{array}$ \\
\hline Ontwikkeling & $\begin{array}{ll}\text { - } & \text { standaardprodukt } \\
\text { - } & \text { grondstoffen }\end{array}$ & $\begin{array}{l}\text { uitbesteder schrijf } \\
\text { specificaties en ontwerp voor } \\
\text { weinig toegevoegde waarde } \\
\text { door leverancier }\end{array}$ & $\begin{array}{l}\text { - globale specificaties aan } \\
\text { toeleverancier } \\
\text { inbreng van toeleverancier } \\
\text { in ontwerpuncties en } \\
\text { maakbaarheid } \\
\text { inbreng know-how door } \\
\text { toeleverancier }\end{array}$ & $\begin{array}{l}\text { - inbreng van toeleverancier in } \\
\text { specificatic, ontwerp en } \\
\text { maakbaarheid } \\
\text { toeleverancier heeft toege- } \\
\text { voegde wasrde in produkt en } \\
\text { produktietechnologie } \\
\text { - } \quad \text { koppeling van ontwerp- } \\
\text { systemen (CAD) } \\
\text { open kostprijscalculatie }\end{array}$ \\
\hline
\end{tabular}

Bron: Broersma (1991. 86). 
defect levering en Total Quality Control in een hele keten (score 4) is echter voor grote delen van de bouw nog een vergezicht.

In 'traditionele' bestekken schrijft de architect de complete set van specificaties en materialengebruik (en daarmee veelal ook de bouwmethodiek) voor. Uitvoerende partijen hebben hier geen inbreng (score 2 op het aspect ontwikkeling). Aannemers die met een prestatie-bestek werken krijgen echter de verantwoordelijkheid voor de technische kwaliteit van het eindprodukt, dat wil zeggen de keuze van materialen, de constructie en de installaties. Het prestatie-bestek en de toegenomen kwaliteitseisen betekenen dan ook een grote inbreng van de aannemer in ontwerp en makkbarheid van het eindprodukt (score 3 ).

Dit laatste is ook het geval als een bouwbedrijf participeert in bouwteam. Opdrachtgever, architect en andere bouwteamleden zijn als 'team' verantwoordelijk voor het gehele bouwproces en dragen wederzijds know-how over. Dit is met name bij industrieel bouwen van groot belang: ontwerp, fabricage en montage moeten hier in een vroeg stadium op elkaar afgestemd zijn. Bij projectontwikkeling en projectongebonden bouwconcepten gaan bouwbedrijven in bepaalde gevallen structurele samenwerkingsverbanden met architecten aan. Soms zijn bij zo'n relatie CAD-ontwerpsystemen tussen architect en aannemer aan elkaar gekoppeld. Het schema van Broersma geeft aan dat in dat geval sprake is van een vergaande co-makership (score 4).

Uit het voorgaande blijkt dat de drie dimensies van co-makership wel te onderscheiden maar niet te scheiden zijn. Integrale kwaliteitssystemen bevorderen logistieke samenwerking, logistieke samenwerking kan intensieve samenwerking bij produktontwikkeling vereisen en gezamenlijke produktontwikkeling komt de kwaliteit van het eindprodukt ten goede.

\subsubsection{Opties voor de verticale actor}

In dit hoofdstuk zijn we op zoek geweest naar partijen die de rol van verticale actor op zich kunnen nemen, d.w.z. de coördinatie van logistieke activiteiten van verschillende bedrijven. Er is aangegeven dat verschillende bedrijven het management van het gehele bouwproces op zich willen nemen. Deze bedrijven zijn te beschouwen als opties voor de rol van de verticale actor.

Bennett (1985) onderscheidt bij een bouwproject vier 'subsystemen': de klant, het ontwerp, het management en de uitvoering (zie figuur 10.5). Het eerste subsysteem is de klant met een bepaalde huisvestingsbehoefte. De wensen en eisen van klanten worden vertaald in een Programma van Eisen. Dit omvat gebruikseisen, functies, prestaties en voorwaarden. Het tweede subsysteem van een bouwproject is het ontwerp. Architecten en adviseurs, de ontwerpende partijen, maken het bestek en de tekeningen voor de uitvoerende partijen. Uitvoering, het derde subsysteem, richt zich op de produktie en verwerking van materialen op de bouwplaats. Het vierde subsysteem is het management van de projectorganisatie. Dit subsysteem richt zich op de afstemming van de verschillende uit te voeren activiteiten en betrokken partijen. In dit hoofdstuk is in feite ingegaan op de vraag welke partij verantwoordelijk kan of moet zijn voor het subsysteem management van het bouwproces. 


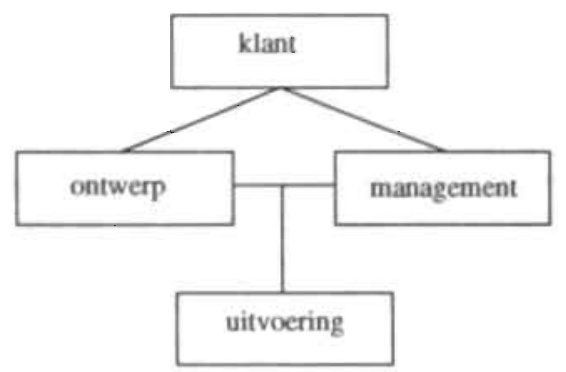

Bron: Bennett $(1985,13)$.

Ten eerste is aangegeven dat het subsysteem ontwerp het management van het bouwproces op zich kan nemen. Dit geldt. met name voor grote en/of innovatieve architectenbureaus. Architectenbureaus kunnen toeleveranciers rechtstreeks benaderen zonder dat er een aannemer tussen zit, zoals bij traditionele bouwprocessen. Het is dan gemakkelijk toeleveranciers mee te laten denken met het ontwerp en zo tot produktverbetering te komen. Dit geldt vooral voor prefab ontwerpen. Het architectenbureau kan bij deze ontwerpen het aantal bouwdelen tot een beperkt aantal terugbrengen en ze in nauw overleg met de toeleveranciers ontwikkelen en produceren. Het werk op de bouwplaats wordt hierdoor een beheersbaar assemblage-proces. Door ook zelf de assemblage van de bouwelementen op de bouwplaats te plannen functioneert het architectenbureau ook als coördinator op de bouwplaats.

Ten tweede ontwikkelt het subsysteem uitvoering zich in de richting van coördinator van een compleet bouwproces. Het zijn vooral de grote aannemers die zich hierop richten. Deze verwerven steeds meer deskundigheid die noodzakelijk is voor de beheersing van het totale bouwproces, inclusief ontwerp. Het coördineren van alle specialismen in een project is een apart specialisme geworden dat vooral door grote aannemingsbedrijven kan worden uitgevoerd. ${ }^{6}$ Het eigenlijke werk op de bouwplaats zal steeds vaker worden uitgevoerd door gespecialiseerde onderaannemers en toeleveranciers die hun eigen produkten in het werk aanbrengen. In specifieke gevallen kan ook de industriële toeleverancier als coördinator van ontwerp en uitvoering optreden.

Integratie van ontwerp en uitvoering door een aannemer of een architectenbureau hoeft nog niet tot een optimale produktkwaliteit te leiden (Lubbers, 1989, 30). Een turnkey-aannemer heeft bijvoorbeeld met de opdrachtgever een totaalprijs voor een project afgesproken. Om de marge tussen de opbrengst en de kosten zo groot mogelijk te laten zijn kan de turnkey-aannemer ernaar streven de verschillende materialen tegen

${ }^{6}$ Ook is het mogelijk dat door het steeds deskundiger worden van de klant deze partij verantwoordelijk wordt voor het subsysteem, management. In $\$ 10.2$ gaven we het voorbeeld van, woningbouwverenigingen die steeds meer kennis in huis halen en daardoor de mogelijkheid krijgen het bouwproces meer naar hun hand te zetten. Het management van een compleet, bouwproces wordt door dergelijke organisaties echter niet als aparte dienst op de markt aangeboden. Om die reden laten we deze optie verder buiten beschouwing. 
een zo laag mogelijke prijs in te kopen. Dit betekent dat de opdrachtgever wellicht niet datgene krijgt, waarvoor hij betaald heeft of dat hij teveel betaalt. De opdrachtgever kan de coördinatie daarom toevertrouwen aan een namens hem optredende architect of adviseur. Maar ook dit garandeert geen optimale integratie van ontwerp en uitvoering. Het architecten- en ingenieursbureau is, buiten zijn managementfunctie, ook verantwoordelijk voor het leveren van alle berekeningen en tekeningen. Daar kan technisch of qua levertijd iets aan ontbreken. Bij een conflict ontbreekt in dat geval een onafhankelijke arbiter.

Bovengenoemde belangenconflicten kunnen worden voorkomen in een structuur waarbij het management niet samenvalt met de inbreng van een bepaalde discipline binnen het bouwproces. Onafhankelijk projectmanagement kan een individu of een bedrijf binnen of buiten de bouwindustrie zijn. Het onafhankelijk management heeft de verantwoordelijkheid voor het tijdsschema en de kwaliteit en staat volledig vrij van iedere partij betrokken bij het bouwproject. Wanneer bijvoorbeeld de tekeningen niet goed of niet op tijd geleverd worden, krijgt het ingenieursbureau exact hetzelfde commentaar als de leverancier van de scheidingswanden die zijn afspraken niet nakomt. In Nederland is een dergelijke organisatievorm nog niet gebruikelijk. Wel zijn in Nederland projectmanagementbureaus actief die bouwvoorbereiding, directievoering en toezicht van een bouwproject als aparte dienst aanbieden. De directievoerder stemt de werkzaamheden van de uitvoerende partijen op elkaar af en waakt over de kwaliteit en voortgang van het werk. Hij heeft de leiding op bouwvergaderingen, houdt controle over termijn- en eindafrekeningen en verzorgt de oplevering van een project.

Er zijn kortom drie opties voor de verticale actor naar voren gekomen. Ten eerste zijn dat de grote en innovatieve architectenbureaus die naast de ontwerpfunctie ook de rol van de coördinator of manager op zich nemen. Ten tweede verwerven middel-grote en grote aannemers steeds meer deskundigheid voor de coördinatie van het totale bouwproces. Een derde optie is dat de coördinatie van ontwerp en uitvoering uitbesteed wordt aan een op zich staande organisatie. Aanzetten daartoe zijn de projectmanagementbureaus. 



\section{Produktielogistiek in vier bouwprojecten en hun ketens}

In dit hoofdstuk wordt geanalyseerd of in de bestaande bouwpraktijk aanzetten tot of nadere concretiseringen van toepassing van integrale logistiek te vinden zijn. Hiertoe worden vier bouwprojecten geanalyseerd waarvan twee in de woningbouw en twee in de utiliteitsbouw. Met deze gevalsstudies proberen we in de bestaande bouwpraktijk antwoorden te vinden op de derde, vierde en vijfde onderzoeksvraag uit hoofdstuk 6 , de vragen die zich richten op eigenschappen en gevolgen van toepassing van integrale logistiek voor de organisatie van bouwprojecten en hun ketens.

Ten eerste geven de gevalsstudies antwoord op de derde onderzoeksvraag, de vraag of bij bouwprojecten sprake is van een organisatie van logistieke activiteiten in nieuwe hiërarchieën. Bij de gevalsstudies hebben we deze vraag als volgt geformuleerd: zijn in het bouwproces of de bouwketen (nieuwe) ondernemingen of organisatie-vormen aan te wijzen die een afstemming van logistieke activiteiten tussen bedrijven mogelijk maken? Tevens wordt geanalyseerd in hoeverre in de bestaande bouwpraktijk sprake is van substitutie van arbeid door nieuwe produktie-technieken die tijdens een bouwproces een logistieke afstemming tussen bedrijven vereisen. Deze vraag sluit aan bij de vierde onderzoeksvraag. Tenslotte zoeken we met deze analyse antwoord op de vijfde onderzoeksvraag, de vraag of bedrijfsoverstijgende informatiesystemen in de bestaande bouwpraktijk een herstructurering van de interne organisatie tot gevolg hebben. In hoofdstuk 9 is al aangegeven dat van een bedrijfsoverstijgende informatisering in de bouw nog nauwelijks sprake is. Wel kunnen we ingaan op de vraag waar in de bouw sprake is van formalisering en/of standaardisering van planning en communicatie en dus mogelijkheden bestaan voor een herstructurering van de interne organisatie door informatisering.

Nadat in de vorige twee hoofdstukken is ingegaan op ontwikkelingen in de omgeving van het bouwproject en zijn keten, omvat dit hoofdstuk vier gevalsstudies van concrete bouwprojecten en hun ketens. Paragraaf 11.1 gaat verder in op de vragen die voor de gevalsstudies uitgangspunt van analyse zijn en de gehanteerde methode. In $\$ 11.2$ tot en met 11.5 worden de gevalsstudies behandeld. In $\$ 11.6$ worden naar aanleiding van de gevalsstudies conclusies getrokken omtrent kenmerken van en aanzetten tot toepassing van integrale logistiek in de bestaande bouwpraktijk.

\subsection{Gevalsstudies van bouwprojecten: vragen en methodologie}

Ter beantwoording van bovengenoemde vragen zijn een viertal bouwprojecten geanalyseerd, twee in de woningbouw en twee in de utiliteitsbouw. De tijdelijkheid van relaties tussen bedrijven in de bouwsector vormde het motief om een concreet bouwproject als uitgangspunt te nemen voor de analyse van informatie- en goederenstromen 
in bouwketens. In feite is een bouwproject nog te omvangrijk om tot een diepgaande analyse te kunnen overgaan. Daarom zijn binnen een project specifieke produkten geselecteerd. Startpunt voor de analyse van een concreet bouwproject is de bepaling welke produkten en hun ketens voorwerp van onderzoek worden. Een heldere formulering van de te onderzoeken keten is belangrijk omdat een produktketen in veel gevallen slechts een deel uitmaakt van het totaal produktenpakket van bedrijven in een keten (zie figuur 11.1). De produkten zijn resp. projectkeukens, hout en installatiemateriaal, prefab gevelelementen en prefab elementen in het algemeen geworden.

\section{FIGUUR 11.I De produktketen}

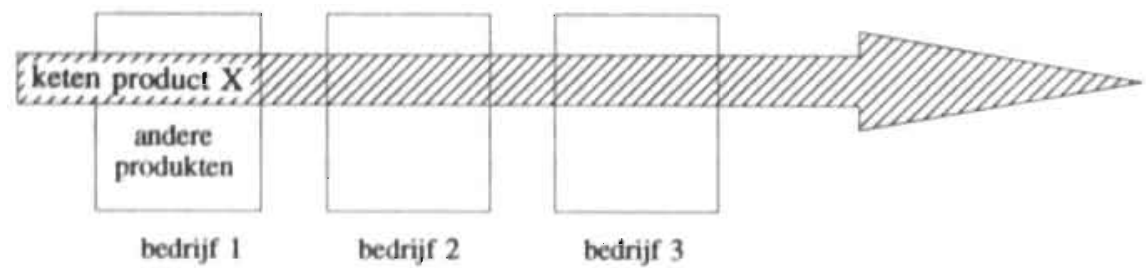

Na de bepaling van project, produkt en keten zijn vervolgens bij de diverse deelnemende bedrijven gegevens verzameld met betrekking tot het produktassortiment, organisatie, produktieproces, materiaalverwerving/inkoop en diverse andere aspecten van het bouwproject. Deze analyse is bedoeld om factoren die mogelijkheden voor logistieke prestaties kunnen beïnvloeden te achterhalen en een redelijk beeld te krijgen van alle relevante bedrijfsaspecten in de opvolgende produktiestadia. De analyse is bij drie van de vier bouwprojecten uitgevoerd door interviews met sleutelfunctionarissen. Deze functionarissen kwamen uit het midden en hoger kader van bedrijven betrokken bij de geformuleerde produktketens (zie bijlage II). Per bouwproject hebben vijf tot tien interviews plaats gevonden. Deze interviews hadden een open eind karakter. Bestudering van het vierde bouwproject is uitgevoerd door documentenanalyse. De vele publicaties over dit bouwproject maakien een goed beeld van de logistieke organisatie mogelijk. De verslagen van de twee gevalsstudies in de woningbouw zijn in één sessie geëvalueerd waarbij alle geïnterviewde functionarissen aanwezig waren. De verslagen van de gevalsstudies in de utiliteitsbouw zijn op individuele basis met de geïnterviewden en betrokkenen besproken.

Op deze wijze zijn vier gevalsstudies uitgevoerd. De eerste gevalsstudie betreft het order- en leverproces van keukens in een keten van bedrijven ten behoeve van een renovatie-project. De tweede gevalsstudie analyseert de planning en toelevering van hout en installatiemateriaal, ook ten behoeve van een renovatie-project. ${ }^{1}$ In de derde gevalsstudie wordt het produktie-proces, van ontwerp tot montage, van prefab gevelelementen voor een kantoorgebouw gevolgd. De vierde gevalsstudie heeft betrekking op de organisatie van levering en montage van prefab betonelementen, eveneens ten

${ }^{1}$ De eerste gevalsstudie is uitgevoerd in samenwerking met drs. W.O. Hazelhorst van het organisatic-adviesbureau Berenschot, de tweede gevalsstudie in samenwerking met ing. J. Bakker van hetzelfde bureau. 
behoeve van een kantoorgebouw. De eerste twee gevalsstudies hebben betrekking op de woningbouw, de laatste twee op de utiliteitsbouw.

\subsection{De keukenketen}

\subsubsection{Het bouwproject en de deelnemende bedrijven}

Het bouwproject betreft in deze gevalsstudie de renovatie van 315 flatwoningen (5 flats). Deze renovatie van de ongeveer 25 jaar oude flats gebeurt in opdracht van het gemeentelijk woningbedrijf. Opdrachtverlening door de opdrachtgever aan de hoofdaannemer voor dit bouwproject heeft in juni 1990 plaats gevonden via een 'traditionele' aanbestedingsprocedure. De renovatie is gestart op 1 maart 1991 en duurt ongeveer een jaar.

De renovatie begint op de bovenste (negende) verdieping van een flat en er wordt sequentieel naar beneden gewerkt. Eerst wordt een flatgebouw helemaal afgemaakt, dan pas wordt de 'bouwplaats' verplaatst naar het volgende flatgebouw. De werkzaamheden aan een flatgebouw beginnen met het inrichten van de bouwplaats (lift etc.) en eindigen met de verplaatsing ervan. De snelheid van de bouwstroom is gemiddeld zeven woningen per week. Na negen weken zijn alle 63 woningen in het flatgebouw voorzien van een keuken. Daarna volgt een pauze van ongeveer drie weken. Deze bouwstroom wordt door de verschillende partijen nauwkeurig gevolgd in verband met de inzet van ploegen. In principe is de stroom vrij constant, afgezien van de periode van de overgang naar een nieuw flatgebouw en de vakantieperiodes.

FIGUUR 11.2 Sequentiële verwerking van flats

Flat 1

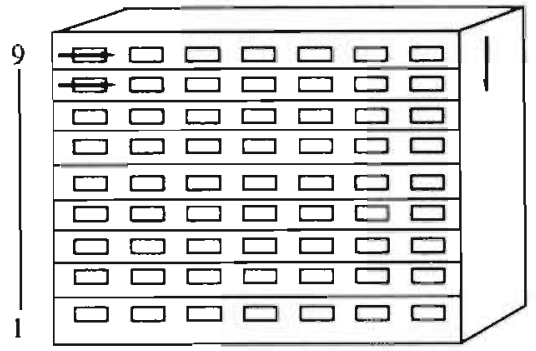

Tijdsduur
Ca. 9 weken keukenplaatsingen in flat 1
Flat 2

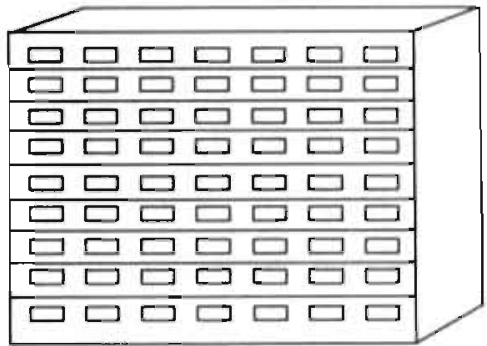

Ca. 9 weken keukenplaatsingen in flat 2

Belangrijkste werkzaamheden die in de flats uitgevoerd worden, zijn het vervangen van de keukenblokken en -kastjes, het aanbrengen van mechanische ventilatie, het vervangen van de wastafel, binnen- en buitenschilderwerk en bij een deel van de flats bovendien aanbrengen van geluidsisolatie. De voornaamste werkzaamheden aan het flatgebouw zijn de nieuwe indeling van de bergingen, nieuwe entree en renovatie van 
het trappenhuis, vernieuwing en uitbreiding van de liftschachten en het buitenschilderwerk.

De analyse heeft zich op een beperkt onderdeel van het bouwproces toegespitst, nl. het order- en leverproces van projectkeukens. In het algemeen wordt op de keukenmarkt onderscheid gemaakt tussen project- en aanbouwkeukens. Projectkeukens zijn sterk gestandaardiseerd: het overgrote deel van de kastjes en blokken (waaruit een projectkeuken grotendeels bestaat) wordt verkocht in enkele standaardmaten met enkele kleurvariaties. Aanbouwkeukens zijn meestal specifiek op de klantenwensen gericht en aanmerkelijk duurder. Tijdens het bouwproces worden standaardkeukenblokken met twee bovenkastjes door de aannemer geplaatst. De huurder kan kiezen uit drie verschillende kleuren van de fronten (dat zijn de keukendeurtjes en de voorkant van de keukenladen). Dit is de enige variatie aan de keuken. Type keuken en mogelijke kleuren zijn bij de aanbesteding vastgelegd door opdrachtgever. De aannemer is daardoor verplicht keukens bij één bepaalde fabrikant te betrekken.

De volgende bedrijiven behoren in dit bouwproject tot de 'keukenketen':

- de 'eindklant': het gemeentelijk woningbedrijf;

- de hoofdaannemer;

- de tussenschakel tussen fabrikant en aannemer: de bouwmaterialenhandel;

- cen inkoopcombinatie van bouwmaterialenhandels;

- de toeleverancier van keukens: een fabrikant van keukens en kasten.

De inkoopcombinatie van bouwmaterialenhandels is in deze gevalsstudie gebruikt als klankbord en algemene informatiebron over de keukenmarkt en toeleveringsprocessen. De keten als geheel is in figuur 11.3 weergegeven.

De hoofdaannemer in het renovatieproject is een middelgroot aannemersbedrijf dat zich alleen richt op de onderhoudsmarkt, niet op de nieuwbouw (dat doet een zusterbedrijf). Het bedrijf heeft 100 werknemers, waarvan 85 in de buitendienst. Het werkt samen met een aantal vaste partners voor schilderwerk, loodgieterswerk etc.

De bouwmaterialenhandel is een klein bedrijf met een omvang van ongeveei 30 mensen. Het bedrijf levert zowel bouwmaterialen voor de ruwbouw als sanitair en keukens. Wat keukens betreft levert het bedrijf zowel aanbouw- als projectkeukens. Met name de laatste groep is belangrijk, in aantal en waarde. Het bedrijf is dealer van de belangrijkste merken. Projectkeukens betrekt het bedrijf vrijwel uitsluitend bij de keukenfabrikant die ook deel uitmaakt van de geanalyseerde keten.

De inkoopcombinatie heeft ongeveer 40 bouwmaterialenhandelaren als leden, verspreid over heel Nederland. Belangrijkste activiteiten van de inkoopcombinatie zijn inkoop (raamcontracten) van diverse bouwmaterialen voor de leden, marktonderzoek, reclame-activiteiten en scholing. Er werken op het centrale kantoor zo'n 25 medewerkers.

De keukenfabrikant is een houtplaatverwerkende fabriek waar circa 20 mensen (inclusief inhuurkrachten) werken. Het heeft geen eigen buitendienst (zoals de grote keukenfabrikanten) voor actieve verkoop van het assortiment. Dit assortiment betreft hoofdzakelijk projectkeukens. Het produktieproces is voornamelijk assemblage van keukens, met wat beperkt zaag- en boorwerk, en afwerking. In de fabriek staat naast de 'keukenlijn', waar assemblage plaats vindt, ook de 'meubel- of machinale lijn'. Daar 
worden vooral boekenplanken en overige artikelen van spaanplaat gemaakt. Deze lijn produceert ook, indien nodig, onderdelen voor de keukenlijn, de zgn. 'Fertig Teile'. Dit zijn voorgezaagde en geboorde onderdelen van keukens.

FIGUUR 11.3 De keten, de deelnemende bedrijven en de keukenstroom.

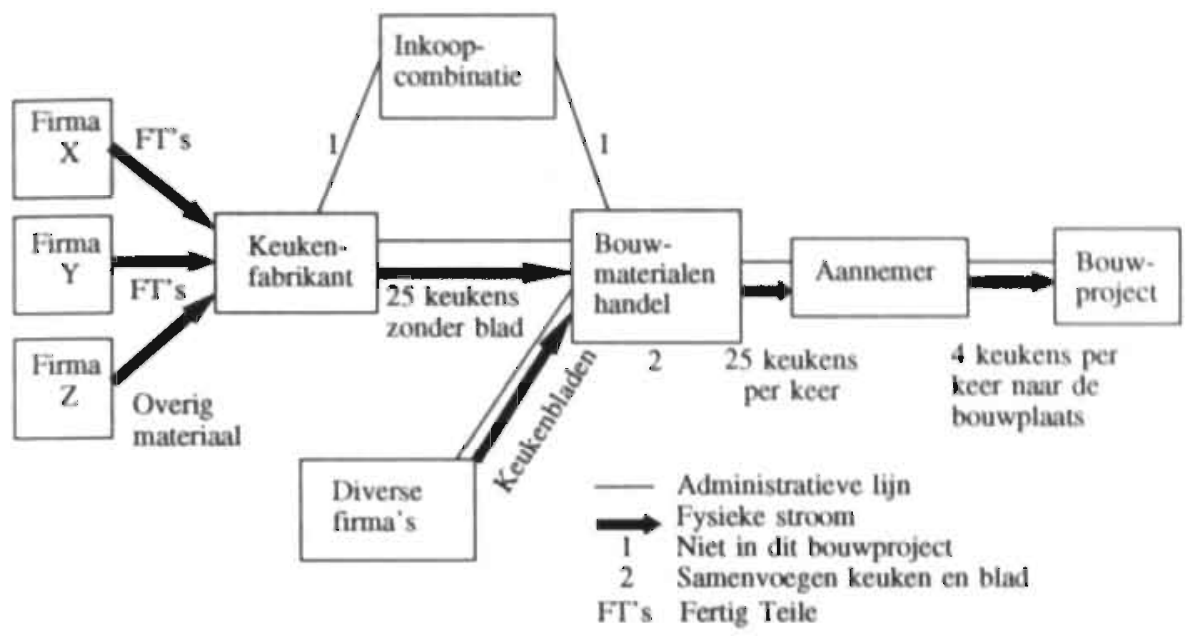

\subsubsection{Hel order-en leverschema van keukens}

Geplaatst worden standaard keukenblokken van 1.70 meter lang, met twee bovenkastjes. De huurder kan kiezen uit drie verschillende fronten: wit, grijs en beige. Het order- en leverschema is in figuur 11.4 aangegeven.

Ongeveer zes weken voor de start van de renovatie van een bepaalde woning vindt de warme opname plaats, d.w.z. het definitief opnemen van wat aan een bepaalde flat moet gebeuren. ${ }^{2}$ De aannemer neemt een hele serie flats tegelijkertijd op, meestal een half flatgebouw (circa 30 flatwoningen). De duur van de opname van al deze woningen bedraagt ongeveer een week. Bij deze opname kiest de huurder de frontkleur van de keuken.

Vijf weken voor de start roept de uitvoerder op de bouwplaats (een medewerker van de aannemer) ongeveer 25 nieuwe keukens bij de bouwmaterialenhandel af (als onderdeel van de totale order) en geeft daarbij de gewenste kleurmix van de fronten op. De eerste afroep van keukens bedroeg 50 stuks en was geheel op basis van de huurdersopgave, latere afroepen hebben plaats gevonden volgens een geregistreerde vraagmix ( $75 \%$ wit, $15 \%$ beige en $10 \%$ grijs) plaats. Door 25 keukens per keer te bestellen krijgt

${ }^{2}$ Op basis van een 'koude opname', een pre-inspectie die al 1 a 2 jaar voor de aanbesteding is uitgevoerd, is het bestek opgemaakt. De 'warme opname' vindt in de regel vlak voor de start van de uirvoeringsactiviteiten plaats. 
de aannemer een bepaalde kwantum-korting. Die 25 keukens vormen de behoefte van circa vier weken.

FIGUUR 11.4 Het leverschema van keukens

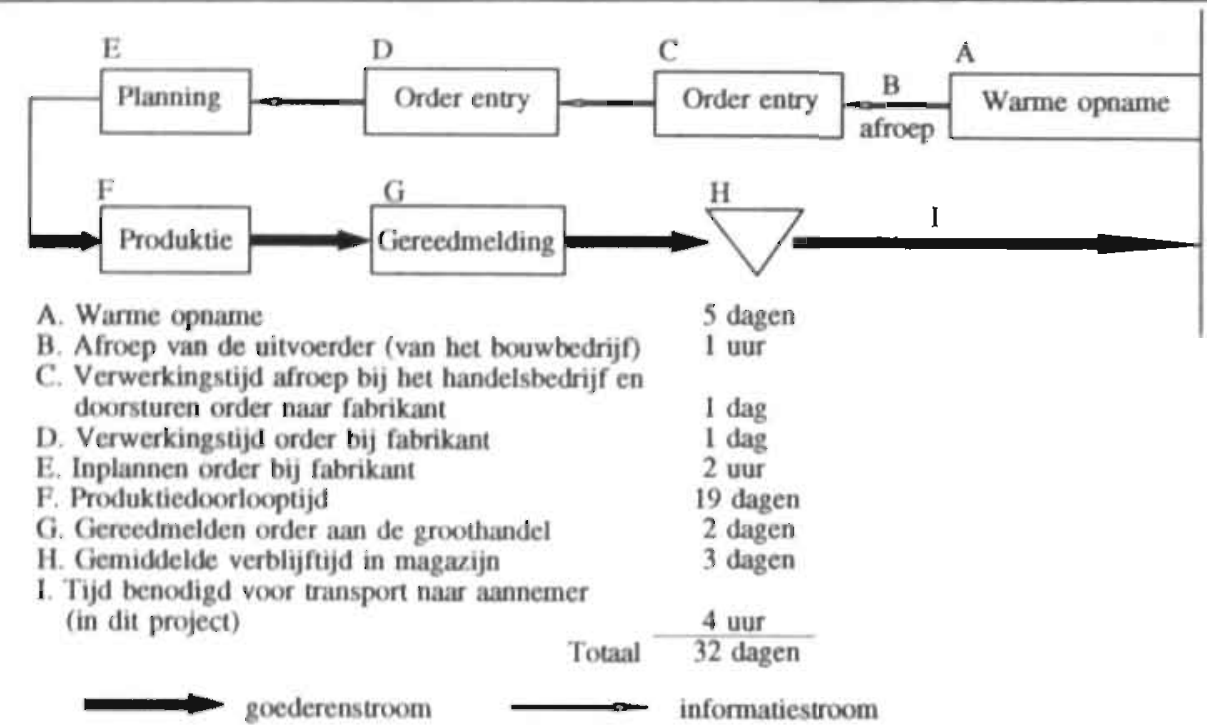

Binnen twee dagen doet de bouwmaterialenhandei een besteliing bij de fabrikant. De fabrikant start de produktie niet voor dit moment. De levertijd van de order bedraagt vier à vijf weken (de garantie van de fabrikant is 20 werkdagen). De fabrikant assembleert de keukens volledig (dus ook de fronten), maar zonder blad. De keukens worden door de fabrikant beperkt verpakt met karton om de randen. Als de order gereed is geeft de fabrikant de bouwmaterialenhandel (die is in dit geval de afnemer) een telefoontje om de keukens op te komen halen. De bouwmaterialenhandel transporteert de keukens naar het eigen magazijn, voegt daar vervolgens keukenbladen toe, en levert ze af bij het magazijn van de aannemer. Keukenbladen worden door de bouwmaterialenhandel tegelijk met de keukens geleverd, maar zijn van een andere toeleverancier afkomstig dan de keukenfabrikant. De bouwmaterialenhandel draagt zorg voor het transport tussen het magazijn van de fabrikant en dat van de aannemer. Naast deze taak is de rol van de bouwmaterialenhandel tijdens dit bouwproject relatief gering. Het is eigenlijk niet meer dan het doorgeefluik van keukenfabrikant naar aannemer.

In het magazijn van de aannemer beheert de uitvoerder van het aannemersbedrijf de voorraad keukens. Twee maal per week worden door een medewerker van het aannemersbedrijf ongeveer vier keukens naar de bouwplaats getransporteerd. Op de bouwplaats zelf zijn weinig opslagmogelijkheden. Het 'stellen' of plaatsen van de keukens gebeurt door de aannemer zelf omdat dit beter in de bouwstroom past. Het stellen van keukens gebeurt bij andere projecten vaak door de leverancier. In dit bouwproject vereenvoudigt het zelf stellen door de aannemer het lever- en montageproces omdat 
nu niet nog een aparte montageploeg afgestemd moet worden op de andere reeds in de woning aanwezige ploegen.

\subsubsection{Analyse van de logistieke onganisatie}

\section{Belemmeringen bij de logistieke afstemming}

In dit project zijn de partijen via een traditionele aanbestedingsprocedure bijeengebracht. Het feit dat de ondernemingen hierdoor niet bij het ontwerpproces betrokken zijn geweest lijkt tijdens de uitvoering niet tot logistieke knelpunten te leiden. Wel is irritatie bij de aannemer ontstaan vanwege het feit dat de keukenfabrikant reeds in de ontwerpfase bij de opdrachtgever, het gemeentelijk woningbedrijf, had weten vast te leggen dat voor dit bouwproject keukens uit zijn fabriek geplaatst moesten worden. Hierdoor is het voor de hoofdaannemer onmogelijk gemaaki om via aanbesteding de goedkoopste leverancier uit te kiezen.

In de uitvoerende fase is de hoofdaannemer de coördinerende instantie. Voor een soepel verlopend bouwproces is de hoofdaannemer echter sterk afhankelijk van factoren die niet geheel door hem te beheersen zijn. Deze factoren zijn bewoning van de flats tijdens de renovatie en levertijden van de bouwprodukten. Beide factoren bemoeilijken een goede logistieke afstemming.

De belangrijkste potentiële storingsfactor voor het bouwproces zijn in dit project de bewoners die tijdens de renovatie in hun woningen blijven wonen. Om te voorkomen dat oponthoud ontstaat is het handig en tactvol omgaan met hururderswensen een 'must'. Met name de uitvoerder van de aannemer krijgt te maken met de wensen van de echte eindklant van de keukenketen, nl. de gebruiker van het produkt keuken. Om te voorkomen dat de bouwstroom stokt worden, naast soepel omgaan met huurderswensen, bewoners vroegtijdig ingelicht over wat wanneer gaat gebeuren. Het komt voor dat huurders kort voor plaatsing van de keuken een andere kleur wensen. Om flexibel op deze huurderswensen te kunnen inspelen worden relatief veel keukens op voorraad gehouden. Dit alles heeft ten doel dat bewoners op de gewenste dagen hun woning beschikbaar stellen voor renovatie.

De bewoners, vertegenwoordigd in het 'Flatkommitee' en 'Buro Bewonersdeskundigen', zijn ook aanwezig tijdens de bouwbesprekeningen die om de vier weken gehouden worden. Bij deze besprekingen is ook Bureau Bouwhulp, het bureau dat voor de opdrachtgever het bestek heeft opgesteld, en de opdrachtgever zelf aanwezig. Het is de hoofdaannemer die tijdens deze vergaderingen een middenweg moet zoeken tussen wensen van de bewoners en de formele opdrachtgever. De bewoners wensen een zo kort mogelijke bouwtijd per flatwoning en een keuken naar wens. Het belang van de formele opdrachtgever, het gemeentelijk woningbedrijf, is een renovatie tegen een zo laag mogelijke prijs.

Naast de bewoning van de flats zijn de levertijden van de keukens een tweede potentiële stoorfactor voor een goede logistieke afstemming.

De huidige levertijd van keukens lijkt te lang te zijn voor het ideale moment van de warme opname. Probleem is vaak dat op het moment van warme opname de eindgebruiker nog niet in zijn directe omgeving kan zien hoe de nieuwe keuken staat. Wat 
nogal eens voorkomt is dat de huurder daarom in een later stadium een andere kleur keuken wenst. Een kortere levertijd van keukens zou het tijdstip van de warme opname dichter bij het ideale tijdstip kunnen brengen. Dit bleek in principe ook mogelijk te zijn. Ten tijde van het onderzoek was de produktieplanning van de keukenfabrikant niet langer dan zeven weken vooruit en uitsluitend gebaseerd op harde orders, dit ondanks het feit dat voor grote bouwprojecten de indicaties voor afname in toekomst betrouwbaar zijn. Voor keukens gold, na plaatsing van de order (de afroep), een levertijd van 20 dagen. Een optie voor de verkorting van de levertijd was het meer stroomafwaarts verleggen van het 'ontkoppelpunt'.

Het ontkoppelpunt scheidt het op planning gerichte gedeelte van de logistieke organisatie van het op klanten-orders gebaseerde deel (Hoekstra en Romme, 1985). In het algemeen valt het ontkoppelpunt samen met het punt waar produkten klant-specifiek worden. Stroomafwaarts doen zich in principe geen voorraadpunten meer voor. In figuur 11.5 zijn de verschillende posities van het ontkoppelpunt in een produktieproces weergegeven. Op dit moment worden keukens deels geproduceerd (positie vier van het ontkoppelpunt) en geassembleerd op order (positie drie). De projectkeuken is echter een eenvoudig standaardprodukt met een voorspelbare vraag door de regelmatige bouwstroom in grote bouwprojecten. Deze motieven maken een verschuiving naar positie twee mogelijk, d.w.z. een stroomafwaartse verlegging van het ontkoppelpunt. De te kleine opslagruimte bij de fabrikant vormde echter een belemmering voor het produceren op voorraad.

FIGUUR 11.5 Overzicht van de verschillende posities van het ontkoppelpunt

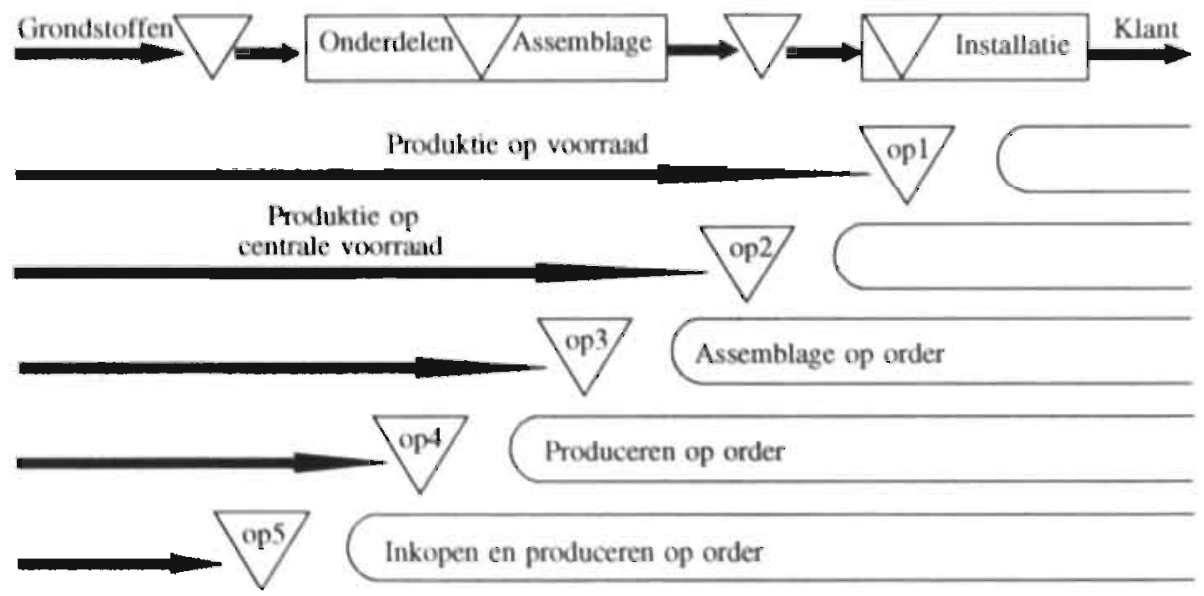

Owerigens zijn levertijden van vier of vijf weken voor standaardprodukten gemeengoed in de bouw: andere fabrikanten hebben even lange levertijden. En het gaat hier nog maar over een relatief eenvoudig produkt als projectkeukens. Voor aanbouwkeukens en bepaalde 'merk' deuren gelden nog langere levertijden die binnen de bouw ook. geaccepteerd worden. Deze lange levertijden zijn met name bij kleinschalige projecten, 
die direct gestart worden, een probleem. Ook financieel: de aannemer krijgt bij dergelijke projecten pas z'n geld nadat het laatste produkt in het project verwerkt is. De toelevering van deuren bijvoorbeeld, van belang voor het dicht maken van de woning, kan negen weken duren. Volgens de ketendeelnemers in deze gevalsstudie zijn produktiebedrijven vaak nog niet ingesteld op kleine projecten.

Dat het zin kan hebben de doorlooptijd te verkorten, bleek uit wat er bij het de start van het bouwproject gebeurde. Aanvankelijk werden keukenblokken van 1,80 meter geplaatst. De lengte van de keukenblokken moest echter veranderen van 1,80 meter naar 1,70 meter. Door een ontwerpfout kwam bij de keukenblokken van 1,80 meter lang de kraan niet boven de wasbak te hangen. De bestelling is direct gewijzigd. De trage reactietijd betekende dat er toch enkele weken lang de te grote maat keukens geplaatst moesten worden. Een verandering aan de kraan loste het probleem op.

\section{Gebrek aan formalisering en standaardisering van de logistieke organisatie}

De bestelgrootte van keukens bedraagt 25 stuks per keer. Deze bestelgrootte is door het bedrijfsbureau van de aannemer gekozen vanwege de kwantum-korting en de mogelijkheid flexibel te kunnen inspelen op huurderswensen. Gevolg is echter wel dat de keukens eerst moeten worden cpgeslagen in het magazijn van de aannemer en vervolgens weer getransporteerd worden naar de bouwplaats. Deze extra voorraad- en transportkosten zijn echter niet tegenover de voordelen van de kwantum-korting gezet. Deze extra kosten werden ook niet zo van belang geacht. Het grootste belang is dat verstoring van de bouwstroom zo veel mogelijk voorkomen moet worden.

Van een systematisch voorraadbeheer van de keukens blijkt tijdens dit project geen sprake te zijn. Hoe hoog de gemiddelde voorraad is in het magazijn bij de aannemer of op de bouwplaats is niet duidelijk geworden, evenmin als de precieze bestel- en aflevermomenten. $E_{r}$ is ook niet bekend geworden wat de werkelijke leveringen van de fabrikant aan de aannemer zijn geweest. Het bedrijfsbureau kon dit niet boven water brengen. Deze constatering geeft aan dat het zeker geen dagelijkse prioriteit van het bedrijfsbureau is om voorraadniveaus te volgen. Ook de keukenfabrikant had op het moment van onderzoek een gebrekkig inzicht in de hoogte van de voorraden hulpstoffen.

Gebrekkig voorraadbeleid bij aannemers blijkt ook uit het feit dat volgens de inkoopcombinatie van bouwmaterialen ongeveer $30 \%$ van de uitvoerders te laat afroept. Dit heeft volgens de combinatie te maken met de bouwcultuur die sterk gericht is op improviseren op de bouwplaats. De afroep in dit bouwproject ging overigens vlot en vormde geen knelpunt. Wat opviel was dat nok de inkoopcombinatie de geleverde diensten van de ingehuurde transporteur slechts marginaal controleerde. Het feit dat de redelijk vooruitstrevende inkoopcombinatie ten tijde van het onderzoek pas met prestatiemeting begon en dat logistieke aspecten daarbij nog nauwelijks werden betrokken, zegt wat over de situatie in de branche.

Een ander probleem was een systematisch inzicht te verkrijgen in klant- en projectgegevens van de hoofdaannemer. De aannemer maakte gebruik van de diensten van de Stichting Computertoepassing Bouwwezen. Deze draait maandelijks een bouwprojectenlijst uit met daarbij vermeld de kosten, gedeclareerde omzet en resultaat. Nadeel van deze lijst was dat niet bij ieder project de opdrachtgever vermeld staat. Dit bestand 
was anders ingericht dan de interne informatiesystemen van de aannemer hetgeen leidde tot aansluitingsmoeilijkheden. Gevolg was dat de aanwezige informatie onvoldoende werd benut voor analyse van de markt. Ten tijde van het onderzoek werd aan een betere opzet voor het gebruik van deze informatie gewerkt.

Tijdens het project is een poging gedaan om, in samenwerking met de ketendeelnemers, te komen tot een systematische prestatie-meting van leveranciers die in het bouwproces eindprodukten toeleveren naar de bouwplaats. Bij een dergelijke meting is van groot belang dat de toeleverancier en de afnemer het onderling eens zijn over de definitie van de te leveren prestaties en over de normering (waardering) ervan. Doel van de prestatie-meting is tot een leveranciersbeoordeling te komen, het signaleren van mogelijke problemen en inzicht te verkrijgen in de oorzaak daarvan. Door een gebrek aan motivatie bij de ketendeelnemers is dit onderzoek niet verder gegaan dan het inventariseren van de bestaande problemen waarbij de zojuist genoemde lange levertijden het voornaamste knelpunt vormde. Wat wel naar voren is gekomen is dat bij aankomst op de bouwplaats de kwaliteit van produkten niet altijd te controleren is omdat de montage in een aantal gevallen door de leverancier zelf wordt uitgevoerd. De nauwkeurigheid van de leveringsafspraken zijn sterk afhankelijk van het samenspel tussen de uitvoerder en de toeleveranciers.

\section{Evaluatie van de gevalsstudie}

Om uiteenlopende redenen (waaronder gebrek aan tijd en motivatie bij de ketendeelnemers en schaars cijfermateriaal) is de logistieke analyse in deze keten slechts gedeeltelijk uitgevoerd. De keukenfabrikant weigerde op concrete vragen in te gaan die een diepere analyse van het bedrijf ten doel hadden. Over wie de voornaamste klanten waren, konden geen mededelingen worden gedaan. De nadere analyse van het voorraadbeheer van keukens is niet gelukt door gebrek aan medewerking van het bedrijfsbureau bij het aannemersbedrijf wegens beperkte personele capaciteit. De poging om tot een prestatie-meting te komen is door gebrek aan motivatie van de kant van de ketendeelnemers niet verder gegaan dan een inventarisatie van bestaande problemen.

Uit deze analyse zijn echter wel een paar conclusies te trekken. Ten eerste werden de mogelijkheden voor logistieke afstemming door de hoofdaannemer sterk beperkt door afhankelijkheid van de medewerking van bewoners en de levertijden van de keukenfabrikant. Dit maakte het onmogelijk tot een strakke planning en centrale sturing van het bouwproject te komen. Ten tweede bleek van enige standaardisering in voorraadbeheer, bestelwijze en aanwezige marktinformatie geen sprake.

\subsection{De keten van hout en installatiemateriaal}

\subsubsection{Het bouwproject en de deelnemende bedrijven}

Het bouwpraject betreft hier de renovatie van 312 woningen en gebeurt in opdracht van een woningstichting. De snelheid van de bouwstroom bedraagt 10 woningen per week. Op dit gemiddelde hebben de partijen elkaar gevonden. De analyse heeft zich met name gericht op het bestel- en aanvoerproces van hout en de vraag of logistieke overwegingen een rol spelen in de voorbereidingsfase van het bouwproces. 
Tot de deelnemende bedrijven en organisaties in de houtketen behoren:

- de 'eindklant': de woningstichting;

- de eindafnemer: de aannemer;

- drie toeleveranciers: dakdekkers- en installatiebedrijf (installateur I);

installatiebedrijf (installateur II);

houthandel.

De houthandel zag geen mogelijkheid een van zijn toeleverende houtfabrikanten of importeurs bij deze gevalsstudie te betrekken. Figuur 11.6 geeft de onderzochte keten aan.

FIGUUR 11.6 De keten

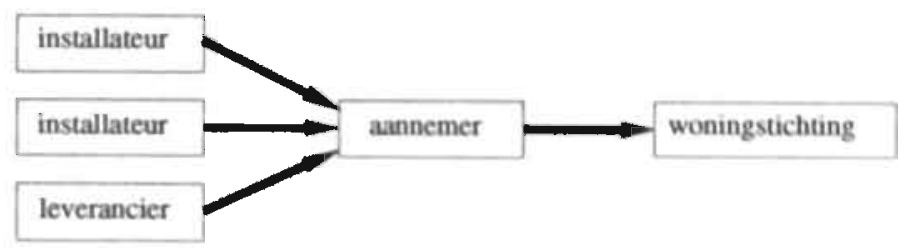

Bovengenoemde partijen werkten samen in een zgn. bouwteam. Dit betekent dat beoogd uitvoerder, de aannemer, door de initiatiefnemer, de woningstichting, al in de ontwerpfase is gevraagd deel te nemen aan de voorbereiding. Op die manier heeft de aannemer in het vroegste stadium al invloed gehad op de totstandkoming van het bouwproject.

De woningstichting, de opdrachtgever, omvat 115 medewerkers en is verantwoordelijk voor de verhuur van 9000 eenheden (inclusief winkels, garages etc.). De woningstichting is opdrachtgever van het renovatieproject. Een projectgroep binnen de woningstichting vervult de functie van architect.

De aannemer is een bouwmaatschappij van middelgrote omvang: 120 medewerkers waarvan 35 kantoormedewerkers en 12 uitvoerders. De aannemer heeft een meerjarige relatie met de woningstichting en is op grond van voorgaande projecten donr deze opdrachtgever gevraagd. De woningstichting geeft formeel opdracht na de subsidieverstrekking. Beide partijen, de aannemer en de opdrachtgever, bepalen in samenspraak met elkaar de potentiële onderaannemers. Ervaringen met onderaannemers in voorgaande projecten hebben grotendeels de keuze voor de onderaannemers bepaald.

De keten kent drie toeleveranciers: twee installateurs en een bouwmaterialenhandel.

De eerste installateur (installateur I) is een middelgrote werkmaatschappij van 100 medewerkers waarvan 35 installateurs. Het bedrijf ontplooit tal van activiteiten. Kern vormen het installatie- en het dakdekkerswerk. Van de twee installatiebedrijven in het renovatieproject heeft dit bedrijf het grootste en meest diverse werkpakket. Het bedrijf heeft een meerjarige relatie met de aannemer. 
De tweede installateur (installateur II) is een iets kleiner bedrijf met een omvang van 78 medewerkers. Het bedrijf richt zich grotendeels op de nieuwbouw. Deze installateur is op voordracht van de opdrachtgever als nieuwe onderaannemer bij het bouwproject betrokken. De reden hiervoor is onduidelijk gebleven.

De derde toeleverancier is een bouwmaterialenleverancier met een omvang van 20 medewerkers. Op het moment van onderzoek is de verkoop van hout en plaatwerk veruit het belangrijkste deel van de omzet. Het bedrijf is een van de vaste leveranciers van de aannemer en levert in dit bouwproject het hout.

Het doorgaan van het renovatieproject was afhankelijk van subsidieverstrekking van de Rijksoverheid. Een interne projectgroep van de woningstichting had de kosten voor verbetering eerst op fl. 30.000 per woning geschat. Later zijn in dit plan verbeteringen toegevoegd om de verhuurbaarheid op lange termijn veilig te stellen en kwam men op fl. 54.000 per woning uit. Na dakbedekking inclusief de isolatie uit het plan te hebben gehaald en minder ketels te plaatsen kwam men uit op fl. 45.000. De verdeling van het activiteitenpakket over de diverse (onder)aannemers is het resultaat geweest van langdurig getouwtrek binnen het bouwteam. De onderaannemers zijn van mening dat het totaal uit te voeren werkpakket uiteindelijk goed verdeeld is over de deelnemers.

Installateur II is verantwoordelijk voor de C.V.-installatie. Daaronder valt de vervanging van de moederhaard door een combiketell en vervanging of aanpassing van radiatoren en leidingwerk. Installateur I richt zich op de rest van het installatie-werk: de rookgasafvoer, de mechanische ventilatie en het loodgieterswerk (water en riolering). De houthandel is verantwoordelijk voor de toelevering van het hout, de voorbewerking, het op lengte maken van hout, het profileren en het transport. De aannemer doet bouwkundige werkzaamheden zoals het slopen, aftimmeren en afschilderen. Tot de activiteiten van de aannemer behoort ook transport en opslag van hout op de bouwplaats, sorteren van de diverse 'houtmerken' en het aanbrengen daarvan in het bouwwerk.

\subsubsection{Het bestel- en aanvoerproces van het hout}

Het toegeleverde hout op de bouwplaats wordt met name gebruikt voor de aftimmering van kozijnen. De werkroute hiervan is in onderstaande figuur weergegeven.

Voor de start van het werk worden door de afdeling werkvoorbereiding bij de aannemer uit bestek en tekeningen de hoeveelheden hout 'uitgetrokken'. Resultaat is een schema met hoeveelheden hout per merk en maat voor het project. Op basis hiervan worden voorlopige leverschema's gemaakt. Per merk wordt een aparte offerte aangevraagd.

Tijdens het werk wordt een halve week voor de daadwerkelijke levering afgeroepen. De houthandel beschikt over definitieve leverschema's gedurende het hele bouwproces en weet al dat in week $\mathrm{x}$ zoveel geleverd moet worden. Een week voor levering wordt de order bij de houthandel klaargemaakt. Tijdens de uitvoeringsfase worden niet al te grote veranderingen in de bestelde hoeveelheid hout evenredig in de prijs verwerkt. 
Eenmalig bij de voorbereidingsfase van het project:

1. Hoeveelheden 'uittrekken' door werkvoorbereiding bij de aannemer.

2. Voorlopig leverschema maken.

3. Offerte-aanvraag bij de toeleverancier.

4. Definitief leverschema maken.

Meerdere malen tijdens de uitvoering op de bouwplaats:

5. Afroepen door uitvoerder op de bouwplaats.

6. Levering: lossen op de bouwplaats door leverancier, controle, sortering en opslaan door medewerkers van de aannemer.

7. Transport naar werkplek.

8. Verwerking in het bouwwerk.

De houtfabrikant levert de houthandel ruwhout en plaatmateriaal. Bij houthandel wordt dit hout en plaatmateriaal op de gewenste maat gezaagd en gegrond. Er zijn echter ook fabrikanten die hout bij bepaalde minimale afname-hoeveelheden op de exacte maat gezaagd, geschaafd en geverfd toeleveren. Ook in dit project wordt een deel van het hout bij de houthandel zo geleverd dat daar geen verder bewerkingen meer nodig zijn. De levertijd van de diverse houtsoorten naar de houthandel toe varieren van drie dagen tot zes weken.

Bij levering op de bouwplaats zet de 'zelflosser' van de houthandel (een hijskraantije op de vrachtwagen) hout in twee bundels voor de nishut. De (assistent-)uitvoerder controleert met leverschema en leverbon merk, aantal en kwaliteit. 's Middags worden in de 'dooie uren' de geleverde bundels gesorteerd naar merk en in de rekken van de nishut gedaan.

Iedere middag worden houtmerken per kozijn voor de produktie van de volgende dag gebundeld. De volgende ochtend worden bundels met gereedschap op een kar van de nishut naar de steigerlift gereden. Vanaf de wagen worden bundels en gereedschap op de lift gelegd. Boven op de steiger wordt dit materiaal van de lift naar de plaats van verwerking gesjouwd. Binnen de woning wordt de maat opgenomen, het hout op maat gezaagd en aangebracht. Tijdens het bouwproces wordt een opname gemaakt van wat wordt verbruikt en of afmetingen kloppen. Op basis hiervan worden eventueel aanpassingen in het leverschema aangebracht.

\subsubsection{Analyse van het planningsproces}

\section{De aannemer en opdrachtgever als dominunte actoren: theorie en praktijk}

In de voorbereidingsfase richten de onderhandelingen in het bouwteam over de verschillende renovatie-varianten zich voornamelijk op de kosten. Er is in dit stadium geen of zeer weinig belangstelling om de logistieke consequenties van de diverse varianten te doordenken. Reden hiervoor is enerzijds het niet beschikbaar zijn van detailinformatie, anderzijds omdat de partijen eerst het werk binnen willen hebben. Nadat het werk 'gegund' is, de opdrachtverlening, en verdeeld over de verschillende partijen begint het planningsproces. Tijdens dit planningsproces blijkt dat de partijen in het bouwteam 
duidelijk te onderscheiden posities innemen. Binnen het bouwteam zitten aannemer en opdrachtgever, die tegelijkertijd de architectenrol vervult, op één lijn en vormen tezamen de sturende partij. De hoofdaannemer stelt zich in het planningsproces op als coördinator en heeft voor de onderaannemers een dagplanning gemaakt (zie figuur 11.8).

FIGUUR 11.8 De dagplanning voor een woning

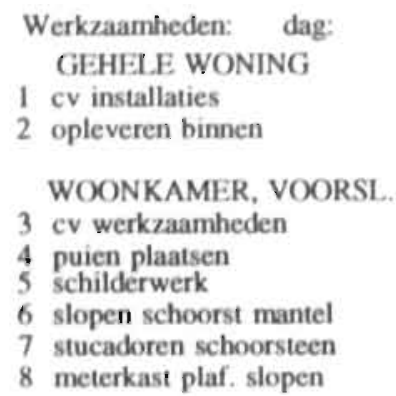

DOUCHEWERKZAAMH

9 boorwerk

10 slopen leid. noodwater

11 slopen lavet, tegels

12 afsteken plaf. wanden

13 uitvlakken wanden

it itgealwerk, inwassen

15 afvoer- en rookgas leiding

16 elektra aanbrengen

17 vloeropstorting

18 afmontage loodgieter

19 schilder-, saucewerk

20 vloer smeren

21 vloer afsealen KEUKENWERKZAAMH

22 boorwerk

23 slopen, noodkeuken

24 afsteken wanden, plafond

25 uitvlakken stucwerk.

26 tegelwerken

27 loodgieterleid.

28 clektrawerken

$29 \mathrm{cv}$ installeren

30 keuken stellen, deur

31. afmontage, loodgieter

32 schilder, saucewerk ACHTERSL.K.,-KAST

33 opvangen water boorwerk

34 boorwerk in kast

35 leidingen rookgas

36 kast afwerken

37 puien aanbrengen

38 cv werkzaamheden

39 schilderwerk

40 VINYLITH VOORGEVEI

41. VINYLITH ACHTERG.

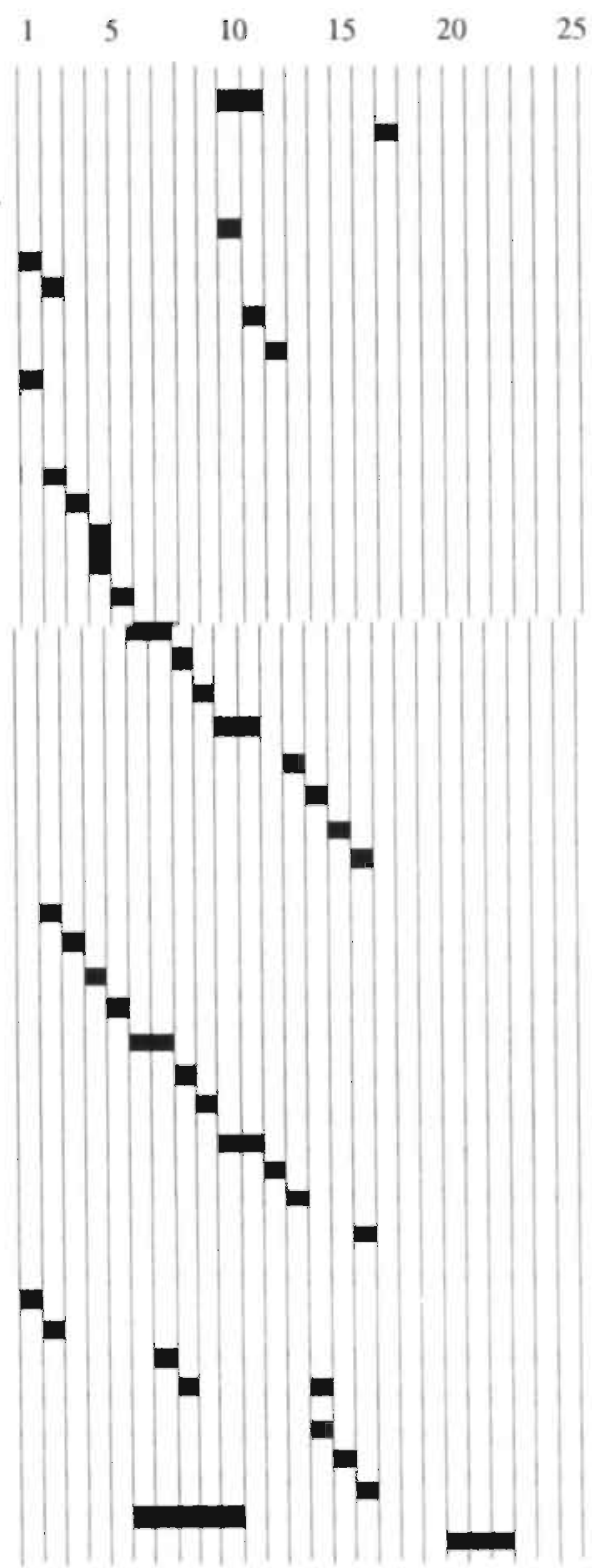


In diverse bouwvergaderingen wordt deze dagplanning ter discussie gesteld. Doelstelling van de aannemer is om de planning van het hele uitvoeringsproces vooraf doordacht en op papier te hebben.

Het installatiebedrijf I met het grootste werkpakket heeft, hoewel hij wel daarvoor is uitgenodigd, geen actieve inbreng in de planning van de aannemer. Het bedrijf beschouwt investeren in planning als tijdsverspilling. Men ziet tijdens de uitvoering wel of het geplande aantal medewerkers voldoet. Het installatiebedrijf II met een beperktere inbreng heeft een veel actievere inbreng in de planning van de aannemer. Dit komt omdat dit bedrijf, gezien zijn afhankelijkheid van andere partijen, gebaat is bij een goede planning. De bouwmaterialenhandel is niet actief in het bouwteam betrokken en doet niet meer dan het op afroep afgeven van prijzen.

Het installatiebedrijf met het grootste werkpakket heeft als uitgangspunt de uitvoering te starten met een minimale bezetting die zonodig in de praktijk bijgesteld wordt tijdens de uitvoering. Gezien de vele werkzaamheden en onzekerheden ziet dit bedrijf geen kans een detailplanning op te stellen. Helemaal vreemd is dit niet. Een echte detailplanning kan pas enige weken voor de start van de werkzaamheden gemaakt worden omdat dan de meeste keuzes van de bewoners bekend zijn. Het komt overigens ook voor dat tijdens de uitvoering nog wijzigingen van bewoners verwerkt moeten worden. Opvallend is dat dit bedrijf van de informatie van de zgn. opname (in welk huis welke werkzaamheden) slechts beperkt gebruik maakt.

Ook na 'gunning' van het werk richt de aandacht van de partijen zich voornamelijk op de te maken kosten die voornamelijk bepaald worden door manuren en materialen. Het belangrijkste uitgangspunt van de individuele bedrijven is ervoor te zorgen dat er tijdens de uitvoering sprake is van een optimale bezetting van de medewerkers. Centrale vraag hierbij is of medewerkers elke werkdag efficiënt ingezet kunnen worden. Ervaringen uit voorgaande projecten vormen hierbij een belangrijke leidraad: men heeft al eerder een vergelijkbaar project gedaan en dat ging goed.

\section{Altematieven voor planning en toelevering}

Het bespreken van alternatieven in planning en toelevering bieden mogelijkheden logistiek in het voorbereidingstraject te betrekken. Twee zaken zijn verder geanalyseerd.

Ten eerste is geprobeerd aan de hand van interviews motieven voor bepaalde keuzes in de dagplanning te achterhalen. Zoals boven is aangegeven kwam daaruit een sterk wisselend beeld naar voren. Het installatiebedrijf met het kleinste werkpakket kan gedetailleerd aangeven waarom gepland is zoals gepland. Relaties met anderen zijn volgens dit bedrijf in de planning goed doordacht. Daarentegen is cle planning bij het andere installatiebedrijf veel minder doordacht. Voor de mensen op bouwplaats van dit bedrijf vormt de weekplanning waarop het aantal 'lichte' en 'zware' woningen aangegeven staat het uitgangspunt. Deze installateur beweert voldoende flexibiliteit te hebben en, zoals gezegd, geen grote waarde te hechten aan een nauwkeurige planning vooraf.

Ten tweede zijn in overleg met de ketendeelnemers alternatieve planningen voor de toelevering van aftimmerhout opgesteld en geanalyseerd. Tijdens het bouwproject wordt ongeveer één keer in de twee à drie weken hout geleverd per blok van 24 wo- 
ningen, gesorteerd op merk. In overleg met de bouwteamleden zijn een aantal alternatieve varianten omschreven om het aftimmerhout van de houthandel aan te voeren naar de werkplek. Deze alternatieven hadden betrekking op een hogere frequentie van toelevering (één keer per week of zelfs iedere dag) en wijze van bundeling van het hout (per merk of per kozijn, d.w.z. de specifieke latjes voor een specifiek kozijn zijn reeds door de houthandel bijeengevoegd). Zowel door de aannemer als door de houttoeleverancier zijn voor- en nadelen van alternatieve vormen van houttoelevering aangegeven. In het meest 'extreme' alternatief vindt iedere dag toelevering van dagproduktie plaats gebundeld per kozijn, d.w.z. toelevering van een aantal bundeltjes hout voor specifieke kozijnen. Dit alternatief is een voorbeeld van 'just-in-time' leveren op de bouwplaats. De voor- en nadelen van deze wijze van toelevering zijn in onderstaande figuur aangegeven.

FIGUUR 11.9 Voor- en nadelen van just-in-time levering van hout op de bouwplaats

$\begin{array}{ll}\text { Voordelen aannemer: } & \text { - geen sorteer uren } \\ & \text { - bijna geen opslag } \\ & \text { - goede materiaa! bewaking } \\ & \text { - } \text { snel in kunnen spelen op maatafwijkingen } \\ \text { Nadelen aannemer: } & \text { - leegloop } \\ \text { Voordelen toeleverancier: } & \text { - versterking concurrentiepositie door flexibiliteit } \\ \text { Nadelen toeleverancier: } & \text { - hogere transportkosten } \\ & \text { - elke morgen transportmiddel kwijt } \\ & \text { - meer sorteerwerk (hoeft geen nadeel te zijn) } \\ & \text { - moet voorraad houden } \\ & \text { - meer omsteluren machines omdat kleinere series } \\ & \text { van houtmerken voorbewerkı moeten worden }\end{array}$

Voor- en nadelen van de andere alternatieven liggen tussen bovengenoemd extreem alternatief́ en de bestaande situatie in.

\section{Evaluatie van de gevalsstudie}

Het ai dan niet doorgaan van het bouwproject was afhankelijk van subsidies van de Rijksoverheid. Gevolg hiervan was dat tijdens het ontwerpproces grote onzekerheden bîeven bestaan en men na subsidieverlening onder enorme tijdsdruk met de uitvoeringsactiviteiten startte. Desondanks werd bij dit project door de aannemer in het bouwteam gestreefd naar een goed doordachte planning en afstemming van uitvoeringswerkzaamheden. Bij het opzetten van deze planning werden direct betrokken onderaannemers en toeleveranciers nauw betrokken. Ondanks deze mogelijkheden om vooraf in het bouwteam tot een logistieke afstemming te komen gaven de onderaannemers de voorkeur aan afstemming van (logistieke) activiteiten tijdens de uitvoering van de renovatieproject. Men dacht dat dit minder tijd zou kosten dan in een vroeg stadium alles gedetailleerd te plannen. Uit de bespreking van alternatieven in planning en toelevering met de ketendeelnemers kwam naar voren dat de behoefte om in andere oplossingen te denken zeer beperkt aanwezig was. Ondanks het feit dat men een bouwteam vormde, prevaleerde het bedrijfsbelang boven het projectbelang. 


\subsubsection{Het bouwproject en de deelnemende bedrijven}

Het bouwproject is een kantoor bestaande uit een gebouw van 6 verdiepingen en een vleugel met drie verdiepingen. De totale aanneemsom van het project bedraagt tussen de 20 en 25 miljoen gulden en de looptijd 22 maandien: van oktober 1992 tot en met juli/augustus 1994. Het is hoofdzakelijk een prefab-gebouw: gevelelementen, balken, kolommen, vloeren, trappen en bordessen zijn van prefab beton.

De analyse beperkt zich in deze gevalsstudie tot de keten van prefab gevelelementen. Deze gevelelementen kunnen onderscheiden worden in enkelvoudige binnenbladen, enkelvoudige buitenbladen en tweebladige elementen (sandwich- of samengestelde elementen). De samengestelde elementen kunnen worden uitgevoerd met een gescheiden binnen- en buitenblad, namelijk met een luchtspouw, In dit project worden sandwich-elementen toegepast zonder luchtspouw. Het prefab skelet met tussen de 200 en 250 gevelelementen vormt een belangrijk onderdeel van het gebouw. De belangrijkste maat van een prefab gevelelement bedraagt in dit project $7200 \mathrm{~mm}$ bij $3500 \mathrm{~mm}$ (7200 $\mathrm{mm}$ is een veel gebruikte maat bij gevelelementen). Het prefab-gevelelement heeft een raamopening en is aan de buitenkant geheel afgewerkt met tegels.

Deelnemende bedrijven aan deze gevalsstudie zijn de aannemer en de toeleverancier van prefab gevelelementen.

Het aannemersbedrijf is onderdeel van een dochter van een van Nederlands grootste aannemers. Het betreft hier een regio-vestiging waarvan de omzet over 1992 ongeveer 30 miljoen bedroeg. In de buitendienst van de regio-vestiging was op het moment van onderzoek niemand in vaste dienst, binnen werkten 17 werknemers. De aannemer richt zich met name op de utiliteitsbouw. Onderhoud en property management wordt als iets voor de toekomst gezien.

De fabrikant van gevelelementen heeft 100 tot 130 medewerkers in dienst. De fabrikant heeft geen andere vestigingen in Nederland en is onderdeel van een groep bestaande uit drie bouwbedrijven, twee bouwmaterialenfabrikanten en een bouwmaterialenhandel. De fabrikant van gevelelementen maakt uitsluitend maatwerk dat direct op de bouwplaats wordt geleverd. Palen, buizen en vloeren behoren niet tot het assortiment. De fabrikant is een specialist in het vervaardigen van prefab constructies in gewapend beton alsmede gevelelementen, zowel enkelvoudig als sandwich.

$\mathrm{Bij}$ dit bouwproject heeft de opdrachtgever de aannemer aangezocht voor een bouwteam. De fabrikant van prefab gevelelementen is niet door de opdrachtgever maar úvor de aannemer via aanbesteding bij het project butrokken. De hoofdaannemer heeft al vaker samengewerkt met deze fabrikant. De fabrikant heeft bij dit bouwproject voorbereidend werk in het offerte-stadium gedaan in ruil voor een aanvraag. Deze aanvraag vormde echter geen garantie dat de fabrikant het werk ook daadwerkelijk zou krijgen.

De voornaamste taak van de aannemer is de coördinatic tussen de verschillende partijen. Produktie en montage van gevelelementen en vloeren zijn in dit project geheel uitbesteed aan de fabrikant. Bij een grote hoeveelheid gevelelementen is een dergelijke 
uitbesteding gebruikelijk. De fabrikant heeft op zijn beurt de produktie van trappen, bordessen en vloerplaten en een deel van de montage uitbesteed. Omdat de fabrikant een grote afnemer van vloerplaten is kan deze prijsvoordelen verkrijgen die een individuele aannemer niet zou kunnen bedingen. Indien in een bouwkundig werk slechts enkele gevelelementen verwerkt moeten worden, monteert de aannemer ze vaak zelf.

\subsubsection{Produktie- en toeleverproces van prefab gevelelernenten}

De produktieketen van gevelelementen bestaat uit de fasen voorbereiding en ontwerp, produktie en transport en montage.

Voorafgaand aan de start van de uitvoering is sprake geweest van jarenlange onderhandelingen tussen de aannemer en in feite drie opdrachtgevers (een administratiekantoor, een projectontwikkelaar voor kantoren en de gemeente voor een parkeergarage). Deze onderhandelingen hebben een aantal wijzigingen in het ontwerp tot gevolg gehad. Dure materiaaltoepassingen zijn vervangen door goedkopere alternatieven. Dit geldt ook voor de buitenkant van het gevelelement. Deze bestond eerst uit natuursteen maar wordt nu met keramiek tegels afgewerkt. Een andere bezuiniging is het verdwijnen van de complete kelder uit het ontwerp. Het project is door de geïnterviewden wel vergeleken met een harmonica. Eerst was er een prachtig ontwerp dat ver boven het budget uitkwam (de architect 'rekte het ontwerp op'). Vervolgens moest in een aantal bezuinigingsronden het ontwerp weer binnen het budget gebracht worden (alles moest verminderd worden).

Nadat het ontwerp in grote lijnen was vastgesteld heeft de aannemer de fabrikant gevraagd wat voorbereidend werk te doen in ruil voor een aanvraag. Nog voordat het werk officieel is aanbesteed aan de fabrikant komt een proces van vervaardigen en controleren van tekeningen op gang.

FIGUUR 11:10 Procedure voor tekeninguitwisseling

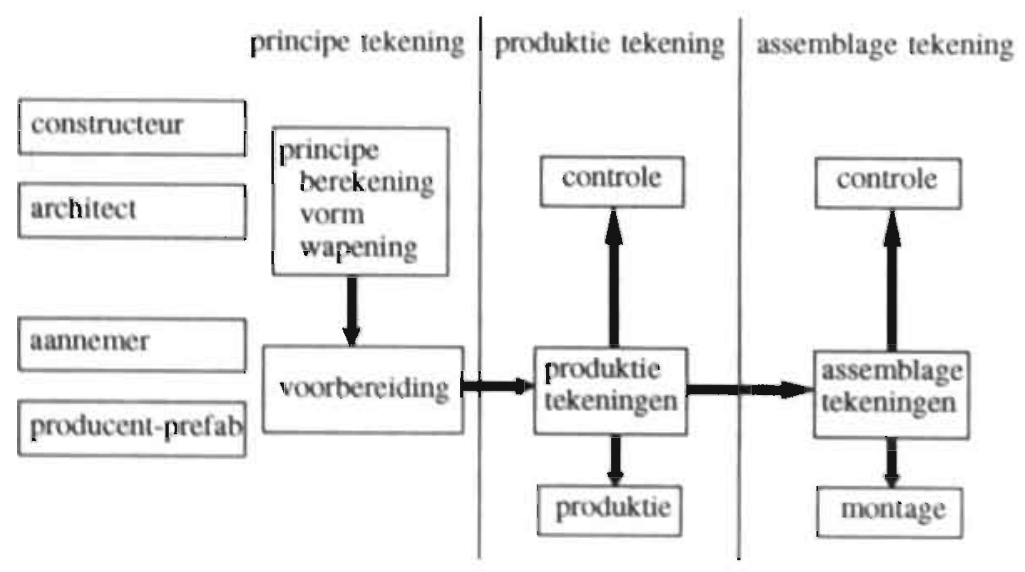


Hierbij worden een aantal 'tekenprocedures' doorlopen gericht op het definitief maken van de tekeningen voor produktie bij de fabrikant. Hierbij maken de ontwerpende partijen (architect en adviseurs, de constructeur en de installatie-technisch ontwerper) de principe-tekeningen. Deze tekeningen bevatten informatie over afmetingen, verbindingen, typen en aantallen. De fabrikant maakt in overleg met de werkvoorbereider van de aannemer de produktie- en assemblage-tekeningen. Deze tekeningen worden vervolgens weer gecontroleerd door de ontwerpende partijen. Het is de aannemer die de uitwisseling van de tekeningen tussen deze partijen en de fabrikant coördineert.

Naast uitwisseling van tekeningen worden om de twee weken coördinatievergaderingen gehouden. Deze vergaderingen worden bijgewoond door de architect, de instailateur, de constructeur, aan- en onderaannemers en toeleveranciers. Tijdens deze vergaderingen komt in overleg een bouwschema tot stand (zie figuur 11.11).

Uit het bouwschema (zie figuur 11.11) blijkt dat maanden voor montage op de bouwplaats het ontwerp van de gevelelementen gedetailleerd moet vastliggen. Van begin oktober tot half mei vindt de produktie van de prefab gevelelementen plaats. Voor de start van de produktie zijn reeds dertien weken aan de uitwerking van tekeningen besteed. In februari wordt met de montage begonnen. De totale voorbereidingstijd voor montage van het eerste element bedraagt ongeveer een half jaar: drie maanden voor de uitwerking van de tekeningen en drie maanden voor de produktie. Omdat een half jaar voor montage gedetailleerde ontwerpgegevens vereist waren begon de fabrikant van de elementen reeds met de werkvoorbereiding op basis van een groffe overeenstemming over tekeningen en bestek. Op dat moment was van een officiële opdracht nog geen sprake en een definitieve keuze van de toeleverancier nog niet gemakkt.

FIGUUR 11.11 Bouwschema

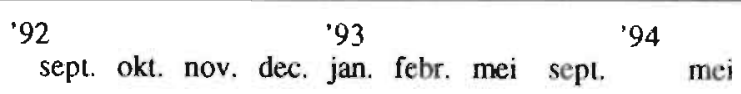

1. Bouwterrein inrichten

2. Heien

3. Fundatie (4 weken)

4. Produklie prefab

5. Montage prefab (70 dagen)

6. Ruwe afbouw

7. Glas- en waterdicht

8. Afbouw 
De uitwerking van tekeningen gaat gedurende de produktie van prefab gevelelementen gewoon door. Van belang is dat voor de start van de produktie de hoofdmaten van een mal bekend zijn. Voor de 'nevenmerken', d.w.z voor de elementen die alleen variëren qua sparingen, verbindingen etc., wordt het tekenwerk tijdens produktie gedaan. Voor de verschillende 'merken' worden zo achter elkaar delen van tekeningen uitgewerkt. Twee weken voor produktie van een specifiek element moet het tekenwerk echter definitief af zijn. De tekeningenplanning hangt dan ook direct vast aan de produktieplanning.

Nadat de tekeningen echt definitief zijn is slechts in uitzonderlijke omstandigheden een verandering mogelijk omdat een kleine verandering grote consequenties kan hebben. Een verdiepingsverlaging van $1 \mathrm{~cm}$. betekent dat iedere tekening aangepast moet worden: trappen passen niet meer en er is minder vrije ruimte bij de plafonds met als gevolg problemen met installatie. De constructie van de mallen en de opbouw van de wapening dienen in details afgestemd te zijn op het ontwerp.

In een vroeg stadium, tijdens de produktie in de fabriek, controleren opdrachtgever en aannemer elementen op maatvoering, uiterlijk, kleur en eventueel krom trekken. Binnen vastgestelde marges mogen hierbij beperkte afwijkingen optreden. Deze controle is van groot belang omdat afkeuring van een gevelelement op de bouwplaats tot grote problemen kan leiden: het gebouw kan niet wind- en waterdicht gemaakt worden of er treedt een ernstige verstoring in de bouwstroom op.

In de fabriek zijn voor de produktie van gevelelementen in dit project vier mallen gebruikt die nagenoeg gelijktijdig worden ingezet. Per mal zijn één tot vier personen nodig afhankelijk van de malgrootte. In de mal, waar al dan niet wapening is ingebracht, wordt betonmortel gestort. Betonmortel bestaat uit zand, grind en cement. De verhardingstijd van betonmortel bedraagt maximaal een dag. Stoom versnelt de verhardingstijd en roept chemische reacties op die de sterkte beïnvloeden. In dit project worden keramick tegels als bekledingsmateriaal aan het gevelelement toegevoegd met de zgn. vacuümmethode. Dit betekent dat in een mal tegels liggen die met vacuümzuigers worden vastgehouden. Men voorkomt zo dat de tegels tijdens het storten van de betonmortel gaan schuiven. Een ander systeem, dat tijdens dit bouwproject niet gebruikt wordt, is het lijmen van tegels op een verhard gevelelement. Dit lijmen kan gewoon door een tegelzetter gebeuren.

Nadat de gevelelementen geproduceerd zijn worden deze op een opslagplaats bij de tabrikant geplaatst. Hier worden de elementen geînspecteerd op eventuele beschadigingen. De aannemer betaalt de fabrikant voor wat geproduceerd is. Daarvoor is door beide partijen een aparte juridische constructie opgezet. De aannemer huurt bij de fabrikant een stukje grond en wanneer daar geleverd wordt geldt dat het element eigendom is van de aannemer. De rekeningen kunnen dan naar de aannemer gestuurd worden. Nadat de elementen korte of langere tijd op voorraad hebben gestaan (dit kan variëren van een dag tot twee maanden) worden de elementen met een dieplader naar de bouwplaats getransporteerd.

De fabrikant monteert in het project zelf de gevelelementen. De totale montage-tijd bedraagt 70 dagen waarvan 55 dagen voor de hoogbouw (zes hoog) en 15 dagen voor laagbouw (drie hoog). De montagetijd per verdieping bedraagt bij de hoogbouw gemid- 
deld negen dagen en bij de laagbouw vier. Het montage-team van de fabrikant bestaat uit één uitvoerder en zes personen uitvoerend personeel.
Bij de discussie over de stapelvolgorde zijn vier alternatieven overwogen:
a. eerst hoogbouw dan laagbouw;
b. eerst laagbouw dan hoogbouw;
c. verspringend: eerste verdieping hoogbouw, dan eerste verdieping laagbouw, tweede verdieping hoogbouw, tweede verdieping laagbouw etc.;
d. verspringend: eerste verdieping laagbouw, dan eerste verdieping hoogbouw, tweede verdieping laagbouw, tweede verdieping hoogbouw etc.;

Gekozen is voor alternatief a. Dit heeft te maken met het feit dat op de zesde verdieping van de hoogbouw op de gevelelementen een staalconstructie komt en vervolgens weer prefab-elementen. De montage-volgorde is daarom als volgt:
a. montage van de hoogbouw;
b. montage van de laagbouw door de gevelfabrikant en tegelijkertijd plaatsing van de staalconstructie op de hoogbouw door een ander bedrijf;
c. afmaken hoogbouw door de gevelfabrikant;
Bij alternatief b. zou de gevelfabrikant een gat in de montage-stroom hebben gehad doordat het moest wachten op plaatsing van de staalconstructie. Met volgorde a. is dit ondervangen.

\subsubsection{Afstemming tussen ontwerp produktie en montage}

Logistieke aspecten hebben bij de discussies over het ontwerp slechts zijdelings een rol gespeeld. Belangrijke oorzaak hiervoor is dat de fabrikant pas bij het ontwerp is betrokken toen dit reeds in grote lijnen vast lag. Een ontwerp voor een prefab gebouw heeft echter grote invloed op de kosten voor het maken van de tekeningen, produktie van de elementen en assemblage daarvan op de bouwplaats. Factoren die de uiteindelijke kosten van produktie en montage bepalen zijn:

a. de verhouding tussen hoeveelheid werk en de hoeveelheid beton: een balk van 50 ton in één mal met $20 \mathrm{~m} 3$ vereist betrekkelijk weinig afwerking en heeft dus een lagere prijs per m3. Twintig balken van 2,5 ton vereisen echter meer werk en hebben dus een hogere prijs per eenheid gewicht.

b. de mate van repetitie: duizend keer dezelfde balk of honderd keer tien verschillende;

c. de complexiteit van het prefab element;

d. de uitvoeringsmogelijkheden op de bouwplaats (ruimte, maximaal hijsgewicht);

e. de bouwtijd: dit bepaalt de hoeveelheid gebruikte mallen. Een korte bouwtijd vereist meer mallen die tegelijkertijd worden ingezet. Dit betekent extra kosten vanwege de opbouwkosten per mal.

Het traditionele bouwproces heeft tot gevolg dat de fabrikant moet werken met ontwerpen waar hij zelf geen invloed op gehad heeft. Daardoor kunnen extra kosten ontstaan in de afstemming tussen produktie en montage. Dit afstemmingsprobleem doet zich in de meest simpele vorm voor als het probleem van de verticale produktie versus de horizontale montage. Bij verticale produktie (een begrip dat niet al te letterlijk moet worden genomen) maakt men eerste de elementen van bijv. merk a, vervolgens van merk b enz. Omdat bij gebouwen gelijksoortige merken vaak boven elkaar liggen spreekt men van verticale produktie. Gebruikelijk is echter ecn horizontale 
montage. Hierbij worden de elementen per verdieping, bouwlaag-gewijs gemonteerd (zie figuur 11.12).

FIGUUR 11.12 Verticale produktie versus horizontale montage

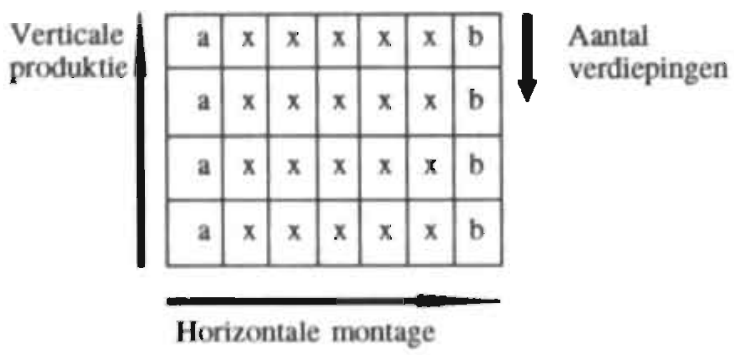

Deze volgorde van stapelen van beton-elementen is vaak niet gelijk aan de meest efficiënte produktie-volgorde in de fabriek. Oorzaak hiervoor zijn hoge op- en ombouwkosten van mallen. De kosten van de malopbouw zijn het laagst als tijdens de produktie de mallen variëren van groot naar klein. Dit betekent dat eerst de grote elementen geproduceerd worden, dan de kleine. Voordeel van deze produktiewijze is dat men met minder opbouw- en ombouwkosten van de mallen kan volstaan. Nadeel is dat in het systeem grotere werkvoorraden liggen besloten. Ander nadeel is dat voor de start van de produktie van elementen het gedetailleerde ontwerp van de laagste tot de hoogste verdieping definitief moet zijn. In het begin van het produktieproces worden ook elementen gefabriceerd die op de hoogste verdieping gemonteerd zullen worden.

Met de inzet van meerdere mallen kan door bouwtijdverkorting voorraadvorming worden verminderd en een betere afstemming tussen produktie en montage plaats vinden. In figuur 11.13 is een voorbeeld gegeven van een kantoorgebouw met vier bouwlagen.

\begin{tabular}{|c|c|c|c|c|c|c|c|}
\hline $\mathrm{A} 3$ & $\mathrm{~B} 3$ & $\mathrm{~B} 3$ & $\mathrm{~B} 3$ & $\mathrm{~B} 3$ & $\mathrm{~A} 6$ & $\mathrm{C} 3$ & $\mathrm{C} 6$ \\
\hline $\mathrm{A} 2$ & $\mathrm{~B} 2$ & $\mathrm{~B} 2$ & $\mathrm{~B} 2$ & $\mathrm{~B} 2$ & $\mathrm{~A} 5$ & $\mathrm{C} 2$ & $\mathrm{C} 5$ \\
\hline $\mathrm{A} 2$ & $\mathrm{~B} 2$ & $\mathrm{~B} 2$ & $\mathrm{~B} 2$ & $\mathrm{~B} 2$ & $\mathrm{~A} 5$ & $\mathrm{C} 2$ & $\mathrm{C5}$ \\
\hline $\mathrm{A} 1$ & $\mathrm{~B} 1$ & $\mathrm{~B} 1$ & $\mathrm{~B} 1$ & $\mathrm{~B} 1$ & $\mathrm{~A} 4$ & $\mathrm{C} 1$ & $\mathrm{C4}$ \\
\hline
\end{tabular}


Het voorbeeld is een vereenvoudigde weergave van het afstemmingsprobleem in het onderzochte bouwproject. De 'langsgevels' bestaan ieder uit zes elementen met ieder een lengte van $7200 \mathrm{~mm}$, de 'kopgevels' bestaan ieder uit twee elementen met een lengte van $6300 \mathrm{~mm}$. De merken A, B en C zijn de zgn. 'hoofdmerken, A1, A2, B1, B2 etc. worden wel aangeduid als de 'nevenmerken'. Zoals gezegd zijn de opbouwkosten van een mal in het algemeen groot en daarom is bij een project de meest economische produktiewijze is per hoofdmerk één mal te gebruiken (zie figuur 11.14).

FIGUUR 11.14 Produktieplanning I

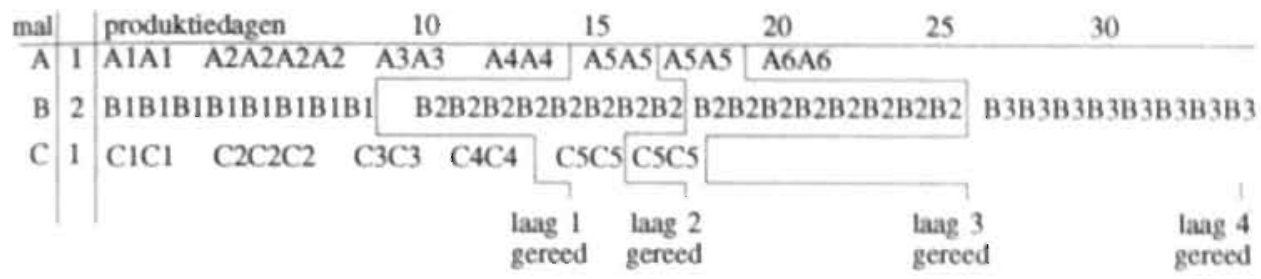

N.B.: Na overgang naar een ander nevenmerk is een dag nodig voor het aanpassen van de mal.

De bouwtijd kan worden verkort door bij het kritieke moment een extra mal in te zetten. Voor merk B worden nu niet één maar twee mallen ingezet (zie figuur 11.15). In dit voorbeeld wordt de bouwtijd daardoor verkort van 34 naar 21 dagen. De start wordt in dit geval niet vervroegd.

In de praktijk is een economische produktie-volgorde zelden haalbaar. Vaak moeten produktie-series een aantal keren onderbroken worden voor elementen die eerder nodig zijn en geproduceerd dienen te worden. Er wordt echter gestreefd naar een zo'n hoog mogelijke seriematigheid. Gevolg is dat elementen soms een dag en soms twee maanden op voorraad staan bij de betonfabrikant.

FIGUUR 11.15 Produktieplanning 11

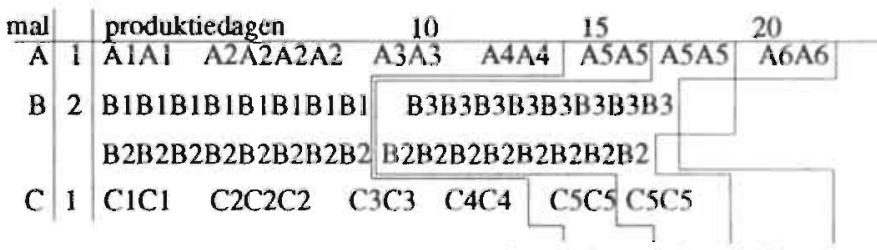

laag 1 laag 2 laag $3 i$ laag 4

gereed gereed gerecd gereed 


\section{Evaluatie van de gevalsstudie}

In deze gevalsstudie is naar voren gekomen dat voor de start van de produktie van gevelelementen de uitwerking en afstemming van detailtekeningen twee tot drie maanden in beslag neemt. Bij prefabrikage van gevelelementen moeten gedetailleerde afspraken over ontwerp reeds in een vroeg stadium bekend zijn.. Dit vereist met name in het voorbereidingstraject veel communicatie gericht op het bereiken van overeenstemming over de ontwerptekeningen. Bij het traditionele bouwproces leidt dit tot een aantal problemen omdat de fabrikant relatief laat bij het bouwproject betrokken wordt. Ten eerste zet dit het voorbereidingstraject voor de produktie sterk onder druk omdat de aannemer na aanbesteding zo snel mogelijk met de uitvoering wil starten en dus elementen op de bouwplaats toegeleverd wil zien. Ten tweede betekent het niet in een vroeg stadium betrokken zijn bij het ontwerp dat de fabrikant minder sturingsmogelijkheden heeft voor een afstemming tussen ontwerp, produktie en montage. Mogelijke kosten-besparingen door een afstemming tussen ontwerp van de constructie, de produktie-volgorde van elementen in de fabriek en de montage daarvan op de bouwplaats blijven hierdoor onbenut.

\subsection{De keten van betonelementen ${ }^{3}$}

\subsubsection{Het bouwproject}

Het project, de nieuwbouw van het Ministerie van VROM, is een gebouw bestaande uit vijf vrijwel identieke dwarsvleugels van 60 meter hoogte. Tussen de dwarsvleugels zitien tussenruimten van 21,60 meter. De vier tussenruimten zijn volledig overdekte serres. Deze serres met een zogenaamd halfklimaat zijn in feite buitenruimten waaruit nadelen als stank, wind- en geluidhinder zijn geweerd zodat men rustig de ramen van de kantoorruimten kan openzetten. Op de begane grond bevinden zich winkels, een kantoof, een centrale hal en de openbare voorzieningen van het ministerie. Van de viepde tot en met de zestiende verdieping worden de verdiepingen onderling verbonden door tussenliggende vloeren. Hierdoor ontstaat een 'middenrif' met een lengte van 140 meter. Op de kruispunien van het middenrif en de dwarsvleugels bevinden zich de zgn. 'kernen', waarin liften, leidingschachten, trappenhuizen en toiletgroepen zijn ondergebracht. Deze kernen zijn (vanaf de vierde verdieping) steeds met elkaar verbonden door een lange gang over de gehele lengte van het gebouw. De kernen zijn voor 99 procent in prefab beton uitgevoerd. De zestiende en de zeventiende verdieping van de dwarsvleugels zijn gereserveerd voor technische installaties.

Het gebouw wordt op de begane grond op twee plaatsen doorsneden door openbare routes: een verhoogde trambaan en een route voor langzaam verkeer. Deze routes bevinden zich tussen de dwarsvleugels. Eisen van het openbaar vervoersbedrijf en de gemeentelijk overheid maakten het niet mogelijk tussen de dwarsvleugels kolommen te plaatsen voor het dragen van middenrifvloeren. Boven de trambaan en de langzaamverkeersroute bevinden zich twaalf bouwlagen. Deze bouwlagen worden d.m.v. een

${ }^{3}$ Deze gevalsstudie is gebaseerd op bestudering van de vele publicaties die over dit bouwproject verschenen zijn. De belangrijkste daarvan zijn 'Nieuwbouw Ministerie VROM' van ing. B.G.M. Geutjes en 'Logistiek en maatvoering' van ir. M. Broos. Beide artikelen zijn verschenen in het vakblad Cement $(1991 / 2)$. 


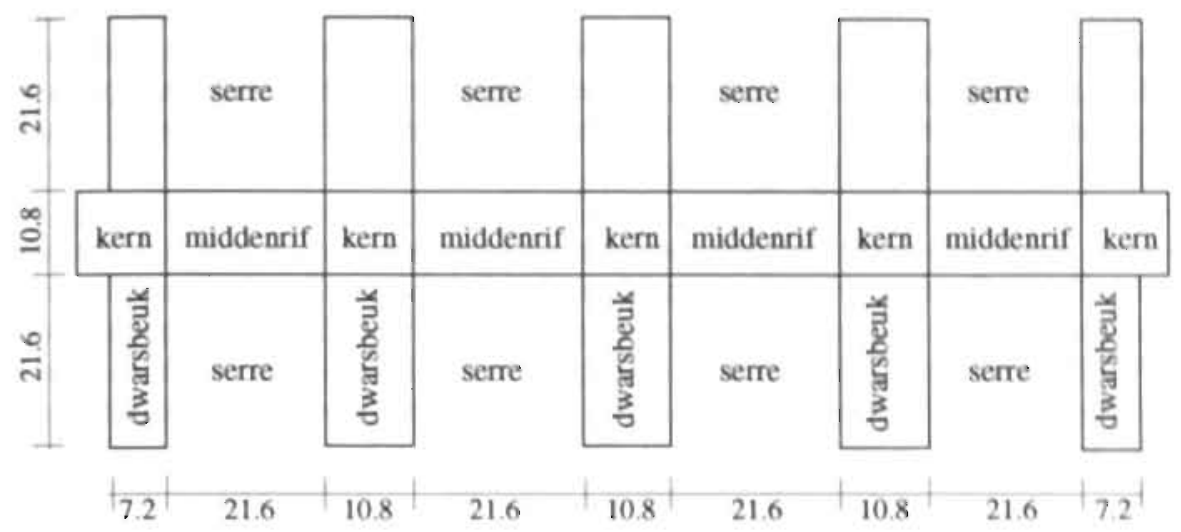

In het ontwerp zijn diverse wijzigingen en verfijningen aangebracht. Bij een gebouw van een dergelijke omvang kan door het herhalingseffect een besparing van enkele tientallen guldens in een standaard-kantoorvertrek tot een essentiële bezuiniging leiden. Het voorlopig ontwerp van het gebouw is eind 1986 gepresenteerd. De plannen zijn verder uitgewerkt tot een definitief ontwerp dat eind 1987 klaar was. Er is daarbij in een bouwteam gewerkt dat bestond uit een vertegenwoordiging van de Rijksgebouwendienst, het architectenbureau, de adviseurs voor constructie, installaties en klimaatregeling, de aannemer en het VROM.

Het skelet van het gebouw bestaat uit dragende prefab gevelelementen, de zgn. piframes, die de vloerelementen dragen (pi-frames zijn betonelementen in de vorm van de griekse letter pi). In de 'kopgevels' van het gebouw zijn de pi-frames vervangen door nagenoeg dichte prefab wandelementen. In totaal zijn meer dan 12000 elementen in het gebouw verwerkt: circa 900 pi-frames in de binnengevels, 5000 wand- en balkelementen, 6000 vloerplaten en meer dan 200 trapelementen. De zwaarste betonelementen wogen zo'n 26 ton. Ook de kernen en de invulling daarvan met wanden, trappen en vloeren zijn geheel uit prefab elementen samengesteld.

Uit economische overwegingen en om risico's van zowel aannemer als producent te spreiden zijn de elementen betrokken van zes prefab leveranciers: Hoco Beton te Weert, Hibex te Groningen, Dycore te Oosterhout, Waco-Liesbosch te Utrecht, Monoliet te Breda en Wilma Beton te Weert. De wandelementen, kolommen en balken komen van Hoco en Hibex, de vloerelementen van Dycore (kanaalplaten), Monoliet (breedplaatvloeren) en Liesbosch Beton (TTN-liggers) en de trappen van Wilma Beton. Een logistiek belangrijk gegeven is dat alle leveranciers op vrij grote afstand van het werk zijn gevestigd. 


\subsubsection{De goederenstromen}

Circa 95 procent van de ruwbouw betreft de montage van zware prefab elementen. Vanwege de beperkte ruimte op de bouwplaats is tussenopslag op de bouwplaats niet mogelijk. De bouwplaats is nauwelijks groter dan de omtrek van het gebouw. Er moet direct vanaf de vrachtwagen gehesen en gemonteerd worden. In dit project zijn bouwkranen een belangrijk hulpmiddel om de betonelementen op hun definitieve plaats in het bouwwerk te brengen. Afmetingen en gewicht van de elementen zijn onder andere bepaald door het maximaal toelaatbare hijsvermogen van deze kranen. Als grens is een massa van acht ton gesteld. Incidenteel zijn zwaardere elementen toegepast, waarvoor andere kraanvoorzieningen zijn getroffen.

In principe krijgt elke vrachtwagen met prefab elementen anderhalf uur de tijd om gelost te worden. Er staan vier vaste en één rijjende hijskraan op de bouwplaats. Deze kranen klimmen in de hoogte-opbouw met de ruwbouw mee. De kraankosten bedragen bij het VROM-project 2,5\% van de totale bouwsom. De montage vindt in bouwstromen per dwarsvleugel plaats. De kraancapaciteit is daarbij een belangrijk criterium. De geplande doorlooptijd is zeven dagen per verdieping, in maximaal drie parallelle bouwstromen.

De meer dan 12000 betonelementen moeten in 18 maanden tijd aangevoerd en gemonteerd worden. De omvang van de leveringen in combinatie met de korte voorbereidingstijd heeft een opdeling, in 18 deelleveringen noodzakelijk gemaakt (zie figuur 11.17). Elke deellevering bestaat uit grofweg een hoeveelheid prefab elementen die in één kalendermaand kan worden gemonteerd. Elke deellevering doorloopt een procesgang van $1(x)$ dagen, waarin afspraken en goedkeuringen voor tekeningen en berekeningen zijn opgenomen, tot en met de produktie en voorraadopbouw. Bij autorisatie van een deellevering door alle partijen zijn alle elementen bepaald voor wat betreft de 'identificatie' (maatvoering, wapening, sparingen etc.) en de locatie (plaats van het gebouw).

In het voorbereidingsproces werd duidelijk dat een grote diversiteit aan typen elementen ontstond als gevolg van sparingen, instortvoorzieningen of uiterlijke vorm. Van de ongeveer 12.000 prefab elementen die worden verwerkt, ligt de gemiddelde seriegrootte onder de 20 stuks. Deze grote diversiteit aan typen, in combinatie met de relatief grote kans op verstoringen ten gevolge van de veelheid aan leveranciers, transportafstanden en korte doorlooptijd per verđieping zijn het motief geweest voor de ontwikkeling van een geautomatiseerd afroepsysteem. De ontwikkeling van zo'n systeem is van belang voor de volgende partijen:

- leverancier en transporteur;

- uitvoerder logistiek;

- uitvoerder ruwbouw;

- montageploeg en kraanmachine;

- hoofduitvoerder;

- hoofdopzichter.

De uitvoerder logistiek is een min of meer nieuw type functionaris op de bouwplaats. Deze functionaris houdt contact met enerzijds de leverancier en zijn transporteur en anderzijds met de (hoofd)uitvoerder, de montageploegen en de kraanmachinisten, alsmede de opzichters. 


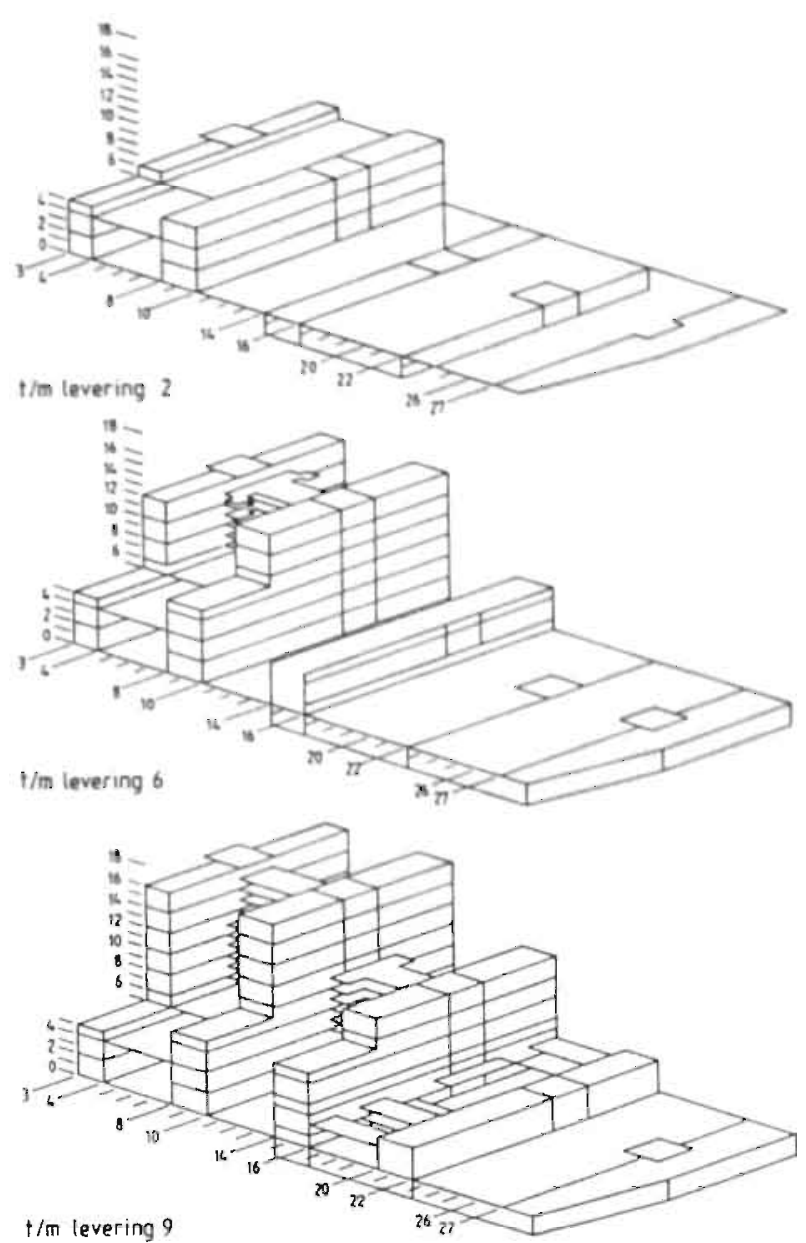

Belangrijke eis voor het afroepsysteem is dat alle partijen snel worden geïnformeerd. De output van het informatiesysteem, de afroeplijsten, is afgestemd op de behoeften van bovengenoemde partijen:

- de leverancier en de transporteur moeten de ladingsvolgorde weten en dag en tijdstip waarop de elementen op de bouwplaats moeten zijn;

- de uitvoerder logistiek moet naast het bovenstaande weten welke kraan de elementen zal lossen;

- de uitvoerder ruwbouw moet weten welke elementen op een bepaalde dag op 'zijn' beuk gemonteerd zullen worden;

- de hoofduitvoerder en hoofdopzichter moeten geïnformeerd worden over de totale aanvoer per dag en per week. 
Op basis van deze uitgangspunten heeft de automatiseringsafdeling van de aannemer in maart 1989 de eerste versie van MARS ontwikkeld. MARS staat voor Materiaal Aanvoer en Registratie Systeem, een geautomatiseerd afroepsysteem voor prefab betonelementen. Na enkele aanpassingen wordt het programma in november 1989 operationeel. Het werkstation op de bouwplaats is verbonden met de main-frame computer op het rayonkantoor van de aannemer in Den Haag. Bediening van het programma heeft plaats op de bouwplaats. Wanneer een uitvoerder geconfronteerd wordt met verstoringen in zijn montageschema, kan hij de keet inlopen en samen met de organisatiemedewerker onmiddelijk de noodzakelijke aanpassingen in het programma vastleggen.

Het programma MARS stelt zowel de dagproduktie als de aanvoertijdstippen vast. Bij de start van het systeem is per leverancier en per elementgroep een code ingevoerd. Op basis van de beschikbare detailplanningen is vervolgens per element ingevoerd:

- soort element;

- locatie op het bouwwerk;

- kraan- en ploegnummer;

- datum van aanvoer;

- tijdstip van aanvoer.

Vanuit het hoofdbestand worden voor de betrokken partijen diverse lijsten uitgedraaid. Een eerste lijst is een sortering op leverancier, datum, kraan, tijd en volgnummer. Deze sortering is gebruikt als afroeplijst voor leverancier en transporteur en als 'werkstuk' voor de uitvoerder logistiek. Een tweede lijst is een sortering op kraan, datum en volgnummer. Deze lijst wordt gebruikt door de uitvoerders ruwbouw en geeft informatie over de kraanbezetting en de dagtaak van de montageploegen. Een derde lijst is een sortering op datum, kraan/ploeg en volgnummer. Deze informatie wordt gebruikt door de uitvoerder logistiek, de hoofduitvoerder en hoofdopzichter. Twee weken voor levering worden de afroeplijsten naar de leveranciers gezonden. Tot vijf dagen voor levering volgt eventueel nog een herziene versie. Noodzakelijke aanpassingen na dit tijdstip worden telefonisch of per fax doorgegeven.

Door MARS is het mogelijk dat tijdens de uitvoering de planning tot op het uur wordt gemaakt. Afwijkingen in het produktieproces in de fabriek of tijdens de uitvoering op de boiwplaats kurinen voortdurend worden ingebracht. Het draaiboek wordt zo min of meer automatisch bijgesteld. Steeds is bekend wanneer de bestelde materialen ter beschikking zullen komen. De montageplanning is hieraan gekoppeld. Ook de specifieke omischrijving van de materialen met gegevens als levertijd, afmeting en wijze van aanvoer en aanbrengen in het bouwwerk zijn bekend en vastgelegd.

Naast MARS wordt ook gebruik gemaakt van een zgn. maatbeheersingssysteem, MOUS genaamd. Met de gegevens uit dit systeem. worden prefab elementen in de juiste positie gesteld. Maatvoerings- c.q. montagegegevens op basis van het systeem MOUS leiden ertoe dat veel nastelwerk voorkomen wordt en maken het mede mogelijk dat de geplande cyclustijd van zeven dagen per (beuk)verdieping is teruggebracht tot zes dagen.

\subsubsection{Prefabrikage als produktietechniek}

In dit project is de bouwlogistiek nadrukkelijk in het bouwteam besproken en was de toepassing van prefab beton zo ver mogelijk doorgevoerd. De uitvoeringstechniek 
kenmerkt zich door assemblage. Aan de keuze voor deze techniek hebben de volgende overwegingen ten grondslag gelegen:

- het beschikbare bouwterrein is erg krap. Op een kavel van 75 bij 140 meter wordt een gebouw neergezet van nagenoeg dezelfde lengte en een breedte van 70 meter. Opslagmogelijkheden zijn er nauwelijks. In feite is er alleen een transportstrook beschikbaar aan de voorzijde van het gebouw tussen gevel en straat. De hele situatie makt het noodzakelijk de materiaalstroom zo beheersbaar mogelijk te maken.

- een snellere bouwtijd. De opdrachtgever heeft de bouwtijd dwingend vastgelegd in 165 kalenderweken, inclusief verlet. Verplaatsing van een groot deel van de werkzaamheden van bouwplaats naar fabriek levert minder verlet op bij betere arbeidsomstandigheden.

- een hogere sterkte klasse beton maakt het mogelijk 'slanker' te bouwen. Minder voluminieuze balken en kolommen kunnen hetzelfde gewicht dragen.

Eventuele kwantumeffecten op de prijs van prefab-elementen hebben bij de beslissing voor prefab geen rol gespeeld.

Het gebouwelement 'kern" kan als voorbeeld worden genomen om aan te geven welke logistieke overwegingen een rol hebben gespeeld bij het zoveel mogelijk toepassen van prefabrikage als produktie-techniek. De kern van een gebouw heeft zowel een 'constructieve' als een 'bouwkundige' functie. Met de eerste functie wordt bedoeld dat de kern als het meest doelmatige element beschouwd wordt om de stabiliteit van een gebouw te garanderen. Deze stabiliteit wordt ontleend aan de buitenwanden van de kernen. Bouwkundig gezien wordt de kern meestal gebruikt als stijgpunt voor liften (liftschacht), leidingen en technische installaties (leidingschacht) en voor loopverkeer (trappenhuis). Ook worden centrale voorzieningen als toiletgroepen e.d. wel in de kern gesitueerd (SBR, 1989a, 81). Alle vijf kernen van het gebouw zijn in de project vrijwel volledig in prefab uitgevoerd.

Prefabrikage van kernwanden is een voor de hand liggende mogelijkheid om tot een snellere voortgang te komen. Toch zijn in het algemeen factoren aan te wijzen die de praktische mogelijkheden voor prefabrikage beperken. Bij het toepassen van prefab elementen voor kernen moet ten eerste veel zorg worden besteed aan de verbindingen. Deze zorg neemt toe bij de toenemende wanddikte bij hoge gebouwen. Een toenemende wanddikte betekent dat meer opdelingen moeten worden gemaakt in verband met het maximaal toelaatbare hijsgewicht. Elementgewichten moeten binnen de perken gehouden worden. Meer opdelingen vereist een toenemende aandacht voor verbindingen. Een tweede aspect is dat bij verticale produktie van elementen produktievoorbereiding zeer belangrijk is. Deze produktiewijze houdt $\mathrm{nl}$. in dat al in een vroeg stadium ook van de hoogste bouwlagen uitvoeringsdetails bekend moeten zijn, bijvoorbeeld in verband met installaties.

Als we de voorwaarden voor prefabrikage van de kernen bezien moet onderscheid gemaakt worden tussen de binnen- en de buitenwanden. Voor de wanden van de binnenkern zijn in dit project de voorwaarden voor prefabrikage gunstig omdat alle verbindingen eenvoudig kunnen worden uitgevoerd en er een sterke repetitiefactor aanwezig is. Voor de buitenwanden, het constructieve dee! van de kern, ligt dit duidelijk anders omdat nogal wat opdelingen noodzakelijk zijn om tot een beperking van het elementgewicht te komen. Tevens zijn de verbindingen niet zo eenvoudig in prefab te realiseren. 
In tegenstelling tot prefabrikage kan de kern ook ter plaatse gestort worden. Dit ter plaatse storten van de kern zou in dit project het bouwtempo echter nadelig beïnvloed hebben. Doordat in dit project de prefab kern binnen één dag gemonteerd en aangegoten wordt ontstaat een behoorlijke bouwtijdverkorting. De keuze voor een bepaalde bouwmethodiek, in dit geval prefab, is ook afhankelijk van de ervaring van de desbetreffende aannemer met een der bouwmethoden en wordt bepaald door het voorhanden zijn van het in te zetten materieel. Een aannemer die bijvoorbeeld een ander type bekistingen in zijn materieel-pakket heeft zal eerder voor de vorm van produceren kiezen waarin hij gespecialiseerd is.

\section{Evaluatie van de gevalsstudie}

Prefabrikage maakte in combinatie met informatietechnologie een zeer beheersbare planning van de assemblage van elementen op de bouwplaats mogelijk. Dit is deels mogelijk geweest doordat logistieke aspecten van het bouwproces nadrukkelijk in het bouwteam tijdens de ontwerpfase zijn besproken. Snelheid en beheersbaarheid van het bouwproces waren voorname motieven voor de keuze van prefabrikage als produktietechniek. Daarnaast heeft dit. prefab bouwproject aangegeven dat de computer een belangrijke ondersteunende rol kan spelen bij het uitvoeren van inkoop van bouwmaterialen, inhuur van materieel, inzet van werknemers, plannen van activiteiten etc. Een vergaande beheersing van het logistieke proces vereiste ook een nieuw type functionaris, de 'uitvoerder logistiek' als full-time coördinator op de bouwplaats.

\subsection{Aanzetten tot toepassing van integrale logistiek}

In dit hoofdstuk staat de vraag centraal waar in de bouw aanzeiten te vinden zijn om tot toepassing van integrale logistiek te komen. In de gevalsstudies zijn een aantal factoren naar voren gekomen die aangeven waar in de bestaande bouwpraktijk zich mogelijkheden en moeilijkheden voordoen bij logistieke afstemming.

\subsubsection{Organisatievorm en logistieke afstemming}

De diverse bedrijven in de geanalyseerde ketens waren op twee verschillende manieren bij de bouwprojecten betrokken geraakt: via aanbesteding of door samenwerking in een bouwteam.

Aanbesteding is onderdeel van het traditionele verloop van een bouwproces. Dit betekent dat eerst een ontwerp voor de bouw gemaakt wordt dat pas, wanneer dit in definitieve vorm gereed is, aanbesteed wordt aan één of meer gegadigden. Belangrijk gegeven voor de sturing van de goederenstroom is dat in het traditionele bouwproces het Programma van Eisen of het ontwerp, afkomstig van de partij die het werk aanbesteed, vaak een tamelijk monoliet en afgebakend geheel vormen ten opzichte van de. partij aan wie het werk wordt uitbesteed: de (onder)aannemer in gevalsstudie een of: de fabrikant in gevalsstudie drie. Een nadrukkelijke scheiding tussen ontwerp en uitvoering ontneemt de (onder)aannemer of fabrikant mogelijkheden van sturing gericht op een logistieke afstemming.

Omdat lang niet alles in het ontwerpstadium is te voorzien ontstaan bij de traditionele organisatievorm vaak problemen. Bouwen is een complex proces met wisselende om- 
standigheden, met name in de uitvoering. Ontwerpen is vaak een groeiproces, dat tot in de fase van de uitvoering, met name als het om de detaillering gaat, doorgaat. Dit neemt echter niet weg dat reeds in het ontwerpstadium belangrijke logistieke keuzes gemaakt zijn. Soms worden door deze vroege beslissingen bepaalde (logistieke) facetten over het hoofd gezien. Dit kan in een latere fase van het bouwproces tot ernstige verstoringen leiden.

Het komt echter ook voor dat reeds in de ontwerpfase contact wordt gezocht met een mogelijke kandidaat voor latere uitvoering. Dit gebeurt meestal in de vorm van deelname aan een 'bouwteam'. Deze tweede variant wijkt op een aantal punten af van traditionele aanbesteding. In een bouwteam wordt de beoogde uitvoerder bij voorbereiding en ontwerp betrokken. Op die manier heeft de uitvoerend (onder)aannemer of fabrikant in het vroegste stadium invloed op de totstandkoming van het project. Bij bouwteamprojecten is de informatie-uitwisseling intensiever en niet geconcentreerd rond het moment van aanbesteding, zoals bij de traditionele organisatie van het bouwproces. Nadeel kan zijn dat een bouwteam met een beperking van de concurrentie gepaard gaat. Als de aannemer vanaf de ontwerpfase al met bepaalde (onder)aannemers of industriële toeleveranciers werkt, kan deze bepaalde onderdelen van het werk niet meer aanbesteden.

In zijn eenvoudigste vorm bestaat het bouwteam uit de initiatiefnemer tot de bouw, de architect en de (tot de aanbesteding nog aspirant-)aannemer. Aangezien bouwteams meestal worden gevormd bij de bouw van gecompliceerde werken, neemt vaak een veelheid van ontwerpers en uitvoerders aan het team deel. Bij het tweede geanalyseerde bouwproject omvatte het bouwteam de architect/opdrachtgever, aannemer, onderaannemers en een toeleverancier, in het vierde architect, opdrachtgever, aannemer, onderaannemers en gebruiker.

Bij het derde bouwproject zat de aannemer weliswaar in een bouwteam mar was de relatie aannemer-fabrikant in dit project door aanbesteding ontstaan. Gevolg was dat logistieke overwegingen ten aanzien van de produktie van elementen geen rol hebben gespeeld bij de totstandkoming van het ontwerp van de architect. Eventuele kostenbesparingen door een ontwerp dat een betere afstemming tussen produktie en montage mogelijk zou maken bleven onbenut. Het vierde bouwproject was wat dat betreft 'voorbeeldig'. Bij de totstandkoming van het ontwerp speelden logistieke overwegingen een belangrijke rol.

Uit de tweede gevalsstudie blijkt echter dat ook een bouwteam niet gegarandeerd tot logistieke optimalisatie leidt. Bedrijven voelen zich, ook in het bouwteam, verantwoordelijk voor hun eigen stuk van de organisatie. Deze houding is terug te voeren op de traditionele organisatie van bouwprocessen waarbij voor ieder nieuw bouwproject weer een nieuwe combinatie van bedrijven wordt samengesteld. In het algemeen kunnen verschillende bouwpartners in een bouwteam verschillende machtsposities innemen.

Uit de gevalsstudies blijkt dat uitvoerende partijen op verschillende tijdstippen bij het ontwerpproces van een bouwwerk betrokken kunnen worden. Dit tijdstip en de daaruit voortvloeiende relaties tussen ontwerpende en uitvoerende partijen en tussen uitvoerende partijen onderling zijn gedurende een bouwproces van grote invloed op de sturingsmogelijkheden van fysieke goederenstromen door (onder)aannemer of fabri- 
kant. In de geanalyseerde projecten werd wisselend gebruik gemaakt van de mogelijkheden die het bouwteam biedt.

\subsubsection{Produktietechniek en logistieke afstemming}

Een belangrijke ontwikkeling in de organisatie van het bouwproces wordt wel aangeduid als de 'produktieverschuiving naar het voortraject'. Hiermee wordt de toename van prefabrikage van bouwelementen bij toeleveranciers en onderaannemers bedoeld. Belangrijke impuls voor de verschuiving van de produktie naar het voortraject is het 'ontkoppeld bouwen'. Bij 'ontkoppeld bouwen' vindt tussen draagstructuur (de ruwbouw) en verdere afbouw en het installatiegedeelte een scheiding plaats.

Verschillende redenen hebben tot groeiend belang van prefabrikage geleid. Ten eerste is door prefabrikage kostenverlaging en produktiviteitsverhoging mogelijk. Verschuiving van een deel van de bouwproduktie naar de toeleverende industrie door prefabrikage betekent in feite, dat de bouwnijverheid zijn produktiviteitsverhoging importeert uit andere bedrijfstakken (Bremer 1991). Ten tweede makt een toenemende complexiteit van bouwcomponenten en -elementen (inclusief micro-electronica) dat een fabrieksmatige omgeving geprefereerd wordt boven produktie op de bouwplaats. Een koude en winderige tiende verdieping is niet de meest ideale omgeving voor assemblage van complexe bouwelementen.

Door bij prefabrikage gebruik te maken van gestandaardiseerde componenten verliest de produktiewijze van een gebouw voor een deel zijn projectmatige karakter. Deze produktie van componenten onder geconditioneerde omstandigheden in de fabriek bieden meer mogelijkheden voor nieuwe vormen van produktie-automatisering en een (ruim) van te voren doordenken en planmatig vastleggen van de verschillende fasen in het bouwproces. Dit was het geval bij het vierde bouwproject. Prefabrikage in combinatie met informatietechnologie maakte een strakke planning van het bouwproces mogelijk. Prefabrikage als produktietechniek vereist dat diverse partijen betrokken bij een bouwproces hun activiteiten op elkaar afstemmen. Deze afstemming heeft betrekking op het ontwerp van het bouwkundig werk, de fabrikage van de bouwdelen of componenten en de assemblage daarvan op de bouwplaats.

Bij het toepassen van geprefabriceerde elementen is het noodzakelijk dat verschillende disciplines al in de ontwerpfase meedenken omdat bepaalde detailleringen voor prefabrikage van groot belang zijn. Ook afspraken over de planning van het bouwproces moeten, veel eerder dan gebruikelijk, gemaakt worden. Uit de derde en de vierde gevalsstudie kwam naar voren dat bij een normale tekeningenprocedure en produktievoorbereiding van prefab elementen de eerste elementen pas na ongeveer 100 werkdagen worden gemonteerd. Om het volle profijt te trekken van prefabrikage, moeten in een zeer vroeg stadium de tekeningen van alle elementen gereed zijn. Alle gegevens betreffende sparingen, instortingen, wapening, bouwkundige detaillering enz. dienen voor produktie in de fabriek bekend te zijn.

Bij prefabrikage zijn niet de levertijden maar de voorbereidingstijd van 8 tot 12 , weken de voornaamste bottle-neck. In het begin van het voorbereidingstraject zijn zelden alle ins en outs van een ontwerp bekend. In het bestek staat echter wel vaak dat twee weken na de gunning met de uitvoering van het project gestart moet worden. Dat zet in projecten waar veel gebruik wordt gemaakt van prefab de voorbereidingsfase onder 
hoge tijdsdruk. Vanuit de traditionele gedachtengang wil de aannemer zo snel mogelijk de elementen toegeleverd zien (zie figuur 11.18).

FIGUUR 11.18 Voorbereidingstijd bij een traditioneel versus een prefab bouwproces

Traditioneel bouwproces

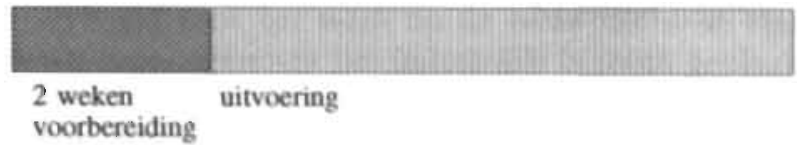

Prefab bouwproces

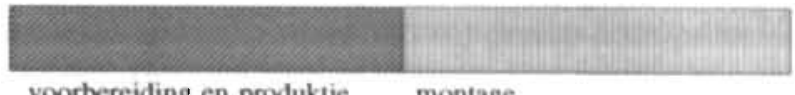

voorbereiding en produktie montage

De beschikbare voorbereidingstijd bij prefab is vaak zo kort omdat geen enkele opdrachtgever bereid is te investeren in mallen en werktekeningen voordat de aanneemsom enigermate in zijn budget past. Zodra echter het contract tussen aannemer en opdrachtgever is getekend wil men direct met de uitvoering beginnen. De aannemer vereist een zo snel mogelijke toelevering van bouwelementen. Dit zet de voorbereiding van de produktie van de elementen sterk onder druk. Werken in bouwteams leidt tot vermindering van deze druk omdat verschillende disciplines vroeg bij het ontwerp betrokken worden. In dat geval kan de produktie van werktekeningen direct na het gereedkomen van de bestekplannen of zo mogelijk nog eerder gestart worden.

Voornaam logistiek afstemmingsprobleem bij prefabrikage is de horizontale montage op de bouwplaats versus de verticale produktie in de fabriek. De volgorde van stapelen van beton-elementen is niet gelijk aan de meest efficiënte produktie-volgorde in de fabriek. Produktie van prefab elementen wordt aantrekkelijker als horizontaal kan worden geproduceerd, d.w.z. bouwlaaggewijs kan worden uitgeleverd. In die situatie kan niet alleen het logistiek zo belangrijke 'just in time'-principe het best inhoud worden gegeven ook wordt de voorbereidingsperiode belangrijk ontlast. Om deze produktiewijze concurrerend te maken zouden betonfabrikanten hun logistieke inspanningen moeten richten op het terugdringen van malopbouw- en ombouwkosten. Op termijn kan produktie-automatisering gericht op een flexibilisering van de malopbouw just-intime toeleveringen naar de bouwplaats mogelijk maken, de voorbereidingstijd verkorten en zo een goede afstemming tussen ontwerp, produktie en montage realiseren.

\subsubsection{Mogelijkheden voor logistieke afstemming}

In de inleiding van dit hoofdstuk is de vraag gesteld of bepaalde organisatie-vormen mogelijkheden bieden voor afstemming van logistieke activiteiten tussen bedrijven. In de gevalsstudies is naar voren gekomen dat bepaalde organisatie-vormen van het bouwproces meer mogelijkheden bieden voor een logistieke afstemming tussen bedrijven dan andere. Het bleek dat ontwerp en uitvoering bij traditionele bouwprocessen twee gescheiden trajecten zijn terwijl in bouwteams uitvoerende partijen direct bij het 
ontwerpproces betrokken zijn. Met andere woorden, tussen traditionele en niet-traditionele bouwprocessen bestaat een verschil van sturing. Bij het traditionele bouwproces is sprake van een 'horizontale sturing' volgens het 'estafettemodel'. Hiermee wordt bedoeld dat gedurende de verschillende fasen van het bouwproces steeds weer andere partijen verantwoordelijk zijn voor de sturing. Bij niet-traditionele organisatie-vormen is sprake van 'verticaal' gestuurde projecten binnen bouwteams en samenwerkingsverbanden. Hierbij worden de verschillende fasen gedurende het bouwproces door één partij of groep van partijen bestuurd.

Bij deze laatste organisatie-vormen is er gedurende het gehele bouwproces sprake van een intensieve informatie-uitwisseling tussen ontwerpende en uitvoerende partijen. Deze informatie-uitwisseling is niet geconcentreerde rondom het moment van aanbesteding, zoals bij traditionele bouwprocessen. Bij deze bouwprocessen is overdracht van informatie gekoppeld aan overdracht van verantwoordelijkheid. Bij verticale sturing van het bouwproces is de overdracht van informatie losgekoppeld van de overdracht van verantwoordelijkheid. Deze sturing vereist duidelijke afspraken tussen de partijen over de wijze van informatie-uitwisseling. Voor goede onderlinge aansluiting van diverse fasen in het bouwproces is een heldere omschrijving van ieders taken en verantwoordelijkheden noodzakelijk. Prestatie-bestekken en kwaliteitssystemen kunnen hiertoe bijdragen. Beide modellen van sturing zijn in figuur 11.19 tegenover elkaar gezet.

FIGUUR 11.19 Twee modellen van sturing

\begin{tabular}{ll}
\hline Estafettemodel & Centrale sturing \\
\hline Horizontale sturing & Venicale sturing \\
Communicatie tevens sturing & Communicatie en sturing gescheiden \\
Afbakening rollen & Open informatie uitwisselen \\
\hline
\end{tabular}

Bron: Mooy (1992).

Een integrale afstemming van logistieke activiteiten vereist de overgang van een "horizontale' naar een 'verticale' sturing. Bij deze laatste organisatie-vorm zijn de kansen op logistieke sub-optimalisatie aanzienlijk kleiner en mogelijkheden om tot logistieke afstemming te komen groter. Desondanks blijven de tijdelijkheid van relaties een belangrijke belemmering voor een goede logistieke afstemming.

Ten tweede is de vraag gesteld of er produktietechnieken zijn die tijdens het bouwproces een logistieke afstemming tussen bedrijven vereisen. In de gevalsstudies is naar voren gekomen dat de behoefie aan logistieke afstemming tussen de bij een bouwproject betrokken partijen nauw samenhangt met de gekozen bouwtechniek. Prefabrikage vereist als produktietechniek een intensieve afstemming tussen ontwerp, fabrikage en uitvoering. Afspraken over ontwerp, produktie en montage moeten, in een veel vroeger stadium dan bij het traditionele proces, gemaakt worden. Bij projecten waar veel prefab gebruikt wordt komt men dan ook eerder elementen van toepassing van integrale logistiek tegen.

De produktietechniek van prefabrikage is sterk fabriek georiënteerd en staat daardoor tegenover de traditionele wijze van bouwen die sterk bouwplaats georiënteerd is. Prefa- 
brikage gaat met een ander type organisatie op de bouwplaats gepaard. Het heeft tot gevolg dat op de bouwplaats ontwerp, de constructie en zelfs een gedeelte van de maatvoering is onttrokken aan de timmerman en de metselaar, dat wil zeggen aan de voormalige ambachtslieden. Werk dat specialistische arbeid op de bouwplaats zou vereisen is reeds in de fabriek onder geconditioneerde omstandigheden uitgevoerd. Dit schept meer mogelijkheden voor het planmatig vastleggen en op elkaar afstemmen van de verschillende fasen van het bouwproces. Dit heeft tot gevolg dat steeds minder vakmanschap wordt verlangd voor het werk op de bouwplaats. In figuur 11.20 wordt de traditionele bouwmethode tegenover het industriēle bouwen geplaatst.

Ten derde vraag is de vraag gesteld of in de bestaande bouwpraktijk sprake is van een formalisering en/of standaardisering van planning en communicatie. Uit de eerste twee gevalsstudies is naar voren gekomen dat hier in veel gevallen nog geen sprake van is. Uit gevalsstudie drie kwam naar voren dat bij prefab-bouwprocessen al wel sprake is van een zekere standaardisering van de communicatie in het voortraject (de tekenprocedures). Toch treden ook bij prefabrikage nog vaak communicatie-stoornissen op. Beperkte budgetten bij de ontwerper, inschakeling van verschillende partijen voor de uitwerking van teken- en rekenwerk en de hoge druk waaronder dit moet gebeuren leiden regelmatig tot storingen in de communicatie. In de vierde bouwproject was de communicatie en informatie-uitwisseling sterk geformaliseerd en gestandaardiseerd. Hier was speciaal ten behoeve van de logistieke organisatie een bedrijfsoverstijgend informatie-systeem ontwikkeld. Men kan echter in het algemeen concluderen dat het niveau van standaardisering en formalisering van de communicatie in de bouw nog een belangrijk obstakel vormt voor logistieke afstemming.

FIGUUR 11.20 Traditioneel versus geïndustrialiseerd bouwen

\begin{tabular}{ll}
\hline Traditioneel bouwen & Geindustrialiseerd bouwen \\
\hline Improviserend & Vaste routines \\
Maatwerk & Standaardelementen \\
Vakmanschap & Assemblage \\
Handgereedschap & Machinaal \\
Unick & Seriematig \\
Bouwplaats-georienteerd & Fabriek-georiènteerd \\
\hline
\end{tabular}

Bron: Mooy (1992).

Conclusie is dat uit de gevalsstudies blijkt dat op basis van deze twee dimensies, organisatie-vorm en produktietechniek, binnen de bestalande bouwpraktijk een beweging naar toepassing van integrale logistiek kan worden aangegeven. Op basis de dimensies organisatie-vorm en produktie-techniek kunnen de vier gevalsstudies worden ingedeeld. Relaties tussen bedrijven in de eerste en derde gevalsstudie zijn via de traditionele aanbestedingsprocedure (horizontale sturing) tot stand gekomen terwijl in de tweede en vierde gevalsstudie sprake was van een bouwteam (een min of meer verticale sturing). Bij de eerste en tweede gevalsstudie kenmerkte de produktie-techniek zich door elementen uit de traditionele bouwwijze, terwijl bij gevalsstudie orie en vier sprake is van prefabrikage. 
FIGUUR 11.21 De gevalsstudies en aanzetten tot toepassing van integrale logistiek

\begin{tabular}{l|lc} 
& \multicolumn{1}{c}{ Traditioneel } & Industrieel \\
\cline { 2 - 3 } Horizontale sturing & 1 & 3 \\
Verticale sturing & 2 & 4
\end{tabular}

De pijlen in bovenstaande figuur geven de aanzetten tot toepassing van integrale logistiek in de bestaande bouwpraktijk weer. Voorzover er in de bouw sprake is van een beweging van 1 naar 4 zal toepassing van integrale logistiek toenemen. 


\section{DEEL III}

Conclusies 



\section{Conclusies: naar nieuwe structuren in de bouw}

Centraal onderwerp in dit onderzoek zijn de voorwaarden en gevolgen van toepassing van integrale logistiek geweest. We spreken van toepassing van integrale logistiek wanneer logistieke functies van bedrijven in een keten (met behulp van informatietechnologie) aan elkaar gekoppeld worden. De centrale probleemstelling luidt:

1. Onder welke voorwaarden of omstandigheden zal het tot toepassing van integrale logistiek komen?

2. Welke veranderingen zullen bij toepassing van integrale logistiek zich voordoen in de organisatie van bedrijfsprocessen in een keten of groep van bedrijven?

Voor de beantwoording van deze vragen zijn in deel I van deze studie de ontwikkelingen in de logistiek onderzocht met behulp van theorieën van de externe organisatie en theorieẽn over rationalisering van bedrijfsprocessen. Op grond van deze theoretische analyse zijn in hoofdstuk 6 stellingen ontwikkeld over de voorwaarden waaronder het tot een toepassing van integrale logistiek komt en de gevolgen daarvan voor de organisatie van de produktie in een keten of groep van bedrijven. In het tweede deel van de studie is empirisch onderzoek gepresenteerd naar ontwikkelingen van de logistiek in de bouwbranche. In dit hoofdstuk proberen we de centrale probleemstelling te beantwoorden door de op de theoretische concepten gebaseerde stellingen uit hoofdstuk 6 te confronteren met de resultaten van het empirisch onderzoek. Paragraaf 12.1 behandelt de eerste twee stellingen, d.w.z. de voorwaarden waaronder het tot een toepassing van integrale logistiek in de bouw komt. In $\$ 12.2$ wordt ingegaan op de laatste drie stellingen, d.w.z. de eigenschappen en mogelijke gevolgen van toepassing van integrale logistiek in de bouw.

\subsection{Voorwaarden voor de ontwikkeling van logistieke netwerken}

In hoofdstuk 4 is aangegeven dat toepassing van integrale logistiek gezien kan worden als een verandering in de externe organisatie van ondernemingen in de richting van netwerkvorming. Twee stellingen hebben aangegeven onder welke voorwaarden of omstandigheden deze logistieke netwerken ontstaan.

Stelling 1: investeringen in informatiesystemen met een gemeenschaps- of gesloten karakter bevorderen door hun transactiespecifieke karakter het ontstaan van logistieke netwerken.

In de huidige situatie, waarin nog geen wereldstandaarden bestaan voor EDI en PDI in de bouw, hebben EDI en PDI-systemen per definitie een gemeenschapskarakter. In hoofdstuk 9 is een aantal stimuleringsprogramma's geanalyseerd dat zich richt op de totstandkoming van Electronic Data Interchange (EDI) en Product Data Interchange 
(PDI) in de bouw. Uit deze analyse is naar voren gekomen dat de tijdelijkheid van relaties en de gefragmenteerde sectorstructuur in de bestaande bouwpraktijk een belemmering vormen voor investeringen in EDI en PDI.

In grote delen van de bouwsector geldt nog steeds dat de opdrachtgever meestal het werk aanbesteed aan die aannemer die tegen de laagste prijs heeft ingeschreven. De aannemer, aan wie het project gegund is, tracht op zijn beurt weer een zo laag mogelijke prijs bij toeleveranciers en onderaannemers te bedingen. Deze prijsconcurrentie, in combinatie met het meestal unieke en gecompliceerde karakter van het bouwproject, heeft tot gevolg dat bij ieder project weer opnieuw namens of door de opdrachtgever met een groot aantal verschillende bedrijven aparte contracten gesloten worden. De hieruit voortvloeiende tijdelijkheid van de relaties tussen ondernemingen vormt een belemmering voor investeringen in bedrijfsoverstijgende informatiesystemen omdat deze investeringen alleen kostendekkend zijn voor bedrijven die regelmatig contact met elkaar onderhouden. Dit is een van de redenen waarom in bouwketens de voorwaarden voor investeringen in EDI in de schakel producent-tussenhandel gunstiger zijn dan tussen aannemers en partijen als tussenhandel of producenten. Eerstgenoemde relatie kenmerkt zich door redelijk vaste afspraken over een periode die langer is dan de duur van één bouwproject.

Naast de tijdelijkheid van relaties in bouwprojecten vormt de sectorstructuur een tweede belemmering voor investeringen in EDí en PDI. In de Nederlandse bouw is geen duidelijke marktieider aanwezig die een potentiële standaard voor een informatietechnologie kan zetten waaraan de bouwwereld zich conformeert. In verschillende subsectoren van de bouw worden niettemin initiatieven genomen om tot dergelijke standaarden te komen. Het EDI-initiatief HCP' van de branche-organisaties van bouwmaterialengroothandels, de HIBIN, is hier een voorbeeld van. Daarnaast werken grote aannemers in de Stichting EDIBOUW aan de ontwikkeling van een EDI-berichtennetwerk. Beide EDI-initiatieven beschouwen elkaar als concurrenten. Deze concurrentie belemmert de totstandkoming van een algemeen EDI-berichtennetwerk dat door de gehele bouwsector, inclusief haar toeleveranciers, gedragen wordt. Ook bij PDI verIoopt de ontwikkeling van een algemeen geaccepteerd stelsel van afspraken niet erg soepel. De ontwikkeling van een algemeen geaccepteerde standaard voor PDI vereist een afstemming van verschillende disciplines en daarmee een coördinatie tussen verschillende subsectoren in de bouw. Branche-organisatie kunnen bij deze afstemming een belangrijke rol spelen. Momenteel zijn verschillende subsectoren, zoals die van de installateurs, de architecten, de producenten van gewapend beton en de grond-, wegen waterbouw bezig met de ontwikkeling van eigen PDI-standaarden. Het gevaar is aanwezig dat deze standaarden straks niet onderling uitwisselbaar zijn tussen de verschillende subsectoren. De voordelen van PDI zijn dan voor de verschillende partijen minimaal.

Uit bovenstaande blijkt dat in een situatie van relatief constante transactiepatronen tussen bedrijven EDI eerder zal worden ingevoerd. Tegelijkertijd leidt het streven om optimaal te profiteren van EDI tot een verdere afstemming en verdieping van relaties. EDI kan zo onderdeel zijn van veranderingsprocessen in de externe organisatie van bedrijven. Partijen hebben geïnvesteerd in een bepaalde technologie om transacties met een bepaalde partner mogelijk te maken en zullen bij problemen niet direct afhaken, zoals bij traditionele marktrelaties gebruikelijk is. Marktrelaties kunnen zich blijkbaar ontwikkelen tot vormen van integratie en samenwerking die niet in termen 
van simpele ruil beschreven kunnen worden, organisatievormen die in de theorie zijn aangeduid als netwerken. Bij deze organisatievormen zijn naast prijzen ook persoonlijke contacten en wederzijds vertrouwen van groot belang. Er is sprake van een 'mutual orientation' die zich uitdrukt in een wederzijdse afstemming van processen die betrekking hebben op de uitwisseling van goederen- en informatiestromen tussen bedrijven.

Conclusie is dat op dit moment in grote delen van de bouw tijdelijkheid van relaties en de gefragmenteerde sectorstructuur transactiespecifieke investeringen in bedrijfsoverstijgende informatiesystemen belemmeren en daarmee toepassing van integrale logistiek.

\section{Stelling 2: een toenemend belang van overdracht van knowr-how, snelheid en wederzijds vertrouwen zijn factoren die de ontwikkeling van logistieke netwerken bevorderen.}

In de beschrijving van organisatorische innovaties die het antwoord vormen op nieuwe marktvereisten (hoofdstuk 10) is naar voren gekomen dat andere motieven dan efficiency een rol gaan spelen bij transacties tussen bedrijven in de bouw. Gevolg is de opheffing van de traditionele scheiding tussen ontwerpende en uitvoerende partijen. Dit streven naar integratie heeft ertoe geleid dat verschillende actoren het management van het gehele bouwproces up zich (willen) nemen.

Aannemer of architect worden verantwoordelijk voor de integratie van ontwerp en uitvoering. Dit heeft tot gevolg dat deze partijen afgeronde bouwdelen uitbesteden aan industriële toeleveranciers en onderaannemers die daardoor tevens delen van het ontwerpen assemblageproces voor hun rekening nemen. Er ontstaat een situatie waarbij architect of aannemer in nauw overleg met toeleveranciers of onderaannemers bouwdelen ontwikkelen en produceren. Een dergelijke samenwerking doet zich ook bij projectontwikkeling voor als opdrachtgever, architect, aannemer en andere partijen in bouwteamverband gezamenlijk werken aan de realisering van een bouwproject. Bij aannemers die met een bouwconcept of prestatie-bestek werken, vindt de selectie van toeleveranciers c.q. onderaannemers steeds vaker plaats op basis van kwaliteit, betrouwbaarheid, technische know-how en pas in de tweede instantie op basis van prijs. Dit betekent een breuk met transactiepatronen zoals gebruikelijk bij traditionele bouwprocessen waar fixatie op kosten en prijs belangrijke kenmerken zijn van transacties tussen bedrijven. Door genoemde veranderingen in de organisatie van bouwprojecten neemt het belang van overdracht van technische know-how en wederzijds vertrouwen toe. Hiermee wordt de basis gelegd voor logistieke netwerkvorming.

Aan deze voorwaarden wordt echter in grote delen van de bouw nog niet voldaan. Zoals reeds bij de eerste stelling is gezegd, geldt nog steeds dat opdrachtgevers er in de regel op uit zijn onroerend goed zo goedkoop mogelijk te laten bouwen. Een recent onderzoek van het TNO (1992) concludeerde dat in de Nederlandse huizen- en kantorenbouw nog steeds grote nadruk ligt op prijsconcurrentie. Gevolg van deze prijsconcurrentie is dat bouwers gefixeerd zijn op kosten en zich vooral richten op het bedenken van efficiency-verbeteringen op de bouwplaats. Men weet zich niet te differentieren door een grote technologische voorsprong, produktontwikkeling, marketing etc. Factoren die van belang zijn voor de ontwikkeling van een op produktdifferentiatie gericht logistiek netwerk spelen bij transacties in de bestaande bouwpraktijk nog geen grote rol van betekenis. 
Bij de traditionele organisatie van bouwprocessen wordt door middel van markttransacties bij ieder project weer een nieuw produktie-apparaat opgebouwd met nieuwe uitvoerende en ontwerpende partijen. De tijdelijkheid van de relaties tussen partijen werkt opportunistisch gedrag in de hand. Men probeert achteraf nog zoveel mogelijk uit een contract te halen. De organisatie van het traditionele bouwproces is te beschrijven als 'organized distrust'. Het feit dat bepaalde bedrijven in het kader van produktontwikkeling en kwaliteit de nadruk gaan leggen op het continue karakter van een relatie betekent een breuk met traditionele transactiepatronen. Bedrijven baseren hun gedrag niet meer op het streven naar winst op korte termijn, maar op het verkrijgen van opbrengsten uit een serie van transacties. Hierdoor ontstaat wederzijds vertrouwen hetgeen opportunistisch gedrag ontmoedigt. Bedrijven zijn zich ervan bewust dat men bij opportunistisch gedrag slechter af is. Voor ondernemingen kan dit een stabilisering van de externe organisatie betekenen.

De conclusie uit het voorgaande is dat in de bouw wel de eerste aanzetten tot toepassing van integrale logistiek te vinden zijn maar dat het op grote schaal tot ontwikkeling komen van logistieke netwerken nog wel even op zich zal laten wachten. In grote delen van deze sector wordt nog niet aan de in de stellingen genoemde voorwaarden voldaan.

\subsection{De gevolgen van logistieke netwerkvorming}

In hoofdstuk 5 zijn de gevolgen van logistieke netwerkvorming geplaatst in het kader van een verandering van rationaliseringsprocessen van Taylorisme naar systemische rationalisering. Drie begrippen stonden hierbij centraal: organisering, technisering en informatisering. Op basis van deze drie begrippen zijn in drie stellingen 'wetmatigheden' in ontwikkelingsvormen of gevolgen van toepassing van integrale logistiek aangegeven.

\section{Stelling 3: bij toepassing van integrale logistiek zal een bedrijfsoverstijgende organise- ring optreden die ertoe kan leiden dat de organisatie van logistieke activiteiten in een bedrijfsketen in nieuwe hiërarchicën plaats vindt.}

In het empirisch onderzoek is naar voren gekomen dat de organisatie van logistieke activiteiten in nieuwe hiërarchieën, in hoofdstuk 2 ook aangeduid als het ontstaan van een verticale actor, zich op verschillende manieren kan concretiseren.

Ten eerste bleek uit de analyse van de EDI- en PDI-stimuleringsprogramma's in hoofdstuk 9 dat een collectieve instantie de oplossing van knelpunten kan zijn bij de implementatie van deze technologieën. Deze collectieve instantie kan een netwerkbeheerder zijn, verantwoordelijk voor ontwikkeling, bouw en exploitatie van een EDI- of PDI-berichtennetwerk. De leverancier van deze voorziening kan bij grote bouwprojecten een belangrijke rol gaan spelen. Hij maakt het mogelijk dat alle bij deze projecten betrokken partijen electronisch met elkaar kunnen communiceren. Deze netwerkbeheerder is dan ook te beschouwen als een concretisering van de verticale actor. Het is deze partij die de (logistieke) informatie-uitwisseling van een keten of groep van bedrijven verzorgt. 
Ten tweede bleek uit de analyse van innovaties in de organisatie van bouwprojecten in hoofdstuk 10 dat bepaalde bedrijven het management van het gehele bouwproces op zich (willen) nemen. Drie opties zijn hierbij naar voren gekomen. Ten eerste bleek dat ontwerpende partijen zich kunnen ontwikkelen tot coördinator van het gehele bouwproces. Dit geldt met name voor grote en/of innovatieve architectenbureaus. Deze architectenbureaus kunnen toeleveranciers rechtstreeks benaderen zonder dat er een aannemer tussen zit, zoals bij traditionele bouwprocessen. Door zelf de assemblage van de bouwelementen op de bouwplaats te plannen functioneert het architectenbureau ook als coördinator op de bouwplaats. Ten tweede kunnen uitvoerende partijen zich in de richting van coördinator van een compleet bouwproces ontwikkelen. Het zijn met name de grotere aannemers die zich met projectontwikkeling en gestandaardiseerde bouwconcepten hierop richten. Deze verwerven steeds meer deskundigheid die noodzakelijk is voor de beheersing van het totale bouwproces, inclusief ontwerp. Het coördineren van alle specialismen in een project is voor deze bedrijven een apart specialisme geworden. Een derde optie is dat de coördinatie van ontwerp en uitvoering uitbesteed wordt aan een op zich staande organisatie. Aanzetten daartoe zijn de projectmanage* mentbureaus. Deze bureaus bieden directievoering en toezicht van een bouwproject als aparte dienst aan.

Ten derde hebben we in de gevalsstudies van bouwprojecten in hoofdstuk 11 bij. niettraditionele organisatie-vormen van bouwprocessen aanzetten gevonden tot de organisatie van logistieke activiteiten in nieuwe hiërarchieën. Bij niet-traditionele organisatievormen van bouwprocessen zijn uitvoerende partijen in een vroeg stadium bij het bouwproces betrokken in de vorm van bouwteams of andere samenwerkingsverbanden. Bij deze organisatie-vormen is er gedurende het gehele bouwproces sprake van een intensieve informatie-uitwisseling tussen ontwerpende en uitvoerende partijen. Deze informatie-uitwisseling is niet alleen geconcentreerd rond het moment van aanbesteding, zoals bij traditionele bouwprocessen. Een vorm van een organisatie van logistieke activiteiten in nieuwe hiërarchieën vinden we bij niet-traditionele bouwprocessen terug in het type sturing dat gehanteerd wordt. Tussen traditionele en niet-traditionele bouwprocessen bestaat een verschil van sturing. Bij traditionele bouwprocessen is sprake van 'horizontale' sturing volgens het 'estafette-model'. Hiermee wordt bedoeld dat gedurende de verschillende fasen van het bouwproces steeds weer andere partijen verantwoordelijk zijn voor de sturing. Bij niet-traditionele organisatie-vormen van bouwprocessen is sprake van 'verticale' sturing. Hierbij worden de verschillende fasen gedurende het bouwproces door één partij of groep van partijen bestuurd. Bij deze verticale sturing zijn goede mogelijkheden aanwezig om tot een logistieke afstemming van activiteiten tussen bedrijven te komen. De overgang van een horizontale naar een verticale sturing: betekent tegelijkertijd een meer gecentraliseerde sturing van logistieke activiteiten gedurende een bouwproces.

Bovenstaande voorbeelden geven aan hoe bepaalde bedrijven, hiërarchiën in termen van Williamson, verantwoordelijk worden voor een integrale afstemming van logistieke activiteiten van een groep van bedrijven. Deze bedrijven zijn te beschouwen als "brokers' in een logistiek netwerk. Door deze bedrijven is een organisering van de logistieke functie op het niveau van een keten of groep van bedrijven mogelijk: regelende activiteiten op het terrein van de goederenstroombesturing worden op dat niveau op elkaar afgestemd en beheerst vanuit een centraal punt. Doel is tot een verhoging van de berekenbaarheid en voorspelbaarheid van produktieprocessen te komen. Het traditionele rationaliseringsprincipe van centrale beheersing blijft ook bij systemische ratio- 
nalisering van kracht. Nieuw is echter dat deze beheersing plaats vindt met behulp van nieuwe technologieën (met name informatietechnologie) en dat de focus niet één bedrijf maar een groep of keten van bedrijven is.

\section{Stelling 4: toepassing van integrale logistiek gaat gepaard met een technisering die zich richt op nieuwe vormen van produktie-automatisering en bedrijfsoverstijgende informatiesystemen en die substitutie van arbeid door arbeidsmiddelen tot gevolg heef.}

Ten eerste bleek EDI substitutie van arbeid tot gevolg kan hebben. Oorzaak hiervoor is dat in bepaalde schakels in de logistieke bouwketen EDI direct gekoppeld kan worden aan interne applicaties. Een dergelijke koppeling gaat met substitutie van arbeid gepaard. De voorwaarden voor zo'n koppeling zijn het gunstigst in de schakel producent-tussenhandel. In deze schakel is sprake van een uitwisseling van standaardprodukten die door produktcodering eenduidig worden vastgelegd, kenmerken relaties zich door redelijk vaste afspraken en worden grote hoeveelheden korte berichten uitgewisseld. In de schakel aannemer-producent zijn de voorwaarden voor een directe koppeling minder gunstig. Er is sprake van een minder intensieve berichtenstroom en de communicatie heeft vaak betrekking op niet-gestandaardiseerde produkten. Ook in de schakel tussenhandel-aannemer is vaak sprake van incidentele informatiestromen. Bij de veelal kleine aannemers laat de automatiseringssituatie vaak te wensen over. In de relatie tussen aannemer en partijen als producent of tussenhandel zal EDI in de meeste gevallen hooguit tot een integratie van in- en verkoopafdelingen van verschillende ondernemingen leiden. $\mathrm{Bij}$ laatstgenoemde schakels zal EDI, in tegenstelling tot de schakel producent-tussenhandel, nauwelijks arbeidsbesparing en substitutie tot gevolg hebben.

Ten tweede is in de gevalsstudies van bouwprojecten in hoofdstuk. 11 naar voren gekomen dat niet-traditionele produktie-technieken van bouwprojecten een aanzet geven tot nieuwe vormen van produktie-automatisering. Met niet-traditionele produktietechnieken bedoelen we de produktieverschuiving naar het voortraject, ofwel de toename van prefabrikage van bouwelementen bij toeleveranciers en onderaannemers. Prefabrikage is als produktie-techniek sterk fabriek georiënteerd en kan tegenover de traditionele wijze van bouwen geplaatst worden die sterk bouwplaats georiënteerd is. Belangrijke eigenschap van prefabrikage is dat ambachtelijk werk op de bouwplaats wordt vervangen door produktie onder geconditioneerde omstandigheden in een fabriek. Deze geconditioneerde omstandigheden scheppen meer mogelijkheden voor nieuwe vormen van produktie-automatisering en het planmatig vastleggen en op elkaar afstemmen van de verschillende fasen van het bouwproces. Bij de afstemming tussen fabrikage, transport en montage kan informatietechnologie een belangrijke ondersteunende rol vervullen. Uit de gevalsstudies is echter ook naar voren gekomen dat bedrijfsoverstijgende informatiesystemen nog niet wijd verbreid zijn in de bouw. Van een arbeidsbesparing door deze systemen is in de bestaande bouwpraktijk dan ook nauwelijks sprake.

EDI is ałs een vorm van technisering en onderdeel van het nieuwe rationaliseringstype te beschouwen. Dit betekent dat EDI zowel een vervanging van mensen door techniek tot gevolg heeft als een sterkere onderlinge afstemming en integratie van processen in deelnemende bedrijven. EDI wordt gebruikt om een integratie van functies te bewerkstelligen die vroeger plaats vond op basis van menselijke handelingen. Daarbij gaat het 
niet alleen om handelingen die aan de randen van de onderneming plaats vinden in inen verkoopafdelingen. EDI kan tevens tot een integratie en stroomlijning van de administratieve organisatie binnen het bedrijf leiden. Daarnaast zien we dat technisering in de bouw gepaard gaat met produktie-automatisering. Hierbij zijn twee techniseringsbewegingen te zien. Ten eerste wordt ambachtelijk werk op de bouwplaats vervangen door geautomatiseerde produktie in de fabriek. Industrieel bouwen biedt meer mogelijkheden om tot een integrerende rationalisering te komen. De tweede techniseringsbeweging is de overgang van 'starre' naar 'flexibele' automatisering. Terwijl traditionele rationalisering plaats vindt door mechanisering en 'starre' automatisering, d.w.z. machines die maar voor één doel gebruikt kunnen worden, gaat het nieuwe type rationalisering gepaard met 'flexibele" automatisering, d.w.z. programmeerbare machines en automaten. Naast vervanging van arbeid door techniek leidt technisering bij systemische rationalisering tot integratie en flexibilisering van bedrijfsprocessen.

Stelling 5: toepassing van integrale logistiek vereist een herstructurering van de interne organisatie door informatisering binnen de onderneming die het bedrijf in stat stelt met standaardberichten informatie uit te wisselen en deze berichten zelf te produceren.

Ten eerste bleek dat EDI ook een herstructurering van de interne organisatie tot gevolg kan hebben. Evenals voor substitutie van arbeid, is de oorzaak voor een interne herstructurering door EDI dat in bepaalde schakels in de logistieke bouwketen EDI direct gekoppeld kan worden aan interne applicaties. Zoals aangegeven, zijn de voorwaarden voor een dergelijke koppeling het gunstigst in de schakel producent-tussenhandel. In de relatie tussen aannemers en partijen als tussenhandel en producenten zal EDI in de meeste gevallen hooguit tot een integratie van de randen van verschillende ondernemingen leiden. In laatstgenoemde schakels zal toepassing van EDI nauwelijks tot een herstructurering van de interne organisatie leiden.

Ten tweede is in de gevalsstudies van bouwprojecten (hoofdstuk 11) naar voren gekomen dat slechts in een klein deel van de bouwsector informatie op een gestandaardiseerde en geformaliseerde wijze wordt uitgewisseld. Van een herstructurering van de interne organisatie door informatisering is in grote delen van de bouw nauwelijks sprake.

Deze herstructurering van de interne organisatie binnen de onderneming bestaat uit een formalisering van bedrijfsfuncties en de koppeling van 'in-house' applicaties. Dieze formalisering van bedrijfsfuncties en de met EDI gepaard gaande standaardisatie van berichtenstromen tussen bedrijven kan de snelheid verhogen maar ten koste gaan van de flexibiliteit. Oorzaak voor dit laatste is dat introduktie van EDI vaak gepaard gaat met een vermindering van het aantal toeleveranciers en een minitieuze beschrijving van wederzijdse verplichtingen van de EDI-partners. Daar staat tegenover dat informatisering indirect nieuwe vormen van flexibiliteit mogelijk maakt. Routine-matige activiteiten worden uitgevoerd door informatie-systemen. Hierdoor ontstaan voor medewerkers meer mogelijkheden voor advisering en het onderhouden van relaties met klanten. Informatisering bij systemische rationalisering gaat gepaard met een 'spanning' tussen nieuwe inflexibiliteiten en een toegenomen commerciële flexibiliteit. 


\subsection{Vitleiding}

In de voorgaande paragrafen zijn voorlopige antwoorden gegeven op de centrale vragen onder welke voorwaarden het tot toepassing van integrale logistiek komt en wat de gevolgen daarvan zijn voor de organisatie van produktie-processen. Deze antwoorden behoeven echter enige relativering omdat toepassing van integrale logistiek in de bouwsector, maar daar niet alleen, zich nog in een pril stadium bevindt. Vanwege de beperkte aanwezigheid van empirisch materiaal hebben we ons moeten beperken tot een kwalitatieve analyse. Een 'harde', kwantitatieve toetsing van de stellingen bleek nog niet mogelijk te zijn. In de nabije toekomst zal nader onderzoek in meer detail moeten uitwijzen op welke wijze logistieke integratie (arbeids-)organisaties in bedrijfsketens doet veranderen. De sociotechnische systeemtheorie van De Sitter zou hier concepten voor kunnen aandragen. De toetsbaarheid van de stellingen werd echter niet alleen belemmerd door het beperkt voorhanden empirisch materiaal. Ook aan de theorie schort het een en ander. Met name theorieën over verschuivende bedrijfsgrenzen, de transactiekosten- en de netwerktheorie, zijn descriptief en niet echt goed meetbaar. Op dit punt kunnen deze theorieën nog aanmerkelijk verbeterd worden.

De resultaten uit dit onderzoek hebben ons niettemin geleerd dat de transactiekostentheorie onder bepaalde voorwaarden een goede verklaring geeft voor logistieke netwerkvorming. Dit is met name het geval in een situatie waar strategische overwegingen een geringe rol spelen en de nadruk ligt op efficiency argumenten.

Minimalisering van transactiekosten verklaart voor een deel het ontstaan van logistieke netwerkvorming bij implementatie van EDI-systemen in de bouw. In het onderzoek kwam naar voren dat implementatie van EDI mogelijkheden creëert voor een foutloze initiëring, bewaking en afhandeling van transacties. De uitwisseling van grote hoeveelheden berichten, die hiermee samenhangt, kan door EDI efficiënter plaats vinden. Deze reduktie van transactiekosten vormt een belangrijke drijfveer voor implementatie van EDI-systemen in logistieke bouwketens. Tegenover deze reduktie staat dat investeringen in een EDI-systeem in de bouw met nieuwe inflexibiliteiten gepaard gaat. Het streven naar efficiënt gebruik van EDI is voor veel bedrijven reden alleen EDI-relaties aan te gaan met bedrijuen waarmee reeds relatief constante transactiepatronen bestaan en tegelijkertijd deze relaties verder te verdiepen. Voor het terugverdienen van de investering raakt men afhankelijk van de continuïteit van de transactie en daarmee van de transactiepartner, die daar misbruik van kan maken. Investeringen in EDI zijn 'relation-specific investments'. Het streven van EDI zo efficiënt gebruik te maken leidt tot een 'governance' die ergens tussen markt en hiërarchie in ligt.

Logistieke netwerkvorming kan met de verschillende door Williamson onderscheiden dimensies van een 'governance structure' omschreven worden als een 'hybrid mode of organization', d.w.z. een organisatie-vorm die zich kenmerkt door elementen van markt en hiërarchie. Logistieke netwerkvorming neemt in de bouw de vorm aan van vaste samenwerkingsverbanden tussen uitvoerende en ontwerpende partijen en tussen uitvoerende partijen onderling. Element van 'market governance' is dat bij ieder bouwproject de autonome partijen weer opnieuw onderhandelen over de voorwaarden. Anderzijds worden 'administrative controls' gehanteerd die typerend zijn voor 'hierarchical governance': aannemers eisen tijdens bouwprocessen toezicht op de produktie bij toeleveranciers waarmee regelmatig wordt samengewerkt. De organisatie van het bouwproces beweegt zich in de richting van een "quasi-firm". Indien partijen niet meer via aanbeste- 
ding aan werk komen, via 'market governance', kan de prikkel tot efficiënt werken geringer worden. Met andere woorden, bij langdurige samenwerking en afwezigheid van prijsconcurrentie neemt de 'incentive intensity' af. In bepaalde gevallen geeft de uitbesteder met raamcontracten de toeleverancier een oriêntatie op de langere termijn.

Tegelijkertijd geeft ons onderzoek de beperkingen van de transactiekostentheorie aan. Logistieke netwerkvorming is niet alleen gericht op minimalisering van transactiekosten en kan niet uitsluitend als coördinatie-mechanisme tussen markt en hiërarchie omschreven, worden.

Implementatie van EDI in de bouw en de daarmee samenhangende netwerkvorming wordt niet alleen gevoed door efficiency-voordelen maar ook door strategische overwegingen. Beide partijen met hun EDI-initiatieven, de bouwmaterialenhandel en de aannemers, concurreren met elkaar om marktkanalen. De tussenhandel wil haar positie veilig stellen door zich: meer te gaan profileren als logistiek dienstverlener, de aannemers willen hun coördinerende rol handhaven ten opzichte van industriële toeleveranciers die door het toenemende 'bouwdeel denken' toegevoegde waarde naar zich toetrekken. Met EDI proberen beide partijen de coördinatie van goederenstromen tot de eigen kern-activiteiten te rekenen: de tussenhandel wil haar afzetkanalen controleren terwijl de aannemers dit juist. voor de toelevering willen doen. De voorwaarden voor toepassing van. EDI zijn. het gunstigst in de schakel producent-tussenhandel. Een belangrijke reden hiervoor is dat de kernactiviteiten van deze partijen (produktie versus distributie van bouwmaterialen), zo verschillend zijn. $\mathrm{Er}$ is sprake van een "partner asymmetry". Beide partijen profiteren van de toepassing van EDI in hun relatie.

Een logistiek netwerk is als aparte organisatievormen te beschouwen die niet uitsluitend in termen van markt of hiërarchie is te beschrijven. Logistieke netwerkvorming kan gezien worden als een nieuwe manier van coalitie- en alliantievorming waarbij niet minimalisatie van transactiekosten het dominante streven is maar "joint value maximization'. Er is geen sprake van opportunisme maar wederzijds vertrouwen. Van groter belang dan beperkte rationaliteit is de overdracht van know-how tussen ondernemingen bij het streven naar kwaliteit en produktontwikkeling. De architect en/of de aannemer ontwikkelen en produceren bouwdelen in nauw overleg met toeleveranciers en onderaannemers. Deze samenwerking tussen ontwerpende en uitvoerende partijen maakt het mogelijk een 'totaalprodukt' met bijhehorende garanties op de markt te presenteren. Netwerken zijn doelbewuste organisaticvormen gericht op concurrentie-voordeel en niet alleen een metafoor waarmee relaties tussen ondernemingen achteraf worden gereconstrueerd.

Met theorieën over rationalisering zijn de gevolgen van logistieke netwerkvorming nader geanalyseerd. Uit het onderzoek is naar voren gekomen dat aanzetten tot toepassing van integrale logistiek, de overgang van horizontale naar verticale sturing, prefabrikage en informatisering, als onderdeel van systemische rationalisering beschreven kunnen worden. Belangrijkste kenmerken van deze rationaliseringsvorm zijn flexibiliteit en integratie.

Bij systemische rationalisering wordt getracht de flexibiliteit van produktie-processen te. verhogen door implementatie van nieuwe technologieën. Informatisering door EDI gaat gepaard met een toename van de commerciële flexibiliteit. De overgang van een 'starre' naar een 'flexibele' automatisering biedt meer mogelijkheden in te spelen op 
veranderingen in de vraag. Daar staat tegenover dat technisering en informatisering in de bouw nieuwe inflexibiliteiten oproepen. EDI gaat gepaard met een standaardisering van de tussen EDI-partners uitgewisselde berichten, een nauwkeurige beschrijving van wederzijdse verplichtingen tussen hen en een vermindering van het aantal toeleveranciers. Met andere woorden, door implementatie van EDI in de bouw wordt de snelheid en efficiency van bestaande processen enorm verhoogd terwijl de mogelijkheid om andere richtingen in te slaan wordt beperkt. Door de overgang van ambachtelijk werk op de bouwplaats naar een geautomatiseerde produktie in de fabriek doen zich in de bouw mogelijkheden voor een rationalisering naar Tayloristisch model en massa-fabricage voor. Dit type rationalisering gaat in veel gevallen met inflexibiliteiten gepaard. In tegenstelling tot de industrie heeft de bouw in het algemeen nog weinig ervaring met deze rationaliseringsvorm. 'Craft administration', de besturing op basis van de professionele ambachtelijke training, vormt in de bouwsector het belangrijkste coördinatiemechanisme.

Integratie heeft als tweede belangrijke kenmerk bij systemische rationalisering ook betrekking op bedrijfsprocessen die buiten de onderneming liggen. Rationalisering door prefabrikage leidt tot meer aandacht voor de aan- en afvoer naar en van de bouwplaats en tot de noodzaak het produktieproces in de werkplaats te stroomlijnen, waarbij produktie-automatisering belangrijker wordt. Dit betekent dat het professionele bouwbedrijf en de bouwindustrie steeds meer aandacht gaan besteden aan ketenlogistiek. Prefabrikage is als produktie-techniek in de bouw dan ook een vorm van een integrerende rationalisering. In combinatie met nieuwe informatietechnologieën is een bedrijfsoverstijgende beheersing van produktie-processen mogelijk. In het algemeen kan gesteld worden dat prefabrikage ertoe leidt dat het onderscheid tussen bouwnijverheid en bouwmaterialenindustrie diffuus wordt. Het bouwen komt bij prefabrikage steeds meer neer op het assembleren van halffabrikaten en begint daarmee op een industrie te lijken. De bouwplaats verandert in een montagebedrijf. Het eindresultaat van een prefab bouwproces is in de meeste gevallen nog steeds een uniek produkt.

Nieuwe vormen van produktie-automatisering en informatietechnologie maken zowel in de bouw als in de industrie (in de ruimste zin van het woord) een integrerende rationalisering mogelijk zonder dat er sprake is van massaproduktie. Deze ontwikkelingen leiden tot een logistiek naar elkaar toegroeien van industrie en bouw. De traditionele. indeling, waarbij de bouw en de industrie worden gescheiden, verliest zijn relevantie. De eerste aanzet tot rationalisering in industriële produktie-bedrijven was Tayloristische rationalisering en massa-fabrikage. Denken in logistieke termen heeft er bij deze bedrijven recentelijk toe geleid dat men met nieuwe technologische mogelijkheden op het gebied van produktie en informatie-uitwisseling kleine series produkten probeert voort te brengen met de efficiency van massa-fabrikage. Het ideaal is een produktie met seriegrootte één, een seriegrootte die bij de bouw al jaar en dag gebruikelijk is. 


\section{Literatuur}

Aggarwal, S.C., 1985, MRP, JIT, OPT, FMS?: Making sense of production operation systems, Hanvand Business Review, vol. 63, Sept.-Oct., pp. 8-16.

Anderson, E., en Schmittlein, D., 1984, Integration of the Sales Force: An Empirical Examination, Rand Journal of Economics, vol. 15, pp. 385-395.

Alchian, A., Demsetz, H., 1972, Production, Information costs, and Economic Organization, The American Economic Review, vol. 62, pp. 777-95.

Altmann, N., Bechtle, G., en Lutz, B., 1978, Betrieb-Technik-Arbeit: Elemente einer soziologischen Analyrik technisch-organisatorischer Veräderungen, Campus: Frankfurt am Main.

Altmann, N., Deis, M., Dohl, V. en Sauer, D., 1986, Ein "Neuer Rationalisierungstyp"-neue Anforderungen an die Industriesoziologie, Soziale Welt, no. 2/3, pp. 191-206.

Altmann, N., Düll, K., en Lutz, B., 1987, Zukunftaufgaben der Humanisienung des Arbeitslebens, Campus: Frankfurt/New York.

Altmann, N., en Sauer, D., 1989a, Zwischenbetriebliche Vernetzung und industriesoziologische Forschung. Mitteilungen, Heft 5, Verbund Sozialwissenschaftliche Technikforschung. pp. 7-23.

Altmann, N., en Sauer, D., 1989b, Systemische Rationalisierung und Zulieferindustrie: Sozialwissenschaftliche Aspekte zwischenbetriebliche Arbeitsteilung, Campus: Munchen.

Amro Bank, 1988, Op weg naar 1992 Toeleveranciers aan de bouw, Amsterdam.

Architect, de, 1991, Top Tien Nederlandse architectenbureaus, Themanr. 45, pp. 13-53, november.

ARTB (Adviesraad Technologiebeleid Bouwnijverheid), 1992, State of the Art, Den Haag.

Augenbroe, G., 1991, R\&D View on Integration in the Building Industry, in: Handout ESPRIT Workshop on Computer Integrated Building, Amsterdam, 23 april.

Axelrod, R.C., 1984, The evolution of cooperation, Basic Bonks: New York.

Baethge, M., en Oberbeck, H., 1986, Zukunft der Angestellten: neue Technologien und beruffiche Perspektiven in Büro und Venwaltung, Campus: Frankfurt/New York.

Bakens, W., 1986, Kansen en bedreigingen op de markt van morgen, BouwWereld, nr. 22, 31 oktober, pp. $62-64$.

Bakens, W.J.P., 1988, Bouwen aan 2005, Tutein Nolthenius: Amsterdam.

Bakens, W.J.P., en Mulder, J.H., 1989, Teveel contracten en regels funest voor samenwerking. Bouw Wereld, nr. 6, 17 maart, pp. 72-73.

Bakens, W., en Feddema, H., 1990, Klaassen: cataloguswoning met onbegrensde variatie, Bouw, nr. 14/15, 13 juli, pp. 16-17.

Bakens, W., en De Mos, P., 1993a, De toeleverancier in het bouwteam?, Bouw, nr. 1, 8 januari, pp. 25-27.

Bakens, W., en De Mos, P., 1993b, Samenwerken voor een betere concurrentiepositic, Bouw, nr. 4, 26 februari, pp. 9-10.

Bakos, J.Y., 1991, A strategic analysis of electronic marketplaces, MIS Quarterty, September, pp. 295-310.

Ballou, R.H., 1985, Business logistics management: planning and control, Prentice-Hall: Englewood Cliffs (2de druk).

Bardi, E.J. en Coyle, J.J., 1985, The management of business logistics, West Publishing Company: St. Paul (etc.) (3de druk).

Bechtle, G., 1980, Betrieb als Strategie: theorerische Vorarbeiten zu einem industriesoziologischen Konzept, Campus: Frankfurt am Main.

Bekkers, V.J.J.M., 1989, Logistieke netwerkvorming als strategisch concept: de Nederlandse wegtransportsector in Europa 1992, Bedrijfskunde, nr. 2, pp. 123-134.

Bemelmans, T.M.A., en Kreuwels, C.M.A., 1990, Electronic Data Interchange: cen overzicht, Informatie, jrg. 32, nr. 9, pp. 681-692.

Bemelmans, T.M.A., Wortmann, J.C., en Rijn, Th.M.J. van, 1985, Produktie-automatisering: een aanzet tot ordening, Informatie, jrg. 27, nr. 1, pp. 6-12.

Benes, J., en Diepeveen, W.J., 1978, Produktiemanagement in het bouwbedrijf, Kluwer: Devenier/Antwerpen, 
Ten Hagen: Den Haag,

Bennett, J., 1985, Construction Project Management, University Press: Cambridge.

Berg, M.A.M.C. van der, 1990, Samenwerkingsvormen in de bouw, Kluwer: Deventer.

Berg, M.A.M.C. van der, 1991, Een faire kans: het UAR als waarborg voor een eerlijke aanbesteding, Kluwer: Deventer.

Bergmann, J., Hirsch-Kreinen, H., Springer, R. en Wolf, H., Rationalisierung, 1986, Technisierung und' Kontrolle des Arbeitsprozesses, Campus: Frankfurt/New York.

Bergstermann, J., en Brandherm-Bohmker, R., 1989, Systemische Rationalisierung als sozialer Prozess, J.H.W. Dietz Nachf: Bonn.

Bertrand, J.W.M., Wortmann, J.C. en Wijngaard, J., 1990 " Produktiebeheersing en material management, Stenfert Kroese: Leiden/Antwerpen.

Betts, M., Cher, L., Mathur, K. en Ofori, G., 1991, Strategies for the construction sector in the information technology era, Construction Management and Economics, vol. 9, pp. 509-528.

Blommestein, F.B.E. van, 1987, Structuur van logistieke informatiesystemen, Tijdschrift voor Inkoop \& Logistick, nr. 4, pp. 9-13.

BNA (Bond van Nederlandse Architekten), 1991, Referentie Informatie Strategie Architectendiscipline, verslag. BNA projectgroep RISA, Amsterdam.

Boer, R. de, 1992, Architect kan met CAD positie handhaven, Bouw, nr. 12/13, 19 juni, pp. 35-37.

Bol, J., 1991, Serregevels VROM: werk op eenzame hoogte, BouwWereld, ni. 10, 17 mei, pp. 26-29.

Bol, J., 1991, Precisiewerk bovenop het serredak van VROM, BouwWereld, nr. 19, 20 september, pp. 54-57.

Bonekamp, H.A.L., en Mars, G.J.M., 1990, Bouwbedrijf krijgt grotere verantwoordelijkheid, Bouw, nr. 11, 1 juni, pp. 52-53.

Bonjer, J.F.D., en Noorman, Th.M., 1990, Architect krijgt er adviestaken bij, Bouw, nr. 6, 23 maart, pp. 30-31.

Bosman, A. en Eyzenga, G.R., 1988, Planning van produktie en logistiek: Een bedrijfseconomisch deelvakgebied in ontwikkeling, Wolters Noordhoff: Groningen.

Botter, C.H. 1984, Industrie en Organisatie, Kluwer/NIVE: Deventer (13e druk).

Bowersox, D.J., 1990, The Strategic Benefits of Logistics Alliances, Harvard Business Review, vol. 68, JulyAugust, pp. 36-45.

Bowersox, D.J., Closs, D.J., Helferich, O.K., 1986, Logistical management: a systems integration of physical' distribution, manufacturing support, and materials procurement, Macmillan: New York, Collier Macmillan: London (3de druk).

Btaverman, H., 1974, Labor and Monopoly Capital: the Degradation of Work in the Twentieth Century, Monthly Review Press: New York.

Bremer, W., 1991. Techniek, nieuwe materialen en arbeid in de bouwnijverheid, Economisch Instituul. voor de Bouwnijverheid, Amsterdam.

Bremer, W., 1991, Theorieên over de arbeidsmarkt en arbeidsmarktgedrag in de bouw, Wolters-Noordhoff: Groningen.

Brevé, B.J.A.M., 1988, Logistiek verbeteren: handleiding voor produktiebedrijven, Kluwer: Deventer.

Bröhner, J., 1990, Impacts of information technology on the structure of construction, Construction Management and Economics, Voll. 8, pp. 205-218.

Brodner, P., 1985, Fabrik 2000: Alternative Entwicklungspfade in die Zukunft der Fabrik, Wissenschaftszentrum Berlin, Sigma: Berlin.

Broersma, H.s 1991, Co-makership. Trend voor de jaren negentig, proefschrift Rijksuniversiteit Groningen, Groningen.

Broos, M., 1991, Logistick en maatvoering, Cement, nr. 2, pp. 16-19.

Brubaker, R. 1984, The Limits of Rationality: an essay on the social and moral thought of Max Weber, Allen \& Unwin: London.

Burbridge Jr., J.J., 1988, Strategic Implications of Logistics Information Systems, The Logistics and Transportation Review, nr. 4, pp. 368-383.

Buckley, P.J., en Casson, M., 1988, A Theory of Cooperation in International Business, in: Contractor, F.J., en Lorange, P., Cooperative Strategies in International Business, Lexington Books: Lexington, pp. 31-53.

Camp, A van de, 1991, Werknemersbelangen en integrale logistieke bedrijfsvoering, Tijdschrifi voor Arbeidsvraagstukken, jrg. 7, nr. 2, pp. 67-78.

Cayseele, P. van, en Schreuder, H., 1988, Strategiebepaling door ondernemingen: een overzicht, Economisch Statistische Berichten, 7 december, pp. 1152-1159.

CBS, 1992, Maandstatistiek bouwnijverheid, april, CBS-Publikaties, SDU/Uitgeverij: Den Haag.

CBS, 1992, Maandstaristick voor binnenlandse handel en diensrverlening, februari, SDU/Uitgeverij: Den. 
CBS, 1993, Maandstaristiek voor binnenlandse handel en dienstverlening, maart, SDU/Uitgeverij: Den Haag.

CBS, 1991, Nationale Rekeningen 1990, SDU/Uitgeverij: Den Haag.

CBS, 1992, Produktiestatistieken industrie 1990, Voorburg/Heerlen.

CBS, 1992, Produktiestatistieken bouwnijverheid 1990, Voorburg/Heerlen.

CBS, 1990, Statistiek van het ondememingenbestand 1990, Voorburg/Heerlen.

Child, J., 1987, Information Technology, Organization, and Response to Strategic Challenges, California Management Review, vol. 30, nr. 1, pp. 33-50.

Christis, J., 1989, Arbeidsprocesdiscussie en sociotechniek, Tijdschrift voor Arbeidsvraagstukken, nr. 2, pp. 43-59.

Christis, J., 1988, Taylorisme en nieuwe produktieconcepties, Te Elfder Ure 41, nr. 3, pp. 43-59.

CLAD/STABU, 1993, "Bouwinformatisering nu - een boeiende opgave", Syllabus studiedag, 11 maart, Rotterdam.

Coase, R.H., The nature of the firm, in: Stigler, G.J., en Boulding, M.E., 1953, Readings in Price Theory, Allen \& Unwin: London, pp. 331-358.

Contractor, F.J., en Lorange, P., 1988, Why Should Firms Cooperate? The Strategy and Economies Basis for Cooperative Ventures, in: Contractor, F.J., en Lorange, P., Cooperative Strategies in Intemational Business, Lexington Books: Lexington, pp. 3-30.

CROW, 1992, Projectdefinitie NOBI-project 'De koppeling tussen Wegonrwerp en Elektronische Theodoliet (WEET)', Ede.

Daems, H., en Douma, S.W., 1984, Concurrentie: Analyse en Strategie, Kluwer: Deventer/Antwerpen.

Dankbaar, B., 1991, Werken in netwerken: De gevolgen van Electronic Data Interchange voor arbeid en organisatie, Ministerie van Sociale Zaken en Wergelegenheid, VUGA: Den Haag.

Dankbaar, B., 1993, Economic crisis and institutional change: the crisis of Fordism from the perspective of the automobile industry, Universitaire Pers Maastricht, Maastricht.

Debets, C., 1992, De legbatterij van VROM is bijna klaar, BouwWereld, nr. 17, 21 augustus, pp. 22-25.

Delsing, E.J.F., 1989, Industrialisering van de woningbouw, Wibro: Eindhoven.

Diederen, P.J.M, Kemp, R.P.M., Muysken, J., Palm, F.C., Bartels, C.P.A. en Webbink, A.H., 1988, Diffusie van technologie: gevolgen voor werkgelegenheid en beroepenstructuur, Economische Faculteit Rijksuniversiteit Limburg: Maastricht, Buro Bartels Economisch Onderzoek en beleidsondersteuning: Oudemolen.

Dijke, J. van, 1992, Andere rol voor bouwpartners, Bouw en Utiliteit, september, pp. 3-4.

Dohse, K, Jürgens, U., en Malsch, T., 1985, From "Fordism" to "Toyotism"? The Social Organization of the Labor Process in the Japanese Automobile Industry, Politics \& Society 14, nr. 2, pp. 115-146.

Donk, D.P. van en J. de Vries, 1990, Logistiek en Resource Management, Bedrijfskunde, jrg. 62, nr. 2, pp. 221-228.

Duivenvonrden, J.J., 1988, CIM in de bouw: Op weg naar computengeintegreerd bouwen, ClAD (Vereniging voor computertoepassingen in de ingenieurspraktijk), Zoetermeer.

Duivenvoorden, J.J., 1992a, Tour d'horizon door EDI-land: huidige en toekomstige ontwikkelingen, voordracht voor CIAD, 9 maart, Zoetermeer.

Duivenvoorden, J.J., 1992b, EDI en strategie, een cultuurfilosofische visie op invoering van EDI in de Nederlandse bouw, in: Congresdocumentatie Derde Nationale EDI-Congres; Den Haag 24-26 november.

Eccles, R.G., 1981, The quasifirm in the construction industry, Joumal of Economic Behavior and Organization, vol. 2, pp. 335-357.

Economisch Instituut voor de Bouwnijverheid (EIB), 1991, Ontwikkelingen in de bouwnijverheid tot en met 1996, Amsterdam.

Economisch Instituut voor het Midden- en Kleinbedrijf (EIM), 1984, Funcric van en functievenulling door de groothandel, Zoctermeer.

Economisch Instituut voor het Midden- en Kleinbedriff (EIM), 1991, Growhandel en logisticke dienstverleners: partner of concurrent? Zoetermeer.

EDIFORUM, 1990, EDI:stand van zaken in Nederland, Congresdocumentatic Eerste Nationale EDI. Congres, 12-13 november Den Haag.

EDIFORUM, 1992, Nationale EDI-Gids 92-93, Leidschendam.

Englander, E.J., 1988, Technology and Oliver Williamson's Transaction Cost Economics, Joumal of Economic Behavior and Organization, vol. 10, pp. 339-353.

Essen, H.R.W.M. van, 1990, Logistiek management met de bouwkraan, BOUWkosten/Signaal, nr. 4, 15 mei, pp. 7-11.

Etzioni, A, 1964, Modern Organizations, Prentice-Hall: Englewood Cliffs. 
Flapper, H.A.J., 1989, Bouwplaats slecht bediend met informatie, BouwWereld, nr. 12, 9 juni, pp. 75-77.

Fuchs, H., 1993, Die Brücke nach Europa, Wirtschaftswoche, nr. 3, 15 januari, pp. 68-69.

Galbraith, J.R., 1977, Onganization Design, Addison-Wesley: Reading.

Ganiotten, H.J., 1987, Dienstverleners tussen handel en transport, Economisch Instituut voor het Middenen Kleinbedrijf, Zoetermeer.

Geraerds, W.M.J., en Igel, M. (red.), 1989, Flexibiliteit in Logistiek, Technische Universiteit Eindhoven, Samson: Alphen a/d Rijn, NIVE: Den Haag.

Geutjes, B.G.M., 1991, Nieuwbouw Ministeric. VROM: Bouwkundig en constructief ontwerp, Cement, nr. 2. pp. 9-15.

Gielingh, W.F., en Kuiper, P., 1988, Produktmodel basis voor informatie-uitwisseling, BouwWereld, nr. 13, 24 juni, pp. 41-43.

Goldberg, V., en Erickson, J.R., 1987 „Quantity and Price Adjustments in Long-term Contracts: A Case Study of Petroleum Coke, Joumal of Law and Economics, vol. 30, 369-398.

Goldratt, E.M., en Cox, J., 1986, Het Doel, Spectrum: Utrecht (vert. van The Goal, North River Press: New York 1984).

Goor, A.R. van, 1988, Trends in Distributie en Logistiek: Denken in toegevoegde waarde, Stenfert Kroese: Antwerpen/Leiden.

Goor, A.R. van, Ploos van Amstel, M.J., en Ploos van Amstel, W., 1989, Fysieke distributie: denken in toegevoegde waarde, Stenfert Kroese: Leiden/Antwerpen.

Goor, A.R., Kruijtzer, A.H.L.M., en Esmeijer, G.W., 1990, Goederenstroombesturing, voorraadbeheersing en materials handling, Stenfert Kroese: Leiden/Antwerpen.

Greveling, N.J.W., en Kokke, C.J.T.M., 1989, De veranderende betekenis van informatietechnologie voor organisaties, Informatie, nr. 9, pp. 662-673.

Groenenboom, G.J., 1992, Organisatie, coordinatie en interorganisationele informatiesystemen, Informatie, jrg. 34, nr. 7/8, pg. 399-408.

Groenendijk, P., 1988, Een transparant Ministerie: het nieuwe Ministerie van Volkshuisvesting, Ruimtelijke Ordening en Milieubeheer, Rotterdam.

Groenewegen, J., 1990, De transaktiekostentheorie nader bezien, Tijdschrift voor Politieke Ekonomie, jrg. 12, nr. 4, pp. 50-76.

Groot, R. de, 1993, De perspectieven voor EDI en PDI in de bouwsector, afstudeerscriptie Technische Universiteit Eindhoven.

Grooting, P., en Hovels, B., 1981, Sociale ongelijkheid in het arbeidsbestel, Instituut voor Toegepaste Sociologie, Nijmegen.

Griossman, S.J., en Hart, O.D., 1986, The Cost and Benefits of Ownership: A Theory of Vertical and Lateral Integration, Joumal of Political Economy, vol. 94, pp. 691.719.

Haan, A.J. đe, 1993, Bouwinformatica: Toren van Babel, Automatisering Gids, 9 april, p. 9.

Hage, H., 1992, Bouwbesluit: mijlpaal in proces van deregulering, Toegepaste Wetenschap, juni, pp. 7-9.

Hagedoorn, J., 1900, Samenwerking bij produktie en innovatie, Tijdschrift voor Politieke Ekonomie, 13e jrg., nr. 1. pp. 17-39.

Hakansson, H., 1987, Industrial Technological Development: A network approach, Routledge: London.

Hakansson, H. en Johanson, J., 1988, Formal and Informal Cooperation Strategies in International Industrial Networks, in: Contractor. F.J., en Lorange, P., Cooperative Strategies in International Business, Lexington Books: Lexington, pp. 396-379.

Harrigan, K. R., 1988, Strategic Alliances and Partner Asymmetries, Management International Review, Special Issue, pp. 53-72.

Hart, O., en Moore, J., 1990, Property Rights and the Nature of the Firm, Joumal of Political Economy, vol. 98, pp. 1119-1158.

Hasegawa, F., 1988, Built by Japan: Competitive Strategies of the Japanese Construction Industry, Wiley: New York.

Hayek, F.A., 1945, The Use of Knowledge in Society, The American Economic Review, vol. 35, pp. 519-530. Helfert, M., 1985, Chancen neuer Produktionskonzepte, WSI Mitteilungen, nr. 3, jrg. 38, pp. 136-140.

Hendrikse, G.W.J., Schreuder, H., 1987, Economische organisatietheoriecn, Economisch Statistische Berichten, 2 september, pp. $810-815$.

Hertog, J.F. den, en Assen, A. van, 1988, Methodologie van ontwerpgericht onderzoek, LIBER, Maastricht.

Heskett, J.L., Glaskowsky jr., N.A., Ivic, R.M., 1973, Business Logistics: Physical Distribution and Materials Management, New York (2de druk).

Hezik, M.L.A.M. van, 1992, Stabu en de informatie-infrastructuur. De Bouwadviseur, december, pp. 34-36. Hezik, M.L.A.M. van, en Woestenenk, K., 1992. Op weg naar prestatiebestekken, Cement, nr. 4, pp. 35-37. 
Hodgson, G. M., 1988, Economics and Institutions, Polity Press: Oxford.

Hoekstra, S., en Romme, J.H.J.M., 1985, Op weg naar een integrale logistieke structuren, Kluwer: Deventer, NIVE: Den Haag.

Hofman, W.J., 1989, EDI handboek: electronische gegevensuitwisseling russen organisaties, Bakkenist Spits en Co Organisatie Adviseurs, Tutein Nolthenius: Amsterdam.

Hove, D. ten, Interactieve Videotex, in: Ruiten, P.J.G.M. (red.), 1986, Informatiesystemen nussen onganisaties, Kluwer: Deventer, pp. 83-108.

Hulst, W.G.H. van, en Willems, J.G.L.M., 1989, Exteme onganisatie: een kennismaking met het ondememingsgedrag in markteconomische stelsels, Stenfert Kroese: Leiden/Antwerpen.

Idema, L.R. en C.B. Maliepaard, 1989, Databanken: ontwikkelingen, knelpunten en oplossingen, BouwWereld, nr. 23, 10 november, pp. 119-121.

Imai, K.L, en Itami, H., 1984, Interpenetration of Organization and Market, Intemational Joumal of Industrial Organization, nr. 2, pp. 285-310.

Jaarboek van Nederlandse ondernemingen 1990/91, 1991, J.H. de Bussy/Tutein Nolthenius: Amsterdam.

Jacobs, D., Kuijper, J., en Roes, B., 1992, De economische kracht van de bouw, Stichting Maatschappij en Onderneming: Den Haag.

Jans, E.J., 1987, Grondslagen van de administratieve organisatie, Samson: Alphen aan den Rijn.

Janse, F., 1989, Bouwen op automatisering, Automatisering Gids, 12 november, p. 11.

Jansen, G.-J., en Kosterman, R., 1992, Te weinig innovatic in de bouw, FEM (Financieel-economomisch magazine), 21 maart, pp. 26-28.

Janssen, B.J.P., en Machielse, C., 1988, Logistiek, Ruimtelijke Onganisatie en Infrastructuur, INRO-TNO, Delft.

Janssen, B., en Nauta, B., 1986, Op zoek naar samenhang tussen logistiek, flexibele automatisering en materiele infrastructuur, Technische Hogeschool, Eindhoven.

Jarillo, J.C., 1988, On Strategic Networks, Strategic Management Joumal, vol. 9, pp. 31-41.

Johanson, J., en Mattson, L.G., 1987, Interorganizational relations in industrial systems: A network approach compared' with the transaction-cost approach, Intemational Studies Organization, nr. 1، pp. 34.48.

Johnston, R., en Lawrence, P.R., 1988, Beyond Vertical Integration - the Rise of the Value-Adding Partnership, Harvard Business Review, vol 66, July-August, pp. 94-101.

Johnston, R., en Vitale, M.R., 1988, Creating Competitive Advantage With Interorganizational Information Systems, MIS Quarterly, June, pp. 153-165.

Jokisch, R., 1982, Techniksoziologie, Suhrkamp: Frankfurt am Main.

Jong, H.W. de, 1987, Concurrentic en samenwerking, theoretische en actuele aspecten, Bedrijfskunde, jrg. 59, nr. 4, pp. 310-315.

Jong, H.W. de, 1985, Dynamische marktheorie, Stenfert Kroese: Leiden/Antwerpen.

Jong, H.W. de, 1981, Marktorganisatic, mededinging en prijsvorming, Economisch Statistische Berichten, 30 december, pp. 1268-1280.

Joskow, P.L., 1987, Contract Duration and Relation Specific Investments: Empirical Evidence from Coal Markets, American Economic Review, vol. 77, pp. 168-185.

Joskow, P.L., 1988, Asset Specificity and the Structure of Vertical Relationships: Empirical Evidence, Joumal of Law, Economics, and Organization, vol. 4, pp. 95-117.

Joskow, P.L., 1991, The Role of Transaction Cost Economics in Antitrust and Public Utility Regulatory Policies, Joumal of Law, Economics, and Organization, vol. 7, pp. 53-83.

Jutte, A.C., 1990, Oprichting Stichting EDIBOUW een logisch gevolg wan succesvol initiatief EDIPRAKT, Stichting EDIBOUW, 24 december.

Kasteren, J. van, 1991, Dreiging uit het buitenland, Ingenieurskrant, nr. 26/27, 19 december, p. 15.

Kasteren, J. van, 1992, Kennisoverdracht blijkt bottleneck, Ingenieurskrant, nr. 25, 19 november, p. 27.

Kern, H., en Schumann, M., 1985a, Das Ende der Arbeitsteilung?, Verlag C.H.Beck: Munchen.

Kern, H., en Schumann, M., 1985b, Kontroverse um "neue Produktionskonzepte", WSI Mitteilungen, nr. 6, jrg. 38, pp. 356-361.

Kettlitz, J.H.Th.O., 1992a, Bouwbesluit maakı produktoriēntatie mogelij̣, Bouw, nr. 10, 22 mei, pp. 17-19.

Kettlitz, J.H.Th.O., 1992b, Hoofdaannemer staat voor moeilijke keuze, Bouw, nr. 11, 22 mei, pp. 36-38.

Kettlitz, J.H.Th.O., 1992c, De moeizame relatie tussen architect en aannemer, Bouw, nr. 16/17, 14 augustus, pp. 10-11.

Klein, S., 1992, Bestek en EDI: de wenselijkheid en mogelijkheid van een elektronisch bestekbericht voor de Nederlandse bouw, Afstudeeronderzock uitgevoerd bij stichting EDIBOUW, 's-Hertogenbosch.

Klein, B., Crawford, R., Alchian, A, 1978, Vertical integration, appropriable rents, and the competitive 
contracting process, Joumal of Law and Economics, vol. 21, pp. 297-326.

Korevaar, K., 1990, Funderingsherstel: over vernieuwing management en vakbondswerk in de bouw, Bouwen Houtbond FNV, Uitgeverij Jan Mets: Amsterdam.

Koskela, L., 1985, The Japanese Example Construction industry towards the information society, FACE Report, No. 7, Melbourne.

Krause, E.A., 1982, Division of Labor: a political perspective, Greenwood: London/Westport.

Kreuwels, C.M.A., en Van Voorthuijsen, J.F. van, 1991, EDI in de bouwnijverheid, Informatie, vol. 33, nr. 1, pp. 9-15.

Kubicek, H., 1988, Technikgestaltung durch Mitbestimmung bei zwischenbetrieblicher Vernetzung, WSI Minteilungen, nr. 11, pp. 663-669.

Kubicek, H., 1992, Die Organisationslücke beim elektronischen Austausch von Geschaftsdokumenten (EDI) zwischen Organisationen, Fassung eines, Vortrags auf dem 16. Workshop der Wissenschaftlichen Kommission "Organisation" im Verband der Hochschullehrer für Betriebswirtschaft "Ōkonomische Theorie der interorganisationele Beziehungen", 2-4 April in Berlin.

Kumpe, T., en Bolwijn, P.T., 1988, Manufacturing: The New Case for Vertical Integration, Harvard Business Review, vol. 66" March-April, pp. 75-81.

Levy, S.M., 1989, Japanese construction: an American perspective, Van Nostrand Reinhold: New York.

Lewris, H.T., Culliion, J.W., en Steel, J.D., 1956, The Role of Air Freight in Physical Distribution, Harvard University, Boston.

Liesker, F, 1992, Aannemers verjaagd uit paradijs, Ingenieurskrant, nr. 21, 24 september.

Littek, W., Rammert, W., en Wachtler, G., 1983, Einfühnung in die Arbeits- und Industriesoziologie, Campus Verlag: Frankfurt/New York.

Littler, C.R., 1982, The Development of the Labour Process in Capitalist Societies, Heinemann Educational Books: London.

Londe " B.J. La, Grabner, J.R., en Robeson, J.F., 1970, Integrated distribution systems: a management perspective, International Journal of Physical Distribution, vol. 1, nr. 1, pp. 43-49.

Los, E., en Gort, D., 1993, Bouwprojectmanagement: een branche in ontwikkeling, Bouw, nr. 12/13, 18 juni, pp. 46-47.

Lourens, E., 1990, De positie van de archilect in het bouwproces, Economisch Instituut voor de Bouwnijverheid, Amsterdam.

Lousberg, L., 1991. RISA: Wat is de positic van de architect in informatiestroom bouwproces, Architectuur/Bouwen, nr. 9, pp. 24-27.

Lubbers, R.M., 1989, Consiruction Management, een dilemma voor de principaal?, Bouwen met Staal, nr. 92, december, pp. 29-32.

Lutz, B. (red.), 1986, Technik und sozialen Wandel, Verhandlungen des 23. Deutschen Soziologentages in Hamburg 1986, Campus Verlag: Frankfurt/New York.

Maas, T., 1992, Nieuwbouw VROM: een formidabele uitvinding, Architecruur/Bouwen, nr. 8, pp. 20-26.

Magee, J.F., Copacino, C.W., Rosenficld, D.B., 1985, Modern logistics management; integrating marketing, manufacturing and physical distribution, Wiley: New York.

Maliepaard, C.B., en Swets, H.L., 1989, Goede informatieverwerking leidt tot hogere produktiviteit, Bouw'Wereld, nr. 5, 3 maart, pp. 52-53.

Malone, T.W.s Yates, J., Benjarnin, R., 1987, Electronic Markets and Hierarchies, Communications of the ACM, vol. 30, pp. 484-497.

Malsch. T., en Seliz, R., 1987, Die neuen Produktionskonzepte auf dem Priffstand: Beiträge zur Entwicklung der Industriearbeit. Edition Sigma: Berlin.

Manske, F., 1987, Ende oder Wandel des Taylorismus, Soziale Welt, Heft 2, pp. 166-179.

Manske, F., 1991, Kontrolle Rationalisierung und Arbeit, Edition Sigma: Berlin.

March, J.G., en Simon, H.A. 1958, Onganizations, Wiley: New York.

Marglin. S.A., 1974, What Do Bosses Do? The Origins and Functions or Hierarchy in Capitalist Production, Review of Radical Political Economics, vol. 6, pp. 60-112.

Mariotti, S., en Cainarca, G.C., 1986, The evolution of transaction governance in the textile-clothing industry, Journal of Economic Behavior and Onganization, pp. 351-374.

Masten, S., 1984, The Organization of Production: Evidence from the Aerospace Industry, Journal of Law and Economics, vol. 27. pp. 403-417.

Masten, S.E., Mechan Jr., J.W., en Snyder, E.A., 1991, The Costs of Organization, Journal of Law, Economics, and Onganization, vol. 7, pp. 1-25.

Mathews, J., 1989, Tools of change: new technology and the democratisation of work, Pluto Press: Sydney. Miles, E.M., en Snow, C.C., 1986, Organizations: New Concepts for New Forms, California Management 
Review, vol. 28, no. 3, pp. 62-73.

Miles, EM., en Snow, C.C., 1992, Causes of Failure in Network Organizations, California Management Review, vol. 34, pp. 53-72.

Ministerie van Economische Zaken, 1981, Bedrijfstakverkenning Metaalprodukten- en machine-industrie, Den Haag.

Ministerie van Sociale Zaken en Werkgelegenheid, 1986, Technologie en werkgelegenheid op sectomiveau, Samenvatting van een onderzoek in de chemische- en rubberindustrie en in de hout- en bouwmaterialenindustrie, Den Haag.

Mintzberg, H., 1979, Structuring of Onganizations, Prentice-Hall: Englewood Cliffs.

Mischgofsky, F.H., 1991, Uitdagingen en bedreigingen voor de civicle techniek, De Ingenieur, nr. 4, april, pp. 7-13.

Monhemius, W.n en Durlinger, P.P.J., 1989, Logistiek Management, Kluwer: Deventer.

Monteverde, K.M., en Teece, D.J., 1982a, Supplier Switching Costs and Vertical Integration in the Automobile Industry, Bell Joumal of Economics, vol. 13, pp. 206-213.

Monteverde, K.M., en Teece, D.J., 1982b, Approriable rents and quasi vertical integration, Joumal of Law and Economics, vol. 25, pp. 321-328.

Mooij, M., 1992, Het scenario-model, De Bouwadviseur, april, pp. 34-36.

Moore, J., 1992, The firm as a collection of assets, European Economic Review, vol. 36, pp. 493-507.

Mos, P. de, 1990, Bouwen steeds meer een tijdgebonden opgave, Bouw, nr. 23, 16 november, pp. 26-28.

Nagel, B., Riess, B., en Theis, G., 1990, Mitbestimmung entlang der logistischen Kette, Der Mitbestimmung. nr. 6-7, pp. 395-401.

Naschold, F., 1985, Arbeit und Politik: gesellschaftliche Regulienung der Arbeit und der sozialen Sicherung. Campus: Frankfurt/New York.

NEDC (National Economic Development Office), 1990, Information Transfer in Building, London.

Nehem, 1982, Structuurschema van de Nederlandse Houthandel, 's Hertogenbosch.

Nelson, R.R., and Winter, S.G., 1982, An Evolutionary Theory of Economic Change, Belknap, Harvard University Press: Cambridge/Massachusets.

Net, D.J. van đer, en Bruijn, D.J., 1992, Ervaringen uit 25 verschillenđe EDI projecten, Informatie, jrg. 34. nr. $7 / 8$, pp. 409-415.

Nevem, 1987, Prestatie-indicatoren in de logistiek, Kluwer: Deventer.

Nooteboom, B., 1992, Transactiekosten en informatietechnologie, Economisch Statistische Berichten, 6 mei, pp. 444-447.

OECD, 1992, Long-1erm prospects for the world economy, Parijs.

Oskam, E.A., 1988, De ontwikkeling van de aan de bouwnijverheid toeleverende industrieẽn in de periode 1969-1985, Economisch Instituut voor de Bouwnijverheid (EIB), Amsterdam.

Ouchi, W.G., 1980, Markets, Bureaucracies, and Clans, Administrative Science Quarterly, vol. 25, pp. 129. 141.

Oude Kempers, J.H.M., 1991, Communicatie bij tekenwerk en keuring van prefab beton, Cemeni, nr. 9, pp. 60-65.

Palay, T.M., 1984, Comparative Institutional Economies: The Governance of Rail Freight Contracting, Joumal of Legal Srudies, vol. 13, 265.287.

Palay, T.M., 1985. Avoiding Regulatory Constraints: Contracting Safeguards and the Role of Informal Agreenents, Joumal of Law, Economics, and Organization, vol. 1, pp. 155-176.

PCR (Programma Coordinatie Rasd), 1990, Narionaal Onderzoekskader Bouwinformatica (NOBI), Rotterdam, 23 november.

Perrow, C., 1986, Complex Onganizations: A Critical Essay, Ranđom House: New York (3de druk).

Pfeffer, J., Salancik, G.R., 1984, The Extemal Control of Organizations, Hasper \& Row: New York.

Pino, R., en Van 't Eind, S., 1990, Logistiek geeft dimensie aan concurrentiestrategie, Tijdschrifi voor Marketing, oklober, pp. 62-72.

Piore, M.J., en Sabel, C.F., 1984, The Second Industrinl Divide: Possibilivies for Prosperiy, Basic Books: New York.

Poist, R.F., 1989, Evolution of Conceptsal Approaches to the Design of Logistics Systems: A Sequel, Transportation Joumal, nr. 3, pp. 35-39.

Porter, M.E., 1980, Competitive strategy: lechniques for anatyzing industries and competitors, Free Press: New York, Collier Macmillan: London.

Porter, M.E., 1985, Competitive advantage: creating and sustaining superior performance, Free. Press: New York, Collier Macmillan: London.

Porter, M.E. en Millar, V.E., 1985, How information gives you competitive advantage, Harvard Business 
Review, vol. 63, July-August. 1985, pp. 149-160.

Porter, M.E., en Fuller, M.B., 1986, Coalitions and Global Strategy, in: M.E. Porter, Competition in Global' Industries, Harvard Business School Press: Boston, pp. 315-343.

Powell, W.W., 1990, Neither Market nor Hierarchy, Research of Organizational Behavior, pp. 295-336.

Putterman, L. (red.), 1986, The economic nature of the firm " Cambridge University Press: Cambridge.

Rainbird, H., en Syben, G. (red.), 1991, Restructuring a traditional society: construction employment and skills in Europe, Berg Publishers: Oxford.

RBB (Stichting Research Rationalisatie Bouw), 1991, Logistieke instrumenten bij de voorbereiding van bouwwerken, Research rapport 71, Zoetermeer.

Rheenen, R.J. van, 1992, MDS Construction, voordracht tijdens Derde Nationale EDI-Congres, Den Haag, 24-26 november.

Ribbers, P., 1991, EDI als een organisatorisch en strategisch vraagstuk, Informatie en informatiebeleid, vol. 9, no. 3, pp. $42-47$.

Riordan, M.H., en Wiiliamson, O.E., 1985, Asset Specificity And Economic Organization, Intemational Joumal of Industrial Organization, vol. 3, pp. 365-378.

Roggen, M., 1991, Traditionele manier van denken staat prefab bouwen in de weg, Polytechnisch Weekblad, 6. juni.

Rooy, M. van, 1992, De ambtenarenvolière, NRC, 11 september, Cultureel Supplement, p. 5.

Roscam Abbing, M., en Dankbaar, B., 1991, Uitbesteding en vakbondsstrategie, FNV Steunpunt Technologic, Amsterdam.

Ruijgrok, C.J., 1986, Logistiek \& Transport: Thematische studie in het kader van Eureka, TNO, Delft.

SBR (Stichting Bouwresearch), 1977, Transport bij het bouwproces, Kluwer: Deventer/Antwerpen, Ten Hagen: Den Haag.

SBR (Stichting Bouwresearch), 1988, Her kan best anders in de bouw, Rotterdam.

SBR (Stichting Bouwresearch), 1989a, Logistiek in de bouw, Rotterdam.

SBR (Stichting Bouwresearch), 1989b, Spelregels voor informatieuitwisseling tussen bouwpartners: Herschikking informatie over het bouwkundige deel van bouwprojecten, Rotterdam.

SBR (Stichting Bouwresearch), 1991, NOBI Uitvoeringsplan met Afsprakenstelsel Bouwinformatica, Rotterdam, sepiember.

SBR (Stichting Bouwresearch), 1992a, Botworganisatievormen in Nederland, Rotterdam.

SBR (Stichting Bouwresearch), 1992b, EDI in de bouw, concept rapport, Rotterdam.

SBR (Stichting Bouwresearch), 1993, Toelevering in de bouw: dynamiek en strategie, Rotterdam.

Schaafsma c.a., A.H., 1986, Concurrentiekracht door logistiek, Kluwer: Deventer, NEVEM: Den Haag.

Schepper, A.A.Th. de, 1991, Dynamiek in logistiek, Coopers \& Lybrand Dijker Van Dien, Tilburg (inaugurele rede).

Scott, W.R., 1987, Onganizations: rational, natural, and open systems, Prentice-Hall: Englewood Cliffs.

Scoli Morion, M.S., 1991, The corporation of the 1990's: information technology and organizational' transformation, Oxfordl University Press: New York/Oxford.

Shapiro, R.D., 1984, Get leverage from logistics, Harvard Business Review, vol. 62, May-June, pp. 120-126.

Sharman, G., 1984, The rediscovery of logistics, Harvard Business Review, vol. 62, Sept.-Oct., pp. 71-79.

Simon, H.A., 1957, Models of Man, Wiley: New York.

Sitter, L.U. đe, 1981, Op weg naar nieuwe fabrieken en kantoren: produktie-onganisatie en arbeidsonganisatie op de fweesprong, Kluwer: Deventer.

Sitter, LU. de, 1986, Het flexibele bedrijf: integrale aanpak van flexibiliteit, beheersbaarheid, kwaliteit van de arbeid en produktie-automatisering, Kluwer: Deventer.

Sitter, U. de, 1989, Modern Sociotechnology, Koers Consultants, Den Bosch.

Sluizer, O., 1993, Het prestatie-concept, Bijlage bij Mededelingenblad van de Bond van Nederlandse Architekien, januari.

Smeets, M., 1991, Het succes van de Aziatische draken, Economisch Statistische Berichten, 31 juli, pp. 764772.

Souwerbren, C., 1989, Kwaliteitszorg in de bouw: over de rol van certificatie, Cement, nr. 2, pp. 12-15.

Stenger, A.J., 1986, Information Systems in Logistics Management: Past, Present, and Future, Transportation Joumal, wol. 26, nr. 1, pp. 65-82.

Sombart, W., 1927, Der moderne Kapitalismus, Duncker \& Humblott: München/Leipzig.

Sorge, A, 1991, Strategic Fit and the Societal Effect: Interpreting Cross-National Comparisons of Technology, Organization and Human Resources, Organization Srudies, vol. 12, nr.2, pp. 161-190.

Spekkink, D., en Gerritse, G., 1992, Aangepast concept benut know-how van zowel ontwerper als 
aannemer, Architecruur/Bouwen, nr. 1, pp. 44-47.

Stad, H., 1992, Drie Fuji-fabrieken onder ến besturingssysteem, LogistiekKrant maart, p. 15.

Stichting STABU, 1988, Standaandbestek Burger- en Uriliteitsbouw, Ede.

Taen, R.J.M., en Versluis, G., 1990, Overkoepelende informatiesystemen vereisen een collectieve aanpak, De Bouwadviseur, juli/augustus, pp. 26-28.

Tangel, T., 1992, Fusie: liefde komt van twee kanten, Architectuur/Bouwen, nr. 11, pp. 22-24.

Tangel, T., 1993, Architecten met planontwikkeling frontaal in de aanval, Architechuur/Bouwen, nr. 1, pp. $38-41$.

Tanja, P.T., en Smook, J., 1988, Edi en logistiek: ontwikkelingsmogelijkheden en beleidsopties, INRO-TNO, Delft.

Technieuws Tokio, 1992, Recente ontwikkelingen van Electronic Data Interchange, jrg. 30, nr. 18, 5 oktober, pp. 3-12

Teece, D.J., 1982, Towards an Economic Theory of the Multiproduct firm, Joumal of Economic Behavior and Organization, vol. 3, pp. 39-63.

Teece, D.J., 1986, Profiting from technological innovation: Implications for integration, collaboration, licensing and public policy, Research Policy, vol. 15, pp. 285-305.

Teece, D.J., 1988, Technological change and the nature of the firm, in: G. Dosi, C. Freeman, R. Nelson, G. Silverberg en L. Soete, Technical Change and Economic Theory, Pinter: London/New York, pp. 256281 .

Thompson, J.D., 1967, Onganizations in action: social science bases of administrative theory, Mc Graw Hill: New York.

Thorelli, H.B., 1986, Networks: Between Markets and Hierarchies, Strategic Management Journal, vol. 7. nr. 1, pp. 37-51.

Tolsma, H., 1993, Ingenieurskrant Top-50 ingenieursbureaus, Ingenieurskrant, nr. 10, 20 mei.

UCB (Universitair Centrum, voor Bouwproduktie), 1991, Hulpmiddelen logistiek management, Concept studierapport deel 1, 1 oktober Eindhoven.

UGCB/ONRI/BNASTAGG, 1985, Elementenmethode 1985; Ede.

Vaan, M.J.M. de, 1988a, De betekenis van logistiek voor de Nederlandse industrie 1900-1980-2000+, Vrije Universiteit, Amsterdami (inaugurele rede).

Vaan, M.J.M. đe, 1988b, Just in time, KJuwer: Deventer.

VABil, 1991, Projecroorstel Gebouwmodel, Delft.

VCA, 1991, Projectvoorstel Bouwkosten en bestek. Den Haag.

VCA, 1992, NOBI/BBB-project Inveniarisatie-rapport, 30 september.

Veld, J. in 't, 1981, Organisatiestructiur en arbeidsplaats, Elsevier: Amsterdam/Brussel.

Vlist, P. van der, 1988, Telematica netwerken: een organisatorisch perspectief, Bakkenist, Spius en Co., Tuteín Nolthenius: Amsterdam.

Vollaard, P., 1993, Cepezed neemt uitvoering in eigen hand, Archilechurr/Bouwen, nr. 2, pp. 44l-47.

Voordijk, H., 1992. Arbeid en organisatie in cen logistieke keten, in: G. B. van Hees et al. (red.), Arbeidsen Organisatie-onderzoek in Nederland, SISWO, Amsterdam, pP. 163-185.

Voordijk, H., 1992, New logistics in construction industry, in: R.J. Streng, C.F. Ekering, E. van Heck, J.F.H. Schultz (red.), Scienific Research on EDI 'Bringing Worlds Together', Samson: Alphen aan den Rijn, pp. 59-74.

Vrede, T. de, 1992, Sluipende doorbraak intelligente gebouwen, Automatisering Gids, 1 april, p. 13.

Waarden, B.F. van, 1989, Onganisatiemacht van belangenverenigingen: De ondememersorganisaties in de bouwnijverheid als voorbeeld, Ambo: Amersfoort/Leuven.

Waegemaekers, J.J., 1992, Van aannemer naar bouwondernemer, Cement, nr. 4, pp. 58-62.

Wagter, H., en Schaefer, W.F., 1992, Bouwkundig automatiseren en geautomatiseerd bouwen: dromen en werkelijkheid, De Bouwadviseur, december, pp. 14-18.

Walta, H., 1993, IT binnen de bouwsector vooral een logisch probleem, Lezing tijdens symposium 'Bouwen met Informatietechnologie; 8 april, TU Eindhoven.

Wassenberg, A., 1980, Netwerken: onganisatie en strategie, Boom: Meppel.

Weber, M., 1976, Wirtschaft und Gesellschaft, J.C.B. Mohr: Tübingen.

Williamson, O.E., 1975, Markets and Hierarchies: Analysis and Antitrust Implications, Free Press: New York, Collier Macmillan: London.

Williamson, O.E., 1979, Transaction-Cost Economics: The Governance Of Constractual Relations, Joumal of Law and Economics, vol. 22, pp. 233-261.

Williamson, O.E., 1980, The Organization of Work, a Comparative Institutional Assessment, Journal of Economic and Business Organization, nr. 1, pp. 1-38. 
Williamson, O.E., 1981, The modern corporation: Origins, evolution, attributes, Joumal of Economic Literature, vol. 19, 1537-1568.

Williamson, O.E., 1985, The Economic Institutions of Capitalism: Firms, Markets, Relational Contracting, Free Press: New York, Collier Macmillan: London.

Williamson, 1988, The logic of economic organization, Journal of Law, Economics, and Organization, vol. 4, 65-93.

Williamson, O.E., 1990, The Firm as a Nexus of Treaties: an Introduction, in: M. Aoki, B. Gustafsson en O.E. Williamson, The Firm as a Nexus of Treaties, SAGE Publications: London/Newbury Park/New Delhi.

Williamson, O.E., 1991, Comparative Economic Organization: The Analysis of Discrete Structural Alternatives, Administrative Science Quarterly, vol. 36, pp. 269-296.

Winch, G., 1989, The construction firm and the construction project: a transaction cost approach, Construction Management and Economics, vol. 7, pp. 331-345.

Winter, S.G., 1988, On Coase, Competence, and the Corporation, Joumal of Law, Economics, and Organization, vol. 4, pp. 163-180.

Wood, S., 1988, Van Braverman naar Cyberman? Nieuwe technologie en arbeidsverhoudingen, Te Elfder Ure 41 , jrg. 29, nr. 3, pp. 74-113.

Wortmann, J.C., 1990, Informatiesystemen en Integratie tussen Logistieke Activiteiten, in: Integratie in Logistiek als Strategie, Syllabus studiemiddag d.d. 26 november 1990, Faculteit Bedrijfskunde, Erasmus Universiteit, Rotterdam.

Wortmann, J.C., 1992, Het effect van EDI op de logistieke besturing van een industrieel bedrijf, in: EDIFORUM, Congresdocumentatie Derde Nationale EDI-Congres, 24-26 november Den Haag.

Yin, R.K., 1989, Case study research: Design and methods, SAGE-Publications: Newbury Park/London.

Zajac, E.J., en Olsen, C.P., 1993, From Transaction Cost To Transactional Value Analysis: Implications For The Study Of Interorganizational Strategies, Joumal of Management Studies, vol. 30, pp. 131-145.

Zwinkels, C., 1990, Is de macht aan de ondernemende architect, De Architect, Themanr. 41, novernber, pp. 51-53. 


\section{Bijlage I Bouwen in Nederland}

In deze bijlage wordt ingegaan op economische en structurele ontwikkelingen van sectoren waarvan bedrijven in ketens in de bouw deel uitmaken. Ten eerste worden ontwikkelingen in produktie en werkgelegenheid van de bouwnijverheid en de belangrijkste toeleveranciers van deze bedrijfstak behandeld. Ten tweede wordt ingegaan op de bedrijfsstructuur van deze sectoren en veranderingen daarin. Ten derde worden de belangrijkste sector-organisaties en onderzoeksinstellingen in deze sectoren behandeld. Deze bijlage is grotendeels gebaseerd op bestaand statistisch materiaal en recente sector-studies. ${ }^{1}$ De eerste paragraaf behandelt de ontwikkeling van produktie en werkgelegenheid over de laatste 20 jaar, $\S 2$ de bedrijfsstructuur en $\S 3$ de belangrijkste branche-organisaties en onderzoeksinstellingen.

\section{Ontwikkelingen in produktie en werkgelegenheid}

\subsection{Produktie en de werkgelegenheid in de bouwnijverheid}

Er kunnen een aantal factoren opgesomd worden die op de lange termijn het totaalvolume van de bouwproduktie en daarmee ook deels de werkgelegenheid van de bouwnijverheid bepalen. Volume-ontwikkelingen worden voor een belangrijk deel beïnvloed door demografische factoren, de beschikbaarheid van overheidsgelden, verwachtingen ten aanzien van de toekomstige economische ontwikkeling en de staat waarin de huidige voorraad gebouwen verkeert (Bakens, 1986).

Een teruglopende bevolkingsgroei heeft gevolgen voor woningbouw en scholenbouw. Gevolgen van bezuinigingen in de gesubsidieerde woningbouw en de weg- en water-

\footnotetext{
${ }^{1}$ De belangrijkste bronnen zijn:
}

a. Statistisch materiaal van het Centraal Burcau voor de Statistiek (CBS):

- Nationale Rekeningen 1990 (1991):

- Produktiestatistieken bouwnijverheid 1990 (1992);

- Produktiestatisticken industrie 1990 (1992);

- Maandstatistiek bouwnijverheid;

- Maandstatistick voor binnenlandse handel en dienstverlening:

- Statistiek van het ondernemingenbestand 1990 (1990).

b. Publicaties van het Economisch Instituut voor de Bouwnijverheid (EIB) waarvan de voornaamste:

- Oskam, De ontwikkeling van de aan de bouwnijverheid toeleverende industrieen in de periode 1969. 1985 (1988);

- Ontwikkelingen in de bouwnijverheid tot en met 1996 (1991).

c. Sector-studies waarvan de belangrijkste:

- Diederen et al., Diffusie van technologie: gevolgen voor werkgelegenheid en beroepenstructuur (1988);

- Jakobs et al., De economische kracht van de bouw (1992);

- Korevaar, Funderingsherstel (1990);

- Van Waarden, Organisatiemacht van belangenverenigingen (1989).

d. Jaarverslagen van branche-organisaties. 
bouw, sectoren van de bouwmarkt waarbij de overheid financieel het meest betrokken is, hebben ook een teruggang van het volume tot gevolg. De invloed van economische ontwikkelingen en verwachtingen is vooral belangrijk bij de produktie van gebouwen voor het bedrijfsleven. Sectoren die rekenen op economische groei zullen meer geneigd zijn te investeren in bedrijfsgebouwen. Tenslotte is de mate waarin bestaande gebouwen verouderd zijn een factor die bepaald op hoeveel werk de bouw mag rekenen in de $z$ in van onderhoud, renovatie of vervanging.

Beiangrijk kenmerk van de bouwproduktie is de conjunctuurgevoeligheid. ${ }^{2}$ In 1980 bedroeg de bouwproduktie een kleine 50 miljard gulden. Een dieptepunt werd in 1983 bereikt met een produktie-omvang van 39 miljard. Gelijktijdig met de recessie in de Nederlandse economie, daalde de bouwproduktie scherp in de jaren '80 en veroorzaakte begin jaren ' 80 een grote uitstoot van werknemers. De werkgelegenheid daalde tussen 1980 en 1983 bij de bouwbedrijven met 30 procent: van 400.000 manjaren in 1980 tot 285.000 in 1983. Weliswaar is de bouwproduktie tussen 1983 en 1989 weer met 28 procent gegroeid, de groei van de werkgelegenheid bedroeg over dezelfde periode maar 12 procent. Verklaringen hiervoor zijn afstoting van minder produktieve arbeid, een verdere verschuiving van werk naar het voortraject en een verandering van de beroepssamenstelling, die te zamen hebben geleid tot een sterke stijging van de arbeidsproduktiviteit.

FIGUUR I De ontwikkeling van đe bouwproduktie en de werkgelegenheid, 1970-1989

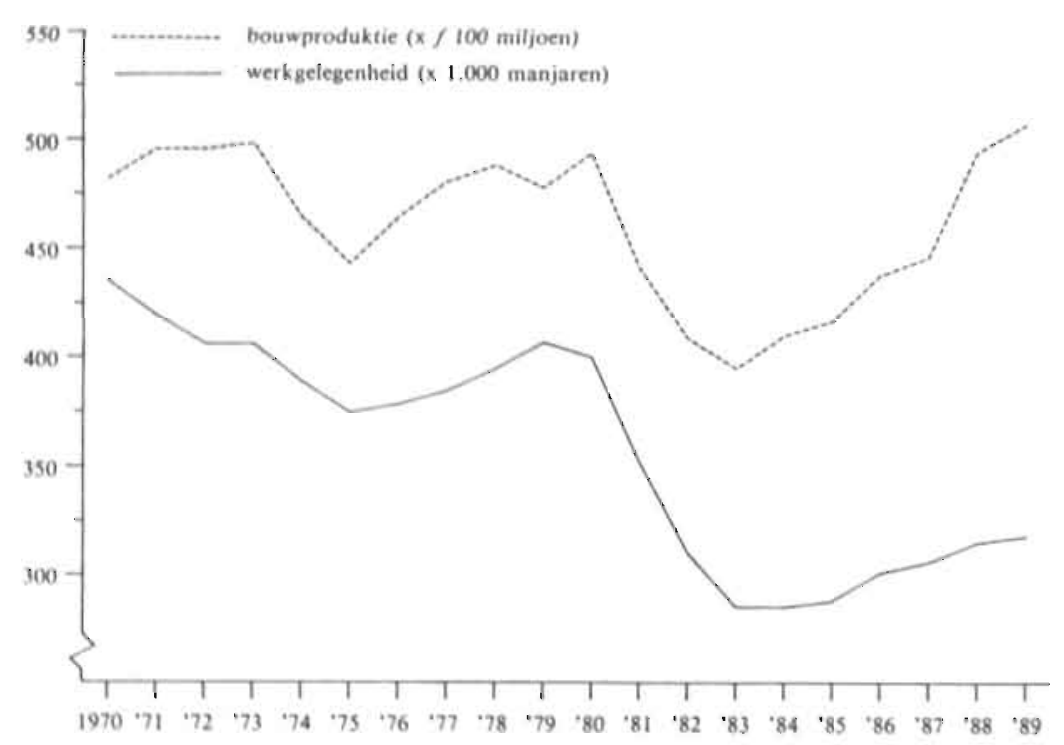

Bron: EIB (1991).

${ }^{2}$ De cijfers in deze paragraaf zijn, tenzij anders aangegeven, afkomstig van de studie 'Ontwikkelingen in de bouwnijverheid tot en met 1996' (1991) van het Economisch Instituut voor de Bouwnijverheid. 
Bouwproduktie en werkgelegenheid kunnen in de bouwnijverheid gesegmenteerd worden naar soorten bedrijven en soorten eindprodukt die worden voortgebracht.

In tabel 1 is de waarde van de produktie en de werkgelegenheid naar soorten bedrijven aangegeven. De sector bouwnijverheid en -installatiebedrijven is een zeer heterogene bedrijfstak in die zin dat bedrijven sterk verschillen naar omvang, segment waarin ze werkzaam zijn en positie in het bouwproces. De bouwnijverheid omvat zowel het bouwbedrijf als een aantal nevensectoren. De tabel geeft aan dat het bouwbedrijf actief kan zijn in de B\&U en de GWW-sector. Onder de nevensectoren van de bouwnijverheid vallen volgens de Standaard Bedrijfsindeling (SBI) de schilderssector, de stukadoorssector en de sector overige afwerking van gebouwen. Bouwbedrijven die tot de SBI-bedrijfsgroepen 51.1 en 51.2 treden veelal als hoofdaannemer van een bouwproject op. Deze hoofdaannemers besteden vrijwel altijd werk uit aan onderaannemers (bedrijven uit de overige bedrijfsgroepen van de SBI 51 en 52).

TABEL 1 De bouwnijverheid ingedeeld volgens de Standaard Bedrijfsindeling (SBI), waarde van de produktie (omzet in mld. gld.) en werknemers (x 1000) (sept. 1989)

\begin{tabular}{|c|c|c|c|}
\hline SBI & & Produkticwaarde & Werkgelegenheid \\
\hline \multirow[t]{6}{*}{51} & Bouwnijverheid & 54,4 & 262,1 \\
\hline & 51.1 Burgelijke, utiliteitsbedr. & 37,5 & 151,5 \\
\hline & 51.2 Grond-, water-, wegenb. bedr. & 12,1 & 65,9 \\
\hline & 51.3 Schilders-, glasz, beh. bedr. & 3,6 & 34,2 \\
\hline & 51.4 Metsel-stukadoorsbedr. & 0.6 & 5.4 \\
\hline & 51.9 Overige afwerking gebouwen & 0,6 & 5,0 \\
\hline \multirow[t]{4}{*}{52} & Bouwinstallatiebedrijven & & \\
\hline & $\begin{array}{l}\text { 52.1 Loodgieters-, fitters, sanitair inst. bedr. } \\
52.2 \text { C.V. en luchtbehandelings inst. bedr., }\end{array}$ & 3,0 & 22,5 \\
\hline & isolatiebedrijven & 4,7 & 27,8 \\
\hline & 52.3 Elektrotechn. inst. bedr (B\&U bouw) & 5,7 & 41,0 \\
\hline
\end{tabular}

Bron: CBS, Maandstatistick bouwnijverheid (april 1992) voor SBI 51 en de Produktiestatistieken bouwnijverheid (1990) voor SBI 52.

Produktie en werkgelegenheid kunnen ook naar soorten eindprodukt worden gesegmenteerd. Deze indeling loopt deels parallel met die naar soorten onderneming. Een belangrijke indeling naar soorten eindprodukt is de segmentatie van de bouwproduktie in woning- en utiliteitsbouw (de B\&U-sector) en de grond-, weg- en waterbouw (de GWW-sector). De woningbouw (ook wel burgerlijke bouw genoemd) omvat nieuwbouw, onderhoud en renovatie van woningen. Onder utiliteitsbouw valt nieuwbouw, onderhoud en renovatie van industriële en agrarische gebouwen en installaties en van kantoorgebouwen. Produktie in de GWW-sector bestaat uit bagger-, kust- en oeverwerk, de beton- en waterbouw, wegenbouw, het kabels en buizen leggen en de milieubouw. ${ }^{3}$

${ }^{3}$ De bagger-, kust- en oeverwerken omvatten het traditionele baggerwerk, het bouwen van dammen en dijken, aangevuld met werkzaamheden als het opspuiten van bedrijfsterreinen en de integrale kusten landwinning. Beton- en waterbouw is de constructie van civiele werken aan, over of onder water: 
In de EIB-studie 'Ontwikkelingen in de bouwnijverheid tot en met 1996' (1991) worden ontwikkelingen in produktie en werkgelegenheid gesegmenteerd naar vier categorieën: woningbouw, utiliteitsnieuwbouw, GWW en onderhoud, herstel en verbouw. De ontwikkeling van de werkgelegenheid per genoemde categorie is in figuur 2 aangegeven.

FIGUUR 2 Ontwikkelingen van de werkgelegenheid per sector, 1970-1989 (x 1000 manjaren)

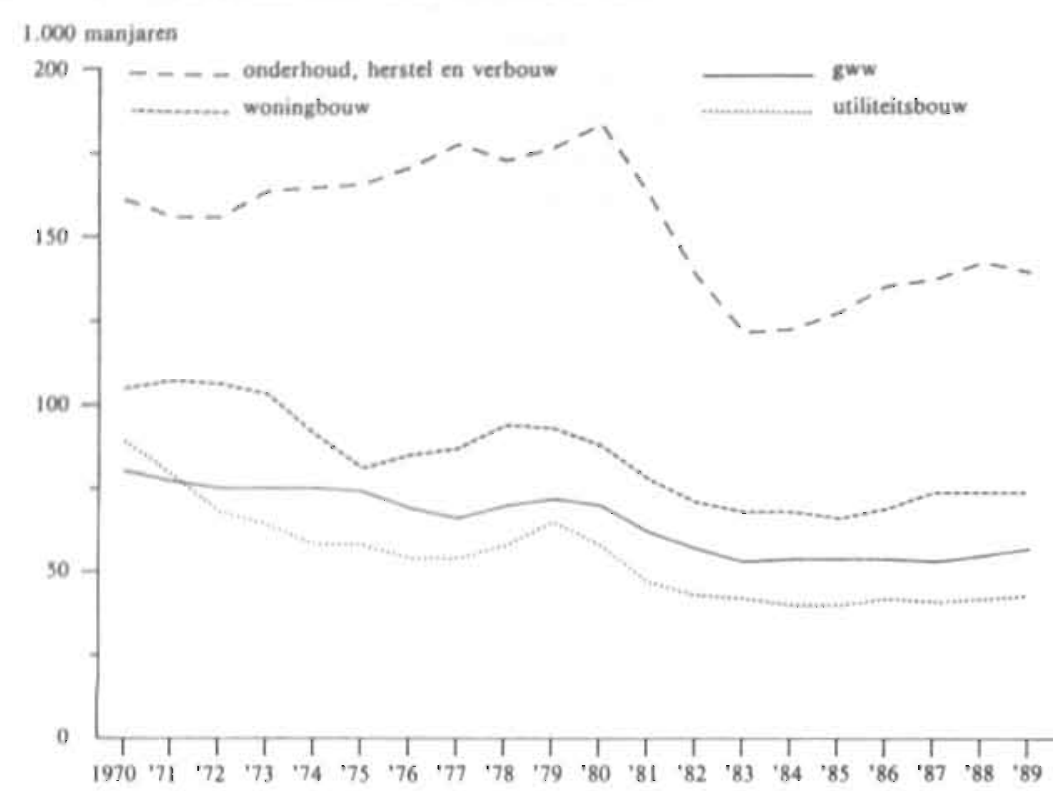

Bron: EIB (1991).

Verreweg de grootste activiteit binnen de bouwnijverheid vindt momenteel plaats in de burgerlijke en utiliteitsbouw. Zeer belangrijk daarbinnen is de nieuwbouwsector, met name de woningbouw. De produktie van woningen heeft zich na de Tweede Wereldooilog in een grote belangstelling mogen verheugen. Nieuwbouw van woningen en de utiliteitsbouw hebben echter een grote terugral gekend. In de woningsector begon dat al halverwege de jaren '70. Het aandeel nam in de bouwproduktie af van eenderde begin jaren '70 tot een kwart begin jaren '80. De werkgelegenheid is de afgelopen jaren in de woningbouw ook voortdurend gedaald. $\mathrm{Zij}$ is in 1989 met ruim 50.000 manjaĩen op het laagste niveau sinds 1970 . In 1970 bedroeg de werkgelegenheid nog 100.000 manjaren. Het herstel van de woningbouwproduktie na 1985 is niet samengegaan met een stijging van de werkgelegenheid.

tunnels, viaducten, aquaducten, bruggen en gehele havenwerken. De wegenbouw heeft betrekking op de aanleg van nieuwe wegen, en het onderhoud van bestaande. Aanleg van kabels, buizen en pijpleidingen onder de grond is ook een specifieke activiteit. Onder milieubouw worden activiteiten op het gebied van bodemsanering, waterzuivering, verwerking van chemisch afval, riolering en advisering verstaan. 
De utiliteitsbouw ervoer tussen 1980 en 1985 de sterkste teruggang met als dieptepunt 1983. Haar aandeel bedroeg in 197030 procent van de totale bouwproduktie, daalde naar ongeveer een kwart in het begin van de jaren, '80, maar nam daarna weer toe tot een aandeel van 28 procent in 1989 . De ontwikkeling van het aandeel in de werkgelegenheid (exclusief herstel en verbouw) in de totale werkgelegenheid kent een totaal ander verloop. In 1970 was het aandeel nog 20 procent. Dat daalde naar ongeveer 15 procent in 1975. Sinds dat jaar is dit aandeel vrij constant gebleven. Ook hier is weer sprake van een sterke stijging van de produktie na 1985 zonder dat dit een gunstig effect heeft op de omvang van de werkgelegenheid. Deze blijft nagenoeg gelijk op het niveau van 45.000 manjaren. In 1970 bedroeg, deze nog bijna 90.000 manjaren.

De werkgelegenheidsontwikkeling in de grond-, weg- en waterbouw vertoont ook een dalend verloop. In 1970 bedroeg de werkgelegenheid nog 80.000 manjaren, in 1989 was dit aantal 60.000 manjaren. Deze teruggang is echter niet zo sterk als in de B\&U. sector. Daar halveerde de werkgelegenheid van 1970 tot 1989 . Het aandeel van GWWproduktie in de totale produktie was in 1970 ruim 17 procent, maar daalde naar ruim 11 procent in 1989. Het aandeel van de GWW-produktie in de werkgelegenheid bedroeg zowel in 1970 als in 1989 ruim 18 procent. In de tussenliggende periode bleef dit aandeel steeds rond dit percentage schommelen.

De werkgelegenheid in de sectoren onderhoud en herstel en verbouw stijgt van 1970 tot 1980 geleidelijk, maar daalt in de drie daaropvolgende jaren sterk. Tot 1989 treedt vervolgens weer een stijging op waardoor het niveau in 1989 gelijk is aan 1970. De bouwproduktie is in deze sectoren echter gestegen, evenals het aandeel in het totaal. Van 1970 tot 1975 stijgt de werkgelegenheidsaandeel van 37 naar 45 procent. Tot en met 1985 blijft de werkgelegenheid rondom dit percentage hangen. Na 1985 stijgt de zij snel naar ruim 50 procent.

Nationaal was de verhouding tussen de belangrijkste segmenten in 1989: woningnieuwbouw $25 \%$, herstel en verbouw van woningen $13,2 \%$, utiliteitsbouw $28,1 \%$, GWW $11,4 \%$, onderhoud $22,3 \%$. Herstel, verbouw en onderhoud nemen dus $35,5 \%$ van de markt voor hun rekening. Ook in Duitsland, Italië en Groot-Brittannië en Frankrijk nemen onderhoud en renovatie rond de $40 \%$ van de markt voor hun rekening.

\subsection{Produktie en werkgelegenheid bij de toeleverende branches}

De bouwnijverheid maken bij het verrichten van bouwactiviteiten gebruikt van goederen en diensten van talloze andere bedrijven en instellingen. Hier wordt ingegaan op de produktie en werkgelegenheid van industriële toeleveranciers, handel en zakelijke dienstverlening.

Industriële toeleveranciers aan de bouwnijverheid komen in zeer veel geledingen voor. In tabel 2 is aangegeven welke industriële toeleveranciers ten minste $5 \%$ van hun totale intermediaire leveringen aan de bouwnijverheid toeleveren. Deze tabel is gebaseerd op de input-output tabel van de Nationale Rekeningen van het CBS. ${ }^{4}$

${ }^{4}$ De input-output tabel in de Nationale Rekeningen van het CBS geven een indruk van de verschillende inputs waarvan de bouwnijverheid gebruik maakt. Deze input-outputtabel bestaat onder anđere uit een matrix waarin de onderlinge leveringen van de verschillende bedrijfstakken zijn weergegeven. Hieruit valt af te leiden in welke mate de bedrijfstak bouwnijverheid en -installatiebedrijven goederen 
TABEL 2 Leveringen van industriele toeleveranciers aan de bouwnijverheid en -installatiebedrijven in 1988 (in percentages)

\begin{tabular}{llc}
\hline SBI & & Levering aan de bouwnijverheid \\
\hline 19 & Overige delfstofwinning & 20,8 \\
25 & Hout- en meubelindustrie & 62,3 \\
28 & Aardolie-industrie & 7,8 \\
31 & Rubber- en kunststofverwerkende & 7,3 \\
& industrie & 70,7 \\
32 & Bouwmaterialenindustrie & 12,4 \\
33 & Basismetaalindustrie & 28,2 \\
34 & Metaalproduktenindustrie & 7,3 \\
35 & Machine-industrie & 5,1 \\
36 & Electrotechnische industric & \\
\hline
\end{tabular}

Bron: CBS, Nationale Rekeningen 1990 (1991).

Naast industriële inputs uit het binnenland verbruikt de bouwnijverheid ook inputs uit het buitenland. De totale invoer wordt door het CBS gesplitst in een concurrerend en een niet-concurrerend deel. In 1990 was $83,8 \%$ van de totale invoer concurrerend met de binnenlandse produktie, dat wil zeggen dat deze produkten ook in Nederland hadden kunnen worden voortgebracht. Het aanhangsel 2.2 van de Nationale Rekeningen splitst de invoer van de bedrijfstak bouwnijverheid en -installatiebedrijven nader op (zie tabel 3).

Een groot aantal industrieën leveren relatief een klein gedeelte van hun produktie aan de bouw. Voorbeelden zijn ondernemingen in de aardolie-industrie, de rubber- en kunststofverwerkende industrie, de basismetaalindustrie, de machine-industrie en de electrotechnische industrie. Overige delfstofwinning en de metaalproduktenindustrie zijn bedrijfstakken die een relatief groot deel van hun produktie aan de bouwnijverheid leveren. Voor de bouwmaterialenindustrie en de hout- en meubelindustrie is de bouw de belangrijkste afnemer. In de rest van deze paragraaf zal op de drie grootste industriële toeleveranciers worden ingegaan. Overige delfstofwinning blijft buiten beschouwing omdat deze bedrijfstak geen inputs toelevert die als bouwmaterialen in een bouwwerk verwerkt worden.

De hoụt- en meubelindustrie omvat een veelheid van bedrijfsgroepen. Dit hangt samen met het feit, dat hout nog altijd in zeer gevarieerde toepassingen wordt gevraagd. Vijf van de zeven bedrijfsgroepen die binnen de bedrijfsklasse hout- en meubelindustrie worden onderscheiden, kunnen niet als direct toeleverancier van bouwmaterialen genoemd worden of leveren slechts in zeer beperkte mate toe aan de bouwnijverheid. Tot deze groep behoren de bedrijfsgroepen houtzagerijen, -schaverijen e.d. (SBI 25.1), houten emballage-industrie (SBI 25.4), overige houtwarenindustrie (SBI 25.5) en de kurk-, vlecht-en borstelwarenindustrie (SBI 25.6).

en diensten aankoopt en verkoopt aan de andere door het CBS onderscheiden bedrijfsklassen. Op basis van de input-outputtabel uit de Nationale Rekeningen kunnen intermediaire leveringen aan de bouw. sector onderverdeeld worden in primaire inputs (inputs uit de land-, tuin- en bosbouw en visserij). industrięle inputs, interne inputs en inputs vanuit de dienstensector. Daarnaast zijn leveringen uit het. buitenland (deze vallen niet onder intermediaire leveringen) de vierde categorie inputs. 
TABEL 3 De invoer van de bedrijfstak bouwnijverheid en -installatiebedrijven (mln gld) naar concurrerende bedrijfsklassen in 1988

\begin{tabular}{llc}
\hline & & $\begin{array}{c}\text { Bouwnijverheid en } \\
\text {-installatiebedrijven }\end{array}$ \\
\hline 1 & Land-, tuin- en bosbouw & 16 \\
4 & Overige delfstoffenwinning & 169 \\
18 & Textielindustrie (overige bedrijven & 8 \\
21 & Hout- en meubelindustrie & 1282 \\
22 & Papier- en kartonindustrie & 6 \\
23 & Papierwaren- en golfkartonindustrie & 96 \\
24 & Grafische industrie, uitgeverijen & 23 \\
25 & Aardolie-industrie & 394 \\
26 & Chemische basisproduktenindustrie & 408 \\
27 & Chemische eindproduktenindustrie & 488 \\
28 & Rubber- en kunststofverwerkende industric & 475 \\
29 & Bouwmaterialen-, aardewerk- en & 1141 \\
& glasindustrie & 615 \\
30 & Basis metaalindustrie & 1890 \\
31 & Metaalproduktenindustrie & 548 \\
32 & Machine-industrie & 1104 \\
33 & Elektrotechnische industrie & 59 \\
34 & Auto-industrie & 3 \\
36 & Instrumenten-, optische en overige industric & \\
\hline
\end{tabular}

Bron: CBS, Nationale Rekeningen 1990 (1991).

Een bedrijfsgroep die weliswaar niet als direct toeleverancier van de bouwnijverheid is te beschouwen, maar wel sterk afhankelijk is van ontwikkelingen in de bouw, is de meubelindustrie (SBI 25.7). Bedrijfsgroepen die in belangrijke mate als toeleveranciers van bouwmaterialen optreden zijn de triplex-, fineer-, vezel-. spaanderplaat- en houtconserveringsindustrie (SBI 25.2) en de timmer- en parketvloerenindustrie (SBI 25.3).

TABEL 4 Produktiewaarde (mln. gld.) en aantal werknemers van relevante branches in de houl- cn meubelindustrie (SBI 25) in $19900^{5}$

\begin{tabular}{lcc}
\hline SBI & Produktiewaarde & Werkzame personen \\
\hline $25.1+25.2+25.5+25.6$ houtindustrie & & \\
(excl. timmer- en parketvloerenind, en & & \\
de houten emballage-ind.) & 528,1 & 1693 \\
25.3 timmer- en parketvloerenind. & 1626,5 & 8834 \\
\hline
\end{tabular}

Bron: CBS, Produktiestatistieken industrie 1990 (1992).

De bouwmaterialenindustrie produceert een grote verscheidenheid aan produkten voor de produktie van bouwwerken. Tot deze bedrijfsklasse behoren volgens de SBI-indeling een achttal bedrijfsgroepen (zie tabel 5). Deze bedrijfsgroepen hebben met elkaar

${ }^{5}$ De cijfers in tabel 4 tot en met 6 omvatten de samengestelde uitkomsten van bedrijven met 20 en moer werknemers. 
gemeen, dat de afzet van hun produkten in zeer belangrijke mate is gericht op de markt van bouwprodukten. Zij levert daarbij zowel produkten toe voor de ruwbouw als voor de afwerking van de bouw. Fijn aardewerk- en porseleinfabrieken (SBI 32.21) is de enige bedrijfssubgroep die niet voor de bouw van belang is. De overige kunnen worden onverdeeld in drie categorieën.

De eerste subgroep levert bouwmaterialen die vrijwel uitsluitend bouwmatige toepassingen hebben. Tot deze categorie behoren de bedrijfsgroepen $32.1,32.3$ en 32.5 . In de tweede categorie bevinden zich industrieën die ook produkten voortbrengen met toepassingen buiten de bouw. Produkten van de natuursteenbewerkingsbedrijven (SBI 32.6) worden in de bouw toegepast maar ook als graf- of siersteen. De glasindustrie en bewerkingsinrichtingen (SBI 32.8) omvat tevens de voortbrenging van huishoudelijk- en verpakkingsglas. De derde categorie bevat bedrijfsgroepen die voornamelijk produkten leveren die worden gebruikt als grondstof voor de produktie van bouwmaterialen. De bedrijfsgroepen 32.4 en 32.7 behoren daartoe. Cement en kalk zijn belangrijke grondstoffen voor de beton- en cementwarenindustrie en kalk bovendien ook voor de kalkzandsteenindustrie.

TABEL 5 Produktiewaarde (mln. gld.) en aantal werknemers in bouwmaterialen-, aardewerk- en glasindustrie (SBI 32) in 1990

\begin{tabular}{lcc}
\hline SBI & Produktiewaarde & Werkzame personen \\
\hline 32.1 baksteen- en dakpannenind. & 559,3 & 2766 \\
32.3 kalkzandsteenind. & 227,5 & 863 \\
32.4 cement- en kalkind. en & & \\
32.7 overige minerale produktenind. & 1197,4 & 3928 \\
32.5 beton- en cementwarenind. & 3154,3 & 12660 \\
32.6 natuursteenbewerkingsbedr. & 85,9 & 299 \\
32.8 glasind. en -bewerkingsinrichtingen & 1458,7 & 6152 \\
\hline
\end{tabular}

Bron: CBS, Produktiestatistieken industrie 1990 (1992).

De bedrijfsklasse metaalproduktenindustrie bestaat uit negen bedrijfsgroepen die in globaal drie categorieën zijn te splitsen.

In de eerste categorie zitten bedrijfs(sub)groepen die geen bouwmaterialen aan de bouwnijverheid leveren. Daartoe behoren de metalen meubelen-industrie (SBI-code 34.5), de metalen emballage-industrie (34.6), de lokale verwarmings- en kookapparatenfabrieken (34.72), de overige metaalwarenindustrie (34.8) uitgezonderd de hang- en sluitwerk en beslagfabrieken (34.83) en smederijen, oppervlaktebewerkingsbedrijven e.d. (34.9). De tweede categorie bevat bedrijfs(sub)groepen die weliswaar produkten leveren aan de bouwnijverheid maar die niet behoren tot de specifieke bouwtoeleveranciers. Tot deze groep behoren de schroeven-, massawerk-, veren- e.d. industrie (34.2) en in mindere mate de tank-, reservoir-en pijpleidingbouw, (34.3), de gieterijen (34.0) en grofsmederijen, stamp- en persbedrijven (34.1).

Tot de derde categorie behoren bedrijven die hoofdzakelijk of in belangrijke mate materialen toeleveren aan de bouwnijverheid. Het zijn: 
- de overige constructiewerkplaatsen (34.4). Hiertoe behoren fabrieken van stalen en non-ferro metalen ramen, deuren en wanden e.d. (34.41) en constructiewerkplaatsen n.e.g. (niet eerder genoemd) (34.49);

- de centrale verwarmingsketel- en radiatorenfabrieken (34.71);

- de hang- en sluitwerk- en beslagfabrieken (34.83).

SBI-bedrijfsgroep 34.41 levert allerlei onderdelen voor de woning- en utiliteitsbouw en kan worden beschouwd als de tegenhanger van de timmerfabrieken waar vergelijkbare produkten worden voortgebracht op basis van hout. De constructieplaatsen niet eerder genoemd produceren naast weg- en waterbouwkundige constructies en onderdelen van bedrijfsgebouwen, ook installaties voor verschillende industrieën, de scheepvaart en de off-shore.

TABEL 6 Produktiewaarde (mln. gld.) en werkzame personen in metaalproduktenindustrie (SEI 34) in 1990

\begin{tabular}{llcc}
\hline SBI & & Produktiewaarde & Werkzame personen \\
\hline 34.4 & Overige constructiewerkplaatsen & 5596,7 & 23229. \\
34.7 & Verwarmings- en kookapparaten & 845,1 & 3625 \\
\multirow{2}{*}{34.8} & industrie (excl, elektr.) & 3260,2 & 15209 \\
\hline
\end{tabular}

Bron: CBS, Produktiestatistieken industric 1990 (1992).

De produktie-ontwikkeling van bovengenoemde toeleverende industrieün volgt een min of meer gelijk patroon. Met uitzondering van de betonmortelindustrie zien tot 1973 of 1974 alle bedrijfsklassen en -(sub)groepen hun produktie stijgen. In het daarop volgende jaar valt de produktie van de meeste industrieën waarover cijfers bestaan terug. Vanaf 1976 is er in vrijwel alle bedrijfsgroepen en -subgroepen sprake van een sterke toename van de produktie. Deze stijgt, al dan niet met een kleine onderbreking, tot 1978 en in een aantal gevallen tot 1980. De ommekeer komt voor de baksteen-, de kalkzandsteen- en de betonwarenindustrie in 1979. Bij de overige toeleveranciers treedt de produktiedaling pas in 1980 of 1981 in. In het begin van de jaren ' 80 is de daling van de produktie in vrijwel alle sectoren buitengewoon fors. De terugval is het minst in de overige constructiewerkplaatsen. In 1983 treedt voor sommige van de bedrijfs(sub)groepen herstel in, voor andere gebeurde dit pas later of helemal niet. Het herstel was vooral sterk in de dakpannen- en kalkzandsteenindustrie en de overige constructiewerkplaatsen.

Naast het buitenland en de binnenlandse industriële toeleveranciers speelt ook de bouwmaterialenhandel een belangrijke rol bij de toelevering van materiaal naar de bouwplaats toe. De bedrijfsgroep groothandel in hout, vlakglas, sanitair en bouwmaterialen (SBI 61.6) is een belangrijke bedrijfsgroep in ketens van bedrijven in de bouw. Omzet en werkzame personen zijn in tabel 7 weergegeven. Wat betreft de produkten van de groothandel in bouwmaterialen kan men een onderscheid maken tussen materjalen bedoeld voor de afbouw en die voor de groffe bouw. Onder de eerste categorie vallen voornamelijk sanitair, keukens, tegels, kachels, kasten, onder de tweede o.a. heton, chemische bouwstoffen, dakpannen, isolatiematerialen, hout en stenen. Materialen in de laatste categorie worden vaker rechtstreeks door de producent rechtstreeks 
op de bouwplaats geleverd. Voor de groothandel is het gemiddelde rendement op materialen voor de afbouw hoger dan voor de ruwbouw.

TABEL 7 Netto-omzet (mln. gld.) en werkzame personen (x 1000) in groothandel in hout en bouwmaterialen (SBI 61.6) in 1990

\begin{tabular}{lccc}
\hline SBI & Netto-omzet & Werkzame personen \\
\hline 61.6 & Groothandel in hout en bouwmaterialen & 20,6 & 30,8 \\
\hline
\end{tabular}

Bron: CBS, Maandstatistiek voor binnenlandse handel en dienstverlening (maart 1993).

Belangrijke dienstenleveranciers in de bouw zijn de ingenieurs-, architecten-, technische ontwerp- en adviesbureaus (SBI 84.4). Deze bedrijven zijn weliswaar niet direct als toeleveranciers van de bouwnijverheid te beschouwen maar spelen wel een belangrijke rol bij de logistieke organisatie van een bouwproject. Omzet en werkzame personen zijn in onderstaande tabel weergegeven.

TABEL 8 Netto-omzet (mln. gld.) en werkzame personen (x 1000) in ingenieurs-, architecten-, technische ontwerp- en adviesbureaus (SBI 84.4)

\begin{tabular}{llcc}
\hline SBI & Netto-omzet & Werkzame personen \\
\hline 84.4 & $\begin{array}{l}\text { Ingenieurs-, architecten- c.a. technische } \\
\text { ontwerp en adviesbureaus }\end{array}$ & 9179 & 69,5 \\
\hline
\end{tabular}

Bron: CBS, Maandstatistick voor binnenlandse handel en dienstverlening (februari 1992).

Ondanks het feit dat de rol van de architect onder druk staat worden bij bijna $80 \%$ van de bouwproduktie nog architectenbureaus ingeschakeld (Lourens, 1990). Voor werken onder de fl. 300.000,- is de rol van architect evenwel beperkter. Hier ondervinden vooral kleine bureaus veel concurrentie van particulieren, bedrijven, woningbouwcorporaties en gemeenten.

\subsection{De relatie ussen bouw = en bouwmaterialenproduktie}

Ontwikkelingen binnen de bedrijtstak bouwnijverheid- en installatiebedrijven hebben een belangrijke invloed op het produktie- en arbeidsvolume van de toeleverende branches. Dit wordt ook wel aangeduid als het 'uitstralingseffect' van de bouwnijverheid op de toeleverende branches. In het EIB-rapport (1988) 'De ontwikkeling van de aan de bouwnijverheid toeleverende industriee n in de periode 1969-1985' is dit uitstralingseffect nader geanalyseerd.

De werkgelegenheidsontwikkeling in de bouwnijverheid hoeft niet gelijk te zijn aan die in de toeleverende branches. Dat deze van elkaar verschillen kan het gevolg zijn van import van bouwmaterialen door de bouwnijverheid of export van bouwmaterialen door toeleverende bedrijven. Volgens het EIB (1988) schommelde het uitstralingseffect van de bouwnijverheid tussen 1969 en 1984 tussen de 31 en 35 procent. Hiermee wordt 
bedoeld dat tegenover elke drie banen in de bouwnijverheid er één in de toeleverende bedrijfsklassen in het binnenland stond. De weggelekte uitstraling, dat wil zeggen de werkgelegenheid die in het buitenland ontstond als gevolg van aankopen van de bouwnijverheid, bedroeg tussen 1974 en 1984 gemiddeld zo'n 15 procent.

Het uitstralingseffect van de bouwnijverheid op de toeleverende branches heeft naast werkgelegenheid ook betrekking op produktie-ontwikkelingen. Het EIB-rapport noemt vier factoren die aangeven hoe omvang en samenstelling van de bouwproduktie de produktie van bouwmaterialen beïnvloeden. Deze factoren zijn de omvang en de samenstelling van de bouwproduktie, de kwaliteit van de bouwproduktie, de verschuiving naar de voorfase en (daarmee samenhangend) veranderingen in de bouwtechniek.

Ten eerste kan de materiaalintensiteit van de ene 'objectcategorie' beduidend hoger liggen dan die van de andere. Hiermee wordt bedoeld dat bijvoorbeeld onderhoud van woningen beduidend minder materiaalintensief is dan de nieuwbouw van woningen. Omvang en samenstelling van de bouwproduktie zijn dus in belangrijke mate bepalend voor de omvang van het gebruik van bepaalde materialen. Momenteel zijn in dit verband relevante ontwikkelingen de verschuiving van nieuwbouw naar herstel, verbouw en onderhoud en de daling van de GWW-produktie. Ook een verandering van het aandeel vrije sectorwoningen in de totale woningnieuwbouw beïnvloedt de samenstelling van de vraag naar bouwmaterialen. Bepaalde materialen worden vooral in duurdere woningen gebruikt. De baksteenindustrie richt bijvoorbeeld zich meer op het duurdere segment van de bouwmarkt. Het terugtreden van de overheid en de opkomst van de vrije sectorbouw is dan ook gunstig voor deze industrie. De positie van de betonmortelindustrie lijkt daarentegen als toeleverancier aan de woningbouw onder druk te staan. Enerzijds omdat betonmortel relatief meer in de sociale woningbouw wordt toegepast, anderzijds omdat ook de verschuiving van nieuwbouw naar herstel en verbouw voor deze industrie ongunstig is.

Ten tweede is de kwaliteit van de bouwproduktie bepalend voor de omzet en produktie van verschillende bouwmaterialen. Kwaliteitseisen waaraan bouwwerken moeten voldoen, bepalen de keuze van de materialen die worden gebruikt en de mate waarin per bouwwerk gebruik wordt gemaakt van bepaalde materialen. Voor wat betreft de kwaliteitsontwikkeling in de woningbouw kan onderscheid worden gemaakt tussen verschillende perioden. Soms ligt het accent op relatief eenvoudige grootschalige en eenvormige woningen, soms wordt veel kleinschaliger en geavanceerder gebouwd. Ook de verschuiving van hoog- naar laagbouw of andersom is in dit kader van belang. $\mathrm{Al}$ deze ontwikkelingen komen tot uiting in de materiaalkeuze.

Ten derde betekent een verschuiving naar de voorfase een verandering in de taakverdeling tussen bouwbedrijven en toeleverende industrieën. Activiteiten die traditioneel op de bouwplaats worden uitgevoerd, verschuiven naar toeleverende industrieën. Deze verschuiving van de produktie naar het voortraject heeft invloed op de gebruikte materialen. De betonwarenindustrie heeft reeds in het verleden bewezen in staat te zijn in te spelen op deze verschuiving zoals die, in bepaalde perioden, in het bouwproces zichtbaar was. De baksteen- en de betonmortelindustrie verkeren wat dat betreft in een moeilijkere positie. De baksteenindustrie is vooral in het nadeel vanwege de arbeidsintensieve en daarmee kostbare en tijdrovende verwerking van het materiaal op de bouwplaats. 
Ten vierde hangen toegepaste bouwtechniek en toegepaste bouwmaterialen met elkaar samen. De keuze tussen verschillende bouwmaterialen is in een aantal gevallen tegelijkertijd een keuze tussen verschillende bouwtechnieken. Bakstenen en betonblokken vinden, naast bijvoorbeeld materiaal als kalkzandsteen, hun toepassing in stapelbouw, betonelementen in de montage- of elementenbouw en betonmortel in de gietbouw.

\section{De bedrijfsstructuur van de bouwnijverheid en de toeleveranciers}

\subsection{De huidige bedrijfsstructuur}

\section{De bouwnijverheid en -installatiebedrijven}

De bouwnijverheid en -installatiebedrijven is een zeer heterogene bedrijfstak in die zin dat bedrijven sterk verschillen naar omvang, segment waarin ze werkzaam zijn en positie in het bouwproces. Het totale aantal bedrijven in de bouwnijverheid is moeilijk te achterhalen, omdat er in de registers van de Kamers van Koophandel ook veel bedrijven ingeschreven zijn die bouwen als nevenactiviteit vermelden. In dat geval ligt de hoofdactiviteit buiten de bouw. Van Waarden (1989) geeft transportondernemers, rijschoolhouders, tankstationbeheerders, caféhouders of landbouwers als yoorbeeld. Dit type bedrijven komen in de bouw redelijk veel voor, onder andere door de geringe investeringen die vereist zijn. In de CBS-statistiek van het ondernemingenbestand telde de bouwnijverheid op 1 januari 1991 ongeveer 33000 bedrijven, waarvan ruim 24000 met maximaal vijf werknemers. Bij de bouwinstallatiebedrijven hebben van de in totaal 9500 bedrijven ruim 6700 maximaal vijf werknemers. Naar omzet gezien hebben 26 bedrijven een omzet tussen de 100 en 500 miljoen en nog eens 9 bedrijven meer dan $500 \mathrm{mln}$. Deze 35 ondernemingen staan voor ruim 30\% van de totale nationale omzet van de sector, de grootste negen voor $20 \%$ (Jakobs, 1992).

TABEL 9 De bouwnijverfheid ingedeeld naar activiteit en grootteklasse, 1 januari 1991]

\begin{tabular}{lrrrrrrrr}
\hline SBI & 0 & $0-5$ & $0-10$ & $10-20$ & $20-50$ & $50-100$ & $>100$ & Totaal \\
\hline 51.1 Burgelijke, utiliteitsbedr. & 9649 & 5228 & 2045 & 1652 & 1194 & 360 & 191 & 20319 \\
51.2 G.w.w.-bedr. & 1734 & 1091 & 580 & 498 & 452 & 126 & 97 & 17523 \\
51.3 Schilders-, glasz., bedr. & 2186 & 2167 & 621 & 431 & 284 & 75 & 16 & 5780 \\
$\begin{array}{l}\text { 51.4 Mersei-,stukadoorsbedr. } \\
\text { 51.9 Overige afwerking geb. }\end{array}$ & 378 & 362 & 123 & 74 & 45 & $\mathbf{x}$ & $\mathbf{x}$ & 988 \\
$\begin{array}{l}\text { 52.1 Loodgieters-, fitters, } \\
\text { sanitair inst. bedr. }\end{array}$ & 413 & 155 & 77 & 48 & $\mathbf{x}$ & $\mathbf{x}$ & 1548 \\
$\begin{array}{l}\text { 52.2 C.V. en luchtbeh. inst. bedr., } \\
\text { isolatiebedrijven }\end{array}$ & 1158 & 1438 & 444 & 308 & 162 & 31 & 11 & 3552 \\
$\begin{array}{l}\text { S2.3 Elektrotechn.inst. bedr } \\
\text { (B\&U bouw) }\end{array}$ & 652 & 253 & 236 & 200 & 57 & 31 & 2200 \\
\hline
\end{tabular}

Bron: CBS, Statistiek van het ondernemingenbestand 1991 (1991).

Het miciden- en kleinbedrijf in de bouwnijverheid en -installatiebedrijven neemt $77 \%$ van de werkgelegenheid en $62 \%$ van de omzet voor zijn rekening. In de grond- weg en waterbouw is het aandeel van het midden- en kleinbedrijf slechts $45 \%$ tegen $90 \%$ in 
herstel en verbouw van woningen en onderhoud. Voor nieuwbouw van woningen en utiliteitsgebouwen bedraagt dit aandeel $70 \%$ (Jakobs, 1992). De kleinere ondernemingen concentreren zich veelal op het onderhouds- en reparatiewerk en op de onderaanneming, de grotere op de nieuwbouw. De meer recente ontwikkelingen in de richting van meer kleinschalige en diversificeerde bouwprojecten en renovatie en herstel hebben het midden- en kleinbedrijf nieuwe kansen geboden.

In de woningbouw, het grootste segment van de bouw, zijn zowel de grootste als de kleine bouwbedrijven met slechts enkele mensen actief. In de utiliteitsbouw treden een aantal gerenommeerde utiliteitsbouwers op. Momenteel zijn er nog slechts tien bedrijven actief in de bagger-, kust- en oeverwerken, waarvan er vijf behoren tot de grote internationale baggerconcerns. De overige vijf zijn kleine, vooral nationaal opererende baggeraars. De beton- en waterbouw is een specifiek Nederlandse activiteit dat de meeste grote Nederlandse bouwconcerns als specialisme in huis hebben. In de wegenbouw zijn een klein aantal grotere concerns actief. Deze bedrijven zijn ook actief in het grondverzet en, in toenemende mate, in de aanleg en onderhoud van riolen. In de branche van het kabels en buizen leggen kan een onderscheid gemaakt worden tussen de veelal kleine, regionaal opererende familiebedrijven in de kabelbranche en een aantal grotere buizenleggers die meestal aan grote concerns zijn verbonden.

De concentratiegraad is relatief gering in de bouw. De grootste vier bouwbedrijven boden in 1990 werkgelegenheid aan ongeveer 34000 medewerkers, $\pm 12 \%$ van de totale werkgelegenheid in de bouwnijverheid. Ook de omzetten van de grote vier geven aan dat de concentratiegraad gering is. Neem daarbij nog in beschouwing dat de grote bouwconcerns uit een aantal relatief zelfstandig opererende en eigen rechtspersoonlijk bezittende dochterondernemingen bestaan. Deze dochterondernemingen staan apart bij het Sociaal Fonds Bouwnijverheid ingeschreven en komen daarom als meeteenheid in de statistiek voor. Qua omzet stonden de grootste vier bouwbedrijven in 1990 op resp. plaats $23,38,42$ en 45 op de ranglijst van Nederlandse ondernemingen (Jaarboek van Nederlandse Ondernemingen 1990/1991).

TABEL 10 De negen grootste bouwbedrijuen in Nederland (1990)

\begin{tabular}{lccc}
\hline & $\begin{array}{l}\text { aantal } \\
\text { werknemers }\end{array}$ & $\begin{array}{l}\text { omzet in } \\
\text { mln. gld. }\end{array}$ & $\begin{array}{l}\text { netto winst } \\
\text { in mln. gld. }\end{array}$ \\
\hline HBG & $15005(1)$ & $4200(1)$ & 65 \\
Volker Stevin & $9665(2)$ & $2301(2)$ & 33 \\
TBI-Holdings & $7417(3)$ & $1516(5)$ & 35 \\
NBM-Amstelland & $5000(4)$ & $1746(4)$ & 12 \\
Ballast Nedam & $4664(5)$ & $2113(3)$ & 83 \\
BAM & $3409(6)$ & $1261(6)$ & 25 \\
Heymans & $2330(7)$ & $856(9)$ & 9 \\
Boskalis & $2200(8)$ & $883(8)$ & 30 \\
Wilma & $1922(9)$ & $1049(7)$ & 34 \\
\hline
\end{tabular}

Bron: Jaarboek van Nederlandse Ondernemingen 1990/1991. Voor TBI-Holdings, Wilma en Heymans is gebruik gemaakt van de jaarverslagen over 1990. 
De grootste bouwbedrijven zijn landelijk actief op het totale terrein van de bouw. Industriële toelevering en handel behoren daar ook toe. Een voorbeeld is de onderneming NBM-Amstelland. Tot deze onderneming behoren ook handels- en industriële toeleveringsbedrijven als Heembeton en Stoel van Klaveren Bouwstoffen. Op het gebied van projectontwikkeling, en vastgoed zijn ondernemingen als Amstelland Vastgoed, Teleport ontwikkeling en Themaplan actief.

Veel van de kleinere ondernemingen zijn de ene keer actief als hoofdaannemer, de andere keer als onderaannemer. Bedrijuen met speciale functies als het schilders-, stukadoors- en het vloerleggersbedrijf zijn strikt genomen ook onderaannemers maar vallen in een ander categorie. In de sector worden zij meestal aangeduid als afwerkingsbedrijven of nevenbedrijven. Vanaf het begin van de jaren '70 is het gebruik van onderaannemers in de bouw geleidelijk toegenomen (Bremer, 1991). Zij kunnen ingeschakeld worden voor taken die het hoofdaannemingsbedrijf ook zelf kan uitvoeren, zoals metsel- en timmerwerk. Reden om werk uit te besteden aan onderaannemingsbedrijven is dat het werk te specialistisch is of het voorkomen van pieken in de produktie.

\section{Industriële toeleveranciers en dienstverleners}

In hoofdstuk 8 is aangegeven dat de industriële toeleveringsindustrie van de bouw onderverdeeld kan worden in twee 'schillen'. Enerzijds zijn er leveranciers en producenten van 'elementaire' bouwcomponenten, zoals beton(elementen), hout, staal, bakstenen, kozijnen/deuren en installaties. Op staal na vinden deze produkten vooral in de bouw hun belangrijkste toepassing. Deze toeleverende bedrijven vallen voor een groot deel onder de hout- en bouwmaterialenindustrie. Anderzijds zijn er de toeleveranciers en producenten van produkten en materialen die in verschillende sectoren worden gebruikt, zoals verven, lijmen en electronische onderdelen. Producenten behoren hier tot de meest uiteenlopende sectoren als de basismetaalindustrie, de metaalproduktenindustrie en de chemie.

Dominante bedrijfsklassen in de eerste schil zijn de bouwmaterialenindustrie en de hout- en meubelindustrie. Voornaamste toeleverancier aan de bouwsector in de tweede schil is de metaalproduktenindustrie. De beschrijuing van de bedrijfsstructuren van industriële toeleveranciers beperkt zich dan ook tot deze bedrijfsklassen.

De hout- en meubelindustrie bestaat overwegend uit kleinere bedrijven; slechts 29 van de 6225 bedrijven telde op 1 januari 1991 meer dan 100 personeelsleden (CBS, Statistiek van het ondernemingenbestand, 1991). Zoals in $\$ 1.2$ gezegd treden de bedrijfsgroepen triplex-, fineer-, vezel-, spaanderplaat. en houtconserveringsindustrie (SBI 25.2) en de timmer- en parketvloerenindustrie (SBI 25.3) op als bedrijfsgroepen die in belangrijke mate materialen aan de bouw toeleveren. Het aantal bedrijven met 10 of meer werknemers in de houtverwerkende industrie is sinds de jaren ' 70 onafgebroken gedaald. Met de opleving in de bouwconjunctuur is de daling in 1986 tot stilstand gebracht. De triplex-, fineer-, vezel-, spaanderplaat- en houtconserveringsindustrie is qua aantal bedrijven zeer beperkt van omvang. Onder andere voor de fabrikage van triplex is zwaar en goed hout nodig en dit is in ons land niet in voldoende mate aanwezig om te kunnen produceren. Om die reden wordt een groot deel van de behoefte aan triplex geimporteerd. De timmer- en parketvloerenindustrie is de op een na grootste bedrijfsgroep binnen de hout- en meubelindustrie. Een relatief groot deel wordt ver- 
vaardigd door bedrijven met minder dan 10 man. Daarbij zijn timmerafdelingen van aannemersbedrijven nog buiten beschouwing gelaten.

TABEL 11 De houtverwerkende industrie naar activiteit en grootteklasse, 1 januari 1991

\begin{tabular}{|c|c|c|c|c|c|c|c|c|}
\hline SBI & 0 & $0-5$ & $0-10$ & $10-20$ & $20-50$ & $50-100$ & $>100$ & Totaal \\
\hline 25.1 Houtzagerijen e.d. & 74 & 41 & 7 & 6 & 4 & * & . & 132. \\
\hline $\begin{array}{l}\text { 25.2 Triplex-, fineer-, vezel-, } \\
\text { spaanderplaat en houtcons.ind. } \\
25.3 \text { Timmer- en parket- }\end{array}$ & 19 & 15 & $x$ & $x$ & 10 & $\mathrm{x}$ & $\mathrm{x}$ & 55 \\
\hline vloerenind. & 692 & 435 & 162 & 114 & 101 & 45 & 14 & 1553 \\
\hline 25.4 Houten emballage-ind. & 43 & 41 & 25 & 27 & 22 & 6 & 6 & 170 \\
\hline $\begin{array}{l}25.5 \text { Overige houtwarenind. } \\
25.6 \text { Kurk-, vlecht-. }\end{array}$ & 539 & 169 & 37 & 23 & 13 & $x$ & $\mathbf{x}$ & 785 \\
\hline borstelwaren & 71 & 11 & $x$ & $x$ & 4 & - & . & 94 \\
\hline $\begin{array}{l}25.7 \text { Meubelindustrie } \\
\text { (excl. metalen meubelen) }\end{array}$ & 1909 & 989 & 229 & 211 & 168 & 54 & 9 & 3569 \\
\hline
\end{tabular}

Bron: CBS, Statistiek van het ondernemingenbestand 1991 (1991).

Ook de bouwmaterialenindustrie wordt gekenmerkt door een groot aantall kleine bedrijven. In de industrie als geheel waren op 1 januari 1991 op het totaal van 1766 bedrijven. slechts 119 bedrijven groter dan 50 werknemers. Kleine bedrijven vinden we relatief veel in de aardewerk-, betonmortel- en glasbewerkingsbedrijven. De grotere bedrijven zijn met name te vinden in de glasproduktie-, baksteen-, cement- en betonwarenindustrie. Qua omzet, werkgelegenheid is de SBI-groep 32.5 de grootste binnen de industrie. Bedrijven in deze groep zijn vaak regionaal gebonden. Bij de betonwarenindustrie is deze situatie min of meer gegroeid omdat kostentechnisch de transportmogelijkheden voor de zware - per eenheid gewicht goedkope - produkten beperkt zijn. Een andere oorzaak voor regionale gebondenheid van de betonmortelfabrieken is dat de aard van het produkt vervoer over slechts geringe afstand toelaat. Grotere betonwarenfabrieken die in Nederland en onringende landen hun afzetgebied hebben, zoals BetonSon en Durox (nu Ytong), maken dan ook gebruik maken van regionale produktie-vestigingen.

TABEL. 12. De bouwmaterialenindusirie naar activiteit en grootteklasse, 1 januari 1991

\begin{tabular}{|c|c|c|c|c|c|c|c|c|}
\hline SBI & 0 & $0-5$ & 0.10 & $10-20$ & $20-50$ & $50-100$ & $>100$ & Totaal \\
\hline 32.1 baksteen-en dakp.ind. & $x$ & 9 & 7 & $x$ & 45 & 5 & 5 & 88 \\
\hline 32.2 aardewerkindustrie & 256 & 104 & 34 & 19 & 18 & 4 & 7 & 442 . \\
\hline 32.3 kalkzandsteenind. & $\mathrm{x}$ & - & - & $\mathbf{x}$ & $\mathbf{x}$ & 7 & $\mathrm{x}$ & 13 \\
\hline 32.4 cernent- en kalkind. & 7 & 8 & $x$ & $x$ & $\mathrm{x}$ & $x$ & $x$ & 22 \\
\hline 32.5 beton- en cementw.ind. & 111 & 93 & 58 & 95 & 77 & 41 & 27 & 502 \\
\hline 32.6 natuursteenhew.bedr. & 100 & 79 & 46 & 33 & 11 & - & - & 269 \\
\hline 32.7 overige minerale prod.ind. & 69 & 20 & $\mathrm{x}$ & 16 & 17 & $x$ & 7 & 141 \\
\hline $\begin{array}{l}32.8 \text { glasind. en -bewerkings- } \\
\text { inrichtingen }\end{array}$ & 154 & 70 & 24 & 16 & 9 & 8 & 8 & 289 \\
\hline
\end{tabular}

Bron: CBS, Statistiek van het ondernemingenbestand 1991 (1991). 
Relatief grote bedrijven zijn bij de metaalproduktenindustrie te vinden in de bedrijfsgroep metalen emballage-industrie (SBI 34.6). In de bedrijfsgroepen overige constructiewerkplaatsen (SBI 34.4) en smederijen, oppervlaktebewerkingsbedrijven e.d. (SBI 34.9) zijn relatief veel kleine bedrijven te vinden.

Zoals gezegd behoren de overige constructienerkplaatsen (SBI 34.4), de centrale verwarmingsketelen radiatorenfabrieken (SBI 34.71) en de hang- en sluitwerk- en beslagfabrieken (SBI 34.83) tot de bedrijfs(sub)groepen die in belangrijke mate toeleveren aan de bouwnijverheid. Binnen de metaalproduktenindustrie is de bedrijfsgroep overige constructieplaatsen qua aantal bedrijven, werkgelegenheid en omzet veruit de grootste. Van het totaal van 3980 bedrijven binnen de metaalproduktenindustrie behoren op 1 januari 1991 maar liefst 2017 bedrijven tot deze bedrijfsgroep. De bedrijfssubgroep 34.71 bestaat uit de centrale verwarmingsbranche en radiatorenfabrieken. In de eerstgenoemde branche waren in 1990 in Nederland in totaal 12 ondernemingen groter dan 20 werknemers actief met in totaal 1638 werknemers (CBS, Produktiestatistieken industrie 1990, 1992). Veel Nederlandse bedrijven hebben in het verleden deze sector verlaten, daartoe gedwongen door buitenlandse concurrentie. In de radiatoren-branche waren in dat jaar 14 ondernemingen groter dan 20 werknemers actief met in totaal 1798 werknemers. Voor de fabrieken van hang. en sluitwerk en beslag waren dit in 199014 ondernemingen met in totaal 1798 werknemers.

TABEL 13 De metaalproduktenindustrie naar activiteit en grootteklasse, 1 januari 1991

\begin{tabular}{|c|c|c|c|c|c|c|c|c|}
\hline SBI & 0 & $0-5$ & $0-10$ & $10-20$ & $20-50$ & $50-100$ & $>100$ & Totaal \\
\hline 34.0 Gieterijen & 37 & 30 & 18 & 15 & 22 & 8 & 17 & 147 \\
\hline $\begin{array}{l}34.1 \text { Grofsmederijen, stamp-en } \\
\text { persbedr. }\end{array}$ & 24 & 20 & 10 & 8 & 25 & 8 & 7 & 102 \\
\hline 34.2 Schroeven-, massadraaiwerk & 26 & 18 & 21 & & 10 & 6 & 4 & 113 \\
\hline $\begin{array}{l}\text { 34.3 Tank-, reservoir- en } \\
\text { pijpleidingbouw } \\
\text { 34.4 Overige consiructie }\end{array}$ & 43 & 44 & 17 & 30 & 45 & 28 & 9 & 216 \\
\hline werkplaatsen & 515 & 527 & 298 & 275 & 281 & 78 & 43 & 2017 \\
\hline 34.5 Metaleñ meubelind. & 46 & 37 & 18 & 25 & 38 & 13 & 17 & 194 \\
\hline $\begin{array}{l}\text { 34.6 Metalen emballage-ind. } \\
34.7 \text { Verwarmings- en kookapp. }\end{array}$ & 8 & 6 & 4 & 5 & $x$ & $x$ & 8 & 36 \\
\hline ind. (excl. elekii.) & 21 & 22 & 6 & 10 & $\mathrm{x}$ & $x$ & 11 & 84 \\
\hline $\begin{array}{l}34.8 \text { Overige metaalwarenind. } \\
34.9 \text { Smederijen, oppervlakte- }\end{array}$ & 290 & 176 & 81 & 103 & 100 & 43 & 38 & 831 \\
\hline bewerkingsbedr. c.d. & 2258 & 1076 & 296 & 208 & 105 & 28 & 9 & 3980 \\
\hline
\end{tabular}

Bron: CBS, Statistiek van het ondernemingenbestand 1991 (1991).

Naast de industriële toeleveranciers is de bouwnijverheid ook afhankelijk van de bouwmaterialengroothandel en de architecten- en ingenieursbureaus.

In de SBI-indeling is de bouwmaterialengroothandel onder de categorie groothandel in hout, vlakglas, sanitair en bouwmaterialen terug te vinden (SBI-bedrijfsgroep 61.6). Deze categorie ondernemingen omvat op 1 januari 19914380 bedrijven waarvan ruim 3200 minder dan vijf werknemers omvatten (zie tabel 14). 
TABEL 14 De groothandel in hout-, vlakglas, sanitair en bouwmaterialen naar grootteklasse, 1 januari 1991

SBI

$$
0
$$
$0-5$
$0-10$
$10-20$
$20-50$
$50-100>100$ Totaal

61.6 Groothandel in hout, vlak-

glas, sanitair en bouwmat.

1995

$1275 \quad 436$

Bron: CBS, Statistiek van het ondernemingenbestand 1991 (1991).

De grootste groothandels zijn De Boo, Van Neerbos en PontMeijer (SBR, 1993). De eindverbruikers of klanten van deze groothandels zijn particulieren, bouw- en aannemingsbedrijven, architecten, projectontwikkelaars en doe-het-zelf zaken. ${ }^{6}$ in tabel 15 zijn omzet en personeelsomvang van een aantal grote groothandels weergegeven.

TABEL. 15 Bedrijfsomvang van enkele groothandels inclusief detailshandelsactiviteiten in 1989

\begin{tabular}{lcc}
\hline & Omzet in mln. gid. & Personeel \\
\hline PontMeyer & 725 & 1700 \\
Van Neerbos & 462 & 1400 \\
De Boo & 397 & 468 \\
Raab Karcher & 200 & 400 \\
Stiho & 117 & 210 \\
De Waardt & 98 & 115 \\
Eshuis & 117 & 110 \\
Buva & 45 & 90 \\
Aberson & 55 & 30 \\
\hline
\end{tabular}

Biron: Dun \& Bradstreet, 1992 (in: SBR, 1993).

Belangrijke bedrijfsgroep binnen de zakelijke dienstverlening zijn de ingenieurs-, architecten-, technische ontwerp- en adviesbureaus (SBI 84.4). Binnen deze bedrijfsgroep zijn de architecten- en ingenieursbureaus het belangrijkst.

De klassieke taak van bouwkundige ingenieursbureaus ligt bij de technische kant van de bouwontwerpen, waarbij de nadruk ligt op bouwfysica, akoestiek, isolatie en op het berekenen van krachten en spanıingen van en in constructies. Aan dit takenpakket zijn stil aan meer adviserende functies toegevoegd als project-- en procesmanagement en kwaliteits- en milieuzorg. In de CBS-statistiek van het ondernemingenbestand 1991 zijn op 1 januari 1991 van de 5295 ingenieursbureaus er 496 groter dan 10 werknemers.

\footnotetext{
${ }^{6}$ Naast de groothandel in bouwmaterialen is er ook nog de detailhandel. Hiermee wordt over het algemeen de doe-het-zelf-markt bedoeld. Deze markt wordt gekenmerkt door vijf grote concerns, c.q. franchise-organisaties, die ongeveer $50 \%$ van de markt in handen hebben. Dit zijn Intergamma (24\%), Praxis-Formido-Hubo (16\%), HBD-groep (7\%), Wickes (2\%) en Superdoe (2\%) (SBR, 1993).
} 
TABEL 16 De ingenieurs-, architecten- e.a., technische ontwerp- en adviesbureaus naar activiteit en grootteklasse, 1 januari 1991

\begin{tabular}{|c|c|c|c|c|c|c|c|c|}
\hline SBI & 0 & $0-5$ & $0-10$ & $10-20$ & $20-50$ & $50-100$ & $>100$ & Totaal \\
\hline \multicolumn{9}{|l|}{84.4 Ingenieurs-, architecten- e.a. } \\
\hline techn. ontwerp en adviesbur. & 7057 & 2603 & 630 & 443 & 259 & 101 & 89 & 11182 \\
\hline 84.41 Ingenieursbureaus & 3529 & 1011 & 259 & 210 & 150 & 70 & 66 & 5295 \\
\hline 84.42 Architectenbureaus e.d. & 1703 & 1034 & 251 & 126 & 53 & $\mathrm{x}$ & $\mathbf{x}$ & 3180 \\
\hline 84.43 Bouwtechn. ontwerp- en & & & & & & & & \\
\hline adviesbureaus & 865 & 211 & 32 & 27 & 15 & $\mathrm{x}$ & $x$ & 1159 \\
\hline 84.44 Expertise- en taxatie- & 344 & 146 & 42 & 29 & 12 & 7 & 3 & 583 \\
\hline 84.49 Technische ontwerp- en & & & & & & & & \\
\hline adviesbureaus n.e.g. & 616 & 201 & 46 & 51 & 29 & 9 & 13 & 965 \\
\hline
\end{tabular}

Bron: CBS, Statistiek van het ondernemingenbestand 1991 (1991).

In tabel 17 zijn de top tien ingenieursbureaus over 1992 aangegeven. De groep bedrijven die in 1992 in de top vier zitten zijn dezelfde als in 1991.

TABEL 17 Top 10 Ingenieursbureaus naar aantal werknemers in 1992

\begin{tabular}{lcc}
\hline & Aantal werknemers & Omzet in mln. gld. \\
\hline Grontmij & $2788(1)$ & $391(1)$ \\
Fugro-McClelland & $2664(2)$ & $279(3)$ \\
Heidemij Holding & $2559(3)$ & $287(2)$ \\
DHV Groep & $2445(4)$ & $277(4)$ \\
Tebodin & $1125(5)$ & $167(5)$ \\
Ingenícursbureau NS & $915(6)$ & $135(6)$ \\
TAUW Iníra Consult & $805(7)$ & $97(8)$ \\
Haskoning & $589(8)$ & $103(7)$ \\
Waterloopkundig Laboratorium & $492(9)$ & $61(10)$ \\
De Weger & $460(10)$ & $70(9)$ \\
\hline
\end{tabular}

Bron: Tolsma, 1993.

In het CBS-statistiek van het ondernemingenbestand 1991 zijn op 1 januari 1991 van de 3180 architectenbureaus er 179 groter dan 10 werknemers. Van architectenbureaus groter dan 50 werknemers zijn in deze statistiek geen cijfers bekend. Van de 1378 leden van de Bond van Nederlandse Architekten (BNA) in 1991 zijn slechts 14 bedrijven groter dan 50 werknemers, dat is ongeveer een procent. Een kleine 60 procent van de BNA-leden zijn 1-2 mans bedrijven (BNA Jaarverslag 1991).

In 1991 heeft het vakblad de Architect (Themanr. 45, 1991) geprobeerd de grootste architectenbureaus in Nederland in kaart te brengen. Daarbij heeft het aantal werkzame personen de rangorde bepaald. In deze rangorde kwam het Architecten- en Ingenieursbureau van Philips (AIB) met ongeveer 300 personen als grootste te voorschijn. De reorganisatie van Philips heeft er echter toe geleid dat dit bureau is afgestoten en in afgeslankte vorm (170 man) verder gaat als zelfstandige werkmaatschappij van het 
ingenieursbureau DHV. De architectengroep Loerakker Rijnboutt Ruijssenaars Hendriks, OD 205 en Buro Wiegerinck Architekten schommelden rond de ondergrens van ongeveer 80 personen. Overige bureaus waren BDG Architekten Ingenieurs BV/Bureau de Gruyter, BV Articon, EGM Architecten BV, Inbo Architecten/Adviseurs en Bureau KuiperCompagnons B.V. Ook wordt het Bureau De Weger (het tiende ingenieursbureau in Nederland volgens tabel 17) bij de top tien van architectenbureaus geplaatst. Verklaring hiervoor is dat dit bureau, dat 150 personeelsleden telt, ook dochterondernemingen (buiten de architectuur) en vestigingen in het buitenland heeft waardoor er bij elkaar circa 450 personen werken.

Binnen de zakelijke dienstverlening zijn met name bouwprojectmanagementbureaus in opkomst. Dit zijn bureaus die het management van bouwprocessen als aparte dienst op de markt aanbieden. Volgens schattingen van Twijnstra Gudde bedraagt de totale omzet binnen deze branche zo'n $100 \mathrm{mln}$. gld. (exclusief projectmanagement dat wordt verricht door architectenbureaus en opdrachtgevers zelf). De grote 'vijf' realiseren circa 90 procent van die totale omzet. Die vijf zijn: Berenschot Osborne, Brink Groep, PCR, Starke Diekstra en Twijnstra Gudde (Los en Gort, 1993).

\subsection{Ontwikkelingen in de bedrijfsstructuur}

Twee belangrijke ontwikkelingen in de bedrijfsstructuur van de genoemde sectoren zijn de concentratie-tendens en de internationalisatie van ondernemingen.

Wat betreft de eerste tendens heeft de bouwnijverheid in de afgelopen decennia twee grote herstructureringen meegemaakt. In de jaren '70 kwamen de grote concerns tot stand, in de periode van 1980-1987 tekende zich de tegenovergestelde ontwikkeling van deconcentratie af (Korevaar, 1990)

De Nederlandse bouwwereld kent een aantal grote aannemingsbedrijven. Hiervan zijn HBG, Volker Stevin en Ballast Nedam in een fusiegolf in 1970 in hun huidige vorm ontstaan. De wens te fuseren was aanvankelijk gericht op diversificatie. In het algemeen werd gestreefd naar vergroting van het financiële draagvlak, verbreding van de know-how en versterking van de organisatic om zo in aanmerking te komen voor grote turn-key projecten in het verre buitenland. In de loop van de jaren "70 werd de aannemerij echter steeds aantrekkelijker voor speculatieve investeringen. Dit leidde tot een onevenwichtige groei en concentratie van bouwconcerns.

In de periode van 1980 tot 1987 tekende zich echter weer een tendens van deconcentratie af binnen de Nederlandse bouwnijverheid. De ineenstorting van de markten in het Midden-Oosten in het begin van de jaren ' 80 als gevolg van de dalende olieprijzen en de dalende binnenlandse bouwproduktie leidden ertoe dat vele bouwbedrijven in ernstige moeilijkheden kwamen. Grote B\&U-bedrijven als Wilma, Bredero en Ogem leden grote verliezen. De laatste twee concerns gingen failliet en werden in delen opgesplitst. De perspectiefrijke OGEM-bedrijven werden voortgezet in de TBI-Holdings, momenteel één van de grootste bouwbedrijven in Nederland. Orok een onderneming als Boskalis viel siteen. Volker Stevin dat net was gefuseerd, overleefde deze periode met moeite. Een aantal bedrijven profiteerden van de crisis door goedkoop bedrijfsonderdelen op te kopen, het zgn. 'lijkenpikken', en zo in de subtop van de Nederlandse bouw terecht te komen (Korevaar, 1990). Voorbeelden van deze bedrij- 
ven zijn Vermeer, Janssen \& De Jong, Wessels Rijssen en Maurik. Er vonden van 1980 tot 1987 vonden weinig grote fusies plaats.

In 1988 veranderde dit. HBG, qua omzet de grootste Nederlandse aannemer, verwierf een meerderheidsbelang in Volker Stevin, qua omzet dat jaar nummer twee. De Verenigde NBM-Bedrijven en Amstelland Concernbeheer, twee grote aannemersbedrijven, vormden medio 1988 samen het NBM-Amstelland concern. De BAM-Holding nam de Geldens Groep, dat wil zeggen de voormalige Bredero-bedrijven, over. In 1989 is sprake van een toename van kleinere overnames. HBG kocht bouwbedrijven in Engeland, België en Ierland. Volker Stevin nam onder meer Van Eijk bedrijven (leidingbouw) in Gouda over. NBM-Amstelland verwierf aandelen in de IGB-Holding om op die manier in het bezit te komen van Dirk Verstoep, een onderneming die gespecialiseerd is in droge waterbouw. Ballast Nedam nam wegenbouwer Van Moel over, TBIHoldings de Utrechtse aannemer Heijmerink en de BAM het Brabantse bouwbedrijf Pennings. Heijmans pleegde een groot aantal kleine acquisities in de wegenbouw. Alle grote bouwconcerns behalve Wilma waren op het overname pad. Soortgelijke concentratie-tendensen deden zich voor in de subtop van aannemersbedrijven. Dat leidde tot een rangorde van bouwbedrijven zoals die in tabel 10 is weergegeven.

In de tussenhandel heeft zich eveneens een concentratieproces voltrokken. In de periode van 1985-1989 heeft zich in de Nederlandse houthandel een snelle concentratie voorgedaan. Marktleider is PontMeyer met een jaar-omzet van $749 \mathrm{mln}$. (over verslagjaar 1992/1993). PontMeyer is het gevolg van een fusie in 1986 tussen William Pont en Meyer International. Een belangrijke overname van PontMeyer was het bedrijf Van der Venne Van der Sluis.

Ook bij fabrikanten van bouwmaterialen behoort tot de belangrijkste ontwikkelingen de concentratie-tendens (Nederlandse Middenstandsbank, 1988). Deze doet zich zowel op horizontaal (concentratie als gevolg van schaalvergroting) als op verticaal niveau voor (concentratic als gevolg van integratie). Zo bestaat er tussen de binnenlandse zand- en grindhandel, de cementleveranciers en de betonmortelindustrie een zeer uitgebreid patroon van deelnemingen. Een van de grootste marktpartijen hierin is de cementproducent ENCl, met grote belangen in de betonmortelindustrie. Dit blijkt uit hei feit dat het bedrijf Mebin, de Maatschappij tot Exploitatie van Betonmortelbedrijven in Nederland, qua omvang en werkgelegenheid veruit de grootste onderneming binnen de betonmortelindustrie, grotendeels eigendom is van de cementleverancier ENCl (Bouw- en Houtbond FNV, 1988). Andere belangrijke Nederlandse bouwmaterialenconcerns die actief́ zijn op de diverse deelmarkten, zijn Cementbouw en Van Nieuwpoort.

Een tweede belangrijke ontwikkeling in de bedrijfsstructuur van de verschillende branches is de internationalisatie.

Een aantal Nederlandse uitwoerende bouwbedrijven is reeds in buitenlandse handen. Ballast Nedam is een dochter van het British Aterospace, IGB in Breda maakt deel uit van het Franse concern Fougerolle, en Hillen en Roosen uit Amsterdam van het Duitse Philip Holzmann-concern. Verder opereert het Duitse Strabag Bau reeds lange tijd op de Nederlandse wegenbouwmarkt en fungeert het Japanse bedrijf Takenaka Netherlands voornamelijk als hoofdaannemer voor Japanse bedrijven die een bedrijf willen vestigen in Nederland. Aan de andere kant geeft HBG er blijk van bij de Euro- 

op.

Voor de Nederlandse houtverwerkende industrie, de baksteen-, kalkzandsteen- en betonwarenindustrie blijkt sterke buitenlandse belangstelling te gestaan. De bouwmaterialenindustrie internationaliseert snel, waarbij de indruk bestaat dat Nederlandse bedrijven meer worden ingelijfd in buitenlandse concerns dan andersom, met Hoogovens en Sphinx als belangrijke uitzonderingen. Bij het uiteenvallen van het Brederoconcern zijn in 1986 de bouwmaterialen werkmaatschappijen ingelijfd in het Engelse Redland-concern (o.a. RBB, Teeuwen) en de Duitse Rheinische Kalksteinwerke (Durox, nu Ytong, en Bredero Beton). De tegelfabrikant Mosa is in 1991 gekocht door een Italiaans concern. Het Finse Partek opereert sinds 1990 in een joint-venture met VBI op de Nederlandse markt en de fabrikanten van isolatiematerialen Isover en Rockwool met Nederlandse produktievestigingen zijn reeds lang Frans, resp. Deens eigendom (Jakobs, 1992, 89). Ook andere buitenlandse concerns zijn actief, zoals het lerse Cement Roadstone (met ondermeer de groothandel Van Neerbos), Readymix, Euroc en diverse Franse, Belgische en Duitse bouwmateriaalproducenten.

In de architectenbranche blijkt bij de meeste bureaus een beperkte belangstelling te bestaan om in het buitenland aan de slag te gaan. Een enkel bureau, in casu De Weger, is al jaren werkzaam in het buitenland. Het ministerie van Buitenlandse Zaken is één van de opdrachtgevers. De Weger is echter een uitzondering. Het Architecten- en Ingenieursbureau (het AIB), voormalig onderdeel van Philips, heeft ook ervaring met het buitenland. Vanwege die ervaring was dit bureau interessant voor het ingenieursbureau DHV dat meer internationaal wilde gaan werken. Zoals gezegd is bij de reorganisatie van Philips het AIB verder gegaan als zelfstandige werkmaatschappij van de DHV Groep.

\section{Organisaties op bedrijfstakniveau}

De hoeveelheid organisaties die branches of delen van de bouwnijverheid of toeieveranciers daarvan vertegenwoordigen is niet te overzien. Alleen al in de bouwnijverheid zijn niet minder dan 220 organisatie actief. Ook industriële toeleveranciers zijn in talloze branche-organisaties vertegenwoordigd. De structuur van de bouw (weinig grooten veel kleinbedrijf, geen dominerende machtsposities voor de grote aannemers, concurrentie tussen de verschillende segmenten om de besteding van overheidsgelden) vormt een belangrijke oorzaak voor het grote aantal versnipperde organisaties. Deze paragraaf gaat in op de belangrijkste branche-organisaties in de bouwnijverheid, de industriële toeleveranciers, handel en zakelijke dienstverlening. ${ }^{7}$

${ }^{7}$ Deze paragraaf is voor een belangrijk deel gebaseerd op de studie 'Organisatiemacht van belangenverenigingen: De onđernemersorganisaties in de bouwnijverheid als voorbeeld' van Van Waarden (1989). 


\section{Ondernemersorganisaties}

De belangrijkste koepelorganisatie is de federatie Algemeen Verbond Bouwbedrijf (AVBB). De AVBB bundelt via zijn lidverenigingen het overgrote deel van de groep hoofdaannemers.

FIGUUR 3 Ondernemingsorganisaties gebundeld in het AVBB:

- Nederlands Verbond van Ondernemers in de Bouwnijverheid (NVOB)

- Vereniging Grootbedrijf Bouwnijverheid (VGBouw)

- Nederlandse Vereniging van Wegenbouwers (NVWB)

- Vereniging Centrale Baggerbedrijf (CB)

- Vereniging Aannemers Grond-, Water- en Wegenbouw (VAGWW)

- Nederlandse Vereniging van Bouwondernemingen (NVB)

- Vereniging van Boorondernemers en Buizenleggers (Bolegbo)

- Nederlandse Vereniging Kust- en Oeverwerken (K\&O)

- Vereniging van Nederlandse Aannemers met Belangen in het Buitenland (NABU).

In de $A$ VBB werken de belangrijkste ondernemingsorganisaties samen. Het $A V B B$ verenigt indirect 146 van de 220 verenigingen in de bouwsector. De stichting Behartiging Opleidingen Bouwnijverheid (de BOB) is het opleidingsinstituut van de AVBB.

In tegenstelling tot de AVBB vormen individuele ondernemingsorganisaties een vrij hecht verband. Met name de kleinere verenigingen en de verenigingen van de grote bedrijven hebben een vrij hoge organisatie-graad. De NVWB, de organisatie van we= genbouwers, is zo'n sterk ontwikkelde vereniging. Zij is relatief onafhankelijk van haar leden door contributieheffing via opcenten op de aanneemsom, heeft een relatief groot budget, veel know-how, een grote staf met veel academici en beschikt over een groot aantal externe contacten met de overheid (vooral Rijkswaterstaat). Naast het NVWB zijn ook andere, vooral verenigingen in de grond- weg en waterbouw, zoals de Vereniging Kust- en Oeverwerken (K\&O) en de Vereniging Centrale Baggerbedrijf (CB), sterk ontwikkeld.

In de B\&U zijn de NVOB en VGBouw de belangrijkste branche-verenigingen. De NVOB is verreweg de grootste vereniging in de AVBB. In principe kunnen alle bouwbedrijven er lid van worden. De grote meerderheid van de kleinere bedrijven in de NVOB heeft vooral behoefte aan informatie en advies. De NVOB is ook actief als lobbyvereniging naar de diverse overheden toe. VGBouw is een relatief nieuwe vereniging die ontsiaan is uit de fusie van de NIVAG en Progresbouw. NIVAG was vooral actief in de belangenbehartiging van de grote bouwers, Progresbouw trad vooral op de voorgrond als markt- en researchorganisatie. Het doel van de nieuwe vereniging is een optimale serviceveriening aan de lid-bedrijven en het nastreven van een goede inbreng als maatschappelijke organisatie.

Daarnaast zijn er algemene belangenverenigingen van hoofdaannemers die niet bij overkoepelende organisaties in de bouw, zoals het AVBB, zijn aangesloten. Deze groep 
omvat verenigingen voor kassenbouwers, slopers, scholenbouwers, houtskeletbouwers, dakdekkers, bitumineuze dakdekkers, riet- en strodekkers, technische bodemonderzoekers, asfaltwegenbouwers, betonwegenbouwers, bouwers van weglichamen en 'lijntrekkers' op wegen. Ook kan een branche-vereniging voor staalbouwers, onderdeel van de metaalwerkgeversorganisatie FME, hiertoe worden gerekend.

In de relatief nieuwe milieubouwsector zijn ook al een vijftal brancheverenigingen actief. Hun activiteiten liggen vooral op het terrein van de standaardisatie van bestekbepalingen en de export. Met name de Vereniging van Leveranciers van Milieuapparatuur en -technieken (VLM), de Orde van Nederlandse Ingenieurs (ONRI) en de Vereniging Procesmatige Grondreinigingsbedrijven (NVG) zijn actief op dit terrein.

\section{De prijsregelende organisaties}

Naast de ondernemingsorganisaties zijn in de bedrijfstak de zgn. prijsregelende organisaties (PRO's) van belang. PRO's zijn aannemersverenigingen die zich bijna uitsluitend met de regulering van de aanbestedingsprocedure bezig houden. De leden van deze verenigingen hebben zich verplicht om melding te maken van elk onderhands verzoek om een offerte door een opdrachtgever. De PRO's registreren deze meldingen. Indien er voor eenzelfde werk meer aannemers uitgenodigd blijken te zijn om een prijsopgave te doen, organiseren deze PRO's vergaderingen van genodigden. Verder zien zij toe op de uitvoering van de administratie van de daar gemaakte afspraken.

Er zijn in totaal 33 prijsregelende organisaties voor verschillende deelmarkten, onderscheiden zowel naar regio, produkt als een combinatie van beide criteria. De markt voor B\&U werken is voornamelijk regionaal opgedeeld: in 21 segmenten met voor elk segment een vereniging. De grootte ervan loopt sterk uiteen. Sommige bestrijken slechts een enkele stad; ander een groot deel van het land, zoals de Zuid-Nederlandse Aannemersvereniging (ZNAV), die de drie zuidelijke provincies dekt. Alleen de sloopwerken vormen een uitzondering. Deze B\&U-branche is ondergebracht in één landelijk. vereniging, de Eerste Nederlandse Vereniging van Aannemers van Sloopwerken (ENVAS). In de GWW-sector daarentegen bestaan zes landelijke produkt-specifieke verenigingen: voor boren en buizenleggen, baggeren, kust- en oeverwerken, beplantingen, wegstrepen trekken en kabelleggen. De resterende GWW-werken zijn bij vijf GWW/regio-specifieke vestigingen ondergebracht en bij drie verenigingen, die ook $B \& U$ aanbestedingen reguleren. Deze 33 taakspecifieke verenigingen coördineren hun beleid in de overkoepelende Vereniging Samenwerkende Prijsregelende Organisaties (SPO).

In 1992 achtte de Europese Commissie het mededingingssysteem, zoals beheerd door de PRO's, ontoelaatbaar. Binnen de EEG zou door dit systeem een gezonde concurrentie verhinderd worden. De kritiek van de Europese Commissie richt zich hoofdzakelijk op twee punten. Ten eerste is dat de omstreden aanbestedings- of voorvergadering. Deze vergaderingen vinden vlak plaats voordat de offertes bij de opdrachtgever moeten worden ingediend. De bedoeling is onder meer vast te stellen welke inschrijver de laagste is en dus als eerste met de opdrachtgever mag onderhandelen. De Commissie heeft hier bezwaar tegen, omdat niet uit te sluiten is dat de aannemers die hebben ingeschreven vlak voor de vergadering nog prijsafspraken maken. Tijdens de voorvergadering wordt ook de hoogte van de 'rekenvergoeding' vastgesteld, het tweede punt van kritiek van de EEG. Elke inschrijver krijgt een vergoeding voor zijn calculatiekosten. Deze vergoeding is afhankelijk van hoe precies de opdrachtgever de benodigde 
gegevens aanlevert, het aantal inschrijvers en het Programma van Eisen. Volgens de Europese Commissie hebben de rekenvergoedingen een prijsopdrijvend effect: het Nederlandse bouwproces zou drie procent te duur zijn (Liesker, 1992). Vanwege de rekenvergoeding schrijven aannemers op een werk in zonder dat men verwacht dit ook daadwerkelijk te krijgen.

\section{Onderzoeksinstellingen in de bouwnijverheid}

Belangrijke onderzoeksinstellingen in de Nederlandse bouw zijn, naast de twee universitaire bouwkunde faculteiten, de zgn. Collectief Onderzoek Programmerende Instellingen (de COPI's). Deze hebben een zekere coördinerende functie ten aanzien van met name onderzoek dat collectief en openbaar is. Deze instellingen zijn werkzaam per toepassingsgebied. Voor de B\&U zijn van belang het ISSO (Instituut voor Studie en Stimulering van Onderzoek op het gebied van gebouwinstallaties) en de SER (Stichting Bouwresearch). De SBR stelt zich ten doel kennis te verspreiden die produktiviteit en kwaliteit van het bouwbedrijf ten goede komen. Het Civieltechnisch Centrum voor Uitvoering Research en Regelgeving, het CUR, bevindt zich op het snijvlak van B\&U en GWW (beton- en waterbouw). In de GWW-sector is het Centrum voor Regelgeving en Onderzoek in de Grond-, Water- en Wegenbouw en de Verkeerstechniek, het CROW, actief. Onder druk van financiers heeft ook een onderlinge terreinafbakening plaatsgevonden tussen de COPI's en de universiteiten en zijn onderzoeksprogramma's beter onderling afgestemd.

Daarnaast bestaan er de collectieve onderzoeksinstellingen van brancheverenigingen in de bouw. Voorbeelden hiervan zijn de drie regionale wegenbouwlaboratoria van de NVWB (Nederlandse Vereniging van Wegenbouwers), die vooral onderzoek doen naar asfaltlagen, funderingen, vorstschade en dergelijke; de onderzoeksafdeling van de Vereniging van Kust- en Oeverwerken en, tot 1990, de onderzoeksactiviteiten van Progresbouw. Na het opgaan van Progresbouw en de NIVAG in de Vereniging Grootbedrijf Bouwnijverheid (VGBouw), heeft de VGBouw haar onderzoeksactiviteiten ondergebracht in de Stichting Research Rationalisering Bouw. Een deel van de financiering voor deze activiteiten is afkomstig uit een fonds van de al eerder genoemde O\&O-opbrengsten en de fondsen van de prijsregelende organisaties. Verder financieren sommige verenigingen onderzoek uit hun eigen budget en maakt men gebruik van overheidssubsidies.

Niet-universitaire onderzoekinstellingen zijn TNO-Bouw (vroeger: IBBC-TNO, Instituut voor Bouwmaterialen en Bouwconstructies) te Rijswijk, Grondmechanica te Delfi en het Waterloopkundig Laboratorium, eveneens in Delft. Deze laatste instelling wordt tevens tot de grootste ingenieursbureaus van Nederland gerekend. Andere niet-universitaire onderzoeksinstellingen voor de hele bouw zijn de Stichting Arbeidstechnisch Onderzoek (SAOB) en het Economisch Instituut voor de Bouwnijverheid (EIB). Het EIB onderzoekt bedrijfseconomische en sociale vraagstukken in verband met het bouwbedrijt. Particulier gefinancierd is het Instituut voor Bouwrecht. Het doel van het IBR is het bevorderen van een wetenschappelijke en praktische beofening van het bouwrecht. 
Een belangrijke overkoepelende organisatie van toeleveranciers van de bouwnijverheid is het in 1988 opgerichte Nederlands Verbond Toelevering Bouw. Aanleiding tot het oprichten van de NVTB was de toenemende behoefte aan een zo breed mogelijk samenwerkingsverband in de bouwtoelevering. Doelstelling van de NVTB is de belangenbehartiging van de leden in de sector bouwtoelevering. Daarbij wordt als uitgangspunt gehanteerd dat datgene wat de leden zelf niet of minder efficiënt kunnen of willen doen in de gezamenlijkheid van de NVTB wordt gedaan. Kerntaken van de NVTB betreffen onderwerpen als kwaliteit, normalisatie, certificering, informatisering en milieu. Bij de NVTB zijn 27 branche-organisaties aangesloten. Een aantal hiervan worden hieronder behandeld.

De in 1946 opgerichte Nederlandse Bond van Timmerfabrikanten (NBvT) is een vereniging van werkgevers in de timmerindustrie die ruim 200 leden kent. Dit ledenbestand bestaat uit timmerfabrieken die gekenmerkt worden door een grote verscheidenheid in omvang en produktspecialisatie. De produktie van deze fabrieken kan zich richten op ramen, kozijnen, deuren, trappen, moduulbouw, prefabelementen, gevelsluitende elementen en speciaal timmerwerk. Belangrijke thema's van het NBvT zijn industrieel bouwen en proces- en produktkwaliteit. Bij dit laatste speelt de Stichting Keuringsbureau Hout (SKH) een belangrijke rol. Deze stichting verleent aan houtprodukten, die daarvoor in aanmerking komen, het KOMO-certificaat.

Ondernemingen van de Nederlandse betonwaren- en prefabbetonindustrie zijn georganiseerd in de Bond van Fabrikanten van Betonwaren in Nederland (BFBN). De ongeveer 150 aangesloten bedrijven produceren op jaarbasis ca. 2 mld gulden aan gereed produkt en bieden werkgelegenheid aan ca. 8300 werknemers. De BFBN overkoepelt acht zgn. sectorverenigingen. Iedere vereniging bestaat uit bedrijven die zich richten op de produktie van een specifieke groep betonprodukten.

De Vereniging Nederlandse Cementindustrie (VNC) is een branche-vereniging met als leden de Nederlandse Cementfabrieken ENCI, Cementfabriek IJmuiden (CEMIJ) en Cementfabriek Rozenburg (ROBUR). De VNC heeft als hoofddoel het beveiligen en bevorderen van betontoepassingen. Daartoe vindt regelmatig overleg, plaats met andere branche-organisaties uit met name de betonmortel- en de betonwarenindustrie zoals de BFBN en de VBN (Vereniging van Betonmortelfabrikanten in Nederland). Ook vindt een stuk afstemming plaats met instellingen voor onderzoek en regelgeving zoals CUR en CROW.

Grote en middelgrote bedrijven in de metaalproduktenindustrie zijn veclal aangesloten bij de FME, de Federatie Metaal- en Electrotechnische Industrie. In het kader van de FME is een aantal branche-organisaties actief. Een aantal van deze organisaties verenigen belangrijke toeleveranciers van de bouw zoals de Branchegroep Staalbouw, de Vereniging van Nederlandse Fabrieken van Ketels voor Centrale Verwarming (VFK) en de Vereniging Fabrieken van Hang-en Sluitwerk (VHS).

In de bouwmaterialengroothandel neemt de Vereniging van Handelaren in Bouwmaterialen In Nederland (HIBIN) een centrale plaats in. Bij de HIBIN zijn bijna alle grote groothandelsvestigingen (de 425 gewone leden) en de belangrijkste producenten en importeurs van bouwmaterialen (de 125 buitengewone leden) aangesloten. Onder deze 
laatste categorie vallen ondernemingen die een belangrijk deel van hun goederenstroom via de bouwmaterialengroothandel laten lopen. Taken van de HIBIN zijn:

a. het maken van standaarden voor in- en verkoopvoorwaarden;

b. het verzorgen van opleidingen en korte cursussen in het commercieel-technische vlak;

c. begeleiden van implementatie van nieuwe technologieën op het gebied van telematica en logistiek.

Bij de Bond van Nederlandse Architekten (BNA), een belangrijke aan de bouw verwante branche-organisatie, zijn een kleine 1400 architectenbureaus aangesloten. De BNA streeft er na dat architecten hun beroep zo optimaal mogelijk kunnen uitoefenen. Aangezien aan die beroepsuitoefening veel aspecten kleven richt de BNA zich ook op een groot aantal beleidsterreinen zoals EG-maatregelen, architectuurbeleid, opleidingen tot architect, kwaliteitszorg, informatisering etc.

Een tweede aanverwante branche-organisatie is de Orde van Nederlandse Raadgevende Ingenieurs (ONRI). De ONRI had in 1990200 bureaus als lid. De ONRI neemt. zitting in normalisatie-commissies en werk- en studiegroepen van technisch en technisch-organisatorische stichtingen en organisaties. Ook is de ONRI lid van een aantal internationale organisaties.

In deze bijlage is allereerst ingegaan op ontwikkelingen in produktie en werkgelegenheid van bedrijfsklassen die deel uitmaken van logistieke ketens in de bouw. Ontwikkelingen in de bouwnijverheid en de belangrijkste toeleverende branches zijn daarbij aan de orde geweest. Ingegaan is op de bedrijfsstructuur en veranderingen daarin van de verschillende branches die deel uitmaken van deze bedrijfskolom. Tenslotte zijn de belangrijkste branche-organisaties in de bouwnijverheid, de industriële toeleveranciers, handel en zakelijke dienstverlening behandeld. 


\section{Bijlage II Geïnterviewde personen}

A. EDI en PDI stimuleringsprogramma's

1. EDI-en PDI-projecten algemeen

Ballast Nedam Engineering

Ministerie van Economische Zaken

Ir. J.J. Duivenvoorden

Ir. E.G. de Jeu

Drs. M. Hoevers

2. EDIBOUW

Beton Son B.V.

Durox Nederland B.V. (nu Ytong)

EDIBOUW

Polynorm N.V.

Vermeulen/Urbibouw B.V.

Koninklijke Volker Stevin N.V.

Wilma Bouw

Dhr. J.B. van Boxel

Dhr. A. van der Veer

Dhr. W.F. de Jong jr.

Dhr. R.B.C. van lipenhof

Dhr. A.C. Jutte

Ing. D.A. Endeveld

Ing. L. van den Haak

Dhr. H.J.E. Visscher

Drs. K. Willems

Ir. G.H.M. Maas

Ing. J.J.G.M. Kitzen

3. HIBIN-Communicatie-Project

De Boo Beheer B.V.

Dhr. J.A.P. Kuijs

Budé Beek B.V.

Dhr. E. Budé

HIBIN

Dhr. M.P. Wabeke

OVD Groep

Drs. J.J. Huygen

Drs. N.J. Vrielink

Redland Dakprodukten B.V.

Drs. J.L. van den Berg

N.V. Koninklijke Sphinx

Dhr. J.M.M. Miessen

4. NOBI-projecten

ARTB

CROW

Ir. D. Spekkink

Ir. P.Ph. Jansen

Stichting Bouwresearch

Ir. C.B. Maliepaard

VABI

Ir. P. van Dam

B. Innovaties in de organisatie van bouwprojecten

1. Bouwmaterialenindustrie

Haitsma Prefab Beton B.V.

Ir. S. Hokwerda

Monoliet Beton Breda B.V.

Ing. S.D. Schrale

Schokbeton B.V.

Dhr., M.H.W. Peters 
Unidek Volumebouw B.V.

Voorbij Groep Wilnis

Waco-Liesbosch Beton B.V.

2. Bouwnijverheid

ERA Bouw B.V.

Koninklijke IBC B.V.

Nevanco Groep B.V.

Sterk Bedrijven Rossum B.V.

Technische Buro Korporaal B.V.

3. Zakelijke dienstveriening

Architectenburo F.J. Westhoff

Bond van Nederlandse Architekten

Buro Wiegerinck Architekten

B.V. Centraal Bureau Bouwtoezicht

Cepezed B.V.

Deerns Raadgevend Ingenieurs B.V.

Mecanoo Architekten

\section{Concrete bouwprojecten en hun ketens}

Alpha Ciboma B.V.

ABT - Adviesburo Voor Bouwtechniek B.V. Ballast Nedam Utiliteitsbouw B.V.

Berenschot B.V.

Bogro B.V.

Bouwmaatschappij Vermeulen B.V.

Bouw Toe B.V.

Felix Glas B.V.

Grootel's Bouwmaatschappij B.V.

Heijmans Bouwstoffen B.V.

De Heus B.V.

HOCO Betonindustrie B.V.

Hollandsche Beton Maatschappij B.V.

Hurks Beton B.V.

Lagro B.V.

Lommaert/ODS Walserijprodukten B.V.
Ing. J.T.A.M. van den Reek

Dhr. A.Th.M. Bisschops

Ing. A.G.M. Roggekamp

Dhr. M.G.M. Pfaff

Ir. N.A.J. Hooijmaaijer

Ir. J.J. Waegemaekers

Dhr. E.J.M. van Casteren

Dhr. L.J. van Dam

Dhr. F.J. Westhoff

Ir. A.J. Molendijk

Ir. G.W. van Veersen

Ir. M.G.M.A. Dumoulin

Ir. H. van Heeswijk

Dhr. A.C. Bijl

Ir. E. van Egeraat
Dhr. M. Kalis

Ing. B.G.M. Geutjes

Ing. J.H.C. Vermaak

Dhr. G. van Zweben

Ing. S. Vievermans

Ing. J. Bakker

Ir. G. ten Cate

Drs. W.O. Hazelhorst

Dhr. J.W.M. van Lokven

Dhr. A. Korevaar

Ing. G.E. Horstman

Ing. W. van Zon

Dhr. J. Vermeer

Dhr. P. Wolfs

Dhr. F.L. van Oorschot

Dhr. F. Camerling

Mevr. C. Vogel

Dhr. K. van Dijk

Dhr. D.B. de Heus

Dhr. P. van den Bosch

Ir. R.P. van Wingerden

Dhr. Th. Buytels

Dhr. W. Frijns

Dhr. W.M.E. Gijsen 
Pennings \& Zn. Gebouwenservice B.V.

PontMeyer N.V.

Wilma Bouw B.V.

Woningstichting Hoogvliet
Dhr. H. van de Broek Dhr. F.P.A. Haijemaije Dhr. P. van Laarhoven Dhr. M. van Rosmalen Dhr. C. van Driel Ir. M. Broos Dhr. F.J. van der Kemp 


\section{Bijlage III Vragenlijst EDI en PDI}

\section{A. EDI-Vragenlijst voor bedrijven ${ }^{2}$}

1. Op welke wijze bent u bij EDI betrokken?

2. Welke omvang heeft uw bedrijf (in aantal werknemers)? Maakt u bedrijf deel uit van een groter concern?

3. Met hoeveel partners heeft uw bedrijf contact via EDI?

4. Verzendt uw bedrijf berichten per EDI of ontvangt u berichten op die manier of allebei?

5. Hoeveel soorten berichten ontvangt/verzendt uw bedrijf electronisch? Kunt u concrete voorbeelden van die soorten geven?

6. Hoeveel berichten worden per dag en per bouwproject gemiddeld verstuurd?

7. Hoe groot was ongeveer het aandeel van de berichten đie nú electronisch verzonden worden, in de totale hoeveelheid vergelijkbare berichten die uw bedrijf verlieten c.q. binnenkwamen (per telex, fax, post of telefoon) vóórdat u overstapte op EDI?

8. EDI maakt het mogelijk dat berichten van handelspartners zonder menselijke tussenkomst verwerkt worden in geautomatiseerde administraties, bestel- en planningssystemen en dan leiden tot bestellingen van materialen en onderdelen of opdrachten aan produktie-afdelingen. Aan welke informatiesystemen binnen uw bedrijf wordt EDI direct gekoppeld?

9. EDI maakt het mogelijk dat gecomputeriseerde systemen in een bedrijf automatisch berichten genereren voor handelspartners. In hoeverre is dat in uw bedrijf het geval?

10. Vanwaar kwam de belangrijkste impuls voor uw bedrijf om zich met EDI bezig. te houden?

11. Welke standaardberichten zijn momenteel voor de bouw ontwikkeld en geschikt voor operationeel gebruik?

12. Problemen bij de invoering van EDI deden zich vooral voor door

- gebrek aan samenwerking tussen de partners

- tekorten in de netwerkservice.

- het ontbreken van standaardberichten

- complicaties bij de implementatie van de vertaalsoftware

- gebrekkige koppeling naar in-house applicaties

- weerstand bij betrokken afdelingen

- beperkte knowhow op het gebied van automatisering in de bouw

- onderschatting van de gevolgen voor de bedrijfsvoering

- tijdelijkheid van samenwerkingsverbanden in de bouw

- diversiteit van partijen

${ }^{1}$ De EDI-vragentijst is afkomstig van de studie "Werken in netwerken: De gevolgen van Electronic Data Interchange voor arbeid en organisatie' (Dankbaar, 1991). De vragenlijst is op een paar punten toegespitst op de bouwsector. 
- andere redenen.

13. Zijn de kosten van invoering van EDI in uw bedrijf vergeleken met de begroting mee- of tegengevallen?

14. Hieronder treft u een lijstje van voor- en nadelen van EDI aan. Geef aan of naar uw mening die voor-en nadelen in het geval van uw bedrijf onbelangrijk, tamelijk belangrijk, belangrijk dan wel zeer belangrijk. zijn.

Voordelen: - arbeidskostenbesparend

- snellere procedures

- lagere voorraden

- klantenbinding

- betere interne planning

Nadelen: - hoge (aanloop)kosten

- gebondenheid aan één handelspartner

15. Is EDI voor uw bedrijf verbonden met just-in-time toelevering op de bouwplaats?

16. Zijn de ondernemingsraad en/of vakbeweging op enigerlei wijze betrokken geweest bij de invoering van EDI?

17. De primaire implicatie van EDI voor arbeid is dat op verschillende plekken in de keten van berichtenuitwisseling data entry activiteiten wegvallen? Is dat in uw bedrijf het geval geweest?

18. Is er in uw bedrijf bij de invoering van EDI (tijdelijk) extra personeel ingezet?

19. Bij welke afdelingen verwacht $\mathrm{u}$ in de toekomst gevolgen voor de personeelsbezetting ten gevolge van een toenemend gebruik van EDI?

20. Zijn in uw bedrijf opleidingsactiviteiten ondernomen ter ondersteuning van EDI?

21. Is de afdelingenstructuur van uw bedrijf veranderd onder invloed van de invoering van EDI?

Graag uw mening over de volgende stellingen:

22. Door EDI zal de functie logistiek in het bedrijf duidelijker geprofileerd worden.

23. In een Amerikaans EDI-handboek wordt gesteld dat het voor een optimaal gebruik van EDI schaalvergroting van de onderneming nodig is.

24. Voor een optimaal gebruik van EDI is het gewenst de inkoopfuncties van de verschillende divisies van een onderneming te centraliseren.

25. Nederland loopt in Europees verband voorop met EDI.

26. EDI wordt door de grote bedrijven aan hun toeleveranciers en/of aannemers opgedrongen.

27. EDI bindt de leverancier met handen en voeten aan zijn afnemer en is daardoor schadelijk voor de flexibiliteit van kleine bedrijven.

28. EDI is primair een zaak van de automatiseringsafdeling.

29. EDI is primair een zaak van het operationeel management.

30. EDI leidt tot centralisatie van de administratie.

31. Medewerking van de ondernemingsraad is belangrijk bij de introduktie van EDI.

B. PDI-vragenlijst voor branche-organisaties

1. Op welke wijze bent u bij het PDI-project betrokken?

2. Welke bedrijuen doen mee met het PDI-project?

3. Wat is precies de taak van de participerende bedrijven?

4. Tot welke bedrijfstak(ken) behoren zij?

5. Wie heeft de projectleiding? 
6. Wat is de doelstelling van het PDI-project?

7. Wat is voor de branche-organisatie de belangrijkste impuls geweest voor de start. van dit project?

8. Op welke berichten- of informatiestroom heeft het te ontwikkelen systeem betrekking?

9. Hoe ziet deze berichten- of informatiestroom er in niet-electronische vorm uit?

10. Waarover wordt in dit specifieke PDI-project produktinformatie uítgewisseld (concreet produkt, bouwproject)?

11. Maakt de in dit project ontwikkelde standaard een koppeling mogelijk tussen ontwerp- en produktiesystemen?

12. Worden soortgelijke PDI-projecten in het buitenland uitgevoerd? Heeft men daar contacten mee?

13. Hoe is het project gefaseerd? In welke fase bevindt het project zich nu?

14. Wat zijn de voornaamste problemen bij de ontwikkeling van een P'DI-standaard?

- beperkte knowhow op het gebied van automatisering in de bouw

- diversiteit van betrokken partijen

- gebrek aan samenwerking tussen de verschillende partijen

- het ontbreken van standaarden

- weerstand uit bepaalde sectoren

- onderschatting van de gevolgen voor de bedrijfsvoering

- andere redenen.

15. Zijn de kosten van het ontwikkelen van een PDI-standaard in dit project vergeleken met de begroting tot nu toe mee- of tegengevallen?

16. Wat zijn de beoogde voordelen van het project?

17. Hieronder treft u een lijstje van voor- en nadelen van PDI aan. Geef aan of naar uw mening die voor- en nadelen in het geval van uw bedrijf onbelangrijk, tamelijk belangrijk, belangrijk dan wel zeer belangrijk zijn.

Voordelen: - arbeidskostenbesparend

- snellere procedures

- betere planning van een bouwproces

Nadelen: - hoge (aanloop)kosten

18. Bij welke afdelingen verwacht u in de toekomst gevolgen vooi de personeelsbezetting ten gevolge van het gebruik van PDI?

19. Verwacht u dat implementatie van PDI-systemen binnen bedrijven extra opleidingsinspanningen vereist?

20. Zullen in de toekomst door invoering van PDI bepaalde functies binnen bedrijven veranderen?

21. Loopt Nederland in Europees verband voorop met de ontwikkeling van PDIstandaarden?

22. Zullen kleine bedrijven vanwege de beperkte financiële mogelijkheden in staat zijn aan te sluiten op een PDI-systeem? 


\section{Bijlage IV}

\section{Vragenlijst Innovaties in de organisatie van bouwprojecten}

\section{A. Vragenlijst voor architecten- en projectmanagementbureaus}

I Algemene bedrijfs- en sectorgegevens

1a. Hoe is het bedrijf georganiseerd (organigram)?

b. Heeft het bedrijf andere vestigingen in Nederland?

c. Is het bedrijf onderdeel van een groter concern?

d. Hoeveel medewerkers heeft de onderneming?

e. Waar zit $u$ in de organisatie?

2a. Is het bedrijf op een bepaald marktsegment gericht? Is dat in de afgelopen vijf jaar nog gewijzigd?

b. Wat is de omzet (verhouding utiliteit/woningbouw, binnen-/buitenland)?

c. Heeft het bedrijf ervaring met het zelf ontwikkelen van projecten en produkten? Zo ja, maakt eigen project- en produktontwikkeling een substantieel deel uit van de omzet?

d. Heeft het bedrijf ook te maken gehad met de algemene tendens in de bouw naar kleinere en meer diverse projecten?

3a. Is er een algemene tendens waarneembaar dat in de bouw steeds vaker gebruik wordt gemaakt van projectmanagementbureaus?

b. Loopt de Nederlandse bouw, in vergelijking met het buitenland, voorop met het gebruik van aparte projectmanagementbureaus voor de organisatie van bouwprocessen?

c. Is de rol van coördinator alleen weggelegd voor grote bureaus met veel bouwtechnische disciplines in huis?

d. Zo ja, betekent dit dat in de branche een schaalvergroting en internationalisatie van bedrijven optreedt of zal optreden?

\section{Projectmanagement}

ta. Hoe is het management van een bouwproject binnen het bureau georganiseerd?

b. Wat zijn de belangrijkste voordelen voor een opdrachtgever om een opdracht uit handen te geven aan een projectmanager van een architecten- of projectmanagementbureau: kostenbesparing, snellere procedures, betere planning van het bouwproces, grotere integratie van activiteiten?

c. Heeft projectmanagement als aparte dienst geleid tot het aanbieden van andere diensten door het bedrijf (bijv. facility management)?

2a. Hoe vindt de selectie van (andere) ontwerpende en uitvoerende partijen plaats? Welke criteria worden daartoe gehanteerd?

b. Worden deze partijen betrokken bij produktontwerp en/of de ontwikkeling van het project? Zo ja, wat is hun inbreng?

c. Wie coördineert de tekeningprocedures in het voortraject: de projectmanager, de architect of de aannemer? 
d. Wie is arbiter bij een probleem tussen de architect en een uitvoerende partij, bijv. de installateur (m.a.w. is het niet beter om ontwerpbedrijf en managementorganisatie te scheiden)?

e. Is er geen spanning tussen architectonische vormgeving en procesmanagement. Met andere woorden: worden kosten- of bouwtechnische zaken niet dominerend in een ontwerp als het bureau verantwoordelijk is voor ontwerp èn uitvoering?

3a. Wie leidt tijdens de uitvoering de bouwvergaderingen?

b. Wie draagt de kosten/baten van meer-/minderwerk?

c. Werkt uw bedrijf voor meerdere projecten samen met dezelfde aannemers en/of toeleveranciers?

d. Welke geautomatiseerde informatiesystemen heeft het bedrijf in gebruik?

e. Welke rol spelen deze systemen bij het coördineren en afstemmen van ontwerpende en uitvoerende partijen.

III Extra vragen aan de architect

1. Prestatie-bestek:

a. Is het prestatie-bestek nog theorie of wordt het al in praktijk gebruikt?

b. Zijn er extra vaardigheden bij de architect vereist om een prestatie-bestek op te stellen (kennis van normen, kwaliteitsverklaringen etc.)?

c. Welke veranderingen treden door gebruik van dit type bestek op in relatie tussen ontwerper/architect en de uitvoerder/aannemer? In hoeverre leiden prestatiebestekken tot een integratie van deze partijen?

d. Loopt de Nederlandse bouw in vergelijking met Europa voorop met het denken in prestatie-bestekken?

2. De bedreigde positie van de architect:

a. Er wordt veel gesproken over de bedreigde positie van de architect. Welke activiteiten ontplooit de BNA (of de architect) om de positie van de architect te versterken?

b. Kapstok van BNA-beleid is dat architecten zich moeten 'classificeren'. Betekent dit dat architectenbureaus zich meer op de markt gaan profileren (bijv. m.b.v. marketing)?

c. Heeft de architect last van concurrentie van projectmanagementbureaus? Leidt dit tot onvolledige opdrachten?

d. Welke geautomatiseerde informatiesystemen heeft uw onderneming in gebruik? Welke rol spelen deze systemen bij het streven de positie van de architect te versterken?

e. Welke activiteiten worden in de architectenbranche ondernomen ter stimulering van communicatie en informatie-uitwisseling d.m.v. informatietechnologie?

\section{B. Vragenlijst voor aannemers en toeleveranciers}

I Algemene bedrijfs- en sectorgegevens

1a. Hoe is het bedrijf georganiseerd (organigram)?

b. Heeft het bedrijf andere vestigingen in Nederland?

c. Is het bedrijf onderdeel van een groter concern?

d. Hoeveel medewerkers heeft de onderneming (wat is de verhouding 'directen'/ $\mathrm{indi}$ recten', bij aannemers 'binnen'/buiten')?

e. Waar zit $u$ in de organisatie? 
2a. Is het bedrijf op een bepaald marktsegment gericht? Is dat in de afgelopen vijf jaar nog gewijzigd?

b. Wat is de omzet (verhouding utiliteit/woningbouw, binnen-/buitenland)?

c. Heeft het bedrijf ervaring met het zelf ontwikkelen van projecten en produkten? Zo ja, maakt eigen project- en produktontwikkeling een substantieel deel uit van de omzet?

d. Heeft het bedrijf ook te maken gehad met de algemene tendens in de bouw naar kleinere en meer diverse projecten?

3. Welke ervaringen heeft het bedrijf met produkt- en procescertificering?

\section{Nieuwe organisatievormen}

1a. Welke geautomatiseerde informatiesystemen heeft het bedrijf in gebruik?

b. Welke rol spelen deze systemen bij het coördineren en afstemmen van ontwerpende en uitvoerende partijen.

c. Zijn toeleveranciers bereid JIT op de bouwplaats te leveren, is dat überhaupt mogelijk? Welke rol spelen geautomatiseerde informatiesystemen hierbij?

2a. Heeft het bedrijf duurzame samenwerkingsverbanden met opdrachtgevers, aannemers of andere uitvoerende partijen? Welk type bedrijven zijn dit?

b. Worden toeleveranciers betrokken bij produktontwerp, projectontwikkeling en/of planning van de uitvoering? Zo ja, hoe vindt dit plaats: in bouwteam-verband, via andere samenwerkingsvormen?

c. Wat zijn de belangrijkste voordelen van deze samenwerkingsvormen: kostenbesparing, snellere procedures, betere interne planning, grote integratie van activiteiten?

d. Treedt een toeleverancier wel eens op als hoofdaannemer?

3a. Heeft het bedrijf ervaring met of ooit gehoord van organisatievormen die aangeduid worden als general contracting en management contracting? Zo ja, hoe is men aan die ervaring of kennis gekomen?

b. Hoe ziet een contract er bij management contracting uit? Wat wordt afgeproken?

c. Wat is een open begroting?

4a. Is het prestatie-bestek nog theorie of wordt het al in praktijk gebruikt?

b. Welke veranderingen treden door gebruik van dit bestek op in relatie tussen ontwerper/architect en de uitvoerder/aannemer? In hoeverre leiden prestatiebestekken tot een integratie tussen deze partijen?

c. Zijn er extra vaardigheden bij de aannemer of toeleverancier vereist om met het prestatie-bestek om te kunnen gaan?

d. Loopt de Nederlandse bouw in vergelijking met Europa voorop met het denken in prestatie-bestekken?

\section{Extra vragen aan aannemers over project- en produktontwikkeling}

a. Is de projectontwikkeling van het bedrijf geconcentreerd in de utiliteits- of in de. woningbouw?

b. Waar kwam de belangrijkste impuls vandaan om als bedrijf met bouwconcepten te gaan werken en/of aan project- en produktontwikkeling te doen (de markt, grote opdrachtgevers etc.)?

c. Heeft projectontwikkeling geleid tot het aanbieden van andere diensten door het bedrijf (bijv. facility management)?

d. Wat zijn de voordelen van het werken met een eigen bouwconcept: klantenbinding, kostenbesparing, snellere procedures, betere interne planning, grote integratie van activiteiten? 
e. Wordt de scheiding tussen de ontwerper en uitvoerenden op de bouwplaats minder sterk door eigen project- en/of produktontwikkeling (ontwerpers op de bouwplaats)?

f. Kunt u voorbeelden geven van hoe de technische mogelijkheden van uw bedrijf (bijv. een bepaalde bekistingstechniek) van invloed zijn op het ontwerp van een bouwproject? Leidt dat ertoe dat logistieke aspecten reeds in het ontwerp betrokken worden?

g. Vereist het zelf ontwikkelen van produkten en projecten nieuwe afdelingen/nieuwe functies: bijvoorbeeld een afdeling Marketing?

h. Is bij het ontwerpen of ontwikkelen van produkten en projecten door het bedrijf een externe architect of projectontwikkelaar betrokken?

i. Lopen Nederlandse aannemers voorop in tendens naar bouwondernemers die zelf aan produkt- en projectontwikkeling doen? 


\section{Samenvatting}

Logistiek is een term die naar een veelheid van produktie-, transport- en distributiehandelingen en -benaderingen verwijst. De logistieke functie wordt gedefinieerd als de bedrijfsfunctie die zich bezighoudt met de besturing van goederenstromen en daaraan gekoppelde informatiestromen. In de literatuur wordt de ontwikkeling in de organisatie van de logistieke functie dikwijls als een voortgaand integratie-proces van deelfuncties beschreven. Door toepassing van informatietechnologie in de logistiek kan dit integratie-proces zelfs de grenzen van de individuele onderneming overschrijden zodat de nadruk komt te liggen op integrale goederenstroombeheersing in ketens van bedrijven. In het laatste geval spreken we van toepassing van integrale logistiek.

Dit onderzoek gaat in op de voorwaarden en gevolgen van toepassing van integrale logistiek in de bouw. Hierbij wordt gebruik gemaakt van concepten uit de theorie van de externe organisatie en theorieën over rationalisering van bedrijfsprocessen. De centrale probleemstelling van het onderzoek luidt als volgt:

1. Onder welke voorwaarden of omstandigheden zal het tot toepassing van integrale logistiek komen?

2. Welke veranderingen zullen bij toepassing van integrale logistiek zich voordoen in de organisatie van bedrijfsprocessen in een keten of groep van bedrijven?

Om deze vragen te kunnen beantwoorden is eerst een theoretische verkenning uitgevoerd die in deel I, de hoofdstukken 2 tot en met 6 , is weergegeven. In de hoofdstukken 2 en 3 is nader uiteengezet wat in dit onderzoek onder toepassing van integrale logistiek verstaan wordt. Hoofdstuk 2 geeft aan dat toepassing van integrale logistiek past in een trendmatige verandering van de organisatie van logistieke activiteiten. Hoofdstuk 3 gaat in op ontwikkelingen die toepassing van integrale logistiek mogelijk maken. In hoofdstuk 4 en 5 is een theoretisch raamwerk ontwikkeld dat voorwaarden aangeeft waaronder integrale logistiek van toepassing wordt en wat de implicaties daarvan zijn voor de organisatie van bedrijfsprocessen. Op basis van dit theoretisch kader zijn in hoofdstuk 6 stellingen en vragen voor het empirisch onderzoek afgeleid.

Ontwikkelingen in de logistieke functie kunnen als een voortgaand integratie-proces omschreven worden (hoofdstuk 2). Tot de jaren '50 organiseren ondernemingen hun logistieke functie op een gefragmenteerde basis. De toepassing van concepten als 'physical distribution', 'materials management' en 'business logistics' leidt voor het eersit in de jaren '60 en '70 tot een geïntegreerde organisatie van logistieke activiteiten binnen de onderneming. In de jaren ' 80 en '90 zijn nieuwe concepten ontwikkeld die de integratie nog een stap verder voeren. Het concept 'integrale logistiek' duidt aan dat zelfstandige ondernemingen met elkaar afspraken maken over de wijze waarop uitwisseling van goederen en informatie zal plaats vinden. Gevolg van deze afspraken kan een geïntegreerde organisatie van logistieke activiteiten op het niveau van een keten of groep van bedrijven zijn. Dit laatste duiden we aan als toepassing van integrale logistiek. Logisch eindpunt van dit integratie-proces zijn organisatie-vormen waarbij een 
zgn. 'verticale actor' een belangrijke rol speelt. De 'verticale actor' staat voor de verzelfstandiging en integratie van logistieke activiteiten in één organisatie op het niveau van een keten of groep van bedrijven.

Recente ontwikkelingen op de markt en in de technologie hebben toepassing van integrale logistiek mogelijk gemaakt (hoofdstuk 3). Tot recente ontwikkelingen op de markt behoort de concurrentie uit Japan die tot gevolg heeft dat producenten meer nadruk op produkt- en proceskwaliteit zijn gaan leggen. Naast kwaliteit hebben de eis van flexibiliteit en de globalisatie van de markt tot een toenemende concurrentie geleid. Deze nieuwe marktvereisten stellen hogere eisen aan de logistieke organisatie. Vervolgens is ingegaan op een aantal nieuwe produktie- en informatietechnologieën die het mogelijk maken aan deze eisen te voldoen. Tot de nieuwe produktietechnologieën worden nieuwe vormen van produktie-automatisering en niet-traditionele concepten van produktie-beheersing gerekend. Nieuwe bedrijfsoverstijgende informatietechnologieën zijn Videotex, Electronic Data Interchange (EDI) en Product Data Interchange (PDI). Toepassing van integrale logistiek als concurrentie-strategie is het instrument om toenemende concurrentie en nieuwe technologische mogelijkheden met elkaar te 'matchen'.

Nadat uiteen is gezet wat we in dit onderzoek onder toepassing van integrale logistiek verstaan is het theoretisch raamwerk ontwikkeld. Dit raamwerk geeft aan onder welke voorwaarden het tot toepassing van integrale logistiek komt en wat de implicaties daarvan zijn voor de organisatie van bedrijfsprocessen, de twee centrale onderzoeksvragen.

We gebruiken concepten uit de theorie van de externe organisatie om aan te geven onder welke voorwaarden het tot toepassing van integrale logistiek komt (hoofdstuk 4). Toepassing van integrale logistiek kan gezien worden als een verandering in de externe organisatie in de richting van netwerkvorming. De transactiekostentheorie geeft aan dat met name transactiespecifieke investeringen een belangrijke verklaring zijn voor de overgang van markt naar netwerk. Investeringen in zgn. gemeenschapssystemen, d.w.z. informatiesystemen warbinnen (een dee! van) de bedrijfstak met elkaar kan communiceren, bevorderen door hun transactiespecifieke karakter het ontstaan van logistieke netwerken. Bij investeringen in gesloten systemen, investeringen die zich kenmerken door een hoge transactiespecificiteit, is de kans groot op het ontstaan van een nieuwe hiërarchie. Deze organisatievorm hebben we hierboven de 'verticale actor' genoemd. In netwerktheorieën zijn het toenemend belang van overdracht van know-how, snelheid en wederzijds vertrouwen een belangrijke verklaring voor veranderingen in transactiepatronen van markt naar netwerk. Bij toepassing van integrale logistiek zijn deze factoren vooral van belang bij het streven naar produktkwaliteit en -innovatie. Het zijn deze factoren die, naast transactiespecificiteit, logistieke netwerkvorming bevorderen.

Concepten uit theorieën over rationalisering van bedrijfsprocessen zijn gebruikt voor de theoretische analyse van kenmerken en mogelijke gevolgen van toepassing van integrale logistiek voor de organisatie van bedrijfsprocessen (hoofdstuk 5). We onderscheiden twee rationaliseringsmodellen volgens, welke bedrijfsprocessen georganiseerd kunnen worden: het Taylorisme en een nieuw type rationalisering. Dit nieuwe type rationalisering, ook wel aangeduid als 'systemische' rationalisering, richt zich op de optimalisatie van het geheel van bedrijfsprocessen binnen en tussen ondernemingen met behulp van informatietechnologie. Drie rationaliseringsdimensies, organisering, 
technisering en informatisering, geven aan in welke richting de organisatie van bedrijfsprocessen zich beweegt bij de transformatie van het Taylorisme naar het nieuwe rationaliseringstype. Toepassing van integrale logistiek wordt beschouwd als onderdeel van het nieuwe rationaliseringstype. Op basis van de drie rationaliseringsdimensies worden eigenschappen van toepassing van integrale logistiek aangegeven. Dit maakt het mogelijk veranderingen in de organisatie van bedrijfsprocessen, die het gevolg zijn van toepassing van integrale logistiek, in kaart te brengen.

Op basis van concepten van deze theoretische analyse worden stellingen ontwikkeld die aansluiten bij de centrale probleemstelling, de voorwaarden en gevolgen van toepassing. van integrale logistiek (hoofdstuk 6).

Gebaseerd op de theorie van de externe organisatie geven twee stellingen aan onder welke voorwaarden of omstandigheden logistieke netwerken ontstaan:

1. Investeringen in informatiesystemen met een gemeenschaps- of gesloten karakter bevorderen door hun transactiespecifieke karakter het ontstaan van logistieke netwerken.

2. Een toenemend belang van overdracht van know-how, snelheid en wederzijds vertrouwen zijn factoren die de ontwikkeling van logistieke netwerken bevorderen.

Met begrippen uit theorieën over rationalisering, organisering, technisering en informatisering, zijn drie stellingen ontwikkeld die eigenschappen en mogelijke gevolgen van de toepassing van integrale logistiek aangeven:

3. Bij toepassing van integrale logistiek zal een bedrijfsoverstijgende organisering optreden die ertoe kan leiden dat de organisatie van logistieke activiteiten in een bedrijfsketen in nieuwe hiërarchieën plaats vindt.

4. Toepassing van integrale logistiek gaat gepaard met een technisering die zich richt op nieuwe vormen van produktie-automatisering en bedrijfsoverstijgende informatisering en die substitutie van arbeid door arbeidsmiddelen tot gevolg heeft.

5. Toepassing van integrale logistiek vereist een herstructurering van de interne organisatie door informatisering binnen de onderneming die het bedrijf in staat stelt met standaardberichten informatie uit te wisselen en deze berichten zelf te produceren.

Deel II van de studie bevat de weergave van het empirisch onderzoek. Hoofdstuk 7 bevat een verantwoording voor de wijze waarop het empirisch onderzoek is opgezet. Hoofdstuk 8 gaat nader in op het onderzoeksobject, het bouwproject in zijn keten. De hoofdstukken 9, 10 en 11 richten zich op een toetsing van de in deel I ontwikkelde stellingen. De hoofdstukken 9 en 10 gaan resp. in op stimuleringsprogramma's gericht op EDI en PDI in de bouw en innovaties in de organisatie van bouwprojecten. Het zijn deze ontwikkelingen die de context vormen waarbinnen veranderingen in de organisatie van concrete bouwprojecten en hun ketens plaats vinden. Hoofdstuk 11 omvat een analyse van vier concrete bouwprojecten en hun ketens. In het empirische onderzoek heeft data-verzameling plaats gevonden door interviews documentenanalyse. In deel III (hoofdstuk 12) zijn de uit het theoretisch raamwerk afkomstige stellingen geconfronteerd met de resultaten van het empirisch onderzoek.

De: eerste stelling roept de vraag op waar in logistieke ketens in de bouw sprake is van transactiespecifieke investeringen gericht op de sturing van goederenstromen tussen bedrijven. In de bouw hebben deze investeringen met name betrekking op bedrijfsoverstijgende informatisering. 
FIGUUR 1 Schematische opzet van het empirisch onderzoek

Onderzoeksvragen

Empirische deel-onderzoeken

A $B \quad$ C

1. Waar is in logistieke ketens in de bouw sprake van transactiespecifieke investeringen gericht op de sturing van goederenstromen tussen bedrijven?

2. Waar zijn bij transacties tussen bedrijven in de bouw overdracht van know-how, snelheid en wederzijds vertrouwen van toenemend belang geworden?

3. Is bij bouwprojecten sprake van een organisatie van logistieke activiteiten in nieuwe hiêrarchieên?

4. Is in logistieke ketens in de bouw sprake van substitutie van arbeid door (flexibele) produktie-automatisering en bedrijfsoverstijgende informatisering?

5. In hoeverre leidt implementatie van informatiesystemen in bouwketens en -processen tot een herstructurering van de interne organisatic door informatisering binnen de onderneming?

A. stimuleringsprogramma's gericht op informatisering in de bouw

B. innovaties in de organisatie van bouwprojecten

C. gevalsstudies van concrete bouwprojecten en hun ketens

Om die reden en het feit dat bedrijfsoverstijgende informatisering in de bouw nog in de kinderschoenen staat is ten eerste een aantal EDI- en PDI-stimuleringsprogramma's in de bouw geanalyseerd (hoofdstuk 9). Deze programma's richten zich op standaardisatie van berichten tussen ondernemingen betrokken bij het bouwproces en de keten van bouwmaterialen. Analyse van deze programma's geeft tevens antwoord op de door de stellingen 4 en 5 opgeworpen vragen in hoeverre implementatie van informatiesystemen tot een substitutie van arbeid en een herstructurering van de interne organisatie van ondernemingen leidt.

De mate waarin deze herstructurering en substitutie plaats vindt is afhankelijk van het feit of EDI en PDI direct gekoppeld worden aan interne applicaties. De voorwaarden voor een dergelijke koppeling zijn het gunstigst in de schakel producent-tussenhandel. In deze schakel is sprake van een uitwisseling van standaardprodukten die door produktcodering eenduidig worden vastgelegd, kenmerken relaties zich door redelijk vaste aispraken en worden grote hoeveelheden korte berichten witgewisseld. In de schakel aannemer-producent is sprake van een minder intensieve berichtenstroom en heeft de communicatie vaak betrekking op niet-gestandaardiseerde produkten. Ook in de schakel tussenhandel-aannemer is meestal sprake van incidentele informatiestromen. Daarnaast is in deze schakel vaak sprake van kleine aannemers waarvan de automatiseringssituatie nogal eens te wensen overlaat. In de relaties tussen aannemer en partijen als producent of tussenhandel zal EDI in de meeste gevallen hooguit tot een integratie van de in- en verkoopafdelingen van de verschillende ondernemingen leiden. Om die reden zal EDI bij laatstgenoemde schakels, in tegenstelling tot de schakel producent-tussenhandel, nauwelijks tot arbeidsbesparing en een herstructurering van de interne organi- 
satie leiden. Gezien het experimentele stadium waarin de ontwikkeling van PDI zich bevindt is het moeilijk aan te geven op welke wijze deze technologie tot een herstructurering van de interne organisatie en arbeidsbesparing leidt. Wel is duidelijk dat PDI voor de architect een middel kan zijn om meer kostenbewust te ontwerpen. Ook lijkt PDI voor ingenieursbureaus de meeste veranderingen tot gevolg te hebben, omdat deze bedrijven zowel aan de input- als aan de output-zijde met PDI te maken krijgen. Aan de input-zijde komen de tekeningen van de architectenbureaus binnen, aan de output-zijde gaan de tekeningen naar uitvoerende partijen.

Ook zijn knelpunten en strategieën bij de implementatie van EDI en PDI in de bouw geanalyseerd. Dit sluit aan bij de vraag naar voorwaarden waaronder het tot toepassing van integrale logistiek komt. Aan de eerste voorwaarde, zoals geformuleerd in stelling 1 , wordt nog niet voldaan omdat de tijdelijkheid van relaties en de gefragmenteerde sectorstructuur in grote delen van de bouw transactiespecifieke investeringen in bedrijfsoverstijgende informatiesystemen belemmeren. Om tot een oplossing van deze knelpunten te komen is een implementatie-strategie vereist waarbij een collectieve instantie een belangrijke rol speelt. Deze instantie zou verantwoordelijk moeten zijn voor de ontwikkeling, bouw en exploitatie van een EDI-berichtennetwerk en het zo mogelijk maken dat bij bouwprojecten betrokken partijen electronisch met elkaar kunnen communiceren. Deze netwerkbeheerder is te beschouwen als een concretisering van wat de verticale actor genoemd is, d.w.z. een nieuwe hiërarchie verantwoordelijk. voor de organisatie van logistieke activiteiten. Dit is in stelling 3 ook wel aangeduid als een bedrijfsoverstijgende organisering van de logistiek.

Stêlling 2 leidt tôt dê vraâag waâr bij transancties in de bouw overdrachi van know-how, snelheid en wederzijds vertrouwen van toenemend belang zijn geworden. Beschrijving van innovaties in de organisatie van bouwprojecten, die het gevolg zijn van nieuwe marktvereisten, kan antwoord geven op de vraag waar in de bouw andere motieven dan efficiency tot logistieke netwerkvorming leidt (hoofdstuk 10). Met deze analyse kan ook aangegeven worden welke partijen de rol van verticale actor op zich kunnen nemen. Dit sluit aan bij de door stelling 3 opgeworpen vraag of bij bouwprojecten sprake is van een organisatie van logistieke activiteiten in nieuwe hiërarchieën.

Aangegeven is dat in de bouw marktvereisten die verder gaan dan de prijs van een produkt en de prestatie-werkwijze belangrijke drijfveren zijn voor een meer kwaliteitsgericht denken in de bouw. Deze ontwikkelingen hebben tot gevolg dat de traditionele scheiding tussen ontwerpende en uitvoerende partijer opgeheven wordt. Deze toenemende integratie leidt ertoe dat bedrijven het management van het totale bouwproces op zich (willen) nemen. Er ontstaat een situatie waarbij architect of aannemer in nauw overleg met industriële toeleveranciers bouwdelen ontwikkelen of produceren. Transactie-patronen tussen ontwerpende en uitvoerende partijen veranderen van karakter. Het belang van overdracht van technische know-how en wederzijds, vertrouwen neemt toe. Volgens stelling 2 worden hierdoor aanzetten gegeven voor het ontstaan van logistieke netwerkvorming. Het is echter nog niet zo dat deze factoren in grote delen van de bestaande bouwpraktijk een belangrijke rol spelen.

Tot de bedrijven die de coördinatie van ontwerp en uitvoering op zich willen nemen behoren vooral de grote en/of innovatieve architectenbureaus, de grotere aannemers die aan projectontwikkeling doen of met gestandaardiseerde bouwconcepten werken en projectmanagementbureaus die bouwvoorbereiding, directievoering en toezicht op een 
bouwproject als aparte dienst aanbieden. Deze partijen maken gedurende een bouwproces toepassing van integrale logistiek mogelijk en zijn te beschouwen als een concretisering van de verticale actor. Een bedrijfsoverstijgende organisering van logistieke activiteiten is het gevolg (zie stelling 3).

Het derde empirische deelonderzoek spitst zich toe op aanzetten tot of nadere concretiseringen van toepassing van integrale logistiek in de bestaande bouwpraktijk (hoofdstuk 11). Er is onderzocht waar in de bestaande bouwpraktijk aanzetten te vinden zijn tot een organisatie van logistieke activiteiten in nieuwe hiërarchieën, substitutie van arbeid door nieuwe produktie-technieken en een herstructurering van de interne organisatie door informatisering (in aansluiting op stelling 3,4 en 5). Voor deze analyse zijn vier gevalsstudies van concrete bouw-projecten onderzocht, twee in de woningbouw en twee in de utiliteitsbouw.

In deze analyse komt ten eerste naar voren dat bij niet-traditionele organisatie-vormen van het bouwproces aanzetten aanwezig zijn om tot toepassing van integrale logistiek te komen. Het voornaamste probleem bij traditionele bouwprocessen is de afwezigheid van centrale sturing. Bij projecten met bouwteams en andere samenwerkingsverbanden, niet-traditionele organisatie-vormen, is van zo'n centrale sturing wel sprake en zijn de kansen op logistieke sub-optimalisatie aanzienlijk kleiner en mogelijkheden om tot toepassing van integrale logistiek te komen groter. Verticale sturing is te beschouwen als een nadere concretisering van de verticale actor en is daarmee een voorbeeid van een bedrijfsoverstijgende organisering van logistieke activiteiten (zie stelling 3 ).

Ten tweede blijkt uit de gevalsstudies dat de behoefte aan logistieke afstemming tussen de bij een bouwproject betrokken partijen nauw samenhangt met de gekozen bouwtechniek. De traditionele wijze van bouwen is als produktie-techniek sterk bouwplaats georiënteerd en staat tegenover prefabrikage dat sterk fabriek georiënteerd is. Ambachtelijk werk op de bouwplaats wordt vervangen door produktie in de fabriek. Dit laatste schept meer mogelijkheden voor het planmatig vastleggen van een bouwproces. Prefabricage leidt tot een substitutie van arbeid en is daarmee een voorbeeld van een technisering die vaak samen gaat met toepassing van integrale logistiek (zie stelling 4)

In de gevalsstudies komt ten derde naar voren dat slechts een klein deel van de bouwsector informatie op een gestandaardiseerde en geformaliseerde wijze vitwisselt. De bestaande bouwpraktijk kenmerkt zich door een informele en niet-gestructureerde wijze van informatie-uitwisseling. Van een substitutie van arbeid of herstructurering van de interne organisatie door implementatie van informatiesystemen is in grote delen van de bouw nog geen sprake. Bij de analyse van EDI stimuleringsprogramma's hebben we echter al aangegeven dat deze nieuwe informatietechnologie wel degelijk op bepaalde punten tot substitutie en herstructurering leidt.

Uit de gevalsstudies blijkt dat in de bestaande bouwpraktijk aanzetten tot toepassing van nieuwe logistiek vooral bestaan uit de overgang van een horizontale naar een verticale sturing van bouwprocessen en prefabricage. In de stellingen 3 en 4 is dit aangeduid als een organisering en technisering van logistieke activiteiten. Daarnaast is in een klein deel van de bouwsector sprake van een bedrijfsoverstijgende informatisering. 


\section{Summary}

The concept of logistics refers to production, transport and distribution activities. The logistical function is defined as the business function directed to the control of product flows and related information flows. In recent literature, the development of the logistical function is described as a continuous process of integration. This development is related to the introduction of new information technology in logistics which result in an integration of logistical activities between different firms. These activities are connected and controlled by means of inter-organizational information systems. In that case we speak of integrated logistics.

This research focuses on changes in the organization of logistics in the building industry. Concepts from theories of industrial organization and rationalization of business processes are used to analyze these changes. Chapter 1 introduces the two central questions in this research:

1. Under which conditions or circumstances will an integrated logistical function for a chain or group of firms develop?

2. What are the characteristics or consequences of this integrated logistical function for the organization of business processes in a chain or group of firms?

To answer these questions, we first developed a theoretical framework which is described in part one, chapter 2 to 6 . Chapter 2 and 3 discuss what is meant by an integrated logistical function and which developments make such an organization of logistics possible. Chapter 4 and 5 contain a theoretical framework that describes the conditions under which an integrated logistical function can develop and the consequences of this for the organization of business processes. In chapter 6 , propositions and questions for empirical research are derived from this theoretical framework.

From a historical point of view, developments of the organization of the logistical function can be considered as a continuous process of integration (chapter 2). Till the 1950's firms organized their logistics in a fragmented way. During the 1960's separate logistical functions were merged into two identifiable approaches: physical distribution and materials management. During the 1970 's, both approaches became further integrated into the concept of business logistics. In the 1980's and 1990's, new concepts that bring this integration a step further have been developed. The concept of integrated logistics means that independent firms agree upon the way in which product and information flows are organized. The consequence of this agreement is an integrated organization of logistical activities on the level of a chain or group of firms. A possible outcome of this integration process in the future are organizational forms where the so called vertical actor plays an important role. With the 'vertical actor', the integration of logistical activities of different firms of a chain or group in one independent organization is meant.

Recent developments on the market require an integrated organization of logistical activities (chapter 3). An important development on the market is competition from Japan: The consequence of this development is that manufacturers put more stress on product 
and process quality. Besides quality, the demand for flexibility and the globalization of the market also result in a growing competition. We described how these market developments demand an integrated logistical function. Next, we discussed that new production and information technologies give possibilities to meet the requirements of new market demands. New production technologies are new types of production automation and non-traditional concepts of production-control. New information technologies are Videotex, Electronic Data Interchange (EDI) and Product Data Interchange (PDI). An integrated logistical function is an instrument to 'match' growing competition and new technological possibilities.

After these two descriptive chapters, the theoretical framework is discussed in chapter 4 and 5.

We use concepts of the theory of industrial organization for the analysis of circumstances under which an integrated logistical function will develop (chapter 4). Implementation of an integrated logistical function can be seen as a transition of the industrial organization of a firm from a market to a network. In the transaction cost theory, transaction specific investments are an important explanation for this transition. Investments in information systems with a so called community character, information systems by which only (a part of) an industry can communicate with each other, result in a growing transaction specificity. When the transaction specificity in a chain is high, new hierarchies will arise. The organization of logistical activities develops in the direction of what we have called the rise of a vertical actor. In network theories, an important explanation for the change of markets to networks is the growing importance of transfer of know-how, demand for speed and mutual trust. These factors are important for the aim of product quality and innovation and can result in logistical networks.

Theories of rationalization of business processes can be used to analyze characteristics and consequences of an integrated logistical function (chapter 5). Two types of rationalization of production processes are distinguished: Taylorism and a new type of rationalization. This new type of rationalization, called 'systemic' rationalization, focuses on the optimization and integration of functions within and between firms, realized by new information technology. Three dimensions of rationalization, 'hierarchization', 'technization', and 'informatization' describe in which direction the organization of production processes will change. New logistics can be considered as parts of the new type of rationalization. On the basis of the three dimensions of rationalization characteristics of the consequences of integrated logistics are described.

From the theoretical framework, propositions are derived for empirical research (chapter 6). In the first two propositions, concepts of the theory of the industrial organization are used to analyze under which circumstances or conditions logistical networks will develop: 1. Investments in information systems with a more or less closed community character stimulate the rise of logistical networks by their transaction specific character.

2. The growing importance of the transfer of know-how, demand for speed and mutual trust are factors that stimulate the development of logistical networks.

With concepts of theories of rationalization, 'hierarchization', 'technization' and 'informatization', three propositions have been developed. These propositions indicate the consequences and characteristics of an integrated logistical function.

3. An integrated logistical function involves an integrated organization of logistical activities that cross the border of firms and results in new hierarchies for the organization of logistical activities. 
4. An integrated logistical function involves a 'technization' of labor focused on new types of production automation and new information technology which result in substitution of labor by technical means.

5. An integrated logistical function requires a restructuring of the internal organization which makes it possible for a firm to produce and transfer standard messages.

Five research questions are derived from these propositions, one from each proposition (see figure 1).

Part two of this study contains the description of the empirical research. Chapter 7 contains a methodological justification and a research design. Chapter 8 deals with our research object: building projects and their logistics chains. Next, chapter 9, 10 en 11 describe the empirical research and a test of the propositions. Chapter 9 and 10 focus respectively on Dutch EDI and PDI projects and innovations in the organization of building projects. Both developments are the context in which changes in the building projects in practice take place. Chapter 11 contains four case-studies of building projects.

FIGURE 1 Schematic design of the empirical research

Research questions
1. Where in logistics chains in the building industry
can we find transaction specific investments directed to
the control of the product flows between firms?
2. Where in the building industry are transactions
characterized by demands of the market which go further
then only the prices of a product?
3. Where in building projects can one speak of an
organization of logistical activities in new hierarchies?
4. Can one speak in building chains of substitution of
labor by new forms of production-automation and new
information technology?
5. In how far results implementation of information systems.
in building chains in a restructuring of the firm by new
information technology?
A. EDI and PDI projects
C. building projects

The first proposition in chapter 6 raises the question where in logistics chain in the building industry transaction specific investments can be found directed to the control of the product flows between firms. For this reason, Dutch EDI en PDI projects are analyzed (chapter 9). The analysis of these projects answers the questions that are raised by the fourth and fifth proposition: in how far will implementation of "new information technology' result in a substitution of labor and a restructuring of the internal organization of the firm. 
EDI and PDI projects are directed to the formalization and standardization of information exchange between firms. The way in which these formalization and standardization result in a restructuring of production processes in the building industry depends on the fact if EDI or PDI is directly connected with internal applications. In the relationship between manufacturer and wholesaler, conditions are most favorable for coupling EDI with internal applications. In this link, there is an exchange of standardized products that can be coded quite easily, are relations characterized by agreements for the longer term and an exchange of a lot of short messages. In the link wholesaler-contractor information flows are more incidental. In this link there are also often small contractors which lack experience with automation and IT. In the relation between contractor and parties as wholesaler and manufacturer, only the selling and purchasing departments are integrated by EDI. For this reason, no substitution of labor by EDI will occur. It is difficult to say how PDI results in a restructuring of business processes because this technology is, more than EDI, in its development phase. For the architect, PDI is an instrument to design in a more costs conscious way. Besides this, PDI makes a quicker feedback and a more efficient exchange of drawings possible. PDI will have the most effect on engineer firms because these firms will be confronted with PDI at the input and the output side. At the input side, architects will send their drawings by PDI, at the output side, drawings of the engineer go to construction parties by PDI.

Obstacles and strategies for implementation of EDI and PDI in the building industry are also analyzed. This subject deals with the first condition under which an integrated logistical function can develop (proposition 1). The first condition is unfulfilled because the temporal character of relations and the fragmented structure of the industry impede transaction specific investments in information systems that cross borders of the firm. To come to a solution for these obstacles, an implementation-strategy is needed in which a collective body plays an important role. This body would be responsible for the development, construction and exploitation of an EDI-network. Such a network makes it possible that parties, related to a building project, can communicate electronic. The manager of this network can be considered as an example of what we have called a vertical actor, which means that an independent firm becomes responsible for the organization of logistical activities for different firms (see proposition 3).

The second proposition raises the question where in the building industry transactions are characterized by demands of the market which go further then only efficiency. A description of innovations in the organization of building projects, a result of new market demands, can answer the question where in the building industry other motives than efficiency result in logistical networks (chapter 10). With this analysis it is possible to answer the question which parties can play the role of vertical actor. This question is related to proposition 3 which focuses on the organization of logistical activities in new hierarchies.

Attention is payed to the trend to formulate construction tasks in the performances to be delivered instead of the building materials to be supplied. Besides this trend, new market demands are an important stimulus for a more quality conscious thinking in the building industry. New market demands, in combination with achievement-oriented working and a more quality conscious thinking result in the removal of the traditional division between designing and contracting parties. A result of this growing integration is that several firms want to become responsible for the complete building process. Transaction patterns between designing and construction parties change. There is a growing 
importance of the transfer of technical knowhow and mutual trust. According to proposition 2, this means a stimulus for the rise of logistical networks.

Firms that want to co-ordinate design and construction are mostly the bigger and/or more innovative architect firms, the bigger contractors who have experience with project development and standardized building concepts and project-management firms who supply the complete management of a building process as a separate service on the market. These parties make an integrated logistical function possible during the building process and can be considered as an example of a vertical actor. This innovation results in an organization of logistical activities in new hierarchies (see proposition 3 ).

The third part of the empirical research focuses on the beginnings of an integrated logistics function in the building practice (chapter 11). This research is connected with the third, fourth and fifth proposition. These propositions raise the questions where in the building practice we can find new hierarchies for the organization of logistical activities that cross the borders of the firm, substitution of labor by new forms of production-automation and new information technology and restructuring of the firm by new information technology. For this analysis, four building projects are investigated.

Firstly, one can see that non-traditionall ways to organize building projects offer opportunities for an integrated logistical function. The main problem with traditional building processes is the lack of central control. Building projects within building teams or other forms of co-operation, non-traditional forms of organization, are more centrally controlled. This means that there are less possibilities for logistical sub-optimization. Central control can be considered as an example of a vertical actor and results in a central organisation of logistical activities (see proposition 3 ).

Secondly, the analysis of case-studies shows that the need for logistical co-ordination depends on the production technique that has been used. The traditional way of building is a production technique which is site-oriented. The 'opposite' is prefabrication which is more factory oriented and means that craft work is replaced by production in the factory. Prefabrication offers more possibilities for a strict planning of the building process. It results in a substitution of labor and is an example of a 'technization' of labor that often goes together with the implementation of integrated logistics.

Thirdly, the case-studies show that only in a small part of the building industry information is exchanged in a standardized and formalized manner: The existing building practice is characterized by an informal and non-structured way of information exchange. This means that in great parts of the building industry there is no substitution of labor or restructuring of the internal organization by implementation of information systems. As already said, analysis of EDI-projects in the building industry shows that these information technologies have possibilities for substitution of labor.

Analysis of the existing building practice shows that in the transition to the central control of construction projects and prefabrication, we can find starting points for an integrated logistical function. This is called the organization of logistical activities in new hierarchies and a mechanization of labor in the propositions 3 and 4 . Only in a small part of the building industry information is exchanged in a standardized and formalized manner. 


\section{Curriculum Vitae}

Hans Voordijk werd op 22 april 1965 geboren te Zwollerkerspel. In 1983 siaagde hij voor het VWO aan het Lambert Franckens College te Elburg en ging vervolgens economie studeren aan de Erasmus Universiteit in Rotterdam. De auteur was in 1988 werkzaam bij het Ministerie van Sociale Zaken in Den Haag. In 1989 studeerde hij af aan de Erasmus Universiteit in de Staatkundige Economie en de Filosofie van de Economie. Van 1989 tot 1994 was de auteur assistent in opleiding aan het Maastricht Economic Research Institute on Innovation and Technology van de Rijksuniversiteit Limburg. Vanaf 1 maart 1994 is hij als universitair docent Organisatie verbonden aan de Economische Faculteit van de Katholieke Universiteit Brabant.

Hans Voordijk (born April 22, 1965 in Zwolierkerspel) studied Political Economics and Philosophy of Economics at Erasmus University Rotterdam from 1983 to 1989. In 1988 he worked at the Department of Social Affairs in The Hague. In 1989, he received Master's degrees in Political Economics and Philosophy of Economics from Erasmus University Rotterdam. Between 1989 and 1994 he held a position as a research assistant at Maastricht Economic Research Institute on Innovation and Technology of the University of Limburg. Since 1 March 1994, he works as assistent professor in Organization at the Economic Faculty of the Catholic University Brabant. 

Snel inspelen op nieuwe markten vereist een flexibele inzet van mansen en materialen. Kenmerkend voor de recente ontwikkelingen is dat (een gedeelte van) de flexibiliteit gezocht wordt in een integratie van logistieke activiteiten van verschillende ondernemingen. Gevolg van deze ontwikkelingen is dat logistieke verantwoordelijkheden binnen en tussen verschillende organisatorische eenheden in een keten van bedriven of bedrifskolom opnieuw worden afgebakend. Deze ontwikkeling naar een 'integrale' logistiek is nauw verbonden met de toepassing van nieuwe informatietechnologieenn. Onderwerp van dit onderzoek zijn de voorwaarden waaronder het tot toepassing van deze integrale logistiek komt en wat de gevolgen daarvan zijn voor de organisatie van produktie-processen.

Deze vragen worden onderzocht voor een specifieke sector, nil. de Nederlandse bouwsector. Er wordt ingegaan op de resultaten van verschillende stimuleringsprogramma's, gericht op informatisering in de bouw. Doel van deze programma's is de totstandkoming van een infrastructuur voor electronische communicatie tussen verschillende partijen betrokken bij het bouwproces. Daarnaast worden innovaties in de organisatie van bouwprojecten beschreven die het antwoord zijn op nieuwe eisen van de markt. Aangegeven wordt hoe relaties tussen ontwerpende, uitvoerende en toeleverende bedrijven in de bouw als gevolg hiervan veranderen. Ook worden een viertal case-studies van concrete bouwprojecten en hun ketens uitgevoerd. Op deze wijze wordt geanalyseerd in hoeverre in de bestaande bouwpraktijk organisatievormen te vinden zijn die als aanzetten tot of nadere concretiseringen van toepassing van integrale logistiek beschouwd kunnen worden. De relevantie van het onderzoek gaat echter verder dan de bouw omdat ontwikkelingen in logistieke ketens niet voor deze sector uniek hoeven te zijn. Zij zijn exemplarisch voor ontwikkelingen in verschillende andere bedrijistakken.

De auteur was van 1989 tot 1994 verbonden aan het economisch onderzoeksinstituut MERIT van de Aijksuniversiteit Limburg. Momenteel is hij als universitair docent Organisatie werkzaam bij de Katholieke Universiteit Brabant.

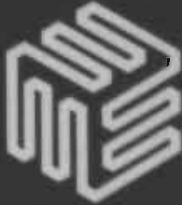

Faculty of Economics and Business Administration University of Limburg Maastricht, the Netherlands

Dissertation no. 94 - 20

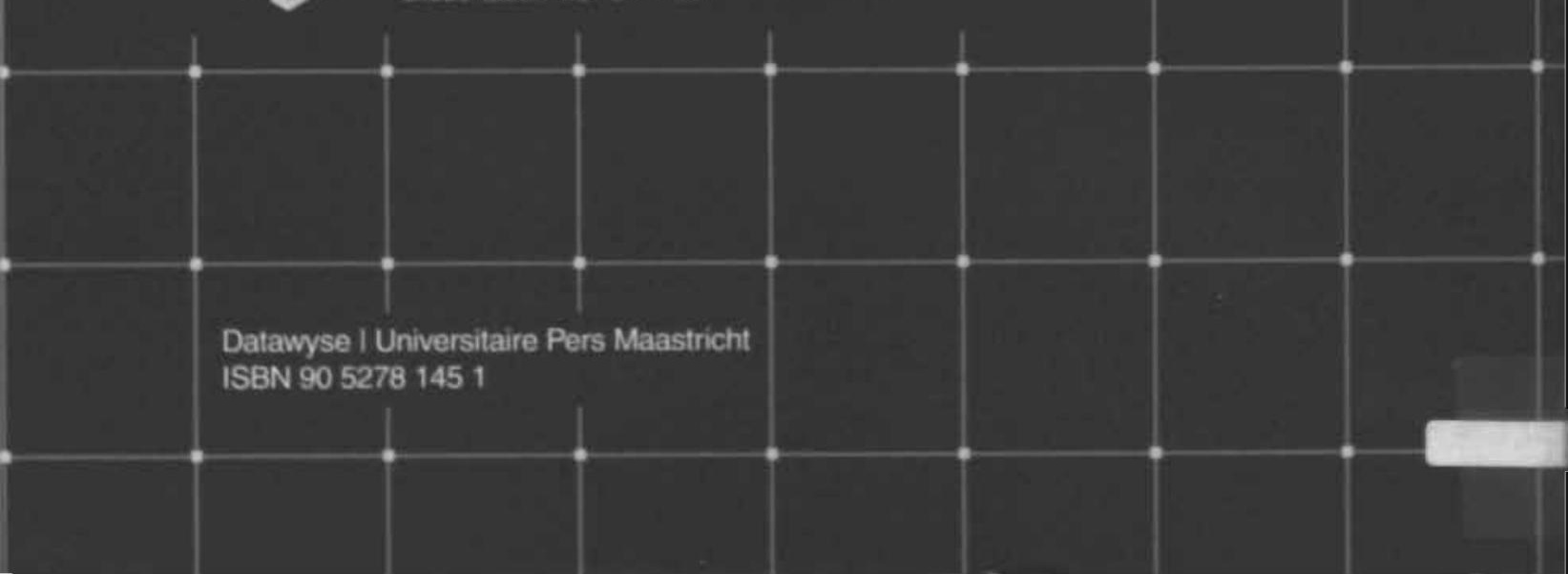

